\title{
POLICING-MOBILITIES IN THE BORDER-STRIP
}

CROSS-BORDER POLICE COOPERATION AND VIAPOLITICS AT THE INTERNAL SCHENGEN-BORDERS OF THE EU AREA OF FREEDOM, SECURITY AND JUSTICE

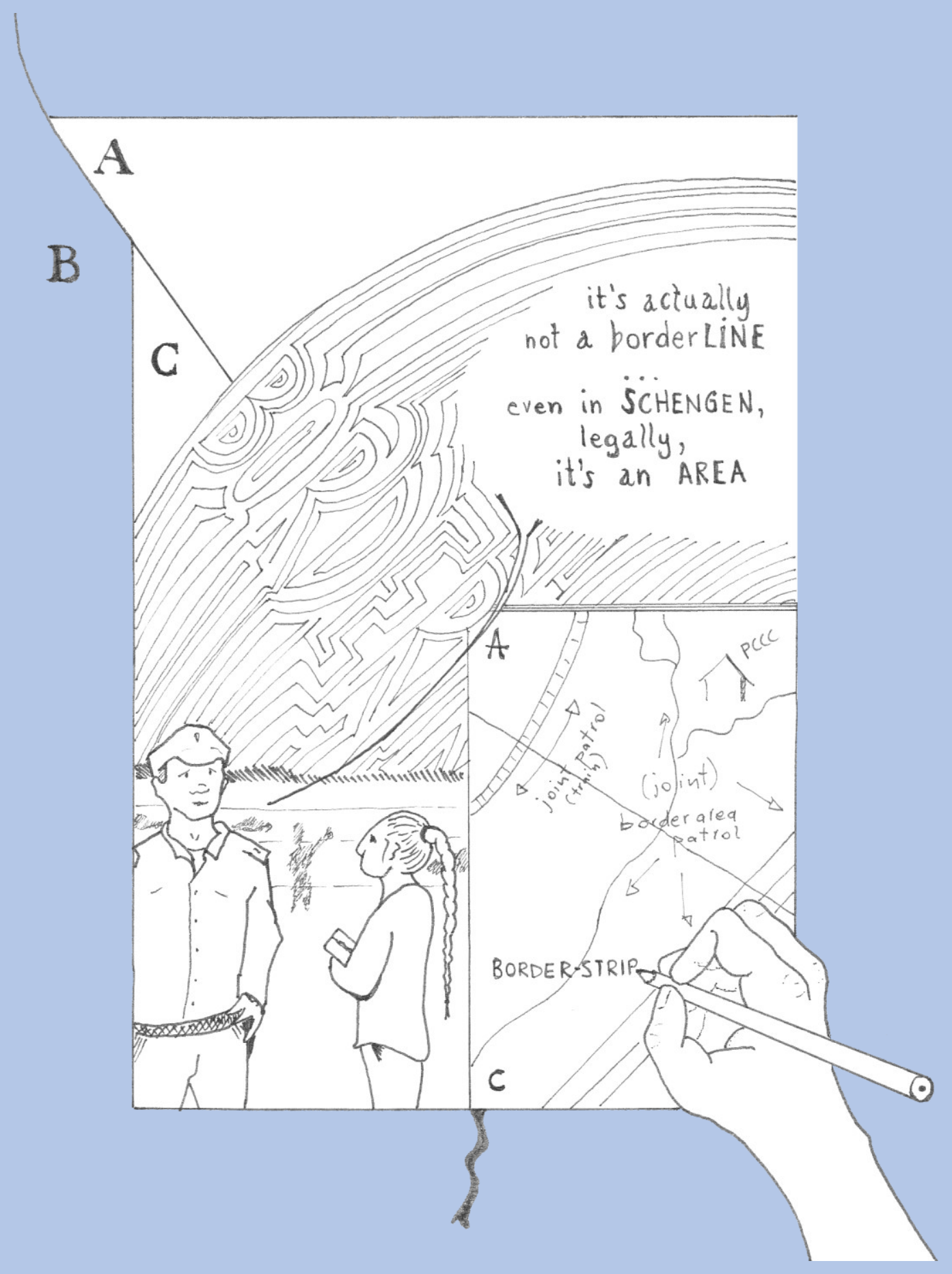

PhD Dissertation

Monika Weissensteiner 
Thesis submitted to Hamburg University and to Utrecht University in partial fulfilment for requirements for the degree of Doctor of Philosophy after following the Erasmus Mundus Doctoral Programme in Cultural and Global Criminology.

\section{Doctoral committee}

Prof. Dr. Keebet von Benda-Beckmann (Max Planck Institute for Social Anthropology)

Prof. Dr. Susanne Krasmann (Hamburg University)

Prof. Dr. Paul Minderhoud (Utrecht University)

Prof. Dr. Hans Nelen (Maastricht University)

Prof. Dr. William Walters (Carleton University)

Academic year 2020-2021

Thesis submission: 15 th of October 2020

Thesis Defence Hamburg University: 13th of January 2021

Thesis Defence Utrecht University: 31st of May 2021

Dissertation Title-Page Utrecht University, pp. iii-iv

Dissertation Title-Page Hamburg University, pp. v-vi

Cover: Central image of Policing-mobilities in the border-strip, p.1

(C) Text and illustration: Monika Weissensteiner, 2021. All rights reserved.

DOI: https://doi.org/10.33540/678

The thesis was accomplished with the financial support from the European Union's Education Audiovisual and Culture Executive Agency's Erasmus Mundus Scheme. 


\title{
POLICING-MOBILITIES IN THE BORDER-STRIP
}

\author{
CROSS-BORDER POLICE COOPERATION AND VIAPOLITICS \\ AT THE INTERNAL SCHENGEN-BORDERS OF THE EU \\ AREA OF FREEDOM, SECURITY AND JUSTICE
}

Politiële mobiliteiten in de grensstrook

Grensoverschrijdende politiële samenwerking en viapolitiek langs de Schengenbinnengrenzen van de EU-ruimte van vrijheid, veiligheid en recht (met een samenvatting in het Nederlands)

Polizei-Mobilitäten im Grenz-Streifen

Grenzüberschreitende polizeiliche Zusammenarbeit und Viapolitik an den Schengen Binnengrenzen im EU-Raum der Freiheit, Sicherheit und Gerechtigkeit (mit einer Zusammenfassung in deutscher Sprache)

\section{Proefschrift}

ter verkrijging van de graad van doctor aan de

Universiteit Utrecht

op gezag van de

rector magnificus, prof.dr. H.R.B.M. Kummeling, ingevolge het besluit van het college voor promoties

in het openbaar te verdedigen op

maandag 31 mei 2021

des middags te 4.15 uur

\section{Monika Weissensteiner}

geboren op 8 februari 1983

te Bolzano-Bozen, Italië 


\section{Promotoren:}

Prof. dr. D. Siegel - Rozenblit

Prof. dr. C. Hentschel

The degree is awarded as part of a Joint Doctorate with Universität Hamburg.

The thesis was accomplished with the financial support from the European Union's Education Audiovisual and Culture Executive Agency's Erasmus Mundus Scheme. 


\title{
POLICING-MOBILITIES IN THE BORDER-STRIP
}

\author{
CROSS-BORDER POLICE COOPERATION AND VIAPOLITICS \\ AT THE INTERNAL SCHENGEN-BORDERS OF THE EU \\ AREA OF FREEDOM, SECURITY AND JUSTICE
}

\begin{abstract}
Thesis submitted by:
Monika Weissensteiner

Date of submission: $15^{\text {th }}$ of October 2020

Submission of minor corrections: 22 ${ }^{\text {nd }}$ of March 2021

Word count: 104.609
\end{abstract}

Submitted to:

Hamburg University

Faculty of Business, Economics and Social Science
Utrecht University Faculty of Law, Economics and Governance

Thesis submitted to Hamburg University and to Utrecht University in partial fulfilment for requirements for the degree of Doctor of Philosophy after following the Erasmus Mundus Doctoral Programme in Cultural and Global Criminology. 
Supervision

Prof. dr. Christine Hentschel

Universität Hamburg

Institut für Kriminologische

Sozialforschung | Institute for

Criminological Research

Fakultät für Wirtschafts-und

Sozialwissenschaften | Faculty of

Business, Economics and Social Science
Prof. dr. Dina Siegel

Universiteit Utrecht

Willem Pompe Instituut voor

strafrechtswetenschappen |

Willem Pompe Institute for Criminal

Law and Criminology

Faculteit Recht, Economie, Bestuur en

Organisatie | Faculty of Law, Economics

and Governance 


\section{Declaration}

I declare that the research embodied in thesis is my own work and that the material contained herein has not been previously submitted at any other university.

I declare that I have not used commercial doctoral advisory services or any other sources of aid other than those listed in this thesis. 
To the young boy,

who, whilst hiding from a border-area police control, got separated from his Syrian family,

at an internal EU border;

to the single man,

who interrupted his trajectory to help in translation, his arrival to destination,

to remain unsure;

to the police officers,

who were there in multiple functions,

with complexities embodied in, and overdetermining,

the encounter. 


\section{INDEX}

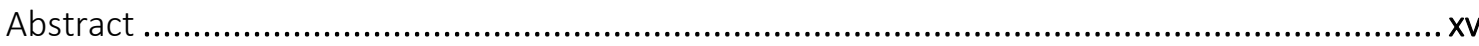

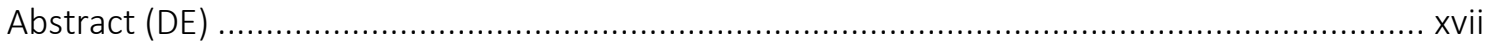

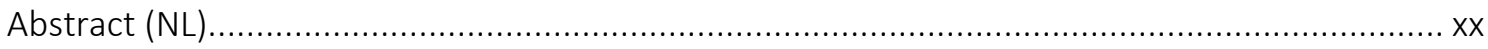

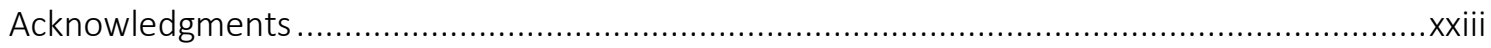

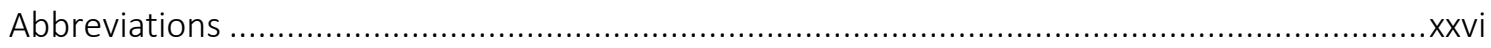

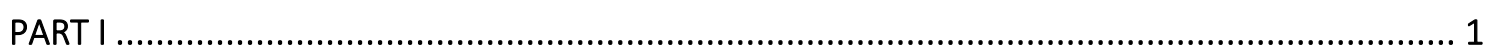

CHAPTER 1

INTRODUCTION

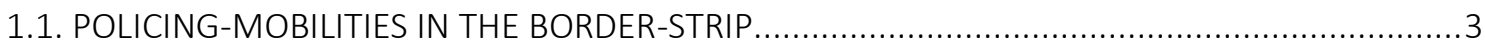

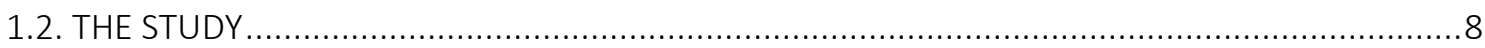

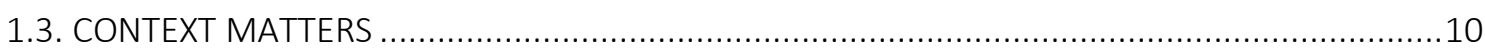

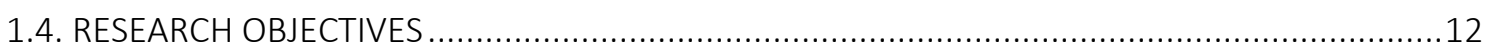

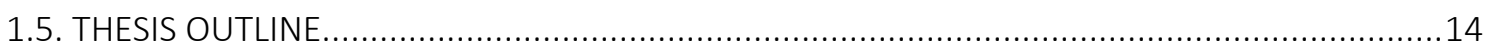

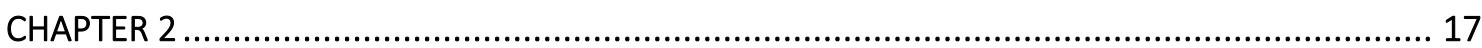

CROSS-BORDER POLICE COOPERATION AND MIGRATION CONTROL AT INTERNAL SCHENGEN BORDERS

2.1. INTRODUCTION: A NAVIGATION THROUGH THE LITERATURE ACROSS BORDERS................17

2.2. CROSS-BORDER POLICE COOPERATION AND POLICING AT INTERNAL BORDERS ...................17

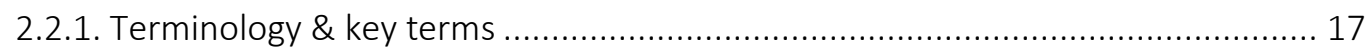

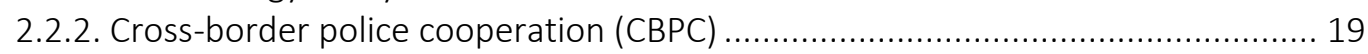

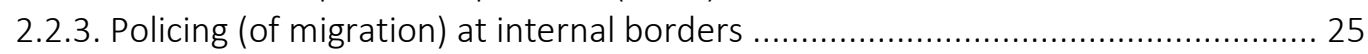

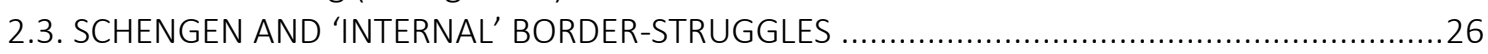

2.3.1. "Schengenland" and the Area of Freedom, Security and Justice ....................... 26

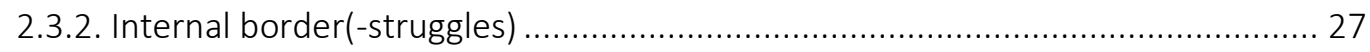

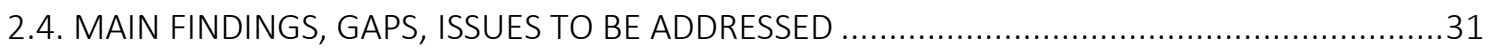

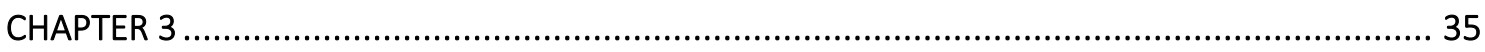

THEORETICAL ELABORATION AND CONCEPTUAL THREADS

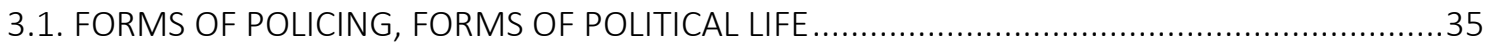

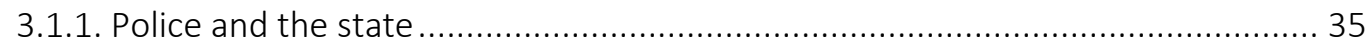

3.1.2. Globalisation, European Integration and the political field of 'internal security' . 37

3.1.3. Practices and effects at the margins and at the centre ..................................... 39

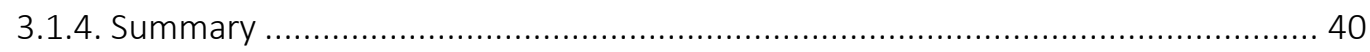

3.2. CROSS-BORDER POLICE COOPERATION: policing-mobilities within plural legal orders ..........40

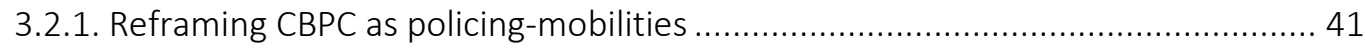

3.2.2. Moving from a "patchwork quilt" of cooperation to plural legal orders ............. 41

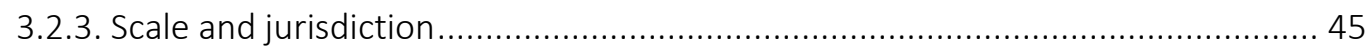

3.2.4. Contribution to other conceptualisations of CBPC ............................................. 46

3.3. MIGRATION-POLICING: BORDERS AND 'SECURITY-MIGRATION-CRIME'-NEXI ....................48

3.3.1. Border* - lines, -spaces, -practices, -regimes, -struggles .................................. 49

3.3.2. Governmentality studies and (in)securitisation............................................. 52

3.3.3. Criminology of mobility, border-criminologies, transnational mobility control.... 54

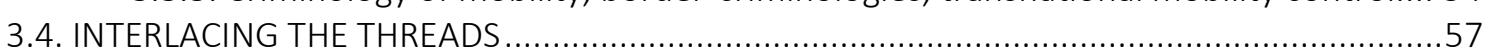

3.4.1. Policing-mobilities, plural legal orders and interlegality ................................... 57

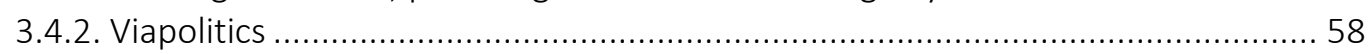

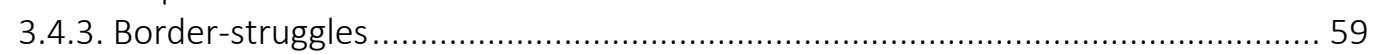

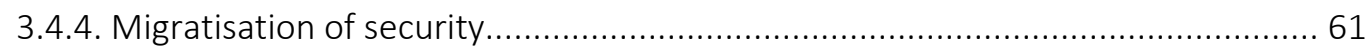

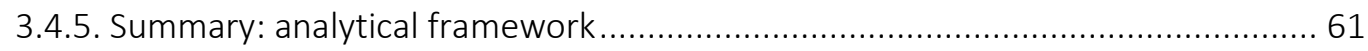




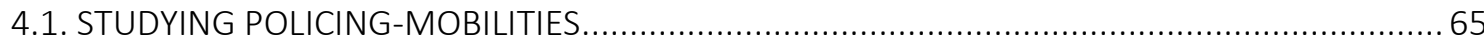

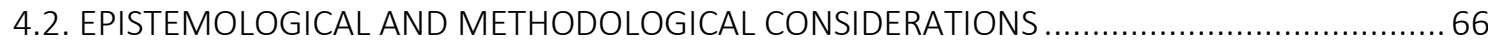

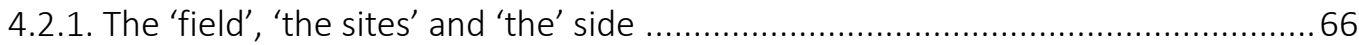

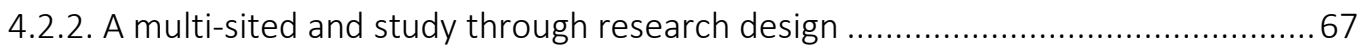

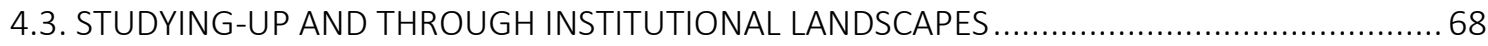

4.3.1. Entering the field: encountering the classical challenges of CBPC ......................68

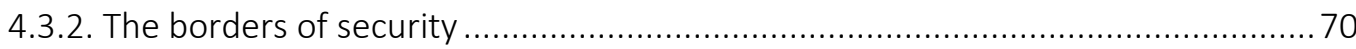

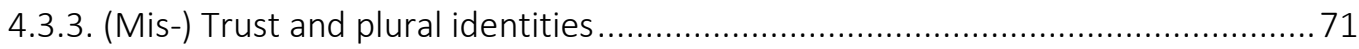

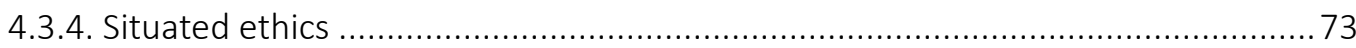

4.4. RESEARCH METHODS AND STEPS

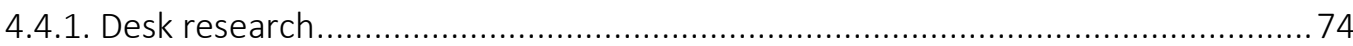

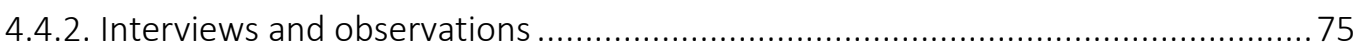

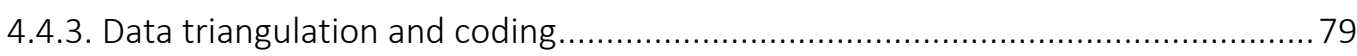

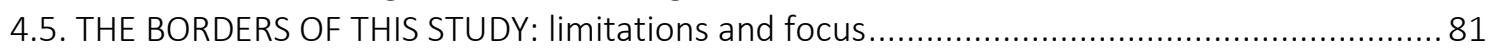

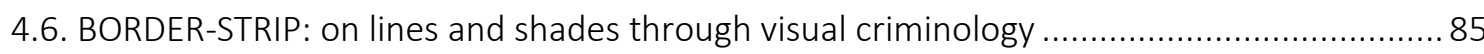

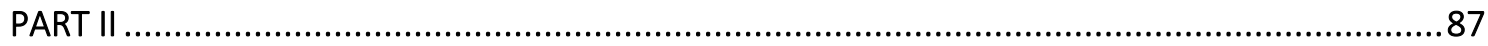

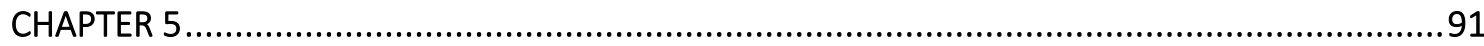

CROSS-BORDER POLICE COOPERATION (I). A GENEALOGY OF POLICING-MOBILITY INSTRUMENTS IN THE BORDER-STRIP AND THEIR SPATIAL-LEGAL CONFIGURATION

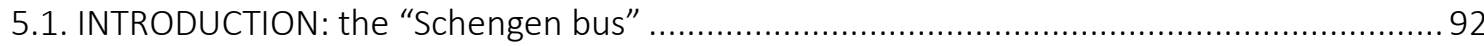

5.2. PCCCs: cross-border mobility of data in direct information exchange ................................93

5.2.1. PCCCs within the landscape of data mobility channels .......................................99

5.2.2. Plural legal orders, inter-legality and the legal geography of data mobility..........98

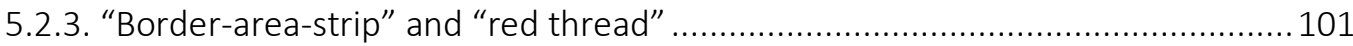

5.3. (JOINT) MOBILE PATROLS IN BORDER-AREAS: mobile borders and mobile officers ............ 103

5.3.1. Mobile patrols - the "mobile frontier" and the mobility of borders.................. 105

5.3.2. Joint patrols in border-areas - mobility of police officers and their powers.......107

5.3.3. Border as practices and their symbolic and spatial-legal dimension...................114

5.4. ELABORATION: Space, law, plural (legal) orders and policing powers .............................. 116

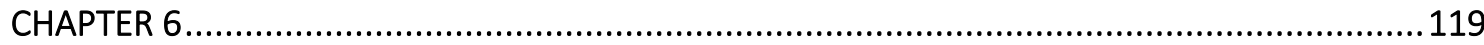

CROSS-BORDER POLICE COOPERATION (II). COOPERATION IN THE FORCED REMOVAL OF '3RD' COUNTRY-NATIONALS ACROSS INTERNAL BORDERS

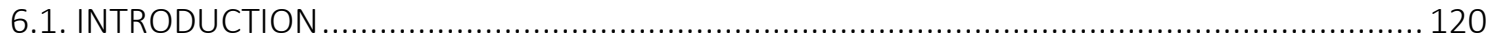

6.2. FAST-TRACK READMISSION - SWIFT REMOVAL ACROSS INTERNAL BORDERS ….............. 123

6.2.1. Tracing through time: readmission agreements ........................................... 124

6.2.2. Historical variants and a barometer for cross-border relations ..........................132

6.3. 'TEMPORARY' BORDER CONTROL: "refusal of entry" and the "fiction of non-entry" .......... 134

6.4. THE 'ORDINARY' WAY OF BORDER-WORK: three generations of measures ........................ 137

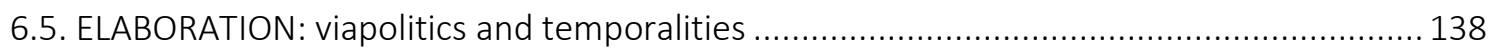


CHAPTER 7

(EXTRA)ORDINARY POLICING-MOBILITIES IN A LANDSCAPE OF MEANINGS AND POWERS

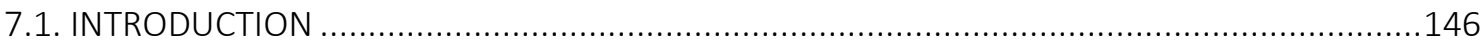

7.2. JOINT POLICE CENTRES AND THE FACILITATION OF POLICE DATA MOBILITY.....................146

7.2.1. Cooperation and data mobility: self-understandings and meanings ................. 147

7.2.2. Migration: moving beyond criminal police information exchange .................... 152

7.2.3. Plural legal orders, space making and the politics of scale .............................. 155

7.2.4. 'Culture' and 'scale' - meaning and power .................................................... 164

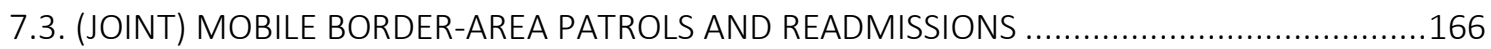

7.3.1. Joint patrols in border-areas: values, aims, challenges ................................... 166

7.3.2. Migration control - ethos of a joint task? ................................................... 170

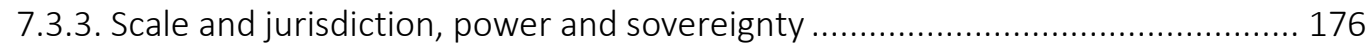

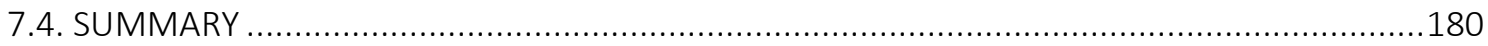

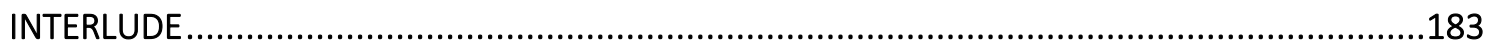

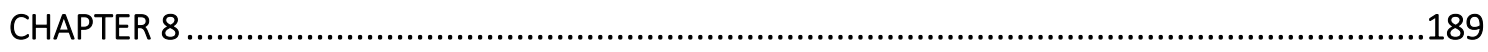

ENCOUNTERS OF SECURITY AND MIGRATION. BORDER-STRUGGLES IN THE POLICING OF "SECONDARY MOVEMENTS" AT INTERNAL BORDERS

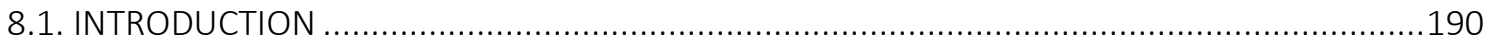

8.2. BETWEEN NORMALISATION AND RESISTANCE - policing "secondary movements" ...........190

8.2.1 Dublin system \& "secondary movements" ....................................... 192

8.2.2. Fingerprinting, "proportionality" and moral geography................................ 194

8.2.3. Migratisation of security and response-ability ...................................... 198

8.3. BALANCING ACTS: (differential) freedom of circulation - border (area) control ...............204

8.3.1. CJEU case law: (judicial) border-struggles surrounding art. 23 of the SBC ....... 205

8.3.2. Lines and shades in border(area)controls and their effects ........................... 210

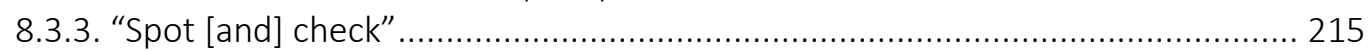

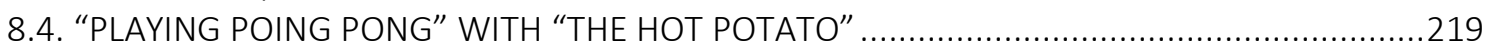

8.4.1. Plural logics of control and chains of interactions ....................................... 220

8.4.2. "Diplomacy down here": from high-politics to capabilities in the border-strip.. 225

8.4.3. The "hot potato" beyond policing .................................................... 228

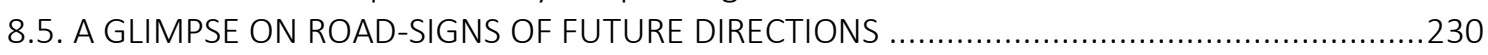

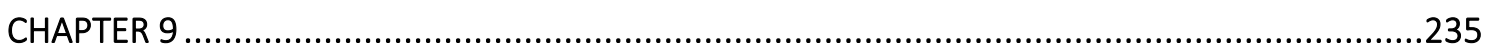

CONCLUSION

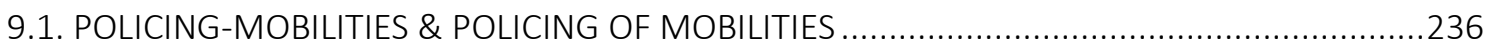

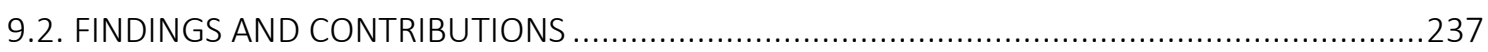

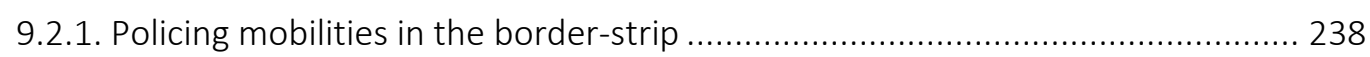

9.2.2. Proliferation and interaction of legal regimes .......................................... 240

9.2.3. Playing "ping-pong" with the "hot potato" ............................................. 241

9.2.4. The "concept of the mobile frontier" and three generations of borderwork.... 243

9.2.5. Ongoing reconfigurations of power and governance ................................. 245

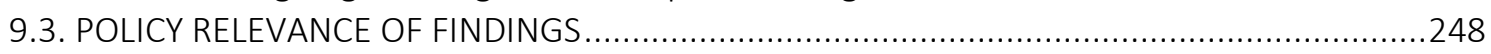

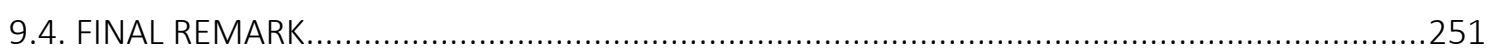




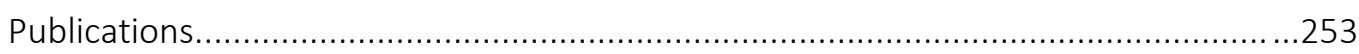

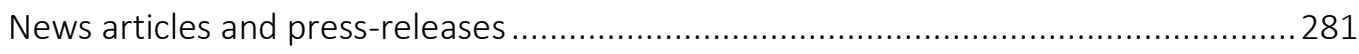

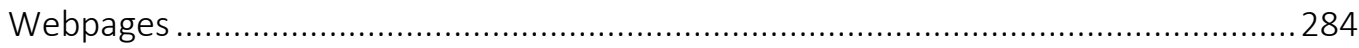

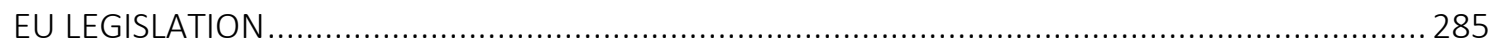

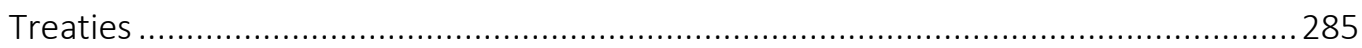

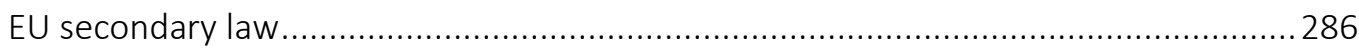

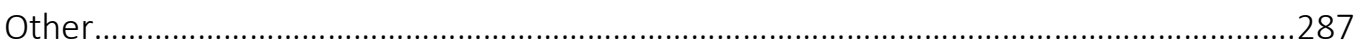

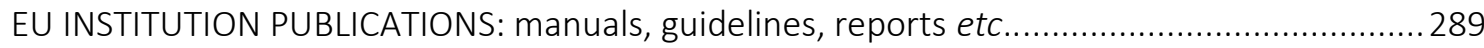

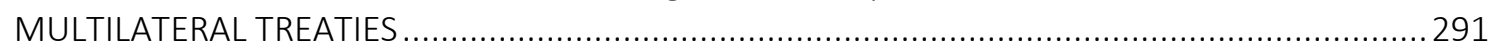

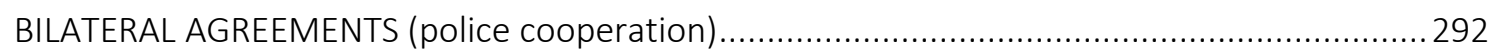

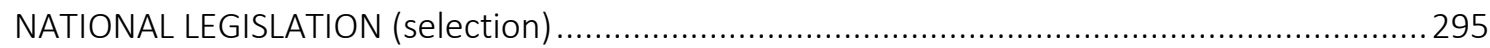

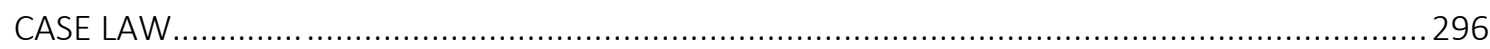

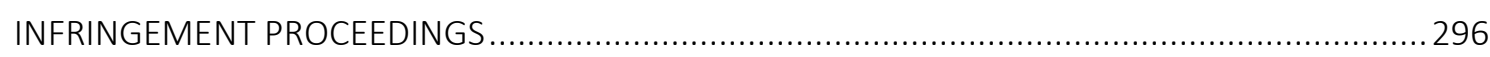

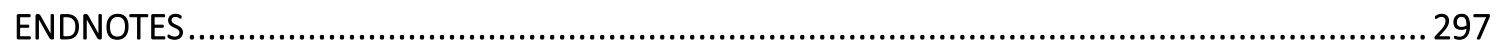

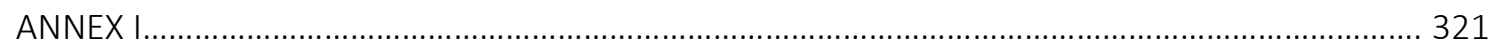

Quotes from non-English public sources

ANNEX II.

A - Background information: police organisation

B - Tables: Schengen, bilateral agreements, case law

ANNEX III 339

Study description: Information sheets for research participants

Required information: $\mathrm{CV}$, declarations

\section{VISUALISATIONS AND TABLES}

\section{Illustrations}

BORDER-STRIP 1: Policing-mobilities in the border-strip, p.1

BORDER-STRIP 2: Schengenland and the Area of Freedom, Security and Justice, pp.87-88 BORDER-STRIP 3: Schengen-bus, p.91

BORDER-STRIP 4: Seismographic readmission traffic, p.119

BORDER-STRIP 5: A piece of border infrastructure, p.143

BORDER-STRIP 6: Lines: threads, traces and surfaces - territory and network, p.145

BORDER-STRIP 7: Sign in place, p.183 and flip, p.186

BORDER-STRIP 8: Border-struggles, p.189

\section{Images}

Image 1: Border(-area)-strips, p.102

Image 2: "Secondary movements" in Europe, p.303

Image 3: Visualisation table 2, p.312

Image 4: Police organisation (AT): Federal Police Directorates, Annex II, p.328

Image 5: Police organisation (IT): Border Police Sectors, Annex II, p.329

\section{Tables}

Table 1: Interviews by stakeholder category, p.77

Table 2: Readmissions (statistical example), pp.123

Table 3: Schengen members and enlargement process, Annex II, p.331

Table 4: PCCC/joint centres (selection), Annex II, p.332

Table 5 (a), (b): Readmission agreements between member states, Annex II, pp.333-335

Table 6: CJEU case law art. 23 SBC, Annex II, pp.336-337 


\section{Abstract}

The establishment of an area of "freedom of movement" without border control within the Schengen-area is deemed one of the major achievements of European integration. However, developments since 2015 have shown a renewed salience of internal borders. This is due, on the one hand, to the introduction and maintenance of temporary border control by several member states, which was justified as a response to unauthorised mobilities problematised as "secondary movements". On the other hand, also border-regions adjacent to internal borders have acquired an increased strategic importance. Particularly the European Commission advanced the recommendation to shift towards enhanced (national) border-area police-checks and police cooperation as an alternative to border control. Both the Treaty on the Functioning of the European Union (TFEU) and explicitly the Convention Implementing the Schengen Agreement (CISA) encourage bilateral police cooperation between member states, foreseeing particular measures for countries that share a common border. Various studies conducted in the 1990s engaged with initially informal, and increasingly formalised, forms of cooperation across borderregions. In current times, practices of cross-border police cooperation as well as of migration policing at internal borders constitute a substantial knowledge gap.

In this dissertation I examine the intersection of cross-border police cooperation (CBPC) with the control of differential mobility rights within today's EU Area of Freedom, Security and Justice. I conceptualise and analyse CBPC as policing-mobilities in the border-strip. Grounded in empirical fieldwork with police officers, this study fills important research-gaps that persist with regards to a twofold inquiry: a) police cooperation at the scale of border-regions and b) the policing of mobilities at internal Schengen borders. Specifically, this study concentrates on three CBPC instruments: joint police centres or PCCCs, (joint) border-area patrols and bilateral simplified fasttrack readmissions. Some of these were also amongst the "best practices" and alternatives which since 2017 the Commission has recommended to enhance. Beyond findings of analytical relevance, this study allows one to critically engage with the envisaged border-area 'solutions'.

In PART I, I place this dissertation at the crossroad of social-science and law within a multidisciplinary field of scholarly engagement. I outline the theoretical framework and methodological approach of a multisited research design. Rather than conducting a research that favours a focus on discourses and laws or on situated practices, I studied both elements and the interdependence between law-as-text and as-practice, aiming to get a grasp of large-scale processes not reducible to one empirical field-locale. In PART II, I draw attention towards the spatial-legal regimes that regulate CBPC and trace their emergence as institutionalised regimes of practices. I argue that they constitute the border-strip as spatial-legal condition of possibility 
for the exercise of specific policing powers: the power to move data, the mobility of officers operating outside their territorial jurisdiction, and instruments for the forced removal of third country nationals. Therefore, I argue that CBPC is not only a cross-border interaction, but that it concerns practices that can be understood as policing-mobilities. Legal pluralism is used as an analytical framework to engage with, and to go beyond, what in policing scholarship has been described as the "fragmented legal terrain" of police cooperation (inter alia Sheptycki 2001, p.153). Studying CBPC today requires analytical tools to be attuned to a context in which police cooperation takes place within hyperlegalised and multinormative spaces. Not only policing law, but legal orders of various fields and scale intersect in the border-strip, e.g. those regulating immigration, asylum, and border control in the specific spatial-legal geography of the Schengen space. Interlegality (Boaventura-de-Sousa 1987) as a midlevel concept allows one to engage with complex negotiations of plural legal orders. In PART III, I present and discuss empirical findings and highlight the analytical necessity and value of not extrapolating the policing of migration from the wider police (co)operation practices in the border-strip and the meanings officers attribute to their work. I address, for example, how an ethos of a 'joint task' plays out in joint patrolling, how officers respond to an increased migratisation of policework, and I examine the role of borderstrip diplomacy in uniform. The analysis is refined by engaging with scalar theory, inquiring how governing unauthorised mobilities plays out within scale politics. Negotiations within policingmobilities, which are nevertheless territorially anchored, in turn shape the ongoing reconfiguration of space, of law, and of Europe's (b)orders.

The findings of this multi-sited study allow one to conclude that CBPC has increasingly acquired salience as a scale and as policy field of response to unauthorised mobilities. Drawing on Walter's midlevel concept of "viapolitics" (2015), the border-strip can be understood as a viapolitical strategic zone. I differentiate between three generations of practices in the border-strip and I analyse the increased approximation between these border-area control-measures and the (politically and legally distinct) practice of border control. An analysis of border-struggles across scales reveals that policing-mobilities in the border-strip are deemed capable of providing a mediating solution to the 'dilemma' of how to enforce differential mobility rights in the absence of border control. But they are also invested with the hope of providing a spatial (re)solution (Smith 2003) to conflicting forces within the reform of the Dublin system and indeed to borderstruggles at the heart of the EU order. Invested with such hope, they might become further invested with powers. As pointed out by Andreas et al. in "Policing the European Union" (1995), attending to the technicalities of police cooperation allows one to reflect upon "forms of policing" within mutating "forms of political life". 


\section{POLIZEI-MOBILITÄTEN IM GRENZ-STREIFEN}

Grenzüberschreitende polizeiliche Zusammenarbeit und Viapolitik an den Schengen Binnengrenzen im EU-Raum der Freiheit, Sicherheit und Gerechtigkeit

Abstract (DE)

Die Schaffung eines (Schengen-) Raumes der Freizügigkeit ohne interne Grenzkontrollen gilt als eine der größten Errungenschaften der Europäischen Integration. Seit 2015 sind jedoch Binnengrenzen wieder stärker in den Vordergrund getreten. Dies ist zum einen bedingt durch die Einführung und Beibehaltung temporärer Grenzkontrollen durch mehrere Mitgliedsstaaten, die dies als Antwort auf sogenannte "Sekundär-Migration" verstehen und begründen. Zum anderen, und dies steht im Mittelpunkt dieser Arbeit, hat aber auch der Binnengrenzraum zunehmend an strategischer Bedeutung gewonnen. So etwa befürwortet die Europäische Kommission den Übergang zu intensiveren Polizeikontrollen, einschließlich im Grenzraum, sowie die verstärkte Anwendung von Polizeizusammenarbeit als Alternative zu Grenzkontrollen. Sowohl der Vertrag über die Arbeitsweise der Europäischen Union (AEUV), als auch das Schengener Durchführungsübereinkommen (SDÜ) unterstützen bilaterale Formen polizeilicher Zusammenarbeit, mit besonderen Möglichkeiten für Mitgliedsstaaten mit einer gemeinsamen Grenze. Studien in den 1990er Jahren haben sich mit der anfänglich informellen und zunehmend institutionalisierten polizeilichen Zusammenarbeit zwischen benachbarten Grenzregionen auseinandergesetzt. Heute stellen diese Praktiken der Zusammenarbeit und das Polizieren von Migration an den Binnen(raum)grenzen eine Forschungslücke dar.

Diese Dissertation untersucht das Schnittfeld zwischen der grenzüberschreitenden polizeilichen Zusammenarbeit (GÜPZ) und der Kontrolle differenzierter Mobilitätsrechte im EU-Raum der Freiheit, Sicherheit und Gerechtigkeit. Ich konzeptualisiere und analysiere polizeiliche Zusammenarbeit an den Binnengrenzen als Polizei-Mobilitäten im Grenz-Streifen - policingmobilities in the border-strip. Diese empirische Studie mit PolizeibeamtInnen füllt in zweifacher Hinsicht wichtige Forschungslücken: zum einen in Bezug auf Erfahrungen polizeilicher Zusammenarbeit in Grenzregionen, zum anderen hinsichtlich polizeilicher Mobilitätskontrolle an den Binnengrenzen. Im Fokus dieser Arbeiten stehen drei Instrumente der GÜPZ: gemeinsame Polizeizentren (GZ, PCCCs), (gemeinsame) mobile Grenzraumkontrollen, vereinfachte bilaterale Rückübernahmen. Mehrere Modalitäten der sogenannten "bewährten Erfahrungen” welche die Europäische Kommission seit 2017 empfiehlt auszubauen, werden in dieser Studie untersucht. Neben Argumenten theoretischer Ausprägung, setzt sich diese Arbeit kritisch mit vermeintlichen 'Problemlösungen' im Grenzraum auseinander. 
Im ersten Teil positioniere ich diese Arbeit, welche sozial- und rechtswissenschaftliche Elemente verbindet, innerhalb eines multidisziplinären Forschungsfeldes. Der theoretische Rahmen und der methodologische Zugang des multisited Forschungsdesigns wird hier erläutert. Anstatt sich entweder nur mit rechtlichen Entwicklungen und Diskursen oder mit Praktiken zu beschäftigen, wird hier beides miteinander verknüpft und beide Elemente und Dynamiken in ihrer wechselseitigen Abhängigkeit untersucht. Dadurch wird angestrebt weitfassende Entwicklungen zu beleuchten, welche sich nicht auf eine einzelne empirisch-situierte Konfiguration im Forschungsfeld reduzieren lassen. Im zweiten Teil fokussiere ich auf die räumlich-rechtliche Ordnungen, welche die GÜPZ regeln und zeichne deren Entwicklung als institutionalisierte Regime von Praktiken nach. Diese schaffen den Grenz-Streifen als eine räumlich-rechtliche Bedingung für die Ausübung spezifischer polizeilicher Befugnisse und Praktiken: die Mobilität von Daten, die Mobilität von Beamten außerhalb ihrer territorialen Zuständigkeit, und "SchubVerkehr" von Dittstaatsangehörigen. Kurzum, ich argumentiere, dass die Praktiken von GÜPZ nicht nur eine grenz-überschreitende Interaktion sind, sondern als Polizei-Mobilitäten verstanden werden können. Rechtspluralismus wird in der Arbeit als analytischer Rahmen angewandt, um sich mit dem sogenannten "fragmentierten rechtlichem Terrain" (inter alia Sheptycki 2001, p.153) der Polizeizusammenarbeit auseinanderzusetzen und um darüber hinausgehen zu können. Eine Studie der GÜPZ bedarf analytischer Werkzeuge, welche einem heutzutage stark verrechtlichten und multinormativen Grenz- und Kooperationsraum gerecht werden. Nicht nur Gesetzgebung im Politikfeld der Polizei (-Zusammenarbeit), sondern eine Vielzahl rechtlicher Ordnungen unterschiedlicher Felder und Ebenen überlappen im Grenzraum, wie z.B. die Asyl-, Einwanderung- und Grenzkodex-Bestimmungen der rechtlich-räumlichen Ordnung des Schengen-Raumes. Das Konzept der Interlegalität (Boaventura-de-Sousa 1987) erlaubt es komplexe Aushandlungen plural rechtlicher Ordnungen zu konzeptualisieren und zu analysieren. Im dritten Teil der Arbeit werden empirische Daten vorgestellt und analysiert. Dabei wird das Polizieren von Migration nicht von anderen Alltags-(Ko-)Operationen im Grenzraum und deren Bedeutung für Polizeibeamten extrapoliert, sondern darin eingebettet betrachtet. Dabei erläutere ich, z.B. symbolische und operative Aspekte einer gemeinsamen Aufgabe durch sogenannte „gemischte Streifen“ (joint patrols), wie Beamte mit einem vermehrt durch Migration geprägten Arbeits-Alltag umgehen und ich betrachte die Rolle von Diplomatie in Uniform im Grenz-Streifen. Einer Untersuchung wie das Regieren unautorisierter Bewegungen sich im Kontext von scale-politics abspielt, verfeinert die Analyse zusätzlich. Aushandlungen pluraler rechtlicher Ordnungen, durch nichtsdestotrotz territorial verankerte Polizeiarbeit, tragen ihrerseits zur Rekonfiguration von Raum und Recht und damit von Europas Grenzen und Ordnung bei. 
Die Ergebnisse dieser Studie zeigen eindeutig, dass GÜPZ in Grenzregionen zunehmend als Politikfeld und als scale an Bedeutung in der Migrationskontrolle gewonnen hat. Mit Walters' Konzept der "viapolitics" (2015) kann der Grenz-Streifen als strategische viapolitische Zone betrachtet werden. Ich unterscheide zwischen drei Generationen von Grenz-Streif-Maßnahmen durch Polizei-Mobilitäten und analysiere die zunehmende Annäherung von diesen Praktiken der Grenzraumkontrolle und jenen der (politisch und rechtlich unterschiedlichen) Grenzkontrolle. Eine Analyse von Grenzkonflikten zwischen Ebenen und Akteuren zeigt auf, wie Maßnahmen im Grenz-Streifen zum einen vermehrt als geeignet erachtet werden um das 'Dilemma' zu lösen, wie differenzierte Freizügigkeitsrechte in Abwesenheit von Grenzkontrollen durchgesetzt werden könnten. Zum anderen fungieren (nationale und bilaterale) Polizei-Mobilitäten im Grenz-Streifen aber auch als vermeintliche oder erhoffte räumliche (Auf)Lösung (Smith 2003) konfliktreicher Kräfte innerhalb der Reform des Dublin-Systems und, nicht zuletzt, im Herzen der Europäischen Ordnung. Damit wird auch der Handlungsspielraum solcher Hoffnungsträger gestärkt. Wie bereits Andreas et. al (1995) in "Policing the European Union“ konstatiert haben, erlaubt eine Auseinandersetzung mit den Details polizeilicher Zusammenarbeit eine Untersuchung der Ausprägung von Polizeiarbeit und der damit verstrickten Ausprägung politischen Lebens. 


\title{
POLITIËLE MOBILITEITEN IN DE GRENSSTROOK
}

Grensoverschrijdende politiële samenwerking en viapolitiek langs de Schengenbinnengrenzen van de EU-ruimte van vrijheid, veiligheid en recht

\begin{abstract}
NL)
De instelling van een gebied van "vrijheid van beweging" zonder grenscontrole binnen het Schengengebied wordt beschouwd als een van de belangrijkste wapenfeiten van de Europese integratie. Maar uit ontwikkelingen sinds 2015 blijkt dat binnengrenzen opnieuw relevant worden. Dat is voor een deel te wijten aan de invoering en handhaving van tijdelijke grenscontroles door een aantal lidstaten, gerechtvaardigd als een reactie op ongeautoriseerde mobiliteiten die werden geproblematiseerd als "secundaire bewegingen". Tegelijkertijd is het strategisch belang van grensgebieden langs binnengrenzen toegenomen. Met name de Europese Commissie heeft aanbevolen om versterkte (nationale) politiecontroles in grensgebieden en politiesamenwerking te hanteren als alternatief voor grenscontrole. Zowel het Verdrag betreffende de werking van de Europese Unie (VwEU) en expliciet de Overeenkomst ter uitvoering van het Schengenakkoord (Schengenacquis) stimuleren bilaterale politiële samenwerking tussen lidstaten en voorzien specifieke maatregelen met betrekking tot aan elkaar grenzende landen. Diverse in de jaren negentig uitgevoerde studies hielden zich bezig met vormen van samenwerking binnen grensgebieden, die in eerste instantie informeel van aard waren, maar later steeds meer werden geformaliseerd. Momenteel bestaat er een substantiële kennislacune met betrekking tot grensoverschrijdende politiële samenwerking en politieel migratietoezicht langs binnengrenzen.
\end{abstract}

In dit proefschrift onderzoek ik het snijvlak van grensoverschrijdende politiële samenwerking (cross-border police cooperation, CBPC) en de controle over differentiële mobiliteitsrechten binnen de huidige ruimte van vrijheid, veiligheid en recht van de EU. Daarbij conceptualiseer en analyseer ik CBPC as politiële mobiliteiten binnen de grensstrook. Dit onderzoek is gebaseerd op empirisch veldwerk met politiemensen en een diepgaande beschouwing van beleid en wetgeving op verschillende schalen en gebieden en vult daarmee belangrijke, hardnekkige onderzoekslacunes op met betrekking tot een tweeledig onderzoeksonderwerp: a) politiële samenwerking op de schaal van grensgebieden, en b) politieel toezicht op mobiliteiten bij Schengenbinnengrenzen. Dit onderzoek legt specifiek de nadruk op drie CBPC-instrumenten: gezamenlijke politiecentra of PCCC's, (gezamenlijke) patrouilles in grensgebieden en bilateraal vereenvoudigde en versnelde wedertoelating. Sommige hiervan behoren tot de 'best practices' en alternatieven die de Commissie sinds 2017 heeft aanbevolen te versterken. Naast analytisch 
relevante bevindingen biedt dit onderzoek de mogelijkheid om de voorziene 'oplossingen' voor grensgebieden kritisch te beschouwen.

In DEEL I positioneer ik dit proefschrift op het snijvlak van sociale wetenschappen en recht, binnen een multidisciplinair veld van academische activiteit. Ik geef een overzicht van het theoretisch kader en de methodologische benadering van een multilokale onderzoeksopzet. In plaats van onderzoek te doen dat de nadruk legt op discours en recht óf op de gesitueerde praktijk, heb ik beide elementen bestudeerd, evenals de onderlinge afhankelijkheid van de wet als tekst en de wet in de praktijk, met als doel inzicht te verwerven in grootschalige processen die niet reduceerbaar zijn tot één empirisch gebied in het veld.

In DEEL II richt ik de aandacht op ruimtelijk-juridische regimes die CBPC reguleren en traceer ik hun opkomst als geïnstitutionaliseerde praktijkregimes. Ik betoog dat zij de grensstrook instellen als ruimtelijk-juridische voorwaarde voor de mogelijkheid om specifieke politiebevoegdheden uit te oefenen: de bevoegdheid om gegevens te verplaatsen, de mobiliteit van functionarissen die actief zijn buiten hun territoriale jurisdictie, en instrumenten voor de gedwongen verwijdering van onderdanen van derde landen. Derhalve betoog ik dat CBPC niet alleen een grensoverschrijdende interactie is, maar praktijken behelst die kunnen worden beschouwd als politiële mobiliteiten. Juridisch pluralisme wordt gehanteerd als analytisch kader om onderzoek te doen naar - en verder te kijken dan - wat in politiestudies wel het "gefragmenteerde juridische terrein" van politiesamenwerking wordt genoemd (inter alia Sheptycki 2001, p.153). Hedendaags onderzoek naar CBPC vraagt om analytische hulpmiddelen die kunnen worden afgestemd op een context waarin politiële samenwerking plaatsvindt binnen hyperjuridische en multinormatieve ruimtes. Niet alleen politiële wetgeving, maar ook rechtsordes van verschillende gebieden en schaal doorkruisen elkaar in de grensstrook, bijvoorbeeld met betrekking tot immigratie, asiel en grenscontrole in de specifieke ruimtelijk-juridische geografie van het Schengengebied van de EU. Interlegaliteit(Boaventura-de-Sousa 1987) als concept op middenniveau maakt het mogelijk om zich bezig te houden met de complexe omgang met meervoudige rechtsordes.

In DEEL III presenteer en bespreek ik empirische bevindingen en benadruk ik de analytische noodzaak en waarde van het niet extrapoleren van politieel migratietoezicht vanuit de bredere politiële (samenwerkings)praktijk in de grensstrook en de betekenissen die functionarissen aan hun werk toekennen. Zo bespreek ik bijvoorbeeld hoe de ethiek van een 'gezamenlijke taak' vorm krijgt bij gezamenlijke patrouillering en hoe functionarissen reageren op een toenemende migratisering van politiewerk, en onderzoek ik de rol van diplomatie in uniform in de grensstrook. Door scherp te kijken naar de aanhoudende herconfiguratie van de praktijk die samenhangt met 
wat tijdens de uitvoeringsperiode van Schengen het 'concept van bewegende grenzen' werd genoemd maak ik onderscheid tussen drie generaties politiële praktijk in de grensstrook. Daarnaast analyseer ik de groeiende toenadering van de controlemaatregelen in grensgebieden en de (politiek en juridisch van elkaar te onderscheiden) praktijk van grenscontrole. De analyse wordt verfijnd op basis van scalartheorie, door te vragen hoe de controle over ongeautoriseerde mobiliteiten binnen schaalpolitiek vorm krijgt. Op hun beurt vormt de interne omgang met politiële mobiliteiten, die weliswaar territoriaal verankerd zijn, de doorlopende herconfiguratie van ruimte, recht en de ordes en grenzen van Europa.

Op basis van de bevindingen van dit multilokale onderzoek kan worden geconcludeerd dat CBPC in toenemende mate relevant is geworden als schaal en beleidsveld met betrekking tot de respons op ongeautoriseerde mobiliteiten. Met gebruikmaking van Walters middenniveauconcept "viapolitiek" (2015) kan de grensstrook worden opgevat als een viapolitieke strategische zone. Uit de analyse van grensconflicten op verschillende schalen blijkt dat politiële mobiliteiten in de grensstrook in staat worden geacht om een bemiddelende oplossing te bieden voor het 'dilemma' van de handhaving van differentiële mobiliteitsrechten bij het ontbreken van grenscontroles. Maar tegelijkertijd zijn zij doordrongen van de hoop een (her)oplossing (Smith 2003) te bieden voor conflicterende krachten binnen de hervorming van asielbeleid - met name het Dublin-systeem - en zelfs de grensconflicten in het hart van de Europese orde. Zoals Andreas et al. opmerken in "Policing the European Union" (1995) maakt aandacht voor politiële samenwerking het mogelijk om te reflecteren op "vormen van politiële activiteit" binnen muterende "vormen van politiek leven". 


\section{Acknowledgments}

Firstly, I wish to express my deep gratitude to all the police officers who shared their time, their experience and their reflections with me for the purpose of this study. I thank, likewise anonymously, all the stakeholders who granted me research access. In this dissertation I have placed officers' experiences in a broader historical context, and I provided an interpretation and explanation thereof informed by analytical perspectives. This process of translation and interpretation is central to ethnographic research. I hope it will be acknowledged also by the research participants as a condition necessary for providing, through this dissertation, a reflection upon current challenges and practices from an academic perspective of an informed outsider. Therein, I hope I succeeded in conveying a recognition and better understanding of this vocational field. I owe you an immense "thank you" for entrusting me with your words, which I do not take for granted, and for guiding me in this journey along the tracks of policework in border-regions.

A PhD trajectory and the accomplishment of a dissertation are embedded within many supportive relations. I am deeply thankful for having been granted an Erasmus+ scholarship to pursue this study and Doctorate in Cultural and Global Criminology, financed by the EU's EACEA Erasmus Mundus Scheme, allocated through DG Education of the European Commission. The therein carried out research is based on my PhD-application research-proposal and the argument advanced in this thesis presents my professional opinion alone.

I express a great "thank you" to my two supervisors, Prof. Christine Hentschel (Hamburg University) and Prof. Dina Siegel (Utrecht University). When reading early parts of this thesis, Christine showed an incredible capacity to spot my main points, even when relegated to a Nebensatz. Thank you for urging me to write as clearly as possible, and therewith for prompting me to think some of these elements through more clearly. Dina and I in instances 'agreed to disagree' and even if this may sound like an odd acknowledgment, it is not. I thank you for our occasional disagreement: this has been an invaluable preparation for both refining and defending my work and my choices within the academic world. I also thank you for the opportunity to engage in seminar teaching at Utrecht University Law School. I am fortunate to have shared this experience also with stimulating colleagues, Vassilis, Lene and by now Dr. Tiwa: whilst teaching on organised crime, I learned a lot myself. I thank both supervisors for advising me to write-up this dissertation where I felt most comfortable doing so, which greatly helped to reconcile work and family life. I also wish to thank my supervisors, the DCGC-selection-board, and especially Dr. Phil Carney and Dr. Bettina Paul, for having supported the visual criminology element of my work. Finally, it was a pleasure sharing parts of this journey with my fellow DCGC cohort colleagues. I thank especially Zhania and Jordan for their support in 'initiating' me - a complete novice - to criminology and I also thank former DCGC PhDs, in particular Dennis and Vero, for their guidance. 
A mobile PhD at three universities involves a lot of bureaucracy. Some of it was taken off me by administrative and academic staff who took very good care of it: a huge "thank you" to Sarah Marsh, Dr. Perkowski, Dr. Paul and Dr. Zaitch. A big thank you to whoever came up with eduroam internet access across academic institutions: practicalities matter in the everyday of researchmobility programs.

Prior to and during this $\mathrm{PhD}$ I received stimulating and encouraging feedback, for example in the case of conferences, ranging from those of my 'home discipline' to the Common Study Session in Criminology. For encouraging me back in 2015 to pursue a PhD, I thank several professors within the Anthropology of Security and the Peace and Conflict Study network of EASA, particularly Greg Feldman, Silja Klepp, Mark Maguire and Nils Zurawski. I would also like to thank two legal scholars outside the DCGC programme who, probably without being aware of it, greatly contributed to fostering my curiosity and capacity to engage with the legal component of this study. I thank Prof. Dermot Walsh (University of Kent), who in 2016 straightaway handed me over a pile of his books on police cooperation and EU law - "the basics you need to know". I am likewise thankful to Prof. Bengt Beutler (University of Hamburg) for welcoming me in a post-grad seminar in EU law on the role of the CJEU. Learning 'legal language' was an almost ethnographic enterprise and while possible errors (and appropriations) in translation are not excluded, this dissertation owes a debt to the generous initial guidance of both.

In addition, I am grateful for the possibility of having been able to carry out an internship at CEPOL, the EU Agency for Law Enforcement Training, during this DCGC-consortium study programme. I thank the CEPOL director and ELTE university who supported my initiative. Personal thanks go my team-colleagues in the Training and Research Unit and especially to Stefano Failla for supervising my internship and for engaging at times in chiacchiere filosofiche - "philosophical chats" - with me. The internship activities - not part of this study - allowed me to gain a better comprehension of the EU security architecture and of the interactions through which EU policy is translated into programmes, and how new policy develops. Having been able to support several Training Needs Analysis for law enforcement across the vast 'EU security' field, it certainly fostered my knowledge and understanding of the field beyond the topic of this dissertation.

I also would like to express my deep gratitude to family-friend Andrew Graydon, who graciously offered to English proof-read this dissertation. I thank Andrew immensely. If now there are more dots between sentences and the reading flows, this is thanks to Andrew. Any still-too-long sentence (suffering from a German-syntax), or a part that is not as easy to read, is purely my own, as is the content of this thesis. 
Finally, I wish to thank my family: to my parents, who were supportive of my decision to return to university to pursue a PhD after several years of employment close to home, and to my partner Daniel and to by-now 10-year-old Thomas. Building up the base of a solid relationship and some sort of family-routine during a mobile $\mathrm{PhD}$ and research, is not something either of us take for granted. I am deeply happy that we have not lost each other on the way and that indeed we grew stronger. I am thankful for all the small and big things we did together: yes, they were distractive, but they also kept me going ;-) Thank you, Dani, we have so much to look forward to.

Thouk you, all!

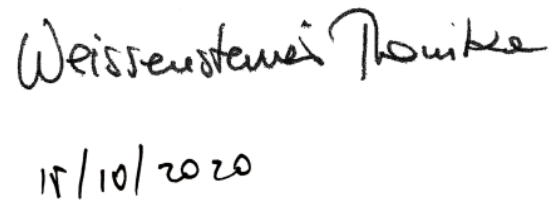


Abbreviations

AFSJ - Area of Freedom, Security and Justice

CEAS - Common European Asylum System

CFSP - Common Foreign and Security Policy

CDSP - Common Security and Defense Policy

CISA - Convention implementing the Schengen Agreement

CJEU - Court of Justice of the European Union

COREPER - Committee of the Permanent Representatives of the Governments of the Member

States to the European Union

DCAF - Geneva Centre for the Democratic Control of Armed Forces

EBCGA - European Border and Coast Guard Agency (Frontex)

ECHR - European Court of Human Rights

ECtHR - European Court of Human Rights

EIXM - European Information Exchange Model

EMPACT - European multidisciplinary platform against criminal threats

EMN - European Migration Network

EUCFR - Charter of Fundamental Rights of the European Union

EURODAC - abbreviation for 'European Dactyloscopy' database

EU - European Union

FII - Facilitation of Illegal Immigration

IBM - Integrated Border Management

IR - International Relations

ICMPD - International Centre for Migration Policy Development

IISG - [Western Balkan] Integrative Internal Security Governance

JHA - Justice and Home Affairs

Mol - Ministry of Interior

LEWP - Law Enforcement Working Party

LO - Liaison Officer

PCCC - Police and Custom Cooperation Centre

SEM - Schengen Evaluation and Monitoring Mechanism

SBC - Schengen Borders Code

SEA - Single European Act

SFD - Swedish Framework Decision

SIENA - Secure Information Exchange Network Application

SIS - Schengen Information System

SLTD - Stolen and Lost Travel Document database

SOCTA - The European Union's serious and organised crime threat assessment

SPOC - Single Point of Contact

TEU - Treaty of the European Union

TFEU - Treaty on the Functioning of the European Union

VIS - Visa Information System

WBBSI - Western Balkan Border Security initiative

\section{Non-official abbreviations adopted in the thesis}

CBPC - cross-border police cooperation

$\mathrm{BAC}$ - border-area control

$\mathrm{BC}$ - border control 


\section{Country abbreviations}

\begin{tabular}{|l|l|}
\hline Albania & $(\mathrm{AL})$ \\
\hline Austria & $(\mathrm{AT})$ \\
\hline Belgium & $(\mathrm{BE})$ \\
\hline Bulgaria & $(\mathrm{BG})$ \\
\hline Bosnia and Herzegovina & $(\mathrm{BA})$ \\
\hline Cyprus & $(\mathrm{CY})$ \\
\hline Czechia & $(\mathrm{CZ})$ \\
\hline Croatia & $(\mathrm{HR})$ \\
\hline Denmark & $(\mathrm{DK})$ \\
\hline Finland & $(\mathrm{FI})$ \\
\hline France & $(\mathrm{FR})$ \\
\hline Germany & $(\mathrm{DE})$ \\
\hline Greece & $(\mathrm{EL})$ \\
\hline Estonia & $(\mathrm{EE})$ \\
\hline Luxembourg & $(\mathrm{LU})$ \\
\hline Hungary & $(\mathrm{HU})$ \\
\hline Iceland & $(\mathrm{IS})$ \\
\hline Ireland & $(\mathrm{IE})$ \\
\hline Italy & $(\mathrm{IT})$ \\
\hline Latvia & $(\mathrm{LV})$ \\
\hline Kosovo & $(\mathrm{XK})$ \\
\hline Liechtenstein & $(\mathrm{LI})$ \\
\hline Lithuania & $(\mathrm{LT})$ \\
\hline Malta & $(\mathrm{MT})$ \\
\hline Montenegro & $(\mathrm{ME})$ \\
\hline Netherlands & $(\mathrm{NL})$ \\
\hline Norway & $(\mathrm{NO})$ \\
\hline North Macedonia & $(\mathrm{MK})$ \\
\hline Poland & $(\mathrm{PL})$ \\
\hline Portugal & $(\mathrm{PT})$ \\
\hline Romania & $(\mathrm{RO})$ \\
\hline Serbia & $(\mathrm{RS})$ \\
\hline Slovakia & $(\mathrm{SK})$ \\
\hline Slovenia & $(\mathrm{SI})$ \\
\hline Spain & $(\mathrm{ES})$ \\
\hline Sweden & $(\mathrm{SE})$ \\
\hline Switzerland & $(\mathrm{CH})$ \\
\hline & \\
\hline
\end{tabular}

https://ec.europa.eu/eurostat/statistics-explained/index.php/Glossary:Country codes. For matters of overview, all country codes of usage have been listed in alphabetical order irrespective of the (member state) status of the country and if reference to a country is made in this thesis or not. 
PART I

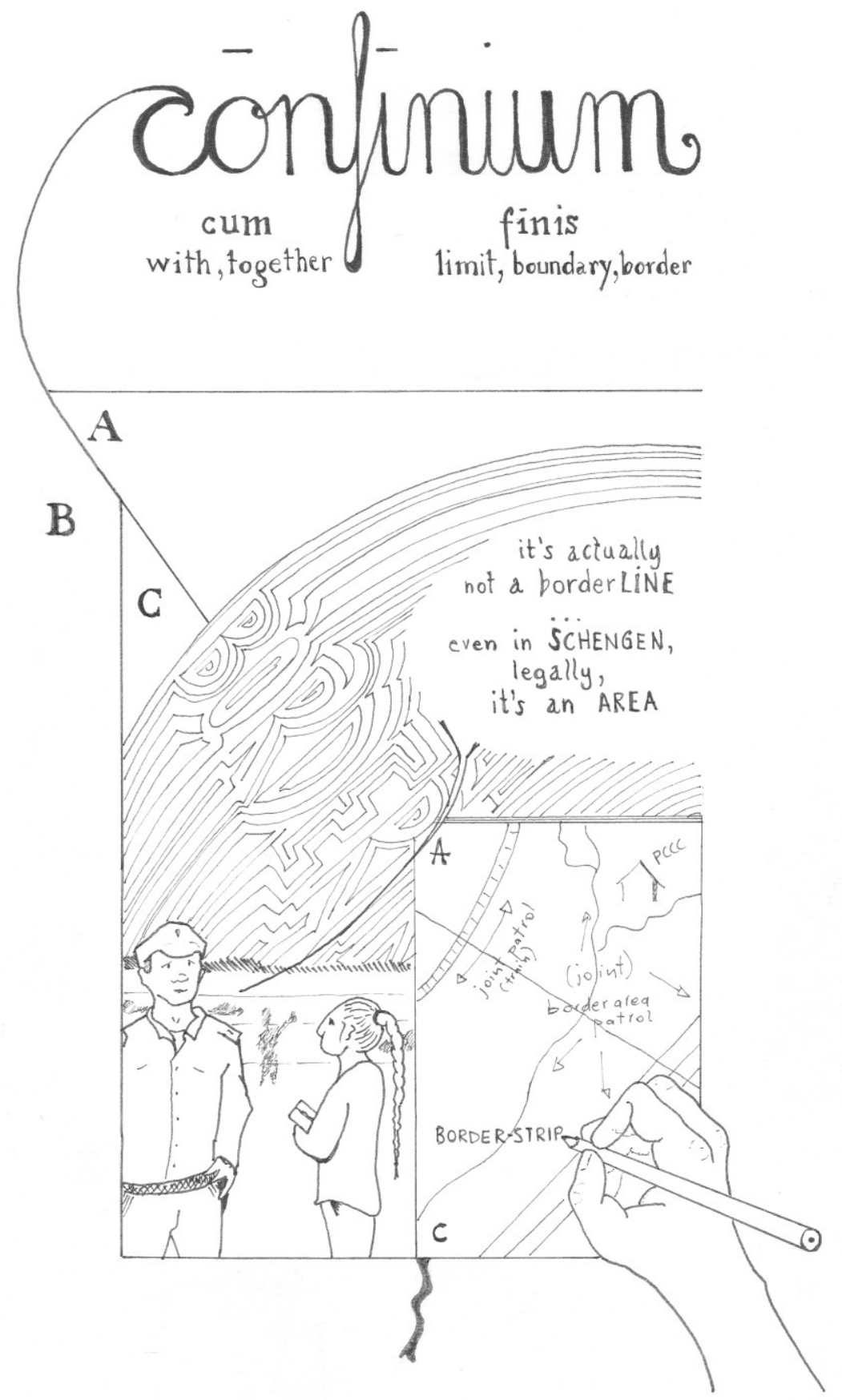




\section{CHAPTER 1 \\ INTRODUCTION}

\subsection{POLICING-MOBILITIES IN THE BORDER-STRIP}

The area of so-called alien-policing, albeit the most important branch of the police, is rather disreputable. Not only does it give a hard time to the theorist due to its unclear limits, but it is undesirable to most of the local officers working in this area, and no less to the public. $\left[{ }^{*}\right]^{1}$

Carl August Ackermann, 1856

The "disreputable" area of "alien-policing" - with this expression Ackermann (1856) opened the foreword of his 500-page compendium of legal and administrative regulations shaping the field of "alien-policing" in the jurisdiction of the Grand Duchy of Mecklenburg-Schwerin. It was the year 1856. Pass-regulations, state-belongingness, emigration, expulsion- and readmissionprocedures of foreign "vagabonds" and "mendicants", the extradition of criminals and more: with this handbook, organised in alphabetical order, the legal scholar aimed to support authorities and police officers to navigate through what was considered a "disreputable" area of policing. The Grand Duchy was a sovereign member state of the German Confederation and, after 1871, a federated state of the German Empire. It was around that time that bilateral agreements on readmission started to emerge as part of a new body of international law, or indeed as a constitutive element of the emerging state-system in Europe. Their 'legal great-grand-children' still regulate so-called "form-less" administrative procedures enabling "simplified" fast-track readmissions of third-country nationals across internal EU-Schengen borders today. These practices fall under the jurisdiction of border-area police departments. A $21^{\text {st }}$ century compendium would certainly be of significant complexity. The aim of this study, however, is of a different sort. In this thesis I inquire how police officers navigate their path through a terrain signed by multiple (legal) orders and how cross-border police cooperation instruments at internal Schengen borders interact with the "disreputable area" of policing differential mobility rights within today's EU Area of Freedom, Security and Justice. This thesis is based on a multi-sited qualitative study carried out between 2017 and 2019 as part of a PhD in Cultural and Global Criminology. I focus on developments of policing practices and of cross-border police cooperation in and across the adjacent areas of the borders between EU Schengen members.

An officer directing a border-region police department in Germany explained to me during an interview: "Schengen, Dublin II, immigration..., it all gets very complicated" (IV_RL-HLO). He was 
reflecting upon the duties and limits of police work in the border-region, pointing out complicated intersections of legal frameworks. Asked about noteworthy developments, he expressed the opinion that matters related to refugees and asylum seekers are "not a genuine police issue" he considered the latter not to be a genuine target-population for the police. It is not surprising, therefore, that the officer referred to "Dublin II" while, at the time, Dublin III was in force and the Dublin IV recast proposal was being discussed. The Dublin Regulation (Reg. (EU) No 604/2013)2 is part of the Common European Asylum System (CEAS): it establishes the criteria for determining the EU member state responsible for processing an asylum application. Nevertheless, the police director had spent long working-days, week after week, in deploying all available resources to deal with what had become "police property" (Lee 1981, in Reiner 2010, p.123): persons seeking international protection in the EU. According to Lee "a category becomes police property, when the dominant powers of society (...) leave the problems of social control of that category to the police" (ibidem). In this specific case, the officer spoke of "refugees", while in other cases the targets of policing measures were identified in "irregular" or "illegal" migrants. At that time 2015 - cross-border refugee movements were, for a short time, officially facilitated by governments. Otherwise such inner-European movements are frequently problematised as unauthorised so-called "secondary movements", since the first country of entry into the Schengen territory is - albeit not the first criterion of the hierarchy established in the Dublin Regulation - the most invoked for establishing responsibility. Frequent cross-border police contacts were also part of the job of this officer: this "everyday police cooperation" (Aden 2001, p.103) is at the centre of this study.

The Schengen Agreement (1985) and the Convention Implementing the Schengen Agreement (1990, hereinafter CISA) ${ }^{3}$ signpost major moments inside the narrative of police cooperation in Europe. The abolition of border control between Schengen members is deemed a milestone and major achievement in the EU integration process. The Schengen-area - with "freedom of movement" as core symbol - started as an intergovernmental agreement between five countries in 1985 and the Schengen acquis was incorporated into the EU legal framework through the Treaty of Amsterdam (1997). ${ }^{4}$ Today it is part of the Area of Freedom, Security and Justice (AFSJ), regulated since the Lisbon Treaty (2009) by Title $V$ of the Treaty on the Functioning of the European Union (hereinafter TFEU). ${ }^{5}$ Title $V$ covers policy areas that range from border management, judicial cooperation in civil and criminal matters to police cooperation, from asylum and immigration policies to the fight against crime. The AFSJ is not represented as a 'territorial' polity, but as an 'area': an area, in which the internal border in absentia (as a line) has become a core symbol. In contrast to what a 'border-free' image of the Schengen-zone might suggest, with the abolition of controls on the border-lines, so-called "compensatory measures" in border-areas 
were institutionalised and cross-border police cooperation (hereinafter $\mathrm{CBPC}$ ) was enhanced on various scales. This is also "Schengen": here situate the bi- and multi-lateral cooperation practices taking place in border-regions, which are the practices the present study investigates. An officer interviewed in Austria described CBPC the following way:

"Cooperation in the border-region... that is joint patrols, that is when the officers know each other, the colleagues along the border; when the neighbouring [police]stations track certain phenomena together; the work provided by the joint centre if an intermediary is needed... and so forth. [A colleague once said, that] when the border-regions work well and strongly together, then this is an important factor for the security of Europe. And I realised that this is really the case. (...) When regional and local cooperation functions well, then Europe functions well, and it increases the feeling of security in Europe as a whole. (...) And that is why I think it is intensified in all member states. It also costs, this cross-border cooperation. So today we are miles away from saying we are not interested in what goes on across the border." (IV_RL-HLO)

As emerges from the quote, police cooperation in border-regions comprises a range of (in)formal practices and interactions. Border-regions are identified by this officer as strategic locations not only with regards to a "shared geo-criminological space" (Nogala 2001, p.139) or a "crimestrategic" space for control and cooperation (Pudlat 2013, p.58 ff), but for public securityperception and as strategic locations for the very functioning of Europe.

Policing scholars have pointed out how, particularly in border-regions, (informal) CBPC has been the rule rather than the exception. In some regions, cooperation was formalised through agreements and structures even before Schengen (Sheptycki 1998a; Gallagher 2002; Fijnaut and Spapens 2010; Kleiven 2012; Hufnagel, Harfield and Bronitt 2012; Hufnagel 2016). Through the EU integration process, collaborative initiatives were further formalised and institutionalised. While initially there was a void of legal frameworks, it is productive to ask what role border-region practices play indeed today, in a context signed by hyper-normative spaces and increased juridification through further legislation or case law.

Inner-European borders have mostly attracted (scholarly and public) attention only in conflicting moments, such as the dispute between Italy and France in 2011, and since 2015 following the reintroduction of border control by several member states. The normative basis for regulating measures at internal (and external) borders is the so-called Schengen Borders Code (Reg. (EU) 2016/399, hereinafter SBC). ${ }^{6}$ It establishes that "internal borders may be crossed at any point without a border check on persons, irrespective of their nationality, being carried out" (Title III, Chapter I, art. 22). But the SBC also specifies that: (1) member states can temporarily introduce systematic border control as last resort in exceptional circumstances; (2) the absence of border control does not affect member states' exercise of police powers to conduct spot-checks and 
identity-controls in border-areas (regulated by art. 23 of the SBC). Per legal definition, spot-checks in border-areas cannot have "border control as objective" and are to be executed in a "manner clearly distinct from systematic checks" (ibidem). This is also part of the "Schengen" mentioned by the quoted officer outlining complicated intersections of legal frameworks in the border-area. Internal border-regions have aquired increased importance not only for member states with internal borders. Also for example officers in Italy highlighted a renewed salience thereof since 2015:

"... not only have the regional border-police post not been closed, but they acquired a strategic importance. Not only in the field of terrorism, but against clandestine migration, against cross-border crimes, such as drugs smuggling or arms smuggling (...), and against so-called 'minor crimes' (...), although personally I don't see them as less important." (IV_RL-HLO)

CBPC instruments, such as joint police checks in border-areas, have increasingly been deployed to contrast so-called unauthorised "secondary movements". The first time I witnessed such a joint police patrol was 2014 in northern Italy. ${ }^{7}$ The patrol comprised officers from Italy, Austria, and Germany. I was intrigued and puzzled, and it made me aware of my ignorance of what is 'possible' in the field of police cooperation. Although joint patrolling between these three forces was set up around the year 2000, I had never seen police officers travelling jointly the tracks through my native region. In late 2014 such trainline-patrolling became daily practice, set up for the purpose of containing "the impact of inner-European migration-pressure" and to "combat international smuggling organisations" (Deutscher Bundestag 2014, p.2). As I kept an eye on developments in this border-region, my searches for any (scholarly) insights made me realise that this knowledge gap was not only mine: there was - and still is - a void in scholarship. Within what is 'possible' in the field of police cooperation, these practices across internal Schengen borders hold a peripheral place, just like the border-regions themselves. These concomitant factors, coupled with prior empirical research experiences in distinct but still related fields ${ }^{8}$, intrigued me to investigate 'police cooperation' at this scale. In my research proposal (Weissensteiner 2016) I set out to explore how "practices at inner-European borders, intertwined with programs aimed at managing (unauthorised) mobilities and at contrasting cross-border crime, unfold through public security actors' experiences of everyday practices and through interactions of different scales, actors and fields of knowledge".

I can confirm Ackermann's statement that, as a theorist, I had a hard time limiting the scope and determining the borders of this study. Grounded in empirical fieldwork, my analytical attention has come to focus on what I conceptualise and analyse in this study as policing-mobilities: the instruments and practices of what is defined in policy and in scholarly literature as "cross-border police cooperation" (CBPC). By concentrating on policing in and across border-areas (the 
territories adjacent to internal Schengen borders), this thesis focuses on the one hand, on the policing-mobility regimes that create the conditions of possibility for the (legal) exercise of specific policing powers in border-areas. I capture the latter's spatial-legal configuration through the emic notion of the border-strip. On the other hand, this study concentrates on practices and negotiations within a landscape that is signed not only by interactions between police officers from different countries ("cooperation"), but also by interlegality (Boaventura-de-Sousa 1987): the complex interaction and co-presence of plural legal orders, pointed out by the officer quoted in the beginning. Legal pluralism provides an important analytical framework to engage with what, in policing scholarship, is referred to as the "patchwork quilt" and the "fragmented legal terrain" of police cooperation (Sheptycki 2001, p.153; see also Benyon et al. 1993; Hebenton and Thomas 1995; Sheptycki 1995; Hufnagel 2012a, Bowling and Kopf 2017). In addition, multi-scalar legal orders of CBPC interact with other legal orders: within the area of migration-policing, in particular those regulating immigration, asylum, and border control in the specific spatial-legal geography of the Schengen space.

This study addresses the ways in which internal borders and policing practices matter in the control of differential mobility rights within the EU Schengen space. Nevertheless, I do not extrapolate the policing of mobilities - sometimes referred by scholars as "le police de migrants" (Barnier et al. 2019) or 'crimmigration' policing (Stumpf 2006; Van der Woude and Van Berlo 2015) - from the wider range and meanings of police activities and of policing-mobilities taking place in border-areas. I rather analyse the former within an understanding of the latter. Scholars have pointed out how the Schengen area's rationality of "freedom of movement" has seemingly shifted territorial-judicial methods of control, associated with sovereignty and the geo-political border, to a biopolitical border(ing) that targets population and filters mobilities (Walters 2002; Huysmans 2006; Bigo 2006; Campesi 2015). As Crowley (2001, p.16) aptly remarked, "differential free movement, cannot, as it claims, be devoid of internal borders". In addition, policing practices have themselves acquired cross-border mobility and have their mobilities regulated. Therewith questions emerge as to the circulation of members of a vocational group considered to be the "specialist repositories for the state's symbolic monopolization of legitimate force in its territory" (Reiner 2010, p.17)

In this thesis I argue that the EU Schengen area and today's Area of Freedom, Security and Justice is a space signed by plural legal orders of varying scales and policy fields, within which policing practices negotiate (legal) orders on a daily basis through practice and (inter)actions. The peripheral sites of inner-European border-regions - not dissimilar to the peripheries along the Mediterranean border (Klepp 2011) - have come to play an increasing role in shaping what succeeds the "basic jurisdictional question" of who governs where: namely how something is 
governed (Valverde 2014, p.382). Governing through migration control (Bosworth and Guild 2008) via security and police cooperation requires and also allows a revisiting of the "basic" jurisdictional question and of power dynamics within the European space. This allows engaging anew with what has been addressed as "tactical" and "functional" definitions of the police (Reiner 2010). In addition, as I will elaborate, the border-strip is invested with the expectation to provide a mediating and spatial (re)solution in border-struggles related to the Dublin and Schengen order, at the heart of the EU order. Policing-mobilities in the border-strip looks at peripheries that hold centre-stage in ongoing reconfigurations of Europe and its (b)order(s).

\subsection{THE STUDY}

My empirical study adopts an epistemological and methodological perspective that a 'small place' like a border-region, and policing practices taking place therein, provide a privileged lens to engage in larger issues at stake, to paraphrase Hylland Eriksen's Small Places, Large Issues (1995). For the moment I use 'border-region' or 'border-area' to refer to the territories on both sides of a state border - the so-called "frontier zone" in anthropological writing (Wilson and Donnan 2012; 1999). In my study I address the following inquiry:

What role does cross-border police cooperation at the scale of innerEuropean border-areas (at the so-called "internal Schengen borders") play in the control of differential mobility rights within the EU Schengen space? What can we learn about the intertwining of security and migration found on a policy level by focusing on everyday policing practices taking place at this scale?

Rather than studying the phenomenon in one 'small place', this thesis is based on a multi-sited research (Marcus 1995; Hannerz 2003; Feldman 2011). I carried out an extensive desk-research and empirical research through interviews and observation in five EU member states with officers belong to these and additional jurisdictions. My aim has not been to systematically compare the different sites, as comparative policing studies or comparative criminology might aim for, but to "study through sites to grasp large-scale processes" (Wright 2011, p.27). I address questions tackled by an anthropologically informed global criminology. The larger question concerns a configuration in which, on the one hand, police cooperation across Europe has been institutionalised and enhanced through specific regimes of policing-mobilities and, on the other hand, in which security and migration have become increasingly entangled and "secondary movements" framed as a risk to security. The expression "secondary movements" made its way into EU policy jargon in 2007/2008 to substitute the earlier (and persisting) notions of "asylum shopping" and "abuse of the asylum system" (Wagner, Perumadan and Baumgartner 2019). Security is neither a fixed concept nor a 'natural' response, but to be understood as "always 
emergent within specific material, historical and socio-economic conditions" (Maguire, Frois and Zurawski 2014a, p.1). I thus paid attention to the discourses and practices through which phenomena problematised in historically contingent ways are constructed and responded to as a matter of security. How do CBPC practices in the border-strip interact with the field of migration control and with what effects, negotiations, dilemmas, border-struggles? My study is composed of two intersecting fields of inquiry:

Firstly, I have inquired in what ways Schengen has enhanced policing-mobilities across national borders and I investigated CBPC developments and experiences. What police (cooperation) practices have developed in Schengen border-regions? How do police officers experience and perceive their work-tasks? I have aimed to inquire what officers identify as the main challenges, what matters to them, what works and what does not, why and how. I situate measures regarding the policing of mobilities within a wider spectrum of border-area policing. The empirical study focuses on contemporary practices but also retrospectively addresses past developments. It is combined with a genealogical approach tracing the emergence of a particular regime of institutionalised practices (Dean 2010, p.31), namely of policing-mobilities in the border-strip. Answering these questions enables one to trace developments in CBPC and of socalled "compensatory measures". It also requires scrutiny of primary sources such as (historical and present) legislation, policy, case law and reports.

Specifically, this study concentrates on three CBPC instruments and practices, of which only the latter concerns per definitionem the policing of migration:

- joint centres / Police and Custom Cooperation Centres;

- mobile patrols, as well as joint mobile patrols, in border-areas;

- "fast track" readmissions procedures of third-country nationals across internal borders.

Secondly, I asked what role the peripheries of internal border-regions, and CBPC instruments situated therein, play in the control of differential mobility rights - as set out, inter alia, through the Dublin Regulation. I have analysed multi-scalar problematisations and solutions for the ways in which security, crime- and migration-control have become intertwined in ways that matter at the scale of CBPC at internal Schengen borders. By connecting policy problematisations and practices, the question emerged: what can we learn about the "difficult balancing act" pointed out in the European Agenda on Migration $(\mathrm{EAM})^{9}$, when investigated through police (cooperation) practices taking place in the border-strip? According to the EAM:

Upholding our international commitments and values while securing our borders and at the same time creating the right conditions for Europe's economic prosperity and societal cohesion is a difficult balancing act that requires coordinated action at the European level. (COM(2015) 240 final, p.2) 
Rather than focusing either on discourses and laws or on situated practices, this research studies both elements and their interdependence. It enables an ethnographic study of the dynamic between law-as-text and law-as-practice. In so doing, this research embraces the necessary complexity for understanding elements of police cooperation in Europe, as well as of security practices and border policing (see also Cote-Boucher, Infantino and Salter 2014). An empirical study of policing-mobilities and the policing of mobilities within Europe allows inquiry into (as it were) the "balancing act" described in the EAM within the historical conditions of possibilities of contemporary bordering practices in Europe.

\subsection{CONTEXT MATTERS}

In the course of late 2015 to early 2016, several member states re-introduced so-called "temporary border control" at certain internal Schengen borders, which was subsequently prolonged. These measures were deemed to be "proportionate" and "necessary" by the European Commission and the Council of the European Union and thus to be compliant with the Schengen Borders Code (SBC), due to so-called "serious deficiencies of external border control", "wave through approaches" by member states and "irregular secondary movements" (see also Guild et al. 2016; Carrera et al. 2018). These were deemed situations in contrast with the SBC rules regarding external borders, as well as with obligations contained in the Eurodac Regulation and the Dublin Regulation. Worried that systematic controls would put 'Schengen at risk', in March 2016 the European Commission published Back to Schengen - A Roadmap (COM(2016) 120 final). ${ }^{10}$ It indicated the wish to return to an implied 'normality' - meaning the absence of border controls within the Schengen area -, supposedly by end of 2016. In May 2017 it set out a recommendation, implemented by the Council, allowing five Member States - Germany, Austria, Denmark, Sweden, and Norway - to prolong for a third time their temporary border control on inner-European Schengen-borders for another six months, regulated by art. 29 of the SBC (according to which systematic border controls can be introduced as last resort in exceptional circumstances, that are deemed to put the overall functioning of the Schengen area at risk). Following up on that, on May $12^{\text {th }}$ the Commission issued a Recommendation on proportionate police checks and police cooperation in the Schengen area $\left(C(2017) 3349\right.$ final). ${ }^{11}$ This document is significant and draws out an explicit recommendation, in minor form contained already in earlier documents of the Commission as well as in Council implementing Decisions, that called for "alternative measures" to border control, i.e. police checks. It recommended, inter alia, that member states enhance and shift towards proportionate police checks in border-areas (regulated by art. 23 of the SBC) instead of border control. Intensified policing of border-areas was considered a necessary and justified measure to counter what has been named together as three 
threats to "public policy or internal security": 1) terrorism, 2) serious cross-border crime, 3) and, literally, "risks of secondary movements of persons who have irregularly crossed the external borders" (point 6). "Secondary movements", and even the mere risk thereof, were problematised as security threat. Remarkably, it is the very European Commission advising member states to make (intensified) use of their policing powers in border-areas for the explicit goal of countering inter alia unauthorised "secondary movements". The Commission is also a key actor in the Schengen Evaluation and Monitoring Mechanism (SEM), responsible in monitoring "both the efficiency of border controls at external borders and the absence of border controls at internal borders (Reg. 1053/2013, para. 13; responsibilities of member states and Commission, art. 3).

Several years after I began my PhD in late 2016, and prior to stated COVID-19 justifications for border control, as of March 2020 Austria, Germany, Denmark, Sweden, and Norway still had "temporary border control" at some of their inter-state borders in place, some intertwining in their justifications "secondary movements" and "terrorism threat". France justified its systematic controls on ground of the latter, at times entangled with the former.

\section{Research implications}

This is a snapshot of some developments on a macro- and meso-level that have shaped the research context at Europe's internal Schengen borders. Initially I was not particularly interested in the mediatised and politicised practices of presumingly "temporary" border control. I aimed to study ordinary micro-level routines and everyday practices, less visible than what can be called a "border-spectacle" (de Genova). Unforeseen at the time, some member states maintained border control and internal borders continued to receive mediatic and political attention, despite a sharp decrease in (the possibility of) arrivals of persons seeking international protection in the EU, e.g. through several measures adopted at the external(ised) EU borders. The ongoing developments enabled and also required the study of "temporary" (but persistent) border control practices: indeed, temporary border control has become daily routine at certain inter-state Schengen borders. This enabled investigation of the (extra)ordinariness of specific practices. I will reflect upon the ways that police officers described both the ease, but also the fuzziness, of delineating in practice a clear border-line between these the two legal regimes and orders: border control and border-area control. The snapshot also indicates that internal borders and CBPC across them are to be analysed within multiscalar border-struggles at the core of the EU order. While the Lisbon Treaty has increased the role the Commission and of the Court of Justice of the European Union (CJEU) in former 3rd pillar Justice and Home Affairs (JHA), member states do hold the primary competency over national security measures.

Over the pages of this thesis, I critically engage with current problematisations and responses, as well as with the complexities of scales and fields in which 'solutions' are sought. While it is likely 
that the politicised climate eventually has impacted on the quantity of research permission granted by authorities, my empirical fieldwork provided a pivotal ground for reflecting with officers responsible for carrying out border (area) measures upon various policing instruments and developments. Their experiences and representations have critically informed my analysis, whereby the arguments developed in this thesis constitute my interpretation and analysis thereof. Committed to an epistemological approach of ethnography and grounded theory, several theoretical and conceptually informed research questions, advanced in chapter 3 , emerged through the research process.

\subsection{RESEARCH OBJECTIVES}

Inner-European (Schengen) border-areas and police (co-)-operation taking place at this scale provide a crucial site for investigation and an analytical entry point to advance both theoretical as well as empirical considerations on pressing issues of our times. This study situates within broader developments in police cooperation and in the transnational governing of mobilities, but also within what de Genova (2017) called the "question of Europe". This thesis has the objective of filling important gaps both of academic as well as public relevance.

Firstly, practices of policing at internal Schengen borders, as well as CBPC across, constitute a substantial knowledge gap, identified as such also in recent scholarship (Fijnaut 2017; Van der Woude and Van Berlo 2015; Van der Woude 2020). Despite increased scholarly work reproblematising a so-called "migration crisis", "refugee crisis" or "Schengen crisis" in Europe, internal Schengen borders and in particular CBPC, as well as empirical (policing) studies thereof have remained rather peripheral to central concerns and important arguments raised in critical scholarship. Notably, on a supranational level, these practices have also been turned into an epistemological object, to enhance what is known on EU level about bilateral cooperation and border-area measures put in place by member states. This development in the first place is worthy of analysis, rather than merely constituting an opportunity to market this thesis for its policy-relevance.

There is still an ongoing (political and scholarly) debate over the question of Schengen - and of Europe - played out at internal borders. Legal and policy scholars pointed out the need for a clearer distinction between border control and border-area control (Brouwer et al. 2015; Guild et al. 2016; Carrera et al. 2018) or called for renewed reflections on the relationship between them (de Somer 2019a, p.125). Such considerations necessarily need to start from empirical insights of how things work and be able to bridge EU policy, migration studies and policing research - social science and law. The empirical study becomes even more salient, as reinforced 
measures in border-areas and CBPC have been recommended to be further enhanced and intensified. Findings must be placed critically into the broader political and policy context, as well as beyond the ongoing normative debate of the interface between border control and borderarea control. Importantly, following the Commission's recommendation to intensify border-area police checks and enhance police cooperation (C(2017) 3349 final), scholars have interrogated the normative implications thereof: no attention has been given yet to what it means and implies when the likewise recommended police cooperation instruments (such as joint patrols) and bilateral readmission-regimes are both enhanced and implemented for the scope of mobility control. Contrary to what scholars suggested (inter alia Bouteillet-Paquet 2003), such bilateral readmission practices have not been substituted by the Dublin Regulation as inner-European multi-lateral readmission agreement, and they have not become obsolete with the establishment of the internal market. In addition, the evident impasse to find an agreement on the Dublin IV recast proposal under co-legislative procedure, will keep this a topic alive in the near future at least. I will argue in this thesis, that this has not only become a high-level diplomacy issue between governments, but also an (every-day) policing issue. As one of my police informants put it: policing at inner-European borders is "low-level diplomacy" work.

Notably, the "New Pact on Migration and Asylum" by the European Commission (released shortly before submission of this dissertation) reiterated that alternatives to internal border controls are to be found in police checks and it was argued that bilateral readmission agreements between member states could be more effectively implemented (COM(2020) 609 final). ${ }^{12}$

Secondly, this theme constitutes an interdisciplinary field of study. The topic is very narrow with regards to legal and praxeological specificity, and broad as to the possible lines of inquiry. Whilst some scholarship shares common epistemic ground - approaches within global and cultural criminology, anthropology, critical security studies and critical migration and border studies (e.g. Mutsaers 2014; Bigo 2016a; Bigo 2014a) - there are also notable gaps or conflicting approaches. In the spirit of an interdisciplinary PhD programme in criminology at the crossroad of social science and law, this study brings together and further develops insights from criminology, police research and social anthropology in dialog with those advanced in legal geography, legal scholarship and critical border and mobility studies.

Who governs where, how and with what effect, according to Valverde (2014, p.382), are important questions for criminology. What is the identified field, scale and jurisdiction to respond to a phenomenon problematised in historically specific and contingent ways - in Ackermann's times the "vagabonds", "foreign mendicants and likewise undesirable persons" (Münsterberg 1887), or today's "unauthorised 'secondary movements'"? These are salient questions of public relevance to be critically answered through empirically based academic scholarship. 


\subsection{THESIS OUTLINE}

This dissertation is structured in three parts. Chapters 2 to 4 sketch the borders of this thesis and set the theoretical and methodological frame for the two main parts. The corpus of the research findings is presented in PART II and PART III.

In chapter 2 I clarify the terminology used, before reviewing empirical research and literature of relevance regarding firstly CBPC and secondly policing (of mobilities) at internal Schengen borders. Subsequently I discuss contributions on Schengen and the AFSJ, specifically focusing on how the 'internal border' matters therein. Policy-documents will not be reviewed in this section, as they are part of the analytical chapters. I conclude by outlining main gaps in knowledge production in this field, and the contribution this study makes.

In chapter 3 I draw out the theoretical approach adopted in this thesis by knotting together conceptual threads at the epistemic crossroad of social science and law. I detail my analytical reconceptualisation of CBPC as policing-mobilities and that of the border-strip as spatial-legal configuration within plural legal orders. In this chapter I also revisit theoretical debates on the relation between policing and the State, on borders, as well as analytical approaches to crimesecurity-migration-nexi. Additional midlevel concepts used to analyse the policing of mobilities, such as viapolitics (Walters 2015a), will be explicated.

In chapter 4 I provide epistemological and methodological considerations that underpin this research. A study of policing-mobilities requires methodological considerations that are twofold: studying mobilities and studying practices of the vocational category of police. Subsequently I outline issues of access, sample, ethics and decisions that informed the empirical study: by placing this 'information' into a reflexive discussion, this provides also a thematic entry into my field, bridging into PART II. I describe the different methods which I integrated into an ethnographic methodology and explicate the underlying line of thought traced through the visual parts of this thesis: the BORDER-STRIP. I conclude by drawing the borders - what is included and excluded into this thesis.

PART II is composed of chapter 5 and 6 . It examines the legal configuration of space from the Area of Freedom, Security and Justice to inner-European border-areas. Here I respond to my first research sub-question and focus primarily on three policing instruments.

Chapter 5 addresses firstly the power to move data across borders: PCCCs are important agents within the legal geography of data mobility for the purpose of police information exchange. Secondly, connected to the so-called emic "concept of the mobile frontier", I focus on the mobility of officers (and of borders) and analyse how (joint) mobile border-area controls emerged as institutionalised practices in the Schengen area, moving from an initial legal void into today's 
hyper-legalised space in a multi-scalar constellation. Whilst joint patrolling falls under a so-called "horizontal" cooperation, the (auxiliary or executive) powers attributed to officers operating outside their jurisdiction, allows to address questions at the heart of the political order.

In chapter 6 I engage with two practices that explicitly concern the policing of migration and imply a forced mobility, i.e. removal, across internal borders: a) (fast-track) bilateral readmissions under conditions of absent border-line-control, b) denial of entry under circumstances of reintroduced border control. Firstly, I engage in a long-term tracing of readmission agreements between today's member states, a line of inquiry that led me to Ackerman's (1856) publication in the first place. $5 r$ Secondly, by engaging with law-as-text I take into consideration contemporary border control in Austria and Germany by looking into the spatial-legal configuration of the border-line and by engaging with another old concept and practice: the "fiction of non-entry". Thirdly, I propose to analytically differentiate between three generations of "compensatory measures" and respective migration control logics by adopting viapolitics as midlevel concept.

PART II engages mainly with law-as-text and process, for which an engagement with "technicalities" (Riles 2005; Valverde 2009) is paramount. By scrutinising the spatial-legal dimension and the legal regimes that enable (and constrain) these practices, I argue that they construct border-areas as a spatial-legal border-strip, which provides the condition for the exercise of specific policing powers and of policing-mobilities: the cross-border mobility of data, the mobility of officers and of borders, and the forced mobility of third-country nationals. What has been described as a "fragmented legal terrain" of police cooperation, will be conceptualised as a landscape signed by a plurality of legal frameworks for police cooperation, which also interact with other legal orders. This allows me to detail in PART III the various ways in which my interlocutors deem meaningful, manoeuvre, and negotiate plural orders in their daily and situated practice and I analyse, in turn, how space is shaped through (policing) practices.

PART III elaborates specifically upon the empirical data and connects my first and my second subquestion in order to respond to my overall inquiry.

Chapter 7 engages with the experiences and perceptions of police officers working in joint centres or involved in joint patrols. It provides the empirical element to respond to my first research question. Subsequently I situate therein the policing of migration and application of CBPC instrument in this field. Responding further to my second sub-question, regarding the intertwinement of migration and security, will allow to interlace my two fields of inquiry and it leads the way for responding the overall inquiry. Bridging into chapter 8 , a brief interlude will zoom into a particular viapolitical policing-mobility route, the so-called "Brenner/o Route" and 
serve as illustrative but also as situated case-study example through primary and secondary document sources.

Chapter 8 examines border struggles that emerge in the encounters of security and migration, and which partially surfaced in prior chapters. I investigate three border struggles in depth, thereby analytically (dis)entangling multi-scalar dynamics. In the subchapter "normalisation and resistance" I place the topic into its broader historical context, which allows one to address the 'why' of border (area) control, its 'targets' and its wider political context. Secondly, multi-level border struggles between differential freedom of movement and border (area) control within the Schengen area will be assessed by relating an analysis across different scales: of case law of the Court of Justice of the European Union (regarding interpretation of art. 23 of the SBC), of positionings of other EU and member state actors, and of struggles and conflicting dilemmas that police officers identify in their day-to-day work on the ground. Thirdly, digging into the microdynamics of internal border (area) policing, in "'playing ping pong' with 'the hot potato'", I discuss readmission practices and related plural logics of control. I conclude with a reflection upon scale politics and jurisdiction before a concluding remark on potential future developments.

Chapter 9 presents my concluding elaboration, in which I connect my theoretical arguments of PART II and PART III. I highlight the public and academic relevance of the findings, especially in the context of ongoing debates and legislative initiatives.

Each chapter in PART II and III is introduced by a BORDER-STRIP: a visual elaboration of the chapter's argument through a 'core symbol' or significant fieldwork encounter. The "splash-page" in the comic-world, sets the climate for what follows (Eisner 2008). 


\section{CHAPTER 2 \\ CROSS-BORDER POLICE COOPERATION AND MIGRATION CONTROL AT INTERNAL SCHENGEN BORDERS}

\subsection{INTRODUCTION: A NAVIGATION THROUGH THE LITERATURE ACROSS BORDERS}

Academic literature on cross-border police cooperation (CBPC) and on policing practices at innerEuropean Schengen borders is scarce compared to other topics within the field of European police cooperation or so-called "internal security". There is a dearth of empirical research. Fijnaut (2017, p.79), long-term scholar in the field of police cooperation, argued that while police cooperation in the EU has a long history and has seen increased developments, there is a huge gap between practices of cooperation and empirical research thereof, especially concerning CBPC. With regards to the policing of internal Schengen borders, criminologists Van der Woude and Van Berlo $(2015$, p.77) identified mobile border-area police patrols as "one of the most empirically under-studied forms of border surveillance". Despite a growing number of ethnographic case studies, Van der Woude (2020, p.9) remarked "the empirical picture of what is actually happening in intra-Schengen border-areas is still very limited". Scholarship necessary to situate the topic within its historical context and broader analysis is indeed abundant. Reviewing the literature (and theoretical approaches, chapter 3) across disciplines requires translation and recognition of epistemic lenses.

In this chapter, I first clarify the terminology used before reviewing empirical research of relevance regarding firstly CBPC and secondly policing (of mobilities) at internal Schengen borders. Subsequently I briefly discuss contributions on Schengen and the Area of Freedom, Security and Justice (AFSJ), specifically focusing on how the 'internal border' matters therein. I conclude by outlining main gaps in the literature and the contribution this study makes.

\subsection{CROSS-BORDER POLICE COOPERATION AND POLICING AT INTERNAL BORDERS}

\subsubsection{Terminology \& key terms}

Lemieux, in International Police Cooperation. Emerging issues, theory and practice (2010b, p.1) defined police cooperation as the "intentional or unintentional interaction between two or more police entities (including public and private agencies), for purpose of sharing intelligence, conducting investigations, and ultimately apprehending suspects". This definition provides for a broad scope of interactions between police agencies (on policing and the police, see chapter 3.1). A descriptive attribute usually goes with the term police cooperation, allocating these interactions within a map of geopolitical constructs. International cooperation for Lemieux 
concerns one type of cooperation, namely interactions across nation-state borders. The geopolitical framing should not come as a surprise as the concept of (national) enforcement jurisdiction is crucial in the field of policing. Nor, however, should it be taken for granted. The attributes 'international', 'transnational', 'cross-border' are often used interchangeably. Authors making a specific use differentiate between international policing based on inter-state relationships and agreements between states, and other types of cooperation deemed less state centred. Walker $(2008$, p.119) uses the broader term of transnational policing to describe multiple forms of cooperation practices and actors. He defines inter-national or inter-state policing as "co-operation and common action between officials and bureaucracies who owe their authority and allegiance first and foremost to the discrete states in question". Sheptycki and Bowling $(2012 ; 2015)$ use transnational as an overall description of practices that transcend or traverse national boundaries, and global policing for practices of global reach. In their global "socio-spatial typology for transnational policing" framework, regional cooperation does not relate to inner-European regions, but instead to Europe itself as a region, and regionalcooperation to entities such as Europol or information-exchange instruments such as SIS. Bi-and multilateral forms of cooperation are categorised as subregional, and border agencies as "transnationally linked" at local levels (Bowling, Reiner and Sheptycki 2019, p.190).

The terminology 'cross-border police cooperation' and the rarer expression 'cross-frontier policing' are - when specified - more frequently employed to refer particularly to police cooperation between subnational levels located in border-regions (Sheptycki 2001; den Boer and Spapens 2002; Gallagher 2002; Block 2011). This is the type of practices this study focuses on.

I use the terminology cross-border police cooperation (CBPC), suited to focus on practices that are situated adjacent to, and performed across, an internal Schengen border, thus between public security actors working on a so-called 'sub-state' level. Gallagher (2002) proposed to differentiate between "local trans-frontier", "inter-regional" and "inter-governmental" cooperation. This differentiation can be taken as a useful starting point: adapted to context ${ }^{13}$ and analytically refined. CBPC at internal Schengen borders involves:

- local police units and police departments adjacent to the border, which for example carry out joint police patrols in trans-frontier cooperation;

- regional police commands (variable), to which local stations are subordinated and which are responsible, for example, for the planning of joint measures through inter-regional cooperation;

- central police directorates located at the Ministry of Interior: matters of international police cooperation are frequently situated within the central department of criminal police, and within a specific sector of international police cooperation. 
In my empirical study I have engaged with local and regional interlocutors. Local, regional, and central however should not be understood as fitting necessarily neatly together like Russian dolls. Part of the question is what meanings the local and regional assumes within politics of scale and plural legal orders. I have concentrated on three cooperation instruments and practices: they are primarily based on bilateral agreements between contracting parties, which interact with legal orders of national and EU scale. An initial simplified definition is due prior reviewing the literature.

Joint centres or Police and Custom Cooperation Centres (PCCCs) are responsible for institutional cooperation in direct formal police information exchange: they situate in border-regions of the contracting parties, comprise in principle officers of those countries and have initially been set up primarily with the aim of supporting operational activities of police agencies located in the border-region.

Joint patrols in border-areas are one modality of joint operations of operational police cooperation. They are a cross-border activity performed by officers from one country acting jointly on the territory of another country alongside officers of that country, mostly being granted auxiliary rather than executive functions.

"Simplified" or "fast track" readmissions are special instances of an administrative procedure based on bilateral agreements between countries that share a common border. Under specific conditions, a person that does not satisfy the criteria for entry or stay, can be returned within spatial-temporal limits to the neighbouring country. This can happen if it is proved that the person entered from there and provided that several other criteria are fulfilled. Fast-track readmissions fall under the jurisdiction of border-area police departments. They are a different regime than so-called Dublin-readmissions or regular (not fast-track) readmissions handled centrally.

This study has additionally focused on mobile border-area patrols carried out internally by one country and on refusal or denial of entry under conditions of (temporary) border control.

\subsubsection{Cross-border police cooperation (CBPC)}

Both the Treaty on the Functioning of the European Union (TFEU $)^{14}$ and the Convention Implementing the Schengen Agreement $(C I S A)^{15}$ encourage member states to stipulate bilateral police cooperation agreements, the latter particularly referring to countries that share a common border. Various studies conducted in the 90s engaged with initially informal, and increasingly formalised, forms of cooperative interaction. Contemporary studies highlight the presence and importance of bi- and multi-lateral forms of cooperation, maintaining that "most executive police cooperation can be found in pockets of regional cross-border cooperation" (den Boer 2010, p.43). 
From a historical point of view, in border-regions CBPC has been the rule rather than the exception, for example, as a response to theft (and escape over the border) or in criminal investigation (Nogala 2001; Fijnaut 2017). In some regions, cooperation was notably formalised through agreements and structures before Schengen: e.g. the Benelux and Nordic countries cooperation, the Cross-Channel Intelligence Conference (CCIC, 1968), and the (informal) Dutch, Belgium and German cooperation network NebedeagPol (Fijnaut and Spapens 2010; Kleiven 2012; Gallagher 2002; Hufnagel, Harfield and Bronitt 2011; Hufnagel 2016; Sheptycki 1998). With the EU integration process, such initiatives were further formalised and institutionalised. Additional ones followed. Both the Schengen and the Prüm framework (see chapter 5), the two main references for police cooperation and today EU law, started out as inter-governmental initiatives and indeed drew on other regional frameworks. Various scholars have reflected upon the effects of increased institutionalisation, multilateral and EU-Agency cooperation on CBPC. Hufnagel (2016, p.119) interpreted the former as a "law generation' process" attesting to the importance of regional frameworks to stimulate innovation and enhance police cooperation in the EU. She argued that the added value thereof is not so much the greater legal certainty and formal fostering of cooperation, but the recognition of regional practitioner efforts at a central and EU level. My study does not seek to inquire what (cooperation form) works better (bi-, multilateral, EU agencies), but how CBPC works. In order to address the 'how', publications feature several factors as to the 'why' of certain particularities of CBPC.

\section{'Particularities' of CBPC}

According to Aden (2001, p.103), while transnational policing involves a relatively small group of highly specialised officers and most police officers have little to do with transnational policing, border-regions are "from this point of view [...] an exception": officers are more frequently involved in what he calls "everyday police cooperation". It is this "everyday police cooperation" upon which the present study focuses. With the establishment of the Schengen Information System (hereinafter SIS) and other databases, officers today do engage in cross-border exchange quite frequently - although remotely and without personal interaction. But it holds true that everyday interaction with officers from across the border is more easily encountered in borderregions, through informal and increasingly also through formalised cooperation. The informal direct interaction across the border between local policing authorities is well encapsulated in the German expression - but not confined to practices in German speaking areas - of kleiner Grenzverkehr: a short, quick, informal, direct traffic across the border, or "petty border traffic" (Nogala 2001, p.132; Anderson et al. 1995, p.47).

According to Gallagher's research, cross-border trans-frontier regional interactions can drive and advance cooperation, supported by sub-central agencies, with or without the influence of 
national governments. Both Gallagher and Hufnagel identified regional developments as loci of innovation that also stimulated increased formalisation. Walsh (2011), in his empirical study on the Irish-UK border, spoke of a "mismatch" between meso- and macro-level regulation, and informal and micro-level practices on the ground. Recognising the co-existence of formal and informal cooperation, legal scholars have pointed out a certain lack of transparency and accountability - and indeed legitimacy - of the latter (Hufnagel 2011; Walsh 2011). Hufnagel (2016) however also made the call not to legally harmonise too much, in order to keep differences and enthusiasm alive. In addition to the "sheer necessity" of cooperation (Brammertz 1999; Gallagher 2002), existing studies mention a number of contextual and local factors deemed to render CBPC distinct from other forms of cooperation: a "shared cultural background", "command of a (regional) language", a "history of network contacts" and the relative "distance from the political centre" (Block 2011; den Boer and Spapens 2002; Gallagher 2002). I will crossreview some of these aspects below.

\section{Empirical insights}

Despite a call for comparative empirical research on police cooperation across border-regions, policing scholars highlight that such endeavour is hampered by several challenges: language competencies of researchers and funding (Fijnaut 2017), willingness of scholars to cooperate and openness to research by the "European policing community" (Bowling and Kopf 2017). Most are single (cross-border) case studies on $\mathrm{CBPC}^{16}$ : comparative or multi-sited studies are the exception. Elements of CBPC entangled with migration control emerge, but more rarely as central object of inquiry.

Of the three instruments this study concentrates on, PCCCs figure most prominently in scholarship. Publications have concentrated especially (but not exclusively) on the GermanFrench PCCC in Kehl due to its extensive functions and longest history (Nogala 2001; Maguer 2004; Felsen 2012; Pudlat 2013), as well as on the "Euroregional Police Information and Cooperation Centre" (EPICC) in Herleen, part of the well-known police cooperation between Germany, Belgium and the Netherlands in the Euroregion Meuse-Rhine (Spapens 2010). These studies also constitute principal sources in several publications about PCCCs. They have been analysed in political science regarding governance relationships, networks, and de/centralisation of information exchange (Block 2011; Block 2007; Aden 2017), but also as best practices for knowledge sharing (Gruschinske, Mario Hirschmann and Füger 2015), or from a legal perspective with respect to data protection (Fiodorova 2018). PCCCs have been identified as important sites of future social science research on how common priority setting, cooperation and trust are achieved and on what triggers cooperation (Nogala 2001), and for investigating a transnational subculture of policing (Bowling and Kopf 2017). Maguer's extensive PhD study (1999-2002) Les 
frontières intérieures Schengen. Dilemmes et stratégies de la coopération policière et douanière franco-allemande is particularly of interest considering the propagation of this instrument (2004; 2007). Maguer followed the development of the first PCCC, and likewise this study, paid close empirical and analytic attention to legal frameworks and practices. She identified several "tensions" between the normative framework on the one hand, and actions and strategies of regional cooperation institutions on the other. Amongst them she spoke of a (technology induced, practitioner driven) "paradox": the extension of the centre's work and shift away from its border-region specificity and its presumed focus on local cross-border crime (2007, pp.207209). ${ }^{17}$ Maguer viewed their potential to turn into rather autonomous cooperation institutions with critical reservation. She argued that the new regional cooperation practices deeply modified pre-Schengen inter-governmental police cooperation: they rendered it more dynamic, but contrary to Europeisation aims also less homogenous. The French-German border-region is often represented as an "experimental zone" or "laboratory" (Maguer 2002; Fijnaut and Spapens 2010). Maguer asked where the place of PCCCs will be in the area of European police cooperation and in the fight against crime in Europe, with developments that were still to come. More recently Gruszczak (2016) appraised some PCCCs' capacity to function as "fusion centres" with relevance to EU crime control priorities - but which are not under the PCCCs' remit of low- and mid-level crime. His analysis of PCCCs exemplifies political science perspectives addressing the handling of information sharing as either "realist" or "functionalist".

From the literature, it emerges that 'the place' of PCCCs within the European landscape of police information exchange is still debated and any relation to migration policing remains empirically unclear. Considering that with the propagation of this instrument today we have around sixty such centres operating in Europe, research has clearly only touched upon an over-represented small fraction thereof.

Readmissions at internal borders are greatly underrepresented in the academic literature. Empirical data and analysis are almost entirely lacking. As readmission has achieved "unprecedented importance in migration and asylum talks" between the EU or its member states and non-EU countries (Cassarino 2017), most scholarly attention has rightly focused on EU and member states' readmission-agreements (or -clauses) with non-EU countries. Such agreements are a precondition for returning persons without regular stay in Europe to their countries of origin but also to non-EU transit countries. Almost no attention has been given in recent times to readmission agreements and particularly to "simplified" fast-track procedures between member states that share a common border. Bouteillet-Paquet $(2003$, p.359) argued that bilateral readmissions "have progressively ceased to be used with the completion of the internal market". Also other authors considered them mostly obsolete. ${ }^{18}$ Along with more dated legal scholarship 
of relevance (Ackermann 1856, Muensterberg 1887; Freiherrn-von-Overbeck 1908; 1912; Heinrichs 1908; Neumayer 1910; Hailbronner 1997, Lehnguth, Maaßen and Martin Schieffer 1998; Lehnguth 1997), an exception is Barbero's (2017) journal article regarding the SpanishFrench border: La readmisión de extranjeros en situación irregular entre Estados miembros: consecuencias empírico-jurídicas de la gestión policial de las fronteras internas. Written by a legal scholar, the practices were analysed as a breach of the legal right to judicial advice. Regarding the Italian-French border publications mention readmissions (Colombeau 2017; 2019), or present an exclusively legal analysis (Pistoia 2018). These practices have more frequently been addressed in NGO reports, identifying unlawful features or denouncing unlawful cases of collective pushbacks (regarding internal Schengen borders and in the Western-Balkan, see AIDA 2019; ASGI 2015a; 2015b; 2016; Schweizerische Flüchtlingshilfe 2016; ASGI et al. 2017; Amnesty International 2018; Push and Back. Respingimenti e Riammissioni in Italia n.d.; Amnesty International et al. 2017; NGO-network 2019; Federación SOS Racismo 2019; ECRE 2019). As critical have emerged instances of readmission of minors, impossibility to make an asylum application, violent treatment, inconformity of the practices with the SBC, and not least the overall informality of the procedure which makes an appeal impossible. 'Eventful' moments have at times been reported in local media or triggered parliamentary debates. An Austrian EMN report on entry-bans titled a subchapter "The Austrian special case: readmissions" (Rutz 2014, p.31). From the wording it is not clear if it considered such readmissions an intra-Austrian aberration (as not resulting in an entry-ban), or a national abnormality within Europe. As to the latter, it certainly is not and there is a critical gap of scholarly engagement.

Joint patrolling, albeit not treated as main theme in publications and research, is sometimes mentioned amongst various cooperation-measures in police or criminology studies (inter alia, Spapens 2008). Other practices, such as hot pursuit, have been frequently addressed. Schwell's $(2008 ; 2017)$ and Darley's (2008) ethnographic studies also include joint patrolling in the context of the EU enlargement (today's internal, at the time external border). These have provided qualitative-research insights on joint patrolling and shown the value of situating practices in their specific context, thereby also addressing power-relations in cooperation. Beyond academia, in 2013 the Geneva Centre for the Democratic Control of Armed Forces carried out a survey aiming to collect experiences of joint patrols in Europe (DCAF 2013): the results are of interest, stating inter alia that practitioners value joint patrols for fostering trust and cross-border relations, over their effectiveness in a particular policing field. ${ }^{19}$ Noteworthy is also short passage of Cuttitta's work (2007), which provides a valuable conceptual refinement of 'police cooperation' in joint patrols for the purpose of migration control, otherwise often under-theorised. He differentiated between uni-lateral and bilateral forms of cooperation (2007, p.95), as well as internalised and 
externalised border flexibilisation. Whilst focusing mainly on cooperation across the EU external border, he maintained that cooperation amongst Schengen members is mostly "truly bilateral". What do contemporary empirical studies provide on that matter? In other fields, namely interagency cooperation in criminal investigations, in the case of the Meuse-Rhine Euroregion (Peters, Vanderhallen and Nelen 2016) scholars argued that a bottom-up study showed how conflicts in cooperation (and at times a perceived unilaterality) resulted primarily at the inter-organisational level, e.g. due to different case management. Schmidt-Sembdner's $(2018 ; 2019)$ ethnographic border-regime analysis has indeed the rare value of analytically connecting police (co)operation at internal borders with matters of the Dublin system. Albeit less engaged in the technicalities of policing, a "re-nationalisation" through internal border measures was identified, shaped by, but also inscribing itself into, "Europeanisation" processes. Trilateral joint patrolling between German, Austrian and Italian officers was however considered by the author rather "peculiar"(Kasparek and Schmidt-Sembdner 2019, p.213).

Finally, in den Boer and Spapens' (2002) noteworthy collaborative study of 6 border-regions (9 member states), the editors identified border-regions as important sites for investigation. The reasons given are twofold. Firstly, due to the increasing importance of regions within Europe set in the context of two processes: a) centralisation of information exchange and b) the formalisation of decentralised cooperation. Secondly, the "assumptions" that cultural linguistic ties as local characteristics facilitate day to day cooperation as they are essential factors in building trust, mutuality, and reciprocity (p.6). The study inquired if centralised and de-centralised criminal investigations into international organised crime are complementary in character or are leading to further fragmentation. The editors outlined that "operating at decentral, interregional level, may automatically lead to pioneering trends in the gray legal zone" (p.14): "to be creativewithin-the-confines-of-the-law" (p.4). I agree that border-regions are important sites of investigation of ongoing processes within the policing field but approached differently. Maybe due to the pilot-project in the Meuse-Rhine Euregion, the administrative entity of Euregions was taken as entity of reference. This is surprising, considering the limited role of Euregios and INTERREG on security matters (Durà et al. 2018). ${ }^{20}$ My study takes the territories outlined in police cooperation agreements as site-of-reference. In addition, findings from other empirical case studies, as well as my own, provide evidence for the need to integrate some of the border-region "assumptions" into studies of CBPC. Linguistic competencies cannot be taken for granted and are often absent. The "common history" may indeed also be a conflicting history (Darley 2008; Schwell 2017; 2008; Walsh 2011).

Sheptycki (2001, p.135) in writing on "organisational dilemmas and operational solutions for policing the internal borders of Europe" made a similar point as the editors, by remarking that 
the complexities of police cooperation in transfrontier settings that arise from linguistic differences pale in insignificance beside those that stem from the fragmented legal terrain on which the transnational practices of police agencies are built.

I return to the important theme of the "grey zone" and the "fragmented legal terrain" (cit. above) in my theory section, providing further analytical tools to engage with space and law. Only a few authors have paid attention to space, thereby engaging with the social and cultural configuration of the border-area from the perspective of policing institutions and practitioners. The borderspace here emerges as a shared "geo-criminological" space (writing on PCCCs, Nogala 2001) and as a polysemantic space: a crimogenic space, a space of control and surveillance, and a space of cooperation (Austrian case study, Pudlat 2013).

\subsubsection{Policing (of migration) at internal borders}

The reviewed policing study literature provides important insights, but in many cases the 'borders' that are being 'crossed' in the cooperation practices of concern (or that have been reconfigured in the course of historical processes), are taken as an unproblematic concept and not further questioned or theorised. In publications addressing the policing of internal borders, often re-problematising the border-as-a-line, the policing of migration constitutes the central theme. Concentrating on national or sovranational developments, CBPC does tendentially not constitute an object of study.

Several authors have highlighted the shift from border control to mobile border-area control, albeit not necessarily grounded in empirical fieldwork. Indeed, Groenendijk's (2003) in-depth study on Germany and the Netherlands promptly pinpointed that new borders had emerged behind old ones. Focusing on the Netherlands, the work of criminologist Van der Woude and colleagues has brought internal border policing to criminological attention (Van der Woude 2012; 2020; Van der Woude and Van der Leun 2013; Brouwer, Van der Woude and Van der Leun 2018; Van der Woude and Van Berlo 2015; Van der Woude and Brouwer 2017). Whilst echoing earlier findings (Groenendijk 2003; 2004), that border control has not disappeared but moved inside the country, the approach of placing long term empirical research into the context of legal complexities provides the needed nuance with regards to the SBC or analysis of street-level police-discretion. Van der Woude's work has focused on national practices and their sovranational embeddedness, but does not take into account CBPC dynamics. Other scholars addressed the policing of internal borders in the Netherlands (Mutsaers 2014), in Belgium (Bernier 2018), or at the French-Italian border (Colombeau 2017; 2019). In social science publications (on CBPC and the policing of migration), patrolling officers are frequently analysed as "street level bureaucrats" (Schwell 2008; Colombeau 2017; Brouwer, Van der Woude and Van der Leun 2018; Bernier 2018; Van der Woude and Brouwer 2017; Moffette 2018). Police 
discretion is a common theme. Fewer articles, but in particular Van der Woude's work, situate local discretion also in detail within broader national and EU policy and legal developments. However, as she pointed out, it is "basically unclear what is happening at Europe's intra-Schengen borders, and why, when and against whom border controls are exercised" (Van der Woude 2020, p.121).

Focusing indeed on the how of bordering practices and engaging in analysis of increasingly deterritorialised borders, critical migration and border studies have adressed border-work dispersed within national territories. Scholars have provided nuanced analysis of policing practices as governmental technologies. Here figures a second multi-sited collaborative publication: La police des migrants: filtrer, disperser, harceler (Barnier et al. 2019) - "to filter, to disperse, to harass". This and other studies have provided important analysis of governmental practices of governing migration by disrupting, decelerating, and dispersing migrants' autonomous movements both through (forced) mobility as well as temporary immobilisation (inter alia Tazzioli 2017; Tazzioli and Garelli 2018). However, works often fail to emplace their fieldsites (notably Ventimiglia, Como, Calais) also within (cross-)border-proximity dynamics. This can be explained, as for example done by Tazzioli (2019), due to the scholars' aim of not reproducing "state's narrative of border zones (Scott 1998)" and, through a methodological, epistemological and political standpoint, of (counter)mapping bordering mechanisms through spaces and frontiers as experienced by migrants.

In my study I have focused explicitly on border-areas and not on controls carried out throughout the territory. I have not investigated migrants' experiences or interactions between police and migrants. I moved into and along what constitutes a certain epistemological blind spot beyond a presumed homogenous "state narrative": as Loftus (2015) rightly remarked, scholarly understandings of border policing is opaque. In criminological research the "neglected cousin within the broader "law-enforcement-family'" (Bowling 2013) is more seldomly sought to be understood through its own terms and lived experiences.

\subsection{SCHENGEN AND 'INTERNAL' BORDER-STRUGGLES}

\subsection{1. "Schengenland" and the Area of Freedom, Security and Justice}

Historical insights and theoretical considerations from different disciplinary angles have been advanced regarding the creation of the (initially intergovernmental) Schengen-area, its inclusion into EU law through the Amsterdam Treaty and subsequent developments (Walters 2002; Bigo and Guild 2005; Guild and Geyer 2008; Pudlat 2013; Cunha, Silva and Frederico 2015; Zaiotti 2011; Peers 2011; Campesi 2015; Siebold 2013). Ground-laying work on transnational policing 
started in the late 80 s and, for Europe in particular, in the 90s. Starting out from early comparative approches on police cooperation in Europe (Roach and Thomaneck 1985; Wilkinson 1985; Bayley 1975; Emsley and Weinberger 1991), publications in the field of police cooperation were produced alongside and engaging with the EU integration process (Hebenton and Thomas 1995; Anderson and den Boer 1994; Anderson et al. 1995; Balzacq et al. 2006; Aden 2015; Schober 2017; Walker 2004, Finjaut 2019). Policing in the name of Freedom, aptly titled by Bigo and Guild (2005), argues that in the EU context where freedom of circulation has been a crucial element in building a EU identity, (delocalised border-) policing is carried out in the name of freedom.

Schengen is considered to have called into question assumptions regarding sovereignty and territoriality along with the geo-political and nation-state border represented as a border line within an ideal type 'Westphalian' state system. Attention was drawn towards post-national, denationalised or biopolitical borders, for example in Zaiotti's Cultures of Border Control (2011) or Walters' influencial article titled Mapping Schengenland: denaturalising the border (2002). Scholars also argued that Schengen has been a laboratory for the government of mobilities (Campesi 2015). The governmental rationale of assuring free movement 'within' created a distinction between "internal borders" (borders between Schengen members) without systematic border control, and "external borders" (borders between a Schengen country and non-Schengen countries) (Campesi 2015; Bigo 2016b; Groenendijk, Guild and Minderhoud 2003). While internal borders became problematised as "obstacles" to internal mobility (Walters 2002, p.567), abolished and eventually internalised, the external borders became reinforced and made into something else than just a national border: the EU's external border. This border has shown to be mobile itself, through ongoing EU enlargement processes.

This process has clearly shifted scholarly attention towards external borders, EU enlargement processes, border-externalisation and so-called "remote control" practices. However, especially during early times, internal border matters were critically scrutinised together with externalisation trends, as for example In search for Europe's borders (Groenendijk, Guild and Minderhoud 2003). Cowley drew attention towards differential freedom of movement and its relation to internal borders $(2003 ; 2001)$. If the aim had seriously been to "abolish" internal borders (in an area without internal borders), so Crowley, they would not be there any more to be crossed. Borders were, in fact, reconfigured into "internal boundary processes, which correspond to diverse institutional patterns of entitlement" (2001, p.16).

\subsubsection{Internal border(-struggles)}

Inner-European Schengen borders and border-areas have mainly attracted scholarly attention only in eventful and conflicting moments. 'Schengen'-scholarship started in the 90's, with a slight increase when the Schengen acquis became part of EU law. There were then two subsequent 
peaks in the quantity of research (Novotná 2018, p.4). First, between 2011 and 2013, when the trigger was the so-called "Franco-Italian Affair"21 and the subsequent Schengen Governance Package (Carrera et al. 2011; Pascouau 2012; 2011; Peers 2013; Zaiotti 2013). Second, from 2015 onwards, scholarship was triggered by the re-introduction and maintenance of temporary border controls at internal borders by several member states. Studies from different disciplinary fields have reflected in particular upon the state of Schengen and its representation as being in 'crisis' (Guild et al. 2016; Brouwer 2015; Carrera 2019; De Somer 2019a; 2019b; Carrera et al. 2018; Brouwer et al. 2015; Fijnaut 2015; Votoupalová 2019). Others have addressed issues such as the impact of border control on the economy (Luecke, Breemersch and Vanhove 2016), on crossborder cooperation-projects of the Euregions (Zillmer et al. 2016) and more besides (inter alia Evrard et al. 2018; Rompuy, Malkoutzis and Pascouau 2016). Scholarship was also prompted during the Summer of 2015, coining the expression of the "long Summer of migration" (Kasparek and Speer 2015; Hess and Kasparek 2017; Schmidt-Sembdner 2019; Hess et al. 2014). Scholars have critically questioned and analysed the framing of "crisis" (inter alia Siegel and Nagy 2018; Cobarrubias et al. 2015). Additionally, a limited number of (academic and non-academic) publications are dedicated to how police forces dealt with the "migration" or "refugee crisis" within Europe (Gratz 2016; Dobretsberger 2018; Conrads, Franke and Hodenius 2016).

Most of the policy and legal-study papers (Brouwer et al. 2015; Guild et al. 2016; Carrera et al. 2018; Carrera 2019; De Somer 2019a) have engaged with normative frames and measures, tracing in detail member states' justification of their border control (prolongations), the application of distinct legal bases provided in the Schengen Borders Code (SBC), as well as the recommendations and decisions by the European Commission and the Council. ${ }^{22}$ For example, Guild et al. ( 2016) assessed if Schengen was "crisis proof", and argued that while legal procedures were respected, the spirit of Schengen was not. Most authors (for an exception, see Votoupalová 2019) have written critiques directed both towards member states' maintenance of border control as well as towards EU bodies for not having applied sufficient scrutiny, i.e. for having considered national justifications as sufficient for meeting the legal "necessity" and "proportionality" requirements. An absence of border control resulting from the creation of the Schengen-area is seen as 'normality': worries were voiced that border control becomes the "new normal" (de Somer 2019a, p.121; 2019b; 2019c). Frequently scholars remind that, according to the rules of the SBC, migration should not per se suffice as 'threat' to public policy or internal security enabling the triggering of border controls. Papers have highlighted a shift in how the targets of the measures are labelled: potential asylum seekers become irregular migrants and the resulting responses through internal border measures deflected the focus from a necessary reform of the Dublin Regulation and CEAS. 
While scholarly production since 2015 has been abundant, I propose to concentrate on a) analysis that shifts from exogenous causes of the migration/refugee/Schengen 'crisis' towards addressing endogenous elements of the Schengen system; b) the knowledge gaps identified in the literature on internal border (area) control.

\section{"Refugee/Migration/Schengen 'crisis"”}

Several authors have shifted away from 'crisis' as moment and primarily normative aspects and have placed developments of 2011 or 2015 into broader historical and political contexts, thereby critically interrogating 'crisis' (e.g. Siegel and Nagy 2018; Cobarrubias et al. 2015; Zaiotti 2013; Hess and Kasparek 2017a; Campesi 2018). Zaiotti (2013) drew attention towards similarities of actors and dynamics of what he called "critical junctures" characterising the Schengen regime since its very creation. Accordingly, the essence of the disputes regarded the the allocation of responsibilities and burden-sharing (p.337). Others considered the 2011 dispute arguing "[o]ne would not expect these sorts of policies 25 years after the kick-off of Schengen", and defining it as a "shameful 'race to the bottom'“(Carrera et al. 2011, p.19). Campesi (2018, p.202) provided quite a sober but to-the-point assessment of how the dispute was deconflicted otherwise:

The fact that the [EU border] regime was largely built on a (more or less explicit) precarious balance between central and northern EU countries on the one side, and frontline EU countries on the other side has also resulted in serious political weakness. The latter received financial compensations and technical support for acting as EU gatekeepers, while the former tolerated a certain degree of secondary movements of migrants not properly identified and fingerprinted according to the EU rules.

Kasparek and Hess (2017, p.63) likewise considered 'crisis' not as an emergency situation of the regime, but as a structural condition: "[...] the life of a regime is a 'result of continuous repair work through practices' (Sciortino 2004)“. Several developments from 2011 to 2015 - starting from the Arab Spring and the civil war in Syria - according to the authors, led to a (temporary) breakdown of the Schengen migration- and border-regime. As many scholars in the field of asylum and migration studies remarked, the Dublin system has seen various internal legal 'limitations' through jurisdiction of the ECtHR and the CJEU prior to 2015. Notable examples are the (temporary) suspension of "Dublin transfers" of asylum seekers back their first country of entry (e.g. Greece in the case of M.S.S v. Belgium and Greece, 2011, and of vulnerable asylum seekers to Italy in Tarakhel v. Switzerland, 2014), as well as the Hirsi case, according to which Italy had violated the non-refoulement principle by diverting migrants back to Libya (Hirsi Jamaa and Others v. Italy, 2012). Finally, asylum seekers have tendentially "self-relocated" across the EU (Guild and Carrera 2016). 
These examples highlight the importance to consider endogenous factors of the EU Schengen and Dublin 'order' and the necessity of shifting from a narrow focus on inner-European border measures towards long term developments across multiple fields of policy and practice. 'Crisis' says less about overemphasised external arrivals and more about Europe, also in terms of accountability and legitimacy. Therein, despite moments of destabilisation, authors suggested a further consolidation of the regime through 'crisis'.

\section{Two knowledge gaps and plural epistemological approaches to knowledge production}

First and foremost, EU bodies and scholars have put a strong emphasis on the need to improve statistical capacities to quantify "secondary movements" in Europe (Council EU 13353/18; Wagner, Perumadan and Baumgartner 2019). Knowledge generation in this field is double edged: a) deemed a means to enhance the government of (unauthorised) mobilities, i.e. control over unruly movements; b) a means to enhance control over governments and to scrutinise what Carrera (2019) called the "secondary movement argument" (emphasis added). Additionally, scholars have sought to understand and explain unauthorised inner-European mobilities, trajectories and causes. Empirical research has also re-problematised the phenomenon by critically highlighting how the Dublin system seeks to immobilize forced migrants and how the relationship between control and so-called "will to movement" produces a (forced) hypermobility (Borri and Fontanari 2015; Picozza 2017; Tazzioli 2017).

Secondly, scholars have highlighted that policing practices at internal borders and the relationship between border-area checks and border control constitute a knowledge gap, pointing out the risk of blurring the line between these two measures (Brouwer et al. 2015; Carrera et al. 2018). Different proposals to fill this knowledge deficit were made. Case law of relevance by the Court of Justice of the European Union (CJEU) has been analysed. A question that runs through various assessment studies is: "Where is the line between 'border controls' and legitimate 'police checks'?" (Guild et al. 2016, p.10), "what exactly is the difference" or the relation between border control and border-area control? (Brouwer et al. 2015, p.16; de Somer 2019a, p.125). The legally drawn 'line' is unclear (Guild et al. 2016, pp.38, 55 ff). Carrera et al. (2018, p.24) argued that both the quantitative use of border-area police checks as well as their qualitative effects constitute a substantial knowledge gap. The envisaged intervention is localised in the former field - e.g. statistics on the uses of SIS were considered a mean to determinate eventual illegitimate systematicity. The recommendation was made to set up an EU monitoring system in order to ensure compliance with EU law, legal certainty, the principle of proportionality and that checks complied with human rights and the principle of non-discrimination (ibidem, p.49).

Regarding the empirical dimension, the literature is much less vocal. More in line with my own study has been Van der Woude's work, which bridges empirical insights and primarily normative 
scholarship. Drawing on theoretical contributions of Valverde (2009) and Moffette (2018), she rightly pointed out the need to place the 'discretion' of member states (and police officers) within a broader legal and political context and to analyse multi-scalar dynamics. She expressed doubts whether increased normative codification would "prevent abuses in the exercise of state power" (Van der Woude 2020, p.15) and argued that discretionary spaces are inbuilt into the multigovernance structure of the EU.

Noteworthy, also on supranational level, the usage of the police (cooperation) instruments this thesis addresses, have themselves turned into an epistemological target, seemingly to make bilateral practices between member states better known on supra-national level and governable within multi-scalar dynamics. Following the Commission's recommendation on enhancing police checks and police cooperation (C(2017) 3349 final), the Committee on Operational Cooperation on Internal Security (COSI) hold an orientation-debate, followed-up by a survey through the Law Enforcement Working Party (LEWP) of the Council (see chapter 5). It was highlighted that little was known about the (bilateral) experiences of member states of joint operations at internal borders. Also the European Migration Network (EMN) carried out surveys on the matter in 2018, in particular the Ad-Hoc Query on Intra-Schengen border monitoring and border control (EMN 2018a; 2018b). ${ }^{23}$ While the results of this survey - filled out at a central level - provide information with regards to policing actors involved and legal frameworks, contemporaneously they say however very little about actual practices taking place in the periphery.

\subsection{MAIN FINDINGS, GAPS, ISSUES TO BE ADDRESSED}

The first objective of my study has been to identify and analyse existing experiences, practices and developments of CBPC through empirical study and an initial review of the literature. The review allows one to conclude that empirical research has mostly concentrated on single case studies (with some border-regions over-represented), but also that there has been more empirical scholarly engagement (across the borders of disciplines and languages) than typically acknowledged. Most studies give historical and institutional background information to their case and some are primarily but not exclusively descriptive. Whilst constituting important sources for tracing the institutionalisation of certain regimes of practices across Europe, the studies present a fragmented picture, due to different disciplinary approaches and research questions, as well as varying period and location of research. Different approaches and diverging aims of inquiry are well captured by the two multi-sited collaborative studies reviewed: a) CBPC in the field of criminal investigation through a multi-governance perspective aiming to identify best practices (den Boer and Spapens 2002) and b) a study of dispersed migration policing as technology of government in need of scrutiny and critique (Barnier et al. 2019). Placed within the context of 
contemporary debates regarding the temporary introduction of border control and police-checks in border-areas, one can confirm that there is little empirical evidence of what both practices mean and imply on the ground. However, the literature does provide a patchwork picture of possible practices, situated in specific locations, at particular times. A review across additional languages would be a further added value.

\section{Empirical gaps}

In both thematic fields of the assessed literature, there are interrelated gaps of crucial importance. Most clearly, one very deep gap concerns fast-track readmissions at internal borders and their relation to other CBPC instruments and to the field of asylum and immigration law enforcement. Why they were deemed obsolete, and what it means if they are not, will be addressed in this thesis, along with more empirical and theoretical arguments. On the one side, readmission practices have been denounced as deportations by advocacy groups and, from a legal point of view, for holding illegitimate features able to amount to unlawful collective pushbacks or for being an instrument lacking due process altogether. On the other side, bilateral readmission agreements have been invoked as a legal base of policing practices, aiming to differentiate them from practices of unlawful pushbacks. In this study I use the technical terminology of readmission. In order to allow for an informed analysis and critical discussion I scrutinise the components of this bilateral instrument (law-as-text and as process) and engage with fast-track readmissions and related practices and logics through empirical data. In addition, while scholars have focused on implications of intensified border-area policing from a normative perspective, little attention has been given to the empirical dimension thereof, and no attention has been given to the other instruments the Commission explicitly advised to enhance, namely cross-border police cooperation (with joint patrols as "best practice" examples), as well as the application of bilateral readmissions between member states as means to counter "secondary movements". This study fills this critical gap. Beyond addressing empirical knowledge gaps - a sine qua non of critical engagement with ongoing developments, including of EU policy and legislation - this thesis aims to contribute to scholarship's analytical considerations, to be further detailed in the theory chapter.

\section{Policing: spatial-legal configurations and negotiations of plural legal orders}

From the review, it appears that border-regions (informal) CBPC has been the rule rather than the exception. While initially operating amid a void of legal frameworks, little is known regarding the role of border-region practices today, in a context that policing scholars have defined as "fragmented legal territory". Scholars pointed out that increased institutionalisation has not led to greater legal certainty or accountability, and that CBPC plays a crucial role in operational cooperation. Taking account of the dearth of empirical data and analysis on bilateral CBPC today, 
in a context signed by hyper-normative spaces and increased juridification, this study contributes in filling this empirical and analytical gap. I propose to analyse the "fragmented legal territory" as a landscape signed by a plurality of legal frameworks for police cooperation. They also intersect with legal orders of other policy fields. Amongst the legal orders that condition (enable and delimit) practices taking place in border-areas, also figures the Schengen Borders Code (art. 23) and jurisdiction of the CJEU. My re-framing of internal border matters and of CBPC as policingmobilities from a theoretical point of view will be outlined in chapter 3.

To further overcome "methodological nationalism" (Aas 2007) and to adopt new lenses to "decipher" multi-scalar security and crime control assemblages (Aas 2012, pp.239, 252), criminology of mobility, of borders and of transnational policing can still go a step further. Firstly, by taking into empirical and analytical account CBPC, and secondly by broadening the analytical scope beyond a "crimmigration" framing. This implies a need to go beyond national practices embedded within sovra-national scalar dynamics and to include within the analysis intergovernmental and transfrontier dynamics that are at play and embodied in CBPC. When analyzing multi-scalar dynamics of disputes or what I will call border-struggles, these are additional dynamics to account for. The SBC and ongoing juridification of the (im)possibilities in the border-strip constitute one of the orders that are negotiated in daily policing practices at internal borders. Drawing on scholarship of legal pluralism (legal geography and legal anthropology), attentive to interlegality, I will investigate what that means for "law enforcement" within plural legal orders.

Lastly, scholars have pointed out that the responses through internal border measures shifted the focus away from the Dublin Regulation and CEAS reform. Likewise, scholarship needs to focus not only on normative questions regarding the interface between border control and border-area control but analytically re-situate practices at internal borders also (albeit not only) within that context. This is required to address the 'how', 'why' and 'when' questions of border control (Weber and McCulloch 2019). Inner-European borders are peripheral but strategic sites, and not least for analysing border-struggles and ongoing reconfigurations at the heart of the European order. 


\title{
CHAPTER 3 \\ THEORETICAL ELABORATION AND CONCEPTUAL THREADS
}

\subsection{FORMS OF POLICING, FORMS OF POLITICAL LIFE}

In Policing the European Union, Anderson et al. (1995; see also Walker 1994) invited reflection upon the relationship between forms of policing and forms of political life. Many considerations of police work have traditionally been entangled with conceptualisations of the state as the main form of "political life". It should not then come as a surprise that, from the 90s onwards, law enforcement and cross-border police cooperation (CBPC) in Europe have been analysed in relation to the sovra-national political life of the EU. The well known debate if the state is withering away, i.e. the role of the state within processes of globalisation (and of European integration), has led policing-scholarship to conceptualise the EU as "post-state polity" (Walker 2004; 2008) and the state as a the postmodern state (Sheptycki 1995) in a transnational order (Bowling and Sheptycki 2012). Anderson and Bigo (2003, p.13) asked if the EU was "a state in the making or an unknown political object (UPO)?". The question remains: what happens to police forces, which are bound to a concept of legal and territorial jurisdiction (Lemieux 2018), when a system that organises "the world into territorially exclusive, sovereign nation-states, each with an internal monopoly of violence" (Caporaso 1996) undergoes historical changes? What does policing tell us about the broader transformations and continuities?

\begin{abstract}
Although the problems associated with this development ["the establishment of new forms of law enforcement co-operation for a 'borderless' Europe"] appear at first sight to be technical and administrative, closer examination shows that it lies at the very heart of the process of European integration and concerns crucial dimensions of state sovereignty. (...)

It raises the general question of the relationship between the forms of policing and the forms of political life. To what extent, and in what manner, are policing arrangements within any society informed by, and informative of the broader institutions, practices and ideas in terms of which that society constitutes itself as a political entity? (Emphasis added, Anderson et al. 1995a, pp.1, 86)
\end{abstract}

With Anderson et al., I contend that scrutinising technical details of CBPC, together with their practices, allows one to tackle questions at the heart of political, legal and social order.

\subsubsection{Police and the state}

Theoretical discussions of the police and of the state often build on similar theoretical frameworks but with different orientations (Walker 1994). Most theories of the modern state place internal security (crime, policing) and external security (defence, military) at the centre of a conceptual scheme with the state retaining a legitimate monopoly of force, often elaborated in 
functional terms of social control and the reproduction of social order (Reiner 2010; Newburn 2003). With police missions abroad and military forces operating within, such external-internal distinction has been reconfigured and de-differentiated (Bigo 2000b, 2001). Scholars also reconceptualised the state as not only holding the monopoly of legitimate force, but also a monopoly over the "legitimate means of movement" (Torpey 2018). The control of movement, and not just of territory, can be traced throughout liberal thought and governance (Kotef 2015).

The police has been defined as "the institution that is formally charged by States to lawfully execute the monopoly over the means of internal coercion" (Deflem 2010, p.6 in Garriott 2013, pp.1, 22) and the police in plural as those individuals that "professionally inhabit" this institution. Policing indeed stands in particular for functions of social control and order maintanance that are carried out by a plurality of actors. Security governance scholars have therein highlighted the increasing role of private actors. Since seminal works of empirical police-study taking off in the 60s, conceptual engagement with police addressed it in "functional" or in "tactical" terms (Reiner 2010). The former has received particular attention in studies on the policing of migration. Fassin's ethnography of police 'stop and search' practices in Paris, as well as Bowlings criminology of mobility approach, have engaged with Marenin's (1982) argument that the police are enforcing a general universally beneficial order, as well as a particular order of social dominance and inequality. Captured in the title Force de l'ordre, Fassin (2013) argued that urban policing enforces a social order by targeting racial minorities in disadvantaged neighborhoods. Making a call to consider borders as sites of punishment, Bowling (2013) placed their social control functions within an order of "global apartheid". Authors concerned with the political economy of the police highlighted the political role: policing upholds a specific status and social order, an increasingly unequal order fostered by a neoliberal system (Reiner 2010; 2015; Tylor, Walton and Young 1973; Hall 1978). A second influential contribution, has been a "tactical" definition (Weber 1919; Bittner 1974; Brodeur 1983): what renders the police distinctive is not its function but being the "specialist repositories for the state's symbolic monopolization of legitimate force in its territory" (Reiner 2010, p.17). As "migration policing is, by its very nature, a transnational enterprise" (Weber et al. 2004, p.199), and although the limits of a Weberian concept of the nation-state and its enforcement actors has been widly recognised, further theoretical considerations are needed. I use the term policing and I refer to activities carried out by the vocational group of public 'lawenforcement' belonging to various police forces. Global and transnational policing of mobility such as in the control of "suspect populations" and facilitation of transit for "bona-fida travellers" (inter alia Aas 2011; Bowling and Sheptycki 2014) - has received scholarly attention in criminology. Together with accountability and legitimacy questions, police interactions through which the policing of mobility takes place, also open up theoretical questions. Rather than 
debating the degree of the transformation of policing into (public-private) security governance ${ }^{24}$, I engage in questions of how the public security field is re-configuring within ongoing developments. I also consider what implications arise for theories concerning forms of political life and correlated understandings of sovereignity and territory, monopoly of force, of inside and outside. I argue it is important to reconnect functional and tactical considerations. When "governing through migration control" (Bosworth and Guild 2008) takes place via an institution and the vocational groups whose distinctive feature is being the repository of legitimate (state) force, then how does one take account of configurations in which borders have become mobile and are patrolled jointly by public police forces of multiple states? How are the "boundaries of the acceptable" (Maguire, Frois and Zurawski 2014b) drawn with regards to 'legitimate coercion' in the government of mobilities? Globalisation has prompted the question of how to think about 'the state' on a theoretical level and, to a lesser extent, how also to think about the vocational group responsible for performing a presumed 'monopoly' of force over its territory.

\subsubsection{Globalisation, European Integration and the political field of 'internal security'}

Cross-border law enforcement and judicial cooperation are often interpreted and analysed as a response to a perceived growth of transnational crime (Albanese and Reichel 2014; Edwards and Gill 2006; Fijnaut and Paoli 2004; 2006; Reichel and Albanese 2014). Globalisation processes are identified as a main driver of transnational or global crime (Galeotti 2004). Authors have highlighted that a 'premise' for international crime control strategies is the criminalisation of certain behaviours and harmonisation of criminal law of different jurisdiction (Andreas and Nadelmann 2006; Lemieux 2010). But the plea was also made not to overestimate the impact of globalisation on crime on the one hand, while downplaying its impact on law enforcement on the other (Andreas 2015). Basically, one should not underestimate factors other than transnational crime that are driving the globalisation of policing: governments, as well as the police themselves, are active driving forces (inter alia Bowling 2009, Walker 2008; Bigo 2006).

In the European context, CBPC is also placed in the context of the European integration process (see chapter 2.3.1). Along with the creation of the Schengen-area came a strong discursive link between the global imagining of 'border-less' crime and enhanced conditions of possibility for crime to propegate throughout a 'border-free' Schengen-area (indicative hereof, inter alia the Palma Document of 1989). Therein, the plea for so-called "compensatory" control measures took shape. Without adopting a neo-functionalist theory per se, the narrative of a "functional spillover" is very present both in scholarly literature as well as in the accounts of practitioners. The aim of creating a single market (so the narrative goes), required the abolition of internal border controls, which caused a security deficit and required increased intervention through police cooperation, as well as harmonised asylum, visa and migration policy, etc. 
Scholars from various disciplines such as political science, critical security studies and law have reflected upon European integration in the field of Justice and Home Affairs (JHA). Different theoretical perspectives have served to engage with developments of today's Area of Freedom, Security and Justice (AFSJ). ${ }^{25}$ The AFSJ is often called interchangeably the EU's "internal security" (Bossong and Rhinard 2016, p.4): a field re-problematised also as an "(in)security continuum", in which phenomena ranging from terrorism, organised crime, irregular immigration and asylum are conflated (inter alia Bigo 1994; Huysmans 2006). Authors have argued that illegal immigration and transnational organised crime "have provided the rationale for building a European governance of internal security" (Mitsilegas, Monar and Rees 2003, p.3), but also that granting freedom of movement of persons has been a "disputed territory" in the first place (Groenendijk, Guild and Minderhoud 2003, p.1).

\section{'Cooperation' therein}

With regards to the theoretical anchoring of analytical frameworks on police- and security cooperation, scholars applying for example a multigovernance framework or (in)securitisation theory have countered a functional explanatory framework of the Schengen development by recognising the active role of police (networks). Analysing the EU as a multilevel political system without one particular actor that steers, the former argued that between intergovernmental and supranational decision-making, a multiplicity of governance dynamics are taking place. Police networks (formal and informal networks complementing one another) were identified as crucial actors and cooperation analysed, for example, through multi-level governance and a differentiation between "vertical" and "horizontal" forms of cooperation (Den Boer 2010, p.43). Whilst providing important insights regarding the regulatory frameworks that govern crossborder policing, institutional developments of actors and recognising multiple loci of power, the approach works within a scheme that the EU itself embraces through its self-representation (Shore 2009). Security scholars informed by governmentality studies have taken a more Foucaultian and Bourdieuan inspired perspective to power and practices. In-formal and semiofficial (in)security networks were likewise deemed as active players within the initial Schengen negotiations (Bigo and Guild 2005; Balzacq et al. 2010): - a "battleground for bureaucracies" (Bigo 1994). By focusing on alliances and conflicts rather than for example network theory, scholars highlighted that beyond the direct relations of a network of actors, these relations have effects within multiple chains of interdependence (Bigo 2016b). As likewise argued in anthropological studies of security embracing an empirical and historicising approach, relations in a regime, apparatus or assemblage are less stable than those of a 'system' (Maguire, Frois and Zurawski 2014b; Feldman 2012; Olwig et al. 2019). The process of establishing an "security continuum" is said, on one hand, to have led to different borders between inside/outside than state-frontiers 
do, and this has reconfigured formerly conceptually and functionally divided fields of internal security (crime, policing) and of external security (war, military, diplomacy). On the other hand, it has led to a "new" field of increasingly de-differentiated (in)security professionals (Bigo 2000b; 2001; 2006, 2014b). Rather than speaking of 'cooperation', attention is here paid to struggles within the so-called field of (in)security professionals and with other fields such as politics, in a transnational field of power (Balzacq et al. 2010; Bigo 2014b).

Legal scholarship as well as descriptive police studies have provided fewer contributions in theorising 'police cooperation' (Hufnagel 2018) and political science is predominantly based on desktop research, albeit with noteworthy exceptions. Bringing the legal and administrative technicalities that govern CBPC into an anthropological analysis, and of which policing and legal scholarship has shown higher scrutiny, allows one to further develop the theoretical field at the interface of legal studies and social science.

\subsubsection{Practices and effects at the margins and at the centre}

Practices and their effects are important 'sites' of study to reflect upon political forms of life. Mitchell (2006) argued that from mundane arrangements of social practices - be it the policing of frontiers or the processes of legal practice - something is manufactured that is perceived to exist above social practice: "the state" and the "law". Accordingly (p.185), the state should be addressed

as an effect of mundane processes of spatial organization, temporal arrangement, functional specification, supervision and surveillance, and repression that create the appearance of a world fundamentally divided into state and society or state and economy.

Not taking the reference object for granted, Huysmans (2006, p.152) pointed out that political community emerges out of micro-level practices that "shape that political unit as both a governmental apparatus and a principle of their application". The work of street-levelbureaucrats and the "margins" of the state were identified as strategic field-sites: places where law and order continually have to be (re-)established (Lipsky 1980; Asad 2004; Das and Poole 2004). Writing indeed on an "ethnography of the state at the age of globalisation" able to capture novel effects of power, Trouillot (2001, p.132) pointed out that "[state] power is being redeployed, state effects are appearing in new sites and, in almost all cases, this move is one away from national sites to intra-, supra-, or transnational ones". Sassen ( 1996b) remarked that under the impact of economic globalisation two major properties of the modern state have been "unbundled": "exclusive territoriality" and "sovereignity". She also pointed out the existance of assembled "third spaces", neither exclusively national nor global (2012). How do such considerations relate to developments in the field of security? Whilst I will return to theoretical 
consideration of borders practices further below, here I content that police forces and their practices are a strategic entry point to engage with theoretically informed questions as to forms of policing and forms of political life.

\subsubsection{Summary}

This study follows ethnographic and constructivist approaches, according to which a reference object - such as 'the state' or the "unknown political object" (Anderson and Bigo 2003, p.13) can be analysed as an "effect of everyday practice, representational discourses and multiple modalities of power" (Gupta and Sharma 2005, p.165). Focusing on police cooperation practices allows one to ask what forms of political life emerge through everyday practices at internal borders, instead of departing a priori from a definition of political entity. Rather than seeking one single answer, the findings of this study allow me to interrogate how multiple political orders, their legal regimes and spatial arrangements, together with correlated understandings of sovereignity and territory, monopoly of force, of inside and outside, interact and are enacted through daily policing-practices. They perform different 'orders' and impact ongoing processes that shape forms of political life. Rather than adopting a governance of policing perspective, this works analyses policing(-mobilities) as both governmental technology and as practices of negotiations between plural (legal) orders, attentive to scale and questions of jurisdiction. In the epistemological approach adopted, the study of policing practices allows the reference object of a political order to shift into the background: for it to re-emerge, as Huysman (2006) nicely formulated, "as a historical question".

\subsection{CROSS-BORDER POLICE COOPERATION: policing-mobilities within plural legal orders}

In order to answer the first question of my two-fold research inquiry, the analysis required a theoretical and conceptual engagement with CBPC. Conceptual approaches to police cooperation frequently focus on 'levels' of cooperation, grappling with issues of scale and recognising that how they "co-articulate in practice" is way more complex (Bowling and Sheptycki 2012, p.26). Approaches have also focused on factors such as culture or (de/centralised) state-approaches identified as facilitating or hampering 'cooperation'. In my empirical study, space and law have emerged as important elements requiring analysis: while they sometimes surface in the literature, further conceptual tools are needed to explore more systematically how they matter in their complexity in everyday policing. Here I outline my theoretical anchoring and elaboration of CBPC as policing-mobilities within plural legal orders. 


\subsubsection{Reframing CBPC as policing-mobilities}

What is the social interaction of police cooperation concretely about? For my study I set out with this slightly different question. Here two activities emerge as central: so-called "information exchange" and "operational cooperation" (on 'police cooperation', e.g. European Commission n.d.; Federal Ministry of the Interior and Building and Community n.d.). By taking the practices instead of relations of interaction across state-borders as a point of departure, I contend that 'cooperation' can be approached and analysed as a (im)mobility-regime. What in policy and law is framed as "law enforcement cooperation" are in fact specific forms of (cross-border) mobility practices and their regulation. Information exchange consists of the cross-border mobility of data. It is carried out, inter alia, through PCCCs. Operational cooperation implies the cross-border mobility of law enforcement personnel (and their equipment), for example during hot pursuit, joint operations or patrols. And there is the mobility of legal instruments aiming to harmonise or to converge criminal or immigration law in order to create a common legal judicial space. Mobility scholarship (on im/mobility regimes, Salazar and Jayaram 2016; Baker 2016) has given little to no attention yet to regulations and practices of police forces 'on the move'.

Globalisation is often mentioned as factor for increased (ir)regular mobility of people and goods and police cooperation is interpreted and analysed as a response to a perceived growth of transnational crime. Without aiming to overstate the extent of the phenomenon, nor to belittle its 'limitations', it needs to be highlighted that mobility also concerns the very same law enforcement agents, technologies and laws. Thus, different regimes of knowledge and technologies of power have acquired mobility and have been, quite literally, mobilised. It is this form of policing-mobilities and the emergence of corresponding (institutionalised) practices and regulatory regimes with which this research engages. As Tsing (2000, p.337) pointed out, "movement depends on defining tracks and grounds or scales and units of agency": policingmobilities do not occur in a legal void, which brings me to harness analytical tools to conceptually engage with what I define as the spatial-legal conditions of policing-mobilities.

\subsubsection{Moving from a "patchwork quilt" of cooperation to plural legal orders}

In my empirical study law and space have emerged as important elements requiring analysis. An understanding of $\mathrm{CBPC}$, and its entanglement with the policing of mobilities, can be enhanced by drawing on legal pluralism as analytical frame, and inter-legality as mid-level concept. After reviewing how law and the law-space relationship are addressed by police cooperation scholars, I turn to scholarship in legal anthropology and political and legal geography that so far has seen little interaction with scholarship on police cooperation. Together with criminological reflections on scale and jurisdiction, important theoretical and conceptual insights can be gained. 


\section{Patchwork quilt, fragmented legal terrain and interstitial zones}

Police cooperation is very frequently described by scholars as a "fragmented legal terrain" (Sheptycki 2001, p.135): a "kaleidoscope of legal rules" or "patchwork quilt", notably "on which the transnational practices of police agencies are built" (ibidem, see also Hebenton and Thomas 1995; Benyon et al. 1993; Sheptycki 1995; 1998; Hufnagel 2012a; Bowling and Kopf 2017). Especially in border-areas, according to Sheptycki (2001, p.153):

The border zone raises issues of its own concerning 'enforcement jurisdiction' and this has led to observations of the 'patchwork quilt' of the legal fabric that covers transnational policing.

Based on a landmark study (Benyon et al. 1993; Benyon 1994), Benyon described bi- and multilateral cooperation on a meso-level ${ }^{26}$ as "a complicated, interconnecting, mesh of formal structures and informal arrangements, serviced by a range of information systems (which are often incompatible)" (1992, quoted in Sheptycki 1995, p.629). Spapens and den Boer (2002, p.14) spoke of the "grey legal zone" in CBPC, where officers might be "creative within the limits of the law". Sheptycki (1995, p.630) addressed "interstitial spaces between governed territories" a "vast and ungovernable patchwork of informated spaces, existing in the transnational interstices of state power". He argued that such interstices "might indeed be a significant diminution of the nation state's near monopoly of policing" (ibidem, p.629). The phenomenon of police officers finding new paths for CBPC has been well analysed, inter alia by Brammertz in the late 90s. He argued that these paths were at times traversing legal grey-zones and beautifully described it as a "constant tightrope walk between between the legally allowed and the factually necessary" (Brammertz 1999, p.3). From these examples arise two insights for further theoretical elaboration.

First, most of the studies engaged with developments in the late 90s-early 2000: at the beginning there was a void of legal frameworks for CBPC. The most prominent example discussed in the literature is that of retrospective legalisation. Schwell $(2008$, p.77) spoke of a fixing through law. Without taking the theme analytically further, also Bigo $(2006$, p.29) remarked that the "materialization of the borders by law or by professional norms" often lags behind the reality of the borders. More recently den Boer (2010) argued that while security was discovered as an EU policy field - the AFSJ - and legal instruments on strategic policy making have proliferated, older instruments were not declared obsolete. She highlighted that executive operational aspects are carried out by member states (principle of subsidiarity) and specifically in the "pockets" of bi- or multi-lateral CBPC. Hufnagel (2012a, p.191) maintained that regional initiatives play a significant role, despite that the "proliferation of a patchwork of legal regimes contributes to legal uncertainty (and indeed insecurity) in the border-regions". Studying CBPC requires the analytical 
tools to be attuned to decipher a context in which police cooperation takes place not in a void of legal frameworks, but within hyperlegalised and multinormative spaces. Not only policing law, but legal orders of various fields and scale intersect in the border-strip, such as asylum and immigration law and the Schengen Borders Code. What "interstitial spaces" and "grey zones" are encountered by police officers today? In the field of CBPC, the proliferation of 'new' laws without declaring 'old' obsolete, suggests that multinormative orders don't necessarily lead to a tighter so-called legal certainty and that co-existing orders bear their temporal signature.

Second, scholars have adopted spatial terms to localise certain policing practices: "interstitial spaces" or "grey zones", notably considered to be between territories and exercised creatively within the limits of the law. While criminology and policing studies have "been slow to take space seriously" (Campbell 2016, p.790), space has more to offer than just being a metaphor.

The space described as fragmented legal territory on which policing takes place, can be conceptualised and analysed as a landscape of intersecting legal frameworks, thereby drawing on legal pluralism as an analytical framework. This requires firstly a study of the relations between plural legal orders and space(s) and secondly of practices, which also reconfigure the terrain "on" which they take place. Turning analytical attention towards policing practices within plural legal orders is neither a normative or policy-oriented task aimed to enhance harmonisation of laws, nor is it a theoretical argument only. As pointed out by Sheptycki (2001, p.158), the "fragmented legal territory" and difficulties posed by multiple enforcement jurisdictions can operate as both a barrier to successful police cooperation and as possibility for police discretion. Between these two extremes lies the potential for two forms of injustice: "injustice borne of the inability to act and injustice borne of the ability to act unaccountably".

\section{Space and law: The legal construction of space - the spatial dimension of law}

Socio-legal scholars and political and legal geographers have for some time engaged in the question of the relationship between law and space (Holder and Harrison 2003; Braverman et al. 2014; Benda-Beckmann, Benda-Beckmann and Griffith 2009). Blomley (1994), in Law, Space and the Geography of Power, argued that law produces space and is in turn shaped by its socio-spatial context. If we consider space as a social and relational product (Lefebre 1991), as the editors of Spatializing Law pointed out, then law becomes an "arena through which politics of space enacted and negotiated" (Benda-Beckmann, Benda-Beckmann and Griffith 2009, p.3). Delaney (2003) provided two complementary moments of analysis: "space-in-law" and "law-in-space". The former referrs to the way law is saturated with spatial metaphors, such as boundary, line, zones - also outlining the limits of legal orders. Police (cooperation) law, as we shall see, is saturated with spatial metaphors, and they are more than just that: they construct specific spaces as legal and territorial jurisdiction. "Law-in-space" questions how situated legal practices 
contribute to the (re)shaping of the "spatialities of social life" (ibidem, p.68). Spatio-legal structures require work to be maintained or transformed, Delaney argued, and much of political action takes place in legal-geopolitical practice.

In my work I discuss and analyse how the border-area-space is constructed by law-as-text and shaped by law-as-practice and process. I used the working-term of border-area, which has fewer connotations than, for example, the conceptually rich but by now analytically over-polysemantic notion of borderlands. ${ }^{27}$ In the course of the research I came to interrogate the following question: what are the border-zones or the border-territories codified as such in (police cooperation) law, that matter for police jurisdiction and policing, and how do they matter? Here the border-(area-)strip has emerged as an emic concept and as legally codified space. I argue that we can better understand the researched phenomena by analysing these spaces as particularly configured spatial-legal conditions of possibility for the exercise of specific policing powers in practice, i.e. policing-mobilities in the border-strip.

\section{Legal pluralism and law in action}

Legal pluralism has been proposed as an analytical framework (Merry 2013, 2014) or sensitising concept (Benda-Beckmann and Benda-Beckmann 2006) to approach the possibility that, within a geographic space or social order, different legal orders and bodies of law exist. These orders are often of different scale and interact with each other. Boaventura-de-Sousa Santos (1987) referred to the interaction between legal orders - at the scale of the local, national, and international, but I return to the issue of scale below - which seemingly regulate the same object as "interlegality" (p.287). Depending on how different orders intersect, the interaction can, but does not have to, be a conflicting one. Therewith, also plural legal constructions of space interact. Legal pluralism, applied in different disciplinary perspectives to refer to plural legal constellations or configurations, has notably been a debated concept. ${ }^{28}$ Scholars who hold an understanding of "normative legal pluralism" and those of "factual legal pluralism" or "social fact legal pluralism" (Benda-Beckmann and Turner 2018; Twining 2010) diverge, for example, on what is considered to qualifiy as law and where to situate the role of the State within legal orders of various scales. However, transnational legal processes are recognised as changing the meaning of state sovereignty with the potential to create "new kinds of political and legal space" (Benda-Beckmann and Benda-Beckmann 2005, p.1): the political and legal (spatial) order produced is part of the question and not the point of departure.

Works in legal anthropology informed by practice-theory have approached law as being a structure that both enables and constrains agency and social practices, producing intended and unintended consequences (Benda-Beckmann and Benda-Beckmann 2005; 2006). This epistemological perspective on law resonates with some approaches in socio-legal policing 
scholarship and in criminology. Law is a powerful tool: constantly in the making, used by different social actors and in multiple ways in the excrecise of power and control. If we consider law as a crucial arena for the negotiation of rights and duties and in the enactment of space politics, practices of law enforcement in plural legal constellations and within plural space politics require empirical study. Anthropological studies on legal pluralism regarding 'enforcement' have rather focused on actors other than that of state recognition, such as rondas campesinas or so-called "indigenous" non-State actors (inter alia Porter 2018). However, scholars in related fields of inquiry have highlighted complex intersections of law, the messiness that emerges from empirical configurations and the crucial role of local agents. One can highlights Klepp's (2011) analysis and conceptualisation of asylum law as a "multisited arena of negotiation" (Benda-Beckmann and Benda-Beckmann 2005) between border control and refugee protection in the Mediterrean (legal anthropology), Corneliesse's (2018) analysis of EU immigration law (legal studies) or Moffette's (2018) study of urban border policing (criminology). These scholars have likewise recognised legal pluralism and interlegality as powerful analytical tools.

My empirical study concerned police officers: the status of the legal order of reference is notably dependent on its recognition within within the state legal system and in that regards I analyse legal orders that mainly qualify as normative legal pluralism. However: orders are not only normative orders, but also commands, moral orders and, as pointed out in the sociology of policing, legal orders are entangled with social and political orders. Together with an analysis of legal and administrative technicalities, emprical research is needed to be attentive to the multiple spaces where law acquires its meaning (Blomley 1994; Griffiths 2011) and to the ways police officers negotiate plural and at times conflicting legal orders. This will also enable a better understanding of how the so-called enforcement (or the "making", Benjamin 1921) of the law by police forces is (also) a negotiation between conditions of im/possibilities within plural legal orders. This approach contributes to scholarship on the discretionary power of street level bureaucrats and opens the field to analysis of multi-scalar power dynamics.

\subsubsection{Scale and jurisdiction}

The crucial importance of regional CBPC has been pointed out by scholars, but the region and regional are however variously and sometimes fuzzily employed terms. Sometimes, the space of interest is identified with the Euroregions (Fijnaut and Spapens 2010; Spapens 2008; den Boer and Spapens 2002; Brammertz 1999). Most often, the regional is not used to refer to the geographical or administrative territory adjacent to borders (border-regions), but to a particular level of police cooperation: regional as differentiated from centralised cooperation or from cooperation on EU level. Are border-regions or police cooperation practices on a certain level a particular scale? What is scale? How to understand dynamics between scales - inter-scalar 
dynamics - or interlegality with regards to scales of legal orders? As argued by Campbell (2016, p.72) criminology and policing studies have often neglected a specific engagement with "spatialities" (e.g. territory, borders, scale, network). From its initial meaning in cartography, scale has been reconceptualised in political geography with a special concern towards political economy, capitalist (uneven) development and the neo-liberal order (Brenner 2004; Smith 1992). While there are various approaches (and critiques) within scalar thinking, "re-scaling" and "scalejumping" (Brenner 2004; Smith 2003) have been proposed as concepts to analyse processes wherein social interaction is re-organised on a different scale, therewith providing an additional valuable perspective on EU integration. While spatialisation assumes verticality and encompassment, analysis should be steered towards how such spatial and scalar orders are produced, rather than taking them as natural preexisting features of the world (see additionally inter alia Ferguson and Gupta 2002; Tsing 2000; Low and Glueck 2017).

In my analysis I draw on socio-spatial theories of scale - politics of scale and scale making as analytical tools - together with socio-legal approaches to jurisdiction (Valverde 2009; 2014; 2008). Legal and territorial jurisdiction in the field of policing is a notion of crucial importance (Lemieux 2018), but as Valverde pointed out, questions of jurisdiction are often taken for granted in criminology. However (Valverde 2014, p.382):

deciding who governs where - the basic jurisdictional question - is not only important in itself but also has the effect of determining how something is governed. Shifting jurisdiction from one organization or level of government to another has the effect of automatically changing how something is governed.

What is the identified policy-field, scale and jurisdiction to respond to a phenomenon problematised in historically specific and contingent ways - e.g. "vagabonds", "foreign mendicants and likewise undesirable persons" (Muensterberg 1887), or today's subjects of "secondary movements"? Who governs where in CBPC and with what effects? Drawing on Valverde's insights, the questions of whether, and in particular of how, inner-European borderregions and $\mathrm{CBPC}$ matter in the governing of mobilities will be scrutinised in this thesis.

\subsubsection{Contribution to other conceptualisations of CBPC}

My theoretical elaboration and the re-conceptualising of CBPC as policing-mobilities within plural legal orders emerged inductively through fieldwork. $1 \mathrm{~m} /$ mobilities, space and law emerged as important elements to be attended to in analysis and an engagement with socio-legal and sociospatial theory can foster understanding and explanation of the phenomenon under examination. I will provide here three examples of how this approach engages with, and contributes to, existing analysis of CBPC. 
Scholarship on CBPC and in particular of information exchange through the work of PCCCs (inter alia Felsen 2012; Weibl 2016; Gruszczak 2016; Block 2007; Aden 2017) frequently refers to Anderson's analytical frame of "centralised and de-centralised state models". Anderson (1989) differentiated between, in extremis, a centralised and decentralised state model, with "qualified centralisation" and "qualified decentralisation" as middle forms. In essence, the more a state works in a centralised manner, the more information exchange has to be channelled through central units only. In contrast, the more decentralised, the more the exchange is supposed to happen through direct cross-border exchange on sub-state level. Providing a less state-centred analysis, in my own work I scrutinize the plural legal constellations that enable data mobility for police purposes through PCCCs, thereby focusing not only on networks but bringing territory back into the analysis through the emic notion of the spatial-legal border-strip. My analysis combines insights by policing scholars on de-centralisation processes in the realm of police information exchange with the analytical concept of scale-making proposed by legal and political geographers analysing de-centralisation processes within a neo-liberal economy. I describe and analyse the work of PCCCs both as social interaction (police cooperation) within a politics of scale, and as active practices of negotiation between plural (legal) orders.

In engaging with the question of what gave rise to transnational police institutions and practices, scholars have highlighted the role of "institutional autonomy" (Deflem 2000; 2002) and that of a "shared occupational subculture" (Sheptycki 1998; Bowling and Sheptycki 2012). Cooperation practices such as, for example, joint patrols are frequently defined as "horizontal cooperation", drawing on Van Reenen's (1989) differentiation between "horizontal" and "vertical" integration. This differentiation has also been drawn on in successive models of police cooperation (den Boer 2010, p.53; Block 2011). Horizontal refers to cooperation in which police obtain the authorisation to operate in another country, or officials from one country are granted authority over the police of another country. Vertical integration is defined as cooperation in which an authority of a higher order than the national authority develops. Today, cross-border hot pursuit, cross-border surveillance, joint patrols, as well as Joint Investigative Teams are considered examples of such horizontal integration (Block 2011, p.31). The practices this study concentrates on would fall under horizontal cooperation, as defined in this scheme. Albeit horizontal, the granting to (lawas-text) and the performing (law-as-practice) of executive or of auxiliary powers by police authorities from one country on the territory of another member state is embedded within broader landscapes of meaning and power. This is particularly evident when these powers are analysed through the spatial-legal mobility regimes, their genealogy and through police-officers' experiences of such "horizontal" interactions. As we shall see, an analysis of horizontal 
cooperation enables one to engage with struggles across scales that are at the heart of the political order.

Police research has frequently addressed the relationship between policing and the law, whereby socio-legal scholars have adopted a similar epistemological perspective as outlined above. It was pointed out how police works with the law, but also how law reproduces social order which makes law inherently political. Scholars have called law a "double edged sword" (Bowling and Sheptycki 2012, p.18). On the one hand, law holds an enabling aspect for policing and is analysed as a tool officers use in discretionary ways. On the other hand, law can be invoked to counter policing practices (ibidem). Legal pluralism figures more seldomly as an analytical frame or concept. In the introduction to Comparative Policing from a Legal Perspective (den Boer 2018) a reference to legal pluralism is found in a table outlining the "transitional impact of the law on policing": legal pluralism is categorised under "absence of a legal framework" and contrasted with legal certainty and "presence of a legal framework" (den Boer 2018, p.3). In addition, the editor remarked that a "living-law" perspective entails that "legislation related to policing should be regarded as a sediment of legislative history: [...] a 'sedimental' journey which takes us across a chronology of different legal layers and regulatory interstices" (ibidem, p.8). Crucially, the editor explicated the importance of temporality, legal interstices and the relation between plural legal orders and uncertainty. Legal pluralism captures a multiplicity of elements that de facto and de juris constitute police cooperation, but rather than being a merely descriptive notion and classified as "absence", legal pluralism - as outlined in the theory section above - constitutes also a valuable analytical framework.

Focusing on specific instruments of law and policing practice through a genealogical and ethnographic approach, enables one to engage with plural legal constellations and with the under-analysed aspect of temporality in space-law configurations (Valverde 2014; BendaBeckmann and Benda-Beckmann 2014; Benda-Beckmann, Benda-Beckmann and Griffith 2009). This is of relevance for an EU context and for tracing a regime of institutionalised practices (Dean 2010, p.31): policing-mobilities. Interlegality is not only a useful mid-level concept to analyse the patchwork of CBPC law, but also to analyse interactions with other legal orders that matter in the border-strip, such as asylum and immigration law, or the SBC. Complementing this primary framework, additional conceptual tools will be used in this study to analyse the policing of mobilities.

\subsection{MIGRATION-POLICING: BORDERS AND 'SECURITY-MIGRATION-CRIME'-NEXI}

In order to answer my research question as to the entanglement between policing-mobilities and the policing of mobilities additional theoretical and conceptual considerations are needed. The 
editors of Borders, Mobility and Technologies of Control (Pickering and Weber 2006, p.3) argued that criminology has been slow to focus on borders even though the expression of state (penal) power is the "prime analytical terrain for criminologists" and borders are notorious sites for the expression of state power (Donnan and Wilson 1999). Today border criminology, criminology of mobility and, to a smaller extent, global policing of mobility scholarship are growing subfields in criminology (Bowling 2013; Pickering and Ham 2014; Aas 2013; Bowling and Sheptycki 2014; Pickering and Weber 2013; Pickering, Bosworth and Aas 2014; Amicelle et al. 2017; Bosworth and Pickering 2018; Bosworth and Guild 2008; Bosworth and Turnbull 2014). It emerged out of, and draws on, early works on identity, migration and crime (such as by the Chicago School), on crossborder crime, and on the global migration control industry. But it was through a "concern with transnational policing that the border moved from being a secondary consideration to a primary concern for criminological inquiry" (Pickering, Bosworth and Aas 2014, p.9). In the field of policing studies, scholars have extended their attention from the policing of migration within a state's territory (Weber et al. 2004), towards the centrality that control of mobility holds within transnational policing (Bowling and Sheptycki 2014), albeit most studies discuss practices within single countries.

In police cooperation-scholarship it is the 'state-border-that-is-crossed' that often emerges as the implicit but qualifying characteristic of this interaction. The border is taken as unproblematic concept and not further questioned or theorised. I will first discuss theoretical framings that allow to denaturalise (Walters 2002) the border and to reconceptualise "borders" as practices and struggles. Subsequently I review approaches to analyse border-security-crime nexi and I conclude with the contribution that criminology - in dialogue with other disciplines - and this study can make to this multi- and transdisciplinary field of inquiry.

\subsubsection{Border* - lines, -spaces, -practices, -regimes, -struggles}

[Borders] are no longer at the border, an institutional site that can be materialized on the ground and inscribed on to the map, where one sovereignty ends and another begins. (Balibar 2011, p.89)

In What is a Border? (1993), Balibar pointed out that there is no easy response to such a question (in Balibar 2011). Inviting a broader view from a geopolitical notion, he pointed out three characteristics of borders. First, no border is only the geopolitical boundary between two states, but it is always overdetermined by other geopolitical divisions. The meaning of a specific border exceeds that of an inter-state demarcation line. For example, the border between West and East Germany was overdetermined by being also a "super-border" between the 'blocks' during the Cold War. The crossing of such a super-border overdetermines the meaning of the inter-state border that is crossed. Second, borders have a polysemic character: borders have not the same 
meaning (and effect) for everyone. He argued that the border does not simply give a different experience of the law (of the police, of freedom of circulation, etc.), but that is task is "actively to differentiate between individuals in terms of social class" (p.82). Third, some borders are not located at the geo-political border-line. Indeed, "some borders are no longer situated at the borders at all [...]" (p.84). Borders are ubiquitous and selective and can take place in heterogeneous fields from health- to security-checks. Consequently, borders are not only performed by official border guards, but the institution of the border is a condition of possibility for a variety of other institutions. Applied to the European context, Balibar spoke of vacillating borders, multiplied and reduced in their localisation and function: thinned out and doubled, becoming border zones, regions, or even countries. According to the philosopher, borders are no longer "at the shores of politics" - understood as at the limits of a community - but they have become "things within the space of the political itself". Notably, according to him, this is happening "perhaps by the way of the police, given that every border control is today an organ of 'internal security'" (p.92).

\section{Border work, bordering - border as practices}

In the mid-90s security actors in Europe formulated the so-called "concept of the mobile frontier", which I will discuss in chapter 5, and related to which border-area policing became an institutionalised regime of practice anchored in law. This not only a discourse, but also concerns the practices through which a mobile frontier takes place in the border-area. I already argued that political forms can be investigated as effects of everyday practices and of processes of spatial-legal organisation. The border is both a spatial-legal configuration an effect of practices. Balibar's reflections are thought-provoking. His considerations regarding the multiplication of borders and their differentiating and selective function constitute an important reference in the field of critical border-studies (Rumford 2006; Paasi 2009; Hess and Kasparek 2017b; Mezzadra and Nielson 2013). Several important inter- or transdisciplinary research-agendas such as Redrawing the Line (Andreas 2003) or Lines in the Sand (Parker and Vaughan-Williams 2009; 2012) advocated for a shift from a traditional focus on border as a noun and on related territorial or geographical spaces (borders, boundaries, borderlands, border-regions, frontiers) towards "border work" (Rumford 2006), "bordering" as a process (Newman 2006) and to ubiquitous "bordering practices". In the fields of policing and immigration control this is reflected in concepts such as "remote control" or "policing-at-a-distance" (Bigo and Guild 2005; Aas 2012; Guiraudon 2002), conflated with security-logics of prevention, pre-emption or deterrence. I follow this reconceptualisation that re-problematises the border as a site of investigation as opposed to a taken-for-granted entity that is imagined as a line separating territorial and sovereign spaces. However, I also call for caution not to simply substitute territorial spaces for practices. Scholars 
have put forward a practice-oriented research agenda for border and security studies (CoteBoucher, Infantino and Salter 2014; Balzacq et al. 2010). Scholars have engaged with different approaches within practice theory, such as Bourdieu's field analysis (e.g. Balzacq et al. 2010; Schwell 2008) or Latour's actor-network theory (Bigo 2014). Since empirical research with border practitioners is only emerging, likewise are grounded theoretical considerations (Aas and Gundhus 2015; Côté-Boucher 2018; Bigo 2014b).

Conceptualising the border-area policing of mobility as border work that includes and excludes (persons but also territories), enables an analysis of borders that take place beyond the borderline. Analytically the focus upon practices goes beyond the normative question of the line separating border-area control and border control. It enables to scrutinise how borders take effect in and through practice, but also what meanings officer give to their (inter)actions, analysed in interdependence with policy programs and the plural legal constellations. Triangulated with an analytic approach to space and law, we will see that territoriality matters also in what were defined de-territorialised borders: specific border practices are not necessarily ubiquitous, as I will further analyse through the midlevel concept of "viapolitics" (Walters 2015a).

\section{Border and im/mobility regimes and security assemblages - border, power, conflict}

Especially in the field of critical migration and border studies, borders are understood not merely as practices enacted by state or parastate actors, but as sites of conflict, struggle, and resistance. In this perspective borders become a "method": a prism through which to analyse broader social and political struggles and power dynamics regarding rights, citizenship and processes of inclusion and exclusion (Mezzadra and Neilson 2013). "Autonomy of migration" scholarship, initially countering the 'Fortress Europe' narrative and proposing the "border-regime" concept (and ethnographic border-regime-analysis) foregrounded the necessity to duly consider the agency of migrants in theorising about borders (Karakali and Tsianos 2007; Klepp 2011; Casas-Cortes et al. 2015; Hess and Kasparek 2017b; 2017a). Epistemologically borders can only be conceptualised as being shaped and produced by a multiplicity of actors, movements and discourses, a practicefocus does not suffice. Herein, migrants are not objects of control practices, but regulation of migration is an effect of migration itself (Tsianos and Karakayali 2010). Border-regime was proposed to refer to a more or less unstable ensemble of practices, knowledge-power and discourses signed by constant "repair-work" to respond to "emergencies" (Casas-Cortes et al. 2015; Karakali and Tsianos 2007). The perspective succeeds in deconstructing what was critiqued as a prominent subject-object relationship (the object being the criminalised or victimised migrant) and in recognising analytically agency of movement. Often however the relationship is inverted, reinforcing one of binary opposition. 
Perspectives focusing on power-dynamics and struggles bring to the fore dialectic relations. Border-regime scholarship has provided invaluable empirical and conceptual analysis of the Schengen mobility- and border-regime. Agents of border control herein however very rarely constitute research participants (exceptions are found in research with multiple actors, see Klepp 2011; Schmidt-Sembdner 2019) and have also analytically remained underexplored. Ethnographic engagement with those who have been considered to be "absolutely superior to migrants" (in terms of power econometrics) in an asymmetric relationship (Tsianos and Karakayali 2010, p.377), allows one to both appreciate (sic) and critically analyse how 'the side' of 'the controller' and power dynamics are much more heterogenous than a 'single state-narrative' suggests (as in Tazzioli 2019). Border struggles are conflicts beyond just those between borderenforcement and crossings.

In policing-mobilities the border ceases to be the implicit but qualifying characteristic of CBPC. How borders 'take place' and unfold in effects through practices and struggles, their entanglement with different migration-control and security logics, but also what type of borders are experienced and acquire meaning in policing-mobility practices re-emerge as objects of inquiry and reflection. Connected with the methodology adopted in this study, the knowledge produced proposes an interpretative-critical analysis. Without adopting a specific strand within practice theory, I concentrate on how policing instruments unfold in practice and on the meanings officer attribute to their (inter)actions, analysed in interdependence with policy programs and plural legal constellations. Such conceptualisation upon the relation between micro-level practices, policy and laws (see also Cote-Boucher, Infantino and Salter 2014) impacts on how we approach analytically, for example, practices of discretion or policy implementation.

\subsubsection{Governmentality studies and (in)securitisation}

Critical security and governmentality studies have provided conceptual approaches for analysing how migration has become problematised and responded to as a security issue. Such approach is attentive towards how practices of government are intertwined with political rationalities (principles set out to guide government) and expert knowledge providing a particular epistemological character: ways of conceptualising and rendering reality intelligible and providing a 'know-how' to elaborate solutions for management (Inda 2006; Foucault 2007; Dean 2010; Rose and Miller 1992). Such problematisations construct particular objects as targets of government and subject them to control and regulation. Specific programmes addressing these problems are made operable through "technologies of government". Law (Tugba 2011), policy (Shore and Wright 1997; Shore, Wright and Però 2011), as well as policing (Inda 2006) can be analysed as governmental technologies: it refers not only to technological devices, but to a "complex set of mundane practices, instruments, calculations, techniques, apparatuses, documents and 
procedures through which authorities seek to embody and give effect to governmental ambitions" (Rose and Miller 1992, p.175). Writing about the US-Mexican border, Inda (2006) analysed policing precisely as "anti-citizenship technology" or Tugba (2011) highlighted the need to consider the cruciality of law in (in)securitisation studies arguing that legal constructions such as waiting-zones in airports enable illiberal practices under liberal rule. Scholarship has drawn attention to how in the Schengen-area within a rationality of "freedom of movement," a biopolitical border(ing) takes place (inter alia Huysmans 2006; Bigo 2006; Walters 2002; Barnier et al. 2019). (Selective) mobility and security are frequently analysed as a matter of government of population (for a review, Fassin 2011): aiming to filter "good" and "bad" circulation (Foucault 2007, p.18).

My sub-questions attentive towards problematisations have been informed by governmentality studies. Rather than holding a unifying theory or a formal methodological approach, governmentality studies are characterised by a particular perspective interested in the way Foucault put forward questions about government, power, and knowledge. This approach provides important threads to analyse specifically the ways that policing practices as technologies are intertwined with political rationalities and (plural) governmental programs to control and regulate what has become problematised in policy (explicitly) as a security threat: "secondary movements". Before highlighting remaining gaps, I briefly engage with the (related) scholarship on securitisation.

\section{(De)securitisation of migration and (in)securitisation}

Extending the Securitisation Theory put forward by Weaver and Buzan in the 90s, Huysmans (2006) analysed how, within the European integration process, migration and asylum were framed as a security issue. Without migration and asylum being directly spoken of as a threat, they were rendered a security question through placement in "domains of insecurity" of policy frameworks that emphasise policing and defence. Therewith he broadened the discursive constructivist, intersubjective approach of the "Copenhagen school", by understanding security as a "technique of government" drawing on Foucault. Writing about a "desecuritisation of migration", scholars further engaged with the question of "de-securitisation" (Huysmans 2006; Skleparis 2018): according to Buzan and Weaver, "de-securitising" means bringing an issue back to the "politics of normality", but it is far from clear what that would mean. In sociological critical security studies (CSS) which coined the notion of "(in)securitisation", (de)securitisation is rather articulated through the struggles surrounding the borders of the (in)security field. Bigo (2001; 2014b) proposed to think of (in)security as a unique phenomenon, arguing that alike in a Möbius strip, there is "one side of a non-orientable surface" - depending on the point of view something can appear as security or its opposite, insecurity. CSS aimed indeed to move from speech acts 
and policy documents closer into a study of practices. It proposed to put (in)security practices and bureaucratic routines and their effects at the centre of analysis and of conceptualisation (C.A.S.E. Collective 2006; Balzacq et al. 2010; Bigo 2016b; Basaran 2011). ${ }^{29}$

\section{Security framings of immigration control and of policing}

Mitsilegas $(2015$, p.2) described the "securitisation of migration" as a "two-fold process": on the one hand, "immigration control is used to achieve security objectives" and on the other hand "security and crime governance methods are being used to conduct border and immigration controls". While criminalisation and punishment express a reactive retrospective logic, preventive and precautionary measures to manage identified, as well as uncertain, 'security threats' sign a shift towards a pre-emptive security "management" logic (Zedner 2007; Zedner 2009; Krasmann 2007). Aspects of the criminal justice system - like policing or sentencing - have been reconfigured under this logic (without getting rid of the "punitive" element). Scholars identified the danger that principles of the rule of law - like certainty, accountability, reliability, justice - and of the criminal justice system do not apply within the pre-emptive security frame. Security framings and logics, this scholarship suggests, has not only effects in migration control, but has also reconfigured elements of the criminal justice system and policing practices. Analysis needs to take account of the logics of control and their temporalities.

An analysis of policing and law as governmental technologies and the important theoretical elaboration of (in)securitisation have provided useful analytical perspectives for this study. However, they need to be triangulated and complemented with other analytical tools. Studied bottom-up, the policing of migration takes shape through plural rationalities, at times contradictory tactics and multiple unfolding effects, which are hard to account for though analysis that fosters homogenising conceptualisations. When combining policy analysis with a study of practices and officers' perspectives, the securitisation of migration is characterised by processes of normalisation and of resistance from within the security field. The latter contrasts with what constitutes seemingly an axiom amongst critical security scholars, namely that security knowledge necessarily constructs migration as security problem. Empirical configurations are more diversified and messier than what CSS scholarship often conveys: departing from situated knowledge I propose instead an analytical viewpoint attentive towards a process that I call the migratisation of security.

\subsubsection{Criminology of mobility, border-criminologies, transnational mobility control}

What does a discipline defined by the study of crime and punishment bring to the study of border work (Bowling 2013, p. 292)? Amongst multiple contributions ${ }^{30}$, I concentrate here on on penality and on developments in policing and the criminal justice system within a security framing and in the context of migration control. With respect to a criminological analysis, Weber and McCulloch 
(2019) argued that only a combining of elements of different theories allows one to investigate the 'how', 'why' and against 'who' question of border control. In the following I review but also analytically expand on their elaboration, thereby reconnecting the theoretical arguments of this section, with those on policing and on CBPC.

\section{Crimmigration}

The term "crimmigration" was proposed to bring to the attention the merging of immigration law and criminal law (initially in the US, Stumpf 2006). It was argued that 'crimmigration' allows one to theorise the "how" of border control (Weber and McCulloch 2019). Stumpf's work has informed for example research on internal border policing (Brouwer, Van der Woude and Van der Leun 2018; Van der Woude and Van Berlo 2015; Van der Woude and Brouwer 2017) and migration control in Europe (Aas 2011). Van der Woude and van der Leun (2013:56) made a call to study the more subtle aspects of crimmigration, not reducible to criminalisation ${ }^{31}$, but understood as a broader social and political process. Beyond de jure criminalisation it regards how migrants are framed as criminals or targeted, for example, through ethnic profiling. I content that while the interactions between immigration and criminal law (and state practices) are important to scrutinise, the concept falls short in considering the plurality of legal orders that 'matter' in their intersection. As Moffette $(2018$, p.3) also pointed out in his analysis: "simplifying the messy assemblages under the umbrella concept of crimmigration risks making us lose sight of (...) interlegality, the non-synchronic, unequal, and unstable play between various laws, techniques, and normative regimes".

In my study I deploy the analytical frame of plural legal orders and interlegality as midlevel concept to analyse the 'how' of policing practices at internal borders, with a focus on law, space, and practices. Certainly, in some institutional, national and historical configurations, practices can be entangled with criminal law. Furthermore, the contrast to 'migrant smuggling' "facilitation of irregular entry or stay" - requires consideration also at internal Schengen borders. However, as emerged from my findings and pointed out in the introduction, a plurality of legal orders is negotiated through practices at internal borders, often intersecting little with interpretatitve or normative criminalisation.

\section{"Governing through migration control"}

Bosworth and Guild's (2008) concept of "governing through migration control" is a valuable framework to answer the "why" of increased penal border powers (Weber and McCulloch 2019). Without downplaying that migration has become "an arena 'governed through crime'", Bosworth and Guild (2008) pointed out that governing through migration can be seen as a governmental technique, the primary objective of which is to formulate "ideal" citizenship and to establishing the "borders of the nation state" (p.713). As Barker (2017, p.445) also argued, there is a 
productive, not just repressive, value to penal borders by "constituting the polity itself". By governing through migration control inherently political objectives are pursued. In addition, border control was identified as form of punishment: outside the penal meaning thereof, but nevertheless with painful and punishing effect (Aas and Bosworth 2013; Bowling 2013) as measures "deprive liberty, inflict harm, and impute wrongdoing" (Barker 2017, p.445). Power at the border was defined as penal, as it is dependent on the means of criminal justice and law enforcement to carry it out (Barker 2017, p.344). Concerns expressed are the application of means of the criminal justice system, law enforcement and the military "without their usual protections" (Pickering, Bosworth and Aas 2014, p.2). Border and criminology scholarship has also critically analysed the merging of measures ranging from border protection, the countering of migrant smuggling to the humanitarian saving of migrant lives (Walters 2011; Vaughan-Williams 2015; Perkowski 2016), mostly however focusing on external(ised) borders. Qualitative empirical research has provided insights that are critical for enhancing understanding of border work. As criminologists Aas and Gundhus (2015, p.14) pointed out: "[t]his type of policing is, paradoxically, often conducted simultaneously with, against and through humanity".

"Governing through migration control" enables one to address the effects of migration becoming a key point in political agendas and electoral debates across different scales. However, returning to the considerations of criminologists upon the changes to the criminal justice system and penology within a security framework - a new penology, or "enemy-penology" (Krasmann 2007): how would (penal) power (and harm) be conceptualised in preventive actions that are not targeting any criminal infraction? And how to re-think indeed the "traditional connections between the police, citizens, the nation-state and its territory" (Pickering, Bosworth and Aas 2014, p.16). Criminology of mobility called precisely for such re-thinking, when addressing policing cooperation, since "migration policing is by its very nature a transnational enterprise" (Weber et al. 2004, p.199). Reconnecting functional and tactical considerations in policingscholarship: when "governing through migration control" takes place via vocational groups whose distinctive feature is being the repository of legitimate (state) coercion, then how to take account of configurations in which borders have become mobile and are patrolled jointly by public police forces of multiple states? And, drawing on anthropological approaches to (in)securitisation: how are the "boundaries of the acceptable" (Maguire, Frois and Zurawski 2014b) drawn in the encounter of security, legitimate force, and mobility?

By addressing these questions, criminology can make important contributions, both to the field of policing scholarship, and to the vast field of border studies. I argue that the 'how' does not necessarily take place through 'crimmigration' but through inter-legality negotiations and, in a very pragmatic sense, through police cooperation. Likewise, this enables to address the role and 
effects of CBPC in border-areas, a theme greatly overlooked by scholarship that scritinised developments at internal borders and the intensification of border-area policing measures. And therewith gretly undertheorised. This requires one to overcome criminology's methodological nationalism and on theoretical level not to take for granted that it is the 'the nation-state' that is re-established as effect when border control is enforced. By empirically studying micro-practices of cross-border interactions and policing-mobilities deployed in the policing of differential mobility rights, the form of political life produced as effect is allowed to re-emerge as a historical question.

\subsection{INTERLACING THE THREADS}

Together with scholars in these overlapping interdisciplinary fields I highlight the need and pragmatic approach to interlace analytical tools, rather than to expect that a single theory or concept will do the job. In "Penal power and border control: Which thesis? Sovereignty, governmentality, or the pre-emptive state?", criminologist Weber and McCulloch (2019) argued that only a combination of elements of different theories may produce a comprehensive understanding. Scholars interested in fostering the theoretical dimension of critical border studies pointed out that, rather than aiming for one overarching explanatory theoretical framework of 'borders', patchworking together different concepts is better suited to elucidate various aspects of diversified border practices (Johnson et al. 2011; Paasi 2009, Parker and Vaughan-Williams 2012; 2009). There are many benefits, but also challenges, of putting different academic fields into a cross-disciplinary dialogue, inter alia due to epistemic, representational, and methodological differences (Pickering, Bosworth and Aas 2014; Bigo 2016a; Crawford and Hutchinson 2016; Maguire, Frois and Zurawski 2014a; Bigo 2014a; Newman 1999; Hayward 2011). Therein it is noteworthy, that both in theoretical and methodological terms, unfortunately at times criminology scholarship misses out on ethnographies of crime and policing published in the field of anthropology and, vice versa, the anthropology of police those of criminology. I contend that the interlaced conceptual threads of my theoretical elaboration share enough epistemic ground to be laced together and be further refined through their entanglement.

\subsubsection{Policing-mobilities, plural legal orders and interlegality}

In my analytical framework I conceptualise CBPC as policing-mobilities in the spatial-legal borderstrip and analyse them both as technology of government and as practices of interaction and negotiation within plural legal orders. Legal pluralism, together with interlegality as a midlevel concept, enables engagement with the "fragmented legal terrain" of police cooperation and provides an analytical tool for (transnational) policing scholarship. In addition to this primary 
framework, outlined in detail above, here I wish to lay out additional analytical concepts I used to analyse the policing of mobilities.

\subsubsection{Viapolitics}

In my analysis I argue that the strategic patrolling of border-areas and of vehicles along specific routes - and the recommended intensification of (joint) border-area and CBPC measures - are instances of migration becoming viapolitical. Viapolitics was proposed by Walters a mid-level concept to draw attention towards the various ways in which vehicles, roads, and routes matter in migration politics and in the governance of mobility (2015a) and how they are "at stake in power relations and political actions" (Walters 2015c, p.10).

When imaginings of the journey acquire a prominent place in public mediations of migration, or when the policing of routes and vehicles becomes a central strategic undertaking in the governance of migration, then migration has become viapolitical. What I am calling viapolitics is not a synonym for migration or the politics of mobility. Rather, it lays claim to a more specific and determinant plane of reality. It draws our attention to those particular instances and situations where aspects of the journey (such as its vehicles, authorities, markets and infrastructure) become prominently entangled in the politics of migration. (Walters 2015b, p.100)

Walters' argued that: a) that the ways vehicles feature in migration controversies and mediate the public understanding of migration are not neutral; b) that vehicles are "mobile zones of governance", but also of contestation; and c) that "under certain circumstances, vehicles and their infrastructures become the objects and settings of political action" (2015a, pp.473-474). While he applied this analytical micro-physical 'zoom-in' to concentrate on the vehicles used by migrants or on political actions such as anti-deportation struggles on airplanes used for deportation, I deem viapolitics is a valuable mid-level concept to be extended in its application to zoom-in on dynamics regarding both policing-mobilities and the policing of mobilities. ${ }^{32}$

As Walters (2015a, p.478) added to Balibar's reflection: borders are not a fixed line, but neither are they completely ubiquitous: they take "new shapes and topographies that [...] materialise within strategic zones of the transport system". Border-areas are such a space. Historical evidence (H.H. 1866; Feys 2019) and my own study highlight the role that border-areas and railtracks have played in the development of control modalities, as I will argue by tracing the genealogy of the law-as-text governing policing-mobilities and border-mobilities in Europe. Drawing on this concept and attuned to routes and their directions, I propose an analytical differentiation between three generations of border-area patrolling, which represent plural logics of migration control and assemble differently with other instruments through which border practices take place, such as readmissions. I will further elaborate upon this argument, when 
engaging with the genesis of readmission practices (chapter 6), which are inscribed in historically specific politics and projects of freedom of movement.

Viapolitics constitutes an analytical device in the context of "governing through migration control" (Bosworth and Guild 2008). On the one hand it allows one to 'emplace' an otherwise often abstract discussion of policing as governmental technology. The concept reads as an invitation to scrutinise different types of vehicles and ways of transport, but also multiple directions of routes; not the trajectories of those targeted, but the vehicles and ways through which mobility seeks to be governed: likewise 'on the move' and along 'routes' problematised and politicised in specific ways. On the other hand, however, the "mobile zones of governance" must be analysed as situated within specific spatial-legal and temporal landscapes, as well as jurisdiction. Such practices are emplaced within plural legal orders, relations of power and of 'control', especially in instances where such mobile zones of governance are strategically entangled in politics of migration. In my analysis I have been less interested in questions regarding the subjectivities produced, but more so in the question as to how actors negotiate plural legal b/orders through practices. Approaches in the field of legal pluralism enable one to analytically include actors, interests, values, meanings, and politics of scale. This analytical perspective allows one to tackle an additional and slightly different set of questions, whilst sharing an understanding of power as relational and diffused.

\subsubsection{Border-struggles}

I refer to the concept of "border-struggle" to analyse various forms of negotiations (between different legal orders, scales, rationalities, regimes of knowledge, etc.): struggles that emerge in the encounter of security and migration along viapolitical routes and across scales, in their specific - and plural - entanglements. The notion of border struggles has been used in scholarship to highlight how struggles and power relationships are inherent in borders, in processes of inclusion and of exclusion. But authors also employed this term in specific ways to address practices of different actors. I outline these before explicating my operationalisation.

\section{Borders as conflict}

In Border as a Method, Mezzadra and Neilson (2013) proposed to take the border as an epistemic viewpoint: border struggles refer to struggles taking shape around the "ever more unstable line between the 'inside' and 'outside', between inclusion and exclusion", but also to the practices by which migrants "come to terms with the pervasive effects of the border" (p.13). Borders in this reading are marked by tensions between practices of reinforcement and of crossing. According to autonomy of migration scholars, this understanding of border struggles indicates "the decisive role migration plays in co- constituting the border" (Hess and Kasparek 2017b, p.60). 


\section{Struggles within and over the borders of the (in)security field}

Bigo employed the notion to analyse the power struggles of different (in)security agencies over the boundaries of security and of "the field" itself: struggles including those over the prioritisation of threats and their own position within the field of (in)security and with respect to other fields, such as that of politicians (2006; 2014b). Within critical security studies (CSS) the concept is placed within an analysis of (in)securitisation processes. Different from the above authors, the struggles analysed in this understanding are those among different (in)security agencies "to conserve or to transform the configuration of the field's own forces" (2006, p.23).

\section{Legal border disputes}

Border-struggles have also emerged in legal scholarship, e.g. in terms of the relationships between EU and member state competencies, or between sovereign and universal understandings of rights. Moorhead (2014) spoke of "border disputes" to indicate conflicting situations between Union and national law and respective competencies, and related "politically charged" decisions by the European Court of Justice. Other authors have addressed similar issues by pointing out legal conflicts in plural orders (Martinico and Pollicino 2012). Peers (2011, p.136) considered border control as a "pivotal battleground" between States' aim to maintain discretion and sovereignty over their borders, and the need to ensure protection of rights and liberties. Border-struggles in this reading, allow the analysis of struggles between political and legal orders, and between different scales and fields of law: struggles that are at the heart of the European political and legal order.

\section{Border struggles in this study}

In my operationalisation of the concept, I draw on two insights. First, Bigo's recognition (2006, p.30) that glocality and transversality "allow us to understand that the field of (in)security is deployed at a level that is reducible neither to the national political field, not to a level between two nations, or even to the European level". Second, understanding law as an "arena of negotiations", in Mobile people, mobile law. Expanding legal relations in a contracting world (Benda-Beckmann and Benda-Beckmann 2005, p.9), the editors suggested the study of "chains of interactions connecting transnational, national and local actors in multi-sited arenas of negotiation along with the power relations that structure these interactions and are reproduced or changed by them." Informed by Bourdieu's theory of practice, both contributions highlighted the importance of considering interactions and relations that derive from practices. But while the "local" of the (g)local mentioned in CSS often disappear in favour of a more conceptual work, the latter apply an ethnographic sensitivity. "Ethnographic border-regime analysis" (and border as conflict) shares many epistemological underpinnings. However, struggles between migrants' border-crossing and border-enforcement have been foregrounded and analysed through 
research positioned on the former 'side' - epistemologically, politically, and mostly also methodologically (Hess 2012, p.341; Tazzioli 2019, p.11; Karakali and Tsianos 2007). What about other forms of relations, and indeed other types of struggles? Indeed, what sort of borders, i.e. border struggles, emerge in policing-mobilities and in encounters of security and migration? What connections, frictions, dynamics emerge among sites, including non-local sites? When epistemologically conceptualising borders through movement, the mobility of police officers (tendentially not categorised as migration) requires being taken into analytical consideration. It enables a situated theorisation of ongoing reconfigurations.

Some struggles at the heart of the EU order which I analyse are legalised border-struggles played out in court, others are less visible and emerge in every-day practices or in the course of policy re-appropriations. Understanding borders as conflicts, implies analysing struggles sensitive to the ways conflict-analysis and operational conflict-transformation approach the so-called "conflicticeberg": from tangible positions to underlying interests, needs, values and identity elements. Some border-struggles, such as those analysed by Bigo, concern the very borders of the (in)security field: where are the borders as well as hyphens between security and migration? Some, indeed, are also struggles of resistance from within the field, towards a process that I propose to define and unpack as migratisation of security.

\subsubsection{Migratisation of security}

While the securitisation of migration has been discussed at length in scholarship, when investigating in my work the entanglements and encounters of security and migration from the angle of practitioners, the question emerged as to which degree can we speak of a process of migratisation of security. I use this expression to grasp unfolding and productive effects of a securitisation of migration from within the field (e.g. funding allocations with migration as priority, the creation of new policing units, an increase of mobility-related policing work tasks) and to analyse the meanings police officers attribute to a process within which in their everyday work certain categories of mobile-non-criminalised subjects become "police property" (Lee 1981, in Reiner 2010, p.123). I will explore what can analytically be gained from such perspective and relate findings to scholarship on securitisation. A related question is thus how both securitisation and migratisation impact on reconfigurations of (border) policing, and with what effects.

\subsubsection{Summary: analytical framework}

The analytical perspective adopted in this thesis is that the EU Schengen-area and today's socalled Area of Freedom, Security and Justice can be understood as a space signed by a plurality of legal orders of varying scales and policy fields, within which policing practices negotiate (legal) orders (and borders) on a daily basis through practice and (inter)actions. 
I conceptualise CBPC as a form of policing-mobilities and inquire how legal regimes construct border-areas as specific spatial-legal configurations. The border-stipe is an emic concept attuned to capture the plural legal codification of border-areas. It provides the conditions of legal possibility for the exercise of specific policing powers, i.e. policing-mobilities. Such practices do not happen in a space of either legal clarity nor legal void, but in hyper legalised (and mobile) spaces signed by a plurality of legal regimes and rationalities of government. Approaching policing through practices and their spatial-legal regimes, allows analytical engagement with the "fragmented legal terrain" (Sheptycki 2001) through the concept of plural legal orders (Griffiths 1986; Merry 2013; Benda-Beckmann and Benda-Beckmann 2005). An analytics attentive to law and space (Benda-Beckmann and Benda-Beckmann 2009; 2014; Holder and Harrison 2003; Blomley 1994) and to interlegality (Boaventura-de-Sousa 1987) enables one to grasp complex and messy intersections, as practices and practitioners actively negotiated between plural (legal) orders. Legal orders are plural in scale, but also in policy-field, and not reducible to an analytics of "crimmigration". Focusing on instances when the policing of specific routes acquires strategic importance (Walters 2015a. 2015b) in "governing through migration control" (Bosworth and Guild 2008), I adopt and further explore the meso-level concept of viapolitics (Walters 2015a), triangulating an analytic of governmentality and of legal pluralism. Finally, refining approaches that have used borders epistemologically to analyse negotiations, conflicts, and struggles, I analyse multi-scalar border-struggles that emerge in the plural encounters between security and migration.

This theoretical elaboration aims to provide a more comprehensive understanding and analysis of cross-border police cooperation and migration policing at internal Schengen borders. Therewith I aim to bring some fresh perspectives into scholarship on police cooperation and transnational policing, and to the nascent sub-field of border-criminology and criminology of mobility and to advance theoretical reflections at the crossroad of law and social science.

Finally, the institution of the police has been considered 'good to think with' (Feldman 2019; Garriott 2013a): major traditions in sociological and philosophical thought have found the police useful to reflect upon their times, such as Weber, Benjamin, Marx, or Foucault. As Comaroff pointed out, many of these scholars were writing in an epoch of rising industrial capitalism and of the modernist nation-state. The main question according to Comaroff $(2013$, p.xix) is the following:

How is our epoch, an epoch still struggling to define itself - it is now often referred to, of course, as the age of global neoliberalism, but with a heavy measure of agnosticism, irony, caveat, uncertainty - to make sense of the way that it is being policed? How, as the nation-state form is mutating, are emerging forms of police power congealing within it? And how are they best to be typified and accounted for? 
These questions resonate with and widen the interrogation of the relationship between forms of policing and forms of political life posed by Anderson et al. in 1995. Focusing on police cooperation allows one to ask what forms of political life emerge through everyday policing practices. Engaging with the technicalities of CBPC in Europe - in law-as-text and law-as-practice - allows me to provide a contribution, small and situated, to questions at the heart of the legal, political, and social order(s) of Europe and of an epoch struggling to define itself. 


\section{CHAPTER 4 \\ METHODOLOGY AND METHODS \\ ON THE MOVE}

\subsection{STUDYING POLICING-MOBILITIES}

A study of policing-mobilities requires twofold considerations of salience specifically for a doctoral degree in global and cultural criminology: studying mobilities and carrying out research with the vocational category of the police. On the one hand, research engagement with a world signed by increasingly "complex mobilities and (uneven) interconnections" (Inda and Rosaldo 2001, p.4) has prompted methodological reflections across disciplines. Considering the impact of globalisation, criminologist have identified the need to refine the 'comparative' agenda (Sheptycki and Wardak 2012; Nelken 2011; Mitsilegas, Cheliotis and Alldridge 2015), but also to overcome "methodological nationalism" of the discipline's traditional nation-state framing (Aas 2007; 2010). In this context, Aas argued that "[c]riminology still seems to be, theoretically and methodologically, somewhat badly equipped for understanding the relevance of global transformations and the emerging 'space of flows'" (2007, p.177). She made a point to move beyond comparative criminology towards a global criminology focusing on transnational connections and "glocality" (Robertson 1995). On the other hand, within cultural criminology and anthropology fieldwork, transformations have triggered reflections particularly with regards to ethnographic practice. Ethnography has historically been grounded in fieldwork described as the "intimate participation in a community" (Keesing and Strathern (1998, pp.7-9, in Robben and Sluka 2007), or as "long term, in-depth participation with those we study" (Ferrell, Hayward and Young 2015, p.155). This understanding has informed ethnographies of police (occupational) culture in criminology and anthropology (e.g. from Banton 1964 and Bittner 1974 to Fassin 2018). These descriptions highlight key features of ethnographic research and its epistemological underpinnings. However, critical reflections have been prompted, concerning the meaning of ethnography and "field-site" (Gupta and Ferguson 1997), and the 'how' of ethnography in "studyup" or policy research (Nader 1972; Gusterson 1997; Wright, Shore, Però 2013).

In this study I adopted a multi-sited and studying through research design, which I deem suited to engage with the "(g)local transnational connections" in migration control and policing, both of concern to a global criminology (Aas 2007; Bowling and Sheptycki 2014). In this chapter I outline the epistemological and methodological underpinnings of this study. I describe the different methods which I integrated into an ethnographic methodology, the steps undertaken and the factors that impacted on the data gathered. I conclude by summarising the limitations and strengths of this study and with a note on the visual component of this dissertation. 


\subsection{EPISTEMOLOGICAL AND METHODOLOGICAL CONSIDERATIONS}

This study adopts an epistemological and methodological perspective, that a small place like a border-area and policing practices therein, provide a privileged lens to engage in larger issues at stake, to paraphrase Hylland Eriksen's (1995) small places, large issues. Rather than studying one particular 'small place' I have adopted a multi-sited research design and carried out multi-local fieldwork (Marcus 1995; Hannerz 2003). Contemporaneously, this study adopts a perspective proposed within an anthropology of policy, wherein policy worlds are studied as a window onto political processes (Shore and Wright 2011). On the one hand, my field-site locations were situated along the empirical border-strip, on the other hand, I 'followed' documents, such as policy, laws, case law, governmental reports. As Wright (2011, p.27) concisely put it:

While it is still essential to engage in the ethnographic particularities and contingencies of 'what is going on' in specific places, that is not the end of the story. The challenge is to find ways of studying through sites to grasp largescale processes of change and track the emergence of new systems of governing and formations of power. This calls for new ways of conceptualising and designing research (...).

This applies very much to the present study, which is informed by and contributes to ongoing reflections regarding transformations of fieldwork practice. This dissertation is not a "police ethnography" in the classic sense. Readers should not expect pages of thick description of borderarea patrolling based on 'ride along' observations (see also Gariott 2018). This is rather a 'borderstrip ethnography of policing-mobilities': an inquiry into transformations of policing powers, attentive towards dynamics between law-as-text and law-as-practice, and for which particularities and contingencies in specific field-sites do matter. This approach enables to track processes of continuity and change in transnational systems of governance and into long-durée re-configurations of Europe's plural legal and political orders.

\subsubsection{The 'field', 'the sites' and 'the' side}

Ethnography "is about deep, sustained immersion into a 'field'" (foreword to Doing ethnography in criminology, Rice and Malz 2018, p.v). In this study my 'field' was traced through my unit of analysis: CBPC or policing-mobilities in the border-strip. They constitute the field-site(s) and were studied in multiple locations: as interpretative and operational practices of police officers working in the physical border-strip; as ongoing reconfiguration of the spatial-legal border-strip in legislation, as instruments entangled with policy problematisations and governmental programs; in law-as-text and in law-as-practice. My empirical fieldsite-locations were situated at the "frontiers", the "territorial zones of varying width which stretch across and away from the state border" charachterised by negotiation and struggles (Wilson and Donnan 1999, p.15). Police officers, albeith being state officials, are - potentially - not less borderland inhabitants and 
engaged in negotiating behaviour and meaning. Welcome to my empirical field-'side': the vocational group of police officers.

\subsubsection{A multi-sited and study through research design}

This study has adopted a multi-sited and a study through research design. The notion of "multisited" ethnography is attributed to Marcus, who in the 90s called for a mobile ethnographic practice researching on multiple sites (1995). Following Appadurai's wink to "follow the thing", he suggested that researchers could follow the people, a metaphor, story or plot, a biography or a conflict, in order to investigate a larger global system. Policy was added to this list (Riles 2006; Shore and Wright 1997; Shore, Wright and Però 2011). According to Marcus (1995, p.96), this enables researchers to construct ethnographically both the "lifeworlds of variously situated subjects" as well as "aspects of the system itself through the associations and connections it suggests among sites". One strength of this research-design is the possibility to trace links, connections, translations between distinctive discourses and practices from site to site (or locality to locality) and across scales. The concept of multi-sited research is distinct but goes along with the practice of a multi-locale fieldwork (Hannerz 2003). Many scholars adopting a multi-sited research design, have contributed to conceptually refine methodological practice on the one hand, and to analytically unpack the therewith studied associations and connections between sites on the other, thereby also critically revisiting understandings of 'system' and identifying more dynamic and less stable connections and relations. The notions of "patchwork ethnography" (Tsing 2000; 2005; Pijl, Oude Breuil and Siegel 2011), "liquid" and "instant" ethnography (Ferrell, Hayward and Young 2015), "extended field site" (Andersson 2014, 2017), "deterritorialised ethnography" (Merry 2000), as well as "study through" (Wright and Reinhold 2011) and "nonlocal ethnography" (Feldman 2011; 2012) are examples of rich reflections upon methodological practice, coupled with important insights through multi-sited research into inquiries related to the present study. Specifically, 'nonlocal' and 'study through' research strategies move beyond the privileging of "evidence obtained through direct sensory contact" (Feldman 2012, p.184). ${ }^{33}$

My study holds a wide conception of the field and moves back and forth and up and down between sites and actors: this is a core feature of what Wright and Reinhold (2011) defined as a "study through" research strategy, when engaging in the task to track the institutionalisation of certain framings and ways of governing. It is an approach that interrogates the conditions that produce the present, but also asks what the "present is producing" (p.102). Multi-sited research enabled me to move with and within the field. Rather than conducting a research in favour of focusing on either discourses and laws or on situated practices I studied both elements and their interdependence (see also Cote-Boucher, Infantino and Salter 2014). On the one hand, I carried 
out fieldwork in multiple physical locations along 'the' border-strip, triangulating data obtained through document analysis, interviews and observations. On the other hand, I followed policy, legal regulations and, to a smaller degree, case law: over time, across countries, at EU, at national and at bilateral scale. The engagement with documents and policy enabled to track structures, processes, institutions, agents and concepts through which policy is developed and operationalised (Shore, Wright and Però 2011; Shore and Wright 1997, Riles 2006). This allowed and required a mapping of involved actors on EU level and, adopting a governmentality perspective, inquiring policy problematisation and proposed programs (Rose and Miller 1992). Within the research process, space and law emerged as important elements, which led me to engage in-depth with the "technicalities" of legal and administrative orders (Riles 2005; Anderson et al. 1995; Valverde 2009). 'Following', again, these technicalities, allowed tracing the genealogy of specific legal instruments and of specific 'articles' therein. The encounter of these datasets enabled to investigate the interdependency between situated practices, legal orders and policy.

This study has been committed to several core features of an ethnographic epistemology, which is not homonymous with the method of participant observation. In line with what Ferrell, Hayward and Young (2015, p.215) defined as "ethnographic sensibility", this study sought understanding through the emic perspectives of police officers, combined with a study of policy and into constellations of plural legal orders. Both ethnography and genealogy hold a historical contingency and constructivist approach. I adopted a critical-interpretative analysis, bridging between interactionist and structural approaches, through which I situated micro-level understandings within the broader historical and structural context. This study shares the critical epistemological perspective that knowledge is 'co-production' - research is an intersubjective process, which requires reflexivity. Haraway (1988) famously called it an epistemology of location, positioning and situating: "situated knowledge". Prior to outlining and describing my research steps and methods, I provide some descriptive and reflexive insights into how some core features of ethnography relate to my field of study. Placing 'information' regarding access or ethics into a reflexive account, additionally allows for a thematic entry into the field of study.

\subsection{STUDYING-UP AND THROUGH INSTITUTIONAL LANDSCAPES}

\subsubsection{Entering the field: encountering the classical challenges of CBPC}

Entering the field meant on the one hand encountering some of the classical challenges of ethnographic fieldwork practice and, on the other hand, to encounter the classical challenges of CBPC. Several factors challenge practical police cooperation, such as language-differences, different national legislation, the variey of organisational forms of different member states' 
policing institutions, or the impact of different or competing national agendas (Lemieux 2010a; Mitsilegas, Monar and Rees 2003; Sheptycki 2001). Some of these I encountered also as researcher entering the field. For example, many times there is no 'homologous' interlocutor on both sides of the border, since police forces are organised according to variable functional and jurisdictional differentiations. As pointed out by Sheptycki (2001, p.151)

The (in)capacity to work within and around this 'policing complex' [the "different police division of labour in each country"] is an important feature of the 'occupational sub-culture of policing', a feature which is quite evident in the context of cross-bordering policing.

Working through this "complex", also meant encountering routes within and towards (research) cooperation (on access, see 4.3.2). The process of getting into the field through access negotiations, was more than a methodological pre-research step: it featured traditional ethnographic fieldwork tasks, such as the learning of (occupational) language(s), culture, social organisation and, importantly, it also provided preliminary indication as to decision making at the scale of border-regions. Additionally, accessing physically my field-sites went hand in hand with gathering information as to available public-transport routes, time-schedules of trains or busses, distances between public transport, the border and the local or regional police stations. This 'search' into routes and transportation was a logistical necessity for my own trajectory (most often, the option to reach remote stations was indeed by private car): this information is not of secondary importance, when inquiring about the policing of migration.

Interlocutors showed an interest in the study and interviews provided engaged encounters to discuss CBPC experiences. The more the spaces of CBPC overlapped with spaces governed through migration control, the landscape turned into a slightly more "politically charged arena" (Maillet, Mountz and Williams 2020). While this study did not aim to gain access to "obscured places" (ibidem), within a viapolitical reading some field-site location were politically charged. I thus do not take for granted that this research was made possible. I hope this study is able to do justice to the work-experiences of my interlocutors: both despite and through the 'translations' of placing emic meanings into the broader historical and analytical context. My prior internshipplacement with an EU agency responsible for law enforcement training ${ }^{34}$, can be considered of indirect benefit for primary and secondary access: some interlocutors (explicitly) positioned me as a research-outsider with some (non-academic) work experience inside the EU security architecture. Previously conducted qualitative research with military actors is likely to have enhanced my skills to engage with police officers. Additionally, I suppose being a female student working through what criminologist might call (or critique as) a non-adversarial or "appreciative" research style (Liebling 2001) was beneficial, however in my view this labelling is misplaced: 
empathy and active listening are crucial elements of ethnographic research and may also enable critical dialogue between researchers and informants (Feldman 2013).

\subsubsection{The borders of security}

Researchers studying up state-agencies highlighted how access (negotiation) is not simply a methodological lengthy procedure, that in the best case pre-cedes actual fieldwork. In policeresearch primary access constitutes a big challenge (Cunliffe and Alcadipani 2016; Fassin 2013a; Rowe 2007) and, as for other research areas, it is an ongoing process also once 'in' (secondary access). Gusterson (1997, pp.115-116) pointed out that (participant) observation does uneasily travel upwards, and that Abrams (1988) argued long ago that 'the state' regularly resists being studied. In discussing the possibilities of an "ethnography of the state", caution was expressed not to reduce the object of study to the object of observation (Trouillot 2001). Security often refuses conventional notions of locality (Feldman 2012). Particularly in the field of security research, aiming to gain research access and navigating around "secrecies" is however also research-data in its own right (de Goede, Bosma and Pallister-Wilkins 2020). I encountered borders and meanings of security that were mobile and multifaced, that took place as walls but also in form of procedures to follow along the lines and the abysses of administrative hierarchies; they took shape as channels that were opening as well as closing, but also in form of bridges facilitating contact and of gatekeepers - which in ethnographic jargon means persons who might facilitate you getting 'in'. Sometimes openings and closures happened through (un)fortunate coincidences and the process benefitted from my slowly increasing knowledge 'who' to contact. Carrying out research in multiple locations also meant engaging in multiple requests for research access. Access was denied on several occasions, for example by stating that "the data to be retrieved in the study consists in part of sensible information, which has to be treated as classified. Due to the planned publication, it is impossible to solve foreseeable conflicts of interest" (e-mail correspondence 2017). Notably, all stakeholders received the same projectdescription (Annex III) and interviews carried out resulted from a final positive response of 15 different stakeholders, albeit not all of them replied positively at first instance. Initially I was quite puzzled that my research theme was interpreted as aiming to access information deemed "classified". At some point I specified in the description ( $f n 1$, see p.340) what is meant by "confidentiality", to assure respondents that I was not interested in any "classified" information. Such motivation for access-denial provides a specific justification and it does also something else: it performs security. In interviews, the 'border control' of thematic areas was more subtle, and I was rarely told explicitly if some questions were 'borderline' or 'beyond'.

Questions of access and secrecy open a road to a conceptual engagement with the field of study. The following anecdote was one of the moments that contributed to my reflection upon what I 
call a process of migratisation of security. In occasion of an interview, my interlocutor brought along some papers, such as press reports, organigrams and activity reports. Some of them I was handed over, while one document that had served my interlocutor to support his verbal expose' with some chart, was for internal use only, I was told. My interlocutor added that the report did not contain any sensitive information, otherwise he would not have brought it along in the first place. But, as he pointed out, the report contained certain data on migration and therefor the orders were to keep it for internal use only. I mention this to make two points. Firstly, as I replied also to the security walls erected in the emails quoted above, this study has not been interested in "classified" information. Occasionally I did receive background information not for reference and accordingly not included into this thesis. But the point I wish to make goes in the opposite direction: of interest here is not the 'secret' but the (de)securitising move at play. What happens in the migration-security nexus, when politics play out by governing though migration control via policing and through the means of security? Thus, what does it mean and do, when migration data is handled as not disclosable sensitive information. In the email quoted above we find a particular framing of "sensitive information, which has to be treated as classified". In the case of the US, Masco analysed the proliferation of documents categorised as "SBU", meaning "sensitive but unclassified": an expansive category of information treated in practice as if it was classified. Masco pointed out, that the use of secrecy in the name of collective security defines the public sphere not as aspect of the democratic order, but as fundamental risk to that order (Masco 2018, p.191). Relevant questions are not only how democracies employ the use of force (Garriott 2013), but also how the possibilities of the security field are used when "governing through migration control" (Bosworth and Guild 2008) within a polarised public sphere. My study does not answer this question, but it is an important one to be named.

\subsection{3. (Mis-) Trust and plural identities}

The following day I got a phone call from an officer, who had expressed his availability to be interviewed for the purpose of this study, whilst my request had also to be approved at higher level. He told me that my request was being assessed and that from further up the hierarchy he had been asked a few things about me. Laughing, he added that of course he had checked what is available about me on the internet. "Don't trust everything the press writes", I replied equally laughing, but also wondering what he would say next. He switched into a serious tone, "I have normally a good understanding of people when I meet them. So, I said you are." He had been asked if I was trustworthy. (Ongoing methodology-memo)

The epistemological value of qualitative research stems from it groundedness. Research is rooted in social relations and the research process and knowledge (co-)production are embedded a landscape of complex relations and inter-subjective encounters. The above excerpt from my methodology-memo raises a couple of questions noteworthy to reflect upon. It was part of a 
longer reflection that I wrote half-way through my research. It proceeded along various instances, including discussions after presenting work-in-progress at conferences. Over the course of this study, I have been asked why I did not disclose my fieldwork locations and the specific policedepartments, why I did not plan to interview migrants, if my aim was to humanise police officers, if I was afraid that disclosing location and agency could endanger my (not my informants) career etc. Questions that bottom line sought to inquire how 'critical' my analysis and positioning was, recalling Becker's (1967) famous question "whose side are we [sic] on?". Once a post-doc colleague asked me if I planned to continue with research in this field, "you know, you can't write critically and continue doing research with the police" - a type of scholarship and a type of research-field deemed incompatible. Sometimes colleagues told me about similar ethical and methodological challenges. This fostered my decision that rendering them reflexively visible also in a PhD thesis is important. In my ongoing-memo I tried to get a grasp of the multiple relations of various type: accountability, trust, power, and what Fassin called the double "loyalty" along relations of deontology and ethics. My reference to the phone call above, not part of my interview data, might indeed be read as a betrayal of trust. Addressed in this context, we see that the writing process requires negotiating plural 'orders': deontological principles, trust and confidentiality, ethics, data integrity and scientific transparency.

A reflection upon identities can provide a reflexivity-tool to methodologically situate "situated knowledge" on the researcher side. Within anthropology the notion of plural identities has put to the fore how identity is always relational and situated - likewise is knowledge production. Identity aspects such as age, gender, class, profession matter during fieldwork: while on the one hand research participants place the researcher somewhere along these lines (for example 'gender', in a still male dominated security field), on the other hand actively emphasising particular identity aspects can also benefit relations. Writing in the field of qualitative security research, Stavrianaskis (2020, p.240) argued she found herself "having to be multiple versions of myself, often at once". Grassiani (2020, p.256) understood the anthropologist as trickster - ambivalent, in and out, empathetical and critical -, which gives the researcher some freedom of manoeuvre, but complex positionalities "go hand in hand with dilemmas". Going in and out of different settings - university, internship, plural field-sites, home(s) -, reminded me constantly of the multiple relations within which such a PhD project is embedded, but also of my multiple identities. Therein, my borderland origin (together with a messy belongingness of three universities and a passport that in a homogenous-nation-state imaginary does not fit my accent and look), was an identity-element which during my fieldwork facilitated a dimension of 'insider-ness' and of establishing relations. I often shared it with my research-interlocutors: (borderland) officers working in border-regions across Europe. The field is always full of surprises. 


\subsubsection{Situated ethics}

Within this study, situated ethics came into play during fieldwork and in the writing process. Interlocutors received a written outline of the study and an informed consent sheet prior to the interview. Interview respondents were informed about the purpose of the interview and the topic of the study in written form (informed consent sheet) prior to the interview. This was also verbally discussed prior of each interview. I did not ask for the signature of an informed consent sheets (see also Bigo 2014b, fn 2): constent was given orally. Officers with whom I was able to engage during observations, were explained the research purpose. As to the handling of data collected, I took necessary means for safe and encrypted storage and substituted identifiers with codes. This study did not encounter some of the grand ethical issues addressed by police-researchers carrying out ethnography during police violence (Jauregui 2014) or participating actively themselves in police tasks during their participant observation (for a review, see Rowe 2007). Instances of observing interactions between police and the policed were of reduced quantity (on passive observation, see 4.4.2). However, degrees of 'participation' require reflexivity also on more subtle configurations of ethical practice whilst in the field. In order to "do no harm", research needs ethically also to account for indirect impact that research can have on the targets of law enforcement measures, also simply through the type of question asked (see Wissink 2020). While I was careful of the phrasing of my questions, I was caught once by suprise, as an officer explained to me that a certain practice lacked a clear legal fundament. Prior interlocutors had always refered to a specific legislation in regards. Not dissimilar to Wissink's reflection upon her question to a deportation-file officer, why the officer did not tick a box usually ticked, I asked my interlocutor about the limits of that legislation for the practice discussed. He replied by thanking me for the hint, which was certainly not the response I had expected to engender.

Fassin (2013b) stated the difficulty to reconcile a double "loyalty" in order to be able to write: that of a deontological relation towards police research participants and one based on ethical principles of social justice towards those most concerned by police targeting practices. The writing process of this thesis and the representation of data and findings was embedded within many decisions and challenges, for example how to respect deontological principles and guarantee anonymisation (including internal anonymity), together with meeting academic standards of data integrity and scientific transparency. I have provided transparency of the research practice and removed identifying features of respondents. In the security field "dual use" is a frequent termalso knowledge production has a political dimension is not exempted from it. There is little control over data after its publication and the co-production of data puts upon the researcher the "ethical duty to control how research materials 'go public'" (Pels et al. 2018, p.395). In this dissertation, empirical fieldwork-data is represented as anonymised and without location. On several instances 
I connect my findings and analytical considerations with concrete CBPC examples (collected in desk-research and referenced through public documentary sources). Said this, I wish to call the reader to the necessary caution, not to deduce that the concrete examples and sites provided over the course of this thesis, necessarily correspond to my anonymised field-site locations.

\subsection{RESEARCH METHODS AND STEPS}

This research combined the study of policy and laws on a European, bilateral, and national level, with that of qualitative research carried out between 2017 and 2019 in border-regions of several member states. Therein carried out interviews and observations were triangulated with a review of documentary sources of relevance to the respective border-region. Therewith, I adopted a mixed method design, recognising the necessity to collect data eclectically from a disparate array of sources (Riles 2006; Shore, Wright and Però 2011; Gusterson 1997; Ferrell, Hayward and Young 2015; Tsianos and Karakayali 2010).

\subsubsection{Desk research}

\section{Documentary sources on specific border-regions}

Initially I carried out a desk research on inter-state borders and CBPC experiences, which was further refined throughout the research process. It included media-reports, governmental documents (Ministries of Interior), police-reports (annual reports, police-journals, press-releases etc.), non-state publications, parliamentary debates etc. Literature of relevance was collected from publications across different languages and countries, published in German, Italian, Spanish, English and French (and to a limited extent in Hungarian and Danish). Firstly, sources were collected and assessed with regards to developments in police cooperation in specific borderregions. Secondly, document sources were of importance for a localised mapping of instances and problematisations through which the phenomenon of "secondary movements" and related matters have taken place in the respective regions. Routes officially problematised as those of "secondary movements" notably cross several internal Schengen borders, producing a particular visualisation and problematisation thereof. ${ }^{35}$ The desk research conflated in identifying stakeholders to be approached for interviews and served for data triangulation and analysis. In addition, documentary sources were used to map developments prior to interviews, enabling me to combine an open interview technique with region-specific prompts during the conversation.

\section{Policy, legislation, jurisdiction}

I have concentrated particularly on policy that focuses on police cooperation, as well as on problematisations of "secondary movements", primarily within the temporal scope of 20142019/2020 and following-up the European Agenda on Migration (EAM) and the European Agenda 
on Security (EAS). In terms of legislation, I engaged with bilateral agreements and EU legalisation in the field of law enforcement cooperation (and the Dublin system), complemented by relevant legislation on national level. Under the purview of bilateral agreements fall those of police cooperation and specific agreements regarding PCCCs and readmissions (see Annex II), whereby I considered not only legislation in force but also anterior agreements. My assessment of case law was restricted to selected cases of the Court of Justice of the European Union and a few cases on national level.

\section{Secondary sources}

In addition, availability of scholarly literature and secondary sources differs greatly amongst countries (for example, if one compares Germany and Italy). This can be explained a) by the varying degree of academic establishment of criminology and policing studies in the respective countries, and since b) scholarship focusing on countries with mostly internal frontiers, present a higher likelihood of discussing matters of relevance, while for countries with internal and external borders, scholarship has mostly concentrated on the latter. While in this study I do not inquire the role of CBPC (and processes of so-called "Europeanisation" or "decentralisation") on national police organisation, further research could contribute filling existing gaps. Where necessary to supplement concrete examples, I provide a background on police organisation for Italy, Austria and shortly Germany in Annex II. Considering the scarce amount of reference literature on Italy, I have provided a longer section on Italy.

\subsubsection{Interviews and observations}

Empirical data was gathered regarding nine inter-state borders and concerned inter-regional or specific trans-frontier police cooperation experiences, situated on sections of the respective inter-state border. Four inter-state borders were studied in more depth.

\section{Access and sample}

For research access, departments at the regional level were approched by email and, if applicable, the department or force responsible for border(-area) policing. I did not approach central ministerial levels for research access, altough at times my request was forwarded up-thehierarchy for approval. In a limited number of cases, access request was approved on site, facilitated by my physical presence. My initial sampling, supported by desk-research, was driven by the research question: empirical research concentrated on inter-state borders, which were along routes officially problematised as those of "secondary movements" (image 2, p. 303). With regards to the sample of my interview participants, only in very limited circumstances did "snowballing" or direct referrals from one respondent to another consitute the sampling. The sample was not respondent driven, but dependent upon which officer a) covered the function investigated in this study, b) was appointed for interview by superiors (in few cases) or c) simply 
who was on duty when for example I gained permission to observe a patrol. Circumstances in which I had asked prior interlocutors if I could make their name when presenting myself to a stakeholder/individual (without referral), facilitated a positive response. Although like in police cooperation 'pulling the string' is useful, I have used these tactics only for three interviews (for reasons of internal anonymity, amongst others). Sometimes my request-interaction never made it passed the person responsible for public-relations and it was denied. In some occasions, a negative initial response was followed by subsequent steps: a) explaining again the research aim or concrete request (clearly circumscribing the committment the stakeholder had to take with me), which in several occasions let to a positive outcome, b) second attempt at a later stage, if the negative response indicated time constrains (not successful), c) through personal-contact with high-level officers working on regional level, for example during public police-events, whereby I paid attention not to undermine the level of command, i.e. not to approach an officer whose superior had denied the request already, d) approaching a different police-stakeholder, if applicable in that border-area/country.

\section{Interviews}

Interviews constituted the main method of qualitative data collection. On several occasions I was asked to submit my interview questions prior to receiving research-authorisation or prior to the interview. Based on a semi-structured interview guideline, I submitted themes and main questions, tailored to the respondents' department (and, if known, to the role covered by the respondent). The guideline structure proceeded by themes and was formulated in open questions. During the interview itself, the style of interviewing could be categorised as open. This enabled me to cover the themes contained also in the semi-structured guideline, whilst allowing for the inclusion of the diversified professional experiences of my informants. In most cases, I carried out a short phone-conversation with the main respondent prior to the interview. Most interviews were recorded upon permission of my interlocutors. In notetaking I differentiated between verbatim expressions and my notes. Interviews were carried out in five EU member states (with officers 'belonging' to more than those five countries). As can be apprehended from Table 2, I carried out twenty-four formal interviews with 28/29 interlocutors. The medium length of interviews was approximately 1 hour and 50 minutes, the longest lasted 2 hours and 40 minutes. Not included in this table as interviews were ethnographic conversations recorded as fieldnotes. Several of the interviews were embedded within a longer interaction, useful to build up rapport, such as coffee-breaks with the respondent or other officers. Seventeen interviews were carried out with police officers working in border-regions, an additional one was carried out with a former central level official, but regarding long term developments of CBPC measures. Material from interviews categorised as "other" were only partially included, since they represent 
different professional categories and also led into additional themes addressed. Initially I had aimed to interview a broader range of stakeholders of relevance, but due to time constrains and the need to delimit the topics and stakeholders, this trajectory could not be pursued within the frame of this study.

Table 1: Interviews (IVs) by stakeholder category ${ }^{36}$

\begin{tabular}{|l|l|l|l|}
\hline Formal Interviews & Interlocutor stakeholder & IVs carried out & interlocutors \\
\hline Border-Regions & PCCCs & 3 & 4 \\
\hline & Regional Police Departments & 11 & 14 \\
\hline & Local Police Departments & 3 & 4 \\
\hline & Former central level official & 1 & 1 \\
\hline \multicolumn{2}{|l|}{ Other (only partially included) } & 3 & 3 \\
\hline & EU Agency & 1 & 1 \\
\hline & Prosecutor & 2 \\
\hline & $\begin{array}{l}\text { Stakeholders dealing with police } \\
\text { cooperation above CBPC scale }\end{array}$ & 2 & Nr IVs \\
\hline Data & Stakeholder & 24 & Interlocutors \\
\hline $\begin{array}{l}5 \text { countries, } \\
9 \text { inter-state borders }\end{array}$ & 15 & 29 (28) \\
\hline
\end{tabular}

\section{Ethnographic conversations and observation}

Research was carried in a few punctual occasions through (passive) observation, for example with border (area) patrol, during readmissions, or in occasion of police events. Albeit instances of reduced quantity, they provided unique occasions to observe practices and to converse also with street level patrol officers. My interlocutors knew (mostly they were informed by their superiors, and sometimes I was accompanied) about the purpose of my presence. With regards to the degree of involvement during observation, in the very few instances where this involved observing an interaction between police officers and persons undergoing a check, I engaged in "passive observation", a role that has been defined as "bystander" (DeWalt and DeWalt 2011, p.23). Moments of ethnographic conversations with officers could be termed a "moderate participation" (ibidem). However: while taking shape in a more 'traditional ethnographic' fieldwork style, these moments lacked the sort of build-up relationship of trust and identification of patterns over time in behaviour, associated indeed with participant observation as long-term research method. Thus, they were rather 'meet-and observe-once' occasions, "instant ethnography" (Ferrell, Hayward and Young 2015). It had the benefit of observation and allowed eliciting additional questions and responses as the conversations took place while or after officers carried out their work tasks. Conversations and observations were jot-noted on paper (fieldnotes, $\mathrm{FN}$ ). 
Observations were carried out also independently in public spaces such as train-stations and 'en route' during my own journeys. During my field-work visits and to familiarise myself with the area, I drove along the main roads, across (former) border-crossing points, and studied possible transport routes. In addition to my travels to reach my field-sites, due to the PhD trajectory between three universities (UK, Germany, Netherlands), an internship period (Hungary) and several trips 'home' (Italy and the UK), I have been travelling through Europe over land-routes many times. I switched between different modes and routes of transport: regional and crossborder trains, cross-border busses, small bus/van, private car. Especially public transport journeys provided not just rich observations of checks but also conversations with other passengers. Crossborder commuters, for example, have quite an astute understanding of border-area and border control policing. As tendentially nobody was informed about my study, these observations served primarily to enhance my understanding and provided at times useful background information to draw on during interviews.

\section{Transcription and translation}

Fieldnotes were reviewed immediately, and material transcribed as early as possible. I kept memos on methodological issues, analytical thoughts, and occasionally fieldwork memos on specific issues that combined various sources. On several occasions I supplemented my handwritten notes by audio recordings immediately after the fieldwork-encounter: audio-notes contained my own observations, conversation elements or my own reflections, that I had not been able to "jot" onto paper. These proved to be a very valuable support. All the material was worked with in the original languages of notetaking and recording. In order to treat data confidentially but enable me in the analysis phase to triangulate data, interlocutors and locations were substituted by codes composed by letters and numbers. All non-English materials were translated by me.

\section{Representation of empirical data}

Sources of quotes from empirical research are identified as interview (IV), fieldnotes (FN) or fieldmemo (FM). To identify and to anonymise the speakers, the following two criteria and codes are used in this study. Firstly, following Gallagher's (2002) differentiation between "local transfrontier", "inter-regional" and "inter-governmental" cooperation, I have identified respondents based on their allocation therein. Most of my informants worked either at regional police departments (abbreviated as RL) and were knowledgeable of "inter-regional" cooperation dynamics, or they worked at departments adjacent to the border (LL) and were engaged in "transfrontier" cooperation. This is a simplification, and while 'local' and 'levels' are analytical objects, I have maintained Gallagher's differentiation for identification purposes only. I have included PCCC respondents into the first category ( $R \mathrm{~L})$, albeit I am aware that in analytical terms they 
should be placed separately. Secondly, respondents are identified according to their functions with respect to the thesis' research theme, not by their police-rank or position in their respective national police organisation. My interlocutors were officers dealing with compensatory measures, border (area) control measures and cross-border police cooperation, but their organisational anchoring was different from country to country, due to functional and jurisdictional differences. The identification serves to provide an indication as to the speakers' professional experience, functions, competencies. I use the following definition:

- high-level-officer (HLO): a) officers with directing functions (director or vice) in the fields of compensatory measures and border (area) control and related operations and procedures; officers engaged in cross-border cooperation exchange with counterpart across the border, and with HLO on lower/higher level; b) officers carrying out the coordinating function in PCCCs;

- mid-level-officer (MLO): a) officers carrying out (mainly) office functions with regards to specific operations and administrative procedures, such as readmissions or joint operations/patrols; b) PCCC staff;

- street-level officer (SLO): patrol officers who carry out border (area) control, joint patrols, etc.

E.g.: 'IV_RL-HLO' stands for 'Interview, Regional Level (inter-regional cooperation), high-levelofficer'. I have not identified each speaker with an interview number. As a mean to differentiate between speakers, I highlight in the text if I am quoting the same or a different interlocutor on the same topic, which allows to outline the evidence supporting my analysis (and an assessment thereof). For the purpose of this study, it was more important to identify the level and function my interlocutors, than the specific border-region of their workplace. In order to guarantee anonymity and confidentiality, it was not possible to provide both identifiers.

\subsubsection{Data triangulation and coding}

As characteristic of a multi-sited study, the type and depth of data varied amongst locations. Data triangulation was hence of importance and enabled through the mixed method approach and extensive use of document sources. Interview material and observations were confronted with each other and with data resulting from the desk research. Whilst I aimed to verify and crosscheck described situations, "ethnographic evidence" (Csordas 2004) was however sought with respect to the identification of certain patterns of practices and the meaning officers attributed to their experiences and to the relations within which their practices are embedded.

Qualitative researchers have both recognised the obvious need to guarantee data integrity, the quality and the credibility of research, but also questioned the application of quantitative 
concepts (such as reliability and validity) to assess qualitative and in particular ethnographic research, or at least called for an adapted conceptualisation thereof in line with a qualitative paradigm (on ongoing debates, see Golafshani 2003; Lecompte 1982). In addition, there are still questions as to the methods to assess multi-sited ethnography (Elliot, Norum and Salazar 2017). Consistent with the epistemological underpinnings of ethnography, I content that transparency about the study, rigor in analysis and think descriptions will allow an assessment and facilitate further research by other scholars. I outlined the conditions of data collection, choices made regarding the sample and methods used, background information on epistemological, ethical, and political implications. On specific empirical fragments, eventual information regarding data saturation and consistency will be provided in the context of my analysis.

I content that the main points of analysis and explanation of ongoing processes advanced in this thesis allow for a certain 'intra-EU-wide' generalisation, due to the multi-sited data collection, in those instances when internal Schengen borders and CBPC come to constitute a strategic zone and instrument for the governance of unauthorised mobilities. Said this, an obvious reservation must be made, considering the multiplicity of internal Schengen borders and regions, stakeholders and regional specificities. Particularly regarding PCCCs, this study presents an insightful but nevertheless small fragment. While my overall research question concerned the entanglement of CBPC with mobility control, it would indeed be of interest to further engage with (CB)PC in other fields of policework. The analytical framework proposed is of value beyond the field of migration policing, as it provides tools to engage with the spatial-legal dimension of police cooperation and the dynamics between law and practices.

\section{Codification}

Initial coding proceeded through in-vivo codes as well as structural codes regarding the different policing instruments, general aspects of CBPC (facilitating factors, challenges), actors, and broad codes such 'migration' and in the research process emerging themes, such as spatial, legal and temporal elements. Subsequent coding refined the in-vivo coding and amplified structural codes through processing codes and versus coding - (border control 'vs' border-area control, centre 'vs' periphery, relations between various scales and actors, law-as-text vs law-as-practice, freedomsecurity-migration - border-struggles). I used NVivo-software as support, but due to pluri-lingual material, in-depth-coding proceeded through manual coding. 


\subsection{THE BORDERS OF THIS STUDY: limitations and focus}

\section{Research question and methods used}

This study has been informed greatly by my decision to carry out a multi-sited research comprising multiple fieldwork locations. While I consider this approach necessary to answer my research question, I am aware that multi-sited research raises open questions, as pointed out in Methodologies of Mobility. Ethnography and Experiment (Elliot, Norum and Salazar 2017, p.10):

This raises unresolved questions about whether one should spend less time in each site (...), and whether this implies forgoing some of the depth often considered the main strength of ethnographic fieldwork (...). Nor is it clear if one should apply the same criteria for 'good' fieldwork of traditional ethnography to multi-sited ethnography - an open query which reveals how mobility may require us not only to think of new methodologies, but also to rethink the very methods through which we judge and assess 'research' itself.

In this study, the type and depth of data varied amongst locations and is based on knowledge gained under conditions of variable access and intensity. Research on cross-border policing, which per definitionem involves police authorities of separate national jurisdictions, necessarily involves some sort of multi-sitedness. Concretely, while in some police departments empirical data was primarily gathered through interviews with 1 to 2 officers, in others I was additionally able to observe (in single occasions) joint patrols, border-area patrol, readmission, was shown the facilities and able to talk to several mid-level and street-level officers. When needing primary clearance for research access and when negotiating additional secondary access, such variables are inevitable. Researchers carrying out multi-sited ethnography have acknowledged (Nader 1972; Marcus 1995; Hannerz 1997; Klepp 2011) that the results of a study-up research as well as of a multi-sited project, might be unsatisfactory in terms of classic ethnography: the knowledge produced is not the outcome of a long term immersion in the lives of a particular group studied, participant observation often does not constitute the primary method and results are likely to be presented in less descriptive terms. Interviews were both a possible and a valuable method to investigate the topic of this study from the perspective of involved police officers. Interviews and observations were triangulated with documentary sources of relevance to the respective borderregion. As highlighted by Gusterson (1997), especially in so-called "study-up" research, it is important to find a way to study what we want to study. However, I may borrow Andersson's (2017) well put expression, who defined his study Illegality.Inc a "borderline ethnography": a) an ethnography of borders, b) aware, that for some it might not constitute 'real' ethnography.

Multi-locale research 'versus' fieldwork in one location over a long period of time produces a different type of knowledge. The depth on which ethnography's particular claim of knowledge rests on, in multi-sited research is diminished in one way, and gained in another. The multi-sited design enabled me to study through different sites, thereby engaging in discourses and practices 
on the side of 'the' police, often imagined as producing a homogenous state narrative. While ambitious in breadth of sites, this study was moderate as to the perspectives it aimed to understand. Different to other multi-sited studies, which analyse interactions or positions across different categories of actors (e.g. police, migrants, NGOs), this study is far more 'restricted'. Therewith it enabled a more in-depth and nuanced understanding from within one vocational category, across several countries. While extended research access in one location provides a richer and locally more embedded verstehen (as police ethnographies show), it would have had shortcomings to account of the widespread dynamics at play across different border-strips and the multiple configurations thereof. This study in turn enabled an in-depth understanding, as to how CBPC configurations matters in the control of differential mobility rights in the Schengen area today, and of processes and patterns through which situated practices contribute to ongoing re-configurations in the legal realm.

A section on long-term developments in the field of CBPC for selected and identified borderregions was initially envisaged to be part of the presentation of the study results (study description, Annex III). This plan did not materialise in this thesis, primarily for matter of space, and because an analytical flow of the chapters was given priority over longer descriptive parts. I am aware that such representation would have corresponded more to writing standards in policecooperation scholarship. It would additionally have enabled an emplacement of interview-data. On several occasions, I was invited to visit border-locations that held a special place in the memory of border-land police officers: not just old border-infrastructure and strategic viewpoints, but bridges, cemeteries, memorials, etc.; invitations which I always took on board. Officers highlighted the need to localise cooperation experiences: notably, not merely at the level of the inter-state border, but at the inter-regional and the trans-frontier level, due to specific historic, symbolic or political meanings. It was beyond the possibility of this thesis to sufficiently localise cooperation experiences in order to do justice to this dimension (and to some degree, to this part of fieldwork data). This is due to space, but also for reasons of anonymisation.

Finally, and of deontological relevance, the multi-locale fieldwork practice was beneficial for discussing empirical data for analytical purpose, without compromising the anonymity of research participants. Research bound to one 'small place' (where notably everyone knows everyone), but also across 'small places', carries a dilemma for the researcher with regards to anonymisation and the 'do no harm' principle. Other scholars have responded to this dilemma by either creating fictitious locations or entities altogether (Feldman 2019), by removing any reference to characteristics of interlocutors whatsoever (Bigo 2014b), or at least partially (Fassin 2013). In research designs without anonymity granted to 'study-up'-interlocutors, at times being public-relation officers or spokespersons, this is less of a dilemma. In this thesis I proceed as 
follows: on the one hand I advance my analysis through empirical data, which I have anonymised and de-localised, and on the other hand, I combine empirically gained analytical insights with a discussion of concrete examples, through data derived from primary documentary materal or secondary sources. The reader is called to the necessary caution, not to deduce that the concrete examples provided, correspond to my anonymised field-site locations.

\section{Research 'sample'}

This study puts at the centre CBPC and actors directly involved therein. This choice is justified by the lack of empirical research. It is likely that the politicised climate eventually has impacted on the quantity of research permission granted by authorities. I deem the positive response of 15 stakeholders a success, considering also the challenges encountered by other PhD students at the time of study (Lindberg and Borrelli 2017). Within the sample of interviewed respondents, most of my interlocutors were police officers working in "compensatory measures" or in border control in local or regional departments. Interviews were carried out mostly with high-level officers and some with mid-level officers. 'Street-level' patrol officers were part of the sample (FN), albeit to a minor degree and therewith there was not sufficient data saturation for a rank differentiation of findings. High-level officers, which consitute the biggest participant group, were very priviledged interlocutors for this study: they are (see description above) also responsible for engaging in cross-border exchange both with their counterpart across the border, and with HLOs on lower and higher level. In-depth preparation for interviews and field-sites through deskresearch, combined with ethnographic fieldwork skills, engendered conversations which went beyond 'PR talk' (sometimes identified as a risk, when using interviews with institutional actors as main qualitative method). The sample enabled to reach sufficient data-saturation on the topics analysed in this thesis. However, considering the sheer amount of internal borders and localised CBPC experiences, further research would be an asset. In addition, the sample mostly consisted of border-regions were "secondary movements" were perceived to constitute a relevant phenomenon: inquiring and comparing cooperation in other fields woud be needed to further enhance understanding as to the role of CBPC across different crime and security priorities.

Initially I aimed for a sample comprising different professional categories, but I soon realised that in order to focus I had to draw a limit as to the stakeholder-typology interviewed. There are additional stakeholder worth including in a study on this specific topic. On the one hand, central state authorities or strategic policing levels, on the other hand, considering the recent role of Frontex and EASO in monitoring "secondary movements", or of Europol and Eurojust in the field of JITS on migrant smuggling, EU Agencies should be included in further research. While the study sample provided several insights into the topic of migrant smuggling, including on cooperation through JITS, I had to abandon the already sketched route and eventual interlocutors for 
interviews, as it would have led me beyond the space and time frame of a PhD. This is unfortunate and would certainly be a very important further route to follow. In addition, considering the important role of EU stakeholders such as the DG Home and Migration of the EU Commission, or Council's working parties of relevance, empirical research with EU stakeholders would be an asset to refine the understanding and analysis. EU stakeholders were only included into this study through their public documentary products.

\section{'Cross-border' or borderland: across disciplines, across countries}

Cross-border research (across disciplinary fields and across countries) has the benefit to overcome disciplinary boundaries in the production of knowledge, but it is faced with the need to make selective choices, as highlighted by Aden (1998) in his comparative PhD study Polizeipolitik in Europa. According to Aden, it is impossible to enter too much into the detail of intra-disciplinary theoretical debates, and the assessment of abundant legal and policy documents on EU and national levels requires making a selection and accepting a certain level of possible imprecision. Different to Aden's PhD, this study is not of comparative nature and I do not compare systematically national legal frameworks. My study's primary asset lies in its empirical study component, or indeed, in the therewith enabled analysis of the interdependence between (law as) practices and law-as-text. A review of (EU and) national legislation of relevance was part of the research, but especially national frameworks are only included selectively. It is fair to say, that it was impossible to assess and in particular to keep track without possible gaps, of ongoing legal developments in interacting fields of law, across scales and for multiple countries. Whilst engaging to my best knowledge with the legal technicalities, which I analyse from a social-science perspective, I welcome feedback on any shortcomings. Also, the empirical data certainly allows for additional strands of social science analysis or theory triangulation. Finally, the challenge of writing for a multi-disciplinary audience, cannot be downplayed. Putting myself in the shoes of a reader's perspective, I have made use of the endnotes to facilitate this task.

\section{Politics of a research design}

Addressing the research problematique along the methodological route chosen produces an analysis of a phenomenon that is not bound to one specific internal Schengen border or reducible to a dynamic particular to a specific cross-border interaction. Whilst, yes, each (border) site presents its particularities, as single case studies have greatly demonstrated and which this study does only scratch on the surface, the research design has enabled me to study through multiple sites, from border-area practices to policy problematisations and case law, in order to grasp largescale processes at the heart of Europe's (re)configuration and ongoing developments. This thesis draws a picture that whilst based on partial and situated patches, requires to be also read as a matter not of a single field-locale, but of the reference object they compose - Europe. 


\subsection{BORDER-STRIP: on lines and shades through visual criminology}

This thesis addresses the reconfiguration of borders and of movement through space: what better suited medium than through drawing techniques - such as drawing a line or shading a space -, to explore and represent the theme of this research. The BORDER-STRIP - merging the 'border-strip' and the 'comic-strip' -, runs through my thesis, each chapter being introduced by a full-panel illustration (occasionally by several). In the comic-world, the so-called "splash page" introduces the narrative and sets the climate for what follows (Eisner 2008).

Drawing has a long history in ethnographic fieldwork and has recently been re-discovered as technique and process of how to see and how to document ethnographically during fieldwork, and as a mean to make sense of the field and the researcher's position therein (Taussig 2011; Geismar 2014; Causey 2016; Bonanno 2018). As pointed out by Causey (2016, p.29), 'graphy' is defined as "processes or styles of writing, drawing, or graphic representation [Murray 1971]". Although Clifford and Marcus (1986) described ethnographic writing long ago as a situated, partial, serious "fiction", (ethno)graphic storytelling is only slowly emerging through a 'graphic turn' in social science (Atalay et al. 2019, Ingold 2011) as a representational method, especially in social medicine and anthropology. Drawing is however frequently facing a double relegation (Dix and Kaur 2019). On the one hand, photography and audio-visual media are usually the privileged means to record and represent fieldwork, considered more accurate and immediate. On the other hand, as academic publishing practice, the supremacy of the written word holds large. 'Writing' - written text codified within particular forms of social science writing -, is still considered the most scientific form of representation of social life (Weissensteiner 2011).

Albeit the written word holds primacy in this thesis, I content that illustrations present important advantages for scholarship (Weissensteiner, forthcoming). Graphic research-monographs would in my opinion be both a powerful mean for public impact and a brilliant educational tool. Drawing - a synthesis between images and words - has much to offer to criminology, as here explored through the splash page. It is an epistemological as well as representational mean for (visual) knowledge production, and an "inscriptive practice in its own right" (Ingold 2011). In cultural criminology images that "say something significant about the world the image encapsulates" (Ferrell, Hayward and Young 2015, p.230) have been identified as visual dimension of an instant ethnography. Images can be drawn. Instances form a narrative. In addition to the possibility of drawing as fieldwork method, I argue that drawing enables us to think through, to analyse and to represent research. Drawing allows to explain complex relations by waving together data, evidence and theory. It enables to represent complex glocal and spatial-temporal entanglements a more immediate way than the order of text can. The author-artist controls the story and creates a multi-layered surface of meaning - the reading allows for and requires the interpretative and 
visual engagement of the reader (McCloud 1993; Eisner 2008). In specific, rather than being of minor "documentary" or "representational value", drawing has the following representational asset: 1) It enables to communicate research on complex and somewhat specialised socio-legal issues to a broader audience, but it is also a powerful mean to engage an academic readership. Different levels of meaning are embedded in the illustrations. 2) Drawing allows to overcome methodological and deontological challenges of criminology research: as visual method during fieldwork (in 'security-spaces' where photography might not be possible), and as a mean of representation: illustration and sequential art allow to depict persons, places, situations, stories through ethnographic non-fiction or fiction, thereby guaranteeing anonymity and confidentiality. It does so, despite and through visual representations. 3) Illustration gives the freedom to steer the focus of the reader. Photography, whilst being maybe more 'accurate', gives equal visual and semantic weight to everything in focus in the picture (see also Causey 2016, p.8). Drawing enables the reader to 'see' what is of analytical value in the argument proposed. 4) Sequential art has the potential to take the reader on to a very tangible journey, whilst respecting deontological principles: to the lived experiences, the routines, the ambiguities and the messiness of the everyday.

Each BORDER-STRIP illustration engages with a significant fieldwork encounter or a core symbol. I have used, and sometime times combined in a single page-illustration several genres: historical and non-fiction, ethnographic (non)fiction, conceptual images. This is certainly a practice and a line of thought to be traced further into the future of cultural and global criminology. Latest since Sousanis' stunning PhD thesis Unflattening (2015) entirely in comic form, it should be clear, that our tools of thought are not only words: academic thinking can be powerfully visual. 


\section{PART II}

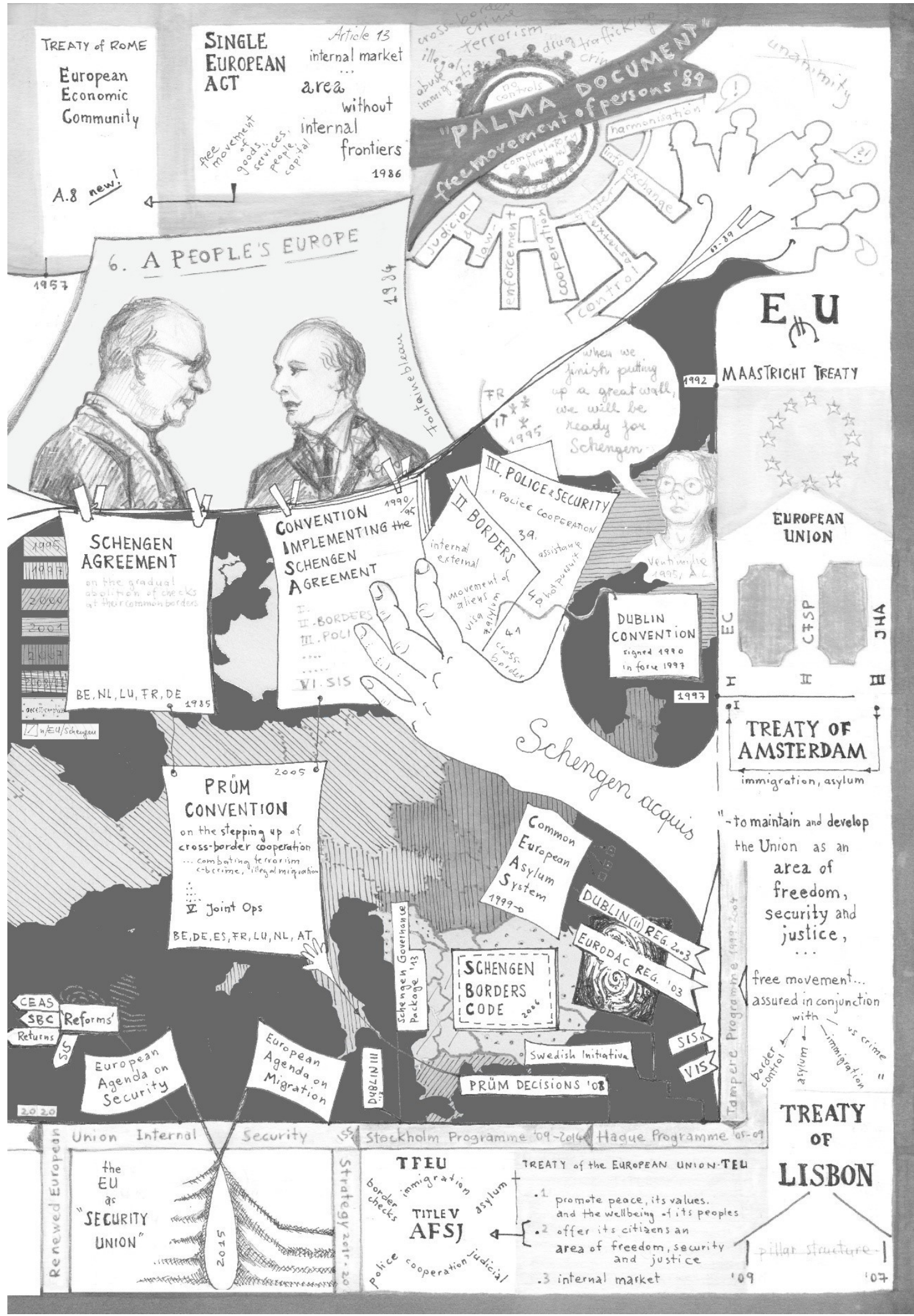




\begin{tabular}{|l|l|}
\hline SCHENGENLAND__ O. \\
\hline
\end{tabular}

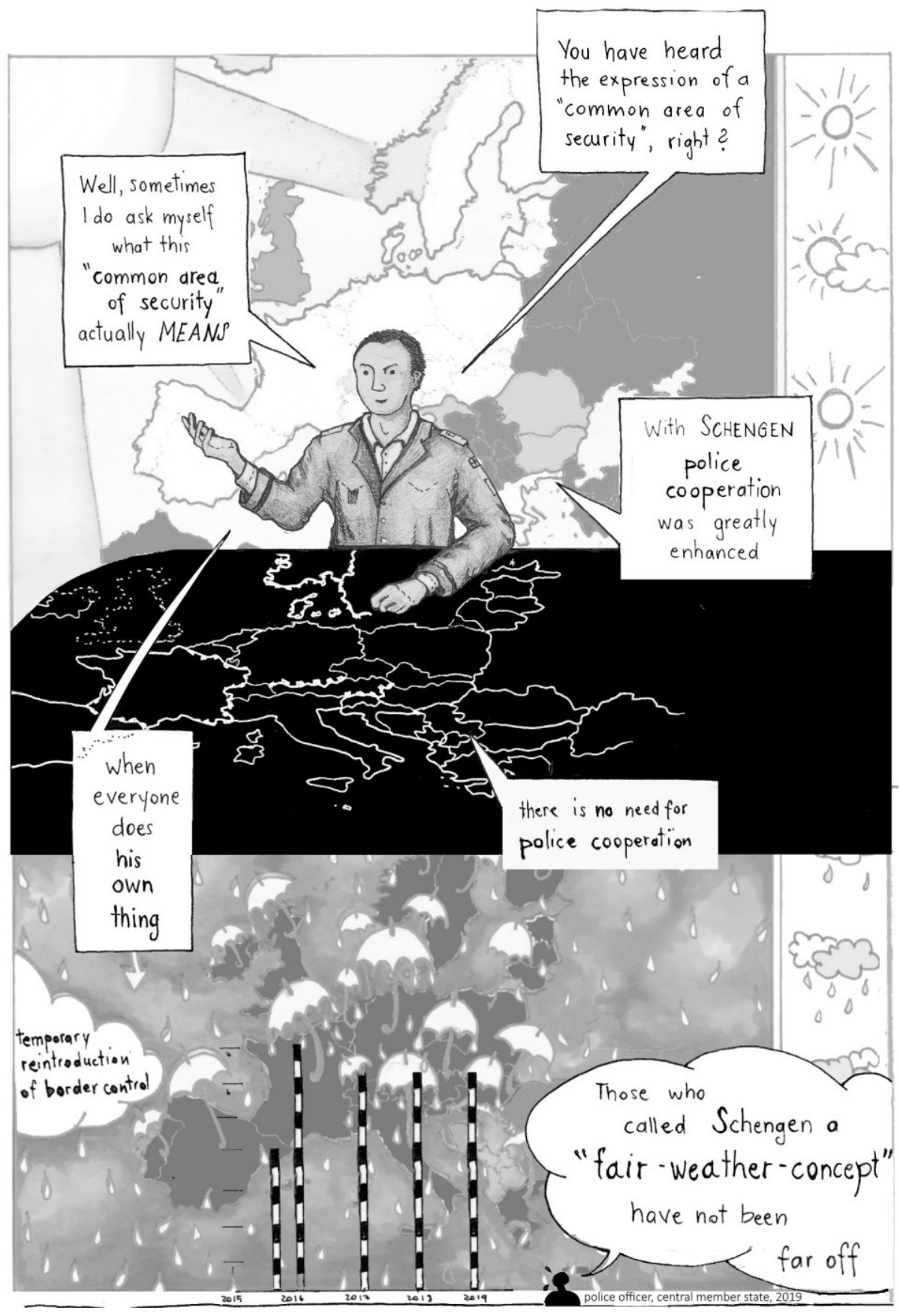


[E]ach new form of state, each new form of political power, introduces its own particular way of partitioning space, its own particular administrative classification of discourses about space and about things and people in space. Each such form commands space, as it were, to serve its purposes (...).

(Lefebre 1991, p.281)

Movement is the order of things. (Kotef 2015, p.ix)

From the perspective of policing, "Schengenland" is deemed to have greatly enhanced crossborder police cooperation throughout Europe, a sentiment that was expressed by the officer quoted in the illustration. As traced through time, the idea of an area of freedom of movement goes back to the Single European Act (1987). It was formulated as an Area of Freedom, Security and Justice (AFSJ) in substantial law for the first time in the Amsterdam Treaty (1997), which incorporated the "Schengen Acquis" into the EU framework. The Schengen area today comprises 26 countries (Table 2, Annex II). The AFSJ now figures as an objective of the EU even before the historically anterior internal market (TEU, art. 3).

The AFSJ is a spatial-political concept and its legal configuration regulates space and mobilities: "things and people in space" (Lefebre 1991, p.281). Police cooperation (e.g. through CISA, the Prüm Decisions, or the Swedish Framework Decision), internal and external border matters (Schengen Borders Code), as well as differential mobility entitlements (legal migration, visa regulations, and the Dublin Regulation as part of the Common European Asylum System) all fall under its purview. Schengenland and later the AFSJ, have been described as a laboratory for the management of differential mobility-rights and border-regions as a laboratory for EU integration. Whilst borders have long been a symbol of sovereignty and of a territorial polity - a line dividing inside and outside - the AFSJ is not represented as a 'territorial' polity, but as an 'area': an area in which the 'internal' border in absentia (as a line) has become a core symbol.

The reintroduction of border control within this area by some member states in response to unauthorised mobilities through the Schengen area in 2015, and maintained over subsequent years, have let the depicted police-officer (wearing the uniform of a country with border control in place) worry that Schengen sceptics, who dismissively called it "a fair-weather concept", could turn out to be proven right. 
CHAPTER 5

CROSS-BORDER POLICE COOPERATION (I)

A GENEALOGY OF POLICING-MOBILITY INSTRUMENTS IN THE BORDER-STRIP AND THEIR SPATIAL-LEGAL CONFIGURATION

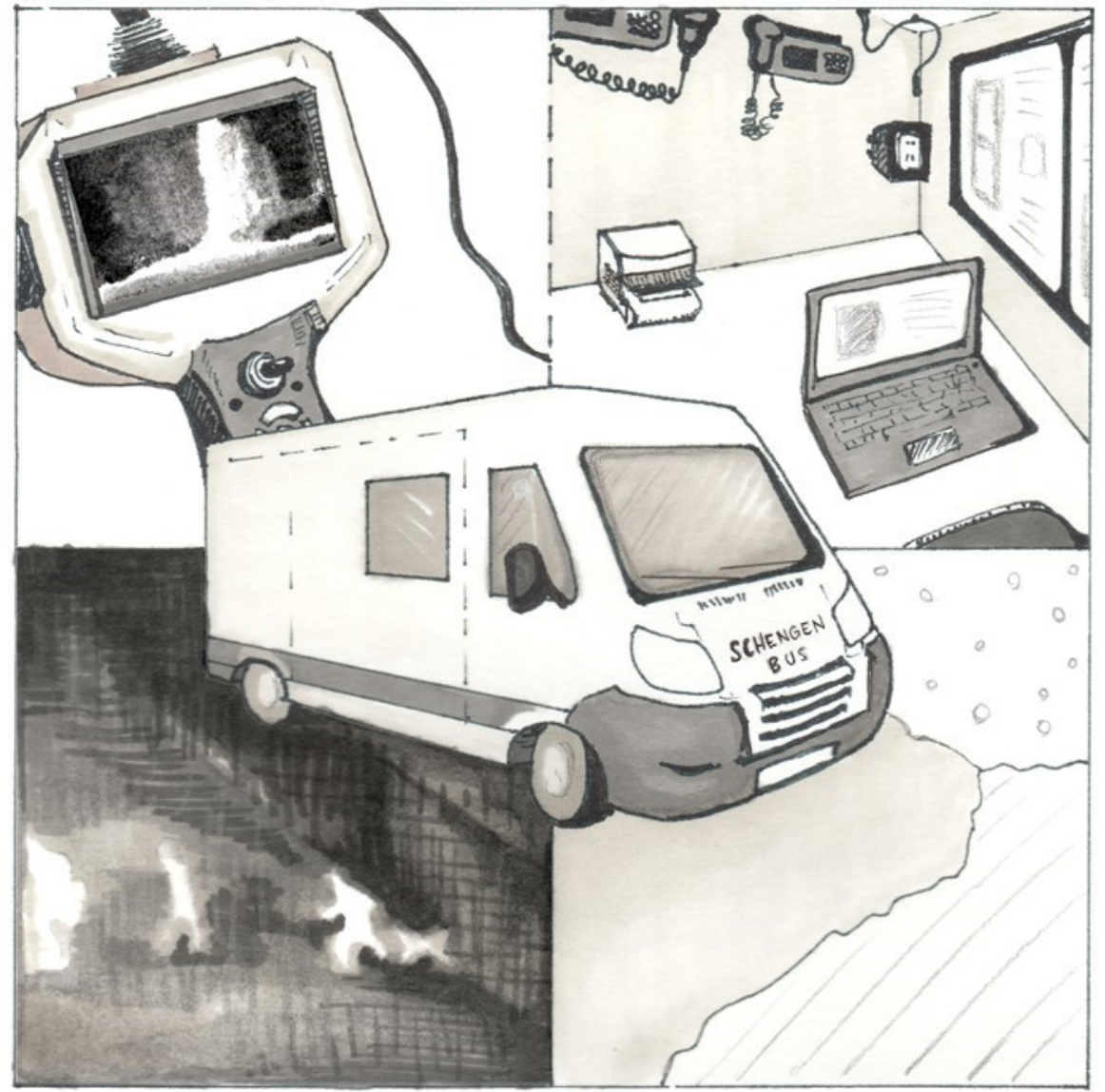




\subsection{INTRODUCTION: the "Schengen bus"}

In 2018, a joint police exercise took place in Albania, in the border-area to Greece. While Greece is an EU and Schengen member, Albania belongs to the so-called Western Balkan countries and has held EU candidate status since 2014. Albania is signatory state to the Police Cooperation Convention of South-East Europe (PCC SEE). ${ }^{37}$ The objective of the joint exercise and operation, together with strengthening cooperation across the region, was to increase practice and knowhow in the "detection of illegal border crossings", in "debriefing of migrants", "readmissions", "joint patrols" and other "compensatory measures". Albania is located along the so-called "Adriatic Route" where, despite statements of a "closure" of the "Balkan Route" in 2016, the interception of persons on the move without regular status, and the effects thereof, have continued. Together with the national Albanian police forces, officers from eight other countries participated in the exercise along with those from the EU Agencies Frontex and Europol. Amongst all the officers and the equipment employed, there it was: the Schengen bus (fieldwork-memo).

$$
--0-0--
$$

The Schengen bus, unlike the "legislative train schedule" of the European parliament (European Parliament 2020), does not trace the lengthy journey and checkpoints along a Schengenaccession trajectory to EU membership. It is, very literally, a vehicle. I propose to have a look inside the Schengen bus and to move with it into the topic of this chapter.

The Schengen bus is a "special purpose vehicle" supplied to border police: according to a manufacturing company, it can support controls at border crossing points, but also comes with everything needed for setting up mobile and remote controls in places where border infrastructure is not present (fercomsystems n.d.). In support of border control performances, it carries tools for "discovering illegal immigrants" as well as "illegal products to be smuggled". It also serves in the "prevention of transfer of stolen vehicles through the border" (ibidem). It comes equipped with a licence plate recognition system, an endoscope to discover "potential hideouts" in a vehicle's interior, gas measuring equipment that analyses airborne-substances inside a vehicle "to look for exhalation of illegal immigrants", a digital microscope to inspect documents and fingerprints, and much more (ranging from a radiation detector to a digital paint-thickness measurement device).

Basically, all you need to be equipped for Schengen's border policing. Although the Schengen bus is set up for border control functions, the technology on board does not differ much from what some police forces may deploy when patrolling border-areas within the Schengen area. Amongst the equipment of the vehicles of the Bavarian Border Police feature mobile finger-print scanners for so-called "identity-management", digital microscopes and endoscopes to check vehicles for 
hiding spots (presentation of the Bavarian Border Police, FN [European Police Congress 2019]; e.g. von Delhaes-Guenther 2019). Some police stations in the border-region have drones carrying a thermal imaging camera. Germany is not an exception: other member states also equip police vehicles of certain units with thermo-imaging technology. Within the field of "civil security research" (Bundesministerium für Bildung und Forschung n.d. ['MEDIAN' 2018-2021; 'Smartldentifikation' 2018-2020]), the German federal government and Research Ministry have invested in the development of "mobile technology" to carry out mobile identity verification and to enable access to police databases while on the move ('MEDIAN'). Germany and Austria also invested in a bilateral project to improve technological possibilities to use data contained in migrants' phones to verify their identity and retrieve information regarding smuggling routes ('Smartldentifikation'). A mobile device to extract data from cell-phones is expected to become part of the specialised toolkit for countering irregular migration.

Notably, the Schengen bus is a vehicle: it is mobile. Likewise, many of the other devices mentioned are designed to facilitate not just mobility governance or the detection of smuggled goods, but to facilitate policing on the move. The Schengen bus materialises the mobility of police- and border-work, an aspect worth of consideration, when addressing the viapolitics of migration governance (Walters 2015a). It vehiculates well one of the characteristics of the police (co)operation practices discussed in this chapter: mobility. In this chapter I discuss a) joint police centres (or PCCCS) engaged in facilitating the cross-border mobility of data, and b) mobile (joint) police patrols in border-areas concerning the mobility of borders and the mobility of officers in operational cooperation. In my study I have concentrated less on technology as electronic device, or on vehicles and databases, although it would have been likewise valuable to 'follow' these objects in more depth. While this thesis concentrates mainly on practices at internal Schengen borders, the fieldwork-memo above should be read as an important reminder: the Schengen bus is also touring beyond the external borders of Schengenland. ${ }^{38}$

\subsection{PCCCs: cross-border mobility of data in direct information exchange}

Police (and Customs) Cooperation Centres (PCCCs) ${ }^{39}$ have been set up with the aim of supporting operational activities carried out by national agencies in the border-area: they provide an institutionalised possibility for formal cross-border information exchange. According to the European Best Practice Guidelines for Police and Customs Cooperation Centres,

[PCCCs] bring together, on one site, all the security authorities of all participating States. Located in positions of strategic importance for observing cross-border crime, PCCCs play a key intelligence role for the operational services. Using a simple procedure they can deliver quick replies in all fields of 
the border agencies' activities. As a tool of local collaboration PCCCs are thus ideally suited to the day-to-day needs of crossborder cooperation. (Emphasis added, Council EU 13815/08, p.5; update 9105/11, p.4 [hereinafter PCCC Guidelines]).

Within today's spatial-legal geography of data mobility, PCCCs are important units of agency to move police information across borders. Despite their 'peripheral' position - geographically and legally - joint centres have increasingly acquired importance as facilitators of cross-border mobility of 'data', including of migration related data. They are indeed 'located' in a position of strategic importance and this "tool of local collaboration" has acquired significance that transcends the meaning of "local" beyond the 'local-ness' of border-regions, even though this is the raison d'etre and territorial jurisdiction for which these centres were initially set up. I propose the emic concepts of the "border-strip" and the "thread" as analytical concepts for untangling the work of joint centres and to analytically engage with the meaning of 'local-ness' in the intersection of plural legal orders.

\subsubsection{PCCCs within the landscape of data mobility channels}

In the room are three tables, country maps and posts on the wall. Two of the tables provide the office space for the forces of one country (A). A few steps away, the office space of the police force of the other participating country (B) is located. When an information request is received by the officer (A), he forwards it through a secure communication channel to his colleague sitting in the same room. He checks the national database (B) and the information returns the same way. Vehicle registrations, residency and residency permits, verification of drivers-licences, phone ... (FN)

In order to situate the space of this field-site-description, a sketch of the channels for cross-border police information exchange is due. Firstly, cross-border data mobility is practiced daily through a plethora of international databases, such as for example in the European context the Schengenand the Visa-Information-System (SIS and VIS) and Eurodac. Secondly, information exchange requests and answers - are channelled between the central (criminal police) departments, located at member states' central authority level. This so-called "central channel" constitutes the primary route of police information exchange (CISA, Title III, art. 39.3.) and all information shared across borders is supposed to be handled and tracked centrally. Member states were recommended to allocate all relevant actors at central level into one so-called Single Point Of Contact (SPOC) and to adopt Europe-wide a so-called "'one-stop-shop" principle for international law enforcement cooperation" (Council EU 11800/1/16 REV 1, p.13). A SPOC comprises mainly the national SIRENE office for SIS, the national Interpol unit "Interpol National Central Bureau" (NCB), the Europol National Contact point (ENC) and a Unit regarding Liaison officers (LOs). Within the European Information Exchange Model (EIXM), the European Commission (COM(2012) 735 
final) speaks of three main channels (SIRENE, Europol, Interpol) and two additional channels (LO and PCCCs).

The office space described in my fieldnote above is not situated here. It is physically located quite literally at the geographical periphery of states, in the border-area of neighbouring member states. Nevertheless, the main business of the officers sitting there is facilitating cross-border mobility of information. The room is the heart of joint police cooperation centres: here is where 24/7 "cross-border information is collected, exchanged and managed" (Felsen 2012, p.79).

PCCCs are one of the so-called "compensatory measures" within the rationality of the Schengen acquis. Peripheries, as emerges from the quote at the beginning, can be of strategic importance for police work. The centres have no so-called "operational" jurisdiction, which is differentiated in police terminology from information exchange. The main task of centres consists of responding to information requests, for example concerning the validity of ID documents, vehicle owners' registrations, residency information, national criminal records etc.: data that is not available through databases such as $\mathrm{SIS}^{40}$, but available to police officers of the respective country.

\section{Traces of institutionalisation and propagation}

While the first of such centres became operational 1999, today more than 60 PCCCs and joint centres operate in Europe (See Table 4, Annex II: selected agreements and centres). The Gemeinsame Zentrum der deutsch-französischen Polizei- und Zollzusammenarbeit/Centre FrancoAllemand de Cooperation Policière et Douanière is frequently identified as the first of such centres in their contemporary understanding. The German-French centre became operational in 1999 in Offenburg in order to support police cooperation in the border-region. The centre was re-located to Kehl in 2002 and is known as the German-French PCCC. Its long history and extensive functions render it the most discussed centre in academic publications and reports (Felsen 2012; Nogala 2001; Gruszczak 2016; Maguer 2004; Pudlat 2013; Wenda 2014). However, it should be kept in mind that police cooperation, in practice and through bilateral agreements, was not something new per se: at various borders, joint police stations existed already prior to the late 90s (Nogala 2001; Felsen 2012; Fiodorova 2018). ${ }^{41}$ France reached an administrative agreement with Spain in 1996 regarding the creation of four joined police stations on the French-Spanish border (Valler 2009). They were included in the subsequent French-Spanish police and customs cooperation agreement of 1998 (Barbero 2017). The first joint centre became operational in 1997, located in La Junquera on French territory, followed by the opening of three other centres, which in 2002 were transformed officially into PCCCs. Spain and Portugal also reached similar agreements in 1997 and set up joint centres. The first explicit inclusion in a bilateral police cooperation agreement of the possibility of having a joint PCCC is seemingly found in the French-Italian "Chambery-agreement" of cross-border police and customs cooperation of 1997. The two joint 
centres were transformed into PCCCs in 2002 (Council EU ST 8095/02; Ministero dell' Interno n.d.). It has been argued that the agreement was informed by the drafting of the French-German Mondorf police cooperation agreement, signed a few days later and that both agreements inspired similar bi- or multilateral agreements (Block 2011; Gruszczak 2016). The first BelgianFrench centre was established in Tournai and the multilateral commissariat between Belgium, France, Germany, and Luxemburg, located in Luxemburg, became operational in 2004 (Block 2011, p.73). In 2005 the joint centre in Heerlen (later moved to Kerkrade) called EPICC (Euregio Police Information and Cooperation Centre) started at the initiative of the "NeBeDeAgPol" (webpage, EVTZ Euregio Maas-Rhein n.d.; 2007, in Spapens 2010).

With the Amsterdam Treaty, the Schengen acquis had become included into the Community framework. The Vienna Action Plan (1999/C 19/01) set out actions for the implementation of the Amsterdam Treaty. It identified "Joint Police Stations" as an "experiment" to be continued and expanded in order to enhance cross-border bilateral and regional police cooperation (IV - I - Art 48b). Reporting on the implementation of these measures, in 2004 the European Commission (COM(2004) 376 final, p.8) positively valued the institutionalisation of cooperation through joint centres, pointing out that the

inter-linkage between bilateral developments and EU police co-operation is made by the Vienna Action Plan, which specifically calls for the further development of such co-operation throughout the Union (emphasis added).

Several centres were established shortly thereafter, some of them out of existing joint centres and/or in the changing political geography of the Schengen enlargement. The joint AustrianHungarian border commissariat Nickelsdorf-Hegyeshalo (set up in 2001, the first joint centre for Austria), was transformed by agreement into a joint centre in 2007 (N.d. 2012). A trilateral ItalianSlovenian-Austrian joint centre became operational in 2005 in Thörl-Magerln. Since 2014 it also counts with the presence of the German Bundespolizei, since half of the requests processed present a link to Germany (Zirknitzer 2015). The German-Polish PCCC in Swiecko became operational in 2008 and the PCCC Petrovice - Schwandorf centre between Germany and the Czech Republic in 2007 (Bayerisches Staatsministerium des Innern für Sport und Integration 2017a). A joint Danish-German police station was set up in 2001 in Padborg: its composition and tasks gradually enlarged and it was renamed a joint centre in 2011. It is a contact point beyond Germany and Denmark and functions as a reference point for all Scandinavian countries (Leaflet, n.d. 2018).

The German-Austrian joint centre was the last bilateral centre Germany and Austria respectively set up with their neighbouring countries. The common language and well-established transfrontier cooperation were considered to provide a sufficiently solid basis for CBPC needs in the 
border-region. The centre was set up 2015 in Passau as an ad-hoc response: its main tasks were the "recording, evaluation and coordination of the cross-border refugee- and asylum-situation" (Bundesministerium des Innern, für Bau und Heimat 2015). In March 2016 it was changed into "Joint Centre Passau" (Gemeinsames Zentrum Passau) and a year later the legal basis for a permanent centre was laid down through an additional intergovernmental agreement.

Joint centres exist not only between Schengen countries. They have also played - and play - an important role in fostering $\mathrm{CBPC}$ and data mobility across the moving external EU border: first with countries that entered Schengen in 2007, and currently with - and amongst - countries from the Western Balkans. Joint centres exist also amongst EU and non-EU countries on other external frontiers or "overdetermined super borders" (Balibar 1993): the joint Spanish-Moroccan centres in Tánger and Algeciras were inaugurated in 2012 (RTVE-EFE 2012; Calvo 2012).

\section{Centre composition and functions}

Most joint centres are bilateral. Also centres with three and four participating countries exist. The Guidelines on PCCCs indicate the following possible activities:

- Collecting and exchanging information (which may also include analysis activities)

- Assisting operations taking place in the border-area: this can include investigations, operations, joint control and surveillance in border-areas, cross-border operations for maintaining or restoring public order, cross-border surveillance and hot pursuit, and preparation of readmission measures.

Migration related activities do not figure here explicitly. However bilateral agreements have included migration as field for mutual cooperation (as we shall see, for PCCCs this is an exception to what otherwise is criminal police information exchange) and assistance to operations can include support in readmissions or joint patrols, thus in practices concerning the policing of migration.

Despite this spectrum, the core activity of PCCCs is information exchange, i.e. moving data across national borders and respective national databases. To give an example, the PCCC Kehl started out with processing 2,928 requests in 1999, 10 years later 16,831 and in 2018 it facilitated information exchange on 20,400 cases $^{42}$ As Block (2011, p.73) pointed out: three PCCCs "together handled more messages in 2004 than the Europol liaison officers did from the then 25 Member States".

Notwithstanding their 'peripheral' legal and geographical position, joint centres have increasingly acquired importance as facilitators of cross-border mobility of data. In order to analyse this 
process and centres' practices, it will first be necessary to engage with the plural legal orders that enable PCCCs to move data across borders.

\subsubsection{Plural legal orders, inter-legality and the legal geography of data mobility}

In 2004 the Commission spoke of an "inter-linkage between bilateral developments and EU police co-operation" (COM(2004) 376 final, p.8). What does inter-linkage mean? PCCCs provide a very specific but privileged entry to the necessary analysis of a "fragmented legal territory" of police cooperation (Sheptycki 2001), as PCCCs are anchored in a plural legal constellation. Attention towards legal pluralism and transnationalisation processes allows one to engage with today's "inter-linkage" as "interlegality" (Boaventura-de-Sousa 1987, p.287) between legal orders of different scales which "regulate the same object": cross-border police data exchange. In this constellation figure both bilateral agreements on police cooperation and respective EU law, and they also interact with legal orders outside the policy field of policing, such as those on data protection. The laws I will briefly outline regulate the mobility of data, they organise the European space and - drawing on Tsing's line of reasoning (2000) - they carve possible channels of information flow across state-borders. I argue that they produce a legal geography of data mobility, wherein PCCCs have emerged as important units of agency.

\section{Plural legal orders}

Joint centres are based on bilateral (or multilateral) police cooperation agreements stipulated between the contracting States that operate a joint centre. Such agreements are not entirely compatible in terms of the possibilities and limits to police cooperation agreed upon by the signatory state parties. In addition, each centre is also based on an (bilateral, or in case of multiple states participating in the centre, multilateral) administrative agreement, which contains further detail upon its composition, location, work-procedure and functions. Bilateral agreements between member states that share an internal border all clearly define their common borderarea by identifying the respective police authorities and delineating the border-area territory. Direct information exchange independently of the central channel is possible across these territories. Usually the jurisdiction includes the administrative-territories adjacent to the border on both sides (eg. provinces, regions or departments, depending on the countries' administrative structure).

Bilateral agreements interact with, and are regulated under, the terms of the Convention Implementing the Schengen Agreement (CISA). Art. 39 regulates mutual assistance in information exchange. Police authorities shall assist each other for the purposes of preventing and detecting criminal offences (mutual assistance, art. 39.1). CISA stipulates that, while information requests for cross-border cooperation are in principle handled at a central level (art. 39.3), cooperation in border-areas can be further regulated through bilateral arrangements (art. 39.4). Art. 39.5 
clarifies that art. 39 CISA does not preclude more detailed bilateral agreements between contracting parties with a common border. In addition, when information is deemed urgent, police authorities can exchange also directly without going through the central channel. While the "Schengen acquis" was incorporated into Community law following the Amsterdam Treaty, the Schengen legislation has seen many subsequent developments.

The Council Framework Decision 2006/960/JHA, known as "Swedish Framework Decision" (SFD) ${ }^{43}$ or "Swedish Initiative", formalised the so-called "principle of availability" and the "principle of equal access" meaning that information exchange should not be handled more strictly at crossborder than at a national level. Notably, according to the SFD, cross-border information exchange can apply to all "information or intelligence" that is already existing and available to police forces nationally. It applies to data, which is directly held by law enforcement authorities, but importantly also

any type of information or data which is held by public authorities or by private entities and which is available to law enforcement authorities without the taking of coercive measures (...). (Emphasis added, SFD art. 2, point d-ii)

While the SFD (art. 12) formally replaced art. 39 (1-3) and art. 46 CISA with regards to criminal police information exchange, its implementation has frequently been highlighted as limited and as complicating the legal framework. Being a Framework Decision and not a Regulation it had to be transposed by member states into national law, re-embedding the legal possibilities envisioned sovra-nationally within different national frameworks. ${ }^{44}$

There are in turn various national differences in terms of what type of (non-police) databases are held or made accessible to police authorities, and the type of information exchangeable through police cooperation and not judicial cooperation channels. Especially for countries with plural police forces, different forces may have access to different datasets. Cross-border data mobility is thus also conditioned by what is legally 'accessible' and 'movable' according to (different) national laws and approaches. As we shall see in chapter 7, these are some of the 'borders' experienced in the facilitation of data mobility.

Let me summarise before taking the next step. Police departments in border-areas are enabled to exchange information directly, also through PCCCs, while non-border-area territories of the contracting states and police forces from other countries in principle must follow the procedure through central contact points (the aforementioned SPOCs). With one exception: art. 39.3 CISA stipulates that if

a request cannot be made in good time using the above procedure [central channel] the police authorities of the requesting Contracting Party may 
address it directly to the competent authorities of the requested Party, which may reply directly. [Conditional, emphasis added]

Various bilateral police cooperation agreements (also between countries that do not have a common border) have followed this principle. The enabler of direct information exchange beyond the border-area territories is the criterion of 'urgency'. In cases of 'urgency', centres can receive and reply to information requests from police authorities outside their primary geographical border-area jurisdiction. This further means that non-border-areas of the participating countries, as well as member states other than the contracting parties could contact a PCCC for information if the request is deemed 'urgent'.

EU level documents highlight that, according to the principle of subsidiarity, it is the best-suited level that should handle activities. PCCCs were deemed of paramount importance along internal borders. In the Updated Catalogue of Recommendations for the correct application of the Schengen Acquis and Best practices: Police cooperation (Council of the EU 15785/3/10 REV 3 ) this recognition explicitly applied not only to the whole territory of the participating states, but beyond: the "[e]stablishment of [PCCC/joint centres] is not only an effective tool of cooperation for the contracting parties since other Member States benefit from them too" (emphasis added, p.10).

When PCCCs exchange data on behalf of non-contracting member states, they move into what is considered the most contentious issue (Fiodorova 2018): so-called "chain-requests". For example: a police authority in Spain needs urgent information from Germany, but rather than contacting the German SPOC, the request is sent to one of the Spanish-French PCCCs, which then forwards it to the French-German PCCC. These practices are deemed contentious because on the one hand they mobilise the PCCC network and surpass the direct (but slower) SPOC, and on the other because they open questions of data privacy. At the PCCC network conference in 2013, it was agreed to carry out chain-requests only in very urgent matters, when bilateral agreements allow for it and with participation of central authorities (ibidem). Fiodorova pointed out that in practice this leaves questions such as which central authorities should be involved, for example including that of the "middle-man" centre or not. Centres and member states are in practice adapting different approaches to the matter.

From this first discussion we see that plural legal orders have produced a differential legal geography of data mobility - a differential mobility regime for information exchange. Factors that matter herein are the spatial-legal configuration that I will call the border-strip, the location of the requesting authority, but also the 'urgency' of a request. In addition, we saw that data mobility is also enabled through exchanges between PCCCs. 


\subsection{3. "Border-area-strip" and "red thread"}

"... what allows the agreement, what is defined in the agreement as "borderarea'. I have a clearly defined border-area-strip: [the officer points out the territories on a map]." (IV_RL-HLO, PCCC)

"The [PCCC] cooperation leads like a red thread throughout Europe." (IV_RLHLO, PCCC)

The "border-area-strip" and the "red thread" are two visual representations brought forward by PCCC police officers: I propose these two emic depictions as analytical concepts for untangling the work of joint centres and to analytically engage with the meaning of the 'local-ness' of this "tool of local collaboration" (PCCC Guidelines). The concept of 'network' has been most frequently associated with the PCCC instrument and in information exchange (Gruszczak 2016; Guille 2010; Aden 2017). Aden (2017, p.9) classified PCCCs as "a particularly strong variation of network-based horizontal administrative cooperation". Indeed, within scholarship on crossborder cooperation or on mobilities, 'flows' and 'networks' are frequently overemphasised over spatial aspects and spatial limits. Less frequent is indeed a focus on territory, which is surprising considering the importance of territorial jurisdiction in policing.

\section{The "border-(area-)strip"}

Bilateral agreements codify space in law and construct the border-strip as spatial-legal condition of possibility for direct information exchange: border-area authorities can exchange information directly. Also, some bilateral agreements specify that if a case has a 'link' to the border-area territory, information requests can also be made directly to the authorities in the border-area. The territorial border-strip, therefore, provides the spatial-legal condition for the exercise of specific policing powers. In the field of information exchange, bilateral agreements allow PCCCs to engage in "direct information exchange" - independently of the central channel - across the territories of the border-strip. As formulated by a PCCC coordinating officer, border-areas present a specific and privileged "condition of possibilities" for information exchange.

The following images visualise the spatial-legal configuration of the border-area for policing purpose, based on a selected number of bilateral police cooperation agreements. We see that border-strips run throughout Europe. This border-space is legally defined as "border zone(s)" or "border territories": zone di frontiera, (Italian), zone frontalière (French), zona fronteriza (Spanish), Grenzgebiete (German), etc. While peripheral to the capital cities of the member states, they are at central and strategic positions within the AFSJ. 
Image 1: Border(-area)-strips

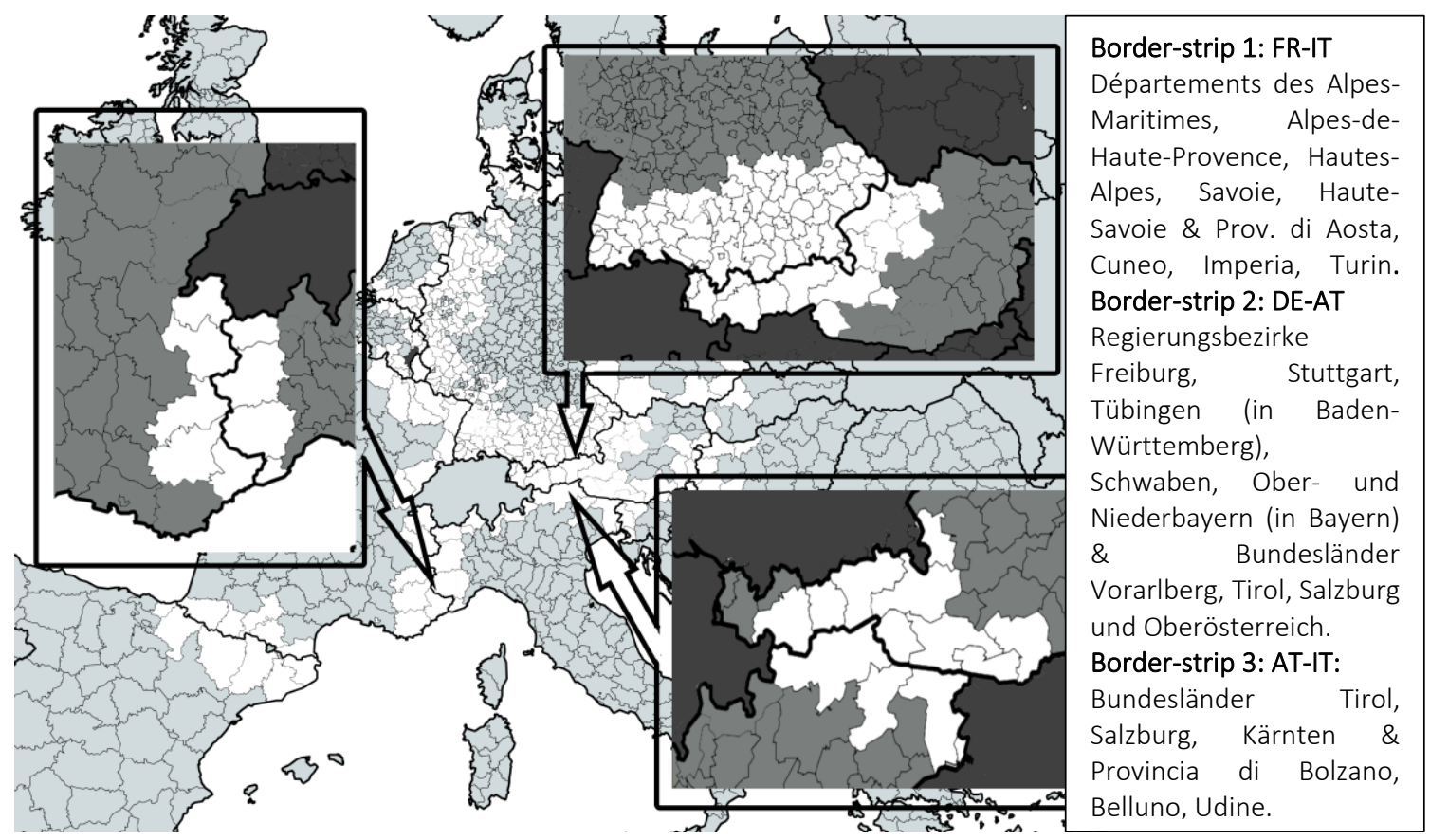

Image composed by the author. Created with mapchart.net \& modified; background-map is indicative only.

Description: The spatial-legal configuration of the border-area territories, the "border(area)strip", is codified in bilateral agreements, as depicted through the examples. Bilateral agreements in turn interact with art. 39.4 CISA.

The first speaker quoted above positioned his workplace in the territory of the border-area-strip where the centre is located. The border-area-strip grounds each centre in the territorial jurisdiction of the border-area territories and constitutes the raison d'être and primary (spatial-) legal fundament of the centres. But he also located the workplace within a complex network of cross-border relationships. Relationships reach locally across both sides of the border and extend throughout Europe through relations between PCCCs. While the cross-border territory provides the legal and territorial bilateral basis for the centres, the "red thread" forms a not a-priory defined space through exchange and interaction between PCCCS. The images overlap: borderstrips run throughout Europe and the nodes of the thread are territorially based.

\section{The "red-thread"}

The second speaker indeed positioned his workplace within the European space and within a network of joint centres and PCCCS. The "red thread" is not only of relevance as an informationexchange-channel, e.g. in chain-requests. PCCCs' so-called "network" activities have benefitted from funding under the ISEC project Strengthening of PCCC Cooperation in the European Union (2011) led by the German Federal Police in cooperation with Europol and Cepol, and the followup project under the ISF Union Action Strengthening of PCCC Activities in the European Union. Activities inter alia involved the exchange of officers, training, implementation of SIENA, information exchange between PCCCs, and additionally increasing the analytical tasks of centres 
by promoting intelligence-led policing in border-areas (Council EU 16879/12; 13285/15). Since 2010, the Presidency and the Commission have jointly organised an annual conference of PCCCs, now hosted by Europol.

\section{Summary}

Law organises space and allocates rights and duties, including those of police entities such as PCCCs engaged in facitlitating the cross-border mobility of data. These legal technicalities matter for describing and analysing how the PCCC officers perceive and perform their work - including information exchange on 'migration'. They also influence how and where officers situate this socalled "tool" for "local collaboration" (PCCC Guidelines), as well as their work within a landscape signed by various (in)formal information exchange channels. However, different legal orders are invoked, negotiated and actualised when a centre decides whether to take on an informationrequest. It is therefore paramount not to stop at law-as-text but to focus on everyday practices in multiple local situations (Benda-Beckmann and Turner 2018). In doing so, we enhance understanding of the practices and processes through which negotiations between interacting legal orders take place and, in turn, how space is shaped through policing practices. As we shall see in PART III, 'enabledness' is a condition produced by a plural constellation of legal orders, but 'acting enabled' is an active process of interpretation that transforms conditions of possibility including along 'grey-zones' of interlegality - into reality. As one officer described it: it is about "living in practice" possibilities given in law-as-text.

\section{3. (JOINT) MOBILE PATROLS IN BORDER-AREAS: mobile borders and mobile officers}

According to a European Migration Network survey (EMN 2018a, 2018b), police checks carried out in border-areas adjacent to internal Schengen borders for the purpose of crime control are common practice in multiple member states ( $A T, P L, P T, B E, C Z, E E, D E, L T, S I, S K, S E, I T)$. In addition, thirteen countries indicated that they carry out such controls for the purpose of immigration related checks (PO, PT, BE, EE, FI, DE, HU, LV, LT, SK, SE, NO, IT - out of 20 respondents). The survey can be read in connection with the Commission's Recommendation on proportionate police checks and police cooperation in the Schengen area $(C(2017) 3349 \text { final })^{45}$ which recommended intensifying proportionate police checks in border-areas and strengthening CBPC.

In the course of 2014-2015 one can identify a tendency of member states to further draw on joint border-area patrolling, experiences which were identified amongst the best practices outlined by the Commission in 2017. These included joint patrols along international trainlines connecting member states of so-called "first arrival" (within the rationalities of the Common European 
Asylum System) and central EU member states. Twenty years earlier, in October 1995, the Schengen Executive Committee discussed the possibility to use bilateral agreements for the setting up of joint police patrols in border-areas. The Committee (Schengen States' ministers) was set up to ensure the correct implementation of CISA and to adopt practical implementation measures (CISA, Title VII). This proposal was supported by France and Germany (see also Zaiotti 2011, p.97). In this occasion the French European Affairs minister argued that France saw the usefulness of border-area control, significantly linking the so-called concept of "mobile controls" with that of "mobile frontiers":

The Schengen Convention does not envisage completely abolishing controls within Schengen, just at frontiers. We now have the concept of mobile controls and mobile frontiers which could be more effective than fixed controls. (Emphasis added, quoted in Statewatch 1996)

Border-area measures became institutionalised practices in the Schengen area, interwoven with what the Minister succinctly called the "concept of the mobile frontier". It suggests mobile patrolling officers becoming the border, the subjects of control being the mobile bodies of police officers.

I firstly trace and analyse how (joint) mobile border-area controls emerged as institutionalised practices. Secondly, I illustrate the plural spatial-legal orders within which mobile patrols are embedded: moving from an initial legal void into today's hyper-legalised space in a multi-scalar constellation. From the genealogy, it will emerge that (joint) mobile patrols in border-areas are not a 'new' solution to the problematisation of irregular immigration. But their deployment to counter unauthorised "secondary movements", the further (recommended) intensification and the ongoing reconfiguration of instruments from a CBPC 'toolbox' are developments worth scrutinising. Thirdly, on a theoretical level, (joint) border-area patrols concern the reconfiguration of the internal border as a space and as a mobile border. The question emerges of how to consider issues of borders and of the modern states' properties of sovereignty and territoriality (Sassen 1996), when the "mobile frontier" is patrolled jointly by officers from different member states. Legal aspects of relevance for operational police cooperation are the competencies and executive powers given to officers operating on another country's territory, the use of equipment (such as weapons or vehicles) and liability. When considering transnational capacity of police agencies, issues are said to arise "out of territoriality, sovereignty and enforcement jurisdiction" (Sheptycki 2001, p.154). Albeit an expression of so-called "horizontal cooperation", joint patrols allow one to address a matter at the heart of the legal and political order: the (formal) powers of officers operating outside their territorial jurisdiction. In this chapter I do so by scrutinising the ongoing reconfiguration of the legal regimes regulating these policing-mobilities. 


\subsubsection{Mobile patrols - the "mobile frontier" and the mobility of borders}

Mobile police patrols in border-areas are a governmental technology which emerged within the neo-functionalist argumentation of "compensatory measures" that accompanied the process of abolishing border control amongst Schengen members. Personnel deployed at internal borders were shifted to airports/harbours, but also assigned to 'alien police departments' in borderregions (Groenendijk 2003; Schwell 2008; Pudlat 2013). Combatting "illegal immigration" was seemingly the most frequent motivation given for the introduction of the "mobile frontier" in the mid-90s by initial Schengen members, but also drug-smuggling, for example in the case of France with the borders to Spain and to the Netherlands. According to Siebold (2013, p.140), the notion of "compensatory measures" already emerged in 1984 in the context of the Saarbrück agreement. ${ }^{46}$ The agreement contained measures for the gradual abolishment of border control for EC citizens on the German-France border and led the way to the 1985 Schengen agreement with the Benelux countries as ulterior signatory party.

As highlighted by Groenendijk (2003), it should be kept in mind that countries introduced their mobile policing measures notably within the context of different national legal frameworks regarding a) the powers of the police to carry out identity checks within the national territory (which includes border-areas), b) the obligation of persons to carry identification documents, c) the obligations for third-country nationals to register with authorities and the way this information was stored and accessible. Countries have found different expressions for mobile police controls in the border-area. In Italian it is referred to as controllo di 'retro valico' (literally "control "behind the pass'") to be carried out in the fascia di fronteria ("strip along the border"). In Austria, the broader term of Ausgleichsmassnahmen or in short AGM ("compensatory measures") as well as the German expression Schleierfahndung are used: a denomination that has no territorial framing, as in Italian, and which has become a reference point for police forces also beyond German speaking territories.

\section{Legal geographies of the "mobile frontier"}

France and Germany have been active players in institutionalising this 'Schengen' instrument. Notably, some possibilities to carry out mobile control inside a strip along the border and particularly along transport routes already predated the "concept of the mobile frontier". In Germany, the Bundesgrenzschutz had the legal possibility to carry out measures within a 30kilometre zone inside the German territory (Law of the Bundesgrenzschutz, now Law of the Bundespolizei), amongst which ID checks for the purpose of countering unauthorised entry. This competency received a successive spatial-legal extension along transport routes, to include trainstations, trains and airports. In the mid-90s several Länder included Schleierfahnung in their policing laws regulating the Länderpolizei (see Annex II). In France, the Police Aux Frontières (PAF 
Border Police) comprised the "Mobile Border Brigades", a unit set up in the 1970s and which already had competency to patrol into the hinterland. According to Colombeau, the legal foundation of that competency was unclear and changed only through several legislative developments presented in the context of the Schengen process (2017; Illamola Dausa 2012). In the Netherlands, after two years of governmental debate, mobile controls in border-areas were introduced only in 1994 (Anderson et al. 1995, p.61; Groenendijk 2003) explicitly defined as mobile toesicht vreemdelingen (MTV) - "mobile control of aliens" -, and later supplemented by tasks in a variety of crime policing fields (Van der Woude and Brouwer 2017). However, already in the late 70s within the frame of the Benelux area the Netherlands had covered border-areas with Belgium through mobile patrols (Groenendijk 2004; see chapter 6).

\section{Temporalities}

Border control in the mid-90s had already been relaxed. Prior to its abolition, along cross-border railways border control was often already carried out 'inside the country', namely within the timespace available until the first train-stop after the border or at the first train stop. An example beyond the initial Schengen members: Austria and Germany already agreed in 1955 that officers could carry out (mobile) border control on moving cross-border transport facilities (trains or boats). ${ }^{47}$ Also, border control could take place in the territory of the neighbouring state: for example, through anticipated control stations in the territory of the neighbouring country (vorgeschobene Dienstellen, in English known as "juxtaposed controls"), and through newly defined six joint train stations (Gemeinschaftsbahnhöfe, literally "community-train-stations") where authorities from both countries were successively to carry out their border control procedures. Here we have examples of an initial legal fundament to "mobile" borders and controls beyond the respective territories of national authorities.

Looking at the institutionalisation of the "mobile frontier" concept and related practices through the Schengen processes (at times predating, as we saw, their full legal backup) also shows how 'solutions' from within the security field were based on experiences that predated the formulation of the 'problem'. Guiraudon (2003) and Huysmans (2006) made a similar argument with respect to other measures adopted through the Schengen process. In addition, although the example of agreements from 1955 are not agreements on police cooperation and they deal with a very specific aspect of border control, they already regulated crucial matters for police cooperation on an intergovernmental level. Such elements as the competencies, liability and legal status of officers operating outside the territory of their national jurisdiction, and the usage of their vehicles and weapons are good examples. This leads me to an additional modality of borderarea policing: joint patrols. 


\subsubsection{Joint patrols in border-areas - mobility of police officers and their powers}

Joint activities emerged initially as trans-frontier practices in border-regions, such as joint patrolling in occasion of specific events taking place in the border-area or in the joint patrolling of major traffic routes. Today they are one modality of so-called "joint operations" also anchored in EU law within the field of operational police cooperation. The Manual on cross-border operations (Council EU 10505/2/09 REV 4, p.25) defines joint operations as "actions in the field of public order and security and crime prevention, jointly carried out by two or more Member States, whereby officers from one Member State act on the territory of another Member State".

Operational cooperation can take various forms: hot pursuit, cross-border surveillance, joint investigative teams, as well as joint operations. Joint patrols are one form of joint operations. The latter also include assistance to tourists and security of tourist sites, traffic controls, accompanying dangerous (such as nuclear) transports; (mutual) support during major events (G8 summits, world football, joint exercises), etc. (ibidem).

Joint patrols can be carried out in the border-areas between neighbouring countries (and they can also involve officers from other countries), or on the occasion of specific events, such as significant sports fixtures or festivals (in the border-region, but also beyond). Joint patrols are carried out either on both sides of the border, or on the territory of one of the participating countries. They can be deployed along entry routes, and/or exit routes (see chapter 7). A less "operational" method of cooperation but also of relevance are practices of "coordinated patrols" in border-areas: each country carries out patrols on its territory, whilst coordinating the zones and times of the patrol measures. For example, Spain and Portugal signed a bilateral agreement in 1994 regarding the coordination of mobile patrols in the border-region, with the explicit aim of countering illegal immigration from third countries and to combat organised crime.

The so-called "concept of mobile frontiers" suggests mobile patrolling officers becoming the border: how can we think this mobile border, that takes place literally through enactments carried out in the border-area jointly by officers belonging to multiple jurisdictions? From the perspective of border functions, this mobile frontier aims to filter through a net of random checks: it does not 'cross' everybody but can be tightened or loosened according to situational police or risk reports. As such it is an expression of governmental power that focuses on population. The question of sovereign power traditionally associated with a state border, may be addressed through the auxiliary or executive powers granted to officers operating in joint patrols outside their territorial jurisdiction. 


\section{From practices signed by legal void to plural (legal) orders}

Available documentation suggests that joint patrols in border-areas initially played a crucial role in the cooperation with not-yet Schengen neighbour-countries. Subsequently they were also formalised between Schengen members. Retrospective legalisation of experimental (joint) practices of mobile patrols (Groenendijk 2003, Schwell 2008; Brammertz 1999), is supported by the fact that the available documentation of joint patrolling varies between practices (flexible dates) and their legal codification, indicating retrospective legalisation. I am not aiming to reconstructing a timeline, but will identify patterns of practices and of their legal configuration.

\section{Across the 'external' border that became 'internal'}

The literature highlights the German-Polish border as a first experience with joint patrols, thus across an external EU border at the time. However, one could also add the Italian-Albanian (maritime-)border, where joint patrols were also introduced in the late 90s. On the PolishGerman land-border patrols started in 1998/1999 (Schwell 2008, pp.103-106; Pudlat 2013, p.229; DCAF 2013; Schelter 2006, p.156; or in 1996 according to Cuttitta 2007, p.88) and were formalised by law in 2002. Very insightful is the statement of a high-level officer interviewed by Pudlat, but not further analysed (2013, p.229):

We started joint patrols without any legal basis [...]. That was 1999. 2002 it [the joint patrol] was then included in the bilateral agreement, thus what we have been doing for three years, became legally anchored. [...]. If there is a need in practice [operational level], then one has to make sure that the laws are adopted accordingly to make information exchange possible.

Authors often contend that law needs to be in place for practices to be carried out legitimately, but some also provided evidence of retrospective legalisation for practices creatively developed in an interstitial grey zone. Schwell $(2008$, p.77) pointed out explicitly that joint German-Polish patrols show that cooperation practices at a local (micro) and intermediate (meso) level preceded legalisation and that the context and imbalance (Schengen member - aspiring Schengen member) was not without impact on the cooperation practice itself.

This experience was said to have inspired the setting-up of joint patrols between Germany and the Czech Republic (in 2003/2004 according to Cuttitta, Schelter and Schwell; DCAF respondents - notably practitioners - indicate the year 2000). Austria and the Czech Republic initiated joint patrols in 2006 (Darley 2008). Both Poland as well as the Czech Republic were at the time in the Schengen accession process: border control was lifted in 2007. Italy and Slovenia set up and implemented joint patrols in 2000/2001 (Council EU 8396/06, DCL 1), for the main purpose of countering irregular migration from Slovenia to Italy. Austria and Slovenia set up joint patrols in 2005, Austria and Hungary in 2006. Slovenia and Hungary joined Schengen in 2007. Based on experience with Slovenian-Italian patrols, Slovenia later set up patrols with other neighbouring 
countries. In March 2006 the (internal) ministers from Albania, Montenegro, Macedonia, Serbia and Bosnia-Herzegovina issued a Ministerial Declaration on Border Security in South East Europe: amongst the shared objectives identified, figured the aim to promote joint patrols and operations. A few months later, the Police Cooperation Convention for Southeast Europe (PCC SEE) ${ }^{48}$ was signed: art. 28 regulates joint ("mixed") patrols. Today joint patrols are a frequent practice throughout the Western Balkan countries and have been set up bilaterally and under the PCC SEE multilateral framework.

As such, joint patrols spread along and across the 'moving' external Schengen border between Schengen and non-Schengen countries, when the latter were in the Schengen accession phase. Cross-border police cooperation (CBPC) can be seen as part of the broader 'accession package'. Or, to paraphrase legal anthropologist (Benda-Beckmann and Benda-Beckmann 2014, p.34), police cooperation is part of the "legal shadow" of the EU space thrown ahead. Albeit less crucial than the national operationalisation of SIS, in the evaluations carried out by the Schengen Evaluation Committee in 2006 of Slovenia and of Hungary (Council EU 8396/06 DCL 1; 8395/1/06 REV 1 EXT 1), the existance of operational police cooperation through joint patrols in the former case and the intention to set them up in the latter, was one of the aspects in the assessment. Also in Schengen accession evaluations today, joint patrols are taken into consideration.

\section{Within}

The Netherlands and Germany started joint patrols in border-areas in 2001 as part of the "NeBeDeAgPol" cooperation (Breuer and Breuking 2007). With countering drug-smuggling as a target, the Netherlands and its neighbouring countries created a number of joint patrolling initiatives. In 2002 France and the Netherlands set up joint patrols, which in 2005 were transformed into "joint hit teams" and enlarged to include also officers from the other Benelux countries, Belgium and Luxemburg (Spapens 2008). France and Germany initiated joint patrols around 2004/2006 (2004 in Pudlat 2013, p.105; 2006 according to press material). France and Italy signed an agreement on joint patrols in 2002 for the purpose of countering irregular migration, to be carried out within a 30 kilometre range from the border. It consisted of train and highway patrols (Milhau [report to Senat, France] 2009; Ministero dell' Interno n.d.). Trilateral patrols composed of German, Italian and Austrian officers on trains between northern Italy and southern Germany across eastern Austria started in 2000/2001 (Deutscher Bundestag 2014; Schelter 2006). Various joint initiatives have been developed amongst the Benelux countries.

Rewinding this development, it needs to be highlighted that already in autumn 1995 the Schengen Executive Committee discussed the value of joint measures in internal border-areas and possibilities to use bilateral agreements for setting them up. Joint patrols initially emerged as responses to local and inter-regional policing needs, and it is likely that participating countries 
had already experimented with this instrument prior to its legal codification. However, operational cooperation has been less addressed in the research literature. Brammertz's (1999, pp.120-124) early in-depth study regarding CBPC in the Maas-Rhein Region (Netherland, Germany, Belgium) collected various instances from the 50s onwards in which officers had been operating separately or indeed jointly in the border-area of the neighbouring country. He argued that operational cooperation basically had no legal basis and therefore efforts were rather made to foster a legal basis for information exchange and hot pursuit. Schober's (2017) extremely detailed analysis of legal frameworks contains examples of CBPC for Austrian-German cooperation. He mentioned occasional deployment of liaison officers during cross-border mass gatherings from 1995 onwards, but also a longer-term deployment of four German officers to Austria in 2001 and to whom executive powers in the field of traffic policing were given. He categorised the latter under "search for unorthodox solutions" (Schober 2017, p.435 ff) and critically highlighted the (legal) creativity employed in the absence of any real legal framework. By stretching the legal possibilities and competency limits to the largest extent possible, according to Schober, practitioners were able to generate pressure at a political level to create new police cooperation instruments that would meet policing needs: the pressure found a response in the German-Austrian police and judicial cooperation agreement of 2003, in force since 2005 (ibidem, p.438). In the literature, but also according to my interview data, this agreement compared to others is up to today considered as very "advanced" or "modern", as it gives police amply powers to cooperate.

\section{Current legal constellations}

Joint patrols are being carried out on the primary basis of bilateral agreements, while the aim, the duration and the procedure of joint patrol operations are further defined by implementing protocols between the directly participating actors. The EU law reference for joint patrols is found in the Prüm Decisions: like Schengen, Prüm was initially an intergovernmental multilateral agreement, stipulated in 2005 between seven member states with the purpose to enhance crossborder police cooperation. ${ }^{49}$ The Prüm Convention was partly incorporated into the 3rd pillar Union framework by Council Decision 2008/615/JHA (Prüm Decision) and the Council Implementing Decision 2008/616/JHA (Prüm Implementing Decision) of 23 June 2008. ${ }^{50}$ Through the Lisbon Treaty the Decisions became part of EU functioning principles. While most of the Prüm Convention and the Prüm Decisions concern information exchange - e.g. DNA, fingerprints and vehicle registration data - the framework also regulates in Chapter 5 "other forms of cooperation", within which "joint operations". The PCC-SEE indeed provides a multi-lateral legal framework for carrying out joint patrols amongst non-EU countries and between non-EU and EU member states. The legal "fixing" of joint border-area patrols through bilateral agreements and 
national law adressed previously, interacts today with EU legislation, i.e. the Prüm Decisions as well as the Schengen Borders Code (art. 23, SBC) concerning police-checks in border-areas.

The Manual on cross-border operations describes the aim of joint patrols as following (Council EU 10505/4/09 REV 4, point 4.2):

Joint patrols aim at facilitating access to law enforcement by citizens from the different Member States concerned [sic!], improving general cooperation between the authorities and officers involved, providing practical and linguistic assistance to the officers of the host State, facilitating communication with the national authorities of the supporting State etc. Joint patrols can take place on land, water and in the air.

It recommends, that for joint patrols in the border-areas between member states "local authorities should be empowered to set up such joint patrols in a very quick, pragmatic and efficient way, depending on operational needs so that each command level can make all the necessary contacts with its counterpart in order to organise common activities or joint patrols" (ibidem). Whilst being an instrument thus primarily at the disposal of local authorities, the national legislator must provide the legal framework.

Legal aspects of relevance for operational police cooperation are the competencies and executive powers given to officers operating on another country's territory, as well as the use of equipment (such as weapons or vehicles) and the liability of officers.

Art. 17.2 of the Prüm Decision 2008/615/JHA outlines in this regard that member states

may (...) confer executive powers on the seconding Member States' officers involved in joint operations or, in so far as the host Member State's law permits, allow the seconding Member States' officers to exercise their executive powers in accordance with the seconding Member State's law. Such executive powers may be exercised only under the guidance and, as a rule, in the presence of officers from the host Member State. The seconding Member States' officers shall be subject to the host Member State's national law. (Emphasis added)

There are differences in the powers given, depending on the cooperating partners. The granting of executive powers to another country's police force either by a) conferring executive powers of the hosting state, and in particular by b) allowing to carry out executive functions as attributed by the sending state) represents a very sensitive topic, expressed also through the explicit reference to national legislation. In comparison, the PCC SEE, foresees powers of identification and stop on the other country's territory, if permitted by national legislation (art. 28.2). Art. 17 (above) is identical in content to art. 24 of the 'original' multilateral Prüm Convention, in which "executive" was however defined as "sovereign" powers. This article of the multilateral Convention, according to a German explanatory note (Deutscher Bundestag 2006, p.40; Schober 
2015, p.921), was oriented on the respective provisions in the German-Austrian and the GermanDutch bilateral cooperation agreement. Here we see instances of ongoing reappropriations between different scales of law.

\section{Joint patrols within multi-scalar problematisations}

Whilst being a cross-border cooperation measure that involves direct trans-frontier contact at micro-level, as well as being primarily based on bilateral intergovernmental agreements, this instrument is also embedded within sovra-national and broader political developments and power relationships.

Following the adoption of the Prüm Decisions and within the Stockholm Programme, in 2010 the newly established Committee on Operational Cooperation on Internal Security (COSI) ${ }^{51}$ was tasked the development of a Guide for Joint Police Operations (JPOs). The guideline addressed joint operations and not specifically joint patrols (one modality of JPOs), but it is nevertheless of interest. In the preamble to its publication (Council EU 16825/10, p.1) it was argued that there was a lack of knowledge of what type of joint operations were carried out, by whom, and that "important actors" - read EU Agencies - were never involved:

Currently regular joint police operations are organised on a bilateral or multilateral level. There is, however, no overview of which operations are being planned and by whom, nor clarity on the procedure to be followed. As a consequence, a number of important actors are not always informed of these bilateral or multilateral operations even if they fall within their mandate and their participation could present an important added value.

Following up on the European Commission's Back to Schengen Roadmap (COM(2016) 120) final) and responding to the continuous prolongation of temporary border controls by various member states in 2016, in 2017 the Commission advised to increase police controls in border-areas instead (C(2017) 3349 final). Since joined patrols and other cooperation means were mentioned as a "best practice" to be further enhanced, the recommended instruments became topic of an "orientation-debate" within COSI. There it was however argued, that

[p]robably due to the ad hoc character of these other forms of cooperation, the practical aspects of cooperation and the preparedness of Member States for such cooperation have not been the subject of discussions within any Council Working Party and are not known to the same extent as those of Chapter 2. (Emphasis added, Council EU 10312/2017, p.2)

"Other forms of cooperation" here refers to Chapter 5 of the Prüm Decision, namely joint operations and patrols, while Chapter 2 regards e.g. online access to DNA, vehicle registration data, etc. The debate in COS/ was followed-up by three meetings of the Law Enforcement Working Party (LEWP) of the Council (11839/17; 11839/1/17 REV 1; 11839/2/17 REV2). ${ }^{52}$ Member states were asked to outline their existing cooperation experiences and their legal base (Prüm Chapter 
5, or bi- multilateral agreements), but also to respond to the question if these instruments (including instruments adopted by other member states) "may constitute alternatives to temporary reintroductions of controls at internal borders" (Council EU 11839/17, p.4).

These mostly local-regional police cooperation practices and governmental technologies have themselves turned into an epistemological target of sovranational bodies, an 'object to be better known' with the aim of making them more transparent but also better governable, as one could suggest from the formulations found both in the 2010 JPO Guidelines, and in the 2017 debate. The final report pointed out that a number of successful cooperations have been developed (Council EU 11839/2/17 REV2): regarding the policing of mass events, between countries with long-lasting close ties and in geographical proximitiy, and "some interesting instruments are rather based on current challenges related to the migratory crisis". The answer to the question regarding "alternatives to temporary reintroductions of controls at internal borders" through enhanced police cooperation, however can mostly not be found in publicly available documents. Only Austria is quoted as having stated that it "is of the opinion that strengthening cross-border police cooperation is always welcome and very useful but it is not an alternative to controls at internal borders". The discussion concluded by noting that mostly bilateral agreements and not the Prüm Decisions were used as legal basis. It was highlighted that Prüm does not prescribe the attribution of executive policing powers, but only that member states "may" give them. According to the final report's conclusion, the current legal framework could possibly be enhanced: on the one hand, by promoting the establishment of more multi-lateral agreements between countries in proximity (rather than maintaining multiple bilateral agreements); on the other hand, enhancing EU instruments through more detailed provisions, which would imply rediscussing the issue of executive policing powers, which in Prüm is not mandatory. Accordingly (11839/2/17 REV2, p.4):

Quite often, this cooperation [examples of very successful cross-border police cooperation], is based on other instruments than the Prüm Decisions, which, according to many contributions, do not cater for the need to define the regime for the use of police powers. Consequently, a discussion could start in order to enhance the current legal framework. Ultimately, this could lead to a less fragmented, and thus more predictable regime where agreements on crossborder police cooperation are multilateral rather than bilateral, and possibly based on harmonized EU instruments rather than local agreements.

\section{At the heart of 'the order of things'}

I discuss these macro-level developments in depth, because they highlight how developments in the regulation and practices of police cooperation - the mobilities (and powers) of police personnel - go to the heart of 'the order of things'. Rather than looking at it from a perspective 
of multi-level governance, governmentality studies interested in power and knowledge have pointed out that a "governmentalisation of government" occurs, when "the mechanisms of government themselves are subject to problematisation, scrutiny and reformation" (Dean 1999, p.193, quoted in Walters 2010; Dean 2010). What started with a recommendation from the Commission to member states to make use of their 'freedom' to employ policing powers in border-regions (as an alternative to temporary border control), brought towards the formulation of a different 'problem' by a Council body: a) that of a lack of knowledge at an EU level of these instruments, and b) that of a fragmented and strongly local and bilateral cooperation practice. It was followed by the proposal to shift towards multi-lateral intergovernmental frameworks and eventually to a discussion on further regulating and harmonising (means: aiming to prescribe?) at an EU level, the executive powers of police forces operating outside their territorial jurisdiction. This would notably be a very sensitive field, but advanced in parallel and indipendent to any consideration whether these means constitute "alternatives" to border control. Some country clearly stated in their responses that they made a strategic use of the fragmented terrain, tailored to best suit their policing needs and that a local set-up was very important. Mobility and its regulation are a crucial field of government (Kotef 2015), even more so when it regards the mobility of bodies which have been considered the specialist repositories of the so-called state monopoly of legitimate force over its territory.

\subsubsection{Border as practices and their symbolic and spatial-legal dimension}

An officer working at a regional police directorate level recalled the development of different generations of 'mobile' compensatory measures in the border-area that accompanied the Schengen implementation and their meaning in the following way:

"To begin with, everyone carried out his own compensatory measures. Then step by step this has been overcome, ceded, like with the European patrols. One started carrying out patrols jointly in the area close to the common border, later also trilaterally. (...). It's about reciprocity, that is also an important European thought." (IV_RL-HLO)

Border-area patrols are controls carried out internally within a country can be considered a first generation "compensatory measure" (with pre-Schengen roots). Joint controls belong to a second and third generation of measures. They are invested with symbolic and representational value, captured in the way the officer defined them as "European patrols" embedded in a notion of "reciprocity". Notably, there is not a body of operational 'European police' as such, but the patrols are composed of officers of different member states, some of whom act on the territory of the other country. Joint mobile patrols are thus carried out both internally and externally, if we start out by taking the border simply to be the dividing line between the participating neighbouring countries. But a more nuanced understanding will also emerge from the analysis in 
the subsequent chapter. I will analytically distinguish joint patrols of second and of third generation: carried out respectively along entry or exit routes. All three generations of measures interact with art. 23 of the Schengen Borders Code (SBC). It establishes that the absence of border control does not affect member states' exercise of police powers in border-areas, albeit limited to spot-checks that do not have an effect equivalent to border control. Following the Commission's recommendation to intensify border-area policing, scholars have interrogated the normative implications thereof: no attention has yet been given to what it means and implies when the likewise recommended CBPC instruments are enhanced and implemented for this scope.

In this chapter we saw a mobile and shifting legally configured border: first that of the 'borderas-line', subsequently that of the 'border-as-space'. The extension and 'deepening' of the 'borderline' to a space for the purpose of policing is not a European peculiarity, one could for example refer to the 100-kilometres border-area (62 miles) in the US. In the EU context Cuttitta (2007) defined it as an inward and outward "flexibilisation" of the border. While countries sometimes do not have specific regulations in place with regards to policing powers in the border-area (some countries do, and indeed CJEU court rulings is requiring states to provide further legal codification thereof), the space in which joint patrols can take place is indeed often legally clearly delineated by bilateral agreements. Joint patrols are possible either in the whole border-zone, or within a kilometre restriction therein. For example: Italy and Slovenia can carry out joint patrols within 10 kilometres on both sides of the border (art. 13), whereby officers of the other country also hold powers to carry out ID checks ${ }^{53}$, while Italy and Austria can set up joint patrols potentially in the whole border-zone territory (art. 19) $)^{54}$. Some policing-mobilities that were initially legally allowed only close to the border through the specific spatial-legal construction of the border-zone, have been further legally 'deepened' into the territory. A measure for which this is very noteworthy is that of hot pursuit. CISA art. 41.3 outlined that it is up to the member states with a common border to agree whether to maintain or not a spatial-temporal limitation. ${ }^{55}$ As we saw, bilateral police cooperation agreements between member states that share a common border contain the definition of a common border-area. Some agreements contain a title "special forms of police cooperation in border zones", amongst which figure hot pursuit, cross-border surveillance, controlled delivery, as well as joint patrols. Sometimes a separate article regulates cooperation along train routes. Recent recasts of bilateral agreements, as for example the agreements between Austria and Hungary, as well as Austria and the Czech-Republic, have lifted the prior existing 10-kilometre restriction of joint patrols. As one of my interview partners called out:

"The 10-kilometres border has fallen as well!" (IV_RL-HLO) 
Joint patrols, aside from questions of their objective and effectiveness, are frequently invested with symbolic and representational value. In my empirical chapters I elaborate how police officers describe and perceive this cooperation practice, what values and meanings such joint operations carry and with respect to which policing phenomena they are employed. While mobile policing in border-areas and joint patrols have found multiple applications, what does it mean and imply when the response to "secondary movements" is sought at this scale and through this policing instrument? And how does this re-configured border - border-practices of the "mobile frontier" - literally take place and effect in the border-area?

\subsection{ELABORATION: Space, law, plural (legal) orders and policing powers}

In this chapter I outlined how space and law are important elements for understanding CBPC and the ongoing reconfiguration of borders. I illustrated how the border-strip emerges as a spatiallegal condition of possibility for the exercise of specific policing powers: the powers to move data across borders (enabled through the border-strip jurisdiction); the powers to carry out mobile border-area patrols (through the concept of the 'mobile frontier') and jointly in operational cooperation. I argued that law organises space and allocates rights and duties, including those of police officers operating in the border-strip.

Inner-European-border peripheries are plurally meaningful space. It is a space for searches and surveillance, a strategic space for crime control and crime prevention, a space of threats; but it is likewise a space of cooperation and of action (Pudlat 2011). I additionally emphasised the legal construction of the border-space and pointed out the importance of engaging analytically with the spatial-legal configurations of the im/mobility regimes that legally enable (and constrain) specific policing instruments: the border-space as institutionalised space of cooperation. The focus on specific policing instruments in this section also allowed me to highlight their role within the Schengen space and in the enlargement process thereof. The EU space in its legal configuration of the Area of Freedom, Security and Justice "throws its legal shadow ahead" (Benda-Beckmann and Benda-Beckmann 2014, p.34).

CBPC instruments can be analysed as governmental technologies embedded within rationalities and governmental problematisations and programs, such as them being "compensatory" measures against a security loss, or as responses to movements problematised as "illegal immigration" or as "secondary movements". But they are also legal mobility regimes to be analysed for the ways space is codified in law and by taking account of the inter-legality of different legal orders. Whilst recognising the importance to refer to bilateral and/or European legal frameworks, both for joint centres and joint patrols it is misleading to deem local, national, 
or European instruments and technologies or scales of legal orders as operating and existing in separation of each other. The policing instruments are rather based on plural legal orders that intersect and relate in particular ways. The geneology and 'social life' of the legal regimes allows to trace ongoing reconfigurations and re-appropriations in the emergence of these instruments as institutionalised regimes of practice. Therein we saw not only 'vertical' interaction, but also 'horizontal' pluralism beyond that of national laws. Bilateral agreements are not entirely compatible in terms of the possibilities and limits to police cooperation agreed upon by the signatory state parties, e.g. in information exchange, hot pursuit, or joint patrolling.

\section{The border-strip within an Area of Freedom, Security and Justice}

The "concept of the mobile frontier" encapsulates the dissociation from the borderline and emphasises borderwork as mobile practice. Related historically contingent concepts - namely sovereignty and territory - are also 'on the move'. If one does not equate a-priori sovereignty with the power of the state to rule over its territory, exemplified through state borders separating political territories, what meanings and forms of 'sovereignty' (and territory, see in subsequent chapters) emerge through such reconfigurations? Before addressing the question through an analysis of (law-as-)practices and their spatial-territorial dimension, let's conclude this chapter by considering law-as-text.

Several cooperation practices institutionalised in law through CISA could be described as "networked-" and "translational liberal policing" (Haahr and Walters 2005) or as a form of relational sovereignty defined through a capacity to participate (Slaughter 2004). Drawing on Slaughter, Aas (2012, p.258) argued that sovereignty needs to be analysed as "multi-sited, multiscalar, networked" and that it can produce effects at-a-distance. According to Slaughter (2004, p.268), when a state grants sovereignty to its components in order to interact with their counterparts in other states (thereby disaggregating state sovereignty internally), this does not weaken the state:

In a world in which sovereignty means the capacity to participate in cooperative regimes in the collective interest of all states, expanding the formal capacity of different state institutions to interact with their counterparts around the world means expanding state power.

In this perspective transnational networks are deemed crucial and as not undermining the centrality of the state in an international system. CISA, in the field of police cooperation (Title III), introduced mutual assistance in information exchange (art. 39), cross-border surveillance (art. 40) and hot pursuit (art. 41), as well as the Schengen Information System. Joint operations became institutionalised multilaterally through the Prüm Convention (2005) and included within the EU framework in 2008. The Schengen acquis, and EU provisions such as the Prüm Decisions today are EU law and infringement procedures can be initiated if member state are deemed not 
be compliant. In a joint Italian publication edited by high level security actors and academics, the authors argued (Capoluongo, Dispenza and Razzante 2018, p.95) that CISA instruments, especially cross-border hot pursuit and cross-border surveillance constitute

some sort of limitation to national sovereignty in favour of a wider cooperation correlated with the countries (...) belonging to the Schengen area, in which instruments of cross-border cooperation are reciprocally recognised and shared.

This resonates with an idea of sovereignty through participation strengthened by mutual crossborder cooperation. The performance of sovereignty in the context of hot pursuit without temporal-spatial restrictions, for example requires an active intervention of the country on the territory of which the pursuit is carried out. Sovereignty, as highlighted by border-scholars, is not an essence but performative. But the excerpt also highlights how perceptions of "limitations to national sovereignty" (emphasis added, ibidem) go hand in hand with sovereignty through participation. "Disaggregated sovereignty" allows one to account for a reconfiguration of sovereignty through legally anchored 'participation' or 'cooperation'. Some of these practices have been defined as "horizontal cooperation" in policing scholarship (Reenen, 1989; den Boer 2004; Block 2011). Nevertheless, the question emerges what meanings 'reciprocity', 'cooperation' and the expression of power acquire for example in information exchange, joint patrolling, or in effects 'at-a-distance'. Such questions need to be investigated empirically and my findings suggest that additional concepts are necessary. It is therefore paramount not to stop at law-as-text and as process: empirical research of the respective practices, experiences and perceptions is required. Not only law-as-text - i.e. the granting of executive or of auxiliary powers to police authorities from one country on the territory of another member state, but even more so as practice - the performance of powers - is embedded within landscapes of meaning and power.

As we shall see, plural performances of sovereignty can take place in the border-area. Stepping closer into the policing of migration, a third police cooperation instrument requires attention. Border-area patrols and joint patrols interact with a cooperation practice which explicitly concerns the policing of mobilities: "fast-track" readmissions across internal Schengen borders. Although these practices across internal Schengen borders were deemed obsolete (BouteilletPaquet 2003), they are not. 


\section{CHAPTER 6 \\ CROSS-BORDER POLICE COOPERATION (II) \\ COOPERATION IN THE FORCED REMOVAL OF '3RD' COUNTRY- \\ NATIONALS ACROSS INTERNAL BORDERS}

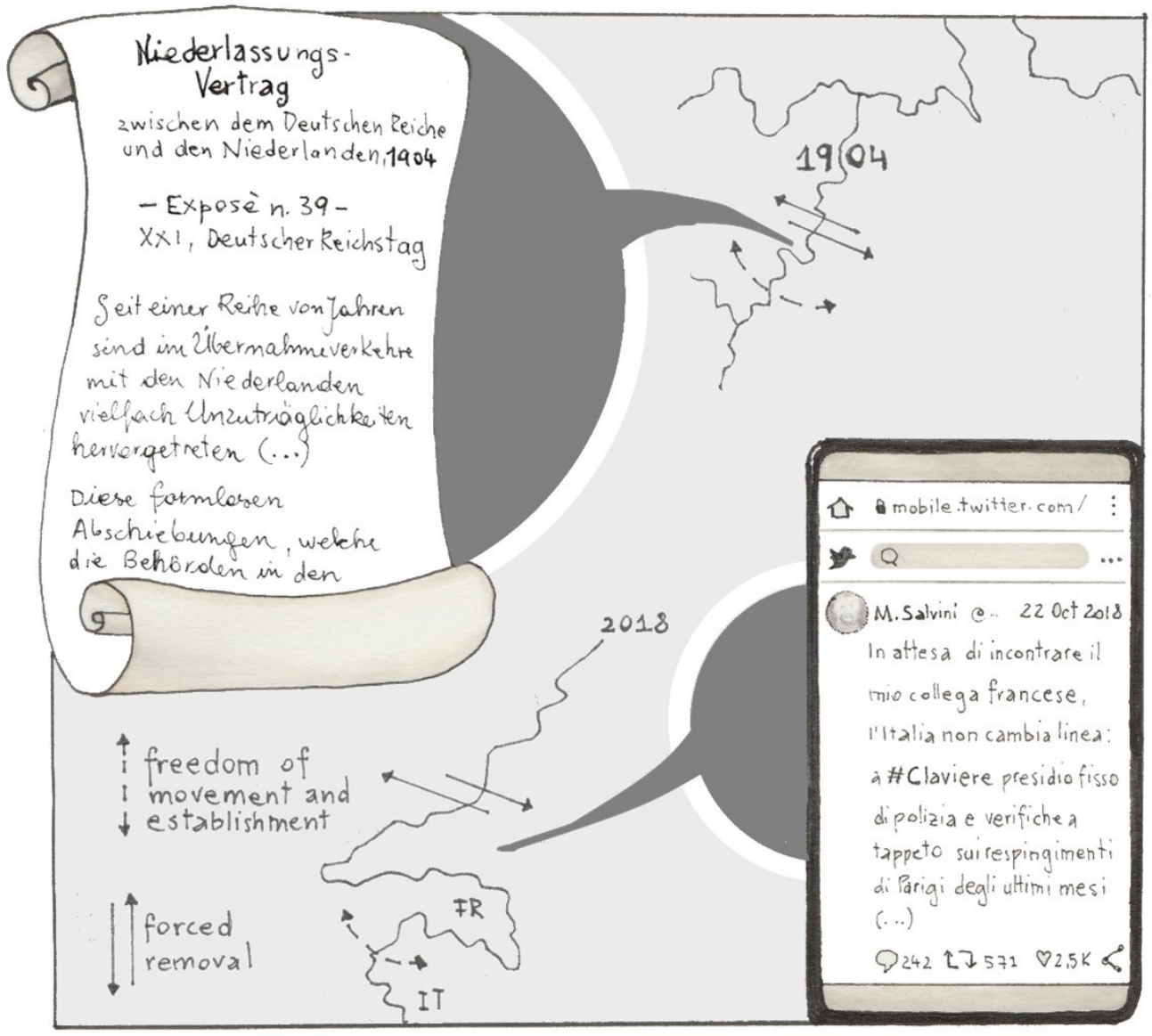




\subsection{INTRODUCTION}

For several years, multiple issues in readmission-traffic with the Netherlands have emerged, partly over different opinions regarding the extent of the obligation to readmit, partly when

persons were expelled from the Netherlands over the German border without any prior request, including persons from third countries. These informal expulsions, which are putting the authorities in the German border-areas in front of difficult policing tasks and which cause considerable expenses, have often led to protracted diplomatic discussions; the German side has repeatedly suggested to contractually bring order into the readmission-traffic.

In turn, the Dutch government has expressed since some time the wish to secure its citizens a contractual right of stay and of establishment in Germany, in order to protect them in this way better against expulsion measures. $\left(^{*}\right)$

Exposé nr 39 of the Reichstag 1904-05, legislative assembly documentation to the 1904 Agreement on Establishment between the German Empire and the Netherlands (in Heinrichs 1908, p.17-18, fn 1)

Awaiting to meet my French colleague, Italy does not change its line: at \#Claviere permanent police control and systematic checks regarding the pushbacks by Paris over the last months. $\left(^{*}\right)$

Tweet by Matteo Salvini, Italian Ministry of Interior, 22 October 2018, 580 retweets, 2.591 likes [online, accessed on 18/7/2019] https://twitter.com/matteosalvinimi/status/1054411895850131456.

Today readmissions frequently do not figure in the list of what police officers identify as their police cooperation practices. "Readmission-traffic" is a form of expulsion and an administrative procedure. However, readmissions require bilateral cooperation between the country that makes the request, and the country which is asked to 'take back' a person. It is considered a state prerogative to deny entry or expel somebody whose presence or entry is unauthorised. However, from a historical perspective - as visible in the opening quote from 1904 - bilateral readmission agreements signed at the intergovernmental level manifest an attempt to shift from unilateral forced removal to interstate cooperation in expulsion through the practice of readmission. While under international law it is considered a state obligation to take back the 'own' nationals, states are not obliged to readmit other countries' citizens, unless stipulated by agreements and decided case by case when conditions such as evidentiary and procedural requirements outlined in the agreements are fulfilled (Hailbronner 1997; Bouteillet-Paquet 2003; Coleman 2009). Historically readmission agreements constituted a crucial form of cooperation in the emerging inter-state system: beyond being an intergovernmental (and trans-frontier) cooperation practice, readmissions can be considered co-constitutive to the development of historically contingent political communities, and their historically contingent "others". Readmissions require police cooperation. Carried out in interaction with other instruments, such as (joint) border-area 
patrols, they are amongst the means employed to police unauthorised mobilities across internal Schengen borders.

Of concern to this study are bilateral readmission-agreements and practices between member states that share a common (internal) border. Readmission procedures (including so-called "Dublin readmissions") are dealt with (mostly, but not exclusively) at a central national level. Contracting partners that share a common border frequently foresee an additional possibility for readmission, i.e. the forced removal of third-country nationals across internal Schengen borders. One officer described this double channel as a "two-level principle":

"The first one, is a simplified readmission, (for) which the local police directorate is responsible. And then the so-called official procedure. In this official procedure the general directorate of the police is responsible." (IV_former-HLO)

While both procedures are in agreements referred to as "nonformal" readmissions, the fast-track or "simplified" procedure falls under the jurisdiction of the border-region police directorates and - depending on the border-region and period - can amount to daily cross-border interactions. In the case of initial refusal, a fast-track readmission request can be re-proposed as ordinary readmission handled centrally. "Readmission-traffic" here concerns mainly the forced removal of persons intercepted by mobile patrols in border-areas, who lack authorisation for entry and stay and who may - under certain conditions - be readmitted back to the neighbouring country from where they entered. This bilateral regime is not to be confused with Dublin readmissions for persons positive on Eurodac, subjected to different procedural rules and safeguards, under responsibility of the Dublin Units. Of concern to this study are fast-track readmissions that can take place after an intercepted unauthorised border crossing on land. I will subsequently discuss practices of refusal/denial at entry at internal land borders during temporary border control.

\section{Border-area control - border control}

The Area of Freedom, Security and Justice (AFSJ) constitutes a spatial regime that embodies a rationality of (differential) freedom of movement. Contemporaneously this regime is sustained by spatial-legal frameworks that create conditions for controlling differential freedom of movement across member states' borders as well as cross-border crime. Inner-European borders are the location of two technologies and practices of police interaction which explicitly concern the policing of migration and which operationally fall under the jurisdiction of border-area police officers. Legally these are two very different procedures and orders, the borders between them are clear. ${ }^{56}$ They are assigned respectively to an 'ordinary' and an 'extraordinary' spatial ordering of the AFSJ: 
- In the ordinary 'normality' frame - absence of systematic border control and presence of "mobile frontiers" - the policing of unauthorised mobilities at the scale of border-regions can take place (in certain circumstances) through a "simplified" fast-track readmission procedure.

- In the 'extra-ordinary' context of a temporary introduction of border control, migration control can deploy the possibility of refusal of entry at the border.

Adopting a formulation of Hailbronner (1997), while the latter are an expression of "territorial sovereignty", the former have been considered embedded in the "principle of neighbourliness". In this chapter I trace and analyse the main features and genealogy of the respective spatial-legal orders and their interaction with other border-area instruments. By scrutinising law-as-text, I suggest that the (in the literature greatly overlooked) fast-track readmission-procedures across internal borders bear traces of former refusal-of-entry practices (territorial sovereignty). Nowadays, however, they are reconfigured: a) being brought into the realm of readmissions, their conditionality dependent upon good "neighbourliness", b) lacking however the procedural safeguards foreseen for returns.

As pointed out by Sassen (1996), in contemporary times where refugee and mass-migration are primarily located outside Europe, it is useful to consider how the history and management thereof is deeply connected with endogenous European processes, the development of the modern European state system and of the notion of citizenship. Today readmission agreements or clauses and the inclusion or non-inclusion of third-country nationals constitutes a pressing issue in negotiations between the EU or its member states with countries of origin and of transit of migration. Today most scholarly attention concerns agreements with non-EU countries, increasingly also since the EU gained competency (shared with member states) with the entry into the Treaty of Amsterdam. This has been analysed as a merging of Justice and Home Affairs (JHA) and Common Foreign and Security Policy (CFSP). I will illustrate and argue, that these developments have their roots in long-term processes. Scrutinising readmission regimes and related instruments over time enables a tracing of genealogy of mobility control, and its intersection with historically contingent politics and projects of freedom of movement.

The two quotes above - the exposé of the German Empire from 1904 accompanying the DutchGerman agreement on establishment (which contained procedures for readmission), and a tweet by the Italian Minister of Interior (2018) - diverse as the communication (channels) and their historical context are - suggest that despite many developments, there are also some pockets of continuity. In the concluding section of this chapter, I reflect upon the role of temporalities in plural legal orders, and that of viapolitical routes in border-area policing. Additionally, the two excerpts suggest that cross-border interaction in the management of unauthorised mobilities can 
be read as a barometer of cross-border relations. The policing of mobilities through forced removal of third-country nationals across a border can still trigger (un) "diplomatic discussions" (1904, above): the permanent police control and systematic checks at Clavier on the FrenchItalian border in 2018 was not aimed at controlling the movement of migrants: the target was the behaviour of the French counterparts.

\subsection{FAST-TRACK READMISSION - SWIFT REMOVAL ACROSS INTERNAL BORDERS}

\section{An ordinary non-formal administrative procedure}

Since the creation of the Schengen-area and the Dublin system as multi-lateral readmission agreement for asylum applicants, bilateral readmission agreements and practices between member states have been considered obsolete or regarding only a very limited practice (Bouteillet-Paquet 2003, p.359). In a book collecting chapters on "how police officers experience the refugee-movement" (Dobretsberger 2018), Oberrat Gufler described as primary task of his police-department the treatment of "persons who are intercepted shortly after they crossed the border" and the decision "if a fast-track readmission to the neighbouring state from which they entered is possible" (Gufler 2018, p.110). In the experience and preception of this Austrian officer, working at the EFGA department of the LDP Tirol (on police organisation in Austria, see Annex II):

[i]f in this job it is even possible to talk of an "experience of success", then it's those situations in which it is possible to intercept illegal immigrants quickly and to readmit them swiftly. (Ibidem)

According to statistical data by the Police Directorate Tirol - one of 9 Austrian federal Länder and workplace of this officer - the following statistical picture can be composed:

Table 2: Readmissions at an AT-IT border-section: 2014-2019

\begin{tabular}{|c|c|c|c|c|c|}
\hline Year & \multicolumn{3}{|c|}{$\begin{array}{c}\text { Passive Readmissions: persons returned to } \\
\text { Tirol, AT (LPD Tirol) }\end{array}$} & $\begin{array}{c}\text { Total of passive } \\
\text { readmissions } \\
\text { (inward) }\end{array}$ & $\begin{array}{c}\text { Total of active } \\
\text { readmissions } \\
\text { (outward) }\end{array}$ \\
\hline & $\begin{array}{c}\text { Border with } \\
\text { DE* }\end{array}$ & $\begin{array}{c}\text { Border with } \\
\text { IT }\end{array}$ & $\begin{array}{c}\text { Border with } \\
\text { CH }\end{array}$ & & \\
\hline 2014 & 197 & 13 & & 210 & 5779 \\
\hline 2015 & 1462 & 339 & & 1801 & 5402 \\
\hline 2016 & 4750 & 222 & 9 & 4981 & 1672 \\
\hline 2017 & 2022 & 111 & 28 & 2161 & 854 \\
\hline 2018 & 1657 & 21 & 5 & 1683 & 325 \\
\hline 2019 & 1994 & 50 & 3 & 2047 & 176 \\
\hline
\end{tabular}

(*Data from Germany since September 2015 includes persons returned through 'refusal of entry' due to border control, and not through bilateral readmission procedures. Source: annual public LPD reports, composed by $\mathrm{M}$. Weissensteiner). ${ }^{57}$ 
Leaving a critical discussion of statistics and 'trends' aside for a moment, the quote and the statistics highlight that readmissions across internal borders (especially in certain border-regions) have not become obsolete. Indeed, for this officer 'successful policing' resulted in swift readmissions of what is problematised as "illegal" immigration. What does it mean when these practices and application of bilateral legal instruments have indeed not become obsolete as envisaged? Why, with respect to whom, how and with what implications? Before returning to these questions through empirical data in PART III, the 'how' of the fast-track readmissioninstrument will be approached through the institutionalisation of its spatial-legal-temporal order.

\subsubsection{Tracing through time: readmission agreements}

Readmission agreements between member states in force today mostly date back to the 90 's, and a few indeed to the late 50's-60s. When tracing this mobility control instrument, one can identify three periods which saw increased legislative activity in the field of readmission agreements among today's member states: the $19^{\text {th }}$ and early $20^{\text {th }}$ century, the 1950 s-60s, and a last period in the 1990s within the Schengen implementation phase. Historical data suggests that readmission agreements emerged in Europe in the $19^{\text {th }}$ century and developed within the contexts of what I identify as three ongoing processes: ${ }^{58}$

1) As outlined in the quote from 1904 above, bilateral agreements aimed to limit arbitrary unilateral expulsions of foreigners over the border of neighbouring states.

2) Readmission clauses were often part of agreements that granted freedom of mobility and establishment to nationals of the contracting parties: they contained the conditions under which this freedom could be revoked, as well as the procedures for readmitting persons to their country of nationality.

3) Readmission agreements also emerged within (prior and later) developments that granted freedom of circulation to persons 'belonging' to different territorial entities, leading to the establishment of a wider political community. They were thus part of what became to be 'internal' developments. In this process over the $19^{\text {th }}$ century the "stranger" from the next province or country became in legal terms the "foreigner" from another country, and the local resident the "national citizen" (Torpey 2018). From the mid 1950 onwards, we find again that creating spaces signed by (differential) freedom of circulation between multiple countries - such as through the Nordic Passport Union (1952), the Benelux Treaty (1958), and later the Schengen Agreement (1985) - gave rise to contemporary generations of readmission agreements.

Readmissions, beyond being an intergovernmental and trans-frontier cooperation practice, have also played an important role in the creation of various forms of political communities. They are one element of a genealogy of mobility control and its intersection with politics and projects of 
freedom of movement. This process also resulted in the shifting spatial allocation of who is labelled a "third" country national, or in older terminology, a person "belonging to another part": within the terminology of bilateral agreements, this refers to persons from other than the contracting parties. (They are not to be confused with the EU terminology of "third-country nationals". Interesting in regard to the latter is the recent shift in various EU policy papers to substitute this expression with that of "non-EU"). An interesting question, which has not received much attention, is how early readmission agreements for exclusion (expulsion), included persons who were not linked to either of the signatory parties and how they relate to specific political projects on freedom of movement. In what follows I discuss a few historical examples to illustrate the three, at times intersecting, processes identified above. Subsequently I address agreements in force today.

\section{Readmissions: from unilateral expulsion to cooperation and towards the notions of citizen and foreigner}

Schubverkehr, literally "push-traffic", was a frequent practice in the $19^{\text {th }}$ century (examples from various countries can be found in Neumayer 1910). In discussing regulations and provisions regarding the "care for the poor", legal scholar Münsterberg (1887) outlined a common practice amongst German Länder in the early $19^{\text {th }}$ century. Länder were taking turns in carrying out forced transport of "foreign mendicants and likewise undesirable persons" over their borders: different, but not totally dissimilar, to what officers describe as the contemporary "ping-pong" game (see chapter 8).

The easiest and insofar for a long time the most preferred instrument for Länder with a high frequency of foreign mendicants and likewise undesirable [translatable also as annoying], persons, was the so-called push [Schub], i.e. the forced transport of the person to be expelled to the border, or over the border, of the neighbouring state, leaving therewith any further care in goodneighbourliness to that state; which might provide temporary support and then in his turn bring the new arrival to the closest border of the Land. (*Münsterberg 1887, p.130)

Such reciprocal "problem expulsions" (Davy 2004) led to conflicts between the neighbouring Länder. Legal scholars writing at the time interrogated in this context the right of one state to intervene (through expulsion) upon another state and upon the composition of the population of that other state. According to Neumayer (1910), the matter of unilateral expulsions and of readmission agreements touched upon the "elementary question of all public international law". He asked intriguingly: where is the "spatial limit to the power of a state [Staatsgewalt]" (emphasis added), considering the external effects of its internal administrative procedures, namely through expulsions? Since states hold the prerogative to deny entry, as well as the obligation to take back their 'own' nationals, this question becomes particularly interesting with regards to the expulsion 
of persons who are not citizen of the state to which they are expelled. This leads to an engagement with a spatial-political process whereby space became organised as (inter-) "national order of things" (Malkki 1995), in which populations (citizens) are linked to territories (nationstates) deemed responsible for them. Notably, beside "criminals" - but frequently addressed together - the figure of the "vagabond" and "foreign mendicant" were the main objects of these practices and later agreements. "Foreign" in the $16^{\text {th }}$ and $17^{\text {th }}$ century meant "non-local" (Torpey 2000). Walters argued that when modern alien-policing took shape in the $19^{\text {th }}$ century, it reproduced the logic to restrict relief to the 'local' poor and basically to expel the 'other' poor, except that in the $19^{\text {th }}$ century the distinction increasingly shifted from "local versus foreigner" to "national versus foreigner" (2010, p.270). He advanced his argument not regarding readmission procedures, but as a form of expulsion, readmissions were an integral and constitutive part of creating the inter-national state system, but also of understandings of citizenship and for providing technologies for sovereign and governmental power to deal with the "Other". 59

Amongst German states, an agreement between Prussia and Bavaria of $1818^{60}$ seems to have been the first agreement to regulate unilateral expulsions between two neighbouring states. It has certainly been the main reference for subsequent developments. The agreement regarded the "reciprocal readmission of vagabonds". Article 1 established:

In the future no vagabond or criminal shall be expelled to the territory of the other of the two contracting parties, unless he is either a citizen of the State to which he is directed [returned], and where he has his had his home, or if he has to cross the territory of that State as a citizen of a State further away. $(*)$

Notably, this article already included the figure of persons not belonging to either of the signatory parties: in form of a readmission for the purpose of transit (and under the condition that the state responsible for that person - a "vagabond or criminal" - accepts the readmission). In Coleman's discussion (2009) of agreements developed at the beginning of the $20^{\text {th }}$ century, he considered the later transit-regulations "very modern". They had a predecessor almost 100 years earlier. The subsequent Treaty of Gotha (1851) at the time was considered the most comprehensive and multilateral regulation on readmissions (Neumayer 1910). Indeed, it extended the 1818 principles between all signatory German States. This was followed by the unification of Germany in 1871: it granted, inter alia, freedom of circulation to nationals of the German States and regulated readmissions to be enforceable for nationals only under certain circumstances. The notion of "citizen" also emerged out of this process, as analysed by Torpey (2000) through engagement with passport policy in the context of $19^{\text {th }}$ century Prussia and the (North-)German Confederation. 


\section{Readmission: rights of mobility and establishment}

Readmission agreements (of citizen or former citizen of the contracting parties) thus also developed within a process of formalising mobility rights: as the example showed, within territories of the German Confederation and later German Empire (1871-1918), but also with neighbouring states.

The Treaty between The German Empire and Switzerland on the Right of Establishment (1876, 1880, and 1909) and the subsequent Treaty between the German Empire and the Netherlands on Establishment (1904) have been considered by legal scholars writing at the time crucial references in what was defined as a new and emerging body of international law. These agreements sought to regulate on the one hand the rights and duties of "aliens" within a territory, and on the other hand the rights of the contracting state parties (Freiherrn-von-Overbeck 1908, 1912). It is the latter element I will discuss here in more detail.

The German-Dutch Agreement on Establishment (1904) ${ }^{61}$ is worth a closer look. It is of relevance here with regards to the different procedures for readmissions contained therein, and for the ways in which persons "belonging to other parts" than the contracting parties were included in the scope of those to be formally excluded.

1) The first readmission procedure was through written notifications between the border police forces of the border-region prior to readmission (art. 7).

2) In circumstances where the belonginess of a person as well as non-fulfilment of criteria to stay was "clear", readmission was also possible without written formalities and not needing any formal acceptance (art. 8)

3) A diplomatic solution was foreseen only in case of an unclear or challenged case (art. 9).

4) In addition, art. 12 outlined a fourth procedure to be applied to persons who did not satisfy the criteria for establishment: when the person of concern was intercepted at the first stop of a border-crossing train, the person could be returned without any formality at all. (This was seemingly the only context in which the practice of "informal expulsions" critiqued in the expose' quoted in the introduction, could be maintained also within the terms of the agreement. However, Heinrichs (1908) foot-noted that although regulated amongst readmissions, legally this procedure would rather be a denial of entry. I return to this remark below.)

The agreement concerned in principle the situation of persons of the contracting parties. The figure of the 'third-country national', a person "belonging to another part", was included twice. 1) Like in the 1818 readmission agreement between Prussia and Bavaria, this figure was included with regards to admission for the purpose of transit through one of the contracting state party's 
territory (art. 13). The requests for transit had to be made through the diplomatic channel and the third country had to accept the readmitted person and if necessary, cover the transit costs. 2) This figure was likewise included amongst the category of persons that can be returned - as outlined in art. 12 - through the $4^{\text {th }}$ procedure: namely immediately and without any formalities to the neighbouring contracting party from which they sought entry. In addition, the GermanSwiss agreement (art. 18) included third-country nationals also within the category of "youngsters, persons in distress or bad health, and in need of help": in case they had been kept in institutions and had escaped over the border (sic).

While scholarship debating possible "obligations" to readmit third-country nationals identify the readmission agreements stipulated in 1950-60 as first having included clauses on third-country nationals (Hailbronner 1997), we already see here earlier forerunners. Except for transit purposes, they present a link to interceptions close to 'the border'. As remarked by Sassen (1996, p.67), it should be reminded that the role of border control and checks at entry and exit before the first World War was comparatively limited.

\section{Readmissions: politics and projects of freedom of movement without border control}

Leaving aside developments between the first and second World War and recognising important developments regarding increasing systematicity and sophistication in border control, the 1950s and 1960s were the next period in which readmission agreements in Europe took shape. Notably, again within a process of creating spaces signed by freedom of circulation and establishment. According to Coleman, the Benelux context served as a "laboratory" for European developments also with regards to readmissions. The 1958 Treaty establishing the Benelux Economic Union entered into force in 1960. It granted citizens of Belgium, Netherlands and Luxemburg freedom of movement and establishment in the Benelux area and lifted the control of what became an 'internal' border. The Treaty also regulated readmissions (including of third-country nationals) amongst member states of the Benelux area, but also towards neighbouring countries. Readmission agreements were stipulated (inter alia) with neighbouring France (1964) and Germany (1966) ${ }^{62}$, regulating readmissions of their nationals, as well as of third-country nationals. Interestingly, within the Benelux area and according to Groenendijk (2004, p.152), the Netherlands, not satisfied with the quality of the controls at the Belgian-French border, had introduced some border-area policing on the border to Belgium in 1976. Therewith, I add, they were able to readmit intercepted persons which might had entered undetected from France to Belgium back to Belgium.

However, one can also look at the Nordic Passport Union (1952) as an earlier example. It aimed to abolish border control and passport obligation and gave freedom of circulation and establishment. This process and aim also led to readmission agreements. Germany's readmission 
agreements with countries of the Nordic Passport Union were stipulated in 1954 with Denmark and with Sweden and in 1955 with Norway. ${ }^{63}$ These bilateral agreements are still in force today (Bundesministerium des Innern für Bau und Heimat 2020) ${ }^{64}$ and do contain a fast-track procedure. For example, the Danish-German agreement contains a clause for fast-track readmissions (within 7 days), as does the German-Benelux agreement (1 month), as opposed to the 6 months frame for making an ordinary readmission request. In both agreements, it needed to be certain that the person entered from the neighbouring country and had spent 2 weeks there before. We shall see, agreements stipulated in the 90s and within the Schengen process, aimed to ameliorate the conditions for successful readmissions, by setting temporal and evidentiary criteria easier to satisfy, and they also introduced stricter time limits for fast-track readmissions.

\section{Between territorial sovereignty and the principle of "good neighbourliness"}

In his detailed assessment of readmission agreements and the Obligation on States under Public International Law to Readmit their Own and Foreign Nationals, Hailbronner (1997) argued that the obligation regarding third-country nationals resulted less from established principles in international law, than from the "principle of good neighbourliness" that found expression in the agreements of the 1950 and was invoked throughout the 1990s (see also Lehnguth, Maaßen and Schieffer 1998, p.62, fn 5). According to Heilbronner (1997, p.27), the obligation resulted because

the requested state allowed the entry of nationals of third states onto its territory who then travelled further onto the territory of the requesting state without the necessary entry permission or residence permit.

Different from the (ironic?) use of "good neighbourliness" made by Münsterberg (1887), here the "principle of neighbourliness" acquires meaning connected to the notion of responsibility: "the responsibility of a state for those impairments to other states emanating from its territory" (Heilbronner 1997, p.31). Thereby the principle "defines a limit to the territorial sovereignty of states" (p.34). Hailbronner pointed out that, irrespective of the question whether unauthorised onward mobility can be considered an "impairment", according to the scholar there was not (yet) enough evidence of member states actually practicing this principle. Readmissions and the principle of neighbourliness in Hailbronner's analysis are qualitatively different from a mere compliance with "territory-related sovereignty": with the latter he seemingly referred to states having to 'accept' a person following a refusal of entry decision (territorial sovereignty).

\section{Schengen - temporal and evidentiary criteria (subject to "good neighbourliness")}

The 1990s thus saw the last configuration of readmission agreements between member states, before readmission agreements with non-EU and non-Schengen members became of more central political concern. Considering the pattern just outlined above (processes of creating spaces signed by freedom of circulation and establishment and renewed agreements with third 
parties), the contemporary merging of Justice and Home Affairs and Common Foreign and Security Policy with the aim of fostering readmission agreements with non-EU countries does not constitute a historical novelty. Nevertheless, the most discussed "historical" agreement in this regard, which included the figure of third-country nationals and clearly formulated readmission obligations regarding third-country nationals, has been the multilateral agreement between Schengen member states and Poland in 1991, as well as the German additional agreements with Poland, and with Czech Republic in 1994 (Lehnguth, Maaßen and Martin Schieffer 1998; Bouteillet-Paquet 2003; Hailbronner 1997).

While police cooperation and bilateral agreements have seen major developments within the EU integration process, this is notably not the case with bilateral readmission agreements amongst member states (see Table 5a and 5b, Annex II). Readmissions were mentioned in art. 23.4 of the Convention Implementing the Schengen Agreement (CISA; art. 23 and 24 were later substituted by the Return Directive, see below) ${ }^{65}$. In reference to CISA, in 1997 the Schengen Executive Committee issued guiding principles "for means of proof and indicative evidence within the framework of readmission agreements between Schengen States" (SCH/Com-ex (97) 39 rev). As motivation the Committee argued in the preamble that

problems have arisen in practice when applying readmission agreements, notably with the means of proof establishing the illegal residence in or transit through the territory of the requested Contracting Party by foreign nationals.

The renewed and new agreements - mostly stipulated in the late 90s - aimed to overcome what Lehnguth defined as "impracticable" aspects of the former agreements. According to this author, obstacles for application were the temporal and evidentiary criteria contained as conditions for a successful readmission, such as the time limit within which a request for readmission could be made, as well as the proofs that the concerned third-country nationals had entered and been present for some time in the neighbouring country (Lehnguth 1997; Lehnguth, Maaßen and Martin Schieffer 1998). We saw such criteria outlined above in the German agreements of the 50 s and 60 s. Some changes of the 90 s were the introduction of a range of evidentiary possibilities, as well as amendments in some agreements to the temporal-spatial criteria in order to facilitate the practical application of readmissions. Notably, by then this was already in the context of the prospect of abolished border control. Agreements of the 90s hold a stricter time-limit for fasttrack readmissions than the agreements of the 50s and 60s, and they are therewith more closely related to border-crossing interceptions in the border-area: 24 hours in the Italian-Austrian agreement $(1998)^{66}, 4$ days in the German-Austrian agreement $(1998)^{67}, 4$ hours in the FrenchSpanish agreement (2002). ${ }^{68}$ Therein it is evident they were meant as a measure to counter 
irregular entry, and not one to end an irregular stay. These temporalities matter in how 'bordering' takes effect by assembling different border-area instruments (see chapter 6.4.).

As we shall see, evidentiary principles and especially (good) "neighbourliness"-relations still are considered 'things that matter' in contemporary readmission practices.

\section{EU legislative context: keeping elements of the 'old' order alive}

In 1999-2000 there was a last proposal to further regulate and 'harmonize' internal European readmission agreements, known as the Finnish Initiative (Council initiative 1999/C 353/05), albeit in view of implementing future $E U$ readmission agreements. ${ }^{69}$ Despite several meetings of the Council's Working Party on Migration and Expulsion, which took place between October 1999 and January 2000, in the end the proposal was not adopted. Asked by the German delegation about the effect it would have, according to the Presidency it would have impacted existing bilateral agreements on readmission between Schengen members (Council EU 5599/00, pg. 2).

The Return Directive (2008/115/EC) ${ }^{70}$ notably replaced the provisions of CISA art. 23 and art. 24. It aimed to set "common standards and procedures in Member States for returning illegally staying third-country nationals". In chapter II (art. 6, "return decisions") we find an explicit reference to bilateral readmission agreements between member states, namely as one of the "exceptions" under which member states may refrain from issuing a return decision, "if the thirdcountry national concerned is taken back by another Member State under bilateral agreements or arrangements existing on the date of entry into force of this Directive" (emphasis added, art. 6.3.). ${ }^{71}$ It is also stated that it is then on the receiving country to issue an eventual return decision. It has indeed also been argued that the directive per se does not preclude the possibility of socalled "chain readmissions", i.e. the receiving country in turn readmitting a person towards another country from which the person had entered (see publication on the normative regulations of the German Bundespolizei, in Kolber, Kreckel and Niechziol 2019).

Bilateral readmission agreements in force today are still those that existed at the entry of force of the Return Directive (see Table $5 \mathrm{a}$ and $5 \mathrm{~b}$, Annex II). This is explainable by taking into consideration intertextual and interlegality relations with the Return Directive. In keeping this 'old' order alive, paradoxically, only agreements in force prior to the Return Directive, continue to provide a legitimate base recognised in EU law. According to fieldwork data, it seems that the agreements have indeed been updated on some aspects, but only in the form of (non-public) implementing or operational protocols. While the Return directive foresees procedural safeguards (decision in writing, effective remedy to appeal, etc.), the fast-track possibility, which is part of several readmission agreements between member states that share a common border, notably does not foresee any such protections within the terms of the agreements. 
In 2018 a recast of the Return Directive was proposed by the Commission (COM/2018/634). ${ }^{72}$ In the recast motivation the "risk of absconding" and "secondary movements" figure as results of inconsistent member state practices on risk interpretation and use of detention, hampering according to the Commission successfull enforcement of return decisions. Maybe not surprisingly, the provision of art. 6.3 was left unchanged, but the date was now specified and all bilateral agreements in force prior to January 2009 are set to remain valid (former art 6.3, art. 8.3 recast; neither the Council nor the Parliament so far proposed amendments in regards). This suggests that rather than being a provision of an 'old' legal order (with even older roots) and an instrument that was overlooked within developments of the 'new' legal and political order, it seems to be willingly maintained 'alive' as such. Additional evidence thereof is found in the Commission's recommendation to enhance border-area policing (C(2017) 3349 final). Under point 19 member states were advised that a "proper" and "efficient" application of the bilateral readmission agreements in accordance with article 6.3 of the Return Directive would be "instrumental in addressing secondary movements of illegally staying third-country nationals". They are in practice also applied to counter irregular entries, not only stay, especially in the case of simplified readmission procedures following border-area interceptions. In an assessment of law-as-text, the fast-track procedures lack the procedural safeguards required for in the Return Directive and this instrument is being kept alive and recommended as such.

From this analysis of law-as-text and as long-term-process, we see that policing instruments at internal borders are considered a valid scale to deal with inner-European unauthorised mobilities. I will return upon the issue of temporality and legal orders in the chapter's concluding elaboration.

\subsubsection{Historical variants and a barometer for cross-border relations}

According to Coleman (2009, p.14), readmission agreements in Europe initially "served primarily to enable the expulsion of undesirable persons - vagrants, persons constituting a threat to public order or national security - to their countries of nationality, or former nationality" - and only from the 1950s were onwards agreements stipulated "for the purpose of regulating migration flows". As we saw, third-country nationals already figured in the early agreements, categorised as "vagabonds", "foreign mendicants", "criminals" or, as formulated by Münsterberg (1887, p.130), "likewise undesirable persons". They find their contemporary problematisation in an (in)security continuum in terms of "secondary movements" and "asylum shopping", but also as threats to national security and potential criminal and terrorist threats. But the merging of perceived to be 'risky others' is nothing new.

According to the Prussian King Frederick William III (1813, quoted in Torpey's 2018, pg. 76), the passing of passport laws in the $19^{\text {th }}$ century aimed to "pay as much regard to the freedom of 
travel and commerce as to the security in the interior of our monarchy". H.H. (1866, pp.142-143) argued that the new passport law (1865) needed to find a middle way between two positions: 1) that to "abandon all deriving protection from it [the passport system] against the intrusion of dangerous persons", 2) to keep a "possibly large territory" within which a "a possible freedom of movement" with strict pass-control on the border of that territory $\left(^{*}\right)$. In the establishment of the Schengen compensatory measures was highlighted the involvement of police-networks, arguing for the need of strong external controls and measures to enable internal freedom of movement. In the $19^{\text {th }}$ century police-networks had played a non-secondary role as well. The impulse for a new pass-port law came from the association of high-level police representatives ('Police Union'), composed of officers from (at the time) Austria, Prussia, Saxony, Hannover, Bavaria, Württemberg and Baden. H.H. (1860, p.250) suggested that the new passport law found the middle way.

\section{A barometer for cross-border relations and of larger issues at stake}

Unilateral expulsions have not completely disappeared through the stipulation of readmission agreements as a means of cooperation. Groenendijk (2003, p.132) argued, with reference to the Belgian-French border, that expulsions over the border carried out in informal ways, and which violated existing laws, were practiced quite frequently by both sides: "[t]his practice of cheating colleague's frontier guards of the neighbouring state was quite common". According to Coleman (2009, p.16), up to the early 90s the so-called "Roosendaal method" was common practice on Dutch borders, resulting in repeated expulsions (also referred to as "migrants 'in orbit'") between the Netherlands and Belgium and in intergovernmental tensions. ${ }^{73}$ Colombeau (2015) documented and analysed practices at the French-Italian border. Persons were denied crossing into France, or also an "accompaniment back to the limits of French territory" (RLT, raccompagnement aux limites du territoire) - 25 meters into the Italian territory - was carried out. French PAF officers outlined several "challenges" in readmissions: a) that Italian officers did not collect persons to be readmitted, b) that the ratio of readmissions was 10:1 (mostly used to readmit from France to Italy, but not vice versa), or c) that the Italian counterparts simply 'released' the migrants afterwards. In the first case, a PAF officer argued they accompanied them themselves over the border. Colombeau defined such procedures as "a deportation procedure between two member states of the Schengen Area" (ibidem, fn. 23), highlighting they were stipulated during the Schengen Implementation phase. Although she pointed out that borderregion departments apply a "simplified procedure" and argued that this constitutes a continuity to pre-Schengen border-practices, this instrument deserves further in-depth analysis.

In contemporary circumstances it has been foremost advocacy and migrant rights groups to accuse states of illegal pushbacks, referring to expulsions outside readmission procedures, but 
also arguing that fast-track readmission procedures can de facto amount to illegal pushbacks (e.g. cases of collective readmissions, impossibility of making an asylum application, readmission of minors), or even that such procedures presented overall both in form and content a lack of due process and guarantees and were to be considered illegitimate. At times policing practices have also precipitated intergovernmental diplomatic conflict. The "permanent police control and systematic checks" (Salvini tweet 2018) at the Italian-French border, notably were not aimed at (outgoing/incoming) migrants but at the conduct ("pushbacks") of French police authorities. But this is far from being the only inter-state border on which pushbacks as well as readmissions are a barometer for larger issues at stake. By intensifying mobile police controls in border-areas of one state, on certain internal borders - as we saw in the Austrian case of Tyrol - readmission requests peaked. (Good) neighbourhood relations were put under stress and on political levels readmission statistics turned into a political contest of numbers and into an (un)diplomatic weapon. In July 2018 Italy's Minister of Interior was quoted in the German press, saying that Italy would only benefit if Austria closed the border, since more persons were being intercepted entering without authorisation from Austria to Italy, than in the other direction (welt 2018). The legitimation of practices anchored in the bilateral agreements on the one hand, and instances of pushbacks as well as doubtful possibilities to make an asylum application prior to and suspending a readmission on the other, emerged in statements by representatives of the Mols on the Spanish-French border for the former (Ormazabal 2018), and most recently on the ItalianSlovenian border for the latter practice (Camera dei Diputati 2020, n. 2-00861). We now shift from practices associated with "good neighbourliness" closer into those of "territorial sovereignty": the possibility to refuse entry on occasion of temporary border control.

\section{3. 'TEMPORARY' BORDER CONTROL: "refusal of entry" and the "fiction of non-entry"}

With the 'extraordinary' temporary reintroduction and continuous prolongation of border control by several Schengen Members since 2015/2016, an additional practice has been (re-)activated on internal borders, namely the possibility of unilateral refusal of entry, which does not require the readmission procedure outlined before. As one of my sources succinctly put it:

"The border control law is alive again. Yes, Schengen covered it, now it is alive again." (IV_RL-HLO)

What does this mean? Practices and legal interpretations are complex and have progressively developed since border control was first reintroduced and they are still ongoing. The initial answer (and in terms of practice) is that border control has been carried out at internal borders applying the regulation of border control at external borders (Schengen Borders Code) and national law. ${ }^{74}$ The SBC border control allows inter alia a refusal of entry for persons "considered 
a threat to public policy, internal security, public health or the international relations of EU countries", but also of persons who e.g. are without valid travel document, as well as those deemed unable to justify to the border control authorities the purpose of the intended stay and to show themselves to be in possession of enough means of subsistence. It also exempts under certain conditions from obligations under the Return directive in favour of swifter simplified procedures, including when a person is intercepted in connection to a border crossing. In 2019, the Court of Justice of the European Union (CJEU, Case C-444/17) stated that contrary to the positions of France and Germany, the internal border is not tantamount to the external one. ${ }^{75}$

Various scholars have discussed the introduction of temporary border control by member states, but less have engaged with specific applications thereof. Focusing on the Austrian border, Josipovic (2019) pointed out the performative, symbolic and political function of border controls at internal borders. He argued that while on the one hand borders have come to be governed biand supra-nationally, on the other hand (following Wendy Brown's argument), they are symbolic acts: a border spectacle to demonstrate sovereignty of the nation-state. Legal scholars have indeed questioned (already before CJEU case law) the conformity with EU law of specific practices that have been set up. Discussing new accelerated administrative Dublin agreements by Germany with Spain as well as with Greece, Hruschka (2019a) argued that the

'fiction of non-entry' (Fiktion der Nichteinreise) has been extended to this [German-Austrian] border-area. It should allow for controls on German soil and the refusal of entry would (legally speaking) push the person that had already reached German soil outside the territory into a perceived no man's land (...). This effect might be called a 'border spell' as the persons (...) have already legally and physically crossed the border between the two states and had previously already entered the Schengen territory.

This so-called "border spell" according to Hruschka created a space outside EU law (the Dublin regulation and $S B C$ ). Border-zones such as airport waiting zones have been analysed as legal constructs that create a distinction between physical presence and legal presence. Basaran (2011, p.49) defined them as a "peculiar invention of states, which are within the territory, but nonetheless regarded outside the guarantee of constitutional principles". She argued that this is not a new security technology, but an old technique created to prevent entry into the state and where liberties are legally restricted, and rights otherwise guaranteed on the territory withdrawn. European airports are indeed 'external borders', unless for intra-Schengen flights. With regards to the spatial-legal configuration of internal land borders an additional aspect has thus to be pointed out.

National law - regulating border control and (denial of entry) procedures - that "is alive again" (cit. above) does not necessarily locate the border only at the borderline. This and the "fiction of 
non-entry" are not an ad-hoc invention (while the agreements Hruschka addresses are). In the German and the Austrian framework, the law claims validity over a spatial zone. In Germany the Bundespolizei has competencies in the 30-kilometre border-area and regulations on external borders (SBC) allow certain measures to be taken also immediately after an unauthorised crossing. ${ }^{76}$ The Austrian border law from 1996 (Grenzkontroll-Gesetz) foresees explicitly that each border-crossing point (BCP) corresponds to a border control-area: it expands in a radius of 10kilometres around the BCP inside the country, as well as along border-crossing railways (art. 7). ${ }^{77}$ The extension of the border inside the territory (explicitly in the second case) is therefore not a recent invention. But in the context of abolished border control, refusal of entry was legally impossible to realise.

Tracing the "fiction of non-entry" brings us to revisit the German-Dutch agreement on Establishment of 1904. With reference to art. 12 - dealing with informal and immediate return after interception at the first train-station of a border crossing train - we find a succinct expression of the logic behind what was literally defined as "fiction". The implementation document to the agreement of 1904 stated:

With this regulation [art. 12] the fiction is created, that the persons have not left the country of provenience and that therefore they do not fall under the readmission procedures established in the agreement. Condition for the return is, that it is carried out immediately after arrival, thus in principle with the first train going back. („Zum Artikel 12“, in Anweisung zur Ausführung des deutsch-niederländischen Niederlassungsvertrages vom 17. Dezember 1904, reprinted in Heinrichs 1908)

Even more explicitly reads the initial Explanatory note that accompanied the agreement. It concluded this very sentence pointedly (in Heinrichs 1908, p.35-36, fn 18):

(...) only in this way, the fiction in question can be maintained.

Such fiction in a contemporary context does not necessarily encounter the benevolence of the neighbours. In case of a denial of entry - which with Hailbronner we can call an expression of "territorial sovereignty" - the person to whom entry is denied should find himself therefor on the territory of the neighbouring country. Contrary to fast-track readmission procedures, after a refusal of entry on a land border there is no request made to the neighbouring country to accept or to deny the person, as required for fast-track readmissions. Additionally, also when entry is denied on a border-crossing-point, without the presence of border-police-personnel on both sides (i.e. in unilateral border control), there is nobody on the border to 'receive' the rejected person. The 'obligation' to re-allow into the territory has not always been smooth and some instances thereof also hit the news. In 2017 on the Austrian-Hungarian border persons were first denied entry by Austria in the context of Austria's border control measures, and subsequently, 
they were (initially) not allowed entry into Hungary (press-reports, see Alon 2017; Oczeret H. 2017). Hungary verbally challenged the conformity with EU law (the SBC) of the "fiction of nonentry" (persons intercepted beyond the border-crossing-point [BCP]) and defined Austria's practice as illegal pushback. It requested that instead of simply sending the persons back to Hungary following a 'denial of entry' decision, Austria had to propose them within an ordinary or a fast-track readmission procedure. In turn, that removal route has seen no incoming traffic since some year before, when Hungary had stopped accepting the persons 'offered'. Fast-track readmissions depend upon cooperation, subject to the conditionality of "good neighbourliness".

The persons stuck between the two police-forces on the Austria-Hungarian border were caught in a border-struggle extending way beyond the interaction between the police authorities and the persons refused entry. In chapter 8 I analyse border-struggles that are carried out in, but are not reducible to, neither this interaction and those of readmissions, nor to the border-strip.

To be added here: the 2019 CJEU ruling considered an interception in the border-area as irregular stay (thus no "fiction of non-entry") and that the internal border (when temporarily controlled) can not be equated with the external border (measures). The General Advocate opinion recalled the SBC rationale, that "internal borders may be crossed at any point without a border check on persons being carried out". Authors like Hruschka (2019b) argued the CJEU uphold "the Schengen space as a space without internal border control" and that therewith border control could not be legally (mis)used for migration control. My point is, that this decision additionally contributes to a stronger search for - and reinforcement of - 'ordinary' means to control irregular mobilities and to govern differential mobility rights within the Schengen space.

\subsection{THE 'ORDINARY' WAY OF BORDER-WORK: three generations of measures}

I previously illustrated how the concept of the "mobile frontier" emerged as a first-generation compensatory measure and was subsequently followed by the deployment of joint mobile controls in border-areas. The shift towards, or possibility of, joint policing should also be analysed in connection with readmissions. It comes with the possibility to shift the logic and temporality of (migration) policing. Adopting an analytical lens attentive to viapolitics (Walters 2015a), routes and directions of mobilities, I propose to analytically differentiate between the following three generations of compensatory measures through mobile border-area policing. They form different assemblages of how bordering takes place under the 'ordinary' framework of abolished border control. Border-area policing and readmission come into relation as technologies, spatial-legal configurations and associated meanings and discourses, and they produce different effects. I provide here an initial analytical differentiation, to be further elaborated upon in PART III. 
First-generation: mobile border-area controls, carried out internally by one country on its territory. The interception of persons without authorisation of entry mostly translates into control of mobilities entering the country. ${ }^{78}$ These practices intervene after the (border-crossing) fact and can result in fast-track readmissions (or, for example, in a formal Dublin-readmission procedure, for persons positive in Eurodac).

Second-generation: joint patrols carried out either on both sides of the border (they are thus 'internal' and 'external'), or on the territory of one of the participating countries (only internal for one country, external for the other). I define joint patrols that are carried out along entry routes as second-generation measures. Similar to first generation measures, the interception of persons without authorisation of entry can result in a readmission.

Third-generation: joint patrols carried out either on both sides of the border or on the territory of one of the participating countries in the direction of exit routes. Here the control aims to intervene in a 'preventive policing' approach before an assumed future border crossing happens.

With this distinction I do not imply necessarily a chronological development and they are not mutually exclusive and in fact often combined. Indeed, the joint patrols between Poland and Germany (chapter 5) did also control exit-routes on the Polish side. However, in inner-European cooperation there has seemingly been a trend towards fostering third generation instruments.

In PART III I address how readmissions and their relation to other border-area CBPC instruments acquire meaning in the every-day work of police officers. What role does police interaction at the scale of inner-European border-areas and respective jurisdiction play within the government of certain mobilities, those that today are problematised as "likewise undesirable"? This means to recognise the role of jurisdiction in the answer to the question of how a phenomenon is governed (Valverde 2008). Whilst recognising the legal, procedural and political differences between border control and border-area control: what are the differences between these two instruments, the border between the two legal orders and their temporality in practice, if we study them from the perspective of mobility control? While scholars have argued that plural legal orders create uncertainty for targets of controls and inhabitants (Benda-Beckmann and BendaBeckmann 2014), how are they experienced on the side of the subjects of control, i.e. police officers?

\subsection{ELABORATION: viapolitics and temporalities}

In this chapter I illustrated how (fast-track) readmissions as well as temporary border control are an instrument for mobility control that is linked to politics of movements and historically specific 
projects thereof. Not only airports, but also railways and roads have been considered strategic places for the governance of migration through policing, also under conditions of abolished systematic control at internal borders.

In drawing out his argument that vehicles, roads and routes require a more crucial place in analysis of migration politics and of mobility governance, Walters (2015b, p.100) argued that "when the policing of routes and vehicles becomes a central strategic undertaking in the governance of migration, then migration has become viapolitical". As emerged in chapter 5, policing has since long responded to changes in the transport-sector. Border-areas cover one track of border-crossing mobility-routes: one of strategic importance. H. H. (1866, 240-241) quoted:

With the changed means of travel, the police have been forced to give up the more trivial things and have, so to speak, acquired an international type of activity with which previously they had nothing to do.

This particularly holds for police-work in border-areas. Feys (2019), in a historical case study on Belgium, documented how from the mid- $19^{\text {th }}$ century to the beginning of the $20^{\text {th }}$ century the development of international rail connections influenced police possibilities for control of entry and for expulsion and removal practices. From the perspective of policing, I argue what matters are not only the vehicles and roads for mobility (authorised or not), but also the vehicles and ways through which mobility seeks to be governed 'on the move': through vehicles such as the Schengen bus, through mobile (joint) patrols in border-areas, through instruments such as readmissions, or through 'mobile' technological devices and increasingly through data mobility in the virtual space.

Attention towards viapolitics enables a consideration of directions of mobility trajectories, which allows for a degree of analytical distinction, such as whether the patrolling of entry or exit routes acquires strategic importance and how. In addition, however, technologies of government need to be analysed in relation to the legal mobility-regimes that enable and constrain policingmobilities and the policing of mobilities. The mid-level concept of viapolitics needs to be combined with an analysis of inter-legality (Boaventura-de-Sousa 1987). We saw that multiple legal frameworks interact. They are plural and bear a particular rapport to temporality. By tracing the genealogy of specific policing instruments and their emergence as institutionalised practices, it has already become apparent how legal orders are creations of their times. They embody a specific legal configuration of space, politics of movement, as well as understandings of such concepts as sovereignty, territory and of the political community the spaces' borders aim to enclose. Benda-Beckmann and Benda-Beckmann (2014, p.39) argued that "phases in which new 
spaces are fading in are typically characterised by the co-existence of the old legal order and an emerging new regulatory regime".

Within the spatial-legal configuration of the AFSJ, temporary border control is constructed as 'extraordinary' measure, as opposed to abolished border control and compensatory measures as the 'ordinary' functioning and spatial-legal ordering of the AFSJ. Fast-track readmission practices operate under the so-called "normality" frame of 'ordinary' borderwork, although - as I argued they have emerged in processes that preceded the creation of Schengen and of the AFSJ. One could debate whether this co-existence of a so-called 'old legal order'and the 'new' EU regulatory regime means that the latter is still in only its emerging phase, or indeed as I would see it, how the co-existence is indeed constitutive to it and requires an analysis thereof. Here I would rather like to point out that the very same space and policy field - police cooperation across borderregions - contains multiple and different expressions of political order(s). Fast-track readmissions ('old' legal order), joint patrolling and hot pursuit ('new' order) is practiced at the same time, in the same space, and often by the very same officers. However, the practices embody, actualise, and perform different manifestations of borders and understandings of sovereignty.

Taking into consideration that scholars argued that bilateral readmission agreements between member states "have progressively ceased to be used with the completion of the internal market" (Bouteillet-Paquet 2003, p.359), what does it mean if they have returned, and why and how does readmission matter today? I will further argue that the renewed salience of these internal border instruments, as well as temporary border control, are not simply a re-territorialisation and return to a pre-Schengen order. Inter-legality enables an analysis of how practices linked to 'old' orders interact with the 'new' order, its instruments (such as joint patrolling) but also its legal regimes such as the Dublin Regulation or the Schengen Borders Code. Practices related to an 'old' order draw on instruments of the new order, but also reconfigure it in interactions, wherein instruments of old and more territorialised orders become alive again.

Such inter-legality negotiations and practices through law-in-action contribute to ongoing reconfigurations. Looking at past long term developments, I would suggest that today's fast-track procedures combine formerly separated practices: a) the (historically and legally documented) practice of nonformal procedures in forced returns after interception of an unauthorised border crossing on border-crossing trains through the "fiction of non-entry", and b) more formalised written readmission procedures under the jurisdiction of border-area police directorates. ${ }^{79}$ While first practice was de facto a 'denial of entry' not requiring any formal acceptation of the neighbouring country, in this reconfiguration it became subject to the possible refusal of a 'readmission offer' by the neighbouring country. In the context of abolition of internal border control possibilities (and impossibility of 'refusal of entry') and with the shift towards mobile 
border-area controls, readmission of third-country nationals following an interception in the border-area thus became the 'ordinary way' within the so-called 'new' order of abolished border control. I argue, however, that it is rooted in a border-practice that was de facto a 'refusal of entry'. Some conflicting aspects surrounding this instrument today, are rooted in its genealogy. The practice is an "expression of territorial sovereignty", if I may borrow the principle proposed by Hailbronner (1997), but with an important difference, that with abolished border control the practice became a fast-track readmission procedure. It is now subject to the cooperation of the neighbouring authorities and it shifted into the realm of conditionality: it is dependent upon cooperation (and therewith of good neighbour-relations).

In both cases - border-area and border control - contemporary internal border (area) measures interact with the EU spatial-legal geography enshrined in the Dublin Regulation: they are another means to enforce the Dublin order (and counter non-registration) through the border-strip policing-mobility possibilities. One of the findings of this study, namely that readmissions and border-area policing have become entangled with the pitfalls of the Dublin system and the political impasse of its reform, led to subsequent questions: can policing be a response and how does this response unfold? Haahr and Walters (2005, p.110) pointed out on the one hand a "disjuncture (...) between the space of border controls and the political-territorial borders of the polity" and on the other a re-territorialisation of borders and territorialisation of Europe. Are we witnessing such a (re-)juncture and in what ways does it 'take place' in practice? How police officers experience and perceive police-work in the border-strip, is at the centre of PART III. 
PART III

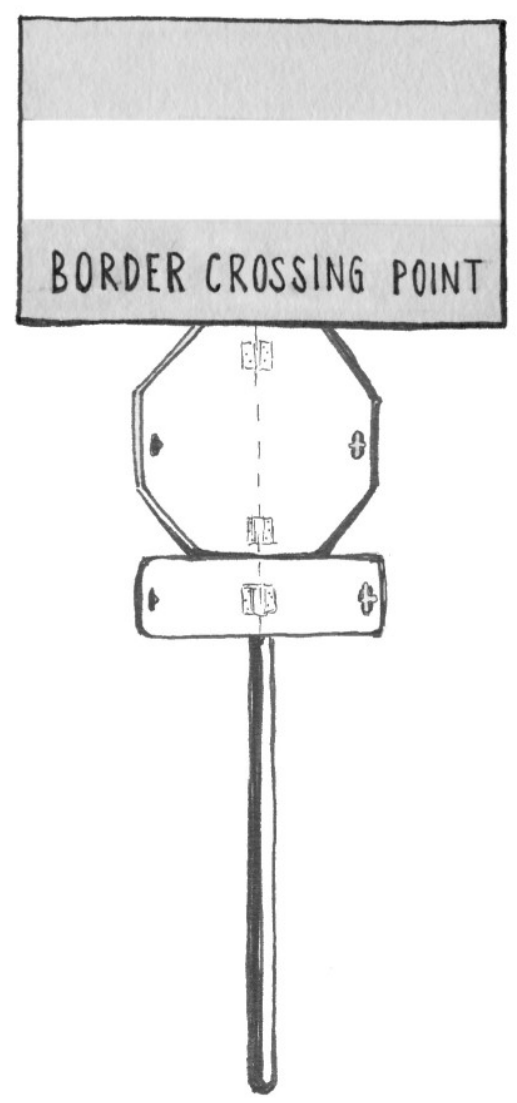




\section{Ethnographic glimpse on a road-sign of border-infrastructure}

The sign is composed of three elements: on top a rectangular sign, with the country flag and name, and letters spelling out "border crossing point". Below there are two flip-signs: one in the shape of an octagon, one rectangular. They are closed, silent, but nevertheless telling. With the illustration I wish to draw attention to the design of the street-traffic sign of borderinfrastructure: the flip-able modality is remarkable. Even more so as the sign was installed in 2016 on an inter-state border-(section) where "temporary systematic border control" according to the Schengen Borders Code has not been introduced. No border crossing point has been put in place and the border was taking place, as it were, through practices of the "mobile frontier" in the border-area. The sign was a mise-en-scene and border-spectacle, but it is a border-performance of no little importance. As Andreas and Nadelman (2006, p.11; Andreas 2003) remind us, the symbolic appeal of (cross-) border policing practices is powerful regardless of their effectiveness. The addressees of the closed flip-sign were unlikely (unauthorised) border-crossers.

A sign like this one is very telling with regards to temporality, law and space: Border crossing points produce a particular configuration of space, they rearrange rights and duties for those on the move - including (border) police officers. In PART III I present and analyse the qualitative data of this study. Adapting a critical-interpretative approach, I engage with emic meanings - how officers make sense of their work and the meanings they attribute to their practices - and in my analysis situate them within the broader historical context. The reconfiguration of space through border crossing points at internal borders is considered extra-ordinary within the spatial-legal configuration of the Area of Freedom, Security and Justice. And if introduced, it becomes something presumed to be not just temporary but also exceptional. The years since 2015 have shown, however, that such reconfiguration of space also persists considering the extension of temporariness by many member states carrying out border control measures at internal borders from 2015 onwards as a response to unauthorised "secondary movements". One of the effects of multi-normative spaces and temporalities according to Benda-Beckmann and BendaBeckmann (2014) is that, far from creating legal certainty, it is often uncertain which rules are applied in a particular space at a particular time. As the product-design of the illustrated sign signals, nowadays things are made to flip, even in border policing. 


\section{CHAPTER 7 \\ (EXTRA)ORDINARY POLICING-MOBILITIES IN A LANDSCAPE OF MEANINGS AND POWERS}

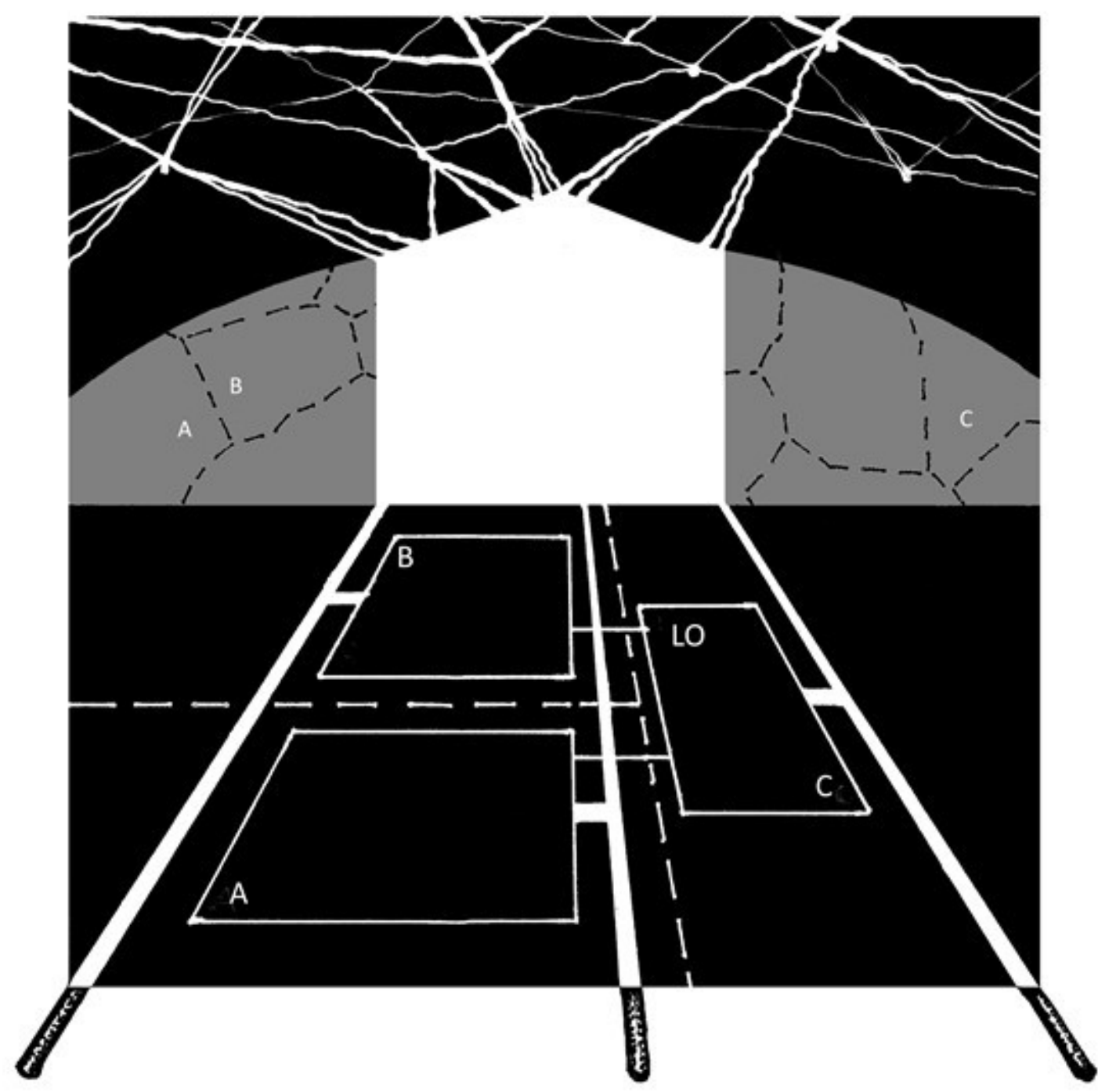

"But just as humans are, par excellence, makers and users of threads, so have they also come into their own as makers of traces with the hands. It is revealing that we use the same verb, to draw, to refer to the activity of the hand both in the manipulation of threads and in the inscription of traces."

"A particular capacity of lines [is] its capacity to create surface [Kandinsky]."

Tim Ingold, "Traces, threads and surfaces", in Lines (2016, pp.45, 46) 


\subsection{INTRODUCTION}

In this chapter I engage with the meanings officers attribute to three CBPC instruments and everyday practices taking place under the 'ordinary' spatial order of the AFSJ. Within this temporality-frame I focus on so-called "compensatory measures" within the context of abolished border control, but I will also attend to extra-ordinariness within ordinary practices. I also provide answers to my question as to the contemporary role of policing-mobilities in the control of differential mobility rights within the EU Schengen space. Situating practices within a landscape of meanings and of power-relations, how does the "ethos of a 'joint task'" - as Haahr and Walters (2005, p.107) identified the collaborative aim for border-zones in Schengenland - play out in the control of unauthorised intra-European mobilities? I argue that the border-strip emerged as a strategic scale, but that the application of CBPC instruments in the field of asylum and migration control is not without internally and externally identified criticalities. Analytically, I refine my analysis of legal pluralism and the spatial-legal configuration of the border-strip by engaging with scalar theory and the question of how governing unauthorised mobilities plays out within scale politics.

\subsection{JOINT POLICE CENTRES AND THE FACILITATION OF POLICE DATA MOBILITY}

A constellation of plural legal orders enables PCCCs to facilitate cross-border data mobility. Within this legal geography, the border-strip provides the spatial-legal condition for direct police information exchange. Recognising how "movement depends on defining tracks and grounds or scales and units of agency" (Tsing 2000, p.337), PCCCs can be identified as important units of agency for police data-movements. Together with geographical position, time and urgency also shape possible routes of data mobility across state-borders. The urgency of requests enables PCCCS to process requests originating from outside border-area territories and to channel information outside the "border-area-strip", for example by pulling the "red thread": the PCCC network connections.

In this section I discuss how service provision and enabled-ness, data-quality and speed shape the understanding officers invest in their day-to-day work. Several of these meanings are condensed in the following excerpt, in which the PCCC officer ${ }^{80}$ represented the centre as a service-unit aiming to provide support to street-level officers through speedy information:

\footnotetext{
"We are like a service-unit for colleagues outside. We want to support colleagues on the spot as quickly as possible, by providing or by forwarding information. (...). Just because a colleague comes from [a non-PCCC-partner country or from the partner country but outside the border-area jurisdiction], has he therefore not the same job as us? He has the same interest as we do,
} 
in solving an offence ... or a crime. He has the same driving motivation as we do."

In addition, we see here that what has been called a subculture of transnational policing ${ }^{81}$ is mobilised in a very precise structural context, namely the differential (unequal) legal geography of data mobility. When assessing only the legal context one might infer that data mobility concerning border-regions constitutes the ordinary mode, and urgent requests beyond it an extra-ordinary channel. When looked upon from the perspective of practice, for PCCCs the latter constitutes as much an ordinary routine as the former. ${ }^{82}$ Notably, in the quoted case, the request came a) from a police unit of a country not represented within the PCCC and b) the information concerned data on the documents and immigration status of a third-country national, held in a national database accessible to PCCC officers. PCCCs are primarily anchored in the jurisdiction of the border-strip and migration related information exchange presents an exception to their primary purpose of mutual assistance in the field of criminal law.

This premise makes clear, that unpacking the quote requires a step-by-step analysis, which will allow to address the question if and how migration-policing tasks figure in the centres' day to day work and what role this so-called "tool of local collaboration" (PCCC Guidelines, 9105/11, p.4) in the border-strip plays within the landscape of data mobilities. I conclude with an analytical section in which I combine the sensitising concept of plural legal orders with scalar theory from the field of critical geography (Smith 2003, Brenner 2004). This will lead to an understanding and analysis of how PCCC officers work with the law in plural legal orders, but also allows one to refine an approach to scale and culture in police cooperation scholarship. Contrary to police units on the ground engaged in exchanging intelligence informally (Feldman 2019), police data mobilities on this institutionalised office level leave traces. Nevertheless, channels can be carved deeper and new routes opened, as I will describe through data from the field of migration-policing. To paraphrase one interlocutor, these channels and their traces need a legal ground - which sometimes presents shades of grey - and not simply a void space. The spatial-legal geography of data mobility is a landscape signed by meanings and power relations: interpretative practices of "local agents" (Blomley 1994) and how and where officers encounter but also draw lines, weave threads and carve channels contribute to the production of space. Lines, as artist Kandinsky (Ingold 2016, p.46) argued, have the capacity to create surface. These threads and channels shape the conditions of possibilities for new things to become real.

\subsubsection{Cooperation and data mobility: self-understandings and meanings}

From interviews with PCCC officers across the specific fieldwork-sites several shared meanings emerged, through which officers also situated their work with respect to other scales and actors of information exchange. 
1. The self-understanding of being a "service provider" to the officer on the street.

2. The identification of "speed" as primary added value of the centres' work, as opposed to the central channel which is considered notoriously slower. The value of speed is complemented by that of providing reach and breadth of potential information; it relates to what one informant defined as "data quality".

3. The awareness of being not just able but also enabled to move information across borders, as opposed to informal channels (addressed in the concluding section).

\section{"A service-unit for colleagues outside"}

When describing the role of the PCCC as a "service-provider", the officers frequently identified with the officer on patrol, remembering the times when they themselves covered this policing role. In the following situation, a police officer checks the documents of a driver on the occasion of a border-area check:

"He looks at the document... passport, driving license, issued by [another country]. He has doubts. When I did the job years ago myself, it was just like that. One has doubts, like, has the picture been exchanged? You consider this and that... and then in doubt, for God's sake, travel on. Today we receive a request, and within 10-15 minutes the officer receives the response."

Often within the same description, officers differentiated the "service" they provide and their competence and jurisdiction, from that of the central channel.

"[Continuation:] Let's say the document [ $\mathrm{nr} \mathrm{X}$ on name $\mathrm{Y}$ ] has never been issued. With this information, the colleague on the spot knows that the document is forged or fake..., he knows that something is wrong. What that is, I cannot undertake. To investigate that is their job. (...) Also, to inform [the other country], that is done by the criminal police department through the SPOC. That has to go the official way, and that is the central unit." [Note: in the field of document fraud, 'forged documents' are lawfully issued documents that have been altered, while 'counterfeit documents' refer for example to unissued documents.]

The relationship with the central unit was described to me both positively - PCCCs being a "meaningful supplement" to the central channel - and contemporaneously as being at times a conflicting relationship. Several interlocutors mentioned instances in which they felt that the joint centre was perceived as a "rival" by the central (criminal) police department responsible for international police exchange. They highlighted how coordination - especially on how to deal with urgent requests - has helped to deconflict the rapport and indeed foster a complementary relationship. Scholars have rightly pointed out that PCCCs do not depend in their day-to-day work on central (vertical) authorisations and hold a level of institutional autonomy (see Block 2011, Maguer 2004). As we shall see, this does not mean that central authorities and the national scale play no role at all. 


\section{Speedy information: more than just information through horizontal direct exchange}

PCCCs provide quick and direct information held in databases of the participating countries and move information on citizen and third-country nationals across borders, for example in support of the patrol officer on the street or in border control. The time the officer has is circumscribed by the legal limits he has to hold a person. "It is useless if my experience tells me that probably I am dealing with a crime. I have to prove it, otherwise the person travels on". Speedy information is thus precious and matters, especially for the officer on the ground. Several non-PCCC interviewpartners praised the centres' value in the directness and the speed provided as their main asset. However, as one officer formulated it, when the centres become better known and their service requests increase, the centres' workload rises and there is a risk that speed slows down. This officer, primarily carrying out criminal investigation tasks, preferred rather to exploit his personal contacts across the border to receive timely and speedy information. Such risk was also mentioned on the 'provider' side. Centres, in turn, did not see themselves as substitutes for crossborder contacts grown in and across the region.

"Those who in past have phoned from police-station to police-station [across the border], and who know each other, they still call each other today. That's true, they exchange this way. They don't need a centre. And none of us has something against that, as long as it serves the objective: why not? But those from further away prefer to use the centre. And the information that is provided by a centre is also much broader, than what is done by phone."

Historically and personally grown contacts are valued and figure clearly in the border-area worldview of scales. From a central state perspective PCCCs were - according to some sources - also intended to institutionalise and render more transparent informal information exchange knowingly grown in border-regions. However, also due to the borderland-ness of the centres (see also 7.2.4), they do not aim to sustitute those contacts, but perceive themselves - and also are perceived - as providing an additional service. Namely, to be an interlocutor for police-units literally "further away". This was also recognised by non-PCCC police officers, here by a HLO officer notably working on regional level:

"I ask the officer [from the police directorate across the border] if I need something: we know each other, we are friends. But the officers further away, those departments and units... with the creation of the PCCC they got an interlocutor. And the PCCC does the work extremely well. They sit together in one office (...)." (IV_RL-HLO)

Information speed interacts with the value of having police officers from different units and countries sharing the same office-space and the so-called "data-quality" of centres. Let's move into the micro-space of the "data exchange room" of PCCCs:

"A centre offers this... very close connection, within one space [room], with all the datasets. I cannot match that with written information requests 
[through the central channel] which might require weeks. The speed that such a centre provides, is of extreme importance. And that is the big extra value, I have to say that."

\section{A micro-space}

The most appreciated element of a centre is a very material, immediate, and concrete configuration: "the directness, immediacy in the office". The officers share a specific space, situated and emplaced in the main information-exchange room: this space is multinational (police officers from different national jurisdictions) and interforce (officers belonging to to different forces). This micro-space creates its very own spatial-legal and social configuration. Centres can also host Liaison Officers (LOs) from other countries, thus creating within the microspace of the PCCC located in the border-strip a vicinity that notably does not have a corresponding geographical spatial arrangement. As I annotated in my fieldnotes and incorporated into the chapter's opening illustration:

The main operational room of the centre includes the desk of a liaison officer. "See," I am told, "the two countries don't even have a common border, but here their officers sit under the same roof, they have direct eye contact and can talk to one another." (FN)

Another interlocutor pointed out: every additional presence "is an added value. (...). He is worth gold". In an exchange system where the goods or currency is information and the value speed, direct access is worth gold.

\section{"Data-quality": emplacement of cross-border and internal data mobility}

PCCC literature predominantly highlights the cooperation of police forces of different countries as added value: the border holding the meaning of a state-border. That is what they are about by definition. However, an integral aspect enabled through a joint centre is also the interaction between forces from the same country. This is not only of relevance for PCCCs including customsofficers, but also in the case of countries with a plural police force. One frequently identified challenge in CBPC is not knowing who in the other country is responsible for a certain policing field, as well as rivalries between forces within a country. Also described were potential pitfalls of not getting in touch with the 'correct' interlocutor across the state-border. The presence of different forces of the same country within the same centre is thus also valued positively by their cooperating partners. As such it is not only the state-border that emerges as the significant one to be crossed, but also the borders between different national police forces. Notably, they are a bridge of access to potentially separate national databases.

While "interoperability" between databases has emerged as buzzword on EU level, in joint centres so-called "data-quality" is produced through the interaction of officers: every differently uniformed officer embodies a (potentially additional) body of data, widening access and 
information exchange possibilities. This is perceived as an added value within one country, as well as across national borders:

"This is always undervalued (...), such data quality can only be offered by a centre. Independently of whichever police force I work with, I will only have access to my data-systems. In such a centre I can bring together data (...), including that of the whole border-region."

This is ultimately due to different police datasets in federal systems or due to different accesses by functionally subdivided police forces. For example, according to a study by the International Centre for Migration Policy Development (ICMPD 2010, p.70), the French-Italian joint centre in 2010 brought together 65 different databases. Such data is primarily used for information exchange, but some centres also use it to elaborate risk-analysis or situational pictures of crime phenomena in the border-region.

The centres visited for the purpose of this study had a 24/7 service: not all police forces are contemporaneously on shift during nights. This means that, while in principle data is accessible and exchangable, it might not be so immediately. According to sources this diminishes speed, but also the certainty with which the units requesting (in principle available) information can rely on the service. This is one of the 'borders' PCCCs encounter, here due to internal organisational resasons.

\section{"We know where they have the limits": on access, competencies and data im/mobility}

One of my interlocutors explained: "In the field of mutual assistance, when crossing borders, the police can only act on what falls under its competency". When facilitating data mobility, competence and jurisdiction not only enable the PCCC officers, they also constitute borders and limitations.

The Swedish Initiative (SFD) ${ }^{83}$ aimed to facilitate the exchange of data held in police databases, as well as data held by other stakeholders, private or public. In the latter case, national frameworks differ on what (non-police held) existing information is accessible to police forces without a formal criminal or judicial procedure. In one country, law enforcement officers may receive from banks the name of the individual to whom an account is registered, or can ask a business which of their employees is registered to have driven a car on a particular day, if it was used for a suspected criminal activity, or an hotel-owner can be asked for their guest-lists etc. In another country, law enforcement officers may ask private entities for such information only within a formal criminal or judicial investigation. In such cases, this information is not requestable and exchangable through PCCCs. In addition, what in some countries can be shared through police information exchange, in other countries is handled through the channels of judicial-cooperation 
and not those of police- cooperation. The specific borders encountered therewith differ depending on the parties that interact and depending on the field of mutual assistance.

In these cases officers highlighted they knew "where" their partner police forces "have the limits" - understood as a not-crossable border for exchange and resulting in data immobility due to national legislation. These 'borders' were mostly recognised and respected.

"Their national legal order does not allow it. When the police asks somebody for information, this can be done only within a criminal or judicial proceeding. (...). We can do informative questioning and carry out that request, regardless of, if the problem was on our territory or theirs. (...) Maybe this is still national thinking. But it is not a problem for us, we know where they have the limits."

A similar knowledge-through-experience emerged for urgency- and chain-requests: officers said they knew by prior experience how the participating countries and other partners tend to apply legal possibilities, thus where the border is drawn. In cases where information was available to police forces nationally but not shared for stated reasons of "data privacy", this was indeed experienced as a border-wall for which interlocutors showed less appreciation and understanding. Data privacy has emerged in several ways during fieldwork, primarily indeed with regards to the use of SIENA. ${ }^{84}$ However, it was also mentioned as a border that was experienced, and critiqued, by several of the officers interviewed. In addition, although officers highlighted that legal orders between member states are quite homogeneous, each border-region has a small set of phenomena that, in one country, consitute a criminal offence, and, in the other, an administrative offence. Centres are only responsible for exchanging police information in the realm of criminal law and not in those regarding possible offences of administrative law. Additionally, centres can act when lives are at risk and a quick intervention is needed, for example in the case of a suicide risk or the rescue of a person.

The fields of information exchange are very broad, as can be apprehended from annual activity reports: in 2017 the German-Austrian PCCC (Schwarz 2018) featured cases on drug smuggling, child-pornography, theft, bank- and internet-fraud, suicide-risk, document forgery, searches of vehicles, and information exchanges that led to the arrests of persons against whom one or more national warrants or an EU warrant were pending etc. Within the overall focus on criminal police information exchange, there is one exception shifting the borders of the criminal police remit into the field of administrative law: migration related information exchange.

\subsubsection{Migration: moving beyond criminal police information exchange}

PCCCs are in some way explicitly set up to deal with mobility - to facilitate the exchange of information on persons and goods moving across the border-strip. With regard to mobilities of third-country nationals, several PCCC tasks are of relevance: information exchange, support in 
coordination of joint operations in the border-area (such as joint patrols), and support in readmissions; plus eventually risk assessments in the field of irregular migration, migrant smuggling, document fraud etc. I concentrate here on the use of PCCCs for migration related police information exchange, a functional extension of joint centres' mandate to a field of administrative law. As a legal base, PCCC have applied clauses in bilateral police cooperation agreements (and PCCC agreements) that include migration as a field for cooperation and mutual assistance. In addition to cooperation in specific areas of criminal law such as smuggling or trafficking, bilateral agreements indicate, quite vaguely, cooperation in the contrast to "illegal" or to "irregular" immigration, or broadly in the field of "alien-" or "immigration-policing".

"This is indeed explicitly mentioned in the agreements: migration. Because migration ... aliens- or immigration law, that is not necessarily criminal law. It is administrative law. And because we are not allowed to act on administrative law, migration was explicitly included into the agreements: criminal police information exchange and migration... asylum.... Otherwise, we would not be allowed to."

As this officer aimed to point out very clearly, the centres' competency lies in the field of criminal police information exchange, and not with regards to administrative law and on potential administrative offences. CISA, art. 39.1., refers to mutual assistance for the "purposes of preventing and detecting criminal offences". Whilst referring to bilateral agreements as base, most officers referred to immigration and some also to asylum (and consequently, if accessible, datasets for these purposes).

The amount of information exchanged within this field seems to vary amongst centres. While the small sample does certainly not allow broader conclusions, it can nevertheless be highlighted that data mobility on immigration-status or permits issued to third-country nationals were part of the ordinary routine. In most instances PCCC officers attributed the very same value to this type of information exchange as for other information provided: speedy information motivated through identification with the patrolling or border control officer, who has doubts whether a document presented was fake or forged. Requests in this field however lie at an intersection of administrative and criminal law, if aimed to ascertain the authenticity of permits issued. Of primary interest to the PCCC figures the criminal policing aspect. Contemporaneously, the information exchanged consequently also produces an effect in terms of the administrative measures applied to the holder of the document, related to his or her immigration status.

Therewith, PCCCs can assemble into the "technical landscapes of control and surveillance" (Paasi, in Johnson et al. 2011, p.63) of border- and migration-control. This is further evidenced by recently enhanced interagency cooperation between PCCCs and Frontex, the "European Border and Coast Guard Agency" (Council EU 13285/2015; FRONTEX / EBCGA 2018). With the aim to 
create a base for information exchange between PCCCs for requests recieved from external borders, Frontex initiated in 2015 a series of workshops with PCCCs (CCPD-Chiasso 2016, p.16).

\section{From criminal to administrative - a process in two directions}

Channels established for mutual assistance in the field of criminal-policing are also an instrument that has been involved in intra-European migration control. The functional extension of the joint centres' mandate to a particular field of administrative law differs from its formal merging with criminal law and produces effects outside the latter field. This provides some preliminary insights into processes highlighted inter alia by Mitsilegas (2015), through which technologies and instruments for security and crime control are applied to support border and immigration control. They might also intersect in their effects on asylum procedures. It was impossible to assess and cross-check the fields of application and their eventual effects in the course of this study. Fragments indicated however that information exchanged with regards to migration can lead for example to the initiation of a Dublin procedure, to the termination of a residence permit and issuing of a removal order, have an impact on an asylum procedure or indeed result in the nonissuing of a Schengen removal order. Within an analysis of the "two-fold process of securitisation of migration", Mitsilegas (2015, chapter 2) pointed out that securitisation has led to a negation of purpose limitation, justified with the argument that personal data of migrants collected for immigration control does not only serve for this purpose, but also for security governance. Focusing on law enforcement access to immigration data collected in EU databases and increasing interoperability of data collected for different purposes, legal scholars have expressed concern and critique as to possible implications on human rights and on the "principle of purpose limitation" (Carrera et al. 2019; Mitsilegas 2015).

As I have described and analysed before with regards to "data quality", at the scale of the borderstrip PCCCs "interoperability" is produced through different means. Including migration as field for criminal police information exchange - information held in national databases and not in EU databases -, coupled with the "principle of availability", potentially enables centres to exchange such data, if accessible to forces on a national level.

\section{The borders in data mobility}

The borders encountered in the cross-border mobility of migration data do not seem to differ substantially from those outlined above: for example, administrative databases might not be accessible to police forces or indeed they are accessible, but only to certain units or forces. If those are not on duty, the information cannot be provided immediately. Officers also pointed out that the provision of data on certain categories of third-country nationals, held by a member state, could have implications for that country due to the responsibility allocation through the Dublin system. Eurodac is not the only data source that can be deemed proof for a first-country- 
of-entry responsibility allocation. However, as opposed to what was experienced as a limitation to data mobility due to "data privacy" (interpreted by some officers as an expression of a state's interests not to cooperate) potential implications regarding Dublin responsibilities were indeed not perceived as having had any impact on the cooperation in the provision of eventual data held about a person that has sought asylum in another member state. While interlegality and "purpose limitation" conflicts can emerge in this type of practices, concerns were not mentioned, but I aim to point out that I did not specifically ask for officers' opinion regarding the legal principle of "purpose limitation".

In 2016 the 6th annual PCCC Network conference identified in "the impact of migration on PCCCs" a theme noteworthy for discussion (Council EU 13285/15). As pointed out in chapter 5, for example, the Joint Centre in Passau was set up initially to respond to the challenges faced in this context. Some centres - joint center Passau or the CCPD-Chiasso along another intra-European route - have also been engaged in situational analysis on irregular migration and smuggling (CCPD-Chiasso 2016; Deutscher Bundestag 2016). My interview interlocturs considered themselves of limited relevance during 2015, whilst recognising that it did lead to more frequent exchanges with PCCCs in countries along the "Balkan Route" during that period. This "impact of migration" enabled PCCCs within Schengen to foster their relationship, including with PCCCS outside the Schengen area through intensified exchanges. These relations were considered an asset also for police information exchange posterior to that period and for many matters not related to migration. In chapter 8 I will address a process of migratisation of security and a productive effect that can be analysed therein: namely, the effect of enhancing also nonmigration-related police work.

\subsubsection{Plural legal orders, space making and the politics of scale}

Critical geographers, addressing spatial politics under capitalism, argued that the nation-state had emerged as geographical means to coordinate and arbitrate economic competition, previously linked to other spatial territorial scales and nowadays undergoing ulterior re-scaling processes (inter alia Brenner 2004). While the economy has notably long been the privileged focus in studies of globalisation and figures prominently in scale-theory, also the political field of security - the states sovereign core, as pointed out by Aas (2012) -, has seen fundamental transformations. In criminology and security studies this has been addressed particularly with regards to the privatisation of security functions in the field of private policing or private military contractors or companies. But public (national) security provision and its legal codification has also undergone notable transformations. In an exchange system in which, as we saw, the good is information and the value speed, competition and cooperation are just as important competing social forces as within the economic realm. Policing-scholars highlighted that police organisation has undergone 
historical processes whereby formal police information exchange has become centralised within the state, for example through national Interpol contact points (Anderson and Malcolm 1989; Andreas and Nadelmann 2006). This process, depending however also on the countries' police organisation (Aden 1998), fostered centralisation. Subsequent developments also involved the decentralisation of police functions, and PCCCs are often discussed to illustrate decentralisation in the realm of information exchange (Block 2012; Block 2011).

To analyse reconfiguration processes within the European security field, PCCCs provide a privileged insight and object of study. Security scholars pointed out how within the rationality of information exchange, shared knowledge through cooperation aims to increase the power of states (Balzacq et al. 2006). 'Knowledge' (intelligence, information, evidence) is a capital of primary importance in police work. Authors from a political science perspective have categorised different handling of information sharing by PCCCs as expressing a "realist" or a "functionalist" understanding: either considering information a "'national property', and thereby guarded and controlled by the originators", or as an "openly available resource which should be used and processed with the aim to contribute to transnational security arrangements" (Gruszczak 2016, p.160). However, we saw with regards to the borders experienced in the work of PCCCs how the limits and channels of data mobility are much more nuanced than this binary analytical frame. Scalar analysis attentive to the negotiation of plural legal orders will allow for a more accurate analysis. In addition, Bowling and Sheptycki (2012, p.130) argued that discretion in invoking the law has played an under-explained role in political science approaches to de-/centralisation. But approaches sensitive to a multi-level configuration of police cooperation and those interested in practitioners' meaning have mostly neglected what this implies within conditions of plural legal orders. Rather than adapting a state centric or a multi-governance approach, debating what is better suited (Blatter 2003, p.185), or aiming to identify sociological "ideal-types", my analytical interest lies in the interpretative practices of so-called "local" agents (Blomley 1994) who, as I will explore, negotiate plural legal orders and therewith are active agents in re-scaling processes and in the production of space.

\section{Re-scaling and scale fixing}

Brenner $(2004$, p.3) argued that political space is being remade both through processes of upscaling, as well as by "processes of state downscaling - the devolution or decentralisation of regulatory tasks to subnational administrative tiers, coupled with a restructuring of subnational institutional configurations". "Re-scaling" has been proposed by Smith (1992; 2003; see also Brenner 2004) as a concept to analyse processes wherein social interaction is re-organised on a different scale. He pointed out that instead of treating geographical scale (the region, the nationstate etc.) as natural metric of physical space, one must recognise both their materiality and 
historical contingency. The question then emerges how "scales are actually set or fixed amongst the flux of social interaction" (2003, p.228 ff). He conceptualised scale making as the "spatial resolution of contradictory social forces", and especially between forces of competition and cooperation. The production of scale, their temporary "fixing" and "scale jumping" thus becomes a highly political and charged process and a question of power. While previously I pointed out the 'legal fixing' of practices through retrospective legalisation and their temporality, scale fixing is also inscribed into a temporal process: "future scales become the 'scale fixes' to existing and imposed scale constraints, if only to create new constraints and opportunities for domination/subordination (Jonas 1994:262)" (Smith 2003, p.229). Scales are therefore also seen as an "anticipation of the future" (Jonas 1994, ibidem). Basically, when a scale becomes fixed, it reorganises social interaction (in my study case, those of police information exchange) on what becomes a different scale: this establishes new constraints, but also new opportunities, thus opening the way for new anticipations. One can say a scale fix creates re-organised conditions of possibilities for new things to become real.

Adopting this analytical perspective, the PCCCs' extension beyond the border-strip is less of what Maguer identified as "paradox" (2004; 2007). It invites an investigation of scale making and into the politics of scale (Ferguson and Gupta 2005; Tsing 2000; Smith 1992; Brenner 2004). One can identify the primary spatial-legal scale-fix in the creation of special regimes for the border-strip. But there is also the potential inclusion of migration related data via re-organised social interactions on such matters. Exchanges on this scale through PCCCs as units of agency, are consequently embedded within the PCCC work ethos of speedy service provision. As we shall see, this opens the way for new "anticipations" (following Jonas 1994, in Smith 2003).

\section{'Being able' and 'being enabled': the facilitators of data border-crossings}

Although knowing the language of the neighbouring partner-country and its legal framework is not a pre-requisite for starting work in a joint centre, it was here where I encountered the highest level of knowledge regarding the possibilities and limits of CBPC. Officers were more likely to be familiar with the language of the work-partners (and/or English), compared to other borderregion police stations. Indeed, what characterises the centres and their personnel, I was told sometimes more and sometimes less explicitly, is that they are both 'able' and 'enabled'. As one officer put it:

"in the centre there are sitting people who know the language and who not only know and can, but who actually can."

Whilst using twice the same verb - "can" - first the officer referred to the abilities and competencies of the PCCC-staff, such as knowing the neighbouring country's language and legal framework, knowing who to contact across the border etc. 'Being able' as infinitive refers to the 
skills or means needed. Then he highlighted that being able is not enough, but that the officers of the centre are also enabled to exchange information in an official and legal way: they "actually can". Being enabled implies being a legitimate actor to engage in cross-border business, as opposed to informal information exchange. 'Enabledness' is a condition produced by the bilateral police cooperation legal fundament, as well as by sovra-national legal frameworks. Plural legal constellations enable centres to facilitate cross-border data mobility, but they have also created a differential legal geography thereof. 'Acting enabled' is an active process of interpreting plural legal orders. When a request is received by a PCCC, the officers and the centre's remit proceed with the following questions and decisions:

"Does the request fall within our remit and competency? Is the request necessary? Is it urgent?"

The last of the criteria mentioned only applies when a request arrives from outside the primary jurisdiction of the border-area territories. Another officer outlined the decision-making-process of the remit and of the information provided in this way:

\begin{abstract}
"The colleague in the office has the obligation to check according to which legal basis he provides information. In the border-region it is easy: up to medium-criminality cases we can exchange through the bilateral agreement. But we also try to live, let me call it in this way, the European frameworks such as the Swedish Initiative and in particular CISA. The European legislator has given to police forces many possibilities which, as I see it, are not yet completely lived in practice."
\end{abstract}

Despite providing the same type of information, different scales of law are invoked to enable the facilitation of data mobility in the second case (requests that go beyond the border-region). One officer enthusiastically highlighted that bilateral legal frameworks and CISA "harmonised" very well: at the border of bilateral conditions of possibilities, those of the EU frame kick in. Therein, borders between the intersecting orders of different scale are represented as bridging contact points. Nevertheless, some interlocutors also highlighted how in this interface a - literally "grey" - border-area emerges: "What is urgency?" another officer rhetorically asked and replied immediately: "it lies in the eyes of the beholder". Urgency is not a quality inherent in information, but matches the centres' main value, the provision of speedy information. Acting enabled through interpretative practices transforms conditions of possibility into concrete practices. The interpretation depends not only on the perception and representation of urgency. It is informed by two elements: a) the understanding of "service provision", and b) by the degree one wants to "live" EU law, as formulated by the officer quoted above. Law-as-text and law "lived in practice" are two pairs of shoes, the officer aimed to point out. The political spaces produced notably differ. Here we see the importance of interpretative practices. As argued by Blomley in Law, Space and the Geography of Power (1994), while law produces space, it is in turn shaped by its socio-spatial 
context and the multilocale places where law acquires meaning. Whether centres "over-step" or indeed "curtail" their competence (e.g. their possibility to carry out chain-requests), as one source defined the matter, was deemed by the officers less a question of their practices but was considered rather dependent upon which legal-political order was taken as reference point.

According to Brenner, scalar transformations are embedded within interscalar relations. They do not imply a "replacement of one scalar configuration by another" but occur through a "pathdependent interaction of inherited scalar arrangements with emergent, often highly experimental strategies to transform the latter" (2004, p.11). In what follows I discuss such interscalar dynamics and experimental strategies and practices, also in the field of migration policing, entangled with interlegality negotiations.

\section{CASE 1: Border-regions and beyond}

Bilateral agreements and CISA created special regimes for border-regions, which were rooted in the territorial jurisdiction of clearly delimited "border-area-strips" or borderstrips. They produced a new scale for formal and institutionalised CBPC: a spatial-legal scale-fix. In a context where the local embeddedness of centres engenders value in the continuity of (informal) horizontal direct cross-border contacts (independent of the central channel), and the primary geographical remit is restricted, the volume of requests would potentially be low and the centres' role rather 'peripheral'. In practice, by applying other legal possibilities practices transcend the strip as part of the ordinary routine. Officers expressed different views as to how the primary territorial border-strip jurisdiction and its borders matter in practice.

"That's the complexity of how one should work, it [cross-border information exchange] should go through the central channel. I can only interrupt that, if there is a normative base, and that is our bilateral agreement. What allows the agreement, what is defined in the agreement as 'border-area'. (...) I have a clearly defined border-area-strip: [the officer points out the territories on a map] these are included in the border-area. Here I can provide information in a legally clean way, according to the data protection possibilities of our agreement. In this area [points to a nearby part of his country but outside the border-area], I must make use of the European directives, and the colleague has to substantiate to me that the information he needs is a case of urgency."

This officer criticised what he felt to be a sort of unequal requirement on the part of requesting officers. This requirement is grounded in the unequal legal geography of data mobility. He pointed out how the border-strip was based on pre-existing administrative territories and that it does not cover, for example, the same geographical distance to the border. The scale-fix was derived from previously drawn administrative intra-state territorial spatial units. The result is that, depending on where a requesting officer works, he can make use of the bilateral border-area possibilities in the first case, whilst having to utilise and motivate the urgency of the information request in the 
second. So, while pointing out that bilateral and EU orders harmonised very well, this officer attached the formulation "in a legally clean way" only to the former case.

"The bilateral agreements only provide for border-area territories, paragraph $[\mathrm{X}]$ of the agreement defines what the border-area is. This border-area could be... enlarged, for example to [the broader administrative territory] or the whole country."

While this officer highlighted territorial jurisdiction as being the primary and only aspect requiring in his opinion a normative improvement, another officer held a different view. I asked why statistical reports did not differentiate between requests from border-areas and those from the wider territory of the participating countries and he replied that nowadays the border-area jurisdiction is not problematised anymore.

\footnotetext{
"'Do we run exactly along the border-area named in the bilateral agreement, or do we also take those from further away?' ... Of course, we do. But since we have such good agreements [in this case referring to the bilateral one], this is not a contravention of the law. Because that is for sure all covered. (...). It's important to reflect and talk about it. What one does, must have a legal fundament, somewhere."
}

According to this officer, through the application of other normative possibilities granted bilaterally between the participating countries the centre's interactions already covered a much wider terrain. Police requests for information were considered tententially of urgent 'nature' and in most cases were deemed legitimate requests within the centre's remit. Notably, the statistical annual report seemed to be based on an EU Guideline template: this EU template likewise only differentiates between requests made by "foreign" and by "national agencies" (Council EU 9105/11, p.21).

\section{CASE 2: Deepening and opening of routes - channel \& traces}

The process of receiving and replying to requests requires taking into consideration further dynamics. Maguer (2007) argued that the normative and spatial extension of PCCCs' work was prompted by cross-border technology, but importantly that it reflects more the pressure of the demands of other services within national territories than action strategies of the PCCC. The following excerpt addresses chain-requests, but it is indicative of the relationship between the demand site and the centre's remit decision. The latter is especially necessary when moving beyond the border-strip:

\footnotetext{
"When [non-PCCC] police forces see that the channel [through the PCCC] is easy and quick, that information spreads and then it [this type of requests] becomes more and more. One needs to be careful when opening something new, a channel, because one can expect it to increase." (Emphasis added)
} 
The primary impulse comes clearly from the demands of service-requesting units, as already highlighted by Maguer. The centres have a remit and their response in turn shapes possibilities for external units. They can open new channels: whilst closing them is deemed not impossible, it is manifestly more difficult. Especially within plural legal orders that shape the conditions of possibilities, the remit is also an interpretation of whether to live one legal frame or another. It is engaged in scale making. Whilst officers pointed out that it is the job of politicians and their legal advisers to provide legal fundaments - and not theirs - the officers' interpretations actively contribute to creating spatial political order. In turn, this is not without effects towards inherited interscalar relations.

At the time of fieldwork an additional channel emerged as potentially in the making, which sheds light upon drivers and dynamics of functional extensions and re-scaling. In the fragment provided below, the officer reflected upon the limits and duties of the PCCC in the field of asylum related data:

"Probably someone (...) contacted us initially, thinking 'let's see if they do this' (...). One could certainly say that all these asylum-issues and suchlike have nothing to do with the police. Yes, it belongs to the Ministry of Interior, but it is not a policing matter in the strict sense. So, I would expect the Ministry at some point to say you can expect these services also from the centre."

While the centre also processed police requests in the field of administrative law, it was this case which caused the officer to reflect upon the limits and duties of police information exchange in a field, which he considered "not a policing matter in the strict sense": international protection. While he expressed certain doubts as to the legal grounds and hoped for explicit directions from the ministry, he also imagined it as possible that such a 'service provision' could become an ordinary channel. The difference in this case, as I myself only realised after the interview took place, was not the data requested per se, but the requesting party: not a police force, but a stakeholder dealing with asylum applications.

I propose to consider this fragment as indicative for what Brenner called "emergent, often highly experimental strategies" (2004, p.11), in plural: it sheds light not only into migration policing (and here additional data would be needed), but also into scalar dynamics and processes. Although I was unable to inquire into its relevance across sites, it provides insights into the role of both demand agents and of the remit in opening new channels. We see how institutional autonomy and decentralisation (Deflem 2002, Block 2011; 2007; Aden 2017) work out in the opening of new channels, which can lead to a loss of transparency and oversight (Bowling and Sheptycki 2012). But while there are discretionary powers at work, we also note a certain laissez-faire (practice or even strategy) from central authorities. This fragment should be placed and analysed within an overall work ethos that aims to respond to all requests as far as it is legally possible, combined 
with the identification with the requesting officer on patrol. I suggest that in other fields this has led smoothly to an extension of the border of service provision. Asylum data is felt to be more ambiguous, and it lacks the identificatory element. But the excerpt also demands a reflection with regards to the extension of the borders of security, and the merging of fields under a national 'Internal-Ministry-umbrella', not dissimilar to that of an internal security field or insecurity continuum on an EU policy level. While law enforcement access to non-criminal EU databases was deemed compromising the principle of purpose limitation, here we see an inverse process potentially in the making. As results from this fragment, it is asylum authorities attempting to experiment (strategically?) the possibility to work through channels intended for criminal police information exchange in order to reach speedy information on third-country nationals contained in databases of other countries. This would certainly lead to a re-organisation of (cross-border) social interaction on international protection. (If such requests are to be channelled under the frame of 'urgency', this would require an additional reflection). On the one hand, this manifests in practice what a (in)security framing of asylum can imply. On the other hand, in addition to and together with migration related exchanges between police-forces, this type of data-flow contributes to a migratisation of criminal police-information exchange channels. This type of data mobility introduces an additional layer of complexity to established interscalar relations with 'the' central channel, responsible for criminal police information exchange.

\section{CASE 3: ongoing reconfigurations}

Considering the interactions of inherited and emergent scalar arrangements, what effect have the described rescaling processes had on the main output-value of centres and on the (inter)institutional anchoring of PCCCS within state structures? Urgency-requests, as well as the broadening of the remit into a field of administrative law, seem to have had an impact on a) the otherwise straightforward obligation to notify the central organ with regards to the information exchanged (unless differently specified in national law) and b) on the centres' workload. Requests beyond the border-strip constitute a significant part of the workload of the centres, which stands in relation to the centres' main value: speedy information.

Central units are informed not case by case, but through daily and monthly reports. While "there is only one central unit", as several informants aimed to give recognition to the central channel competency, this seemingly gets more complicated when administrative and non-criminal information is exchanged:

“(...) the central criminal police unit says we are not interested in that. But then I would need to inform another central unit... like the Dublin Unit. So, if one wants to be precise, there are 3-4 central units with which we cooperate, or on behalf of whom we act. (...). That is a question that accompanies us with every request, shall we inform the central unit and in what form." 
Informing the central authority is interpreted by this officer as an obligation but through experimental practices, inter-scalar relations become fuzzy and the 'centre' plural. When this type of information exchange (administrative) is evidently removed from the interests of the central authorities responsible for criminal policing, another central unit should be informed. Who is informed also re-draws, within the national institutional landscape, the borders between fields and actors of criminal law, asylum and immigration: a process that has been analysed as an (in)security continuum on an EU level. Following up on these experimental "anticipations", the officer anticipated (in thought) by reflecting whether, consequently, asylum and immigration authorities should also be informed when criminal information exchanged does indeed concern third country citizens. What would it mean and imply if non-police entities became not only a potential source of demand, but envisaged as possible recipients of information apprehended in criminal police exchanges? Possible effects, if I may likewise anticipate, can, besides allocation of Dublin responsibilities, also be a 'criminal screening' of asylum seekers as to whether they came to the attention of the police in another EU country, notably in ways that do not qualify for inclusion in SIS. Not only purpose limitation but also due process are underemphasised interlegality-conflicts along such translations and transmission of data mobility. Beyond legal aspects, these are also strategic considerations by plural actors. Taking into consideration interaction across scales, actors, and fields in a possible so-called "alliance" (Tsing 2000) between asylum and criminal-police authorities, we see that interests and identity factors "stimulating" (ibidem) experimental scalar processes are not reducible solely to the PCCC as a lone actor. Contemporaneously, the migratisation of channels for criminal police exchange has effects of pluralising the central authority level.

Migration, I wish to recall, is but one of the fields in the work of the centres and it is necessary to place this rather specific fragment within that of the broader PCCC activities. Centres process a considerable volume of requests from outside the border-strip and through the "red thread". Highlighting the impact of working through the PCCC network on the centre's workload, an officer pointed out:

"Our house receives many requests that go in that direction [a PCCC located in another border-region]. For us this constitutes an extreme workload, for which we actually do not have the human resources. Also, because it does not want to be justified, since this is not what we were created for. But the requests... because the exchange with the colleagues works very well, and we don't want to miss that... as long as we can, we want to provide this service to the colleagues."

The "red thread" does notably not come in a ready-made-package together with the EU legal fundament: it needs to be actively knotted together in order to establish well working channels. To some extent, rather than a network that connects all dots or nods, it is made of less systematic 
interwoven threads. Policing needs such as those posed in 2015, the presence of liaison officers, exchange visits or contacts made during network conferences: these practices have all contributed to interweaving the strings of the "red thread". PCCCs seem to have established certain privileged channels and the thread is not necessarily pulled equally in both directions, but along ties strengthened over time. Within the EU's space projected ahead (see PART II), officers working within the Schengen-space pointed out that very often they relied on data exchange with PCCCs situated for example in the Western-Balkan countries - "they do a lot of work for us" - and that the thread was pulled only to a lesser extent in the other direction. An officer working in another centre, where about one third of requests regarded other member states, pointed out that "we definitely don't want to develop backwards, on the contrary, it can be developed further, thus sooner or later there will be the question of human resources".

Human resources were a theme associated with the extension of the work(load). An increase in human resources "does not want to be justified", since centres were initially not set up to process a large amount of urgency-requests. And not set up - one could, and I do argue - to facilitate data mobility that is crossing into a terrain other than that of speedy information for the purpose of criminal police cooperation. My remark here is of analytical nature and not a plea for increased funding: indicative as to which 'order' member states aim to strengthen will be the allocation of human resources to PCCCs, rather than further normative developments. And decisions will have to be made as to what type and breadth of information PCCC should exchange if, in the end, direct and speedy information for criminal policing purpose is to be maintained.

\subsection{4. 'Culture' and 'scale' - meaning and power}

Bowling and Kopf (2017) argued that PCCCs challenge the way police "make sense of their work" through professional identity and competition with other forces. They probed their potential to "foster a transnational subculture of policing in which police officers 'experience a common sense of purpose, objective, and aim (...)'” (p.52). The question posed as to local-transnational configurations of meaning with regards to PCCCs work-culture or subculture can in part be misleading. From a central state perspective, PCCCs were also aimed to institutionalise and render more transparent informal information exchange knowingly developed in border-regions. Due to the 'local' embeddedness of the centres and their staff, centres mostly do not aim to sustitute historically and personally grown contacts (pre-Schengen cooperation), but perceive themselves (and are perceived) as providing an additional service. This in turn widens exchange possibilities. It is also a service requested from non border-strip national territories. Although the composition of centres and the provenance of the officers are heterogenous, in the case of the three PCCCs I visited for the purpose of this study, crucial roles were covered often by "borderlanders" (Donnan and Wilson 1999; Baud and Van Schendel 1997, Van Schendel 2005), 
inhabitants of the borderland, i.e. officers that grew up or had spent considerable time of their police career within the region, as well as by "transborder commuters" (Je and Dokoupil 2018, p.110). Although not applied to (borderland)-officers, such a 'scaling of the world lived in' (Van Schendel 2005) or scale-ideology (Tsing 2000), has also emerged from other studies of borderland practices. As we saw, the identification with the patrolling officer through personal professional experience and the conceptualisation of the PCCC work as a "service unit" provide the phenomenological and interpretative ground to what Anderson and Nadelman defined as the culture of transnational policing. The so-called "local police subculture" (Bowling and Kopf 2017) of borderland policing in many cases departs from a pre-existing scale of relations. Beyond the field of direct (informal) information exchange, this also emerged in the possible supportive role of PCCCs in joint operations, such as joint patrols. Interlocutors highlighted that the planning of joint operations was better localised at the scale of regional police directorates.

"We have many joint operations, but that doesn't go through us, it's done by the [police authority on regional level]. This is again a case where history can tell us why. These relations [between police stations across the border] have always existed."

Some centres provide a level of coordinative support to joint patrols, and when for example language differences were identified as barrier to cooperation and to exchange in planning joint operations, centres have for example provided linguistic support. However: cross-border contacts that frequently predate Schengen cooperation instruments are held dear. Returning to the field of information exchange, it is particularly in a structural context signed by differential and unequal access to the PCCC service beyond the border-strip - analysed as the unequal spatial-legal configuration of data mobility - in which a so-called "transnational culture" is mobilitised as argumentation. It is such a configuration of local (as a scale not delimited by the nation-state scale) which also contributed to extending through re-scaling the local tool (PCCC Guideline) beyond its spatial-legal locality of the territorial border-strip jurisdiction. Notwithstanding the PCCC's peripheral legal and geographical location, this "tool of local collaboration" has acquired a strategic scale: not only for facilitating criminal police information exchange, but also for exchanging data upon immigration and asylum status of third-country nationals. The motivation of such exchange is principally for criminal police purposes but also, with some doubts as to the reconfiguration of policing-identity, eventually also extending beyond traditional police remits.

PCCCs operate also in relation with another CBPC instruments: border-area patrols, joint operations and readmissions. 


\section{3. (JOINT) MOBILE BORDER-AREA PATROLS AND READMISSIONS}

With the "concept of the mobile frontier" (1995, see chapter 5) bordering takes place through mobile border-area controls carried out within the 'ordinary' frame of abolished border controls: I argued that in the field of immigration policing, mobile patrols interact with the instrument of fast-track readmissions. In this section I turn to the meanings that officers attributed to their experiences of joint border-area patrols: their values, aims and challenges. Subsequently I detail how officers addressed the deployment of joint patrols in contrast to irregular migration. I argue that in the interaction between joint patrolling (new order, second and third generations compensatory measures) and readmissions (old order) we can analyse a reconfiguration of border policing and of intra-European mobility control, but also novel meanings of 'cooperation' and configurations of sovereignty.

\subsubsection{Joint patrols in border-areas: values, aims, challenges}

"Tell me", an officer said as we sat down for our interview, "does it work well there, have you found out something?". He was referring to joint patrols carried out in another border-region. I asked him what he meant with "working well". I did so not simply to turn around the interviewingroles, but I was intrigued to start with a discussion on 'what matters' in joint patrolling, even if in my research I have not been interested in evaluating their 'effectiveness'. There was no straight answer, and to be fair neither was my reply to his question. Indeed, the officer's response developed over the course of the interview: the main value of joint patrols is not their degree of effectiveness with regards to a specific crime field - certainly not in the field of migration control, according to this officer - but their representational value. Although not all my interlocutors would share the view that joint patrols are of such limited operational efficiency, almost unanimously they highlighted the symbolic and representational value with which joint policing is invested. What does "working well?" mean, then, if we also consider their symbolic value and effects?

\section{Aims, values and challenges of patrolling jointly}

Officers, remembering the setting up of the first joint patrols in their respective border-regions, pointed out very similar aims and values of this practice. First and foremost, joint patrols aimed to build up trust through direct contacts between officers in order to enhance cross-border cooperation. These contacts were deemed an important asset also beyond patrolling, useful for other situations when a quick response (and direct cross-border contact) was needed.

"Police officers are sitting together for 8 hours, talking about everything... (the joint) patrols are useful also from that point of view. But the most important thing is the mutual trust. The mutual trust is something in policing which is ... I think I would call it a kind of 'pearl of cooperation' - it is a conditio sine qua non." (IV_former-HLO) 
Second, several officers pointed out that joint patrols aimed to slowly familiarise the border-area population with seeing foreign officers, and to increase the security perception of the local population.

"At the time joint policing was a new phenomenon. At the start it was about getting the public used to seeing foreign officers going around here ... you know, with the opening of the border (...) and then, it was about further strengthening that. Subsequently one has covered shared security interests through joint patrolling." (IV_RL-HLO)

Schengen had also introduced the possibilities of hot pursuit: getting the local population accustomed to eventually seeing a foreign police car or armed officers wearing a different uniform, was not only for purposes inherent to joint patrols.

Another officer elaborated:

"These patrols have also the aim to increase the security perception of the population and to be also a sign for the population that we have good cooperation. I think the population would not really understand it if we were to carry out joint patrols [within the legally allowed 'border zone', but further away]. But indeed, the people understand it quite well, when a joint patrol carries out a control [in border proximity]." (IV_RL-HLO)

In some border-regions, recasts of bilateral agreements have also extended the area within which joint measures can be carried out: interviewed officers welcomed this, and some pointed out that this spatial extension is very useful for joint action days carried out in the course of a year. The officer quoted above argued that as an ordinary practice (and not limited to specific action days), joint patrols need to be deemed legitimate in the eyes of the population. According to this officer, local legitimacy (which is not the same as legitimacy by the law) is an important factor to consider when deciding if and where to deploy joint patrols. This speaker also highlighted what most interlocutors identified to be a core aspect of joint patrols: their representative value - they show that there is "good cooperation".

An officer, who witnessed first-hand the Schengen developments, framed compensatory measures not only within the problematisation of "open borders - security deficit". Very practically, the abolition of border control meant that the daily contact with colleagues across the border came to an end. The prior border control had provided a space of interaction and of informal cooperation. Joint operations thus met a local interest to continue contact and exchange, whilst creating more formalised and institutionalised forms of cooperation.

\section{Challenges}

Officers identified several challenges and values of carrying out patrols jointly. Existing language barriers emerged as the main challenge (see likewise in Darley 2008; Schwell 2008). Other, but 
less frequently mentioned, challenges were technological differences: the use of different radio frequencies was found to hamper practical cooperation in some cases, while differences in equipment were also experienced. One interlocutor remembered how initially he felt completely underequipped and thus of lesser 'value' compared to colleagues of the neighbouring country, while another officer happily recognised that the advanced technological equipment of their partners was a great operational benefit and allowed them to learn something new. In other contexts, national differences in the officers' respective salaries were amongst the barriers that hampered officers' enthusiasm for this new form of 'joint' enterprise.

During an observation, I noticed how officers in the unit took for granted that their colleagues would not understand a word of what they were saying. The "building of trust" is not an automatic consequence of "forcefully tying them together in a joint patrol" - as one directing officer described the joint patrolling -, especially when language presents a barrier. This is a critical reminder to CBPC scholarship that takes cultural-linguistic ties and their positive impact on trust, as well as mutuality and reciprocity for day-to-day cooperation in border-regions, as pregiven. What roles cultural, linguistic and historical factors play would be an inquiry indeed. An oldergeneration high-ranking officer of borderland origin, a region signed by war and conflicts in the course of the $20^{\text {th }}$ century, recalled that when driving across the border he had somehow still "a weird feeling... you know with whom you are dealing with and also they know, we weren't any better". He argued that while the EU integration development has been good and many years passed, "to keep that memory is important" (FN). Several officers pointed out how also language competencies were deeply connected to the (conflicting) history of the respective border-region. The presence of linguistic minorities - a reality in several of the border-regions I visited for this study - should not be taken a-priori as a guarantee of improved communication and facilitating cooperation across border-regions. In one case, an interview partner pointed out that other members of the minority group seldomly joined the public police force due to historical reasons and tensions. An officer working in another border-region explained indeed, how the learning of the 'second' language for a long time was not perceived well by the local linguistic majority: language competencies were lost. But he added that today, officers of the younger generation are rather familiar with English. Thus, communication has become less facilitated by local linguistic-cultural ties, and more through English. For sure, language competencies and crossborder exchanges are present in border-regions and I met officers who were plurilingual and had long lasting trusting cross-border work-connections and at times also family-relations. Nevertheless, one needs to acknowledge also the conflicting (and not just the facilitating) aspects of a 'shared history' that ties inner-European border-areas together. 


\section{Added values}

Several added values of patrolling jointly were highlighted, which are in line with findings of the DCAF survey (2013, p.8), according to which "better police cooperation among neighbouring countries" emerged as the most valued aspect of joint patrols, while the perceived effectiveness in countering targeted phenomena scored lower. In addition to the building of trust and direct contact, interlocutors pointed out that having officers that speak the language of the other country and have access to their national databases was of crucial value during patrols, especially when persons from across the border were stopped in the adjacent border-area and territory of the neighbouring country. This resembles the definition provided in the Manual on cross-border cooperation (Council EU 10505/4/09 REV 4, point 4.2), according to which joint patrols "aim at facilitating access to law enforcement by citizens from the different Member States concerned". Experiences of joint patrols during events taking place in the border-region were discussed as particularly positive: officers appreciated these deployments, pointing out that there they not only carry out repressive functions but can also provide information in the native-language of the event-participants. Since officers have access to their national databases, the possibility to combine different datasets and information systems during a patrol emerged as another value of patrolling jointly, similar to the discussed "data-quality" for PCCCs. However, one officer also pointed out that since PCCCs provide this service too, this is not a value of joint patrols only. A mono-national patrol can access the same or even broader information by asking for PCCC support.

\section{Joint patrols as "something that can be shown": on representation}

The study results highlighted one aspect of joint patrols which was expressed and identified by most interlocutors as a crucial characteristic of joint patrols: their representational and symbolic value. The five statements below are different officers addressing joint patrolling (in four different cross-border settings)

"Not secondary is also it has a symbolic effect: one shows that one works on the same thing. That is carried by the European idea." (IV_RL-HLO)

"Yes, well... it might not be necessarily so successful, but it is an important form of cooperation. To basically show that one can here together. It is also quite good, if there is any problematic issue, for example with a citizen of the other country in the border-area across the border or vice versa, then these joint patrols can be deployed very usefully, they provide a different approach to communication." (IV_RL-HLO)

"Well...its positive aspect is that we show... by patrolling together, that we do cooperate, and we show this to the public. But well, I am not sure. (...). At the beginning there was a lot of enthusiasm, but now ..." (FN_LL-SLO) 
"It has a visual quality; it is something that can be shown. And politicians sell it obviously also very well, and eagerly." (IV_RL-HLO)

Further elaborating upon the decisional roles in the set-up of joint-patrols:

"(...) if one is really honest, then it is a politicum. It is wanted, no question about that. The added value, of course, is that I get to know the people, know the players, it is easier for me when I have any request, if I know them directly. It's always good to go directly (...). And of course, the big added value that it fosters comradeship and friendships, that is not to be forgotten. We are neighbouring countries, we work together. If they have a search warrant, before it arrives through the official way, he calls me up (...). We receive the information anyway the official way, but if you know someone it goes quicker, and that is a big added value. (...). But it is politics, the Ministry of Interior level, that prescribes whether to have bilateral patrols or not." (IV_RL-MLO)

Officers often linked operational and symbolic value in their reflection. Especially those who deemed the operational success rather limited, emphasised the symbolic value, but the representational value was also pointed out by those who recognised an operational use of joint patrols. The responses also point towards a differentiation between a political and an operational policing-level: setting up joint patrols needs to be supported (and wanted) on political level. It requires a legal base and the set-up of additional operational protocols, but it also implies considerable financial expenses for the country sending officers abroad to be allocated on the strategic policing level. Authorities in some border-regions opted for the "chess version" of coordinated patrols to meet the local operational policing needs. Officers pointed out this was a quicker means than joint patrolling, not needing the above-mentioned support. Such bottom-up initiates can precede joint patrolling, which not necessarily needs to be 'imposed' from above.

Joint patrols have found several applications and have mostly been set up to meet local crossborder objectives in different policing fields: traffic policing, security and order policing during festivities in the border-region, criminal policing measures against theft or other small-medium crime fields that characterise the respective border-area ${ }^{85}$, and increasingly in the field of immigration control. In this last section, I analyse how police officers reflected upon the use and experiences of joint patrols as a mean to counter unauthorised mobilities.

\subsubsection{Migration control - ethos of a joint task?}

An Italian, a German, and an Austrian - that is how jokes start. Then a mess happens. The Italian tries to get out of the affair with grandezza [grandeur], but the German insists upon law and order. And the Austrian? Waits what the German does - and then pitches in diligently. This scene repeats itself every day in northern Italy. A German, an Austrian and one or two Italian police officers enter the train for Munich [Germany] in Trento [Italy] and search for refugees. (Sterkl 2015) 
In the above reportage, die Zeit portrayed the deployment of joint patrols as a (tragic comic) "game in the field of asylum politics", an asylpolitisches Planspiel. Writing about PCCCs, Nogala (2001, p.141) suggested that investigating what triggers cooperation and how it is achieved could be a strand for future qualitative research. Indeed, this is a poignant question when addressing joint patrolling. One of my interview partners pointed out how bilateral agreements conceptualise joint patrols as a response to shared common security interests. He asked how to do justice to this - as he aimed to emphasise - legal bilateral requirement:

"However, both sides have security interests. So, the question is, how can we bring both security interests into, and unite them within, one patrol?" (IV_RLHLO)

The officer pointed out how joint patrols have increasingly been set up or intensified for the purpose of countering irregular migration. The country whose uniform he wore has been amongst the driving forces in promoting joint patrolling to counter unauthorised "secondary movements". By trying to put himself in the neighbours' and partners' shoes, he critically reflected:

"I am curious, I mean, do they [the neighbouring country participating in the joint patrols] really want this, or are they only doing it because we [the country's ministerial level] have proposed it. Do they want that? They don't want them [migrants], to stay there. One should be able to say this openly. They have no interest in that. And they are also saying it loudly in the media (...) and it's written on the posters. This isn't really any secret. So why should a joint patrol then be so effective, that through the joint patrol they help us so that he doesn't enter our country. (...) This is... this is an illusory world that we are setting here up. Or, what is it? And, if we are setting it up, for whom are we doing this?" (IV_RL-HLO)

I deem this dense excerpt of importance to start an interrogation of an "ethos of a 'joint task"” (Haahr and Walters 2005, p.107) on migration in the Schengen border-zone. The officer pointed towards the difficulties of considering "migration control" necessarily a truly shared security objective, he indicated the role of power relations in 'cooperation' on migration matters, and he spoke about existing silences regarding what seemingly can - and cannot - be voiced, but everyone knows. Member states have diverging opinions, especially regarding the way that rights and duties are allocated within the EU landscape of asylum (on CEAS and the Dublin Regulation, see chapter 8). At the same time, the European Commission Recommendation to enhance proportionate police controls and police cooperation in border-areas (C(2017) 3349 final) highlighted joint patrolling in border-regions as best practice examples that other member states should follow. Considering on the one hand the symbolic value of joint patrols as a crucial characteristic and taking account of the recommendation to deploy joint patrols for the purpose of migration control on the other, it is worthwhile to further analyse their symbolic as well as concrete effects. The quoted officer perceived these (recommended) 'joint' patrols as the setting 
up of an "illusory world". He wondered what it was, what it was for and, consequently, who the audience of such fiction would be.

\section{Second and third generations of "compensatory measures": witnessing, discipline and control}

I had scheduled an interview-appointment with an officer to talk about joint patrols. For the first part of our talk, he elaborated upon strategies for countering irregular migration and problems encountered with readmissions of third-country nationals. He then pointed out, that in order to understand the "philosophy" of joint controls, they needed to be placed within that context. Remembering the setting up of the first experience of joint patrols in his country, he argued:

\footnotetext{
"All that [readmissions and strategies to counter irregular migration] is also about joint patrols. You will understand the philosophy behind it. Nowadays the joint patrols idea sounds completely different (...), but it is important to understand why we introduced the joint patrols. Simply because when the joint patrol apprehends the migrant, officers (from both countries are) part of the control. So, there is no need for additional procedures or proof. He [the police officer] was there, he saw. Was a kind of witness and proof [where] that migrant came from." (IV_former-HLO)
}

Within the rationality of the "mobile frontier", first generation controls are carried out along entry routes into the country with the possibility, under certain conditions, of a readmission of thirdcountry nationals. Evidentiary criteria have already been identified in the 90 s as having hampered the effective application of readmission procedures ( $\mathrm{SCH} / \mathrm{Com}$-ex (97) $39 \mathrm{rev}$; see chapter 6). A country, through the police department of the border-area jurisdiction, can refuse a non-formal fast-track readmission request, if the proofs are deemed insufficient. The request can then be reproposed as formal readmission handled at a central level. In the situation of the quoted officer, non-formal readmission requests were frequently denied, and a high-level dialogue was sought between the countries. He argued that his country was interested in having efficient readmissions back into the country: on the one hand as a deterrence strategy addressing migrants, with the aim of rendering their movement more difficult and eventually closing-down the route, and on the other hand to improve the relationship with the neighbouring country.

\section{Second-generation measures: evidentiary bodies}

The shift towards joint policing in the field of immigration control needs to be analysed in connection to readmissions and mostly as a means to facilitate swift and correct application within the terms of a fast-track readmission procedure. Joint patrols carried out along entry routes can assume the function of proof. Evidentiary criteria are at times still a conflicting topic. The officer quoted above defined the patrolling officer as a 'witness'. Officers become not only subjects of mobile borders, but they function also as witnesses, as 'bodies of evidence': means of proof of an unauthorised crossing. Officers interviewed in different border-regions and countries referred to this practice of witnessing also as a "control" function - sometimes placed under 
explicit brackets. 'Control' can encompass several aspects: control in that the neighbouring country/officers do not request the readmission of a person who had been intercepted elsewhere, or control that no one fabricates the alleged documentary evidence. One officer also mentioned the possibility to exercise a witnessing-control, that the person intercepted has not voiced the word "asylum". In such case, countries are not allowed to readmit a person because of his or her right to ask for international protection. "But at times one wonders", the officer added, referring to readmitted persons - negative in Eurodac - who asked for international protection after having been readmitted through a simplified administrative procedure.

In addition, further attention needs to be paid to where in space and along which routes joint patrols take place. It is here that staying attuned to viapolitics allows further analysis.

\section{Third-generation measures: patrolling exit routes jointly}

Joint patrols have not only been applied along 'entry', but also along 'exit' routes, thereby leading to a reconfiguration of how the border takes place in the border-strip, i.e. how the border manifest itself and becomes actualised. Such controls aim to act 'preventively' or 'pre-emptively' before a presumed border-crossing happens. By aiming to limit the possibility of a potential irregular border crossing in the first place, no readmission procedure post-factum would be needed. Notably, in the opinion of most interviewed officers, the controls mostly simply produce the effect of displacement. This spatial dislocation, that of policing, opens a space for (sometimes) fuzzy representations and practices of the executive functions and sovereign powers at play.

According to many bilateral police cooperation agreements, officers participating in joint patrols on foreign soil, whilst allowed to wear their uniform and weapon, can only carry out an auxiliary function and they do not retain any executive police powers. Most of my interlocutors were very explicit about this. Depending on the cooperating partners, sometimes the agreements differ in the detailed definition of what auxiliary function implies, and there are differences in whether any executive powers are given and if so, which. We saw how also 'witnessing' plays a role in this auxiliary function but along exit routes it assumes additional functions. The following excerpts allow one to dig deeper into complex cross-border inter-state and inter-personal relations, but also highlight diverging perspectives on 'who' is in control, and of 'whom'. An officer working in a high position at a regional department level explained to me:

"On operational levels in the field of contrasting illegal migration we have very good cooperation (...) we carry out joint patrols both on the street and on the trains. That means all trains that come from [country A] and pass [here, country B], as well as every train coming from the other direction [country C], are monitored through a joint patrol, composed of officers from both countries $[\mathrm{B}$ and $\mathrm{C}]$. And the controls are already carried out respectively in the other country. If the train goes in this direction, then the control takes 
place in [the last train station] before leaving the country and the persons who... who have no permission to enter the country are taken from the train." (Emphasis added, IV_RL-HLO)

Asked to provide a clarification regarding executive powers, he specified:

HLO: "This is a joint, a mixed patrol, and the same happens on the [last train station on the other side of the border] ... where you also have persons to whom entry is denied."

M: "You mean the officer can do that within the other territory?"

HLO: "Yes, they have the possibility to carry out checks in the other country's territory. But they don't have any executive powers. That is why there is also a responsible officer present [an officer from the country within which jurisdiction the control takes place], but they can wear their uniform and weapons and carry out the control."

In the understanding of this officer, the main acting agent and interest in the joint control was respectively the country and officers that aimed to prevent irregular entries. Joint controls were set up explicitly to meet the 'other' country's requests to limit irregular entries, and he attributed the main control function as being carried out not only in the interests but also in the acts of the respective neighbours' force. However, things are not that straight forward. The term "denial of entry" was used by the officer not in a legalistic sense, but it represents the way he experienced these practices, their aim and effects. On the one hand, compensatory measures are not carried out within a border control frame. Therefore, what the officer described as "denial of entry" is technically not a legal denial of entry decision. On the other hand, such executive power would not be possible to execute on the neighbour's territory and the bilateral agreement in place here did not grant any executive but only auxiliary powers. The description of the officer should be read in practical-operational and not in legalistic terms, but it provides therefore not less insights into the meanings attributed to this performance and into law-as-practice.

On the other side of the border, the officers presented the controls slightly differently: as spotchecks with the aim of intercepting persons travelling without authorisation to leave the country. In practice this meant the interception of persons that were either irregularly present, or legally present but unauthorised to cross the border. Here the control was described as carried out primarily by the police force of the respective country, on both sides of the border. The neighbouring forces were deemed of auxiliary function on this side, and responsible on their side of the border. It is clear that with two different understandings of who is (responsible for) doing what, conflicting moments or misunderstanding might arise. Formally it is a border-area control in which the police force of the country where the control is carried out holds the executive functions as well as responsibility of measures carried out. 
The challenges encountered here resembled those of other border-regions along exit routes. Amongst them is also the interception of persons who are legally present on the territory, but without authorisation to leave. They are legally allowed to travel throughout the country: "you can not really block the person if not within the act of attempting to leave the country", as one officer pointed out. In the 'ordinary' frame of the AFSJ, the time and space of this act can however not be through interception at the borderline. With papers in order, after the check and being removed from the border-crossing train, this category of persons is free to go. As we shall see, especially but not only for this category of control-targets, 'exit'-controls rush ahead into the grey zone which today extends between border-area and border control (chapter 8). As an officer explained to me, although referring to a different practice, officers enjoy working in the greyarea: in instances it can get very dark-grey, but one shouldn't stay in such space too long.

Finally: the forces of the two countries in example were perceived as 'equal' partners, notably not because they are together on patrol, but since both countries carried out this function on the partner's side of the border. Such a set-up was defined elsewhere by an officer as a "balanced" approach: joint patrols carried out equally on the territory of both participating countries. This is not always the case. In 2014-2015 joint police patrols were set up to patrol international trains leaving Italy for Austria to Germany, as well as from Hungary to Austria and Germany. The former was introduced in November 2014 from Trento to the Brenner/o border, the latter in February 2015 from Budapest to Gyor. In addition, since 2011 Hungarian and Austrian officers carried out joint measures against migrant smuggling on Hungarian territory. The tri-lateral patrols are examples of third generation measures. In addition, they are not carried out in a so-called "balanced approach", but only on the territory of one participating country, respectively on Italian and on Hungarian territory. In both cases the trilateral patrols were set up following a German initiative (Deutscher Bundestag 2017, p.20). An Italian police unionist critiqued them as "unilateral trilateral patrols" (Deriu, in Bertoncin and Weissensteiner 2016), and as implying a sort of "subalternity" since they were taking place only along exit routes on Italian territory.

\section{Patrolling exit routes - standard practice?}

While checks along entry routes are a common practice adopted by member states to counter intra-European unauthorised mobilities, this is not the case for outward mobilities. One officer, whom I asked whether they and their neighbours also carried out checks along exit routes, was surprised that controls along these vias were something to even ask about. The answer was a clear no. He put it succinctly, by providing his definition of a "good migrant" in this context: a 'good migrant' is one that travels outward.

"They [neighbouring country] are not interested in that, because for them, everything that leaves the country... is a 'good migrant'. It would be the same 
for our country. Everybody who here... well, we don't stop anybody who goes in their direction, let me put it like this." (IV_LL-HLO)

Only certain inner-European mobility routes have acquired a particulary configured viapolitical salience: exit-route patrols emerge as an expression of request from the neighbouring country, not as a measure which states seemingly put in place for their own interest. Other interview data indicated the perception of an officer, that some country rather than setting up a joint patrol along its exit-routes, preferred to step-up its own border-area measures targeting outward mobilities, fearing - according to the officer - otherwise too much interference from the neighbours through the joint patrol instrument. In addition, considering the cost of deploying officers abroad, a country might decide to have a 'non-balanced' patrol and invest its resources elsewhere. Rather than implying necessarily a "subalternity", unilateral patrols can also be the outcome of a strategic-level decision where to invest available resources. In another borderregion, indeed, third-generation measures were described as in the interest of the country that hosted them. They were a means to show the neighbour that checks were carried out properly:

"Those who are not intercepted by us, end up [in the neighbouring country]. Thus, we said, come and take part in the controls here. In this way everyone gets a feeling of what the other country does. It's about reciprocity, that is also an important European concept. (...) The joint operation enables a certain... well, a certain... I don't want to say 'control', but also that. If everyone does his own thing.... Well in a joint operation, you see what everyone does. And that fosters reciprocal trust."

In a historical-political context in which accusations of state- "wave-through" as a means to facilitate "secondary movements" have loomed large, getting a "feeling of what the other country does", means for one actor to show the other actor that checks are being carried out, and for the other to exercise some witnessing-control. Reciprocity also means to share the responsibility for those persons, who indeed are not jointly intercepted. In such a border-area configuration, the "ethos of a 'joint task'" (Haahr and Walters 2005, p.107) during a patrol can be established: but it seemingly acquires such meaning only if placed in landscape of (mutual) distrust.

\subsubsection{Scale and jurisdiction, power and sovereignty}

The Recommendation to enhance proportionate police controls and police cooperation in borderareas (C(2017) 3349 final) mentioned several best practice examples: besides those of intensified police checks in the border-areas (by $\mathrm{AT}, \mathrm{BE}, \mathrm{CZ}, \mathrm{DE}, \mathrm{DK}, \mathrm{NL}, \mathrm{FR}, \mathrm{IT}, \mathrm{SI}, \mathrm{CH}$; point 10), also "joint train patrols in Austria, Germany, France, Italy, and Hungary, or the recruitment by German police of nationals from other Member States, in particular for patrolling in the border-regions". It encouraged other Member States "to follow these best practices" (point 16). Already in September 2014 the head-of-office of central border-police-directorates of several member states ( $A T, B E, F R, D E, I T, N L, B X, L X, C H)$ met in Germany to discuss possible bi- and multi-lateral 
responses towards the "migration emergency" (Ministero dell'Interno 2016, p.24). According to an Italian report, amongst the provisional agreements figured inter alia "the activation of bi- or trilateral joint control mechanisms along the main traffic arteries of interest to so-called secondary movements of migrants, who from South of Europe, especially from Italy, aim to reach countries of final destination" (emphasis added, ibidem).

Joint patrols have also been included in a strategy to counter irregular migration along the BalkanRoute. According to the joint statement of the Chiefs of Border Police Services of the Western Balkans of June 2018, readmission practices should be improved. An increased use of mixed patrols was mentioned as a means to simplify readmissions (IISG-WBBSI 2019 Annex 1, point 3). ${ }^{86}$ The Commission recommendation, in addition to intensified (and joint) border-area patrolling, advised a "proper" and "efficient" application of the bilateral readmission agreements to counter "secondary movements", albeit without making explicit the link between readmissions and second-generation patrols. As we saw, fast-track readmissions seem to be an inherited old order, willingly kept alive.

With CBPC joint control instruments to be activated "along the main traffic arteries of interest to so-called secondary movements" (Ministero dell'Interno 2016, p.24), inner-European borderregions have become strategic zones in the governance of routes that have become via-political. Policing-mobilities are deemed an appropriate tool of response, also due to the policing powers and policing-mobilities provided for in the spatial-legal border-strip. Notably, responses taken initially bilaterally, upon the initiative of member states, have now also been embraced on EU level. While I will further analyse what this means for the Schengen area and the AFSJ, here I highlight the meaning thereof in the reconfiguration of joint patrolling.

\section{Meaning and power}

We saw that joint patrolling is deeply invested with symbolic character and deemed an instrument to foster trust and CBPC necessary to tackle regional cross-border challenges. Joint patrolling visually represents a joint endeavour and is considered a symbol of unity and 'common purpose' of policing the Schengen area. If abolished border control and the removal of border infrastructure is Schengen's core symbol, joint patrols are a visual symbolic equivalent in police cooperation. When they perform the "mobile frontier", joint patrols show that the removal of borders does not equal to indiscriminate freedom of movement: considered together, these two core symbols of Schengen stand for differential mobility rights and the reconfiguration of border technology. Applied in the field of migration control, beside the symbolic message of showing through joint patrols that unauthorised inner-European "secondary movements" are apparently tackled together, we also see that joint patrols are equally invested with the expectation of a practical impact - such as to simplify readmissions. 
For the officer quoted in the beginning, the joint patrol in this context signifies an "illusory world". When comparing the first and the second section of this sub-chapter, one does note a shift in the semiotic field of joint policing. In the latter part, within this "horizontal" form of cooperation, officers associated their own and their colleagues' actions with reciprocal practices of witnessingcontrol of each other's behaviour. The mobile frontier patrolled jointly aims not only to observe and control unauthorised movements. The ethos of a joint task in migration-control can emerge, but the joint patrol then seemingly symbolises rather an absence of mutual trust and presence of a perceived necessity of control. It would be interesting to compare the depoloyment of joint patrols and operations in the field of migration control with those of other fields. My point is not a claim that this instrument has been chronologically transformed from a 'pure' and representational cooperation into a modality to exercise control over partners. The ongoing reconfiguration of this instrument and its deployment in the field of migration control, highlights contradictions and power relations in 'cooperation' which are deeply embedded in the broader historical-political context. Besides the fact, that some initially identified goals and values of joint patrolling are clearly lacking in this type of operations, such as their aim to facilitate access to law enforcement by citizens from the different member states concerned. Joint patrolling becomes a joint task deemed capable to mediate between contradictory social and political forces at play beyond the field of policing. The question remains: what happens to trust as "conditio sine qua non for police cooperation", when embedded in this context?

In chapter $5 \mathrm{I}$ asked what sort of sovereign power is expressed through mobile joint frontiers and I argued that analytically engaging with joint patrolling enables issues to be tackled at the heart of the political order, as macro-political discussions regarding the lack of legal anchoring of executive powers in the Prüm framework indicated. In qualitative research attention must be paid to what meanings 'reciprocity' or 'cooperation' hold in lived experience. What sort of political forms emerge out of policing practices, such as those of mobile frontiers patrolled jointly? Gazit (2009) called attention towards the "politics of small things" and proposed the analytical concept of "fragmented sovereignty" to analyse political power beyond the limits of its official boundaries of territorial jurisdiction. He defined fragmented sovereignty as "comprised of multiple, localized, and relatively autonomous cores of power, instead of an all-encompassing structural and centralized modality of control" (p. 83). In situations of fragmented sovereignty, the 'state' does not enforce political control, but its ground-level agents operating outside its jurisdiction and within a certain autonomous space of agency. Albeit not developed with respect to police actors, this concept is a useful supplement to that of "horizontal cooperation" (Van Reenen 1989, in Block 2011, den Boer 2010) and "disaggregated sovereignity" (Slaughter 2004) - a reconfiguration of sovereignty through legally anchored 'participation' or 'cooperation'. It captures some of the 
lived experiences of officers and certain interaction-dynamics of 'cooperation' and of enforcement. The exercise of power by officers attributed auxiliary functions outside their territorial jurisdiction - in this case through the border-strip and joint operation possibilities - it is not the state of these agents enforcing its laws over its territory, but it is the practices of officers in the interaction with their counterparts that produces a local and temporary effect of power. They may act as witnesses, as controllers or even as active enforcers. As we saw, joint patrols were frequently set up in the interest of countries aiming to counter entries, but they likewise enforce EU law, i.e. the 'Dublin order of things in space': an order that excludes certain subjects from freedom of movement and regulates rights and duties of member states.

\section{Scale and jurisdiction}

Second generation compensatory measures, and especially third generations are 'remote' from the territorial jurisdiction of one of the control-agents. The latter presents a different legal border configuration than those of juxtaposed controls (Home office 2017), but also some common features. They have been analysed for example in the UK-France Channel cooperation context (see Gallagher 2002), as forms of "'offshore bordering" (Vaughan-Williams 2012, p.19), "debordering" (Cassidy, Yuval-davis and Wemyss 2018) or "security-at-a-distance" (Aas 2012, p.238). Third-generation measures are an expression of de-bordering and security-at-a-distance if viewed from one country's perspective, albeit formally this is not a border control and officers do not hold any executive powers. Cuttitta (2007) captured such joint patrols as "externalising flexibilisation" of the border. He differentiated between bilateral cooperation - when controls are carried out on both sides of the border - and unilateral cooperation, when this is not the case. The former can be identified in the "balanced approach" in the words of my police-interlocutors, while the latter was literally defined as unilateral (trilateral) patrol by an officer (above). In the context of migration control, according to Cuttitta, if one participating country is of destination and the other of origin or transit, it is a measure for migration control only for the former and as such never truly bilateral. Unless the cooperation fullfills other functions of mutual interest, the latter will experience the cooperation as imposition and obligation due to political-economic subalternity (p. 95-96). Within Schengen he spoke of mostly bilateral cooperation through joint patrols. This conceptualisation is important, but insufficient to capture the multiple and diversified experiences, as well complexity of polidirectional routes and viapolitics, both those of the subjects of (unauthorised) movement, as well as those of uniformed officers. We saw that on the one hand cooperation between member states can be perceived as a unilateral imposition of interest within the 'unequal landscape of asylum' created through the Dublin system. On the other hand, it is misleading to categorise and homogenise countries and migrant trajectories too easily as being either of 'arrival', of 'transit', or of 'destination' within Europe in a route simplified 
(as in the visualisation of "secondary movements") as a straight line from A to B. Likewise, in policing practices, localised policing experiences on exit-routes frequently present similar challenges in different countries and can indeed differ from those within the same country primarily concerned with irregular entries.

Border-areas emerged as important scale in the response to unauthorised mobilities and the question of jurisdiction and of how undesired intra-European mobility is governed remains intriguing. As Valverde pointed out "deciding who governs where - the basic jurisdictional question - is not only important in itself but also has the effect of determining how something is governed" (2014, p.382). Policing powers within the border-area jurisdiction, enabled through plural spatial-legal constellations that provide a certain configuration of instruments, can in their practice temporally assemble and produce bordering effects. In addition, the concept of "fragmented sovereignity" allows one to draw attention to the criticality that ground- or streetlevel agents - including those deployed outside their territorial jurisdiction - have on how unauthorised secondary movements are governed, thereby producing spatial and bordering effects. This also goes hand in hand with highlighting the crucial importance as well as delicacy of rapports within units of joint operations in the context of migration control, or in readmissions. As I will exemplify in chapter 8, there is a great deal of street-level diplomacy involved in keeping policing-mobilities running.

\subsection{SUMMARY}

In my research I asked what role CBPC at the scale of inner-European border-areas plays in the control of differential mobility rights within the EU Schengen space. As emerged from this chapter, policing-mobilities and the spatial-legal border-strips have turned into "strategic zones" along the transport system (Walters 2015a, p.478) and within the digital transport system, i.e. the channels for police information exchange. We also saw processes of a territorialisation of Europe that both transcend exclusive territoriality of the nation-state, whilst drawing on elements of its territorial jurisdiction.

This chapter also highlights the analytical value of not extrapolating the policing of migration from the broader meanings and practices police carry out in the border-strip and through CBPC. Therein surfaced a process of migratisation of security, when policing instruments are increasingly deployed in the control of unauthorised mobilities. According to fieldwork data, differences were encountered as to the degree that joint patrols 'prescribed' from above as instruments to counter irregular migration were used to meet several policing needs beyond this specific (politically emphasised) target, or whether they were perceived - not without frustration 
by local police - as concentrating all resources on migration. Without the migration target, one officer exclaimed, they would be focusing on the usual staff in the border-region, that currently became relegated to a secondary (political) priority. Jokingly asking if a 'solution' to intraEuropean unauthorised mobilities would deprive him of his work, he exclaimed:

"Oh no! Drug smuggling, stolen vehicles.... we could focus on all the other aspects! Now we don't. All our patrols and forces are deployed on the immigration issue." (FN_LL-HLO)

Inner-European border-regions have become strategic zones in the governance of routes that have become via-political: policing-mobilities are deemed an appropriate tool of response. Taking Smith's (2003, p.228), definition of scale making as the "spatial resolution of contradictory social forces" in the final chapter I will analyse how the border-strip emerges also as a scale deemed capable of mediating between plural contradictory forces which deeply entangle micro-practices and ground-level-politics with those of macro-level developments. As a bridge, a brief interlude based on public document sources, will relate the empirical findings and abstract considerations of chapter 7 to a specific context: along the so-called "Brenner/o-Route". 


\section{INTERLUDE}

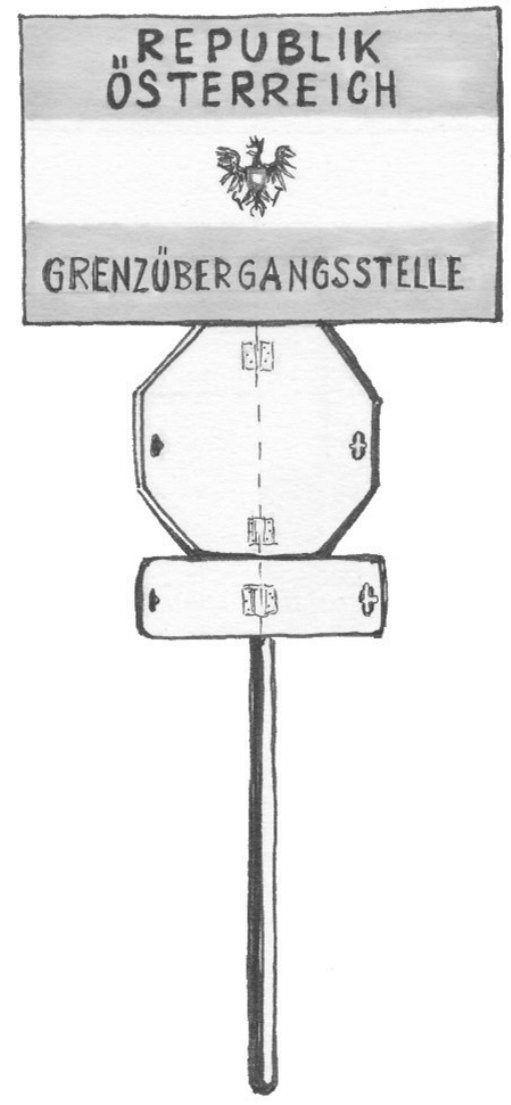

The Brenner/Brennero and the path that traverses it, is modestly put simply historical. (...). It connects since ever the North with the South and the South with the North (...) as a bridge and a clamp at the same time, and as doorstep from the South to the North and from the North to the South.

Trenkwalder 1999, pp.65-66

Historian and former priest of the Brenner/o municipality 


\section{Sign in place}

This sign - made to flip - was installed in 2016 as part of a so-called "border-management" put in place by Austria at its inter-state Schengen border with Italy. It was announced as measure enabling Austria to set up border control within 48 hours on the border to Italy (RedaktionAPA 2016). The depicted sign was placed at the Brenner/o pass.

The Austrian-Italian 400-kilometre-long inter-state Schengen border covers various Italian provinces and Austrian Länder. The Brenner/o is located at the border-section between the provinces of Bolzano/Bozen (South-Tyrol, IT) and Nord-Tirol (Nord-Tyrol, AT). As the lowest Alpine passage point at 1.374 meters above sea level, the small village and Alpine crossing named Brenner/o (i.e. Brenner in German and Brennero in Italian) has been for centuries the most trafficked Alpine crossing for goods and persons. It presents a strong cross-border mobility infrastructure, given symbolic names such as the highway "Bridge of Europe".

Covering the Austrian "border-management" developments, in 2016 the British newspaper the Guardian titled that this very region, "once symbol of Europe's peaceful cohesion" would be turned into an "emblem of Europe's disintegration" (Kirchgaessner 2016). This border-section crossing-point emerged as a core symbol of freedom of movement and of European integration also in many other political and media representations. The Italian newspaper la Repubblica quoted the German counsellor, saying that "if we close the Brenner[/o], Europe is destroyed" Berizzi 2016). "Europe's pass of destiny - is the border burning again?", titled the German die welt (Schümer 2016), and the Austrian der Standard simply stated: "The Brenner is not a normal border" (Mumelter 2016). Two years later, in 2018, a journalist of the Sueddeutsche Zeitung argued that "[t]he Brenner/o is the central symbol for freedom of movement in Europe. When the gates close at the Brenner/o, then they do so for Europe" (Gasser 2018). It is fascinating to see, how actions at this border received a very clear symbolic meaning and a broader echo, than for example the de facto and de juris re-introduction of border control at the former Iron Curtain, between Austria and Hungary.

\section{Sign, place, meanings}

This section of the Austrian-Italian border has historically ${ }^{87}$ and in contemporary times received the most border-political and public attention. Further east, along the main border-crossing route between Friuli-Venezia-Giulia (IT) and Kärnten (AT) leads a major transport route on the triple border between Austria, Italy and Slovenia. This is a border triangle with another conflicting history, but this border-section has been less politicised in recent years. On the $1^{\text {st }}$ of April 1998 border control on the Italian-Austrian border ceased. At the main border-crossing point between Udine (IT) and Kärnten (AT), the former border-barriers today are a visible and left-to-decay piece of memory. Contrarywise, on the Brenner/o all signs of border (control) infrastructure were 
immediately removed in 1998 with the Schengen reconfiguration of the border. It was deemed also a symbolic act of overcoming what at times was still called an Unrechts-Grenze: a so-called "border of injustice" tearing Tyrol apart since 1919.

Regional historian Hans Heiss (2012) pointed out three features of the Brenner/o in the course of its $20^{\text {th }}$-centry history. It was 1$)$ "a seismographic point for intergovernmental relationships, where also symbolic actions could produce considerable effects" (post-Word-War I, p.105); 2) it had a "double function as a representative place of inter-governmental mise-en-scène (...) [and as an] increasing utilisation as crossing point for the transfer of population and troops" (World War II period, as also Hitler and Mussolini met here, p.140); 3) that "is part of the particularity and of the fascination of the Brenner/o-Pass, that it was able to maintain its role as crossing passage and as demarcation line throughout history" (p. 96). Other authors have suggested, that "[a]fter losing its political meaning and brisance, the Brenner seems now to mutate from a place of negative experience into a mere place of memory" (Gehler 2009, p.146). In the 60-70s this border had been thickened by police and the military in the context of the Bomben Jahre that followed the notte dei fuochi, dynamite attacks by persons called freedom fighters by some, terrorists by others. This border would present itself for an intriguing case study, also historically, on border-policing in border-regions. ${ }^{88}$ Since 1998 South-Tyrol, Trentino and North-Tyrol form also a European cross-border-region, later institutionalised as Euregio Tyrol-SouthTyrol-Trentino - European Grouping for Territorial Cooperation. Today, not less symbolic for Schengen's economic dimension, a big shopping mall found its place at the borderline. The opening of the border in 1998, the physical and symbolic removal of the border-barriers must be embedded within these historical processes and the sign and the reactions also analysed by taking account of historical meanings of place(ment).

\section{Sign in context}

Finally, the illustrated flip-sign also needs to be placed in the wider context of migration politics. The Austrian Land of Tyrol, where this sign was installed, borders with southern Germany in the North, northern Italy in the South, and with Switzerland to the West.

The "border management" was presented also in the context of a newly adopted Austrian national legislation, which inter alia introduced a highly debated Obergrenze (an absolute upper number of asylum applications allowed per year). ${ }^{89}$ If reached, the government could trigger a Notstand-Verordnung (emergence decree). This was legally justified, in short terms, by declaring that a high number of arrivals, alike in 2015, would endanger public order and internal security and that the measure was necessary to maintain them. Albeit such measures have not been triggered, the set-up of border-management infrastructure also needs to be placed within this context. 
In addition, Austria's northern border with Germany constitutes the longest internal land border for both countries $(815 \mathrm{~km})$. As part of this border runs along the river Inn, a police-magazine titled that Bavaria and Upper-Austria were "separated by the Inn - united in security" (Sternberger 2016, p.32). This 'unity' saw also troublesome moments. According to the book-testimonial of officers of the German Bundespolizei "[t]he refugee crisis posed completely new challenges to the border-relations of the two neighbour-countries [Austria and Germany]" (Conrads, Franke and Hodenius 2016, p.28): the months following the introduction of border control by Germany were signed by "lacking or insufficient coordination" and there was a feeling of distance and suspicion between the officers of the two countries. Joint patrolling stopped at the time. In 2018 the German Mol released a Masterplan Migration, containing measures in the field immigration aiming at "order, regulation and limitation"(Bundesministerium des Innern für Bau und Heimat 2018, p.13; see also in SchmidtSembdner 2019). It caused an intergovernmental conflict, since it envisaged to refuse processing Dublin-readmissions for persons intercepted who are positive in Eurodac: they should simply be sent from where they entered, mostly Austria.

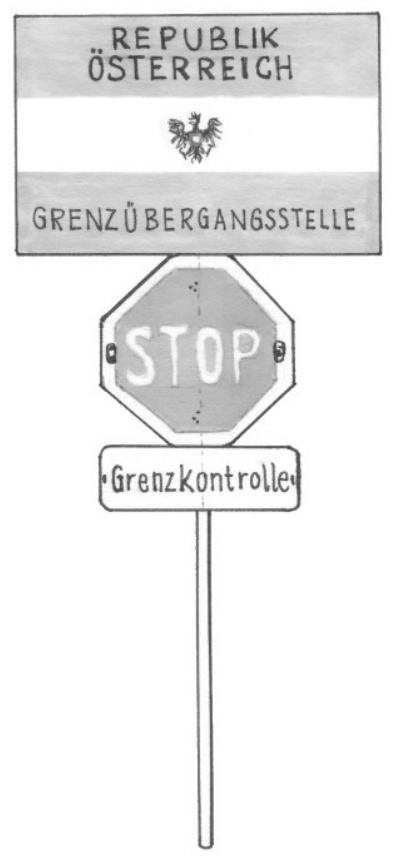

\section{Impact on CBPC measures along the Brenner/o Route}

Despite the announced "border-management" plan the so-called 'closure' of this likewise symbolic but also economically highly relevant border and route was considered a no-go area. According to an Austrian Mol report "the lack of legal basis for the exercise of border control on the border between Tirol and Italy (Brenner) allows along the Mediterrean Route through Italy only compensatory measures in accordance with Schengen (AGM controls on roads and train)" (Bundesministerium für Inneres 2017, p.20). The initiative of the German Mol proposal did not materialise. Both countries however had all interest to introduce indeed more 'cooperative' measures along their shared viapolitical routes, albeit both the Balkan and the Mediterrean Route had decreased in arrivals, not at least due to (external/ised) border-politics further South and East. Compensatory measures have flourished.

The Eurostar train that connects Northern Italy with Munich in Southern Germany five time every day vehiculates this clearly: within Italy, trilateral mobile border-area checks are carried out within the train until reaching the Italian-Austrian border (third generation measure, since 
November 2014; Deutscher Bundestag 2014); at the border train station, Austrian border-area patrol units enter the train (first-generation measure), and when crossing from Austria into Germany, temporary border control checks are in place (since September 2015). In addition, joint measures on trains transporting goods are carried out likewise through trilateral (IT-AT-DE) and bilateral (AT-DE) measures: on the Italian side of the border since November 2017 and since June 2018 also in Austria (LPD Tirol 2020). In 2020 the 'unthinkable' became real, and in the context of anti-COVID measures cross-border transport was interrupted and border control introduced.

Notably, compared to the situation in 2015 (table chapter 6), rather than dealing with readmissions back to Italy, between 2016 and 2019 the LPD Tirol has had numerically more to deal with returns from Germany following denial of entry decisions..$^{90}$

Tri-lateral joint patrols between Germany-Austria-Italy existed since 2000/2001 and according to the German Bundestag $(2014$, p.2) they were "re-conceptualised" $(*)$ in 2014 in ongoing efforts to "contain the impact of inner-European migration" and to fight international smuggling organisations. It consisted in an intensification of patrols, as well as modification of their spatial distribution (only on Italian territory). Prior to 2014, such "containment" was aimed for through first-generation measures carried out in Austria. According to data provided by the Italian Mol, passive fast-track readmissions from Austria to Italy on the Bernner/o had increased of $237 \%$ with respect to 2012 (Saltarelli and Weissensteiner 2015). The readmitted persons mostly were of Syrian and Eritrean nationality, who had aimed to reach a central or north-European country in order to make an asylum application. In 2014 a political solution was found in the reconfiguration of the trilateral police patrols. The new set-up of patrols was officially presented as introduced with the stipulation of a renewed bilateral Austrian-Italian police cooperation agreement in 2014 (which however entered into force only after its ratification in 2017). During a hearing at the Italian Senate, a police unionist claimed that controls were carried out systematically and not occasionally and that "the German and Austrian officers do not limit themselves to a 'participating and flexible observation"' (Commissione straordinaria [...] 2016, p.3). Police cooperation, according to this testimony, assumed "different and distant functions and purposes" than those envisaged by the "founding fathers" of Europe.

\section{Sign and space making}

In discussing this route and trilateral police cooperation, Kasparek and Schmidt-Sembdner argued that the "peculiar transnational police cooperation at hand was an effort to stabilize the European system of internal mobility control for non-European migrants" (emphasis added, 2019, p.213). While I agree on the aimed function of enforcing the Dublin-regime but in a further differentiating analysis, I disagree considering the trilateral patrols a strange and unusual 'peculiarity at hand'. Notably, the officers quoted earlier who, e.g. critically reflected as to whether migration was a 
shared security concern, or who attributed to officers operating outside their jurisdiction an active rather than auxiliary function, reflected upon joint patrolling along other viapolitical intraEuropean policing routes. This highlights how neither the transnational cooperation practices, nor some of the dynamics are restricted or peculiar to this specific case of joint-patrolling and to these inter-state dynamics. They should be understood and analysed as characteristics and, why not, as 'shared struggles' when applying CBPC in the field of immigration control.

While joint patrols were perceived as "unilateral" along the Brenner/o-Route, also Italy took initiative to set up joint-patrols, for example with Austria on the eastern part of their common border to counter irregular entries from Austria (2016), and on the Italo-Slovenian border (2019) to contrast irregular entries to Italy of persons through the so-called "Adriatic route" ${ }^{91}$ It seems as if through the proliferation of joint controls, an eventual 'unilaterality' is 'balanced out'. Certainly, however, along the Bernner/o route compensatory measures have flourished and rather than having been ready made "at hand", they have been especially experimented with. While Schmidt-Sembdner (2019, p.179) rightly argued that one can identify re-territorialisation and re-nationalisation processes with a nation-state imprint which in turn impact on Europeanisation, there is not such a neat distinction between nation states politics on the one hand, and the Commission's aim of a territorial external "border controls in order to homogenize the inner" on the other (Kasparek and Schmidt-Sembdner 2019, p.215). The peculiarity of these measures, if called such, consist precisely in the scalar dynamics at play to be analysed in chapter 8 , in which inter-governmental measures and the border-strip scale are embraced on EU level. Inverting Schmidt-Sembdner's formulation: is this only a "national solution" in a European vest" (2019, p.179), or indeed not increasingly a European solution in national uniforms? The production of a European space and order is aimed to be maintained, and is thereby shaped, by cooperation in the field of policing, including elements of an internal non-nation-state territorialisation. As I will further elaborate through analytical focus on law-space-practices, these and entangled process have further impacted on the spatial-legal configurations of the AFSJ.

The Brenner/o as line and route is certainly also in the $21^{\text {st }}$ century a seismographic point for intergovernmental relationships (Heiss 2012) and it has maintained its double function: as intergovernmental mise-en-scène, where also symbolic actions produce effects, and as crossing point for "population and troops" (ibidem), i.e. today police (but also Austrian and Italian soldiers). It is a crossing passage and a demarcation line: one of the small places in Europe, where large issues cross and unfold in space. 
ENCOUNTERS OF SECURITY AND MIGRATION. BORDER-STRUGGLES IN THE POLICING OF "SECONDARY MOVEMENTS" AT INTERNAL BORDERS

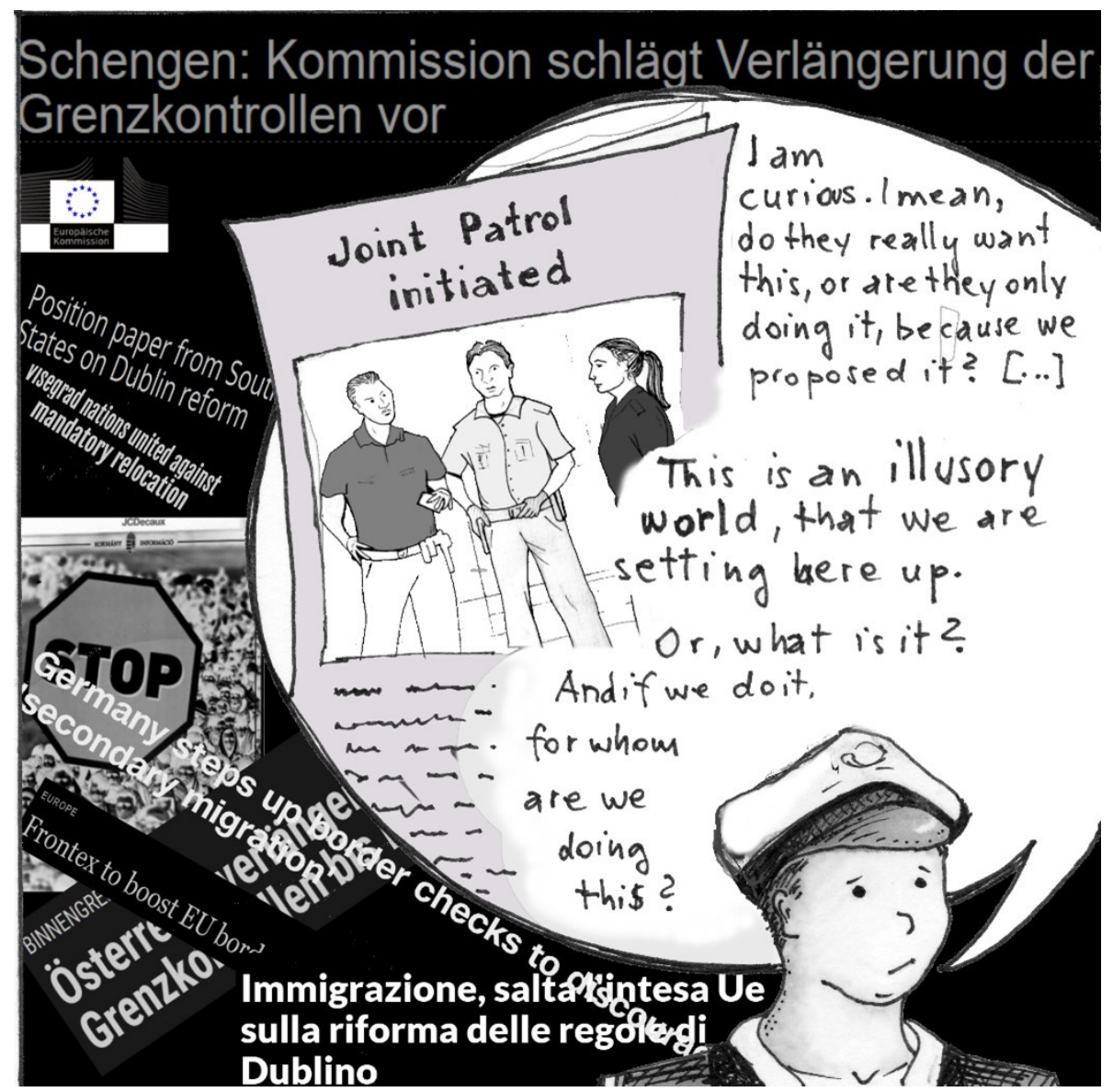




\subsection{INTRODUCTION}

"Upholding our international commitments and values while securing our borders and at the same time creating the right conditions for Europe's economic prosperity and societal cohesion is a difficult balancing act that requires coordinated action at the European level".

A European Agenda on Migration, $\operatorname{COM(2015)~} 240$ final, p.4

"Common high standards of border management, in full respect of the rule of law and of fundamental rights, are essential to preventing cross-border crime and terrorism".

The European Agenda on Security, $\operatorname{COM(2015)~} 185$ final, p.6

In this chapter I analyse border struggles emerging in, and from, the encounters of security and migration in their situated - and plural - entanglements. Specifically, I consider such encounters in the context of (joint) policing measures at internal borders which target mobile inner-European routes of so-called "secondary migration". The European Agenda on Migration (EAM) - which made an inter-textual reference advising to read the EAM in conjunction with the European Agenda on Security (EAS) -, pointed towards a "difficult balancing act" between coexisting political rationalities, aimed to be achieved through the coordinated actions of a political union: economic prosperity, societal cohesion, securing borders, respect of fundamental rights, rule of law.

Building on the previous chapters, I elaborate upon how the policing practices studied provide situated insights at the micro-level into such a "difficult balancing act". The border-strip can be understood as a viapolitical "strategic zone of the transport system" (Walters 2015a, p.478) in the governance of mobilities and a "mediating solution" between the twin imperatives of Schengenland (Haahr and Walters 2005). As I will further argue, I has emerged as envisaged scale of response deemed able to provide a "spatial resolution" (Smith 2003) for struggles between contradictory social forces, which play out in the "balancing act" surrounding the reform of the Dublin and Schengen System. Studying through different sites enables one to grasp large-scale processes and negotiations between scales, actors and policy fields and touch upon some of the institutions, practices and ideas through which Europe constitutes itself. It enables one to investigate, as highlighted by Anderson et al. (1995), forms of political life.

\subsection{BETWEEN NORMALISATION AND RESISTANCE - policing "secondary movements"}

The European Police Conference held annually in Berlin, in 2019 was dedicated to "Security Migration - Integration". It featured a panel on "Border Security in Europe". Simultaneously a demonstration took place opposite to the securitised building that hosted the conference and the related security-industry exhibition-space. The panel was composed of a moderator and four 
speakers, belonging to central border police departments of Poland, Romania, Italy and Germany. The former three were asked to describe the situation on the "external border". The German representative was prompted to explain the phenomenon of "secondary migration". "I don't want to add fuel to the fire," the police officer started, pointing out that the situation in 2018 had much improved, but as "pressure" at the external borders continued, Germany still encountered some secondary migration and thus monitored intra-European routes closely. The officer added that thanks to several policing measures "now migrants often take half a year to reach Germany." Secondary migration, according to the officer, presents "a clear element for criminality", leads to "issues of readmissions and returns" and was presented in relation to statistics on illegal border crossings (Frontex) and on asylum applications lodged in EU member states (Eurostat). Asked to provide further information on Dublin readmissions, the officer said: "The Dublin procedure might sound straightforward, but it is not, it is not so easy. There is the time frame of 6 months in which persons can be returned [to the EU country deemed responsible], otherwise the case is closed. This is for persons who made an asylum application. In addition, there are the returns to their countries of origin." He added an illustration of "how Dublin looks like in Europe": "If we talk about Dublin... some fly without baggage to Italy [are flown, through a formal Dublin readmission, i.e. return flight], and once there, they return with a bus-company back to Germany. That's how Dublin looks like in Europe". As the speaker invoked Italy, the moderator turned towards the Italian police officer: "Are Dublin-readmissions also a problem for Italy?" "It is a very sensitive issue," the officer replied. "For a long time, our governments have been discussing Dublin. To discuss this here would be too long." He highlighted that the Dublin system was set up in different conditions and that "it is not easy to find a compromise between different member states. For us, from the Italian perspective, the rule should be changed. The... pure rule, that makes the first member state of entry responsible for processing asylum applications, is a rule which is not working. It has not worked. It could work only when we are facing small numbers". (FN, Berlin 2019)

As emerges from this description, inner-European mobilities represented as "secondary movements" or "secondary migration" are entangled with the so-called Dublin system of the Common European Asylum System (CEAS). These mobilities have become a conflicting issue: one on which seemingly not only governments disagree, but also one the police are dealing with. In the conference setting, the high-level officers of central border departments responded to the prompted matter diplomatically, whilst highlighting the divergence of positions. Therein, the measures put in place with the effect of slowing down movement towards Germany, or the borders crossed by the bus-journey mentioned above, highlight how the routes across intraEuropean borders have become of viapolitical relevance and a locus of political controversary. In 
addition, as epitomised in the two-concomitant gatherings, public opinion regarding the nature of the problems as well as the appropriate responses, do not necessarily align. Between what was addressed inside the panel and outside (a demonstration of one position within a divergent and polarised public opinion), there was no overlap creating a meeting ground. The posters held up by the demonstrators stated: "Protect people, instead of 'securing' borders! How many more must die?", "Freedom dies with security" and "Protect yourself from the protectors of the State". Some day earlier, a separate demonstration against police powers had taken place, likewise organised with reference to the conference. Indeed, while the deaths of persons in the Mediterranean were mentioned in other panels during the conference, they were - even more so - only a ghostly presence in the panel-debate on border security.

In order to address the why' of border (area) control and its 'targets' it is necessary to place the topic into its broader historical context and to provide additional detail to the policy problematisations of "secondary movements". Subsequently I outline how the EU space acquires meaning as uneven moral geography, and as a polity that is as divided as these two events over what the problem is and which solutions or responses to actualise. I do so through a zoom-in on problematiques of the use of force in fingerprinting for the purpose of Eurodac registration. I analyse how normalisation and resistance sign the ongoing migratisation of security.

\subsubsection{Dublin system \& "secondary movements"}

The Dublin system is composed of the Dublin Regulation (Reg. (EU) No 604/2013), establishing the criteria for determining the member state responsible for processing an asylum application, and by the Eurodac Regulation (Reg (EU) No 603/2013) ${ }^{92}$, the European Asylum Dactyloscopy Database containing (not only, but as an initial and primary purpose) the fingerprints of asylum applicants. The Dublin system has been amply reviewed, discussed and critiqued over the durée of its several reforms, most recently on occasion of the 2016 Dublin IV recast-proposal. Therein the Commission reiterated that the Dublin system constitutes "the cornerstone" of the Common European Asylum System (COM(2016) 270 final/2 p.4). ${ }^{93}$ While the criterion of "first-entry" is situated at the bottom of a hierarchy of criteria for determining responsibility, it has been the most commonly invoked and it is backed-up through "hard evidence' of a "hit" in Eurodac. Enforcing the Dublin system, as the officer in the conference highlighted, is another issue (see also European Commission 2015a). The geographical scope and legal foundation of the Dublinregime changed over time, but its essence remained, although its demonstrated ineffectiveness and inefficiency (inter alia Maiani 2016). The recast of the Dublin Regulation was part of an envisaged 'reform' of the overall CEAS. As the major "pitfall" of CEAS but even as a risk to the Schengen acquis figures frequently one phenomenon: "secondary movements". Drawing on an UNHCR source from 1989, the EMN (webpage glossary) uses "secondary movements of migrants" 
defined as "the movement of migrants, including refugees and asylum seekers, who for different reasons move from the country in which they first arrived to seek protection or permanent resettlement elsewhere".

These movements have become a top policy priority at an EU and European level. According to the European Council conclusions of $28^{\text {th }}$ of June 2018 (EUCO 9/18. point 11)

secondary movements of asylum seekers between Member States risk jeopardising the integrity of the Common European Asylum System and the Schengen acquis. States should take all necessary internal legislative and administrative measures to counter such movements and to closely cooperate amongst each other to that end.

The subjects of these inner-European movements are categorised as two-fold (Council EU 13353/18): "unregistered asylum seekers" and "registered persons". "Unregistered" refers to persons aiming to make an asylum application in another country and who managed to avoid Eurodac registration. "Registered" refers to registration in Eurodac and thus to persons who left the country of registration. In practice, the targeting of "secondary movements" includes additionally persons already registered as holders of a protection status. In the absence of mutual recognition of positive asylum determination outcomes, holders of protection status can travel to other member states for determined periods, but without holding any employment rights. They are notably bound to their country of registration also after leaving the asylum system with a legal status. ${ }^{94}$

\section{Enforcing the Dublin System}

The explicit aim to "discourage abuse and prevent secondary movements of applicants within the EU" (Dublin IV recast-proposal, p.4) notably runs through the whole CEAS reform proposal and beyond. ${ }^{95}$ The punitive approach taken is especially visible in the "proportionate procedural and material consequences in case of non-compliance" (Dublin IV proposal, p.4). "Secondary movements" also find mention in policy fields such as migrant smuggling and irregular employment. Within the EUs "four tier access control model" contained in the Integrated Border Management (IBM) concept, control measures within the area of free movement $\left(4^{\text {th }}\right.$ tier) nowadays also include "effective countering of secondary movements" (COM(2018) 250 final, Annex 6, p.3). ${ }^{96}$ In addition, the EU Agencies Frontex (EBCGA), EASO, EUROPOL and EU-LISA have acquired new roles in the monitoring of "secondary movements", and changes of relevance are to be introduced to the EU databases EURODAC and SIS.

The enforcement of the Dublin system relies initially on fingerprint-registration, regulated by the Eurodac Regulation. As part of the EAM the Commission set out to "ensure that all Member States comply with their legal obligation to fingerprint" and to provide guidance to "facilitate systematic 
fingerprinting in full respect of fundamental rights and (...) of the right to data protection" (SWD(2015) 150 final, p.2). The practice of fingerprinting upon entry in the EU for a specific purpose within the field of international protection (CEAS) embodies a specific encounter of migration, asylum and security.

\subsubsection{Fingerprinting, "proportionality" and moral geography}

I discuss the so-called "proportionate" use of force in fingerprinting for the purpose of Eurodac registration when encountering "passive resistance", by drawing on publicly available statements. It is important to consider when and how this practice entered the domain of public visibility. While several coercive means have been proposed to enforce compliance with the Dublin immobility regime, developments in 2015 allow to tackle questions as to police-work in liberal democracies when governing through migration (Bosworth and Guild 2008) control occurs via the police - the (state's) beholder of legitimate violence - enforcing fingerprinting and therewith asylum policy.

\section{(I)legitimate force}

In September 2015, the Austrian Mol released a press-statement (Bundesministerium für Inneres 2015). It aimed to provide a public answer to "the crucial question" of how the Austrian police forces would handle the situation of increased migratory pressure from Austria to Germany, as the news spread that Germany would suspend Dublin-procedures for Syrians. It was titled quoting the Austrian Minister of Interior "We are fighting against smugglers, not against refugees. [Subtitle:] The police are acting according to the principle of proportionality" (ibidem). It stated that Austria continued to apply the Dublin Regulation and that every "refugee" could make an asylum application. It stated that there were likewise clear rules regarding the persons that wanted to travel onwards, but that the "principle of proportionality" would be upheld in all police actions. Basically, "our" police officers would "not oppose with violence" persons who refused to be registered "within the conditions of proportionality", because "in principle they aimed to continue their travel peacefully to Germany" (emphasis added, *). This was placed within a frame of diminishing any risk of escalation of violence. At the time, one of the central concerns for which Austria kept squinting towards Germany, was whether the persons would be allowed into Germany or if they would remain as "worst case scenario" stuck in Austria (Gratz 2016, p.58) and Austria stuck with them.

Upon arrival in Germany the persons were distributed through the König Steiner-Schlüssel throughout the German Länder, where registration was also carried out. Onward travel did not necessarily stop in Germany. The "principle of proportionality" was also invoked in Germany for example - but not by chance - in its northern border-region of Schleswig-Holstein. Several presscomunications and orders by the Landespolizeiamt Schleswig-Holstein in September 2015 
specified that the use of force was likewise excluded. The internal-ministry of Schleswig-Holstein (Ministerium für Inneres und Bundesangelegenheiten Schleswig-Holstein 2016) stated that "approximately 68.000 so-called 'transit-refugees' have transited through Schleswig-Holstein" and "travelled on to Scandinavia" (August 2015 to mid-April 2016). Already in September 2014, national news defined Northern-Germany literally as a "Transitland" towards Scandinavian countries (Fromm 2014). Those countries seemingly handled registration similarly, which caused intergovernmental tensions between Denmark, Finland and Norway. On the Scandinavian case, Weber et al. (2019, p.15) argued, that "the Nordic countries gave their failure to register migrants a legal, even humanitarian, gloss to fit their own self-image".

In Italy the issue of police officers applying force in fingerprinting was increasingly discussed after the introduction of the so-called "hotspot approach". It has been addressed by police unions (UGL, COISP, SAP or SIULP), NGOs, and in parliament. COISP denounced a perceived contradiction: on the one hand Italy was being blamed for a lack of identification and for not applying (force in) fingerprinting, and on the other hand migrants were given more means to denounce human rights violations (Giornale di Montesilvano 2015). The national representative of SIULP took a different position, arguing that the use of force for the purpose of fingerprinting was "ethically wrong", "technically flawed" and - different from the worries expressed by COISP - that "whoever has information about violence should denounce them" (Felice Romano, videoreportage, Brigida and Poeta 2016). He called out that "Europe has made a fundamental mistake, the one of approaching this phenomenon as a problem of policing or as a threat to public order". He likewise pointed the finger towards "Europe", however placing the phenomenon outside the field of security and policing. As the national representative argued, "[t]his stuff has nothing to do with the police, it is a social problem, a human issue, and as such it has to be responded to" (ibidem*).

The hotspot-approach (in Greece and Italy) was one of the measures introduced through the EAM. Contemporaneously with evaluation of the relocation program and hotspot implementation in December 2015, the European Commission urged Italy to correctly implement the Eurodac Regulation and to

provide a more solid legal framework to perform hotspot activities and in particular to allow the use of force for fingerprinting and to include provisions on longer term retention for those migrants that resist fingerprinting. The target of a $100 \%$ fingerprinting rate for arriving migrants needs to be achieved without delay." (Emphasis added, COM 2015679 final, p.4)

A few days earlier, Greece, Croatia and Italy were notified infringement procedures for not having correctly implemented the Eurodac Regulation (European Commission 2015b). Scholars have pointed out that member states like Greece (but also Italy) actively restrained from fingerprinting 
in order to "Europeanise' the unfairness of the Dublin Regulation" (on Greece, Skleparis 2018 p.986) by forcing solidarity in asylum matters. The "European response" (Guild, Costello and Moreno-Lax 2017, p.58), through the EAM and a subsequent hotspot-approach and relocationscheme, indeed "Europeanised" the responses of Greece and Italy through deployment of EU Agency field-officers, as well as through financial support. Registration and Dublin responsibilities (except for a small number of relocation cases, of minor scope according to the initial goals of the program) remained those of the first EU country of arrival. As suggested by Campesi (2018, p.211), "the objects of control here are not only migrants and refugees, but also the border authorities of frontline member states". This opens questions of accountability and liability in the transnational legislative and executive realm.

As a parliamentary inquiry considered the Italian normative framework, the various reports submitted presented diverging opinions as to its interpretation (Commissione parlamentare di inchiesta [...] 2016a; 2016b). Police union representatives had every interest to become vocal: police officer experienced a double "conflict of duties". Firstly, the use of force in fingerprinting touched upon the issue of criminal liability and the practice, according to some union representative, put officers in a moral dilemma. Secondly, a prosecutor (cit. in Commissione parlamentare di inchiesta [...] 2016a, p.36) said officers live a "conflict of duties" and he highlighted that indeed the non-fingerprinting could result in charges for "dereliction of an act of their duty of justice". "Justice" here refers to an order directly authorised by a law, such as fingerprint obligations. He called this an "extreme hypothesis and abstractly theoretical", underlining however that "this is not a meta-juridical hypothesis, but none of us dreams of pursuing it" (ibidem). Some unions called upon the government to bring clarity to the legal framework, highlighting that the normative base to use proportionate force for Eurodac purposes was not provided for in law and that a respective circular of the ministry did not suffice (UGL 2016). Others called to refrain from any normative anchoring of the use of force for Eurodac fingerprinting: according to SIULP it was the wrong (European and Italian) response, would clash with the Italian constitution and produce both existential and legal issues to the police officers (SIULP 2016). Put succinctly but with a critical hint towards (multiscalar) legislative powers and accountabilities:

The criminal liability, in our country, remains personal and not of those who make laws that then can't be actualised. (Emphasis added, ibidem)

Basically, who is responsible for any violence committed (Amnesty International n.d.; ECRE 2016) in order for Italy to archive its $100 \%$ fingerprinting goal and to comply with the Eurodac Regulation? In December 2016, the infringement procedure against Italy was closed (European Commission 2016). 
In 2015 the Commission had issued a working document to facilitate the fingerprinting of socalled "data subjects" that refuse to cooperate (SWD (2015) 150 final) ${ }^{97}$. Considering the wording of this guideline, it comes less as a surprise that contradictions were perceived (COISP, cit. above). With regards to asylum seekers it recommended that "the Member State may consider resorting, in full respect of the principle of proportionality and the EU Charter of Fundamental Rights, to coercion as a last resort" (para. 7). The guideline indicates that not only the measures (and responsibility) on how to assure compliance with EU law through subsidiarity, but also on how to negotiate a conflicting interaction of different EU legal orders - the Eurodac (and in extention Dublin) Regulation, the EU Charter of Fundamental Rights and those of Data Protection - was formally placed upon the member state. ${ }^{98}$

\section{Internal borders}

On intra-European borders the increase of fast-track readmissions (and shift to joint patrols) were ways in which member states responded to the onward mobilities (of non-registered, but increasingly also registered persons). On the French-Italian border, this resulted several times in forced backward mobilities, in which migrants were transferred also within Italy from the northern border-town of Ventimiglia to the so-called "hot-spot" facility of Taranto, 1200 kilometres south (Tazzioli 2019)..$^{99}$ Readmissions peaked on the Italian-Austrian border. The Schengen accession had also in Italy lead to a reorganisation of the border-police sector and the reduction of (human) resources and border-police sections on its internal border(s). Ongoing developments, including since 2015 the renewed salience of tasks to carry out at its northern borders, are traceable through various reform (proposals) of this sector. We saw that notably intra-scalar interlegality negotiations of EU law was placed upon member states. The Italian legislation was fuzzy. In terms of 'safety at the workplace', employers provided little accountability for the occupational category of public security officers. According to SIULP, local level officers on the Italian-Austrian border seemingly asked for clearer guidance and explicit orders from their superiors on how to deal with passive resistance to fingerprinting (interview, Deriu, in Bertoncin and Weissensteiner 2016). A COISP representative in another province likewise denounced that "nobody has the benevolence or enough guts to say exacly what to do, what not to do, and how" (COISP, above). There were seemingly no explicit orders neither indicating the use of force, nor exemption for reasons of "proportionality".

In another country (with a more solid legal framework for the use of force in fingerprinting), I happened to interview a high level officer who during 2015 gave explicit orders to refrain from the use of force for fingerprinting. At the time of our interview he had pending an accusation of dereliction of duty, notably presented by private citizen. He said he would make the same decision again, and that the purpose of a hierarchy is that those in a position to take on 
responsibilities should do so. The Dublin order not only consitutes a spatial-legal geography that allocates rights and obligations. The EU Area of Freedom, Security and Justice beyond its normative configuration is also a moral landscape. In addition to his position and 'sense of hierarchy' therein, this officer was placed in a spatial-moral position, where the use of force for Eurodac fingerprinting in cases of passive resistance, in those circumstances, was called "violence". Within a diverging public opinion, the officer nevertheless faced accusations of dereliction of duties, presented by citizen.

\subsubsection{Migratisation of security and response-ability}

From a philosophical point of view, according to Seyla Benhabib (2004, p.2) transnational migration brings to the fore the constitutive dilemma at the heart of liberal democracies between "sovereign self-determination" and "adherence to universal human rights principles". From a practical point of view, 2015-2016 has brought such dilemma also into the heart of Europe. The application of the "principle of proportionality" normatively is the dividing line between the State's 'legitimate use of force' and 'State violence'. Public claims that migrants are not a policing but a "political problem" or a "human issue", or the anti-deportation slogan Verantwortung kann man nicht abschieben, address issues of responsibility, who is responsible - but likewise of response-ability, how to respond. It is also a question of the art of government and of the ability to respond.

How policing should respond to situations during 2015 in the heart of Europe emerged as dilemma in several interviews, wherein officers addressed retrospectively what they experienced as the 'extra-ordinary' period of 2015-2016. Officers involved were pushed beyond their limits, likewise as, I add, Europe's highly individualised asylum system and application procedure. Officers felt abandoned and expressed their fustration that the situation was defined as "migration or refugee crisis" only when movements reached the regional main city. Responses were also very attentive to the image produced at the heart of Europe: images of "policeviolence" were to be avoided. To give but one of several empirical examples: prompted by an initial (and withdrawn) order that the border had to be held, an officer remembered his astonishment and perplexity: "How?", he asked, and added that this could only have been done through one means: shooting. It is fair to say that 2015 forced a response that, in order to live up to the image of a Europe that upholds its international commitments and values, it also had to live up to expectations of policing in liberal democracies. However, as some police officers remarked, and as alluded to also in a German prosecutor opinion worth mentioning ${ }^{100}$, this response did not follow clearly the principles of the rule of law, although the countries would have had the instruments (entry for humanitarian reasons) and authority to do so. Several officers remarked with a point of irony that "governments were the biggest smugglers" facilitating 
"secondary movements" in 2015. Nothwithstanding expressing critiques, most interviewed officers stood behind the response given. Only one of my interview respondents aimed to emphasise that the subjects on the move were not "refugees" and he defined Germany's response as "suicidal".

\section{Migratisation of security: normalisation and resistance}

"Secondary migration" - and even the mere risk thereof - has been framed explicitely as security threat and acquired a cross-sectorial priority-status. Securitisation theory provides valid conceptual approaches for the problematisation and response to migration and asylum as a security issue. However, this analytical frame falls short in accounting for how, in practice, an increased migratisation of police work is experienced from within the policing field. Here one can identify normalisation as well as resistance. Critical security scholars commonly retain that security practitioners frame "phenomena, such as migration, and the related social and political relations in the form of a security problem" (Huysmans 2006, p.32), thereby promoting solutions through policing means. It is therefore important to revisit this assumption and consider dynamics of policing-actors mobilising security knowledge and its constitutive dimensions in forms of resistance. Shifting migration and asylum from a security question into another policy field has been considered a desecuritising move of minor form (Huysmans 2006, p.142) - a desecuritising "change through stabilisation", although the framing shifts, the larger issue remains (Skeparis 2018). While not challenging a 'security field' and indeed placing security needs elsewhere, expressions such as "[t]his stuff has nothing to do with the police" but needs to be responded to as "social problem" or "human issue", require more attention. Like other mobilisations of security knowledge, they are bound to a vision of the political, of politics of policing, and of police identitity.

As normalisation we see, for example, the inclusion of irregular migration or immigration policing into police cooperation agreements, an awareness of police officers that immigration related offences are an additional enforcement-field, or when border-area policing task are increasingly focusing on irregular migration. Or, as outlined by Carrera et al. (2019), the access of asylum databases for law enforcement purposes. This process also finds correspondence in the field of training: "facilitation of illegal immigration" was ranked as first thematic priority by high level national stakeholders in terms of law enforcement training needs on EU security priorities (CEPOL 2019). However, (with exceptions of specific elements, e.g. training on "hotspots"), the report reveals that particular training needs identified on operational level correspond to those of other (politically lower ranked) thematic fields: e.g. to increase competencies in the field of financial, cyber and OSINT investigations, and to foster cross-agency and public-private cooperation. More specifically regarding border-areas, we can highlight the creation of new police forces or police 
units, which also normalise the renewed salience of internal borders: the Bayrische Grenzpolizei - the Bavarian Border Police - or the PUMA unit in Austria both became operational in 2018. However, despite migration constituting in practice a target for police checks in border-areas, there is also resistance. This relates also to the self-understanding of police officers and their professional identity.

\begin{abstract}
"This work [referring to the situation in 2015] is not really in our understanding of police-work. We are used to go on patrol, to deal with offences of all sorts, not to process migrants. (...) [With reference to the situation in 2018:] We are not only here for migration control, primarily it is about criminality, that is what important to us, what defines us as police. If there is somebody with an arrest warrant or something like that (...) The migrant... well, that's how it is now. Bottom line, they are poor people." (IV_LL-HLO)
\end{abstract}

Whether or not "secondary movements" are perceived to be an appropriate police target, is also dependent upon the (heterogeneous) ways in which officers framed the subjects of unauthorised mobilities. ${ }^{101}$ Officers however unanimously identified a lack of identification through registration (either during the so-called "corridor" in 2015 or along other routes) as potential security risk. Identification and fingerprinting was presented as both prescribed by law and important for security reasons. An Italian police-union representative (interview, Bertoncin and Weissensteiner 2016) highlighted the importance of fingerprint-obligations, officers' duty but also moral dilemmas in the application of force. He went a step further, by proposing the de-coupling of fingerprinting from the governance of asylum. He deemed that this would increase cooperation in identification - without (ab)use of force: "If one could remodel Dublin III, I think these persons would voluntarily agree to be identified" (ibidem). If a lack of identification is presented as security risk, this would enable a better security provision. In such reasoning, what is enforced through fingerpringing for Eurodac (asylum responsibility allocation) is in the first place a securitised Dublin order, but not security in a non-migratised understanding of the latter. In other words: securitising Dublin results counterproductive to security aims.

\title{
Proportionality within spatial-moral orders, law and justice
}

Framing processes as migratisation of security and drawing attention towards normalisation and resistance might be considered to be a "sociology of critique", rather than a critical sociology or criminology/anthropology (Fassin 2013, p.198 and note 135). ${ }^{102}$ Fassin argued that it was necessary to go beyond administrative-normative (and police-internal) definitions of violence to show the limits of normative ethics, in order to engage in a critique of violence. A critique of violence, in Benjamin's terms, is a claiming of the right of judgment, the right to put into question the established order (1921). However, moral and power relations are at play beyond the policepoliced interaction and are deeply invested in the way normative ethics acquire meaning and 
power and ultimately in the (re)production of violence. They are not of minor importance in encounters between migration and security, especially when the aim is migration and asylum governance via policing. The recommendation to Italy to include the use of force for Eurodac fingerprinting (not found in the regulation itself) into its normative framework, highlights how (in)securitisation processes re-draw the boundaries of the acceptable. This concerns the legal boundaries of what is considered acceptable within liberal democracies - what (in)security scholars called the "illiberal practices of liberal regimes" (Balzacq et al. 2010; Basaran 2011). It also concerns the boundaries of what is perceived or experienced to be morally right and wrong, just and unjust. As Asad (1997) insightfully argued, modern thought brought forward the idea that subjective pain and suffering can be objectively compared and calibrated (as in punishment, Bentham). Historical (moral and political) projects aiming to render the world more 'just', 'humane' and 'civilised', differentiated between "suffering and suffering": that to be eliminated, and that deemed necessary to an end. One could reflect upon today's turn towards coercive means through Asad's notion of "non-wasteful pain", suffering produced for a perceived superior end.

While morality today is often mobilised to justify new security measures, legitimise spending or is deeply invested in the anti-smuggling discourse, less has been said about morality in forms of resistance. Non-fingerprinting has indeed been analysed as a minor form of desecuritisation (Skleparis 2018), as an "irregular bureaucracy" (Rozakou 2017) and as strategy of migrationmanagement through outward movement, alike deportations (Weber et al. 2020). Humanitarian border-security has been rightfully critiqud for (re)producing the 'irregular' migrant is "as potentially both a life to be protected and a security threat to protect against" (Vaughan-Williams 2015). As constructivist approaches to security have highlighted, migration can be governed through policy fields other than the expanding security domains, and security itself is a contested concept. The borders of the (in)security field are ever shifting and not prone of internally perceived ambiguity. Morality matters therein.

The use of Gewalt against persons "who otherwise would continue their journey peacefully" through central Europe (and beyond) was deemed wrong: a disproportionate, illegitmate (ab)use of force. Due to the intra-textual context of its use, I translated Gewalt as "violence". However, the mere translation into English requires that in my analyis I briefly cross into the field of legal philosophy. The word "Gewalt", designates both the "historically recognised, the so-called sanctioned, as well as non-sanctioned violence" (Benjamin 1921, p.106). Gewalt 'translates' into both: illegitimate violentia, as well as legitimate, rightful potestas, as one can see in the term Staatsgewalt, the 'power of the state'. Gewalt in English is power, force, violence. This translation engages Derrida's (2003) question as to the difference between the force of law - law by 
definition needs to be enforceable - and violence judged as illegitimate. The so-called "principle of proportionality" engages with justice in the historical conditions of the law. It is an entry point into the moral landscapes of (the Area of) freedom, security and justice. In this internal reasoning, legitimate force becomes violence when non-justified or disproportionate (Fassin 2013). Proportionate refers to the means. Justified refers to the ends, with respect to a threat posed and to the severity of a crime. This also engages with the question, "when, how, and for whom does violence (...) become 'necessary' or 'legitimate'?" (Jauregui 2014, p.146).

Interlocutors highlighted that the application of this principle in 2015 in central Europe had to be situated and understood within that precise context. Nevertheless, the similarity of certain practices and the differences in problematisations and justification for non-fingerprinting are telling. A smiliar moral judgment was made further South, but with less success within the overall landscape configured through the Dublin system. It had to draw additionally for example on the argument that forced fingerprinting was technically flawed. As such, the spatial-legal Dublin order not only distributes rights and obligations unequally, but through the ways it has been established as meaningful the AFSJ takes shape as an unequal moral geography. Fingerprinting through the use of force in the face of passive resistance (wherein "passive" is also an act of agency and power) was not deemed violence, if applied (as in the hot-spots) as a means to protect the intraEuropean Dublin as well as Schengen order, i.e. "non wasteful pain". In the interpretation of what is morally right and wrong, the latter is aimed to be kept away from the heart of Europe and impacts on what is in turn legally "proportional" at its moving outer edges, and beyond. It aims to uphold and protect Europe's image but also to protect the order of the law against any potential Other law founding force/violence/power (rechts-setzende Gewalt). Benjamin (1921, p.130) differentiated between the founding and the maintaining violence of law and argued that the maintaining violence of the law (which represents its founding violence) suppresses the (potential founding) violence (and future law) of its adversary, and so weakens itself.

The outward shift is not without ambiguities. As I was living in Hungary, I came across a joke more than once, which does address - in its own way - this border struggle. It goes somehow like this:

\footnotetext{
"As Hungary let the migrants on their way to central Europe pass, it was accused of 'wave-through'. As Hungary put up the fence and increased detention and other means to prevent entry and onward travel, it was accused of violating human rights. 'What does Europe want?'”
}

An officer, who like many others had valued positively the impact of Hungary's measures on intraEuropean unauthorised mobilities along this route, asked me if I had visited the HungarianSerbian border. After describing the procedure adopted, which according to the officer "very often ends in Serbia", he described the visual impact of the "transit camp" in which asylum 
applicants were held: a "high security wing", surrounded by piled up "NATO razor wire". But, he added, "they also have a playground inside. One needs to say that too, they can play inside." He laughed and looked me. In that precise moment, his phone rang. Instead of taking the call, he let it ring for a long time whilst looking at me. Before picking up the phone, he added what he seemingly still had to say: "That is so... somewhere this whole thing is ambivalent and paradoxical”. In 2020 the CJEU ruled that this holding centre amounted to unlawful detention and was to be closed. But the question, "what does Europe want?", is still open.

\section{Summary}

The hotspot approach at the EU's external borders was the most 'visible' response to reinforce the Dublin system. However, on intra-European borders, besides the introduction of border control, member states responded to onward mobilities through border-area controls and readmissions. Struggles surrounding "secondary movements" and fingerprinting, go from (inter)subjective and moral micro-level conflicts of officers, as well as "conflicts of duties" and potential legal consequences in plural directions, to 'Dublin' related power struggles between member states on a meso-level, to struggles over who is liable and should be held accountable for practices that were (de)legitimised in specific times and specific places either as necessary force or as violence, i.e. unlawful and illegitimate. This leads to macro-level struggles in the "balance" between a political union, border protection, fundamental rights and rule of law, but also to struggles over what the problem - and solution - is and where to draw the line.

The Dublin IV proposal (2016) has not been adopted under the ordinary legislative procedure. ${ }^{103}$ No agreement was reached in the Council regarding the stated aim of finding a so-called "balance" between two identified items of conflict: "responsibility" and "solidarity" (Council EU $6600 / 19$, p.3). The former regards the maintained (and in part reinforced) first-country-of-entry criterion (opposed by so-called "frontline"-member states), the latter the proposal of a fairer distribution mechanism in cases of increased arrivals, similar to the previous relocationprogramme (opposed by several member states). With the European elections in May 2019, the reform was carried over into the strategic agenda for 2019-2024 (Council EU 14364/19). The Council welcomed the new European Commission's announcement to present a "New Pact on Asylum and Migration" (van der Leyen 2019). It was released on $23^{\text {rd }}$ of September 2020 (see chapter 9). The proposal is supposed to be replaced by an intersectorial compromise, as "the most sensitive parts of the reform (...), proved so far not to be possible without a wider deal on the overall balance" (Anonymous [leaked] 2019, p.100). "Inextricable links" between the CEAS reform and the Schengen rules were highlighted.

In the following section I analyse how and why intra-European border-measures and CBPC have been embraced on EU level in the context of such an "overall balance". I detail what it is, that is 
negotiated and 'balanced' via border-area policing and I zoom-into the border(area) between border control and border-area control. I shall return upon the Dublin system links to the SBC in the final part. This will allow us to further engage with the envisaged means and unfolding effects of producing "coordination actions" of a political Union within the "balancing act".

\subsection{BALANCING ACTS: (differential) freedom of circulation - border (area) control}

Border-areas have become a strategic zone in the quest to govern the intra-European mobilities of subjects excluded from the right to freedom of circulation. These are state responses to the agency of persons on the move, but these are also responses within an unresolved political conflict concerning a legislative agreement in the field of asylum policy, the Dublin Regulation. In addition, both the Council and the Commission have called upon member states to reinforce national border-area policing-measures, and to resort to border control only as last resort. Embracing this line of reasoning, a resulting border-struggle in the legal field, was formulated precisely in an Advocate General Opinion of the Court of Justice of the European Union (CJEU). The problematique was framed as follows:

Apart from the temporary reintroduction of internal border controls, how, within the area of freedom, security and justice of which the Schengen area forms part, can that illegal immigration [i.e. 'illegally staying third-country nationals (...that) take advantage of the facilities offered by that area of free movement'] be countered without jeopardising the freedom of movement promised to citizens of the European Union and third-country nationals legally resident in the European Union? (Emphasis added, Opinion of Advocate General Bot, 6 September 2018 [Joined Cases C-412/17 and C-474/17, para.2.])

How can differential and unequal mobility rights (and immobility prescriptions) coupled with a neoliberal rationality of a freedom of circulation be legally enforced within conditions of abolished border control? He formulated what scholarship has addressed as the "control dilemma" (Lahav and Guiraudon 2000) in terms of rule of law. For governmentality scholars analysing the Schengen area, this materialised through a shift from judicial-territorial sovereign power, expressed through (external/ised) border control, towards a biopolitical rationality of population control through filtering functions: through selective and mobile bordering practices, which do not "cross" everybody (in 'critical border study' terminology). Therein, certain sites were deemed key in the search for procedures capable of mediating between the "twin imperatives of Schengenland": security and freedom (Haahr and Walters 2005, p.110). Internal Schengen border-areas can be analysed as of one of these sites. Additionally, however, border(-strip) measures negotiate between plural legal orders and forms of political life. Political struggles do 
not only regard the Dublin order (prior section), but the political life of the EU order, within which the "safeguarding of internal security" is a member state responsibility not affected by the AFSJ. Here I study-through multi-level border struggles between differential freedom of movement and border (area) control within the Schengen area by relating an analysis across different scales. Firstly, I situate struggles in courtrooms and primarily engage with jurisdiction of the Court of Justice of the European Union (CJEU) regarding preliminary rulings on art. 23 of the Schengen Borders Code (SBC): it regulates the exercise of policing powers in border-areas. Secondly, I focus upon struggles taking place along border-crossing roads and train-tracks. I discuss where and how police officers draw the line between border control (hereinafter $\mathrm{BC}$ ) and border-area-control (hereinafter BAC), and how officers identify and negotiate the line of the hyphen connecting and separating these two measures and orders. Lastly, I scrutinise micro- and macro-level understandings of "spot-checks".

\subsubsection{CJEU case law: (judicial) border-struggles surrounding art. 23 of the SBC}

In 2011 Peers (p. 179) argued that one key question, not answered by the Schengen Borders Code itself, is whether border-area-controls would infringe the SBC, if carried out for the purpose of migration control. Today these measures, including for that purpose, are encouraged on an EU policy level as favourable alternatives to temporary border control and they have also seen an increased juridification, inter alia through case law of the CJEU. The preliminary rulings of the Court are a privileged site for investigations into the way negotiations unfold between different legal orders (plural in policy field and scale). As can be apprehended from the table in the annex (pp.336-337), the preliminary rulings showcase several of the interacting plural normative regimes when it comes to policing the border-strip. ${ }^{104}$ Dissecting and following case law decisions gives insights into institutional arrangements of a variety of actors and renders visible borderstruggles that highlight multi-scalar power dynamics.

\section{Case law (see Table 6, Annex II)}

- Joint cases Aziz Melki (C-188/10) and Selim Abdeli (C-189/10) vs France (hereinafter Melki \& Abdeli [2010]); Adil vs Netherlands (C-278/12, hereinafter Adil [2012]); A vs Germany (C9/16, hereinafter $A$ [2016])

- Germany vs Touring Tours und Travel GmbH (C-412/17) and Sociedad de Transportes SA (C-474/17) (discussed in chapter 8.5)

The preliminary rulings of the CJEU provided interpretation of primary and secondary Union law regarding the principles of freedom of movement and absence of border control. Specifically, the CJEU has provided further interpretation of art. 23 of the SBC, specifically of art. 23.a i-iv. ${ }^{105}$ The rulings are deemed to have established important legal benchmarks to assess the lawfulness of 
national legal frameworks regulating the exercise of police powers specifically in border-areas (Carrera et al. 2018). In short, the court established that border-area control (BAC) is not a breach of art. 22 SBC concerning the absence of BC (former art. 20, SBC 2006), provided that the checks do not have an effect equivalent to BC. When national legislation grants police authorities the powers to check the identity of any person in the border-area - irrespective of his or her behaviour and of specific circumstance - it needs to provide guarantees that the practical exercise of such policing powers does not have an effect equivalent to border checks. To this end, according to the jurisprudence, national law is required to specify (criteria and limits regarding) the intensity, the frequency and the selectivity of such policing powers. The rulings reiterated that, to conform to Union law, controls must be "non-systematic" and "spot-checks" - interpreted as "selective" - and be based on police-information. While the first case (Melki \& Abdeli [2010]) regarded checks to assure the compliance with the obligation to hold or carry papers and documents (art. 23 b), in the subsequent two rulings the court interpreted that controls could serve other purposes than those listed under art. 23 a (ii). BAC, according to the court, can include objectives of targeting illegal immigration and unauthorised residency. Border-area checks (territorial scope) aimed at detecting irregular immigration (objective pursued) were deemed "evidence" in need of a clear and precise legal framework of limitations (see Adel [2012], para 75; A [2017], para 59 and 40 $\left.{ }^{106}\right)$. Notably, both these case-law decisions regarded first-generation measures: cases where the policing powers were applied along entry routes, by and on the territory of the concerned member state. I will discuss further below a case in which the CJEU issued a ruling of potential relevance for third generation measures.

\section{Court jurisdiction and plural actors}

It has been pointed out (Van der Woude 2020) that discretionary space is built into the SBC and that the CJEU case law illustrates how a) member states make use of this space, and b) how interests are in tension between two scales and actors: the EU through the CJEU, and the national scale. However, it is important to further specify the jurisdiction and competencies of the court, as well as those of other actors.

The CJEU preliminary rulings concern the interpretation of EU law but not their application to a concrete case, the validity of national law (Melki \& Abdeli [2010], para 59; already in Costa v ENEL [1964] ECR 585). While the CJEU has indeed assessed national laws, it is the role of the national court to draw conclusions. Even more importantly, the CJEU has no competency to review the validity or the proportionality of law enforcement operations carried out by member states, as stated in an exception clause of the TFEU (art. 276). ${ }^{107}$ Within the European order, the "maintenance of law and order and the safeguarding of internal security" are a member state responsibility not affected by the AFSJ (TFEU, art. 72). ${ }^{108}$ The same holds for forms of cooperation 
and of coordination between member states to safeguard "national security" (art. 73). ${ }^{109}$ The CJEU certainly further defined the meaning of Union law and set standards to be complied with by national laws. But, on an EU level, it is indeed the European Commission that, with the Lisbon Treaty, became (co)responsible (with member states) in the "Schengen evaluation and monitoring mechanism" (Reg. 1053/2013, intr. para 13) and invested with the overall coordinating and evaluating role. As main enforcement mechanism the Commission also has the powers to initiate an infringement procedure against a member state in case of perceived noncompliance with Union law (TFEU, art. 258 ff).

Therewith, it is worth emphasising, the main EU actor responsible for monitoring and enforcing the application of the Schengen rules (as interpreted by the CJEU), and for assessing the "proportionality" of checks is the same that is recommending intensified border-area policing, i.e. the European Commission.

\section{Focus: Germany}

Germany presents an interesting case: it was the subject of an infringement procedure, had cases before the CJEU, plus multiple court cases on a national level regarding border-area checks (for an overview of the latter, see Deutscher Bundestag 2019). In October 2014 the Commission issued an infringement procedure against Germany, regarding the implementation of the Schengen Borders Code. ${ }^{110}$ It considered the respective German legal framework regulating police checks in internal border zones (in specific art. $23.1 \mathrm{BPolG}{ }^{111}$ insufficient to guarantee that the application of ID checks in border-areas would not amount to border control. In March 2016 Germany issued an advisory decree as to the application of art. 23.1 BPolG (without amending the law). After outlining that measures had to be flexible in order to be able to respond to the changing 'situational picture' of cross-border crime, the decree 'specified' the following "frame" (non-verbatim translation):

- Control-measures are not set up long term but take place intermittently at different times and in different places through spot-checks and by taking into consideration travel activity.

- Control-measures are not only carried out due to a border crossing but are based on upto-date situational pictures and/or (border)police experience; as such the measures, their intensity and frequency, depend upon specific information or experience of bordercrossing criminality (its means and routes) and the analysis thereof $(*)^{112}$

The Commission closed the infringement procedure in February 2017, contending that "[t]he German authorities adopted an advisory decree providing the necessary legal certainty on this matter" (2017, point 7). It also stated that "in general, the Commission encourages Member 
States to make use of the possibility under the Schengen Borders Code to carry out police checks in border-areas". Three months later it issued the already discussed recommendation to enhance border-area policing and police cooperation (C(2017) 3349 final). In June 2017 the Court of Justice of the European Union (CJEU) issued its preliminary ruling in A [2017], reiterating the interpretation of prior case law. The court indicated a lack of guarantees in German law regarding frequency and intensity of police powers. But, notably, the Court did take note of the additional advisory decree, although without opinioning on its merit. To even consider an administrative decree as a possible means to concretise the legal framework guarantees and to produce socalled "legal certainty" was deemed a quite unusual practice by the court compared to other cases (Tischbirek and Wihl 2017; Becker 2017). It was thus left to the referring court to assess compliance with EU law of the national framework and to assess the decree.

To 'follow' this judgment is intreaging. Subsequent decisions by German courts referring to $A$ [2017] and calling upon their competency to assess the compliance of German law with EU law, have reached diverging opinions as to the legal value of the decree as well as its content, i.e. as to the compliance of the national legal frame and legitimacy of controls therewith. A snapshot thereof is worthwhile. The Saarland administrative appeals court ruled that art. 23.1 BPolG, further specified in its application through the decree, conformed to EU law. ${ }^{113}$ The closure of the infringement procedure was taken as evidence thereof. Contrarywise, an administrative court in Stuttgart subsequently argued that the closure of the infringement procedure by the Commission did not absolve the court from carrying out an examination. ${ }^{114}$ It called for independence of the judiciary and argued that both form and content of the decree were insufficient. As such art. 23.1 BPolG was judged not to be compliant with EU law and that the checks lacked legitimacy. The interpretation of the former ruling by the Saarland court was reaffirmed at highest judicial level: the German Federal Administrative Court expressed that the decree satisfied the criteria outlined by the CJEU jurisdiction (para 9). ${ }^{115}$ Contrary to prior documents regarding the application of art. 23.1 BPolG (such as the BRAS 120) ${ }^{116}$, the advisory decree had been made public. Although not meeting the status of law, the decree was therewith able to figure at least in its 'public form' to satisfy the very minimum requirements of legal certainty and rule of law. Issuing and rendering visible what previously were internal policing regulations, is less an act enhancing transparency but one to overcome issues of legitimacy, embedded within broader processes of juridification.

We see that struggles here are both between scales but also about the borders of the trias politica, the separation of powers. One notes the ongoing reconfiguration of the meaning of principles within 'rule of law', such as legal certainty and seemingly a ruling with the law. The 'afterlife' of EU jurisdiction also on [sub]national level would call for further multi-sited investigation into the interpretative space of national courts. 


\section{Border-disputes and negotiations}

The rulings of the CJEU and their 'social life' across scales and actors are a privileged site to investigate how negotiations unfold between different legal orders and arrangements of a variety of institutions. It becomes tangible how law is a multisited arena through which politics of space are enacted and negotiated, and how legal spaces - like the border-strip - are embedded in broader social and political claims. Moorhead (2014, p.88) spoke of "'border' disputes" to indicate conflicting situations between Union and national law and respective competencies and consequently, politically charged CJEU decisions. He attributed to the court a double role beyond the interpretation of EU law: a) that of the promoter of the Union Treaty objectives (furthering EU integration), b) one of institutional stability between the Union and the member states. Quoting a former judge:

The Community judge will thus try to establish 'the middle-line' which has the best chance of 'surviving' the relentless conflicts between the requirements of Community law and the interests of national systems. In other words, he will seek a solution that does not risk encountering incomprehension or resistance in some Member States, which could undermine the effectiveness and the uniform application of Community law. (Lenaerts 2003, in Moorhead 2014, p.55)

This resonates with the developments traced above. The various "observations submitted to the court" by member states and by the Commission show that most member states have considered border-area control to comply with the SBC. The Commission shifted from initial worries of "disguised" BC in need of legal guarantees delimiting powers, to promoting such police checks as an alternative to border control. The 2017 recommendation updated prior guidelines on the matter. ${ }^{117}$ In the infringement procedure the Commission adopted a seemingly quite relaxed attitude towards what is deemed sufficient to delimit the exercise of such powers - both in content and form - and therewith in the production of legal certainty (see on the Dutch legal framework, assessed in Adel [2012] and in Brouwer et al 2015). ${ }^{118}$ Considering the political tensions 'along the way' of the Back to Schengen Roadmap (COM(2016) 120 final) ${ }^{119}$, the subsequent CJEU case law as well as the handling of the infringement procedure have to be placed in the context of prolongation of temporary BC by several member states.

Struggles do not only regard the control dilemma and mediation between freedom and security. They are also a "balancing act" between the prerogative of member states to take measures for "internal security and public order" (grounded in the European order), the Commission's aim of abolished border control and effective application of Union law, and the Union treaty objective of a political unity. By attending to the technicalities and scrutinising "chains of interactions" (Benda-Beckmann and Benda-Beckmann 2005, p.9), we see how struggles carried out in court 
connect actors across scales, whereby the interactions structured by power relations are (re)configured in the process.

The recommendation to enhance proportionate policing in border-areas, in turn, was embraced by some states with an explicit reservation. As the German Minister of Interior de Maizière stated in May 2017 (Bundesministerium des Innern, für Bau und Heimat 2017),

the recommendation of the Commission to intensify the possibilities for policing-search-measures in the border-areas is an important and correct sign. No doubt. The so-called Schleierfahndung is already a well-established and successful policing-instrument in many German Länder, which should find increased usage by all member states and all German Länder. But: Schleierfahndung is no substitute for border control. $\left(^{*}\right)$

The closure of the infringement proceedings was also taken as opportunity by some police unions and minister of the Länder to call upon the inclusion of this policing-measure in the police-laws of all Länder (Bayerisches Staatsministerium des Innern für Sport und Integration 2017b). Austria replied along the same line, considering an enhancement of CBPC useful but not an alternative to border control (cit. in Council EU 1189/2/2017). Austria's internal security report likewise reiterated that "the protection of the internal border receives highest priority" (Bundesministerium für Inneres 2017, p.20).

The case law decisions navigate between what, on the one hand, are the principles of free movement of persons and an absence of BC on internal borders and, on the other hand, various other legal regimes and dynamics that make clear that these are not absolute principles. The increased juridification of border-area policing practices has had the effect of introducing, on the on hand, legal limits and, on the other, of legally enabling and anchoring the practices therein. It remains noteworthy that today the very EU entity responsible for monitoring compliance with the SBC and responsible for eventual infringement proceedings, encourages member states to intensify police checks in border-areas.

I now turn to empirical data and to the interface of these two measures from the perspective of practices and of the practitioners of control.

\subsubsection{Lines and shades in border(area)controls and their effects}

At inner-European land-borders we are empirically dealing less with a border-line between border control (BC) and border-area control (BAC). Instead - with differences which I will outline and to be understood along an empirical continuum -, in contemporary historical conditions of possibilities this border-line is not a line, but a space. It is a grey area, with demarcation lines around clear no-go-zones. I argue that this results from a two-way approximation: 
1) $B C$ at internal borders interacts with rationalities and other legal orders of the AFSJ, which for example reconfigure border control into "spot-checks" in order to avoid limiting traffic speed (freedom of circulation understood as a rationality of speed), but also by extending the (bordercrossing) points on a line towards border control within the adjacent space (see chapter 6).

2) Compensatory measures through BAC, to do the same job as $B C$ (as recommended by the Commission), or to do an even a better job (as some officers argue), can resemble $\mathrm{BC}$ reconfigured as "spot- checks".

I will substantiate and further refine this argument by discussing how officers perceived their recent $\mathrm{BC}$ possibilities and how officers reflected upon $\mathrm{BAC}$ measures.

\section{Border control}

Several of the officers whom I interviewed and who carried out operational or decisional functions in $B C$ measures at regional or local level, considered $B C$ an enhanced instrument for cross-border crime control. Examples provided ranged from the interception of persons under arrest warrants (and who otherwise would less likely have been stopped), the identification of vehicles which did not meet the standards to be on the road, the collection of information to support criminal investigations, and not least the tackling of pretty cross-border crime and its overall decrease in border-area regions. Notably, most of the "operational cases" reported to me had nothing to do with "secondary movements" (except for eventually one case regarding migrant smuggling). I therefore suggest that in this case we see how a migratisation of security has the productive effect of enhancing non-migration-related policework. However, some interlocutors - also who highlighted the added value of BC for policing - expressed considerations like the following:

"Border control makes sense from an operational perspective. (...). However, I need to know what it is that I want. Security comes at the cost of freedom... it is a bridge, or a scale. I can say I can guarantee absolute security, but that comes with limitation to one's freedoms - in whichever form: controls, cameras, curfews (...). Do I want that? And at this point I need to say, that as a democrat I need to try to keep the scale balanced. That I say, I guarantee security, but opposite there is the freedom, and among that there is now also the freedom of circulation. (...). In the past it was normal to have controls on the border crossing points. And there I have to say, what do I want? We were on a such a good way with this common Europe, with the freedom of circulation, great. And all that populism is destroying a lot. (...)." (IV_LL-HLO)

The speaker is the head of a local police department in charge of $B C$ and $B A C$. BC is great for the police authorities, he stressed. But in his reasoning, it had to be placed as a weight on a 'securityfreedom-scale'. The "balance" metaphor is commonly found in policy problematisations: the increase of security diminishes freedom and vice-versa; freedoms becoming a vulnerability for 
security. They are indeed not to be understood as separate entities but defined through the hyphen and as highlighted in the metaphor of the "balancing act" negotiated also together with other weights on the scale. The officer also placed BC and interestingly 'what it is that one wants' (politically), within what Reiner et al. called "the politics of the police" (2010, 2015): democratic policing in relation to other forms of policing. Across the spectrum of opinions of officers who shared with me what they defined as their purely "personal" views upon the '(non)appropriateness' of maintained BC (most considering it not appropriate [anymore]), all considered it a politically and not operationally driven decision. The 'if' and the 'where' of BC was deemed dependent upon (sub)national politics, elections and inter-governmental dynamics and not upon policing needs. What role the strategic policing level played, was not assessable through this study.

\section{Spot-check border control}

"But then, what's the difference between the compensatory measures and border control?", I asked a high-ranking officer, prompted both by our interview-conversation as well as by my observations. As reply, the officer responsible at a regional level for both modalities of controls, shook his head. "Nothing," he laughed. "In either case, we do spot-checks. Therefore, it does not matter at all, if we do that through compensatory measures or border control. Only the legal status, that's a problem". The "problem" or difference of the legal status of the measures impacts indeed on a step subsequent to the control itself: BC enables denial of entry decisions, while BAC require readmission-procedures. As far as the controls are concerned, from an operational perspective, according to this officer, the police have "the same possibilities within mobile border-area control". He added that "the only negative consequence" was that they would lose the tactical possibility to shift and to also carry out stationary BC. This officer's statement should not simply be taken as evidence in support of considering BAC a valuable 'alternative' to BC. It requires likewise a look into ongoing reconfigurations of what BAC means in practice.

$\mathrm{BC}$ manifests itself for police officers differently, depending on the means and routes of transport. While there is seemingly not much a difference during checks for example of cross-border trains, the controls and control possibilities can be experienced differently on the road:

"In the compensatory measure one is mobile, parked somewhere observing the traffic. When according to my profiling, I say there could be something, I (...) stop that car and perform a control. Now with the border control, everybody has to drive past me. I look into the car. And that is obviously something quite gigantic, for a police officer. Because I say everybody has to drive past me, I see how many people are in the car, what they look like, and then I can decide what I do, do we take him out or not. With the compensatory measures (...), for sure many are driving past that are not so 'clean', but that are not checked." (IV_LL-HLO) 
In addition, several officers pointed out that while $B C$ is attributed a deterrent function (preventive), BAC was however more successful than BC for catching cross-border crime or irregular migration (retro-active). These cross-border mobilities, while to some degree deterred by $\mathrm{BC}$, are deemed to be mostly only displaced in effect. Countermeasures by the police, to be "dangerous" need to be "mobile":

"Stationary controls are not really of any use as a countermeasure. Everyone knows there is a control, including the smugglers. Even the normal track drivers, they inform each-other when and where and how tight controls are. Indeed, if you are mobile, you are more dangerous". (FN, RL-MLO)

A mid-level officer interviewed in another country remarked likewise:

"(...) it is even better to be able to do that in a mobile and flexible manner (...). In the end, one must be aware that at every location one can be subjected to a control, anytime". (IV_RL-MLO)

In principle, nobody should be outside the reach of surveillance.

The court judgments have notably not engaged with the meaning of BC in terms of 'effect', which is not contemplated in the definition provided by the SBC for "border control". The SBC (art. 2.10) defines border control as "the activity carried out at a border (...) in response exclusively to an intention to cross or the act of crossing that border, regardless of any other consideration, consisting of border checks and border surveillance". The main difference between BC and BAC in terms of immigration control, concerns in the ways that the border can take effect: e.g. as denial of entry in $\mathrm{BC}$, and as readmission in the absence thereof and with $\mathrm{BAC}$. Beside the political (and legal) differences of the two measures, this is one line that separates BAC from BC: two measures that in terms of control practices are indeed connected by a grey zone. This space was described by several officers:

X: "We don't have border control (...). We have covered it [a recent displacement of an irregular entry route] intensively through compensatory measures. (...)"

M: "Is that working? ... Is it enough?"

$\mathrm{X}$ : "Well, ... where does border control start, and where... where do compensatory measures end? That is a grey area." [IV_RL-HLO]

Within this grey zone, there are also clear no-go areas, which during interviews took shape for example in a humorous expression:

"This comes very close to border control (...), but we are careful ... If it comes to a traffic-jam... there, then we trigger a thunderstorm. (...) [laughs], then we probably end-up straight in Brussels." [IV_RL-HLO] 
The imagined (illegitimate) border control effect leading straight to "Brussels" (proportionality complaints), was the causing of traffic queues on roads, or delays of trains. In turn, for subjects granted freedom of movement, borders are not a matter of passing through or not, but a matter of speedy passage. Interacting with this rationality that identifies (and confuses) freedom with speed, has likewise led to the (also top down) reconfiguration of BC into spot-checks. Another officer, who adopted a less operational and more legalistic framework of meaning, pointed critically towards "intensification" of BAC and highlighted that the two regimes were strictly to be differentiated and kept differentiated in order not to reach a situation of "absurdity".

"Within the framework of compensatory measures only limited control is allowed: spot-checks, they are accordingly porous. They are not comparable with border control, otherwise they would be illegitimate. Many manage to get through, the system is designed as such." (IV_RL-HLO)

Notably, the speaker worked in a border-region which presents quite a 'density', a combination of intensity and frequency, of checks. As he proceeded to explain:

\begin{abstract}
"We are placed quite well with our compensatory measures. To increase their density through intensification, I don't see why... it would reach an absurdum. Because, this is a compensatory measure, otherwise it is a systematic border control, and that is not what one wants. When the external border is well controlled, there is no necessity to densify. And the control [compensatory measure] is not allowed to be systematic. Of course (...) there is some creative scope. And the checks are also more intense, depending on whether the political level supports that more, or less (...). For sure, one can also view all that critically, if one considers how much certain countries have invested financial means in compensatory measures, human resources, equipment..." (IV_RL-HLO)
\end{abstract}

In this dense excerpt we see in addition how measures across the "tiers" of the EU IBM model matter as sites of enforcement and as sites of interaction along a border-continuum. We also see the recognition of the "creative scope" resulting from the grey area, despite this officer's plea for a clear separation. It is a discretionary space of the police, but likewise to be placed within topdown political instructions. "Governing through migration control" (Bosworth and Guild 2008) also sets political policing-priorities and impacts (symbolically and effectively) the intensity of practices and the allocation of resources.

Some officers highlighted indeed very explicitly what they defined as a complete uselessness of internal BC and of (joint) BAC.

\footnotetext{
"As practitioner, I would say, that both border control as well as border-area control on the internal border is very egoistic. (...) I don't think they are effective. At internal borders, these are small skirmishes, through which the member states make each other's life hard. (...) This is an internal border. No one ever came up with the idea, that by shifting a person back and forth between $X$ and $Y$ [two regions within one country], one would solve the
} 
European problem. That's likewise naïve. From my perspective, it does not serve anything, it is only a gaming between authorities. Useless." (IV_RL-HLO)

I will later return upon the notion and scale of a "European problem" and the proposed solutions.

\subsection{3. "Spot [and] check"}

BACs are "spot-checks" by legal definition; BC is also practiced as "spot-checks", i.e. not everybody is stopped and checked. The former are legally limited in intensity and frequency, the latter are in principle not. In recommending the prolongation of internal border control in exceptional circumstances (art. 29), the Council however likewise required BC to be of limited intensity and to take place through "targeted controls" in order to impede "as less as possible the crossing of the respective internal borders for the general public" (Council EU 8835/16, para. 19). Also the SBC (emphasis added, para. 22) outlines an "allowing for the temporary reintroduction of internal border control in exceptional circumstances, but without jeopardising the principle of the free movement of persons." In practice: both result in "spot-checks". Intensity and frequency are thus not de facto determining differentiation, albeit the "check" of the controls is nevertheless de juris embedded in (legally) different conditions of possibility. Officers at times addressed what "targeted" and "selective" means and implies in practice.

\section{When "the orders are to check every train"}

The following excerpts derive from officers of different nationality and hierarchical levels, working at different inter-state borders.

\section{Border-area 1}

"It is also an image, such a joint patrol. The $[\mathrm{x}]$ and the $[\mathrm{y}]$ with their different national police caps, they act together. But yeah, when one shows such image in the papers [press], then we are obviously immediately the bad guys. Cause one sees that the person checked is not a [national of the country], they are mostly from the Arab area, and 'the bad police for sure does not check the lady sitting behind, she is elven-white, but nooo, the dark-skinned persons are controlled'. And yes, that's how it looks. And that is also the reality. [Short pause]. Obviously, the police have, especially under the current government, the assignment to make targeted checks (...)." (IV_RL-HLO)

Border-area 2 [only this situation prompted by a question on how they decide who to check]

[Officer A] "The target of the control is illegal immigration. You use your stomach, your intuition...". [B] Well, but you also need to be careful, otherwise it is claimed that you are doing racial profiling. So, one checks [multiple persons]". [C] "Yes, but actually it is absurd. I mean, a citizen of this country cannot commit an illegal immigration offence, why would you control that person. At the end it does not matter, one checks them too."

M: "What sort of responses do you get during patrols?" 
[B] "Some complain about the delay, others ask why they are checked, others ask 'why don't you control me?'. You get used to that. And in case they bother, you just talk back with your policing voice, then they normally shut up. You just develop some sort of thick skin..."

Later a patrol officer pointed out that the issue of border control not only causes diverging responses from the public, but also divides the opinions of colleagues and families. He preferred not to talk about how he dealt with the latter situations. (FN, on patrol, LL-SLOS)

\section{Border-area 3}

"The orders are to check every train. But one is not allowed to check everybody, you know with Schengen, we are not allowed to do that. So, one can only check those who are somehow suspicious. Thus, one starts with the people of colour. We are not allowed to check everybody." (LL-HLO)

Articulated above we see how plural (legal) orders and requirements, which both enable and constrain the social interaction of spot-checks, are negotiated at street level:

- orders received from higher up the hierarchy to check every (in these cases) cross-border train $(1,2,3)$;

- requirements for selective and targeted checks, immigration control as objective $(1,2)$;

- for BAC, the art. 23 SBC requirement to conduct selective spot-checks (3);

- operating in an environment of multiple 'publics', travellers holding diverging opinions over the governance of migration and of police conduct $(1,2)$;

- $\quad$ tactics of how to respond to the public as well as for avoiding 'no-go' areas (2);

- $\quad$ speed/delay (2).

Checks also aimed to target irregular migration of citizens from specific countries or geographical areas, related to their available police information (selection criteria) $(1,2,3)$. In addition, crossborder dynamics during tense moments require officers to ensure as much as possible that no one without authorisation gets over the border (when the "only" objective of the check, this contrasts with SBC requirements for BAC). Likewise, national orders, that aim for 'successful' statistics count: immigration related offences are considered a type of offence wherein the more control is carried out, the higher the statistics. (Legal) orders are also a rationalisation and justification. I might have well been a member of the public to whom they perceived a response was due. Amongst all the (legal) orders invoked, the EUCFR or ECHR (including prohibition of discrimination) were only mentioned once during fieldwork and with regards to another topic.

$\mathrm{BAC}$ and its objective of countering irregular migration (BAC can, according to the $\mathrm{SBC}$, not have border control as only objective) coupled with an expectation of effectiveness, is not void of contradictions and interlegality conflicts. This type of control is legally delimited in intensity and 
frequency. Carrera et al. (2018, p.5) emphasised that "[n]ational law on police checks must be sufficiently clear and precise, provide limitations to the intensity and frequency of the checks and limit the discretion of police authorities". So, what about discretion? When carried out in the border-area and not based on the behaviour of the targets ("without suspicion"), the criteria of selectivity and target - delimiting police discretion - need to be based on police-information to be compliant. The objective steers the target of spot-checks and police-information and experience provide the necessary criteria for the selectivity. ${ }^{120}$ Discretion is limited, but paradoxically the more intensity and frequency are delimited, the less room there seems to be, in practice, for street-level discretion not to target and select by combining police information and physical characteristics ranging from skin colour to number plates. Officers "spot" and "check". Otherwise instead of a "spot-check", there is no "spot", just a random "check". Rather than discretion increasing down the hierarchy in organisational analytical terms, as is often argued, when seen from this angle, some discretion diminishes on the ground. In addition, this "spot [and] check" practice is tightened by an understanding wherein freedom of movement requires speed and by an expectation of successful controls. It becomes a systematic control, within its selection criteria. For being compliant both with SBC art. 23 and art. 22 SBC - "internal borders may be crossed at any point without a border check on persons, irrespective of their nationality, being carried out" (art. 22) -, 'perceived' nationality seemingly matters only if we are talking of border-check, not border area check. In policing scholarship discretion is often connected to "suspicion" as trait of "cop-culture" (Bowling, Reiner and Sheptycki 2019, p.173), which reproduces "the structure of power in society" and draws on cognitive maps of the social world (Bowling, Reiner and Sheptycki 2019, p.173). To 'spot' requires a process of visualisation, the check is an effect thereof. When the target is immigration control spotting draws on imaginaries of 'foreignness' which coupled with 'perceived nationality' steers selectivity towards 'non-white' or certain country number plates. As inverted consequential effect results the production of a specific space and order, unless 'non-suspicious' persons outside the set target are checked too.

Analysis would be reductive to simply assess these practices in Lipsy's terms as individual discretion and racial profiling (Mutsaers 2014, p.832) supported by institutional discrimination, or deemed to be solved through derogation norms. There is no clear norm hierarchy, but a complex struggle of negotiations and of power between multiple actors. This requires one in criminological scholarship not stop in analysis by providing "bad apples" or "subculture" explanations, but to seek structural theoretical explanations. Policy- and law-makers also play a role in a multiscalar "allocation" of discretion (van der Woude and Leun 2017). However: taking account of interlegality and chains of interactions, we saw that such checks are not supposed to 
be "random", but targeted and selective, configuring (also legally) discretion and "controls without suspicion" in paradoxical ways. The enforcement of an order that does not guarantee indiscriminately freedom of movement, but that discriminates - separates - in terms of mobility rights, (re)produces through this means of control, its objective and expectation of success, a situational discrimination through separation in the "spot [and] check". This consideration is valid for BAC and BC spot-check. Additionally, the intensification of such checks also potentially increases a service demand that contributes to the migratisation in the field of police information exchange, i.e. PCCCs channels for criminal police information exchange.

\section{"Spot [and] check" within border-disputes}

Finally, I return to the question of intra-scalar chains of interactions. Dissecting case law allows one to trace developments and shifts in case law and to "understand the conditions which made a particular pronouncement 'thinkable'” (Dembour 2015, p.27). The CJEU has provided important legal benchmarks, but simultaneously a legal base for BAC carried out for immigration control purposes. In the interaction of multiple actors across and within scales, there has been a refined understanding of what the 'boundaries of the acceptable' are. Likewise the Commission, considering also its area of competencies, plays a major role. The Council of the EU has issued several implementing decisions (upon proposal of the Commission) referring to "alternatives" to border control, such as BAC and readmissions. ${ }^{121}$ Discussions in COSI and in the LEWP did not express a conclusion upon whether these were 'alternatives', but national stakeholders were not opposed to strengthen police (co)operation. Also the European Parliament recalled member states to make use of other tools available, such as targeted police checks (P8_TA(2018)0228, point 13). ${ }^{122}$ In its first reading of the SBC recast proposal of 2016 (which mostly concerned intended amendments of criteria for temporary BC), the Parliament likewise approved enhanced $B A C$ and even required it prior any possible $B C$, provided that guarantees are given that these controls do not have BC as their objective (P8_TA(2019)0356). ${ }^{123}$

There is without any doubt increasing support across EU actors to intensify BAC, i.e. the performance of (national) policing powers in the border-strip. But when related to empirical data, this support as well as purely normative debates, seem quite remote from the analysed interscalar dynamics, practices and unfolding effects on the ground. Recommending and accepting enhancement of BAC for the intended purposes, equates to political support for the inherent contradictions and their unfolding effects in practice and in law. Indeed, what is aimed to be produced therewith as an effect of a quid pro quo is a political 'Union': potentially avoiding the exercise of national prerogatives through border control at internal Schengen borders by in turn amplifying prerogatives of national border-area policing powers. The border-strip is thereby invested with the expectation to provide the spatial resolution to contradictory social forces and 
complex and shifting alliances of cooperation and competition. By investing the border-strip with such expectations, it possibly becomes invested with yet more powers.

\title{
8.4. "PLAYING POING PONG" WITH "THE HOT POTATO"
}

\begin{abstract}
"In principle Schengen provides a uniform basis, but not everyone has the same parameters, there are different approaches, as we saw in the case of Dublin III. That does not work. For a long time, persons were not registered. It is, and I apologise for the expression, a 'hot potato' that one passes on." [IV_RL-HLO]
\end{abstract}

"However, you can't respond to this situation by playing ping pong. And that is what happens. No one wants to keep the hot potato. And the whole situation is deeply dependent on politics." [IV_LL-HLO]

"Playing ping pong" and "the hot potato" were two related metaphors that some of my interlocutors employed to depict a border-struggle embodied in their daily policing practices. Scholars as well as NGOs have sometimes called border-related practices and interactions a bracketed "game". Andreas (2009, p.xiv), writing about US-Mexican "border games", explained in his preface that the metaphor was not meant "to belittle or trivialize border policing and its effects, but rather to capture its performative and audience-directed nature". It was used to draw attention to the "strategic interaction between border enforcers and illegal border crossers". The joint NGO report A dangerous 'game': the pushback of migrants, including refugees, at Europe's borders, grounded the "game" metaphor in testimonial accounts of persons on the move through the Balkans. With "cynical humour" they described "their efforts to continue their dangerous journey the 'game', a cruel 'game' where safety and protection are replaced with violence and intimidation from people in authority" (Oxfam, Belgrade-Centre-for-Human-Rights and Macedonian-Young-Lawyers-Association 2017, p.2).

While here 'the game' referred to multiple micro-level interactions between border enforcers and migrants, the entangled metaphors of "playing ping-pong" with "the hot potato", which I encountered during my fieldwork amongst police officers, was not used to describe in primis the interaction between the police and the targets of their control measures. The first metaphor "playing ping pong" - was used to draw attention to the interactions between stakeholders belonging to different countries regarding the ways the officers - and jurisdictions - were dealing with a phenomenon, captured in the second metaphor, the "hot potato": namely, to pass it on. I use the emic conceptualisation to unpack this game and the former interactions in analysis. The first speaker, working in a central EU member state, talked about the wider EU picture and the Dublin system, triggered by a discussion about fast-track readmissions at internal borders and the (im)possibilities and limits of responding to the issue through border(-area)-policing. The second 
speaker, working in a country with an external EU border, described fast-track readmissions across one of its internal borders. Both interlocutors critically interrogated whether police forces were the right sort of players to deal with the "hot potato" in a 'game' where the police are the main protagonist and policing measures the playground. An "EU solution" and possibly in another policy field, was deemed the response needed. The "hot potato" depicts the larger issue at stake, but it is also embodied in the bodies of unauthorised border-crossers.

As other authors, I do not draw on this emic conceptualisation to trivialize either the effects or the role that this game has on the encounter between migrants and authorities. While this entangled metaphor falls short in considering the active role of migrants and effects on their "forced im/mobilities" (Weissensteiner 2018a [2016]), the analysis allows a differential attention towards the players in this game, the rules, logics and the strategies, as experienced on the controllers' side(s), without homogenising and totalising it. While migration policing is not necessarily only cross-border, one of its core functions makes it "a transnational enterprise" (Weber et al. 2004, p.199). The practices are therefore part of an array of strategies and tactics to be analysed across states and within transnational power dynamics. This enables us to look beyond the more tangible "border struggles" between border enforcers and irregular border crossers, even if those might be considered to constitute the priority in critical scholarship.

\subsubsection{Plural logics of control and chains of interactions}

Logics of migration-control are also logics and struggles of power that are at play dynamically in inter-state interactions and in cross-border police cooperation (CBPC). The micro-physics of control-dynamics in joint patrols, elaborated upon in depth in chapter 7, could be placed likewise in this chapter-section and should therefore be kept present throughout. Here I focus upon fasttrack readmissions, the most tangible manifestation of the "ping-pong" game at this scale. During an interview with an officer talking about policing measures along the Balkan Route, he pointed out that "they push... well it's not a pushback, it's a readmission", as if he were replying inter alia to the NGO-report quoted above. He aimed to emphasise the legal basis and lawfulness of the latter practices. This historically sedimented Schubverkehr is a contested instrument also within the Schengen-space, to be analysed both as law-as-text and in practices. Subsequently I briefly outline additional logics that can intersect in the border-strip.

\section{Fast-track readmissions}

First-, second- and third-generations of border-area measures assemble differently with the instrument of fast-track readmissions at internal borders. Therein the border takes effect within two determinants: the spatial dimension of the border-area controls and the temporal dimension, as fast-track readmissions can only be practiced within a set time limit following the 
border crossing. Space and time are also crucial elements in the logic of migration control through fast-track readmissions.

\section{Parallel, first- and second-generation measures}

After observing an administrative fast-track readmission, wherein the 'hand over' had proceeded quickly, an officer of the 'receiving' country expressed his surprise, as well as a 'dilemma'. The third-country national concerned had already been apprehended and checked the day before: he was legally in the country, had nothing pending in terms of police-history, and there was nothing else the police could do with him. The neighbouring police forces had intercepted the man at night: just as he had crossed the abolished Schengen border on foot, his path and that of mobile police officers crossed. He was kept overnight in administrative detention, a readmission request was sent, and upon acceptance he was returned and 'handed over' to the neighbouring country. What caused this officer to be surprised, he explained to me, was that instead of going for a fasttrack readmission procedure, why had the officers not simply brought the man back and left him on the other side of the border, after he was intercepted in fieri? Seemingly, from time to time the border 'takes place' this way. "That's what we [read: both sides] normally do in such case, when they [migrants] are caught in the act of crossing". He added: "It's nothing formal at all".

The officer explained the readmission, as opposed to the other (non-official and unlawful) 'option', by outlining that through the readmission, the person would be brought to a police station slightly further away from the border itself. I may add that the practice of returning a person in a "nothing formal at all" manner, actually puts the intercepted person in a good place to try again. This is notably a comparatively favourable position in case the person aimed to pass through (officially) undetected. It puts the person likewise in an unfavourable position to legally challenge an unlawful expulsion, since this practice is outside of any proof beyond those involvedor third-party eyewitnesses. A readmission (and likewise a denial of entry) re-place the person into a space tendentially more distant from the borderline itself and into the hands of the neighbouring police forces. Many officers across border-regions expressed however also a Sisyphus-like effort: after receiving the readmitted person, a check is done (the further process depends on prior 'police' history, immigration status etc.) and often there are no grounds for further proceedings or detention. The person is 'in order', and free to move (frequently giving it another try). Practices outside the spaces of the law remain mostly invisible, but they have also led to diplomatic conflicts and not only historical ones - as on the French-Italian border (chapter 6) - or become the object of NGO-reports or, less likely, court cases. While readmissions are not valid for persons positive in Eurodac, this criterium is unlikely of relevance in pushbacks. I suggest that for pushbacks being an option pursued in the 'game', cross-border relationships seemingly need to be either pretty good and practices 'reciprocal', or indeed be fairly bad. 
A fast-track readmission (and denial of entry) not only counters an irregular entry and enforces national immigration law as well as obligations within the Dublin order (for persons not yet fingerprinted). The logic goes that the measure should discourage further attempts to cross the border and displace the person as much as possible away from the border. Discouragement (and disciplining) through displacement emerges as an important second logic beyond that of detecting and countering an irregular entry in the first instance. It figures as a means to increase both the time and the economic outlay a migrant would need to invest in a second (or third, or forth, or fifth ...) attempt, unless there were grounds to detain him or her in the country the person aimed to exit. In this logic, coupled also with deterrence strategies, migrants' agency plays a contemplated and indeed crucial factor in the drawing of future scenarios and tactics to deal with it. While the prior example concerned a fast-track readmission between two countries, the following explains a so-called "chain-readmission".

"(...) you [the intercepted person] are not entitled to be in country A, so the easiest and cheapest way for country $A$ is to send the person back to country $B$, to the previous country. One step. We followed that. (...) And of course if we got them back within [a certain time frame] we were able to send them back to [neighbouring country in the other direction]. This way it is not only one step, but two steps back, [that] multiplied the impact in that moment." [IV_former-HLO]

I would therewith like to draw attention towards how temporal aspects of different bilateral readmission agreements, together with the time for administrative detention grounded in national law, can create a legally delimited space and time that opens a route to re-move persons through fast-track readmission procedures multiple steps 'backwards' along their alleged trajectory. As we saw in chapter 6, bilateral readmission agreements have been willingly maintained within the EU legislative developments of CISA and the Return Directive, even without explicitly referring to fast-track readmissions (between countries that share a common border), which lack certain legal guarantees otherwise foreseen. In addition, we saw that, according to a police law manual, chain-readmissions are in principle considered possible. Put differently and regarding interlegality in practice, there seems to be no impediment to a chain readmission, if the neighbouring country is deemed a "safe third country", as long as the bilateral internal conditions for fast-track readmissions, as well as periods for administrative detentions, are met. Through "chain-readmissions" persons could be re-moved (and necessarily within a short timeframe) between multiple countries, potentially also into a country across the EU external border. This spatial-legal non-formal removal route is both created and enacted through chains of interactions of sub-state authorities through cooperation across border-strips. I suggest that chain-readmissions are more likely to take place along routes where the persons on the move are less likely to intend submitting an asylum application, unless they do so to avoid a further 
readmission backwards. An expressed asylum intention (and in principle also a "hit" in Eurodac) would disallow a fast-track readmission. Having said that, however, two points need to be added. On the one hand, advocacy and legal reports and a fieldwork fragment suggest that the right to seek asylum should not completely be taken for granted. On the other hand, that (chain)readmissions through CBPC are a smoothly running route, should likewise not be taken for granted.

As previously analysed, joint patrols have been set up with a particular aim, which is also part of the "ping-pong" game: second-generation measures aim to facilitate readmissions with patrolling officers becoming bodies of evidence, and third-generation measures aim to prevent a possible readmission by intervening before the (presumed) fact. They thus shift from a reactive logic towards a security logic aiming to 'get ahead' of the "ping pong" game. Different to fast-track readmissions, they - temporarily - effect also persons registered in Eurodac or with legal status.

\section{Plural logics}

Foucaultian inspired scholarship has drawn attention towards how technologies of government interact with a political rationality of "freedom of movement" (Huysmans 2006; Bigo 2006; Walters 2002; Barnier et al. 2019). While border control draws on territorial-judicial methods associated with sovereignty and the geo-political border, a biopolitical border(ing) takes place with population (not territory) as a target, internalising the danger and monitoring it through surveillance. Arguing that migration control has developed primarily into a policing of migration, Barnier et al. identified three main mots d'ordre of migration policing across Europe: to filter, to disperse, to harass (Barnier et al. 2019).

When paying closer attention to the spatial-legal regimes and practices, we saw how in the border-strip plural logics and rationalities are at play, together with multiple and reconfigured meanings of sovereignty and territory. Sovereignty is notably also performed through practices and technologies that have mostly been categorised in scholarship as a biopolitical expression of power. There is notably not a chronological shift from sovereignty, to discipline, to governmentality. Additionally, practices express plural and at times also contradicting logics that need to be attended to: they can aim to filter and to detect, but also to deter, to discourage, and to discipline. They can aim to facilitate outward mobility both by 'closing eyes' or by readmitting backwards; or they might aim to break the will of those who try and try again; or indeed to intercept them once, knowing they will succeed the next day. They can also aim to counter migrant smuggling and can aim to save lives. In the case of third generation measures, they embody a preventive and pre-emptive security logic. Several logics complement those of readmissions. 
When addressing border-area policing and the logic of detection most often officers pointed out an effect of dislocation. "Think about it as a pillow," a police officer explained. "...You can press the air out here," he pointed out a spot in front of me, "but then...," his hand concluded the sentence, suggesting that the air moves further into space. Whilst pointing out the constant displacement (which can also displace 'routes' away into other countries - yet another dimension of the "game"), he valued the intensified measures for having had, in his opinion, an effect of deterrence. Interceptions had decreased, and this was interpreted as confirming the aim of producing a deterring effect. At the time, a specific border-crossing track had become visible as a potential displaced 'route' to focus on. By concentrating police presence there, the police hoped to co-author the message, which they imagined the migrants would spread: not the message of an easy path, but one that was patrolled, aiming therewith to prevent it becoming a 'route'. Unable to affect border-crossers agency as such, it was about working through it: it was about putting their signature on the migrants' message.

For some officer, the effect of increasing the economic means needed to progress along the route (by depending on smuggling services), is deemed an explicit benefit, likely to decrease the number of those who (can) attempt it. In such a logic, the necessity of a smuggling service and relative increase thereof within Europe cannot really be considered merely a 'counter'-productive effect. It has been argued that, while overall arrivals to the EU have decreased, intra-European facilitation is deemed to have remained constant and, in some regions, increased in demand (Europol - EMSC 2019). The modalities used (such as concealment in vehicles) have become more dangerous. They fall consequently more frequently into the priority of tackling the 'facilitation of illegal immigration' (EMPACT) "whose methods endanger people's lives". 124 There are particularly two inner-European events, "Dover" (2000) and "Pandorf" (2015), which figure as important reference points to officers I interviewed. The events have also served as a trigger in developments in the field of legislation and policy programmes to counter migrant smuggling, as well as in the enhancement of operational and judicial cooperation. ${ }^{125}$ Notably, the death of 71 persons in Pandorf took place along a route, which at the time was patrolled (jointly) through BAC along train-routes. Along the parallel road route, the high number of arrests particularly of drivers was considered by sources to have had an impact on the "quality" of the smuggling service. According to one source, it was feared that without an "opening of the border (... which) was never closed" [sic], "Pandorf" would have repeated itself in the heart of Europe. While the joint operations on the train could ultimately not prevent people from crossing the border, they did contribute to shaping the conduct of 'unauthorised border crossers' and conditions of possibility. Scholarship has predominantly focused on external(ised) EU borders, but the relation and dynamic between "secondary movements", border-measures and intra-European "migrant- 
smuggling" or even "self-smuggling", as well as police and judicial cooperation in this field, call for further research. Europol defines "secondary movements" as "journeys undertaken by thirdcountry nationals and stateless persons from one EU or Schengen associated country [sic] to another without the prior consent of national authorities, with or without the support of migrant smugglers" (emphasis added, 2019, p. 6). The latter type of "secondary movements" - "facilitated by the migrants themselves" - was also defined as "self-smuggling" (2017, p.13).

At times on specific routes, detection and indeed salvation are conflated, including at intraEuropean borders. The possibility of discovering a dead body can be a haunting reality in streetlevel patrolling. Even if, when a person is discovered alive, a readmission or other policing measures can follow. Critiquing the former, due to the dynamic outlined, only as a self-produced deadly harmful risk, or the latter as a humanitarian border, does not do justice to the experience of street level officers haunted by such a possibility, nor to the broader struggles within which measures and their effects are to be analysed.

While these logics interact within the "ping-pong" game, they are seemingly characterised by one common denominator, the aim to pass the "hot-potato" on. Often it is practiced together with another game, which according to one officer can be called the "domino" game. When one country steps up its border(area) measures along a 'route', the neighbouring country will, in response and in a preventive logic, likewise do so on its respective outer border. Notably, innerEuropean unauthorised mobilities were a reality before 2015, and before them becoming an EU and in some case a national priority. One of my interlocutors, notably not working in a "first country of entry", pointed out that cross-border police information exchange in the past also regarded onward travels:

"We exchanged weekly with [neighbour country] police representatives, and also acted based on their promise that they would let them in. [Neighbour police, equivalent function] at the time pointed out, that their political level would not take any decision upon the matter... this was purely a policing decision." (IV_RL-HLO)

Operational decisions placed border-area policing priorities elsewhere, altough the legal frame (Dublin system) at that time was the same. We see how intra-European mobility routes becoming viapolitical has not merely "activated" (see chapter 6 ) but also led to a reconfiguration of CBPC in the border-strip. In turn, when operational, strategic and political decisional-levels converge to counter "secondary movements", scale politics are nevertheless at play in the "ping-pong" game.

\subsection{2. "Diplomacy down here": from high-politics to capabilities in the border-strip}

On several occasions my interlocutors pointed out dynamics and interactions that they either defined as "diplomacy down here" or that I deem to provide evidence of police-work that would 
usually be attributed to "diplomats" or, in the policing field, to the specific role of 'Liaison Officers' (Bigo 2000a; Bowling and Sheptycki 2012; Block 2012). Within "everyday police cooperation" (Aden 2001) and especially surrounding fast-track readmissions - the "ping pong" game with the "hot-potato" -, there is a lot of diplomacy involved or required. I conclude by taking up my analysis of scale politics, thereby situating this capability into the broader context.

The question of how to respond, for example, to a hot pursuit that might not have followed the letter of the agreement, or to a situation when neighbouring police cars are seen on the 'wrong' site of the border without any notified reason (just to provide some empirical examples), requires from the officer in charge diplomacy-capabilities. In street-level patrolling, how to interact within the, at times quite complex, setting and circumstances of a joint patrol requires likewise skills. Diplomacy acquires meaning as part of various (in)formal interactions and transactions. Readmissions are often entangled therein, even indirectly. While PCCC's legal fundament allows them to act in a supporting function to readmissions, the degree of involvement varies from centre to centre and has several reasons. One of the reasons was described by an interlocutor as follows:

"It would be quite counterproductive, that when the units that carry out compensatory measures intercept someone, then pass it on to us to quarrel with [the neighbouring country] over whether they take it [him/her] back." Prompted by my nonverbal reaction: "Well, this is a practical example. One should be able to call a spade a spade. In that case we would have to quarrel for them to take him back. And then, five minutes later, we would like to have proper information and cooperation from them. So, the way I see it, it was well done to separate these things somehow. Yes. That was an act of diplomacy." (IV_RL-HLO)

Readmissions are considered cross-border interactions associated with struggles, different opinions, and potential non-collaboration: a different form of interaction than the positively connotated term "cooperation". Since their very inception, readmission agreements foresaw the possibility of conflicting cases, and for them, a high-level diplomatic solution (chapter 6). The officer quoted above feared that the PCCCs main work could potentially be affected by negative interactions in the case of readmissions, and thus be counter-productive to the aim of cooperating in information exchange. He considered the non-involvement of the centre an "act of diplomacy" for the purpose and a value gained for the PCCC work. Border-area police directorates are not in the position to have such a choice. Here, diplomacy spans across policing fields, also at times in view of creating or maintaining favourable conditions for successful cooperation in readmissions.

"Over the years it [police cooperation/information exchange] has become increasingly institutionalised. However, much work is done through relationships: phone-calls, informal dinners, meeting up for a coffee. All this 
then makes the machine work. (...) These are horizontal relations, between you and the colleague that carries out your function in the other country. Of course, I always say you need to be open; you can't expect others to give you information, if you don't give them anything. If you want information, you also need to give information, and not wait for others to make the first step. (...) This relationship is important because, you know, requests for readmissions can also be refused. At the end, also the 'proofs', ... you can always find a reason to say 'no' and refuse the readmission. Well, you see ..." (IV_RL-HLO)

Evidentiary principles of the fast-track readmission procedure - despite the formal 'easing' of criteria and amplification of evidentiary elements in the 90s - are dependent upon good neighbourhood relations. This, it should be remembered, was also one of the logics behind the setting up of secondary-generation joint patrols. At the end of the day, a fast-track readmission request can easily be refused. This excerpt reaffirms findings with respect to informal direct crossborder exchanges through the kleiner Grenzweg. In this case, fostering informal horizontal cooperation through (pro-active) transactions of information, was also deemed instrumental to pursue this stakeholder's interest of cooperation in readmissions. The value supposed to be gained in the proactive transaction of information was to get a better chance of persons being readmitted back to the other country. In another border-region, whilst one officer explained to me some readmission statistics, a second officer turned towards me exclaiming: "you see, the statistics embody the relationships!". He referred to the 'quality' of the cross-border police relations

\section{Police-officers replacing diplomats}

"When policemen replace diplomats", was how Guiraudon (2003) captured the emerging intergovernmental cooperation on migration control in the 90s. In the context of the Schengenprocess, security and "high policing" experts had an active role in promoting a (in)security framing (see PART I). High ranking officers in "elitist" coordination groups also played a major role earlier, such as in the setting up of Interpol in the 1920's or through the Trevi Group (Aden 2001) or in indicating the direction for reforms of passport laws in $19^{\text {th }}$ century German territories $(H . H)$.

Police officers replacing diplomats is not restricted to the level of "high policing" or to "elitist" cooperation. Within sociological policing-scholarship "the diplomat" figures amongst the idealarchetypes of police agents and "diplomacy" as a policing style (Sheptycki 1998; Reiner 2010). Bowling and Sheptycki argued (2012, p.88) that, whilst being a useful role in the complex architecture of policing, it is the most difficult role, very demanding and rarely found. Except for research on LO's, the authors argued, diplomacy in policing has not been the object of much research, although they provided a pretty impressive set of skills for this archetypal role. No wonder the role is deemed rare. Certainly, this would be an intriguing topic to be further investigated. Here I make the point that, within CBPC and especially with regards to fast-track 
readmissions, there are a lot of diplomatic capabilities and work requested of officers. Taking up my analysis of scale politics, allows one to situate these capabilities into the broader field of struggles. As visible in the co-legislative impasse of the Dublin IV proposal, and especially in the Council and COREPER II debates, high politics and diplomatic representatives of member states could not reach any agreement on how to proceed in the reform of the Dublin Regulation and the established rights and obligations therein. Specifically, they were unable to agree on how to deal with the "hot potato". While, on several instances, internal borders have become the platform for (un)diplomatic inter-governmental conflicts, meanwhile the Dublin order continues to be negotiated daily through 'low politics' in the border-strip: diplomacy in the vest of the police.

The way(s) borders take place within Europe, is a seismograph of intra-European relationships. Keeping or rendering them smooth is part of the (diplomacy) work by police officers in the borderstrip. According to research data, these efforts can fail or are hampered for example when intergovernmental rapports are in tension due to undiplomatic moves or statements of political representatives, or when a local cross-border 'incident' is not contained at this scale. Maintaining good relationships and trust throughout periods of tensions, and in the worst case the need to start from scratch, requires active work. This might impact to a lesser degree on established longterm personal rapports, but certainly can be valid for roles higher up the hierarchy or in interactions between officers without strong personal ties.

By identifying the border-strip as an appropriate scale and field of response to deal with the "hot potato" and the symptomatic unauthorised "secondary movements", high-level political diplomacy is re-scaled into the every-day interactions of sub-state police officers working in the border-strip, and their diplomatic capabilities. In asking how something is governed, situated within politics of scales and choices of jurisdiction, this scale of 'diplomacy' needs to be considered. Embedded in long-term cooperation relationships necessary across policing fields, actors at this scale might have in comparison a greater interest and capacity in creating interaction that is cooperative. This, in turn, may render micro-level practices an 'attractive' scale. In critically posing the question if Europe's rebirth from the crisis will be through policing, Campesi (2016) probably did not have in mind uniformed diplomats in the border-strip.

\subsubsection{The "hot potato" beyond policing}

Analysis also requires one to move beyond what is tangible through policing practices. This requires a final reflection, which (also by following the field) leads outside that of policing.

The Dublin system was not a topic in all interviews. Officers held different levels of knowledge on CEAS and some preferred not to engage in a discussion on what they considered outside their professional field. Officers who did express an opinion in regard (not only those operating in a 
"first country of entry") highlighted the need for changes within the legislative frame regulating asylum and particularly of the Dublin system. An officer of a central member state approached the theme with the question "what instruments do I have to keep such a person?". Whilst calling for the need of proper fingerprinting upon arrival into the $\mathrm{EU}$, he pointed out that according to him any eventual future (emergency) relocation programme, would not work:

"Their [asylum seekers] redistribution, well also that does not work. I mean, how shall I keep somebody in the country, who does not want to be here, and who wants to go to a third [other member] state? (...) In addition, in Schengen there is the freedom of movement. So, the question is, what instruments do I have to keep such a person?" (IV_RL-HLO)

The officer responded to his question in the following way:

"[continuing from above:] A crucial factor are the huge differences between the member states (...) [his examples: e.g. services during reception, aspects of the asylum determination procedure]. But the approach needs to be the same. I mean, the same story, in one country receives asylum, in the other it does not. [Pause]. But all these are not policing instruments [emphasis added]. Here an EU solution is needed. Movements will be there, as long as there are these huge differences. Differences within the asylum system creates certain attractivities, pull-factors. This is self-created. Thus, it will be necessary to render the system more uniform." (IV_RL-HLO)

Subsequently he added that his country had already curtailed the service provision to asylum applicants. This interlocutor, responsible for border (area) policing, was additionally exceptionally well as up to date on policy developments in asylum matters. According to him, a crucial question is "how to keep somebody" in a place where he or she does not want to be or to remain. In the view of this officer, on the one hand the envisaged responses needed are localised in asylum policy and not through policing instruments. None of the interviewed officers made a plea for increased detention possibilities (see inter alia legislative proposals to enhance detentionpossibilities to counter risk of absconding), even when pointing out the uselessness of internal measures in the face of persons who had not committed any offence and without any grounds to be detained. This can be a coincidence of the sample, but it is noteworthy. On the other hand, we see how the question of how to keep such persons becomes a question of how not to attract them. Whilst the officer highlighted the need for a harmonised CEAS implementation, the European space and the countries that compose it was nevertheless pictured not as uniform, but diversified, also beyond any CEAS implementation.

A non-harmonised asylum system is frequently deemed a pull-factor of "secondary movements" and therewith the underlaying pitfall of CEAS. With regards to the Dublin system, studies have highlighted the need to abandon the "no choice" mantra and to take into account asylum seekers' connections to particular 'destinations', rather than responding to onward mobilities through 
what Carrera et al. (2019) called a "punitive" and "criminalising" approach. Studies have highlighted on the one hand how asylum conditions (reception, procedure, status determination) - as critiqued by the officer - are very diverse amongst member states. On the other hand, social, historical-colonial and other connections between asylum seekers and specific member states are not duly taken into consideration and, for example, family re-unification (on the top of the hierarchy of criteria for determining responsibility) is hampered, both due to the narrow interpretation of "family" and of the evidentiary principles applied. So-called "secondary movements" are thus likely to persist, regardless of differences or homogeneity of CEAS implementation.

\subsection{A GLIMPSE ON ROAD-SIGNS OF FUTURE DIRECTIONS}

What follows are two final proposals worth scrutinising: they provide indications as to 'anticipations' on macro-level and how to 'solve' some of the border-struggles scrutinised in this chapter.

\section{An Advocate General Opinion}

The Advocate General of the CJEU who asked how to legally solve the control dilemma, advanced a proposal which called upon operational police cooperation through joint patrolling. Both the case assessed ${ }^{126}$, and his proposal regarded controls along exit routes. The case took into consideration the compliance of a German carrier sanctions law with EU law, dealing with ID checks carried out by private bus companies to avoid sanctions imposed. According to the court, checks (in this case along exit routes) with the sole objective of targeting transport crossing an internal border, inasmuch as that it is specifically that crossing which triggers the checks, reveal the objective of having a border control effect, in violation of art. 22 SBC (para. 68). ${ }^{127}$ In discussing the non-compliance in the case assessed, the Advocate General argued that

(...) there is nothing to prevent the Member State of departure and the Member State of destination from using existing instruments of operational cooperation in order jointly to counter that illegal immigration, by exercising their police powers in their respective territories, in particular in and around bus stations. (ECLI:EU:C:2018:671, para. 107)

So far, there has not been any CJEU case law on exit controls through third-generation measures and the Opinion lacked further elaboration. According to the General Advocate, there would be nothing to legally prevent member states proceeding in this way. One could suggest that by carrying out the checks under the jurisdiction of the country of departure, controls formally figure as ID checks on the territory, under the jurisdiction and liability of the hosting country, and would 
adopt so-called targeted "spot [and] check". However: the targeting of border-crossing transport, through third-generation measures, likewise reveals what the objective of the checks is.

\section{"Reinforcing the Schengen Area" - a not minor reform of the SBC}

Under the heading "reinforcing the Schengen area" in the Commission's (leaked) programme for 2020, featured the intention for an SBC amendment. The DG HOME section is worth a closer look, even if this is not (yet) an official policy proposal. Notably, the outcome of (these envisaged) 'Schengen' discussions found mention also in the section on CEAS, as being of relevance for finding a "balanced compromise" in the struggles regarding the Dublin and CEAS reform. The proposal is thus a means to facilitate a "balance compromise" in the impasse on the Dublin reform. It reads as follows:

Tabling a new, targeted legislative proposal amending the provisions of the Schengen Borders Code setting out inter alia the possibility for enhanced police checks within the territory including in the internal border area and on the measures that can be taken on the basis of such police checks and of internal border checks (e.g. issuing decisions on return, refusals of entry). Reviewing further alternatives to internal border controls, building on the strategies of those Member States that have not reintroduced internal border controls although they are confronted to similar threats; envisage additional measures for operational police cooperation to guarantee a 'security continuum' reinforcing therefore the Schengen area. (Anonymous [leaked] 2019, p.99)

Albeit presented as a targeted proposal, indicating that small legislative changes to the SBC are envisaged, the real target is very clear, and the changes are not minor. It aims, as stated, to enhance police checks throughout the territory and in the border-strip. It furthermore aims to redefine the powers given therein and during temporary internal border control. Lumping together BC, BAC and checks on the territory is a clearer statement, than the syntax of the sentence suggests. It confirms the trend identified and critically addressed in this study and is indicative of the conflation of $\mathrm{BC}$ and $\mathrm{BAC}$. We have seen that while the $\mathrm{SBC}$ and jurisdiction have not provided an interpretation of what "border control effect" means, we saw that the main difference between $\mathrm{BC}$ and $\mathrm{BAC}$ lies in the ways the border 'takes effect', i.e. as a consequence of the "measures that can be taken" - up to now refusal of entry during $B C$, readmission in the absence thereof.

The proposal envisages changing the measures to be taken by policing actors on the territory and in border-areas, within the overall aim of enhancing police checks. Notably, placed within an aim towards alternatives to border control, the plea for guarantees that BAC does not amount to BC and scrutiny in assessing proportionality, is seemingly substituted, although I welcome being proven wrong. There seems to be an intention to attribute BC functions - expressed particularly in "refusal of entry", placed only at the end of the sentence - to police checks carried out in the 
territory and in the border-strip (I do not concentrate here on the other big policy priority, which is returns, likewise addressed in the quote). On the one hand, conceptually introducing the powers of "refusal of entry" under the frame of BAC (and on the territory) which operate explicitly in the absence of 'internal border control', would legally lift and shift away from the institution of the state-border the power to decide upon an entry or exit, i.e. what formally and legally defines one of its functions. It potentially shifts it away, not as in the case of the legal-spatial configuration of airports, but throughout the territory. On the other hand, practically and in the backward management of undesired mobilities, this would (re)transform a readmission regime currently dependent on the principle of "good neighbourliness" - and on a practice thereof to be effective - into one of "territorial sovereignty". Notably, the latter does not rely on cross-border cooperation and "good neighbourliness". Practical implications and discussion aside this would be, even as a policy intention, a statement of crucial symbolic significance for contemporary Europe and of its political form of life.

Cooperation is of course not forgotten. Operational police cooperation is also to be provided with additional measures. While the envisaged measures are not mentioned in the paper, one could think of cooperation with Frontex also within the territory. Or indeed the review and enhancement of executive powers of officers in joint patrols (chapter 5) so they could issue a refusal of entry whilst operating jointly, for example, at a bus station checking border-crossing transport. This is already envisaged without additional powers, in the example provided by the General Advocate Opinion of the CJEU. Exit-controls move within the grey zone which today extends between $B C$ and $B A C$. An officer explained to me referring to another practice, that police like working in the grey area: while in instances it can get very dark-grey, the officer added, one shouldn't stay in such space too long. In this case, rather than a movement out of that space, seemingly there is another movement towards brightening up the grey.

I am aware that I might have engaged in an 'over-interpretation' of this leaked paper and paragraph: I run this risk to highlight that an upcoming legislative reform and its unfolding effects require critical academic engagement and scrutiny. As well pointed out by Delaney (2003), political action takes place in the realms of "legal-geopolitical practice": such practice transforms and shapes the spatial-legal and political form of Europe.

Overall, my discussion of border-struggles reaches the conclusion that policing-mobilities in the (maybe further extended) border-strip, will continue to be deemed to be a necessary field and scale of response, unless fundamental changes to CEAS are introduced. By investing the borderstrip with such expectations, it becomes invested with more powers. Despite, or because of, the dynamics discussed earlier with regards to the production of an "ethos of a "joint task" on 
migration policing - what one officer called the creation of an "illusory world" - operational cooperation e.g. through joint patrolling, is invested with symbolic and material expectations. The "domino game", when played together, shifts the "ping-pong" game with the "hot potato" more strongly to the outer edges of Europe, and possibly outside. The migratisation of security and particularly border-strip measures on the ground are not perceived to be the most appropriate field and scale of response - I recall frequent comments that a "EU solution" was needed, but most officers did not see themselves to be that solution. Nevertheless, it also has the productive effect of enhancing policing possibilities, beyond the field of migration and therewith facilitating normalisation. Notably, if according to CJEU case law on temporary border control at internal border, the internal border is not tantamount to external border in terms of control, also the difference between border-area control and border control needs to be assessed against the reconfiguration into "spot-checks" of the latter: the difference between the practices, as I argued, lays primarily in the measures that can be taken subsequent to the control: e.g. readmissions in the former, denial of entry in the latter. As a glimpse in the proposals on CEAS suggest, other means that would intervene upon "secondary movements" in an arguably more efficient way do not seem to be on the horizon of political imagination. One example: as mutual recognition is a principle of EU and national criminal law, why not suggest a so-called "spill over" in another direction: mutual recognition of protection statuses. Instead of collecting additional wood, it would be time to take the "hot potato" from the fire. 
CHAPTER 9

CONCLUSION 


\subsection{POLICING-MOBILITIES \& POLICING OF MOBILITIES}

The objective of this study was to investigate the intersection of cross-border police cooperation (CBPC) with the control of differential mobility rights within the Schengen area, today's Area of Freedom, Security and Justice (AFSJ). The bottom-up approach that drew on the perspectives of police officers also sought to enable a nuanced reflection on the entanglement between security and migration as problematised on a policy level.

This thesis has addressed important gaps in the scholarship on cross-border police cooperation and on migration policing at internal Schengen borders. Taking also into consideration that several of the instruments investigated in this study were recommended by the European Commission to be enhanced as possible "alternatives" to border control (C(2017) 3349 final), this study fills gaps that are both of scholarly and of political importance.

More specifically, this investigation engaged with three CBPC instruments: joint centres, joint border-area patrols and fast-track readmissions. It combined the study of policy and laws on a European, bilateral, and national level, with that of empirical research carried out between 2017 and 2019 in border-regions of several member states. Interviews and observations were triangulated with a review of documentary sources of relevance to the respective border-region. In response to my overall research question, I sustain that the border-strip has become a viapolitical "strategic zone" (Walters 2015a) in the physical as well as digital transport system: strategic both for policing-mobilities and for the policing of mobilities. The aim of this study was not that of a comparative research agenda, but to "study through sites" (Wright 2011, p.27), in order to get a grasp of large-scale processes of change and of continuity not reducible to one empirical field-locale. Police cooperation is thus considered a situated and strategic entry point for engaging with ongoing transformations of governance and formations of power within the political and legal order of the EU.

By way of conclusion, I am compelled to refine my introduction: it is not enough to speak of border-areas as 'peripheries': due to scale politics and dynamic relations of power, the borderstrip and its localised level of cross-border police cooperation play a centre stage in the production of a European territory and in the making of law, no less so than they were in the 90s in transforming the legal void and in making enhanced police cooperation an integral part of the Schengen project.

In this final chapter, I draw together some of my main findings and further outline the contribution this study makes at the crossroad between law and social science, bridging - not only but particularly - legal and criminological scholarship on police cooperation and mobility control with scholarship in the field of legal anthropology. 


\subsection{FINDINGS AND CONTRIBUTIONS}

An initial summary of the main findings for each of the three instruments will set the stage for a more detailed exposition.

Contrary to what some scholars formerly suggested, evidence shows that bilateral readmissions

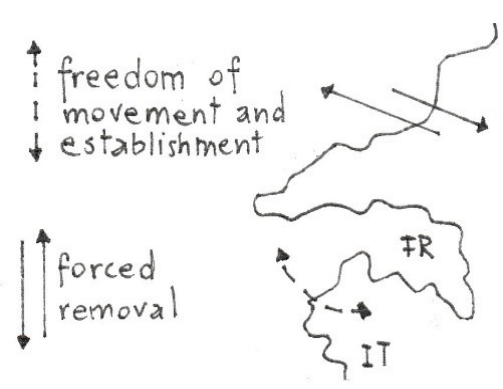
between member states have not become obsolete. Under the jurisdiction of border-area police stations falls a so-called fasttrack readmission procedure, foreseen in several bilateral readmission agreements stipulated between member states that share a common border (see table 5(b), Annex II). Indeed, while this instrument has its roots in a pre-Schengen political order, it has been upheld in post-Schengen EU legislation (e.g. Return Directive), albeit lacking legal guarantees required otherwise. Not being obsolete as a normative reference is one thing. Not being an obsolete social practice is another finding. Fast-track readmissions have gained renewed salience as a governmental measure to counter so-called unauthorised "secondary movements" of persons not yet registered in Eurodac. While these practices are frequently not listed amongst police cooperation instruments, findings highlight that they do require cooperation to become real. Contrary to a positively connotated "cooperation", officers viewed readmissions as contentious cross-border interactions with different opinions, and potential noncollaboration between neighbouring police. Despite the formal easing of criteria and the amplification of evidentiary elements for readmissions in the 90s - identified as having hampered the effective application of these bilateral administrative procedures -, fast-track requests can be denied and are deemed dependent upon a good rapport between police forces. Joint patrols along entry routes also serve - and were at times set up with the explicit aim - to lessen this crossborder struggle.

(Joint) border-area patrols interact with fast-track readmissions, but also, for example, with

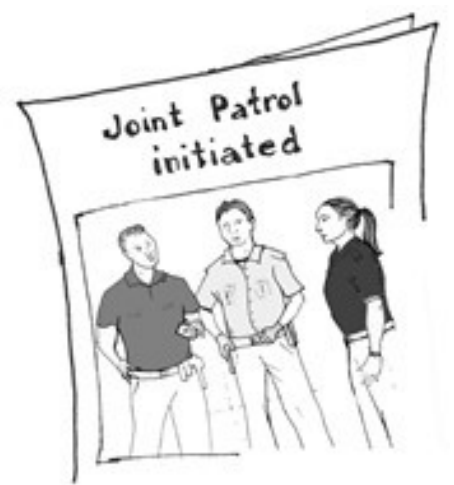
regulations of the Schengen Borders Code (SBC). Mobile checks are the physical manifestation of the "concept of the mobile frontier" formulated in the 90s that led to the legal institutionalisation of border-area checks to be carried out in the absence of systematic border-line control. In this thesis I proposed a differentiation between three generations of such mobile border-work. Whilst joint patrols are largely valued for fostering trust and enabling enhanced cooperation between neighbouring police forces (see also DCAF 2013), empirical data contemporaneously showed a semantic shift in the "ethos of a 'joint task'" (Haahr and Walters 2005, p.107), when officers reflected upon joint patrolling for migration 
control purposes. Overall, it was however their representational and symbolic value as "European patrols", that was given most weight. Beyond the topic of migration policing, joint patrolling as a modality of joint operations provides insights into transformations at the heart of the political order, as they concern the politically sensitive issue of executive or auxiliary functions attributed to officers operating outside their territorial national jurisdictions.

Joint centres (or Police and Custom Cooperation Centres, PCCCs) have become important agents

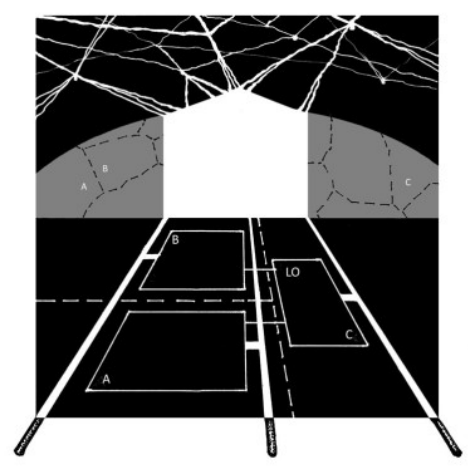
within the landscape of cross-border police data mobility. Whilst the primary channel for cross-border exchange leads through the central level SPOCs (Single-Point-Of-Contact), plural legal constellations enable PCCCs to facilitate formal and direct information exchanges in specific circumstances (borderregions, urgency requests). Despite being geographically and legally placed at states' outskirts, PCCCs play an important role

in facilitating cross-border information exchange, also beyond their primary border-area jurisdiction, and at times beyond their criminal-police remit. This spatial and functional extension becomes less of a "paradox" (Maguer 2004) when explained through the interdependency between the meanings officer attribute to their job (service providers, speedy information, complementing and not substituting historically and personally grown cross-border contacts, etc.), the role of the 'service demand' side, and the unequal landscape of formal policeinformation exchange, conditioning what information can be moved across national borders, by whom, and when. Albeit further research would be needed for a more detailed understanding, data from three centres indicates that even if centres are primarily engaged in criminal police information exchange, they also participate in the "technical landscapes of control and surveillance" (Paasi 2001, p. 63) of border- and migration-control.

\subsubsection{Policing mobilities in the border-strip}

Police cooperation is usually defined and frequently analysed by scholars as an "interaction" (Lemieux 2010b). Findings showed how, in practice, CBPC concerns mobilities and (im)mobilityregimes. With regards to the three instruments discussed, we have a) the mobility of data, facilitated by joint centres; b) the mobility of officers beyond their territorial jurisdictions, as in joint operations; c) fast-track readmissions, enabling a forced removal of third country citizens across internal Schengen borders. Whilst researchers in the field of global criminology, border criminology and policing have engaged with the "transnational policing of mobility" (Aas 2011, Bowling and Sheptycki 2014), further understanding can be gained by paying attention to policing-mobilities, i.e. the legal (im)mobility regimes and mobility practices of police work itself. Approaching police cooperation through practices and their spatial-legal regimes, called for an 
analytic engagement with what policing scholars have described as the "fragmented legal terrain" (inter alia Sheptycki 2001) of police cooperation (see 9.2.2).

The border-strip, or "border-area-strip", in turn, is an emic term used by police-officers, an area

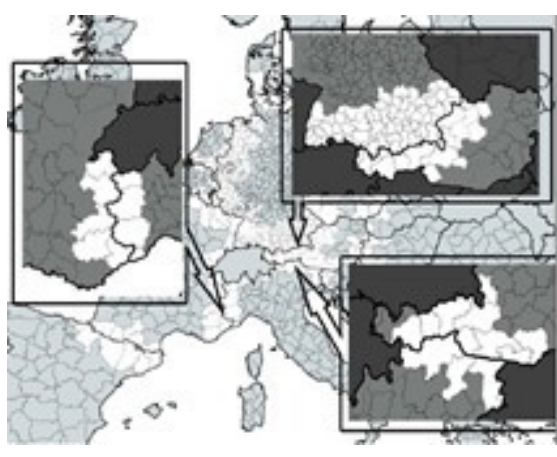
on a map, as well as a legally codified space, i.e. "space-inlaw" (Delaney 2003). Bilateral police cooperation agreements between member states that share an internal border codify the adjacent territories, thereby drawing on previously demarcated administrative territories. Here police authorities can engage in special forms of cooperation, those of CBPC. The rights and obligations of officers engaging in cross-border activities are agreed upon bilaterally by the signatory countries 'sharing' the border. The bilateral agreements vertically interact with the national police laws of the signatory parties and with relevant EU law. Border-strips, each with a bilaterally configured particularity, run throughout Europe. This is an interesting form of horizontal pluralism, not one between different state laws, but between different bilateral orders. The particularities of what can be legally done in the border-strip with one neighbouring country is not 1:1 compatible with what the same country can do in the border-strip with the other neighbouring country, as discussed for hot pursuit, joint patrolling and in information exchange. The border-strip is also "law-in-space" (Delaney 2003) and the practices of police agents contribute to the production of this space and the production of spatial-political ordering of the EU.

In my work I therefore conceptualise and analyse CBPC as policing-mobilities in the border-strip. In policing scholarship CBPC denotes a specific 'level' of police cooperation, usually differentiated from central- or EU-level cooperation. We have seen elements of both continuity and change regarding what over time this level of police cooperation and governance is formally enabled to do, or does within the grey zones of interlegality. I argue that we can analyse aspects of this process as one of re-scaling, a notion proposed by Smith (1992; 2003; see also Brenner 2004) as a concept to analyse processes whereby social interaction is re-organised on a different scale. One can think of the processes leading to the spatial and functional extension of PCCCs work, following the spatial-legal scale-fix of the border-area-strip for CBPC, and of some current experimental practices attempting to reorganise some information exchange on asylum matters through PCCCs; or, on the very dynamics through which struggles regarding the reform of European asylum policy becomes re-scaled - downscaled - when enforced through social interactions of substate police officers and their diplomatic capabilities. Expressions such as border-strip "diplomacy", discussed with regards to readmissions, or that of "service provision" in the case of PCCCs, allowed to analyse in this thesis how meanings and (interpretive) practices 
of "local agents" (Blomley 1994) - borderland police officers - together with the spatial-legal conditions of possibilities of border-area jurisdictions, contribute to rendering inner-European border-areas an attractive scale for transnational governance.

\subsubsection{Proliferation and interaction of legal regimes}

I began my thesis by juxtaposing a quote from an officer who highlighted how different legal regimes interact in complicated ways that matter for police work in the border-region, with a passage from a legal scholar writing in the $19^{\text {th }}$ century, thereby suggesting that despite many noteworthy historical developments, policing challenges in the "disreputable area" of alien policing (Ackermann 1856) - and certain (un)diplomatic conflicts surrounding fast-track readmissions - are not necessarily a historical novelty. As multiple fieldwork examples discussed in this thesis showed, not only police and criminal law, but also immigration, international protection, and Schengen regulations are at stake when policing the border-area. My discussion of the preliminary rulings of the Court of Justice of the European Union showed that plural normative regimes interact when it comes to policing the border-strip and I explained how they have been negotiated by courts. However, this study emphasised that plural (legal) orders and wider border-struggles are actually negotiated on a daily basis through policing practices. Therein, the policing of migration at internal borders - the famous 'how' question of migration and border control (Weber and McCulloch 2019; Van der Woude 2020) - often intersects little with interpretative or normative criminalisation, but rather takes place through negotiations between multiple (legal) orders and, in a very pragmatic sense, through cross-border police cooperation.

Scholarship in the 90s highlighted an increased institutionalisation of CBPC which had emerged in the context of an initial legal void or grey area, and the role of (experimental) policing practices therein. Regulation has proliferated even more so with EU legislation in the field of Area of Freedom, Security and Justice and is said to have hampered "legal certainty". Today CBPC is embedded within hyper-legalised and multi-normative spaces. I proposed legal pluralism as a framework to analytically engage with, but also to go beyond, what in policing scholarship has been described as the "fragmented legal terrain" or "patchwork quilt" of police cooperation (inter alia Sheptycki 2001, p.153). Rather than being a merely descriptive notion and classified as "absence" of a legal framework (den Boer 2018), legal pluralism captures a multiplicity of elements that de facto and de juris constitute police cooperation. Interlegality (Boaventura-deSousa 1987) as a midlevel concept allowed me to engage with complex negotiations of plural legal orders in the border-strip.

Additionally, the focus on specific policing instruments such as joint patrolling or joint centres allowed me to highlight their role in the production of the Schengen space and its ongoing expansion. As pointed out by legal anthropologist engaging with temporality and space, the "EU 
space throws its legal shadow ahead" (Benda-Beckmann and Benda-Beckmann 2014, p.34). This point becomes even more intriguing when analysed in the political field of so-called "internal security", particularly the AFSJ. A focus on the regulated freedoms of mobility of police personnel showed 'externalisation' also within the European space, as well as processes through which this space is internalised beyond its mobile external border.

I therewith argue that the Area of Freedom, Security and Justice is a space signed by plural legal orders of varying scales and policy fields, within which policing practices negotiate (legal) orders on a daily basis through practice and (inter)actions. Therein, the border-strip provides a spatiallegal configuration that both enables and constrains the exercise of these policing powers and of similar policing-mobilities, such as hot pursuit or cross-border surveillance. Additionally, it also enables specific powers for the policing of mobilities. As Valverde pointed out "deciding who governs where - the basic jurisdictional question - is not only important in itself but also has the effect of determining how something is governed" (2014, p.382). Policing powers within the border-area jurisdiction, enabled through plural spatial-legal constellations that provide specific policing powers in the border-strip, can in their practice temporally assemble and produce bordering effects. These policing-mobilities have become increasingly involved in responses to so-called "secondary movements".

\subsubsection{Playing "ping-pong" with the "hot potato"}

"Playing ping pong" and "the hot potato" were two related metaphors that some police interlocutors employed to depict the interactions and ways the officers and jurisdictions deal with the phenomenon of "secondary movements", captured in the second metaphor, the "hot potato": namely, to pass it on. The "hot potato" depicts a larger issue at stake, but it is also embodied in the bodies of unauthorised border-crossers. 'Passing it on' is inscribed into a plurality of migration control logics and practices, which in their plural effects have one common - albeit not the only - denominator: dislocation.

Whilst the hotspot approach at the EU's external borders was the most 'visible' response to reinforce the Dublin system, this study showed how (intensified) border-area control and fasttrack readmissions were a way in which member states respond(ed) to onward mobilities on intra-European borders, besides the more politically contentious introduction and maintenance of border control. Drawing on Walters' midlevel concept, I argue that these movements have become viapolitical (2015a). Especially from 2014 onwards, along certain routes and bordersections, border-area patrols were intensified, readmission requests peaked and CBPC was strengthened. Notably, what had initially been national and intergovernmental responses became embraced on an EU level. While some of the interviewed officers called for a "European answer" instead of border-strip policing and the "ping-pong" game, one of the European answers 
has been precisely to endorse and enhance this intergovernmental scale and policing response in the enforcement of asylum policy.

In this study I have addressed in depth dynamics of the "ping-pong" game and border-struggles in the encounters of security and migration. Empirical findings and analysis of micro-level practices and dilemmas, 'discretion' and ground-level politics cannot be analysed separately from the broader historical-political context within which they, and their multiple effects, unfold. Indeed, what the EU Agenda on Migration (COM(2015) 240 final, p.2) described as a "difficult balancing act" between a political union, economic prosperity, border protection, fundamental rights and rule of law is a macro-level border-struggle that is embodied and negotiated in these micro-level practices.

Therein, I have highlighted inter alia that even though border control and border-area control are politically (and in principle, legally) very different measures, my findings showed that there is an increasing approximation between the two measures. Albeit carried out under different conditions of possibility, both types of control take place as control practice through what I analysed in depth as "spot [and] check" within broader border-struggles. Not frequency and intensity, but how the border takes effect (denial of entry / readmissions) are distinguishing features. Border-area control with the objective of countering irregular migration, coupled with an expectation of effectiveness, is not void of contradictions and interlegality conflicts. Policing micro-practices shed light on the negotiation of a plurality of conflicting (legal) orders.

While migration-policing is often analysed as separate from the broader operational contexts and policing fields, I underlined the analytical necessity and value of not extrapolating the policing of migration from the broader policing practices in the border-strip and the meanings officers attribute to their work. Complementing the well known concept of securitisation of migration, I have proposed migratisation of security to refer to a process wherein policing instruments are increasingly deployed in the control of unauthorised mobilities, and as a means to analyse responses of normalisation as well as of resistance from within the field of security practitioners. Responses of resistance, at times coupled with explicit reflections upon "democratic policing" and "police identity" by police officers, were particularly brought to the fore when "governing through migration control" (Bosworth and Guild 2008) occurs via police - the (state's) beholder of legitimate violence - enforcement of asylum policy. I questioned the axiom or assumption that security knowledge necessarily securitises migration, by drawing analytical attention to the ways security knowledge has at times been mobilised in resistance strategies or provided a viewpoint for alternative problematisations (and solutions). Such testimonies can be read as a positioning within the unequal landscape of the Dublin order, or as expressing the interests of police unions, but they are also connected to values officers attribute to their job and regarding their 'police 
identity'. This is not a homogeneous identity and normalisation seemingly prevails: not least, since migratisation of security can foster policing possibilities in other fields.

In my analysis of border-struggles I argued that policing-mobilities are deemed capable to provide a mediating solution to the "control dilemma" of how differential and unequal mobility rights and immobility prescriptions, coupled with a neoliberal rationality of the freedom of circulation, could be legally enforced within conditions of abolished border control. But they have also emerged as envisaged scale of response deemed able to provide a "spatial resolution" (Smith 2003) for struggles between contradictory social forces, which play out in the "balancing act" surrounding the reform of the Dublin and Schengen System. The "ping-pong" game at an inter-governmental micro-level cannot be analysed separately from conflicting forces epitomised in the political impasse in the co-legislative reform of the Dublin system. Struggles however do not only regard the Dublin-order and by extension the Schengen regime, but the political life of the EU order, within which the "safeguarding of internal security" is a member state responsibility not affected by the AFSJ. The Commission's recommendation and the embracement of intensified border-area measures across most EU stakeholders is a quid pro quo not irrelevant to the objective of securing the political form of a 'Union': potentially reducing the exercise of member state prerogatives through border control at internal Schengen borders by, in turn, amplifying prerogatives of national border-area policing powers.

In my analysis I have operationalised the concept of "border-struggles". This concept has been used by scholars to analyse conflicting power dynamics inherent in borders in what are often separate fields of research and objects of study: e.g. Autonomy of Migration scholarship focusing on border crossing/enforcement (Mezzadra and Neilson 2013), critical security studies addressing struggles of the (in)security-field (Bigo 2006), EU law scholarship addressing border disputes between Union and national law or competencies (Moorhead 2014). The findings of this study would certainly allow for a further reflection back into these fields of studies. Additionally, several situated fragments in this study indicated, that while reinforced controls ultimately do not cancel out the reality of people from crossing the border and rather displace trajectories, they do shape the conduct of 'unauthorised border crossers' and the conditions of possibility to do so undetected. The relation and dynamic between "secondary movements", border-(area)measures and intra-European "migrant-smuggling", as well as police and judicial cooperation in this field, call for further research.

\subsubsection{The "concept of the mobile frontier" and three generations of borderwork}

Related to the "concept of the mobile frontier", which was formulated in the 90s during the Schengen implementation process, my findings allowed for a differentiation between three generations of border-area "compensatory measures" under conditions of abolished border-line 
control: mobile border-area control ( $1^{\text {st }}$ generation), joint mobile border-area control along entry routes $\left(2^{\text {nd }}\right)$, and joint mobile border-area control along exit routes $\left(3^{\text {rd }}\right)$. Border-work through border-area control carried out in the field of migration policing can interact with the instrument of fast-track readmission. Joint centres contribute to this assemblage, as border-area controls constitute a potential demand side: while the movement of bodies across borders can slow down, the speed of the virtual ID increases.

Three developments must be pointed out, which are indicative of the ways that internal borders are being reconfigured within the border-struggles analysed in this thesis and played out in the border-strip, and how the latter impacts on ongoing reconfigurations of Union law and of the EU order. 1) The increased juridification of border-area policing practices through case law of the Court of Justice of the European Union (CJEU) has had the effect, on the one hand, of introducing legal limits and, on the other, of legally enabling and anchoring, and thus legitimising, borderarea control for immigration control purposes. 2) The so-called "intensification" constitutes a quantitative reconfiguration of border-area policing. While I agree that the "proportionality test of national police checks is in hands of the Commission and has been 'Europeanised' within the Schengen governance framework" (Carrera et al. 2018, p.5), the meaning of "Europeanisation" denotes a process in which member states use, and are invited to enhance, their national powers and prerogatives in the border-strip. 3) Second- and third-generation experiences have proliferated and were aimed to be enhanced within the Schengen space and across the WesternBalkan countries: they produce a qualitative reconfiguration of border-area measures.

Two findings may summarise the more detailed exposition in this thesis. On the one hand, intensifying (joint) border-area controls opens the path to a so-called "grey area" between border control and border-area control: paraphrasing several police informants, that is an area in which one can move, as long as one is careful not to cross into a few clear no-go-areas. On the other hand, the shift towards joint patrolling comes with the possibility to facilitate fast-track bilateral readmissions and to shift the logic and temporality of migration policing by aiming to intervene before a border-crossing. According to empirical findings, second-generation measures can facilitate smooth fast-track readmissions with patrolling officers becoming witnesses or 'bodies of evidence'. Third-generation measures aim to intervene not after the fact but upon a future reality. By aiming to prevent or 'cancel out' a potential unauthorised border-crossing, the border control objective is clear.

From an analytical point of view, the differentiation of three generations of border-work benefitted from attention towards routes and vehicles as proposed by scholars interested in viapolitics and governmentality, combined with an attention towards space and law in an analysis of interlegality as developed in legal anthropology. Space and law emerged as crucial elements in 
this study, which should not surprise, considering the importance of territorial jurisdiction for police work. Governmentality scholars have interpreted the (internal) Schengen regime as a shift from judicial-territorial sovereign power (border control) towards a biopolitical rationality of population control through de-territorialised filtering functions. When scrutinised as space-inlaw and law-in-space, the practices of the latter are but a reconfiguration of sovereign power and territorialisation (see below). As we saw, CBPC instruments in the border-strip are themselves not a fixed tool to be simply 'activated'. They are signed by ongoing reconfigurations in the interdependence between context based experimental practices and their legal anchoring. Therein we see instances of the constant experimentation, repair-work and adjustments of government, whereby through crisis novel constellations of power may emerge.

\subsubsection{Ongoing reconfigurations of power and governance}

My distinction between three generations of border-work additionally allows to foster understanding of ongoing reconfigurations of power and governance. Notably, in the very same space and policy field - police cooperation - multiple and different expressions of political order(s) and understandings of borders, territory and sovereignty are actualised. By drawing on scholarship relating to law, space and temporality, I analysed how 'old' and 'new' orders interact, including in processes of "Europeanisation" (within the European space). Their associated understandings of sovereignty and territory co-exist in the border-strip. Fast-track readmissions (pre-Schengen), mobile border-area control and hot pursuit (Schengen), as well as joint patrolling (post-Schengen) are practiced at the same time, in the same space, and often by the very same officers. But the instruments bear the signature of their 'times'. Combining empirical data with a study of long-term developments, I outlined in this thesis how these instruments and practices are each (and in their assemblage) entangled with historically contingent projects of freedom of movement and politics of mobilities within European contemporary history. Schengen is but one of them. Police cooperation is thus a strategic entry point for engaging with large-scale processes of change and of continuity in transformations of governance and power within what today is the political and legal order of the EU. I conclude with two theoretical points.

While the spatial-legal configuration of the border-strip has played an important role in the institutionalisation of border-areas for police cooperation purposes, the role of territories is frequently overlooked in analyses that focus on networked-cooperation or flows. Agnew, known also for his critique of the "territorial trap" (1994), himself specified that the binary opposition of "a world of flows versus a world of territories" $(2009$, p.33) is misplaced. Police research allows, and requires, revisiting these debates. For example: PCCCs can pull the "red thread" - the PCCC network connections - through the condition of 'enabledness' grounded in the territorial "border(area)strip" jurisdiction. The border-strip is 'below' the central level, but by comprising 
territories from both sides of an inter-state border, also beyond it. Centres are located inside the territory of one hosting state and the "thread" connects sites across the EU and beyond. In the example of Liaison Officers, we saw that the relations and social interactions produced in the information exchange room can create a landscape of social and spatial relations that indeed has no geographical territorial correspondence of vicinity. Likewise, as we saw, joint patrolling enables the exercise of power outside the national territorial jurisditcion: agents are not enforcing state law over their state's territory, but the practices of officers in the interaction with their counterparts produce a local and temporary effect of power 'at-a-distance', thereby also enforcing EU law. These are pockets of a slightly different territorialisation of Europe, working through the territorial-jurisdiction of the bilateral border-strip.

This is not a purely theoretical point: as findings of this thesis highlight, spatial configurations (spatial-legal territorial jurisdiction and network) as well as temporal ones (urgency in information requests, and temporal limits in readmissions and pre-readmission administrative detention) enable speedy practices that can move data and (re)move third country nationals across borderstrips without passing central or supranational checkpoints, as in the case of chain-requests or chain-readmissions.

Bilateral fast-track readmissions are practices in which different actors have simultaneously mobilised 'the law' to challenge as illegitimate certain features or the practice as a whole and invoked 'the law' to highlight its legality. In this thesis I suggest that fast-track readmissions are rooted in what is an exercise of territorial sovereignty (prior "denial of entry"). However, in conditions of abolished border control, this practice became dependent upon cooperation in readmission and thus in need of "good neighbourliness" to be effective. Fast-track readmissions combined with border-area control - the "mobile frontier" - became the 'ordinary' frame for governing differential mobility rights in the absence of border-line control. Readmissions today directly or indirectly also interact with 'new' orders, such as the (multilateral readmission agreement of the) Dublin Regulation in the field of asylum law, and with 'new' instruments, like those of operational police cooperation. Regulation of joint patrolling - today also anchored in EU law as one form of joint operations (Title V, Prüm Decisions, rooted in the prior multilateral Prüm Convention) - shows ongoing re-appropriations between different scales of law, dealing with the sensitive issue of executive or auxiliary functions attributed to officers operating outside their respective territorial jurisdictions. When attending to the meanings officers attributed to joint patrolling, empirical data showed on the one hand the symbolic and representational value, as well as an appreciation of joint patrolling as a means of fostering trust and direct relations. On the other hand, however, lived experiences of joint patrols employed in migration control were also represented as a practice of "witnessing" and "control". "Disaggregated sovereignty" 
(Slaughter 2004; Aas 20012) allows one to account for a reconfiguration of sovereignty through legally anchored 'participation' or 'cooperation', such as those of Schengen police cooperation instruments enabling "horizontal cooperation". However, this concept needs to be supplemented by what may be better conceptualised with Gazit (2009) as "fragmented sovereignty", addressing not only the legal attribution but the practical exercise and the lived experience of powers exercised beyond a force's (state's) territorial jurisdiction. In situations of fragmented sovereignty, according to Gazit, the 'state' does not enforce political control, but its ground-level agents operating outside its jurisdiction and within a certain autonomous space of agency.

Whilst engaging with the usefulness of Bosworth and Guild's (2008) concept of "governing through migration control" and moving beyond a nation-state framing, I also asked how to take account of configurations in which borders have become mobile and are patrolled jointly by the public police forces of multiple states. Notwithstanding the introduction of new activities of EU agencies and particularly in the monitoring of "secondary movements", in the border-strip the inter-governmental response has prevailed. Whilst joint patrols are often set up in the interest of states aiming to counter entries, they notably also enforce EU law, i.e. the 'Dublin order of things' and related immobility prescriptions. Thus, bilateral patrols likewise enforce, protect, produce this spatial-legal order of a sovranational form of political life: first and foremost symbolically, but, as we saw, not without practical effects, such as the disruption and dislocation of unauthorised trajectories.

In particular third-generation measures of joint patrolling along exit-routes thus require revisiting both functional and tactical considerations regarding police work and go to the heart of emerging transformations in governance. They concern the performance of powers beyond a state jurisdiction, enforcing EU legal orders alongside others. They could well be experimental practices 'anticipating' a potential legal extension of executive powers in bilateral and EU legal orders. An interpretation in hypothetical terms: while retrospectively legalising some dynamics of fragmented sovereignty encountered in this study, this would be an extension in a sensitive political field. Engaging with future EU developments, one can recall again the LEWP discussion (prompted by the Commission recommendation on "alternatives" to border control) and proposal for a future discussion upon the Prüm Decisions, which currently do not prescribe executive functions for joint operations, or the intended reform of the Schengen Borders Code, aiming to enhance police checks in the border-strip and throughout the territory, thereby intending to refine the powers and measures to be applied. Here we see the value of a study through (Wright and Reinhold 2011) research strategy, that moves back-and-forth and up-anddown between sites and actors and between qualitative research data and document sources. It enables to inquire what the present may produce (p.102). A potential fostering of policing powers 
in 'cooperation' is not restricted to migration policing, which gives insights into the productive effects of a migratisation of security. However, migration policing is but one operational field and further research into other fields of joint operations would be necessary before making such a claim. The border-strip has demonstrably played an important role in the experimentation of new formations of power, and future developments of law-as-text require attention.

\subsection{POLICY RELEVANCE OF FINDINGS}

In my study, I have taken account of processes and dynamics between (experimental) practices (law-as-practice) and ongoing developments in the realm of legislative and policy making processes (law-as-text). From the findings of this study emerges a mobile and shifting legally configured border: first that of the 'border-as-line' and subsequently that of the 'border-as-space' through the "concept of the mobile frontier". This ongoing reconfiguration also led to the spatial extension of some policing-mobilities (on a bilateral level), that were initially legally allowed only close to the border through the specific spatial-legal construction of the border-zone, and which have been further legally 'deepened' into the territory (for example in hot pursuit, or by extending joint patrolling beyond a prior kilometre restriction to the whole border-region). The analytical insights into the rescaling processes and of scale politics assessed with regards to PCCCs should not be considered as irrelevant to the other instruments analysed. From a conceptual point of view, the realm of "legal-geopolitical practice" is also one of political action (Delaney 2003): linked to the politics of space and the formation of political order. At times, as discussed in this thesis, anticipatory experiments that can lead to novel forms of governance and power. These findings are of relevance for ongoing EU policy and legislative developments, such as the Schengen Borders Code, the Common European Asylum System policy, or the Return Directive.

The Commission's New Pact on Migration and Asylum (COM(2020) 609 final) was released a few days prior to submitting this dissertation and not included into this study. The proposal has, however, not overcome in principle the shortcomings of the Dublin system and the first country of entry criteria, albeit it did enhance inter alia recognition of family ties. It indeed emphasises "solidarity" in the field of returns. In its general note, the Commission reiterated that alternatives to internal border controls are to be found e.g. in police checks and it was more explicitly argued that bilateral readmission agreements between member states could be more effectively implemented (COM(2020) 609 final). Notably and importantly, in the Pact, "secondary movements" is exchanged with the formulation "unauthorised movements, both of asylum seekers and of migrants who should be returned" (p.14). It broadens the scope of (targeting) mobilities deemed to put the well-functioning of Schengen at risk. 
I am aware that the ongoing legislative proposals are many and interrelated. In addition to the points made in the prior section regarding police-cooperation instruments, three concise points shall nevertheless be made:

1) The recast of the SBC will seemingly be addressed by a new Schengen Forum and the Commission foresees to present a "Strategy on the future of the Schengen area of free movement" including "solid alternatives to border controls". These reforms require close attention, especially for amendments to the rules on internal borders and within the territory. Regarding the previously leaked intentions of envisaged changes (Anonymous [leaked] 2019, p.99): these changes are not minor. While CJEU case law contrasted the "fiction of non-entry" during temporary internal border control, a new fiction - maybe this time anchored in EU law - might be in the making: the fiction of abolished border control.

2) The Return Directive recasts should consider current art. 6.3. which maintains bilateral readmission mechanisms in force prior to 2009 and anchors them - and thus fast-track procedures - through inter-textuality in EU law. Notably, in the 2020 Pact the Commission highlighted that "[a]t the moment, readmission agreements also remain between Member States which could also be implemented more effectively" (ibidem, p.15). With "at the moment" it is not clear if this is a reference to the recast of the Return Directive, or if changes to the SBC - aimed to enhance policing powers - or in police cooperation will render readmissions less attractive to the extent that under renewed conditions authorities might be able to apply stronger measures. Indeed, the extension of scope (p.14) as well as the notion of "solidarity in returns" reflects a trend also encountered in the field, aiming to reduce one aspect of the "ping-pong game": officers in one country explicitly highlighted that rather than engaging in bilateral fast-track readmissions of non-asylum seekers or persons without permission to stay in the EU, the government strategy has shifted towards enforcing the deportation of the concerned persons, not back to the EU country from where they entered, but outside Europe.

3) For the reasons outlined and not reducible to ground-level dynamics, intensified border-area police-checks for the purpose of migration control, coupled with an expectation to do the same job or even a better job than border control, appears to be hard to reconcile, if not outright incompatible, with the usual reference to invoked guarantees.

In addition, however, both "secondary movements" and enhanced CBPC and intensified borderarea checks are symptomatic of the pitfalls of the Dublin system and the political impasse in the co-legislative reform of the Dublin Regulation. As such a call for alternatives to border control to counter "secondary movements", is already expressing a future imaginary of failure. I am compelled to say, that a political agreement on finding a so-called balance between 
"responsibility" and "solidarity" by introducing a different mechanism than that of first-entry, might redefine the allocation of "responsibility", but the "ping-pong" game and internal borders are reproduced as a supposed scale of response. The crucial question to be addressed is rather how much decision makers will be willing to create a system that also considers asylum seekers' links and perspectives. And if not, how much are member states and Europe (its legislative and judicial components, and the electorate) aiming and willing to resort to coercive means. Police enforcement of asylum policy - as we saw for example in the discussion on "proportionate" use of force in fingerprinting for Eurodac purposes - brings forward a core dilemma of 'justice' in the realm of the law and of policing under liberal democracy.

These ongoing legal-geopolitical practices in interaction with emplaced (experimental) policing practices shape the spatial-legal and political European order, the meaning of policing in liberal democracies, and they territorialise the AFSJ. One question frequently expressed by officers across these chapters, was also "what is it that one wants?", i.e. what direction does 'Europe' and its member states want to take? Despite the challenges of everyday police cooperation in the field of migration control, in which the representation of an ethos of a joint task was expressed by one officer, literally, as the set-up of an "illusory world" (IV_RL-HLO), it still seems easier to cooperate in policing at this scale, than cooperating on asylum through high-level political processes. It has not only a symbolic but also a productive effect. When the "domino game" is played through disaggregated and fragmented sovereignty, it tends to shift responsibilities outwards and transforms what is deemed morally wrong at the centre into 'justice in the realm of the law' to be enforced at the outskirts. Borders, as phrased by de Genova, lead us to the heart of the question of Europe (2019), but also of its unequal moral geography and beyond its territorial external borders.

During a conference at an early stage of this study, I had a coffee-break conversation with a central-level border and coast guard. Although emphasising that I worked on a study on police cooperation across internal EU borders, he insisted that if this was the topic of my PhD study, I needed to investigate cooperation with North Africa. While my presence at a Coast-Guard conference indicates a certain interest in matters beyond the internal Schengen border, at the time I did not expect to find the Schengen-bus, depicted in chapter 5, touring beyond one of the other external borders of the EU Schengen space. Despite the bus moving through a different geopolitical area, the officer was closer to the point than at the time I expected. Not only, as occasionally pointed out in this study, do struggles taking place within the "fourth tier" of the IBM model produce effects across the other and externalised tiers of border management. Also there, spatial-legal configurations and interlegality matter. The officer localised the strategic border of internal security to be 'crossed in cooperation' way South of Europe's external borders. 


\subsection{FINAL REMARK}

In this study, I highlighted the value of paying analytical attention to the spatial-legal dimension of police cooperation, re-conceptualised as policing-mobilities in the border-strip, and to dynamics between law-as-text and law-as-practice. I argued that this provides a fruitful approach at the crossroad of social science and law to analyse forms of policing within mutating "forms of political life" (Andreas et. al 1995) in an epoch, as pointed out by Comaroff (2013, p.xix), still struggling to define itself. The analytical framework of policing-mobilities in the border-strip can prove productive also beyond this particular case study: for the analysis of joint operations and of police cooperation in other fields, or in the analysis of other spatial-legal configurations enabling border-work beyond the border-line.

Finally, from a research perspective, I think there are challenging but exciting times ahead for police research, with enhanced policing-mobilities in several fields. Regarding legal migration and international protection, there is little spatial-legal enhancement of mobilities in sight and the horizon to investigate seems rather grim. This study has also sparked two broader interrelated questions: On the one hand, to which degree is 'sensible information to be treated as classified' indicative of a type of governing through migration control and through the means of security, in which the public sphere is potentially viewed not as an aspect of the democratic order, but as a fundamental risk? And on the other hand, what does it mean and do, when that same public sphere, divided over what the problem and solution is, favours the governing of migration and asylum through policing and thus contributes redrawing the boundaries of 'accepted' use of force in democracies? Lastly, this shift is officially justified in the name of guaranteeing not only the (economic) Schengen space of freedom of movement, but specifically the speed of circulation of EU citizen. 


\section{BIBLIOGRAPHY}

Note: if not otherwise specified, links were last accessed on 10/10/2020.

\section{Publications}

Aas, K.F. (2007). Globalization \& Crime. London: SAGE Publications Ltd.

Aas, K.F. (2011). 'Crimmigrant' bodies and bona fide travelers: Surveillance, citizenship and global governance. Theoretical Criminology 15:331-346.

Aas, K.F. (2012). (In)security-at-a-distance: rescaling justice, risk and warfare in a transnational age. Global Crime 13:235-253.

Aas, K.F. (2013). The ordered and the bordered society: migration control, citizenship, and the northern penal state. In: Aas, K. F. and Bosworth, M. eds. The Borders of Punishment: Migration, Citizenship, and Social Exclusion. Oxford: Oxford University Press, pp. 21-39.

Aas, K.F. and Bosworth, M. eds. (2013). The Borders of Punishment: Migration, Citizenship, and Social Exclusion. Oxford: Oxford University Press Online [online]. Available at: https://oxford.universitypressscholarship.com/view/10.1093/acprof:oso/9780199669394. 001.0001/acprof-9780199669394.

Aas, K.F. and Gundhus, H.O.I. (2015). Policing humanitarian borderlands: Frontex, human rights and the precariousness of life. British Journal of Criminology 55:1-18.

Ackermann, C.A. (1856). Repertorium Der in Das Gebiet Der Fremdenpolizei Einschlagenden, Im Großherzogthum Mecklenburg-Schwerin Geltenden Gesetzlichen Vorschriften Über Paßwesen, Verfahren Gegen Landstreicher Und Bettler, Staats- Und Ortsangehörigkeit, AusLieferung von Verbrechern, Auswanderung, Gewerbebetrieb im Umherziehen u.s.w: 2012th ed. Schwerin: forgotten books.

Aden, H. (1998). Polizeipolitik in Europa. Eine Interdisziplinaere Studie Über Die Polizeiarbeit in Europe Am Beispiel Deutschlands, Franksreichs Und Der Niederlande. Opladen/Wiesbaden: Westdeutscher Verlag GmbH.

Aden, H. (2001). Convergence of Policing Policies and Transnational Policing in Europe. European Journal of Crime Criminal Law and Criminal Justice 9:99-112.

Aden, H. ed. (2015). Police Cooperation in the European Union under the Treaty of Lisbon. BadenBaden: Nomos Verlagsgesellschaft.

Aden, H. (2017). Cooperation among Security Agencies in the European Union: Europeanisation of Public Administrations in Just Another Variation? Paper for the 15th Biennual EUSA Conference, Special Interest Section on the AFSJ, Miami (FL), May 4-6, 2017 [online]. Available at: https://www.eustudies.org/conference/papers/download/505.

Albanese, J.S. and Reichel, P.L. eds. (2014). Transnational Organized Crime: An Overview from Six Continents. Los Angeles: SAGE.

Amicelle, A. et al. (2017). Criminology in the face of flows: reflections on contemporary policing and security. Global Crime 18:165-175.

Amnesty International (2016). Hotspot Italy. How EU's Flagship Approach Leads to Violations of Regugee and Migrant Rights [online]. Available at: https://www.amnesty.org/en/documents/eur30/5004/2016/en/.

Amnesty International (2018). Francia: Amnesty International Denuncia Violazioni Sistematiche 
Alla Frontiera Franco Italiana, 17 Ottobre 2018 [online]. Available at: https://www.amnesty.it/francia-amnesty-international-denuncia-violazioni-sistematichealla-frontiera-franco-italiana/.

Anderson, M. et al. (1995). Policing the European Union. Oxford: Clarendon Press.

Anderson, M. and Bigo, D. (2003). What are EU frontiers for and what do they mean? In: Groenendijk, K., Guild, E. and Minderhoud, P. eds. In Search of Europe's Borders. The Hague, London, New York: Kluwer Law International, pp. 7-45.

Anderson, M. and den Boer, M. eds. (1994). Policing across National Boundaries. London, New York: Pinter Publishers.

Anderson and Malcolm (1989). Policing the World: Interpol and the Politics of International Police Co-Operation. Oxford: Oxford University Press.

Andersson, R. (2014). Illegality, Inc. Clandestine Migration and the Business of Bordering Europe. Oakland California: University of California Press.

Andersson, R. (2017). From radar systems to rickety boats: Borderline ethnography in Europe's 'illegality industry'. In: Elliot, A., Norum, R. and Salazar, N. B. eds. Methodologies of Mobility: Ethnography and Experiment. New York: Berghahn Books, pp. 88-108.

Andreas, P. (2003). Redrawing the Line. Borders and Security in the Twenty First Century. International Security 28:78-111.

Andreas, P. (2009). Border Games: Policing the U.S.-Mexico Divide. 2nd ed. Ithaca, London: Cornell University Press.

Andreas, P. (2015). Illicit Globalisation Myths and Misconceptions. In: Mitsilegas, V., Alldridge, P. and Cheliotis, L. K. eds. Globalisation, Criminal Law and Criminal Justice: Theoretical, Comparative and Transnational Perspectives. Oxford: Hart Publishing, pp. 45-64.

Andreas, P. and Nadelmann, E. (2006). Polizing the Globe. Criminalization and Crime Control in International Relations. Oxford, New York: Oxford University Press.

Anonymous [leaked] (2019). DGx Proposed Priorities [online]. Available at: https://www.politico.eu/wp-content/uploads/2019/08/clean definite2.pdf.

Asad, T. (1997). On Torture, or Cruel, Inhuman, and Degrading Treatment. In: Kleinman, A., Das, V. and Lock, M. eds. Social Suffering. Berkeley: University of California Press, pp. 285-309.

Asad, T. (2004). Where are the Margins of the State? In: Das, V. and Poole, D. eds. Anthropology in the Margins of the State. New Mexico: School of American Research Press, pp. 279-288.

ASGI ed. (2015a). Far Away so Close. I/ Diritto Di Asilo Tra Accoglienza Ed Esclusione. Roma: Edizioni dell'asino.

ASGI (2015b). Le Riammissioni Di Cittadini Stranieri a Ventimiglia (Giugno 2015). Profili Di Illegittimita [online]. Available at: http://www.asgi.it/wpcontent/uploads/2015/07/Documento-Ventimiglia.pdf.

ASGI (2016). Le Riammissioni Di Cittadini Stranieri Alla Frontiera Di Chiasso: Profili Di Illegittimità [online]. Available at: http://www.asgi.it/wp-content/uploads/2016/08/ReportRiammissioni-Chiasso ASGI 31.8.16 def.pdf.

ASGI et al (2017). Lungo La Rotta Del Brennero: Un Rapporto Di Monitoraggio [online]. Available at: https://www.asgi.it/wpcontent/uploads/2017/09/2017 Report Monitoraggio Bolzano Brennero 25 09.pdf.

Atalay, S. et al. (2019). Ethno/Graphic Storytelling: Communicating Research and Exploring 
Pedagogical Approaches through Graphic Narratives, Drawings, and Zines. American Anthropologist 121:769-772.

Ausschusses für innere Angelegenheiten (2016). Bericht Des Ausschusses Für Innere Angelegenheiten Über Die Regierungsvorlage (996 Der Beilagen): Bundesgesetz, Mit Dem Das Asylgesetz 2005, Das Fremdenpolizeigesetz 2005 Und Das BFA-Verfahrensgesetz Geändert Werden. 1097 der Beilagen zu den Stenographischen Protokollen des Nationalrates XXV. $\quad$ GP. Available a https://www.parlament.gv.at/PAKT/VHG/XXV/I/I 01097/index.shtml.

Baker, B. (2016). Regime. In: Salazar, N. B. and Jayaram, K. eds. Keywords of Mobility. Critical Engagements. New York, Oxford: Berghahn Books, pp. 152-170.

Balibar, E. (2011). Politics and the Other Scene. London, New York: Verso.

Balzacq, T. et al. (2006). Security and the two-level game: The treaty of Prüm, the EU and the management of threats. CEPS Working Documents No. 234, 1 January 2006 [online]. Available at: $\underline{\text { http://aei.pitt.edu/6678/1/1292 234.pdf. }}$

Balzacq, T. et al. (2010). Security practices. In: Denemark, R. A. ed. International Studies Encyclopedia. Wiley-Blackwell [online, 2017]. Available at: https://www-oxfordreferencecom.chain.kent.ac.uk/view/10.1093/acref/9780191842665.001.0001/acref9780191842665-e-0337?rskey=AGVPwf\&result=385.

Barker, V. (2017). Penal power at the border: Realigning state and nation. Theoretical Criminology 21:441-457.

Barnier, S. et al. (2019). La Police Des Migrants: Filtrer, Disperser, Harceler. babels.

Basaran, T. (2011). Security, Law and Borders. At the Limits of Liberties. London \& New York: Routledge.

Baud, M. and Van Schendel, W. (1997). Toward a comparative history of borderlands. Journal of World History 8:211-242.

Bayley, D.H. (1975). The Police and Political Development in Europe. In: Tilly, C. ed. The Formation of the National States in Western Europe. Princeton: Princeton University Press, pp. 47-102.

Bayley, D. and Shearing, C. (1996). The Future of Policing. Law and Society Review 30:585-606.

Becker, F. (2017). Entscheidungsbesprechung. Zur europarechtlichen Zulässigkeit von verdachtsunab- Aufgrund der Verzahnung von Polizei- und Europarecht hängigen Identitätsfeststellungen durch die Bundespolizei - EuGH, Urt. v. 21.6.2017 - C-9/16. Zeitschrift für das Juristische Studium 6:705-712.

Becker, H. (1967). Whose Side Are We On? Social Problems 14:239-247.

Benda-Beckmann, F. von and Benda-Beckmann, K. von (2005). Mobile People, Mobile Law: Expanding Legal Relations in a Contracting World. Ashgate: Routledge.

Benda-Beckmann, F. von and Benda-Beckmann, K. von (2006). The dynamics of change and continuity in plural legal orders. Journal of Legal Pluralism and Unofficial Law 38:1-44.

Benda-Beckmann, F. von and Benda-Beckmann, K. von (2014). Places that come and go. A legal anthropological perspective on the temporalities of space in plural legal orders. In: Braverman, I. et al. eds. The Expanding Spaces of Law: A Timely Legal Geography. Stanford: Standford University Press, pp. 30-52.

Benda-Beckmann, F. von, Benda-Beckmann, K. von and Griffith, A. eds. (2009). Spatializing Law: 
An Anthropological Geography of Law in Society. Ashgate: Routledge.

Benda-Beckmann, K. von and Turner, B. (2018). Legal pluralism, social theory, and the state. Journal of Legal Pluralism and Unofficial Law 50:255-274.

Benjamin, W. (1921). Zur Kritik der Gewalt. In (1992) Sprache und Geschichte. Philosophische Essays. Stuttgart: Reclam GmbH, pp.104-131.

Benyon (1994). Policing the European Union. The changing basis on cooperation on law enforcement. International Affairs 70:497-517.

Benyon, J. et al. (1993). Police Cooperation in Europe: An Investigation. University of Leicester, Centre for the Study of Public Order.

Bernier, A. (2018). Les Contrôles de Police Au Sein de l'espace Schengen. L'impact de l'article 23 Du Code Frontières Schengen Sur La Réalisation Des Contrôles de Police Belges Aux Frontières Nationales. Mémoire - Master en sciences politiques, finalité politiques européennes, Liège université [online]. Available at: http://hdl.handle.net/2268.2/4929.

Bertoncin, B. and Weissensteiner, M. (2016). La scorta trilaterale. Intervista a Mario Deriu. una città 229 [online]. Available at http://unacitta.it/it/intervista/2493-la-scorta-trilaterale.

Bigo, D. (1994). The European internal security field. stakes and rivalries in a newly developing area of police intervention. In: Anderson, M. and den Boer, M. eds. Policing across National Boundaries. London, New York: Pinter Publishers, pp. 161-173.

Bigo, D. (2000a). Liaison officers in Europe: New officers in the European security field. In: Sheptycki, J. W. E. ed. Issues in Transnational Policing. Routledge. London \& New York, pp. 67-100.

Bigo, D. (2000b). When two become one. Internal and external securitisations in Europe. In: Kelstrup, M. ed. International Relations Theory and the Politics of European Integration Power, Security and Community. pp. 171-204.

Bigo, D. (2001). The Möbius Ribbon of Internal and External Security(ies). In: Albert, M., Jacobson, D. and Lapid, Y. eds. Identities, Borders, Orders: Rethinking International Relations Theory. Minneapolis: University of Minnesota Press, pp. 91-116.

Bigo, D. (2005). Frontier controls in the European Union: who is in control? In: Guild, E. and Bigo, D. eds. Controlling Frontiers. 2016th ed. Oxon, New York: Routledge, pp. 45-88.

Bigo, D. (2006). Globalized (In)Security: the Field and the Ban-opticon. In: Bigo, D and Tsoukala, A. eds. Illiberal Practices of Liberal Regimes. Paris: Centre d'Etudes sur les Conflits, pp. 5-45.

Bigo, D. (2014a). Afterword. Security: Encounters, Misunderstandings and Possible Collaborations. In: Maguire, M., Frois, C. and Zurawski, N. eds. The Anthropology of Security. Perspectives from the Frontline of Policing, Counter-Terrorism and Border Control. London: PlutoPress, pp. 189-205.

Bigo, D. (2014b). The (in)securitization practices of the three universes of EU border control: Military/Navy - border guards/police - database analysts. Security Dialogue 45:209-225.

Bigo, D. (2016a). Rethinking Security at the Crossroad of International Relations and Criminology. British Journal of Criminology 56:1068-1086.

Bigo, D. (2016b). International Political Sociology. Internal Security as Transnational Power Fields. In: Bossong, R. and Rhinard, M. eds. Theorizing Internal Security in the European Union. Oxford Scholarship Online [online]. Available at: https://www.oxfordscholarship.com/view/10.1093/acprof:oso/9780198739487.001.0001/ acprof-9780198739487-chapter-4. 
Bigo, D. and Guild, E. (2005). Policing in the Name of Freedom. In: Guild, E. and Bigo, D. eds. Controlling Frontiers. 2016th ed. Oxon, New York: Routledge, pp. 1-13.

Bittner, E. (1974). Florence Nightingale in Pursuit of Willie Sutton: A Theory of the Police. In: Jacob, H. ed. The Potential for Reform of Criminal Justice. Beverly Hills: Sage.

Block, L. (2007). Decentralisation Trends in European Union Police Cooperation: Implications for Efficacy and Accountability. Paper for the Third Challenge Training School 'Police and Judicial Cooperation in Criminal Matters in the EU: Which Future for EU's Third Pillar? C. SSRN Electronic Journal [online]. Available at: https://papers.ssrn.com/sol3/papers.cfm?abstract id=1101680.

Block, L. (2011). From Politics to Policing: The Rationality Gap in EU Council Policy-Making. PhD Thesis, Vrije Universiteit Amsterdam. The Hague: Eleven International Publishing [online]. Disseration available at: https://research.vu.nl/en/publications/from-politics-to-policingthe-rationality-gap-in-eu-council-polic.

Block, L. (2012). EU joint investigation teams: political ambitions and police practices. In: Hufnagel, S., Harfield, C. and Bronitt, S. eds. Cross-Border Law Enforcement. Regional Law Enforcement Cooperation - European, Australian and Asia-Pacific Perspectives. London: Routledge. ProQuest Ebook Central [online]. Available at: https://www.taylorfrancis.com/books/e/9780203813058/chapters/10.4324/97802038130 $\underline{58-13 .}$.

Blomley, N.K. (1994). Law, Space, and the Geographies of Power. New York: Guilford.

Boaventura-de-Sousa, S. (1987). Law: A Map of Misreading. Toward a Postmodern Conception of Law. Journal of Law and Society 14:279-302.

den Boer, M. (2010). Towards a governance model of police cooperation in Europe: the twist between networks and bureaucracies. In: Lemieux, F. ed. International Police Cooperation. Emerging Issues, Theory and Practice. London, New York: Routledge, pp. 42-61.

den Boer, M. (2012). Go with the flow and undo the nots: intelligence and interconnectivity in transnational organized crime policing. In: Allum, F. and Gilmour, S. eds. Routledge Handbook of Transnational Organized Crime. Oxon, New York: Routledge [online]: https://www.taylorfrancis.com/books/e/9780203698341/chapters/10.4324/97802036983 $\underline{41-41}$.

den Boer, M. (2018). Introduction to Comparative Policing from a Legal Perspective. In: den Boer, M. ed. Comparative Policing from a Legal Perspective. Cheltenham, Northampton: Edward Elgar Publishing, Inc, pp. 1-14.

den Boer, M. and Spapens, T. eds. (2002). Investigating Organised Crime in European Borderregions. Law Enforcement and Judicial Cooperation with Regards to Organised Crime: A Comparison between European Border-regions. IVA Institute for Social Policy Research and Consultancy, Tillburg University.

Bonanno, L. (2018). Drawing as a Mode of Translation. American Anthropologist [online]. Available at: http://www.americananthropologist.org/ethno-graphic-bonanno/.

Border Violence Monitoring Network (2019). Illegal Pushbacks and Border Violence. Balkan Region. November 2019 Report [online]. Available at: https://www.ecre.org/widespreadpushback-and-violence-along-borders-in-the-balkans-continues/.

Borri, G. and Fontanari, E. (2015). Lampedusa in Berlin: (Im)Mobilität innerhalb des europäischen Grenzregimes. PERIPHERIE 2-2015, Jg. 35 138/139:193-211.

Bossong, R. and Rhinard, M. eds. (2016). Theorizing Internal Security in the European Union. 
Oxford Scholarship Online [online]. Available at: https://www.oxfordscholarship.com/view/10.1093/acprof:oso/9780198739487.001.0001/ acprof-9780198739487.

Bosworth, M. and Guild, M. (2008). Governing through migration control: Security and citizenship in Britain. British Journal of Criminology 48:703-719.

Bosworth, M. and Pickering, S. (2018). Punishment, globalization and migration control: ' Get them the hell out of here'. Punishment \& Society 20:34-53.

Bosworth, M. and Turnbull, S. (2014). Immigration Detention, Punishment, and the Criminalization of Migration. In: Ham, J. and Pickering, S. eds. The Routledge Handbook on Crime and International Migration. London: Taylor \& Francis Group, pp. 91-105; ProQuest Ebook Central [online]. Available at: https://www.taylorfrancis.com/books/e/9780203385562.

Bouteillet-Paquet, D. (2003). Passing the Buck: A Critical Analysis of the Readmission Policy Implemented by the European Union and Its Member States. European Journal of Migration and Law 5:359-377.

Bowling, B. (2009). Transnational Policing: The Globalization Thesis, a Typology and a Research Agenda. Policing 3:149-160.

Bowling, B. (2013). The Borders of Punishment: Towards a Criminology of Mobility. In: Aas, K. F. and Bosworth, M. eds. The Borders of Punishment: Citizenship, Crime Control, and Social Exclusion. Oxford: Oxford University Press, pp. 291-306 [online]. Available at: https://www.oxfordscholarship.com/view/10.1093/acprof:oso/9780199669394.001.0001/ acprof-9780199669394.

Bowling, B. and Kopf, C. (2017). Transnational policing in Europe and its local effects. European Police Science and Research Bulletin 3:47-57.

Bowling, B., Reiner, R. and Sheptycki, J.W.E. (2019). The Politics of the Police. 5th ed. Oxford: Oxford University Press.

Bowling, B. and Sheptycki, J. (2015). Global Policing and Transnational Rule with Law. Transnational Legal Theory 6:141-173.

Bowling, B. and Sheptycki, J. (2014). Global policing, mobility and social control. In: Pickering, S. and Ham, J. eds. The Routledge Handbook on Crime and International Migration. London: Taylor \& Francis Group, pp. 57-74. ProQuest Ebook Central [online]. Available at: https://www.taylorfrancis.com/books/e/9780203385562.

Bowling, B. and Sheptycki, J.W.E. (2012). Global Policing. London: SAGE Publications Ltd.

Brammertz, S. (1999). Grenzüberschreitende Polizeiliche Zusammenarbeit Am Beispiel Der Euregio Maas-Rhein. Freiburg: Max-Plank-Institut für ausländisches und internationals Strafrecht.

Braverman, I. et al. eds. (2014). The Expanding Spaces of Law: A Timely Legal Geography. Stanford: Standford University Press.

Brenner, N. (2004). New State Spaces: Urban Governance and the Rescaling of Statehood. New York: Oxford University Press.

Breuer, O. and Breuking, A. (2007). Mehr Sicherheit Im Grenzgebiet - Polizeiliche Zusammenarbeit [online]. Available at: https://www.uni-muenster.de/NiederlandeNet/nlwissen/rechtjustiz/polizei.html.

Brouwer, E. (2015). Migration Flows and the Reintroduction of Internal Border Controls: Assessing Necessity and Proportionality, Odysseus Network blog, 13 Nov 2015 [online]. Available at: 
https://eumigrationlawblog.eu/migration-flows-and-the-reintroduction-of-internal-border controls-assessing-necessity-and-proportionality/.

Brouwer, E. et al. (2015). What Is Happening to the Schengen Borders? CEPS Paper in Liberty and Security in Europe 86 [online]. Available at: https://www.ceps.eu/ceps-publications/whathappening-schengen-borders/.

Brouwer, J., Van der Woude, M. and Van der Leun, J. (2018). (Cr)immigrant framing in border areas: decision-making processes of Dutch border police officers. Policing and Society: An International Journal 28:448-463.

Bundesministerium des Innern für Bau und Heimat (2018). Masterplan Migration. Maßnahmen Zur Ordnung, Steuerung Und Begrenzung Der Zuwanderung. 04.07.2018 [online]. Available at:

https://www.bmi.bund.de/SharedDocs/downloads/DE/veroeffentlichungen/themen/migr ation/masterplan-migration.pdf? blob=publicationFile \&v=7.

Bundesministerium des Innern für Bau und Heimat (2020). Abkommen zur Erleichterung der Rückkehr ausreisepflichtiger Ausländer. Stand Februar 2020 [online]. Available at: https://www.bmi.bund.de/SharedDocs/downloads/DE/veroeffentlichungen/themen/migr ation/rueckkehrfluechtlinge.pdf? blob=publicationFile\&v=3.

Bundesministerium für Bildung und Forschung Bewilligte Projekte Aus Der Bekanntmachung 'Zivile Sicherheit - Fragen Der Migration' [online]. Available at: https://www.sifo.de/de/bewilligte-projekte-aus-der-bekanntmachung-zivile-sicherheitfragen-der-migration-2314.html.

Bundesministerium für Bildung und Forschung Mobile Berührungslose Identitätsprüfung Im Anwendungsfeld Migration (MEDIAN, 2018-2021) [online]. Available at: https://www.sifo.de/files/Projektumriss Median.pdf.

Bundesministerium für Bildung und Forschung Smartphone-Basierte Analyse von Migrationstrends Zur Identifikation von Schleuserrouten (Smartldentifikation, 2018-2020) [online]. Available at: https://www.sifo.de/files/Projektumriss Smartldentifikation.pdf.

Bundesministerium für Inneres (2017). Sicherheitsbericht 2017. Kriminalität. Vorbeugung Und Bekämpfung. BMI Wien [online]. https://bmi.gv.at/508/files/SIB 2017/01 SIB 2017Hauptteil web.pdf.

C.A.S.E. Collective (2006). Critical Approaches to Security in Europe: A Networked Manifesto. Security Dialogue 37:443-487.

Camera dei Diputati (2020). Resoconto stenografico dell'Assemblea Seduta n. 379 di venerdì 24 luglio 2020, XVIII Legislatura. [Online]. Available at: https://www.camera.it/leg18/410?idSeduta=0379\&tipo=stenografico\#sed0379.stenografi co.tit00020.sub00040.

Campbell, E. (2016). Policing and its spatial imaginaries. Theoretical \& Philosophical Criminology 8:71-89.

Campesi, G. (2015). Polizia Della Fronteria. Frontex e La Produzione Dello Spazio Europeo. Roma: DeriveApprodi.

Campesi, G. (2018). Crisis, migration and the consolidation of the EU border control regime. International Journal of Migration and Border Studies 4:196-221.

Caporaso, J. (1996). The European Union and Forms of State: Westphalian, Regulatory or PostModern. Journal of Common Market Studies 34:29-52. 
Carrera, S. et al. (2011). A Race against Solidarity The Schengen Regime and the Franco-Italian Affair. CEPS Research Paper [online]. Available at: https://www.ceps.eu/cepspublications/race-against-solidarity-schengen-regime-and-franco-italian-affair/.

Carrera, S. et al. (2018). The Future of the Schengen Area: Latest Developments and Challenges in the Schengen Governance Framework since 2016. Study for the LIBE Committee. European Parliament, Policy Department for Citizens' Rights and Constitutional Affairs, LIBE committee, Study, 2018/PE 604.943 EN [online]. Available at: http://www.europarl.europa.eu/thinktank/en/document.html?reference=IPOL STU(2018) $\underline{604943 .}$

Carrera, S. et al. (2019). When mobility is not a choice Problematising asylum seekers' secondary movements and their criminalisation in the EU. CEPS Paper in Liberty and Security in Europe 11 [online]. Available at: https://www.ceps.eu/wp-content/uploads/2019/12/LSE2019-11RESOMA-Policing-secondary-movements-in-the-EU.pdf.

Carrera, S. (2019). The State of the Schengen Area in the Light of the 2019 European Parliament Election. Robert Schuman Centre for Advanced Studies Policy Papers; RSCAS PP 2019/12 Special Edition for the EP Elections 2019 [online]. Available at: https://cadmus.eui.eu/handle/1814/61595.

Casas-Cortes, M. et al. (2015). New Keywords: Migration and Borders. Cultural Studies 29(1), p.55-87.

Cassarino, J. (2017). Readmission Policies in Europe. In: Mullen, E. J. ed. Oxford Bibliographies in Social Work. New York: Oxford University Press. New York: Oxford University Press [online]. Available at: https://www.oxfordbibliographies.com/view/document/obo9780195389678/obo-9780195389678-0259.xm|\#obo-9780195389678-0259-div1-0006.

Cassidy, K., Yuval-davis, N. and Wemyss, G. (2018). Debordering and everyday (re) bordering in and of Dover: Post- borderland borderscapes. Political Geography 66:171-179.

Causey, A. (2016). Drawn to See: Drawings as an Ethnographic Method. Toronto: University of Toronto Press, Higher Education Division.

CCPD-Chiasso (2016). Rapporto Annuale 2015. Centro Comune di Cooperazione di Polizia e Doganale Chiasso [online]. Available at: http://www.ccpdchiasso.ch/pdf/CCPD rap2015.pdf.

CEPOL (2019). European Union Strategic Training Needs Assessment 2018-2021. CEPOL [online]. Available at: https://www.cepol.europa.eu/education-training/our-approach/typeslearning/eu-stna.

Cobarrubias, S. et al. (2015). Europe / Crisis : New Keywords of "the Crisis" in and of "Europe" [online]. Available at: http://nearfuturesonline.org/europecrisis-new-keywords-of-crisis-inand-of-europe/.

Coleman, N. (2009). European Readmission Policy: Third Country Interests and Refugee Rights. Leiden: Martinus Nijhoff.

Colombeau, S.C. (2017). Policing the internal Schengen borders - managing the double bind between free movement and migration control. Policing and Society. An International Journal of Research and Policy 27:480-493.

Colombeau, S.C. (2019). Crisis of Schengen? The effect of two 'migrant crises' (2011 and 2015) on the free movement of people at an internal Schengen border. Journal of Ethnic and Migration Studies, published online: 30.03.2019 [online]. Available at: https://www.tandfonline.com/doi/abs/10.1080/1369183X.2019.1596787?journalCode=ci ms20. 
Comaroff, J.L. (2013). Foreword. In: Garriott, W. ed. Policing and Contemporary Governance: The Anthropology of Police in Practice. New York: Palgrave Macmillan, pp. xi-xxii.

Comitato Parlamentare Schengen (2019). Testo Del Resoconto Stenografico, Seduta n. 1 di Mercoledi 10 Luglio 2019, XVIII Legislazione. Comitato Parlamentare Di Controllo Sull'attuazione Dell'Accordo Di Schengen, Di Vigilanza Sull'attività Di Europol, Di Controllo e Vigilanza in Materia Di Immigrazione [online]. Available at: http://documenti.camera.it/leg18/resoconti/commissioni/stenografici/html/30/indag/c30 migranti/2019/07/10/stenografico.0001.html.

Commissione parlamentare di inchiesta sul sistema di accoglienza e di identificazione ed espulsione, nonché sulle condizioni di trattenimento dei migrant e sulle risorse pubbliche impregnate (2016a). Relazione Di Minoranza. Doc. XXII-Bis, N. 8-Bis, Camera Dei Diputati, XVII Legislatura, 26.10.2016 [online]. Available at: http://www.camera.it/_dati/leg17/lavori/documentiparlamentari/IndiceETesti/022bis/008 bis/INTERO.pdf.

Commissione parlamentare di inchiesta sul sistema di accoglienza e di identificazione ed espulsione, nonché sulle condizioni di trattenimento dei migrant e sulle risorse pubbliche impregnate (2016b). Relazione Sul Sistema Di Identificazione e Di Prima Accoglienza Nell'ambito Dei Centri 'Hotspot'. Doc. XXII-Bis, N. 8 - Camera Dei Diputati, XVII Legislatura, 26.10.2016. [online]. Available at: http://www.camera.it/ dati/leg17/lavori/documentiparlamentari/IndiceETesti/022bis/008 /INTERO.pdf.

Commissione straordinaria per la tutela e la promozione dei diritti umani (2016). Resoconto Sommario n. 98 del 08/06/2016, XVII Legislatura [online]. Available at: https://senato.it/japp/bgt/showdoc/17/SommComm/0/978446/index.html?part=doc dc.

Conrads, D., Franke, P. and Hodenius, M. (2016). Mittendrin! Drei Polizisten Berichten Aus Der Fluechtlingskrise. Hamburg: tredition $\mathrm{GmbH}$.

Cornelisse, G. (2018). Legal pluralism in the European regulation of border control: disassembling, diffusing, and legalizing the power to exclude. In Davis, G. and Avbelj, M. eds. Research Handbook on Legal Pluralism and EU Law. Northampton: Edward Elgar Publishing Limited, pp.373-391 [online]. Available at: https://www.elgaronline.com/view/edcoll/9781786433084/9781786433084.00029.xml.

Cote-Boucher, K., Infantino, F. and Salter, M.B. (2014). Border security as practice: An agenda for research. Security Dialogue 45:195-208.

Côté-Boucher, K. (2018). Of "old" and "new " ways: Generations, border control and the temporality of security. Theoretical Criminology 22:149-168.

Crowley, J. (2001). Differential free movement and the sociology of the 'internal border'. In: Guild, E. and Harlow, C. eds. Implementing Amsterdam. Immigration and Asylum Rights in EC Law. Oxford: Hart Publishing, pp. 13-33.

Crowley, J. (2003). Locating Europe. In: Groenendijk, K., Guild, E. and Minderhoud, P. eds. In Search of Europe's Borders. The Hague, London, New York: Kluwer Law International, pp. 27-44.

Csordas, T.J. (2004). Evidence of and for what? Anthropological Theory 4:473-480.

Cunha, A., Silva, M. and Frederico, R. eds. (2015). The Borders of Schengen. Brussels: P.I.E. Peter Lang.

Cunliffe, A.L. and Alcadipani, R. (2016). The Politics of Access in Fieldwork: Immersion, Backstage Dramas, and Deception. Organizational Research Methods 19:535-561. 
Cuttitta, P. (2007). Segnali Di Confine. I/ Controllo Dell'immigrazione Nel Mondo-Frontiera. Milano: Mimesis.

Darley, M. (2008). Le contrôle migratoire aux frontières Schengen: pratiques et représentations des polices sur la ligne tchéco-autrichienne. Cultures \& Conflits 71:13-29.

Das, V. and Poole, D. eds. (2004). Anthropology in the Margins of the State. Comparative Ethnographies. New Mexico: School of American Research Press.

Dean, M. (2010). Governmentality: Power and Rule in Modern Society. 2nd ed. SAGE Publications Ltd.

Deflem (2000). Bureaucratization and Social Control: Historical Foundations of International Police Cooperation. Law \& Society Review 34:739-778.

Deflem, M. (2002). Policing World Society. Historical Foundations of International Police Cooperation. Oxford: Oxford University Press.

Delaney, D. (2003). Beyond the Word: Law as a Thing of this World. In: Holder, J. and Harrison, C. eds. Law and Geography. Oxford: Oxford University Press, pp. 67-84.

Deutscher Bundestag (2006). Gesetzentwurf der Bundesregierung. Entwurf eines Gesetzes zu dem Vertrag vom 27. Mai 2005 zwischen dem Königreich Belgien, der Bundesrepublik Deutschland, dem Königreich Spanien, der Französischen Republik, dem Großherzogtum Luxemburg, dem Königreich der Niederlande und der Republik Österreich über die Vertiefung der grenzüberschreitenden Zusammenarbeit, insbesondere zur Bekämpfung des Terrorismus, der grenzüberschreitenden Kriminalität und der illegalen Migration. Deutscher Bundestag 16. Wahlperiode: Drucksache 16/1108, 31.03. 2006 [online]. Available at: http://dipbt.bundestag.de/dip21/btd/16/011/1601108.pdf.

Deutscher Bundestag (2014). Antwort der Bundesregierung auf die Kleine Anfrage der Abgeordneten Andrej Hunko, Ulla Jelpke, Jan van Aken, weiterer Abgeordneter und der Fraktion DIE LINKE - Drucksache 18/3397 - Gemeinsame trilaterale Patrouillen österreichischer, italienischer und deutscher Polizeien gegen unerwünschte Migration. Deutscher Bundestag 18. Wahlperiode: Drucksache 18/3607, 18.12.2014 [online]. Available at: http://dip21.bundestag.de/dip21/btd/18/036/1803607.pdf.

Deutscher Bundestag (2016). Antwort Der Bundesregierung Auf Die Kleine Anfrage Der Abgeordneten Andrej Hunko, Jan van Aken, Sevim Dağdelen, Weiterer Abgeordneter Und Der Fraktion DIE LINKE. - Drucksache 18/8493 - Eröffnung Eines Internationalen Ermittlungsbüros Gegen Migrantenschmug. Deutscher Bundestag 18. Wahlperiode: Drucksache 18/8669, 03.06.2016 [online]. Available at: http://dipbt.bundestag.de/dip21/btd/18/086/1808669.pdf.

Deutscher Bundestag (2017). Antwort Auf Die Kleine Anfrage Der Abgeordneten Ulla Jelpke, Wolfgang Gehrcke, Frank Tempel, Weiterer Abgeordneter Und Der Fraktion DIE LINKE. Drucksache 18/11218 - Polizei- Und Zolleinsätze Im Ausland (Stand: Viertes Quartal 2016). Deutscher Bundestag 18. Wahlperiode: Drucksache 18/11391, 07.03.2017 [online]. Available at: http://dipbt.bundestag.de/doc/btd/18/113/1811391.pdf.

Deutscher Bundestag (2019). Antwort der Bundesregierung auf die Kleine Anfrage der Abgeordneten Ulla Jelpke, Dr. André Hahn, Gökay Akbulut, weiterer Abgeordneter und der Fraktion DIE LINKE. - Drucksache 19/9637 - Problematik des "Racial Profilings" und anlasslose Kontrollen der Bund. Deutscher Bundestag 19. Wahlperiode: Drucksache 19/10065, 10.05.2019 [online]. Available at: https://dip21.bundestag.de/dip21/btd/19/100/1910065.pdf.

DeWalt, K. and DeWalt, B. eds. (2011). Participation Observation. A Guide for Fieldworkers. 2nd 
ed. Plymouth: AltaMira Press.

Dix, B. and Kaur, R. (2019). Drawing-Writing Culture: The Truth-Fiction Spectrum of an EthnoGraphic Novel on the Sri Lankan Civil War and Migration. Visual Anthropology Review 35:76111.

Direzione Centrale per gli Affari Generali della Polizia di Stato (2014). Progetto di rimodulazione della Polizia Di Frontiera. Roma, 18 Novembre 2014 [online]. Available at: http://www.fsppolizia.it/wp-content/uploads/2014/11/uffici181114.pdf [annex].

Dobretsberger, C. ed. (2018). An Der Grenze. Wie Polizistinnen Und Polizisten Die Fluechtlingsbewegung Erleben. Wien: OEGB GmbH.

Donnan, H. and Wilson, M.T. (1999). Borders. Frontiers of Identity, Nation and States. London, New York: Oxford.

Durante, B. (2012). La Valigia Del Doganiere. alpha beta. Meran/Merano: Edizione Alpha Beta verlag.

Dyevre, A. (2011). The Melki Way: The Melki Case and Everything You Always Wanted to Know About French Judicial Politics (But Were Afraid to Ask). Published 18.09.2011 [online]. Available at: https://ssrn.com/abstract=1929807.

ECRE (2016). The Implementation of the Hotspots in Italy and Greece. A Study [online]. European Council for Refugees and Exiles. Available at: https://www.ecre.org/wpcontent/uploads/2016/12/HOTSPOTS-Report-5.12.2016..pdf.

ECRE (2019). Widespread Pushbacks and Violence Along Borders in the Balkans Continues [online]. Available at: https://www.ecre.org/widespread-pushback-and-violence-along-borders-inthe-balkans-continues/.

Edwards, A. and Gill, P. eds. (2006). Transnational Organised Crime: Perspectives on Global Security. London: Routledge.

Eisner, W. (2008). Comics and Sequential Art. London, New York: W.W. Norton \& Company.

Elliot, A., Norum, R. and Salazar, N.B. eds. (2017). Methodologies of Mobility. 2019th ed. New York: Berghahn Books.

EMN (2014). Ad-Hoc Query on EURODAC Fingerprinting. Requested by COM on 10 Th July 2014 Compilation Produced on $22 \mathrm{Nd}$ September 2014 [online]. Available at:https://ec.europa.eu/home-affairs/sites/homeaffairs/files/what-we-

do/networks/european migration network/reports/docs/ad-hocqueries/border/588 emn ahq eurodac fingerprinting en.pdf.

EMN (2018a). EMN Ad-Hoc Query on Intra-Schengen Border Monitoring and Border Control. Requested by NL EMN NCP on 4th June 2018 [online]. Available at: https://ec.europa.eu/home-affairs/sites/homeaffairs/files/2018.1303 - intraschengen border monitoring and border control.pdf.

EMN (2018b). Summary of EMN Ad-Hoc Query No. 2018.1303 Intra-Schengen Border Monitoring and Border Control. 22-10-2018 Prepared by NL EMN NCP. [Online]. Available at: https://www.emnnetherlands.nl/sites/default/files/2018-12/AHQ NL 2018.1303 Summary - Intra-Schengen border monitoring and border control.pdf.

EMN - National Contact Point Austria - IOM (2017). Austria Annual Policy Report 2016. [Online]. EMN. Available at: https://www.emn.at/wp-content/uploads/2016/12/APR-2016 NationalReport-Austria-Part-2 Final.pdf.

Emsley, C. and Weinberger, B. eds. (1991). Policing Western Europe. Politics, Professionalism and 
Public Order, 1980-1940. Westport: Greenwood Publishing Group, Inc.

European Commission (2015a). Evaluation of the Implementation of the Dublin III Regulation. Final Report. DG Migration and Home Affairs, prepared by ISF [online]. Available at: https://ec.europa.eu/home-affairs/sites/homeaffairs/files/what-wedo/policies/asylum/examination-ofapplicants/docs/evaluation of the implementation of the dublin iii regulation en.pdf.

European Commission (2015c). Study on the Implementation of the European Information Exchange Model (EIXM) for Strengthening Law Enforcement Cooperation. Final Report. DG Migration and Home Affairs, prepared by Deloitte [online]. Available at: http://ec.europa.eu/dgs/home-affairs/e-library/documents/policies/policecooperation/general/docs/eixm study - final report en.pdf.

Europol - EMSC (2016). Migrant Smuggling in the EU [online]. Available at: https://www.europol.europa.eu/sites/default/files/documents/migrant smuggling euro pol report 2016.pdf.

Europol - EMSC (2017). European Migrant Smuggling Centre. First Year Activity Report. Jan 2016 - Jan 2017 [online]. Available at: https://www.europol.europa.eu/sites/default/files/documents/european migrant smuggl ing centre emsc - first year activity year 1.pdf.

Europol - EMSC (2019). European Migrant Smuggling Centre. 3rd Annual Activity Report - 2018. [online]. Available at: https://www.europol.europa.eu/sites/default/files/documents/emsc report final 20192 final.pdf.

Evrard, E. et al. (2018). The Temporary Reintroduction of Border Controls Inside the Schengen Area: Towards a Spatial Perspective. Journal of Borderlands Studies, published online 08.02.2018 [online]. Available at: https://www.tandfonline.com/doi/abs/10.1080/08865655.2017.1415164.

Fabiano, L. (2010). The French "priority" Constitutional exception shall give way to the European preliminary reference: the Melki- Abdely judgement of the ECJ. DPCE online [online] 4. Available at: http://www.dpceonline.it/index.php/dpceonline/article/view/192.

Fassin, D. (2013a). La Forza Dell’Ordine. Antropologia Della Polizia Delle Periferie Urbane. Bologna: Edizioni La Linea.

Fassin, D. (2013b). Why ethnography matters: On anthropology and its publics. Cultural Anthropology 28:621-646.

Fassin (2017). Ethnographying the Police. In: Fassin, D. ed. Writing the World of Policing: The Difference Ethnography Makes. ProQuest E. Chigaco: University of Chicago Press, pp. 1-20.

Fassin, D. ed. (2017). Writing the World of Policing. The Difference Ethnography Makes. Chigaco: University of Chicago Press.

Feldman, G. (2011). If ethnography is more than participant-observation, then relations are more than connections: The case for nonlocal ethnography in a world of apparatuses. Anthropological Theory 11:375-395.

Feldman, G. (2019). The Gray Zone. Sovereignty, Human Smuggling, and Undercover Police Investigation in Europe. Stanford: Standford University Press.

Felsen, O. (2012). European police cooperation: the example of the German-French Centre for Police and Customs Cooperation Kehl (GZ Kehl). In: Hufnagel, S., Harfield, C. and Bronitt, S. 
eds. Cross-Border Law Enforcement. Regional Law Enforcement Cooperation - European, Australian and Asia-Pacific Perspectives. London: Routledge, pp. 73-86. ProQuest Ebook Central [online]. Available at: https://www.taylorfrancis.com/books/e/9780203813058/chapters/10.4324/97802038130 58-12.

Ferguson, J. and Gupta, A. (2002). Spatializing States: toward an ethnography of neoliberal governmentality. American Ethnologist 29:981-1002.

Ferrell, J., Hayward, K. and Young, L. (2015). Cultural Criminology. 2nd Editio. London: SAGE Publications Ltd.

Feys, T. (2019). Riding the rails of removal: The impact of railways on border controls and expulsion practices. Journal of Transport History 40:189-210.

Fijnaut, C. and Paoli, L. eds. (2004). Organised Crime in Europe : Concepts, Patterns, and Control Policies in the European Union and Beyond. Dordrecht: Springer.

Fijnaut, C. and Spapens, T. (2010). The Meuse-Rhine Euroregion: a laboratory for police and judicial cooperation in the European Union. In: Lemieux, F. ed. International Police Cooperation Emerging Issues, Theory and Practice. London, New York: Routledge, pp. 101125.

Fijnaut, C. (2015). The Refugee Crisis: The End of Schengen? European Journal of Crime, Criminal Law and Criminal Justice 23:313-332.

Fijnaut, C. (2017). Reinforcing the European dimension of comparative police research. European Police Science and Research Bulletin. Special Conference Edition [online] 2:75-84. Available at: http://91.82.159.234/index.php/bulletin/article/view/204.

Fijnaut, C. (2019). A Peaceful Revolution: The Development of Police and Judicial Cooperation in the European Union. 1st ed. Cambridge: Intersentia.

Fiodorova, A. (2018). Information Exchange and EU Law Enforcement. Oxford, New York: Routledge.

Foucault, M. (2007). Security, Territory, Population. Lectures at the Collège de France 1977-78. NY: Palgrave Macmillan.

FRONTEX (EBCGA) (2018). Programming Document 2018-2020. [online]. FRONTEX,. Available at: https://frontex.europa.eu/assets/Key Documents/Programming Document/2018/Progra mming Document 2018-2020.pdf.

Galeotti, M. (2004). Introduction : Global Crime Today. Global Crime 6:1-7.

Gallagher, F. (2002). Sheer Necessity: The Kent Experience of Regional Transfrontier Police Cooperation. Regional \& Federal Studies 12:111-134.

Garriott, W. (2013a). Introduction. Police in Practice: Policing and the Project of Contemporary Governance. In: Garriott, W. ed. Policing and Contemporary Governance: The Anthropology of Police in Practice. New York: Palgrave Macmillan, pp. 1-28.

Garriott, W. ed. (2013b). Policing and Contemporary Governance: The Anthropology of Police in Practice. New York, US: Palgrave Macmillan.

Garriott, W. (2018). Becoming a Police Ethnographer. In: Rice, S. K. and Maltz, Michael, D. eds. Doing Ethnography in Criminology. Discovery through Fieldwork. Springer International Publishing, pp. 187-192 Available]. at: https://www.springer.com/gp/book/9783319963150. 
Gazit, N. (2009). Social Agency, Spatial Practices, and Power: The Micro-foundations of Fragmented Sovereignty in the Occupied Territories. International Journal of Politics, Culture and Society 22:83-103.

Gehler, M. (2009). Der Brenner: Vom Ort negativer Erfahrung zum historischen Gedächtnisort oder zur Entstehung und Überwindung einer Grenze in der Mitte Europas (1918-1998). In: Gehler, M. and Pudlat, A. eds. Grenzen in Europa. Hildesheim, Zuerich, New York: Georg Olms Verlag - Weidmannsche Verlagsbuchhandlung, pp. 145-182.

Geismar, H. (2014). Drawing It Out. Visual Anthropology Review 30:97-113.

De Genova, N. ed. (2017). The Borders of 'Europe'. Autonomy of Migration, Tactics of Bordering. Durham \& London: Duke University Press.

De Genova, N., Mazzadra, S. and Pickeles, J. (2015). NEW KEYWORDS: MIGRATION AND BORDERS. Cultural Studies 29:55-87.

Gerspacher, N. and Dupont, B. (2007). The nodal structure of international police cooperation: An exploration of transnational security networks. Global Governance 13:347-364.

de Goede, M., Bosma, E. and Pallister-Wilkins, P. eds. (2020). Secrecy and Methods in Security Research. A Guide to Qualitative Research. London, New York: Routledge.

Golafshani, N. (2003). Understanding Reliability and Validity in Qualitative Research. The Qualitative Report 8:597-606.

Grassiani, E. (2020). Critical engagement when studying those you oppose. In: de Goede, M., Bosma, E. and Pallister-Wilkins, P. eds. Secrecy and Methods in Security Research. A Quide to Qualitative Fieldwork. Routledge, pp. 248-161.

Gratz, W. (2016). Das Management Der Flüchtlingskrise. Never Let a Good Crisis Go to Waste. Wien, Graz: NWV.

Griffiths, A. (2010). Anthropological Perspectives on Legal Pluralism and Governance in a Transnational World. In: Freeman, M. and Napier, D. eds. Law and Anthropology: Current Legal Issues. Oxford Scholarship Online, pp. 164-186 [online]. Available at: https://www.oxfordscholarship.com/view/10.1093/acprof:oso/9780199580910.001.0001/ acprof-9780199580910-chapter-7.

Griffiths, J. (1986). What is legal pluralism? Journal of Legal Pluralism and Unofficial Law 18:1-55.

Griffiths, A. (2011). Pursuing legal pluralism: The power of paradigms in a global world. Journal of Legal Pluralism and Unofficial Law 43:173-202.

Groenendijk, K. (2003). New borders behind old ones: post-Schengen controls behind the internal borders and inside the Netherlands and Germany. In: Groenendijk, K., Guild, E. and Minderhoud, P. eds. In Search of Europe's Borders. The Hague, London, New York: Kluwer Law International, pp. 131-146.

Groenendijk, K. (2004). Reinstatement of Controls at the Internal Borders of Europe: Why and Against Whom? European Law Journal 10:150-170.

Groenendijk, K., Guild, E. and Minderhoud, P. eds. (2003). In Search of Europe's Borders. The Hague, London, New York: Kluwer Law International.

Gruschinske, Mario Hirschmann, N. and Füger, L. (2015). Effective cross-border knowledge sharing between police forces - the German-Polish Police and Customs Cooperation Centre (PCCC). In: Aden, H. ed. Police Cooperation in the European Union after the Lisbon Treaty. Opportunities and Limitations. Baden-Baden: Nomos, pp. 177-188. 
Gruszczak, A. (2016). Police and Customs Cooperation Centres and Their Role in EU Internal Security Governance. In: Bossong, R. and Carrapico, H. eds. EU Borders and Shifting Internal Security. Springer International Publishing Switzerland, pp. 157-175.

Guild, E. and Bigo, D. eds. (2005). Controlling Frontiers. Free Movement Into and Within Europe. 2016th ed. Oxon \& New York: Routledge.

Guild, E. and Geyer, F. eds. (2008). Security versus Justice? Police and Judicial Cooperation in the European Union. Aldershot: Ashgate.

Guild, E. et al. (2016). Internal Border Controls in the Schengen Area: Is Schengen Crisis-Proof. Study for the LIBE Committee. Directorate General For Internal Policies Policy Department C: Citizens' Rights And Constitutional Affairs Civil Liberties, Justice And Home Affairs [online]. Available http://www.europarl.europa.eu/thinktank/en/document.html?reference=IPOL STU(2016) $\underline{571356 .}$.

Guild, E. and Carrera, S. (2016). Rethinking Asylum Distribution in the EU. Shall We Start with the Facts? Centre for European Policy Studies, Policy Brief, 17.6.2016 [online]. Available at: https://www.ceps.eu/publications/rethinking-asylum-distribution-eu-shall-we-start-facts [Accessed: 17 September 2017].

Guild, E., Costello, C. and Moreno-Lax, V. (2017). Implementation of the 2015 Council Decisions Establishing Provisional Measures in the Area of International Protection for the Benefit of Italy and Greece. Study for the LIBE Committee [online]. Available at: https://www.ceps.eu/wp-content/uploads/2017/03/pe 583132 en All(1).pdf.

Guille, L. (2010). Police and judicial cooperation in Europe: bilateral versus multilateral cooperation. In: Lemieux, F. ed. International Police Cooperation. Emerging Issues, Theory and Practice. London, New York: Routledge, pp. 25-41.

Guiraudon, V. (2002). Before the EU Border: Remote Control of the "Huddled Masses". In: Groenendijk, K., Guild, E. and Minderhoud, P. eds. In Search of Europe's Borders. The Hague: Kluwer Law International, pp. 191-214.

Guiraudon, V. (2003). The constitution of a European immigration policy domain: A political sociology approach. Journal of European Public Policy 10:263-282.

Gupta, A. and Sharma, A. eds. (2005). The Anthropology of the State. A Reader. Oxford: Blackwell Publishing.

Gusterson, H. (1997). Studying Up Revisited. PoLAR: Political and Legal Anthropology Review 20:114-119.

Haahr, J.H. and Walters, W. (2005). Governing Europe: Discourse, Governmentality and European Integration. ProQuest Ebook Central [online]. Available at: http://ebookcentral.proquest.com/lib/uunl/detail.action?doclD=200476. [Accessed: 9 February 2020].

Hailbronner, K. (1997). Readmission Agreements and the Obligation on States under Public International Law to Readmit their Own and Foreign Nationals. Zeitschrift für ausländisches öffentliches Recht und Völkerrecht 57:1-49.

Hall, S. (1978). Policing the Crisis : Mugging, the State, and Law and Order. London, Basingstoke: MacMillan Press LTD.

Hamdy, S. et al. (2017). Lissa. A Story about Medical Promise, Friendship, and Revolution. North York, Plymouth, New York: University of Toronto Press. 
Hannerz, U. (2003). Being there... and there... and there! Ethnography 4:201-216.

Haraway, D. (1988). Situated Knowledges : The Science Question in Feminism and the Privilege of Partial Perspective. Feminist Studies 14:575-599.

Hebenton, B. and Thomas, T. (1995). Policing Europe. Co-Operation, Conflict and Control. London: MacMillan.

Heinrichs (1908). Deutsche Niederlassungsverträge und Übernahmeabkommen. 2017th ed. forgotten books.

Heiss, H. (2012). Reale und symbolische Grenzen. Der Brenner 1918-2010. In: Di-Michele, A. et al. eds. An Der Grenze. Sieben Orte Des Uebergangs in Tirol, Suedtirol Und Im Trentino Aus Historischer Und Ethnologischer Perspektive. Raetia, pp. 93-134.

Hess, S. (2012). De-naturalising Transit Migration. Theory and Methods of An Ethnographic Regime Analysis. Population, Space and Place Space Place 18:428-440.

Hess, S. et al. eds. (2014). Grenzregime II. Migration, Kontrolle, Wissen. Transnationale Perspektiven. Berlin, Hamburg: Assoziation A.

Hess, S. and Kasparek, B. (2017a). De- and Restabilising Schengen. The European Border Regime after the Summer of Migration. cuadernos europeos de deusto 56:47-77.

Hess, S. and Kasparek, B. (2017b). Under Control? Or Border (as) Conflict : Reflections on the European Border Regime. Social Inclusion 5:58-68.

Holder, J. and Harrison, C. eds. (2003). Law and Geography. Current Legal Issues Volume 5. Oxford, New York: Oxford University Press.

Hruschka, C. (2019a). The Border Spell: Dublin Arrangements or Bilateral Agreements? Reflections on the Cooperation between Germany and Greece / Spain in the Context of Control at the German-Austrian Border. Odysseus Network blog, 26.02.2019 [online]. Available at: https://eumigrationlawblog.eu/the-border-spell-dublin-arrangements-orbilateral-agreements-reflections-on-the-cooperation-between-germany-and-greece-spainin-the-context-of-control-at-the-german-austrian-border/

Hruschka, C. (2019b). Binnengrenze $\neq$ Außengrenze: Klärendes vom EuGH zur Wiedereinführung von Grenzkontrollen. Verfassungsblog 19.03. 2019 [online]. Available at: https://verfassungsblog.de/binnengrenze- $\neq$-aussengrenze-klaerendes-vom-eugh-zurwiedereinfuehrung-von-grenzkontrollen/.

Hufnagel, S. (2011). Cross-border police co-operation: Traversing domestic and international frontiers. Criminal Law Journal 35:333-344.

Hufnagel, S. (2012a). (In)security crossing borders: a comparison of police cooperation within Austrialia and the European Union. In: Hufnagel, S., Bronitt, S. and Harfield, C. eds. CrossBorder Law Enforcement Regional Law Enforcement Cooperation - European, Australian and Asia-Pacific Perspectives, 1st Edition. New York: Routledge, pp. 177-207. ProQuest Ebook Central [online]. Available at: https://www.taylorfrancis.com/books/e/9780203813058.

Hufnagel, S. (2012b). Harmonising police cooperation laws in Australia and the European Union: the tension between local/national and national/supranational interests. Australian Journal of Forensic Sciences 44:45-62.

Hufnagel, S. (2016). Mapping police cooperation strategies in the EU and Australia: improving inter-agency understanding. European Police Science and Research Bulletin: Policing civil societies in times of economic constraints - Special Conference Edition nr.1:114-122.

Hufnagel, S. (2018). A comparative legal history of international policing. In: den Boer, M. ed. 
Comparative Policing from a Legal Perspective. Edward Elgar Publishing, Inc, pp. 16-44.

Hufnagel, S., Harfield, C. and Bronitt, S. eds. (2012). Cross-Border Law Enforcement. Regional Law Enforcement Cooperation - European, Australian and Asia-Pacific Perspectives. London: Routledge. ProQuest Ebook Central [online]. Available at: https://www.taylorfrancis.com/books/e/9780203813058.

Huysmans, J. (2006). The Politics of Insecurity. Fear, Migration and Asylum in the EU. Oxon: Routledge.

Hylland-Eriksen, T. (1995). Small Places, Large Issues: An Introduction to Social and Cultural Anthropology. London: Pluto Press.

IISG-WBBSI (2019). IISG RESPONSE ACTION 2018-2019 [online]. Available at: https://wbiisg.com/wp-content/uploads/bp-attachments/6319/IISG-RESPONSE-ACTION-2018-2019Final.pdf.

Illamola Dausa, M. (2012). Tjue - Sentencia de 22.06.2010 (Gran Sala), Aziz Melki y Sélim Abdeli, C-188/10 Y C-189/10 - “Artículo 67 TFEU - Libre circulación de personas - supresión de controles en las fronteras interiores - Normativa nacional que autoriza controles de identidad a . Revista de Derecho Comunitario Europeo 41:205-220.

Inda, J.X. (2006). Targeting Immigrants. Government, Technology, Ethics. Oxford: Blackwell Publishing.

Ingold, T. ed. (2011). Redrawing Anthropology: Materials, Movements, Lines. Oxon, New York: Taylor \& Francis Group.

Ingold, T. (2016). Lines. 2nd ed. London, New York: Routledge Classics.

Jansen, Y., Celikates, R. and de Bloiis, J. eds. (2015). The Irregularization of Migration in Contemporary Europe. Detention, Deportation, Drowning. London, New York: Rowman\&Littlefield.

Jauregui, B. (2014). Dirty Anthropology: Epistemologies of Violence and Ethical Entanglements in Police Ethnography. In: Garriott, W. ed. Policing and Contemporary Governance: The Anthropology of Police in Practice. New York: Palgrave Macmillan, pp. 125-153.

Johnson, C. et al. (2011). Interventions on rethinking 'the border' in border studies. Political Geography 30:61-69.

Jones, T. and Newburn, T. (2002). The Transformation of Policing? Understanding Current Trends in Policing Systems. British Journal of Criminology 42:129-146.

Karakali, S. and Tsianos, V. (2007). Movements that matter. Eine Einleitung. In: Transit-MigrationForschungsgruppe ed. Turbulente Ränder. Bielefeld: transcript Verlag, pp. 7-22.

Kasparek, B. and Schmidt-Sembdner, M. (2019). Renationalization and spaces of migration: the European border regime after 2015. In: Mitchell, K. et al. eds. Handbook on Critical Geographies of Migration. Elgar Online, pp. 206-218.

Kasparek, B. and Speer, M. (2015). Of Hope. Hungary and the Long Summer of Migration [online]. Available at: http://bordermonitoring.eu/ungarn/2015/09/of-hope-en/.

Kleiven, M.E. (2012). Nordic police cooperation. In: Hufnagel, S., Harfield, C. and Bronitt, S. eds. Cross-Border Law Enforcement. Regional Law Enforcement Cooperation - European, Australian and Asia-Pacific Perspectives. London: Routledge, pp. 63-71. ProQuest Ebook Central [online]. Available at: https://www.taylorfrancis.com/books/e/9780203813058/chapters/10.4324/97802038130 58-11. 
Klepp, S. (2011). Europa Zwischen Grenzkontrolle Und Flüchtlingsschutz. Eine Ethnographie Der Seegrenze Auf Dem Mittelmeer. Bielefeld: transcript Verlag.

Kolber, I., Kreckel, J. and Niechziol, F. (2019). Recht Auf Streife Bei Der Bundespolizei: Die Wichtigsten Eingriffsnormen Nach BPolG, AufenthG Und StPO. 5th ed. Richard Boorberg Verlag.

Kotef, H. (2015). Movement and the Ordering of Freedom: On Liberal Governances of Mobility. Durham \& London: Duke University Press.

Krasmann, S. (2007). The enemy on the border: Critique of a programme in favour of a preventive state. Punishment \& Society 9:301-318.

Landespolizeidirektion Tirol (2015). Polizei. Bilanz. Tirol. 2014. Innsbruck: LPD Tirol [online]. Available at: https://www.polizei.gv.at/tirol/publikationen/bilanz/start.aspx. [Accessed 15.01.2019].

Landespolizeidirektion Tirol (2016). Polizei. Bilanz. Tirol. 2015. Innsbruck: LPD Tirol [online]. Available at: https://www.polizei.gv.at/tirol/publikationen/bilanz/start.aspx. [Accessed 15.01.2019].

Landespolizeidirektion Tirol (2017). Polizei. Bilanz. Tirol. 2016. Innsbruck: LPD Tirol [online]. Available at: https://www.polizei.gv.at/tirol/publikationen/bilanz/start.aspx. [Accessed 15.01.2019].

Landespolizeidirektion Tirol (2018). Polizei. Bilanz. Tirol. 2017. Innsbruck: LPD Tirol [online]. Available at: https://www.polizei.gv.at/tirol/publikationen/bilanz/start.aspx. [Accessed 15.5.2018].

Landespolizeidirektion Tirol (2020). Polizei. Bilanz. Tirol. 2019. Innsbruck: LPD Tirol [online]. Available at: https://www.polizei.gv.at/tirol/publikationen/bilanz/start.aspx.

Lechevalier, A. and Wielgohs, J. eds. (2013). Borders and Border Regions in Europe. Changes, Challenges and Changes. Bielefeld: Transcript.

Lecompte, M.D. (1982). Problems of Reliability and Validity in Ethnographic Research. 52:31-60.

Lefebre (1991). The Production of Space. Oxford: Blackwell Publishing.

Lehnguth, G., Maaßen, H.-G. and Schieffer, M. (1998). Rückführung Und Rückübernahme: Die Rückübernahmeabkommen Der Bundesrepublik Deutschland: Textsammlung Mit Einführung Und Erläuterungen. ZFSH/SGB-S. Starnberg: Schulz.

Lemieux, F. ed. (2010a). International Police Cooperation. Emerging Issues, Theory and Practice. Cullompton: Willan Publishing.

Lemieux, F. (2018). Police Cooperation Across Jurisdictions. In: Oxford Research Encyclopedia Criminology and Criminal Justice. Oxford University Press [online]. Available at: https://www.researchgate.net/publication/328791694 Police Cooperation Across Jurisd ictions.

Lemieux, F. (2010b). The nature and structure of international police cooperation: an introduction. In: Lemieux, F. ed. International Police Cooperation. Emerging Issues, Theory and Practice. London, New York: Routledge, pp. 1-22.

Liebling, A. (2001). Whose side are we on? Theory, practice and allegiances in prisons research. British Journal of Criminology 41:472-484.

Lindberg, A. and Borrelli, L. M. (2017). Let the Right One In - On Migration Authorities' Resistance to Research [online]. Available at: https://www.law.ox.ac.uk/research-subject- 
groups/centre-criminology/centreborder-criminologies/blog/2017/11/let-right-one.

Lipsky, M. (1980). Street-Level Bureaucracy. Dilemmas of the Individual in Public Services. 2010th ed. New York: Russel Sage Foundation.

Loftus, B. (2015). Border regimes and the sociology of policing. Policing and Society 25:115-125.

Low, S. and Glueck, Z. (2017). A sociospatial framework for the anthropology of security. Anthropological Theory 17:281-296.

Luecke, M., Breemersch, T. and Vanhove, F. (2016). Schengen Border Controls: Challenges and Policy Options. Study for the IMCO Committee. European Parliament, DG for Internal Policies, Committee on Internal Market and Consumer Protection (IMCO), IP/A/IMCO/201601 PE 578.990 [online]. Available at: https://www.europarl.europa.eu/thinktank/en/document.html?reference=IPOL IDA\%282 $\underline{016 \% 29578990 .}$.

Maguer, A. (2007). La sécurité en frontière intérieure, tentations européennes et réflexes nationaux. Politique européenne 23:93.

Maguer, A. (2004). Les Frontières Intérieures Schengen. Dilemmes et Stratégies de La Coopération Policière et Douanière Franco-Allemande. Freiburg: Max Planck Institute for Foreign and International Criminal Law.

Maguire, M., Frois, C. and Zurawski, N. (2014a). Introduction. The Anthroplogy of Security: Prospects, Retrospects and Aims. In: Maguire, M., Frois, C. and Zurawski, N. eds. The Anthropology of Security. Perspectives from the Frontline of Policing, Counter-Terrorism and Border Control. London: PlutoPress, pp. 1-23.

Maguire, M., Frois, C. and Zurawski, N. eds. (2014b). The Anthropology of Security. Perspectives from the Frontline of Policing, Counter-Terrorism and Border Control. London: PlutoPress.

Maiani, F. (2016). The Reform of the Dublin III Regulation. Study for the LIBE Committee. European Parliament, DG internal policies, Deparment C, Citizs Committee on Civil Liberties, Justice and Home Affairs and commissioned, overseen and published by the Policy Department for Citizen's Rights and Constitutional Affairs [online]. Available at: http://www.europarl.europa.eu/RegData/etudes/STUD/2016/571360/IPOL STU(2016)571 360 EN.pdf.

Maillet, P., Mountz, A. and Williams, K. (2020). Researching migration and enforcement in obscured places: practical, ethical and methodological challenges to fieldwork. Geographical Research with 'Vulnerable Groups' 18:33-56.

Makremi, C. and Parciboula, M. (2019). Prisonniers Du Passage. Paris: Steinkis.

Marcus, G.E. (1995). Ethnography in / of the World System: The Emergence of Multi-Sited Ethnography. Annual Review of Anthropology 24:95-117.

Martinico, G. and Pollicino, O. eds. (2012). The Interaction between Europe's Legal Systems: Judicial Dialogue and the Creation of Supranational Laws. Glos; Massachusettes: Edward Elgar Publishing, Inc.

Masco, J.P. (2018). The Secrecy/Threat Matrix. In: Maguire, M., Rao, U. and Zurawski, N. eds. Bodies as Evidence. Security, Knowledge, Power. Durham, London: Duke University Press, pp. 175-200.

McCloud, S. (1993). Understanding Comics: The Invisible Art. Northampton: Kitchen Sink Press.

Merry, S.E. (2013). McGill Convocation Address: Legal Pluralism in Practice. McGill Law Journal 59:1-9. 
Merry, S.E. (2014). Global legal pluralism and the temporality of soft law. The Journal of Legal Pluralism and Unofficial Law 46:108-122.

Merry, S.E. and Canfield, M.C. (2015). Law: Anthropological Approaches. In: International Encyclopedia of the Social \& Behavioral Sciences. Second Edi. Elsevier, pp. 535-541 [online]. Available at: http://www.sciencedirect.com/science/article/pii/B9780080970868121014.

Mezzadra, S. and Neilson, B. (2013). Border as Method. Or, the Multiplication of Labor. Durham \& London: Duke University Press.

Milhau, J.M. (2009). Rapport N 496, Annexe Au Procès-Verbal de La Séance Du 24 Juin 2009, SÉNAT SESSION ORDINAIRE DE 2008-2009, RAPPORT Par M. Jean MILHAU, Sénateur, de MILHAU, Fait Au Nom de La Commission Des Affaires Étrangères, Déposé Le 24 Juin 2009. [online]. Available at: http://www.senat.fr/rap/l08-496/I08-496.html.

Ministero dell'Interno (2009). Riorganizzazione dell'assetto dei presidi di Polizia di Frontiera terrestre. Decreto Capo della Polizia 559/A/I/131.5.5. del 22 settembre 2009. Circolare n.555-DOC/C/SPEC/SPMAS/6568-09 del 10 Ottobre 2009 [online]. Available at: https://www.siulp.it/riorganizzazione-dellassetto-dei-presidi-di-polizia-di-frontieraterrestre-3.html.

Ministero dell'Interno (2016). Relazione Sull'attività Delle Forze Di Polizia, Sullo Stato Dell'ordine e Della Sicurezza Pubblica e Sulla Criminalità Organizzata - Anno 2014 - DOC. XXXVIII, N. 3 Tomo II. Senato della Repubblica, Camera dei deputati, XVII Legislatura [online]. Available at:

http://documenti.camera.it/apps/commonServices/getDocumento.ashx?sezione=docume ntiparlamentari\&tipoDoc=pdf\&idLegislatura $=17 \&$ categoria $=038 \&$ numero $=003$ t02 RS\&doc =INTERO COM.

Ministero dell'Interno (2019). Progetto di riorganizzazione della Polizia Di Frontiera. Informazione preventiva ai sensi dell'art. 25, comma 2, d.P.R. n. 164/2002. Roma 22. November 2019 [online]. Available at: http://www.fsp-polizia.it/progetto-riorganizzazione-della-poliziafrontieral.

Mitchell, T. (2006). Society, Economy, and the State Effect. In: Sharma, A. and Gupta, A. eds. The Anthropology of the State. a Reader. Malden, Oxford, Victoria: Blackwell Publishing, pp. 169-186.

Mitsilegas, V. (2015). The Criminalisation of Migration in Europe Challenges for Human Rights and the Rule of Law. Heidelberg, New York, Dordrecht, London: Springer.

Mitsilegas, V., Monar, J. and Rees, W. (2003). The European Union and Internal Security. Guardian of the People? New York: Palgrave Macmillan UK.

Moffette, D. (2018). The jurisdictional games of immigration policing: Barcelona's fight against unauthorized street vending. Theoretical Criminology, published 04.11.2018 [online]. Available at: https://journals.sagepub.com/doi/10.1177/1362480618811693.

Moonen, T. (2011). Case Law. 129 Joined Cases C-188/10 And C-189/10, Proceedings Against Aziz Melki And Sélim Abdeli Or Howthe Last Shall Be The First: The Court Of Justice Rules On Priority Constitutional Review. Columbia Journal of European Law 17:129.

Moorhead, T. (2014). The Legal Order of the European Union: The Institutional Role of the Court of Justice. Oxon: Routledge.

Muensterberg, E. (1887). Die Deutsche Armutsgesetzgebung Und Material Zu Ihrer Reform. Leibzig: Verlag von Duncker und Humblot.

Mutsaers, P. (2014). An ethnographic study of the policing of internal borders in the Netherlands: 
Synergies between criminology and anthropology. British Journal of Criminology 54:831848.

N.d. (2012). Kooperation an der Grenze. Öffentliche Sicherheit. Das Magazin des Innenministeriums 9/10:33-34.

N.d. (2018). Padborg - Gemeinsames Zentrum der deutsch-dänischen Polizei- und Zollzusammenarbeit - Faelleskontor Padborg. Information Leaflet:Oktober.

Nader, L. (1972). Up the Anthropologist - Perspectives Gained from Studying Up. In: Dell, H. ed. Reinventing Anthropology. NY: Pantheon Books, pp. 284-311.

Newman, D. (2006). Borders and Bordering: Towards an Interdisciplinary Dialogue. European Journal of Social Theory 9:171-186.

Nogala, D. (2001). Policing Across a Dimorphous Border: Challenge and Innovation at the FrenchGerman Border. European Journal of Crime, Criminal Law and Criminal Justice 9:130-143.

Novotná, M. (2018). Schengen Cooperation: What Scholars Make of It Schengen Cooperation: What Scholars Make of It. Journal of Borderlands Studies. First published 06.04.2018 [online]. https://www.tandfonline.com/doi/full/10.1080/08865655.2018.1457974.

Oxfam, Belgrade-Centre-for-Human-Rights and Macedonian-Young-Lawyers-Accociation (2017). A DANGEROUS' GAME'. The pushback of migrants, including refugees, at Europe's borders' [online]. Available at: https://www.oxfam.org/en/research/dangerous-game-pushbackmigrants-including-refugees-europes-borders.

Paasi, A. (2009). Bounded spaces in a 'borderless world': border studies, power and the anatomy of territory. Journal of Power 2:213-234.

Paoli, L. and Fijnaut, C. (2006). Organised Crime and Its Control Policies. European Journal of Crime, Criminal Law \& Criminal Justice 14:307-327.

Parker, N. and Vaughan-Williams, N. (2012). Critical Border Studies: Broadening and Deepening the 'Lines in the Sand' Agenda. Geopolitics 17:727-733.

Parker, N. and Vaughan-Williams, N. (2009). Lines in the sand? Towards an agenda for critical border studies. Geopolitics 14:582-587.

Pascale, D. (2020). Respingimento dello straniero e controlli delle frontiere interne ed esterne del diritto dell'UE. Diritto, Immigrazione e Cittadinanza 2:1-47.

Pascouau, Y. (2011). Internal Border Controls in the Schengen Area: Much Ado about Nothing? European Policy Centre, 28.06.2011 [online]. Available at: https://www.epc.eu/en/Publications/Internal-border controls-in-th 1c1574.

Pascouau, Y. (2012). Policy Paper: Schengen and Solidarity: The Fragile Balance between Mutual Trust and Mistrust. European Policy Centre, Policy brief 04.07.2012 [online]. Available at: https://www.epc.eu/en/Publications/Schengen-and-solidarity-the-f 246080.

Peers, S. (2011). EU Justice and Home Affairs Law. 3rd ed. Oxford: Oxford University Press.

Peers, S. (2013). The Future of the Schengen System. Report 2013/6, SIEPS Swedish Institute for European Policy Studies [online]. Available at: http://www.sieps.se/en/publications/2013/the-future-of-the-schengen-system-20136/.

Pels, P. et al. (2018). Data management in anthropology: the next phase in ethics governance? Social Anthropology 26:391-413.

Perkowski, N. (2016). Deaths, Interventions, Humanitarianism and Human Rights in the Mediterranean 'Migration Crisis'. Mediterranean Politics 21:331-335. 
Peters, M., Vanderhallen, M. and Nelen, H. (2016). Cross-Border Criminal Investigation in the Meuse-Rhine Euroregion: International Policing and the Theory of (inter-) Organisational Conflict. European Journal on Criminal Policy and Research 22:41-60.

Pickering, S., Bosworth, M. and Aas, K.F. (2014). The criminology of mobility. In: Pickering, S. and Ham, J. eds. The Routledge Handbook on Crime and International Migration. Taylor \& Francis Group [online] ProQuest Ebook Central, pp. 382-395.

Pickering, S. and Ham, J. eds. (2014). The Routledge Handbook on Crime and International Migration. London: Routledge.

Pickering, S. and Weber, L. eds. (2006). Borders, Mobility and Technologies of Control. Dordrecht: Springer Verlag.

Pickering, S. and Weber, L. (2013). Policing transversal borders. In: Aas, K. F. and Bosworth, M. eds. The Borders of Punishment: Migration, Citizenship, and Social Exclusion. Oxford: Oxford University Press, pp. 93-110.

Picozza, F. (2017). Dublin on the Move Transit and Mobility across Europe's Geographies of Asylum. movements. Journal for Critical Migration and Border Regime Studies 3(1) [online]. Available at: https://movements-journal.org/issues/04.bewegungen/05.picozza--dublinon-the-move.html.

Pijl, Y., Oude Breuil, B. and Siegel, D. (2011). Is there such thing as 'global sex trafficking'? A patchwork tale on useful (mis)understandings. Crime, Law and Social Change 56:567-582.

Pistoia, E. (2018). II muro invisibile ma impervio di Ventimiglia. federalismi. rivista di diritto pubblico, comparato, europeo 3:2-16.

Porter, A. (2018). Non-State Policing, Legal Pluralism and the Mundane Governance of 'Crime'. Sydney Law REview 40:445-468.

Pudlat, A. (2013). Schengen. Zur Manifestation Grenze Und Grenzschutz in Europa. Hildesheim, Zürich, New York: Georg Olms Verlag.

Reichel, P. and Albanese, J. (2014). Handbook of Transnational Crime and Justice. 2nd revise. London: Sage Publications Ltd.

Reiner, R. (2015). Political Economy and Policing: A Tale of Two Freudian Slips. In: Mitsilegas, V., Alldridge, P. and Cheliotis, L. K. eds. Globalisation, Criminal Law and Criminal Justice: Theoretical, Comparative and Transnational Perspectives. Oxford: Hart Publishing, pp. 6585.

Reiner, R. (2010). The Politics of the Police. 4th ed. Oxford: Oxford University Press.

Rice, S.K. and Maltz, Michael, D. eds. (2018). Doing Ethnography in Criminology. Discovery through Fieldwork. Springer International Publishing [online]. Available at: https://www.springer.com/gp/book/9783319963150.

Riles, A. (2005). A New Agenda for the Cultural Study of Law: Taking on the Technicalities. Buffalo Law Review 53:973-1033.

Roach, J. and Thomaneck, J. eds. (1985). Police and Public Order in Europe. Dover, New Hampshire: Croom Helm.

Rompuy, H. Van, Malkoutzis, N. and Pascouau, Y. (2016). Migration Panorama. Schengen in the Spotlight: A Europe with or without Borders? European Policy Centre Discussion Paper, 12/04/2016 [online]. Available at: https://wms.flexious.be/editor/plugins/imagemanager/content/2140/PDF/2016/Schengen 
in the spotlight.pdf.

Rose, N. and Miller, P. (1992). Political Power beyond the State. Problematics of Governement. British Journal of Sociology 43:173-205.

Rowe, M. (2007). Tripping Over Molehills: Ethics and the Ethnography of Police Work. International Journal of Social Research Methodology 10:37-48.

Rozakou, K. (2017). Nonrecording the "European refugee crisis" in Greece navigating through irregular bureaucracy. Focaal 2017:36-49.

Rumford, C. (2006). Theorizing Borders. European Journal of Social Theory 9:155-169.

Rutz, J. [EMN] (2014). Österreichs Rückkehrpolitik: Anwendung von Einreise-Verboten Und Durchsetzung von Rückübernahmeabkommen. Internationale Organisation für Migration (IOM), Landesbüro für Österreich; EMN [online]. Available at: https://www.emn.at/de/emnstudie-oesterreichs-rueckkehrpolitik-anwendung-von-einreiseverboten-und-durchsetzungvon-rueckuebernahmeabkommen-2014/.

Salazar, N.B. and Jayaram, K. eds. (2016). Keywords of Mobility Critical Engagements. New York: Berghahn Books.

Sassen, S. (1996a). Migranten, Siedler, Flüchtlinge. Von Der Massenauswanderung Zur Festung Europa. 3rd ed. Fischer Verlag.

Sassen, S. (1996b). Sovereignty in an Age of Globalisation. New York: Columbia University Press.

Sassen, S. (2012). Neither global nor national: Novel assemblages of territory, authority, and rights. International Comparative Social Studies 26:93-114.

Van Schendel, W. (2005). Spaces of engagement: how borderlands, illegal flows, and territorial states interlock. In: Van Schendel, W and Abraham, I. eds. Illicit Flows and Criminal Things: States, Borders, and the Other Side of Globalization. Bloomington: Indiana University Press, pp. 38-68.

Schleswig-Holsteinischer Landtag (2016). Niederschrift. Innen- Und Rechtsausschuss 18. WP - 120. Sitzung, Am Mittwoch, Dem 27. Januar 2016. Schleswig-Holsteinischer Landtag [online]. https://www.landtag.Itsh.de/infothek/wahl19/aussch/iur/niederschrift seite/ [Accessed: 31.03.2017].

Schmidt-Sembdner, M. (2019). Europa und die Bewegung der Migration. Das Dublin system im Kontext nationaler Grenzkontrollen entlang der Brenner-Route. In: Johler, R. and Lange, J. eds. Konfliktfeld Fluchtmigration: Historische Und Ethnographische Perspektiven. Bielefeld: transcript Verlag, pp. 165-182.

Schmidt-Sembdner, M. (2018). Grenzkontrollen als 'dauerhaftes Provisorium'? Renationalisierungsprozesse im Schengenraum am Beispiel der Brennerroute. movements Journal for Critical Migration and Border Regime Studies 4:57-77.

Schober, K. (2017). Europäsche Polizeizusammenarbeit Zwischen Trevi Und Prüm. Mehr Sicherheit Auf Kosten von Freiheit Und Recht? Heidelberg: C.F. Müller.

Schwell, A. (2008). Europa an Der Oder. Die Konstruktion Europäischer Sicherheit an Der DeutschPolnischen Grenze. Bielefeld: transcript Verlag.

Schwell, A. (2009). De/Securitising the 2007 Schengen Enlargement: Austria and "the East". Journal of Contemporary European Research 5:243-258.

Schwell, A. (2010). The iron curtain revisited: the 'Austrian way' of policing the internal Schengen border. European Security 19:317-336. 
Schwell, A. (2017). When Worlds Collide : Negotiating Work Ethics on the German - Polish Border. East European Politics and Societies and Cultures 31(2):269-289.

Senato della Repubblica (2012). Resoconto assemblea 803a, giovedi 27 Settembre 2012. XVI legislatura [online]. Available at: http://www.senato.it/urires/N2Ls?urn:nir:senato.repubblica;assemblea:resoconto:16.legislatura;813.

Sheptycki, J.W.E. (1995). Transnational policing and the makings of a postmodern state. British Journal of Criminology 35:613-635.

Sheptycki, J.W.E. (1998a). Police Co-operation in the English Channel Region, 1968-1996. European Journal of Crime, Criminal Law and Criminal Justice 7:216- 236.

Sheptycki, J.W.E. (1998b). The Global Cops Cometh: Reflections on Transnationalization, Knowledge Work and Policing Subculture. The British Journal of Sociology 49:57-74.

Sheptycki, J.W.E. (2001). Patrolling the New European (In)Security Field; Organisational Dilemmas and Operational Solutions for Policing the Internal Borders of Europe. European Journal of Crime, Criminal Law and Criminal Justice 9:144-159.

Shore, C. (2009). 'European Governance', or 'Governmentality'. Reflections on the EU's System of Goverment. Webpapers on Constitutionalism \& Governance beyond the State, ConWEB No. 3/2009 [online]. Available at: https://econpapers.repec.org/scripts/redir.pf?u=https\%3A\%2F\%2Fwww.wiso.unihamburg.de\%2Ffachbereichsowi\%2Fprofessuren\%2Fwiener\%2Fdokumente\%2Fconwebpaperspdfs\%2F2009\%2Fconwe b-3-2009.pdf;h=repec:erp:conweb:p0037.

Shore, C. and Wright, S. eds. (1997). Anthropology of Policy: Perspectives on Governance and Power. London: Routledge.

Shore, C., Wright, S. and Però, D. eds. (2011). Policy Worlds. Anthropology and the Analysis of Contemporary Power. Oxford, New York: Berghahn Books.

Siebold, A. (2013). ZwischenGrenzen. Die Geschichte Des Schengen-Raums Aus Deutschen, Französischen Und Polnischen Perspektiven. Paderborn: Verlag Ferdinand Schöningh.

Siegel, D. and Nagy, V. eds. (2018). The Migration Crisis? Criminalization, Security and Survival. The Hague: eleven international publishing.

SIULP (2016). Migranti: SIULP, NO a Uso Della Forza per Prelievo Impronte. Appello Al Governo. News, 17 Marzo 2016 [online]. Available at: https://www.siulp.it/migranti-siulp-no-a-usodella-forza-per-prelievo-impronte-appello-al-governo.html.

Skleparis, D. (2018). 'A Europe without Walls, without Fences, without Borders': A Desecuritisation of Migration Doomed to Fail. Political Studies 66:985-1001.

Slaughter, A.M. (2004). Disaggregated Sovereignty: Towards the Public Accountability of Global Government Networks. Government and Opposition 39:28-37.

Smith, N. (1992). Contours of a Spatialized Politics: Homeless Vehicles and the Production of Geographical Scale. Social Text 33:54-81.

Smith, N. (2003). Remaking scale: competition and cooperation in pre-national and post-national Europe. In: Brenner, N. et al. eds. State/Space. A Reader. Blackwell Publishing, pp. 227-238.

de Somer, M. (2019a). Schengen and internal border controls. In: de Bruycker, P., de Somer, M. and de Brouwer, J.-L. eds. From Tampere 20 to a New European Consensus on Migration. EPC, EMN Finland, Odysseus Network, Friedrich Naumann Foundation, pp. 119-130 [online]. Available at: http://odysseus-network.eu/from-tampere-20-to-tampere-2-0- 
towards-a-new-european-consensus-on-migration/.

de Somer, M. (2019b). Safeguarding Schengen. The next EU leadership should return to factbased policies. In: EPC ed. Challenge Europe. Yes, We Should. EU Priorities for 2019-2024. Vol. 24 European Policy Centre (EPC), pp. 77-83 [online]. Available at: https://www.epc.eu/en/Publications/Chapter-9--Safeguarding-Schengen-The-next-EUleadership-should-return 2cbf14.

de Somer, M. (2019c). Background Note: "Borders and Schengen". Conference 'From Tampere 20 to Tampere 2.0', organised by the European Migration Network Finland, Odysseus Network, European Policy Centre, 24-25 October 2019, Helsinki [online]. Available at: https://e.eventos.fi/events/migri/emn-conference-24-25-october-2019/home\%0A.

Sousa, L. De (2013). Understanding European Cross-border Cooperation: A Framework for Analysis. Journal of European Integration 35:669-687.

Sousanis, N. (2015). Unflattening. Cambridge, London: Harvard University Press.

Spapens, T. (2008). Policing a European Border Region: The Case of the Meuse- Rhine Euroregion. In: Geyer, F. and Guild, E. eds. Security versus Justice? Police and Judicial Cooperation in the European Union. ProQuest Ebook Central [online].

Spapens, T. (2010). Police cooperation in the Dutch border areas. In: Ouwerkerk, J. and Fijnaut, C. eds. The Future of Police and Judicial Cooperation in the European Union. Leiden: EBSCO eBook Collection [online], pp. 73-102.

Stavrianakis, A. (2020). Searching for the smoking gun? Methodology and modes of critique in the arms trade. In: de Goede, M., Bosma, E. and Pallister-Wilkins, P. eds. Secrecy and Methods in Security Research. A Quide to Qualitative Fieldwork. London, New York: Routledge, pp. 231-247.

Sternberger, K. (2016). Bayern und Oberösterreich: Durch den Inn getrennt - Durch Sicherheit verbunden. Polizei Oberösterreich. Das Infomagazin der Landespolizeidirektion 3:32-33.

Stumpf, J.P. (2006). The Crimmigration Crisis: Immigrants, Crime, and Sovereign Power. American University Law Review 56:367-419.

Taussig, M. (2011). I Swear I Saw This: Drawings In Fieldwork Notebooks, Namely My Own. Chicago, London: University of Chicago Press.

Tazzioli, M. (2017). Containment Through Mobility at the Internal Frontiers of Europe. Border Criminologies blogpost, 15.03.2017 [online]. Available at: https://www.law.ox.ac.uk/research-subject-groups/centre-criminology/centrebordercriminologies/blog/2017/03/containment.

Tazzioli, M. (2019). The politics of migrant dispersal. Dividing and policing migrant multiplicities. Migration Studies, published 13.02.2019 [online]. Available at: https://doi.org/10.1093/migration/mnz003.

Tazzioli, M. and Garelli, G. (2018). Containment beyond detention: The hotspot system and disrupted migration movements across Europe. Environment and Planning D: Society and Space, first published 19.02.2018 [online]. Available at: https://journals.sagepub.com/doi/10.1177/0263775818759335.

Tischbirek, A. and Wihl, T.: (2017). Schengen Schlägt Zurück!? Verfassungsblog, 22.06.2017 [online]. Available at: https://verfassungsblog.de/schengen-schlaegt-zurueck/

Torpey, J.C. (2018). The Invention of the Passport. Surveillance, Citizenship and the State. 2nd ed. Cambridge, Melborne, New York: Cambridge University Press. 
Trenkwalder, A. (1999). Brennero. Storia Di Un Paesino e Di Un Valico Internazionale / Brenner. Bergdorf Und Alpenpass. Brennero, G. B. / C. di ed. Bozen/Bolzano: Athesiadruck.

Trouillot, M.-R. (2001). The Anthropology of the State in the Age of Globalization. Close Encounters of the Deceptive Kind. Current Anthropology 42:125-138.

Tsianos, V. and Karakayali, S. (2010). Transnational Migration and the Emergence of the European Border Regime: An Ethnographic Analysis. European Journal of Social Theory 13:373-387.

Tsing, A. (2000). The Global Situation. Cultural Anthropology 15:327-360.

Tugba, B. (2011). Security, Law and Borders. At the Limits of Liberties. London, New York: Routledge.

Twining, W. (2010). Normative and legal pluralism - a global perspective. Duke Journal of Comparative \& International Law 20:473-517.

Tylor, I., Walton, P. and Young, L. (1973). The New Criminology: For a Social Theory of Deviance. London, New York: Routledge.

UGL (2016). Uso Della Forza Nelle Operazioni Di Foto-Segnalamento e Nella Rileva-Zione Delle Impronte Digitali Di Stranieri e Cittadini Italiani. UGL Segreteria Provinciale di Catania Unione Generale Lavoratori di Polizia Polizia di Stato Prot. Nº39/16/CT, lettera al capo di polizia, 20.01.16 [online]. Available at: http://www.fsp-polizia.it/uso-della-forza-nelleoperazioni-di-foto-segnalamento-e-nella-rileva-zione-delle-impronte-digitali-di-stranieri-ecittadiniitaliani/index.php?option=com rubberdoc\&view=doc\&id=4189\&format=raw\&ltemid=116.

Valler, C. (2009). La coopération policière frontalière bilatérale: les centres de coopération policière et douanière L'exemple de Vintimille. Les Cahiers de la sécurité intérieure 8:135140.

Valverde, M. (2008). Analyzing the governance of security: Jurisdiction and scale. Behemoth. A Journal on Civilisation 1:3-15.

Valverde, M. (2009). Jurisdiction and scale: legal 'technicalities' as resources for theory. Social \& Legal Studies 18:139-157.

Valverde, M. (2014). Studying the governance of crime and security: Space, time and jurisdiction. Criminology \& Criminal Justice 14:379-391.

Vaughan-Williams, N. (2011). Off-shore biopolitical border security: The EU's global response to migration, piracy, and 'risky' subjects. In: Bialasiewicz, L. ed. Europe in the World: EU Geopolitics and the Making of European Space. Farnham, Burlington: Ashgate, pp. 185-200.

Vaughan-Williams, N. (2012). Border Politics: The Limits of Sovereign Power. Edinburgh: Edinburgh University Press.

Vaughan-Williams, N. (2015). Europe's Border Crisis: Biopolitical Security and Beyond. Oxford: Oxford University Press.

Votoupalová, M. (2019). The wrong critiques: Why internal border controls don't mean the end of Schengen. New Perspectives 27:73-99.

Wagner, M., Perumadan, J. and Baumgartner, P. (2019). Secondary Movements. Chemnitz: CEASEVAL Research Horizon 2020, Nr.34. [online]. Available at: http://ceaseval.eu/publications/34 SecondaryMovements.pdf.

Walker, N. (1994). European integration and European policing: a complex relationship. In: Anderson, M. and den Boer, M. eds. Policing across National Boundaries. London, New York: 
Pinter Publishers, pp. 22-45.

Walker, N. (2008). The pattern of transnational policing. In: Newburn, T. ed. Handbook of Policing. 2nd ed. Devon, Portland: Willan Publishing, pp. 119-145.

Walker, N. (2004). Europe's Area of Freedom, Security, and Justice. Oxford: Oxford University Press.

Walsh, D.P.J. (2011). Police Cooperation across the Irish Border: Familiarity Breeding Contempt for Transparency and Accountability. Journal of Law and Society 38:301-330.

Walters, W. (2002). Mapping Schengenland: denaturalizing the border. Environment and Planning D: Society and Space 20:561-580.

Walters, W. (2010). Deportation, Expulsion and the International Police of Aliens. Citizenship Studies 6:265-292.

Walters, W. (2011). Foucault and Frontiers. Notes on the Birth of the Humanitarian Border. In: Bröckling, U., Krasmann, S. and Lemke, T. eds. Governmentality. Current Issues and Future Challenges. New York: Routledge, pp. 138-164.

Walters, W. (2015a). Migration, vehicles, and politics: Three theses on viapolitics. European Journal of Social Theory 18:469-488.

Walters, W. (2015b). On the Road with Michel Foucault: Migration, Deportation, and Viapolitics. In: S. Fuggle, Y. Lanci, M. T. ed. Foucault and the History of Our Present. London: Palgrave Macmillan, pp. 94-109.

Walters, W. (2015c). Reflections on Migration and Governmentality. movements. Journal für kritische Migrations- und Grenzregimeforschung 1:1-25 [online). Available at: https://movements-journal.org/issues/01.grenzregime/04.walters-migration.governmentality.html

WBBSI (2018). Integrative Plan of Action 2018-2020 [online]. Available at: https://wbiisg.com/wp-content/uploads/bp-attachments/5033/WBCTi-iPA-2018-2020.pdf.

Weber, L. et al. (2004). Policing Migration: A Framework for Investigating the Regulation of Global Mobility. Policing and Society 14:195-212.

Weber, L. et al. (2020). Beyond deportation: researching the control of outward mobility using a space of flows logic. Global Networks 20(1):65-84.

Weber, L. and McCulloch, J. (2019). Penal power and border control: Which thesis? Sovereignty, governmentality, or the pre-emptive state? Punishment and Society 21:496-514.

Weber, M. (1919). Politik als Beruf. In: Geistige Arbeit Als Beruf. Vier Vorträge Vor Dem Freistudentischen Bund. Muenchen, Leipzig: Verlag von Duncker \& Humblot.

Weibl, D. (2016). Poilice Abd Border Cooperation in Schengen: The Police and Customs Cooperation Centre (PCCC). Master Thesis Political Science: Leiden Universiteit [online]. Available at: https://openaccess.leidenuniv.nl/handle/1887/40745.

Weissensteiner, M. (2009). Torture Evidence on Trial: (Missing) Scars, 'Innocent Scars', Invisible Wounds. Anthropological Reflections on the Documentation of Fear and Violence in European Asylum Procedures. Unpublished Master Thesis, Joint EU Master in Social and Cultural Anthropology 'Cultural Differences and Transnational Processes', National University of Ireland, Maynooth (IR); Université Lumière Lyon II (FR); Universitat Autónoma de Barcelona.

Weissensteiner, M. (2010). Borders and Borderlands: A Common European Asylum System. In: 
Zapata Barrero, R. ed. Migrations and Borders in the European Union. Barcelona: GRITIMCIDOB, pp. 139-159 [online]. Available at: https://www.cidob.org/en/publications/publication series/monographs/monographs/sha ping the normative contours of the european union a migration border framework.

Weissensteiner, M. (2011). Ogma [cover illustration and note]. Irish Journal of Anthropology 14, Special Issue 'The Value of Ethnographic Writing', cover note p.2. [online]: Available at: http://anthropologyireland.org/wp-content/uploads/2018/05/IJA 14 1 2011.pdf.

Weissensteiner, M. (2014). The Civil-Military Hyphen. Experiences and Perceptions of Civil-Military Interaction in Afghanistan: Case Study Italy. Unpublished thesis for vocational post-diploma 'Conflict Mediators - Peace Operators'.

Weissensteiner, M. (2015). Expert Translations of Torture and Trauma: A Multisited Ethnography. In: Zinn, D. and Tauber, E. eds. The Public Value of Anthropology. Engaging Critical Social Issues Through Ethnography. Bolzano: University of Bolzano Press, pp. 143-172.

Weissensteiner, M. (2016). Research Proposal for the Doctorate in Cultural and Global Criminology: POLITICS, POLICIES AND PRACTICES OF BORDERING "EUROPE": Securities and Rights between European, National and Local Landscapes of Meaning and Power.

Weissensteiner, M. (2018). Experiences and perceptions of refugees and forced migrants in the EU, aiming to cross an internal Schengen border. In: Wacker, E., Becker, U. and Crepaz, K. eds. Refugees and Forced Migrants in Africa and the EU Comparative and Multidisciplinary Perspectives on Challenges and Solutions. Wiesbaden: Springer Fachmedien, pp. 163-201.

Weissensteiner, M. (2021, forthcoming).| BORDER-STRIP: a border-criminology ethnography. In (working title) Criminographics: a visual approach to cultural and global criminology.

Wenda, G. (2014). Polizeiarbeit ohne Grenzen. Öffentliche Sicherheit 5-6:49-52 [online]. Available at: https://www.bmi.gv.at/magazinfiles/2014/05 06/files/polizeikooperation.pdf

Wilkinson, P. (1985). European Police Cooperation. In: Roach, J. and Thomaneck, J. eds. Police and Public Order in Europe. Dover, New Hampshire: Croom Helm, pp. 273-286.

Wissink, L. (2020). Material guides in ethically challenging fields: following deportation files. In: pp. 291-305.

Van der Woude, M. (2012). Mobile Surveillance Operations at the Dutch Borders. Or Restricting the Right to Free Movement for Dangerous Others? [Presentation, online]. Available at: https://www.crimmigrationcontrol.com/content/news/Presentations/[Presentation 42] Maartje van der Woude.pdf.

Van der Woude, M. (2020). A Patchwork of Intra-Schengen Policing: Border Games over National Identity and National Sovereignty. Theoretical Criminology 24:110 -131.

Van der Woude, M. and Van Berlo, P. (2015). Crimmigration at the internal borders of Europe? Examining the schengen governance package. Utrecht Law Review 11:61-79.

Van der Woude, M. and Brouwer, J. (2017). Illegal Junk in the Trunk: Underlying Intentions of (Cr)immigration Controls in Schengen's Internal Border Areas. New Criminal Law Review 20:157-179.

Van der Woude, M. and Van der Leun, J. (2013). A Reflection on Crimmigration in the Netherlands. On the Cultural Security Complex and the Impact of Framing. In: Guia, M. J., van der Woude, M. and van der Leun, J. eds. Social Control and Justice. Crimmigration in the Age of Fear. The Hague: eleven international publishing, pp. 41-60.

Van der Woude, M. and Van der Leun, J. (2017). Crimmigration checks in the internal border areas 
of the EU: Finding the discretion that matters. 14:27-45.

Wright, S. (2011). Studying policy: methods, paradigms, perspectives. Introduction. In: Shore, C., Wright, S. and Pero, D. eds. Policy Worlds. Anthropology and the Analysis of Contemporary Power. New York, Oxford: Berghahn Books, pp. 27-31.

Wright, S. and Reinhold, S. (2011). 'Studying Through': a Strategy for studying political transformation. Or Sex, Lies and British Politics. In: Shore, C., Wright, S. and Pero, D. eds. Policy Worlds. Anthropology and the Analysis of Contemporary Power. New York, Oxford: Berghahn Books, pp. 86-104.

Zaiotti, R. (2011). Cultures of Border Control. Schengen \& the Evolution of Frontiers. London, Chicago: University of Chicago Press.

Zaiotti, R. (2013). The Italo-French Row over Schengen, Critical Junctures, and the Future of Europe's Border Regime. Journal of Borderlands Studies 28:337-354.

Zedner, L. (2007). Pre-crime and post-criminology? Theoretical Criminology 11:261-281. Zedner, L. (2009). Security. London: Routledge.

Zillmer, S. et al. (2016). EGTC Monitoring Report 2016 and Impacts of Schengen Area Crisis on the Work of EGTCS. European Committee of the Regions [online]. Available at: https://op.europa.eu/sk/publication-detail/-/publication/6adec7cb-24cd-11e7-b61101aa75ed71a1/language-en/format-PDF/source-117154048.

\section{News articles and press-releases}

Alon (2017). Patthelyzet a magyar-osztrák határon, 58 migráns tûnt fel Hegyeshalomnál. alon, 20.02.2017 [online]. Available at: https://www.alon.hu/aktualis/2017/02/patthelyzet-amagyar-osztrak-hataron-58-migrans-tunt-fel-hegyeshalomnal-

Amnesty International et al. (2017). Frontière Franco-Italienne: Des Atteintes Inadmissibles Aux Droits Des Personnes Migrantes et Réfugiées. Communiqué de presse interassociatif, signataires: Amnesty Internationnal, La Cimade, Médecins du Monde, Médecins Sans Frontières et Secours Catholique Caritas France, 16.10.2017 [online]. Available at: https://www.msf.fr/communiques-presse/frontiere-franco-italienne-des-atteintesinadmissibles-aux-droits-des-personnes-migrantes-et-refugiees; https://www.lacimade.org/presse/frontiere-franco-italienne-atteintes-inadmissiblesaux-droits-personnes-migrantes [Accessed: 22 December 2019].

Asylum Information Database [AIDA] (2020). Asylum in Europe 2019: Human rights under pressure. 26/08/2020 [online]. Available at: https://www.asylumineurope.org/news/2608-2020/asylum-europe-2019-human-rights-under-pressure.

Berizzi, P. (2016). Barriera al Brennero, ecco come sarà. Renzi: "Una sfacciata violazione delle regole Ue". la Repubblica, 27.04.2016 [online]. Available at: https://www.repubblica.it/esteri/2016/04/27/news/brennero barriera-138562961/

Bayerisches Staatsministerium des Innern für Sport und Integration (2017a). Zehn Jahre Gemeinsames Zentrum Petrovice - Schwandorf München. Pressemitteilung, 18.12.2017 [online]. Available at: https://www.stmi.bayern.de/med/pressemitteilungen/pressearchiv/2017/452b/index.p $\underline{h p}$

Bayerisches Staatsministerium des Innern für Sport und Integration (2017b). Bayerisches Konzept der Schleierfahndung voll bestätigt. Pressemitteilung, 17.02.2017 [online]. Available at: https://www.stmi.bayern.de/med/pressemitteilungen/pressearchiv/2017/49/index.php 
Bundesministerium für Inneres (2015). Mikl-Leitner: Wir kämpfen gegen Schlepper, nicht gegen Flüchtlinge. Die Polizei geht nach dem Prinzip der Verhältnismäßigkeit vor. Pressemitteilung Artikel Nr. 12752, 04.09.2015 [online]. Still available at: https://www.ots.at/presseaussendung/OTS 20150904_OTS0190/mikl-leitner-wirkaempfen-gegen-schlepper-nicht-gegen-fluechtlinge. [Accessed: 5 May 2020];

Bundesministerium des Innern, für Bau und Heimat (2015). Deutsch-Österreichisches Polizeikooperations-zentrum Ist Am Netz. Erfassung, Bewertung Und Koordinierung Der Grenzüberschreitenden Flüchtlings- Und Asylsituation. Pressemitteilung, 20.11.2015 [online]. Available at: https://www.bmi.bund.de/SharedDocs/pressemitteilungen/DE/2015/11/deutschoesterreichisches-polizeikooperationszentrum.html.

Bundesministerium des Innern, für Bau und Heimat [BMI DE] (2017). Weiterhin Binnengrenzkontrollen an deutsch-österreichischer Landesgrenze. Rat der Europäischen Union ermöglicht Fortsetzung der Binnengrenzkontrollen um weitere sechs Monate. Kurzmeldung, 11.05.2017 [online]. Available at: https://www.bmi.bund.de/SharedDocs/kurzmeldungen/DE/2017/05/verlaengerungbinnengrenzkontrollen.html.

Bundesministerium für Inneres, Digitalisierung und Migration Baden-Württemberg (2019). 20 Jahre Gemeinsames Zentrum Der Deutsch-Französischen Polizei- Und Zollzusammenarbeit. Presse- und Öffentlichkeitsbereich, 14.3.2019 [online]. Available at: https://im.baden-wuerttemberg.de/de/service/presse-undoeffentlichkeitsarbeit/pressemitteilung/pid/20-jahre-gemeinsames-zentrum-derdeutsch-franzoesischen-polizei-und-zollzusammenarbeit/

Brigida, V. and Poeta, M. (2016). Hotspot - Le Impronte Dei Migranti. internazionale, 12.05.2016 [online]. Available at: https://www.internazionale.it/video/2016/05/12/hotspot-leimpronte-dei-migranti.

Calvo, E. (2012). Las comisarías hispano-marroquíes se limitarán a intercambiar información. El Mundo, 28.05.2012 [online]. Available at: https://www.elmundo.es/elmundo/2012/05/28/espana/1338208647.html.

Council of the European Union (2006). 2768th Council Meeting Justice and Home Affairs Brussels, 4-5 December 2006. Press release EN, C/06/34:102-117 [online]. Available at: https://ec.europa.eu/commission/presscorner/detail/en/PRES 06341.

Council of the European Union (2020). Border Management: EU Concludes Agreements with Montenegro and Serbia on Frontex Cooperation. Press-release, 26.05.2020 [online]. Available at: https://www.consilium.europa.eu/en/press/pressreleases/2020/05/26/border-management-eu-concludes-agreements-withmontenegro-and-serbia-on-frontex-cooperation/?utm source=dsmsauto\&utm medium=email\&utm campaign=Border+management\%3A+EU+concludes+a greements.

von Delhaes-Guenther, A. (2019). Kontrolle ist besser. Bayern Kurier, 21.01.2019 [online]. Available at: https://www.bayernkurier.de/inland/36506-kontrolle-ist-besser/.

RTVE-EFE (2012). España y Marruecos inauguran comisarías conjuntas y refuerzan la cooperación policial. rtve, 28.05.2012 [Online]. Available at: https://www.rtve.es/noticias/20120528/madrid-rabat-dan-salto-cooperacion-policialcomisarias-conjuntas/532033.shtml. 
European Commission (2017). February infringements package: key decisions. Brussels, 15 February 2017, press-release MEMO/17/234 [online]. Available at: https://ec.europa.eu/commission/presscorner/detail/EN/MEMO 17234.

European Commission (2016). December infringements package: key decisions. Brussels, 8 December 2016, press-release MEMO/16/4211 [online]. Available at: Available at: https://ec.europa.eu/commission/presscorner/detail/en/MEMO 164211.

European Commission (2015b). Implementing the Common European Asylum System: Commission escalates 8 infringement proceedings. Brussels, 10 December 2015, pressrelease $\quad \mathrm{P} / 15 / 6276 \quad$ [online]. Available at: https://ec.europa.eu/commission/presscorner/detail/en/IP 156276.

European Council (2018). Conclusions adopted by the European Council 28 June 2018. Pressrelease 29.6.2018 [online]. Available at: https://www.consilium.europa.eu/en/press/press-releases/2018/06/29/20180628euco-conclusions-final/; $\quad$ Conclusions, 28.06 .2018 https://www.consilium.europa.eu/media/35936/28-euco-final-conclusions-en.pdf.

Fromm, Carolin (2014). Der Zug der Flüchtlinge. ndr, 25.09.2014 [online]. Available at: https://www.ndr.de/nachrichten/Transitland-Norddeutschland,transitland102.html.

Gasser, L.M. (2018). "Schließt der Brenner, schließt Europa”. salto, 04.06.2018 [online]. Available at: https://www.salto.bz/it/article/03072018/heribert-prantl.

Giornale di Montesilvano (2015). 'In Europa ci vogliono punire perché non usiamo la forza per prendere le impronte, e allo stesso tempo agevolano le denunce dei clandestini per presunti abusi e violazioni dei loro diritti.' A riferirlo è il Segretario Generale Provinciale Pescara COISP Giovanni Catitti. Giornale di Montesilvano, 17.12.2015 [online]. Available at: https://www.giornaledimontesilvano.com/2194-ue-impronte-cladestini-coisp-punitiperche-non-usiamo-forza-e-che-siamo-imbecilli [Accessed: 22 March 2020].

Kirchgaessner, S. (2016). Austrian border plan risks turning South Tyrol into emblem of EU disintegration. Region once seen as a symbol Europe's peaceful cohesion braces for Austrian effort to contain migration crisis. the Guardian, 31.05.2016 [online]. Available at: $\quad$ https://www.theguardian.com/world/2016/mar/31/austrian-border-plan-risksturning-south-tyrol-into-emblem-of-eu-disintegration.

Ministero dell' Interno (n.d.) Approfondimento. Centro Di Cooperazione e Di Dogana Di Ventimiglia. sala stampa [online]. Available at: https://www1.interno.gov.it/mininterno/export/sites/default/it/sezioni/sala stampa/pr efetture/Liguria/imperia/app notizia 21236.html.

Ministero dell' Interno (2017). Meno 33\% gli sbarchi nel 2017. Notizie, 20.12.2017, ultimo aggiornamento 11.12 .2018 [online]. Available at: https://www.interno.gov.it/it/notizie/meno-33-sbarchi-nel-2017.

Ministerium für Inneres und Bundesangelegenheiten Schleswig-Holstein (2016). BAO Innenminister Studt veranlasst Auflösung der BAO Flüchtlinge. Pressemitteilung, 21.04.2016 [online]. Available at: https://www.schleswigholstein.de/DE/Landesregierung/IV/Presse/Pl/2016/Integration/160421 im BAO Auflo esung.html.

Mumelter, G. (2016). "Der Brenner ist keine normale Grenze ". Der Standard, 15.02.2016 [online]. Available at: https://apps.derstandard.at/privacywall/story/2000031143550/derbrenner-ist-keine-normale-grenze. 
Oczeret H. (2017). Ungarn wirft Österreich illegale Rückschiebung von Flüchtlingen vor. die presse, 20.02.2017 [online]. Available at: https://www.diepresse.com/5172615/ungarnwirft-osterreich-illegale-ruckschiebung-von-fluchtlingen-vor.

Ormazabal, Mikel (2018). Interior admite incumplimientos en la entrega de inmigrantes en la frontera de Irún. El pais, 28.10.2018 [online]. Available at: https://elpais.com/ccaa/2018/10/25/paisvasco/1540483881 258223.html.

RedaktionAPA (2016). Migration. Grenzmanagement am Brenner mit 370 Meter Zaun. BVZ.at, 27.04.2016 [online]. Available at: https://www.bvz.at/in-ausland/grenzmanagement-ambrenner-mit-370-meter-zaun-suedtirol-asyl-fluechtlinge-illegale-italien-migration12456310\#.

Salvini, M. (2018). In attesa di incontrare il mio collega francese, I'Italia non cambia linea: a \#Claviere presidio fisso di polizia e verifiche a tappeto sui respingimenti di Parigi degli ultimi mesi. L'aria è cambiata: a differenza del Pd, noi proteggiamo le frontiere e non abbassiamo la testa [Twitter]. 22 October 2018, 6:39 pm [online]. Available at: https://twitter.com/matteosalvinimi/status/1054411895850131456.

Schümer, D. (2016). Europas Schicksalspass - brennt der Brenner wieder? welt, 14.04.2016 [online]. Available at: https://www.welt.de/kultur/article154324123/EuropasSchicksalspass-brennt-der-Brenner-wieder.html.

Schweizerische Flüchtlingshilfe (2016). Südgrenze: Es Braucht Mehr Transparenz. Medienmitteilung, 18.8.2016, Bern [online]. Available at: https://www.fluechtlingshilfe.ch/medien/medienmitteilungen/2016/suedgrenze-esbraucht-mehr-transparenz.html [Accessed: 22 December 2019].

Sterkl, M. (2015). Transit ins Irgendwo. die zeit online, 03.08.2015 [online]. Available at: https://www.zeit.de/2015/31/fluechtlinge-zug-eurocity-italien-oesterreichdeutschland-europa-asylpolitik.

Zirknitzer, I. (2015). Polizeikooperationszentrum Thörl-Maglern feiert 10-jähriges Jubiläum. Meinbezirk, 23.04.2015 [online]. Available at: https://www.meinbezirk.at/hermagor/clokales/polizeikooperationszentrum-thoerl-maglern-feiert-10-jaehrigesjubilaeum a1322679.

WeLT (2018). Kontrollen am Brenner? 'Für uns ein gutes Geschäft'. WeLT, 03.07.2018 [online]. Available at: https://www.welt.de/politik/ausland/article178662724/Matteo-Salvinibegruesst-Grenzkontrollen-zwischen-Italien-und-Oesterreich.html.

\section{Webpages}

AIDA (2020). Country reports [Online]. Asylum Information Database. Available at: https://www.asylumineurope.org/reports.

EUR-Lex (n.d.). Standing Committee on Internal Security [Online]. Glossary of Summaries. Available at: https://eurlex.europa.eu/summary/glossary/internal security committee.html.

European Commission (n.d.). Police Cooperation [Online]. Migration and Home Affairs. Available at: https://ec.europa.eu/home-affairs/what-we-do/policies/police-cooperation en.

European Migration Network (n.d.). Secondary movement of migrants. [Online]. EMN glossary. Available at: https://ec.europa.eu/home-affairs/what-wedo/networks/european migration network/glossary search/secondary-movementmigrants en. 
European Parliament (n.d.) Legislative Train Schedule [Online]. Available at: https://www.europarl.europa.eu/legislative-train/.

EVTZ Euregio Maas-Rhein (n.d.). Euregio Police Information \& Cooperation Centre (EPICC) [Online]. Euregio-MR. Available at: https://euregio-mr.info/euregio-mrde/themen/sicherheit/epicc.php.

Federal Ministry of the Interior and Building and Community (n.d.). Cross-Border Police Cooperation [Online]. Themen. Available at: https://www.bmi.bund.de/EN/topics/security/international-cooperation/policecooperation/police-cooperation-node.html

fercomsystems (n.d.) Schengen-Bus [Online]. fercomsystems. Available at: www.fercomsystems.hu/schengen-bus.html. [Accessed: 11 February 2019].

General Secretariat of the Council (2020). Infographic - Border management: agreements with non-EU countries, 7 July 2020 [Online]. Available at: https://www.consilium.europa.eu/en/infographics/border-management-agreementsthird-countries/.

Home office (2017) Fact sheet: The UK's juxtaposed border controls. Fact sheet 11.07.2017 [Online]. Available at: https://homeofficemedia.blog.gov.uk/2017/07/11/fact-sheet-theuks-juxtaposed-border controls/.

Police Cooperation Convention For Southeast Europe Secretariat (n.d.) [Online]. Available at: https://www.pccseesecretariat.si/index.php?item=9\&page=static [Accessed: 23 April 2020].

Push and Back. Respingimenti e Riammissioni in Italia [Online]. Available at: https://pushandback.com/ [Accessed: 22 December 2019].

Western Balkan Border Security initiative [Online]. Available at: http://wbbsi.wb-iisg.com/

[Western Balkan] Integrative Internal Security Governance [Online]. Available at: https://wbiisg.com/event/meeting-of-border-police-chiefs/.

Europol (n.d.). Secure Information Exchange Network Application (SIENA) [Online]. Available at: Europol - activities-services. https://www.europol.europa.eu/activities-services/servicessupport/information-exchange/secure-information-exchange-network-application-siena

\section{EU LEGISLATION}

\section{Treaties}

Treaty of Lisbon amending the Treaty on European Union and the Treaty establishing the European Community [2007] OJ C 306/1 [Treaty of Lisbon].

Consolidated version of the Treaty on European Union [2012] OJ C 326 [TEU].

Consolidated version of the Treaty on the Functioning of the European Union [2012] OJ C 326 [TFEU].

Protocol (No 19) On the Schengen Acquis Integrated into the Framework of The European Union [2012] OJ C 326/1.

Treaty of Amsterdam amending the Treaty on European Union, the Treaties Establishing the European Communities and Certain Related Acts [1997] OJ C 340/1 [Amsterdam Treaty].

Single European Act [1987] OJ L 169/1 [SEA]. 


\section{EU secondary law}

\section{Regulations}

Regulation (EU) No 604/2013 of the European Parliament and of the Council of 26 June 2013 establishing the criteria and mechanisms for determining the Member State responsible for examining an application for international protection lodged in one of the Member States by a third-country national or a stateless person (recast) [2013] OJ L 180/31 [Dublin Regulation].

Regulation (EU) No 603/2013 of the European Parliament and of the Council of 26 June on the establishment of 'Eurodac' for the comparison of fingerprints for the effective application of Regulation (EU) No 604/2013 establishing the criteria and mechanisms for determining the Member State responsible for examining an application for international protection lodged in one of the Member States by a third-country national or a stateless person and on requests for the comparison with Eurodac data by Member States' law enforcement authorities and Europol for law enforcement purposes, and amending Regulation (EU) No 1077/2011 establishing a European Agency for the operational management of largescale IT systems in the area of freedom, security and justice (recast) [2013] OJ L 180/1 [Eurodac Regulation].

Council Regulation (EU) No 1053/2013 of 7 October 2013 establishing an evaluation and monitoring mechanism to verify the application of the Schengen acquis and repealing the Decision of the Executive Committee of 16 September 1998 setting up a Standing Committee on the evaluation and implementation of Schengen [2013] OJ L 295/27.

Regulation (EU) 2016/399 of the European Parliament and of the Council of 9 March 2016 on a Union Code on the rules governing the movement of persons across borders (Schengen Borders Code) (codification) [2016] OJ L 77/1 [consolidated version, with subsequent amendments] [Schengen Borders Code - SBC].

Regulation (EU) No 610/2013 of the European Parliament and of the Council of 26 June 2013 amending Regulation (EC) No 562/2006 of the European Parliament and of the Council establishing a Community Code on the rules governing the movement of persons across borders (Schengen Borders Code), the Convention implementing the Schengen Agreement, Council Regulations (EC) No 1683/95 and (EC) No 539/2001 and Regulations (EC) No 767/2008 and (EC) No 810/2009 of the European Parliament and of the Council [2013], OJ L 182/1 [SBC 2013].

Regulation (EC) No 562/2006 of the European Parliament and of the Council of 15 March 2006 establishing a Community Code on the rules governing the movement of persons across borders (Schengen Borders Code) [2006] OJ L 105/1 [SBC 2006].

\section{Directives}

Directive 2009/52/EC of the European Parliament and of the Council of 18 June 2009 providing for minimum standards on sanctions and measures against employers of illegally staying third-country national [2009] OJ L 168/24.

Directive 2008/115/EC of the European Parliament and of the Council of 16 December 2008 on common standards and procedures in Member States for returning illegally staying thirdcountry nationals [2008] OJ L 348/98. 


\section{Council (Implementing) Decisions \& initiatives}

Council Decision of 25 February 2010 on setting up the Standing Committee on operational cooperation on internal security [2010] OJ L 52/50.

Council Decision 2008/615/JHA of 23 June 2008 on the stepping up of cross-border cooperation, particularly in combating terrorism and cross-border crime [2008] OJ L 210/1.

Council Decision 2008/616/JHA of 23 June 2008 on the implementation of Decision 2008/615/JHA on the stepping up of cross-border cooperation, particularly in combating terrorism and cross-border crime [2008] OJ L 210/12.

Council Framework Decision 2002/946/JHA of 28 November 2002 on the strengthening of the penal framework to prevent the facilitation of unauthorised entry, transit and residence [2002] OJ L 328/1.

Council Framework Decision 2006/960/JHA of 18 December 2006 on simplifying the exchange of information and intelligence between law enforcement authorities of the Member States of the European Union [2006] OJ L 386/89, corrected by Corrigendum [2007] OJ L 75/26.

Council Implementing Decision (EU) 2017/818 of 11 May 2017 setting out a Recommendation for prolonging temporary internal border control in exceptional circumstances putting the overall functioning of the Schengen area at risk [2017] OJ L 122/73.

Council Implementing Decision (EU) 2017/246 of 7 February 2017 setting out a Recommendation for prolonging temporary internal border control in exceptional circumstances putting the overall functioning of the Schengen area at risk [2017] OJ L 36/59.

Council Implementing Decision (EU) 2016/1989 of 11 November 2016 setting out a recommendation for prolonging temporary internal border control in exceptional circumstances putting the overall functioning of the Schengen area at risk [2016] OJ $L$ 306/13.

Council Initiative of the Republic of Finland with a view to the adoption of a Council Regulation determining obligations as between the Member States for the readmission of thirdcountry nationals (1999/C 353/05) [1999] OJ C 353/6.

\section{Other}

\section{Commission (proposals, recommendations, other)}

Commission Proposal for a Directive of the European Parliament and of the Council on common standards and procedures in Member States for returning illegally staying third-country nationals (recast). Brussels, 12.9.2018, COM(2018) 634 final.

Commission Proposal for a Directive of the European Parliament and of the Council on common standards and procedures in Member States for returning illegally staying third-country nationals (recast), COM/2018/634 final.

Commission Proposal for a Regulation of the European Parliament and of the Council establishing the criteria and mechanisms for determining the Member State responsible for examining an application for international protection lodged in one of the Member States by a third-country national or a stateless person (recast). Brussels, 4.5.2016, COM(2016) 270 final 2016/0133 (COD) [Dublin IV recast proposal].

Commission Proposal for a Directive of the European Parliament and of the Council laying down standards for the reception of applicants for international protection (recast). Brussels, 13.7.2016, COM (2016) 465 final, 2016/0222 (COD) [reception directive recast proposal]. 
Commission Proposal for A Regulation Of The European Parliament And Of The Council on the establishment of 'Eurodac' for the comparison of fingerprints for the effective application of [Regulation (EU) No 604/2013 establishing the criteria and mechanisms for determining the Member State responsible for examining an application for international protection lodged in one of the Member States by a third-country national or a stateless person] , for identifying an illegally staying third-country national or stateless person and on requests for the comparison with Eurodac data by Member States' law enforcement authorities and Europol for law enforcement purposes (recast). Brussels, 4.5.2016, $\operatorname{COM}(2016) 272$ final.

Commission Proposal for a Council Implementing Decision setting out a Recommendation for prolonging temporary internal border control in exceptional circumstances putting the overall functioning of the Schengen area at risk, Strasbourg, 25.10.2016, COM(2016) 711 final.

Commission Recommendation of 12.5 .2017 on proportionate police checks and police cooperation in the Schengen area. Brussels, 12.5.2017, C(2017) 3349 final.

Commission Staff Working Document on Implementation of the Eurodac Regulation as Regards the Obligation to Take Fingerprints EN. Brussels, 27.5.2015, SWD(2015) 150 final.

\section{Pre 2000}

Action Plan of the Council and the Commission on How Best to Implement the Provisions of the Treaty of Amsterdam on an Area of Freedom, Security and Justice ("Vienna Action Plan"), 3 December 1998, 1999/C 19/01. OJ C 19, of 23 January 1999/C 19/01.

Decision of the Executive Committee of 15 December 1997 on the guiding principles for means of proof and indicative evidence within the framework of readmission agreements between Schengen States (SCH/Com-ex (97) 39 rev.). The Schengen acquis [2000], OJ L 239/188.

Schengen Executive Committee (1995). Erklärung des Exekutivausschusses zur grenzüberschreitenden polizeilichen Zusammenarbeit, Oostende, den 20. Dezember 1995, SCH/Com-ex (95) decl 3.

Schengen Executive Committee - Arbeitsgruppe I "Polizei und Sicherheit" (1995). Notiz des Vorsitzes Arbeitsgruppe I "Polizei und Sicherheit". Bericht u8er die Vereinbarungen zur polizeilichen Zusammenarbeit an den Binnengrenzen des Schengener Raums (OR FR), Brussel, den 28. November 1995, SCH/I (95) 46 Rev 2(1995).

Schengen Executive Committee (1997). The Schengen acquis - Decision of the Executive Committee of 15 December 1997 on the guiding principles for means of proof and indicative evidence within the framework of readmission agreements between Schengen States (SCH/Com-ex (97) 39 rev.), OJ L 239, 22/09/2000 P. 0188 - 0190.

Schengen Executive Committee (1996). Notiz des Vorsitzenden der Französischen Delegation in der Zentralen Gruppe - Annex 1 „Bilanz der von Frankreich ergriffenen Massnahmen zur Verstärkung der Kontrollen an den Binnengrenzen. Anwendung von Art. 2 Abs. 2 des Übereinkommens zur Durchführung des Übereinkommens von Schengen" [presented on 20/12/1995 by the French delegation to the Schengen Executive Committee] (OR FR), SCH/Com-ex (96) 1, Brussel, 6. Februar 1996, Annex.

Coordinators' Group on the Free Movement of Persons (1989) The Palma Document. Free Movement of Persons. A Report to the European Council by the Coordinators'Group, 
endorsed by the European Council, Presidency Conclusions, Madrid 26 and 27 June 1989, SN 254/2/89 p.6.

Action Plan of the Council and the Commission on How Best to Implement the Provisions of the Treaty of Amsterdam on an Area of Freedom, Security and Justice ("Vienna Action Plan"), 3 December 1998, 1999/C 19/01. OJ C 19, of 23 January 1999/C 19/01.

\section{EU INSTITUTION PUBLICATIONS: manuals, guidelines, reports etc.}

\section{European Parliament}

(2019). European Parliament legislative resolution of 4 April 2019 on the proposal for a regulation of the European Parliament and of the Council amending Regulation (EU) 2016/399 as regards the rules applicable to the temporary reintroduction of border control at internal borders (COM(2017)0571 - C8-0326/2017-2017/0245(COD)), P8_TA(2019)0356.

(2018). Annual Report on the functioning of the Schengen area European Parliament resolution of 30 May 2018 on the annual report on the functioning of the Schengen area (2017/2256(INI)), P8_TA(2018)0228.

\section{Council of The European Union}

(2019). Way forward for EU Migration and Asylum policy - outcome of discussions - Presidency report [Note - Presidency to Permanent Representatives Committee/Council]. Brussels, 22 November 2019 (OR. en) 14364/19.

(2019). Note from the Presidency to Permanent Representatives Committee: Reform of the Common European Asylum System and Resettlement (...) [Note - Presidency to Permanent Representatives Committee]. Brussels, 26 February 2019 (OR. en) 6600/19.

(2018). Note from Presidency to the Strategic Committee on Immigration, Frontiers and Asylum (SCIFA): Secondary Movements, 23. October 2018, Brussels, 19 October 2018 (OR. En) 13353/18 LIMITE. [Online]. Available at: https://data.consilium.europa.eu/doc/document/ST-13353-2018-INIT/en/pdf.

(2017). Presidency to the Standing Committee on Operational Cooperation on internal Security (COSI): Commission Recommendation on Proportionate Police Checks and Police Cooperation in the Schengen Area - Orientation Debate. Brussels, 15 June 2017 (OR. En), $10312 / 2017$.

(2017). Presidency to Law Enforcement Working Party: Commission Recommendation on proportionate police checks and police cooperation in the Schengen area - follow-up to the orientation debate in COSI on 20 June 2017. Brussels, 6 September 2017, 11839/17.

(2017). Presidency to Law Enforcement Working Party: Commission Recommendation on proportionate police checks and police cooperation in the Schengen area - follow-up to the orientation debate in COSI on 20 June 2017. Brussels, 11 September 2017 (OR. en), $11839 / 1 / 17$ REV 1.

(2017). Presidency to Law Enforcement Working Party: Commission Recommendation on proportionate police checks and police cooperation in the Schengen area - follow-up to the orientation debate in COSI on 20 June 2017. Brussels, 22 September 2017 (OR. en), 11839/2/17 REV 2.

(2016). Manual on Law Enforcement Information Exchange. Brussels, 16 December 2016 (OR. en), 11800/1/16 REV 1 [Manual on LE information exchange]. 
(2015). Outcome of the 6th Annual Conference on Police and Customs Cooperation Centres (PCCCs) on 7 and 8 September 2015, Europol, The Hague, The Netherlands. Brussels, 23 October 2015, 13285/15.

(2012). Note from the Presidency to the Working Party on Information Exchange and Data Protection (DAPIX): Outcome of the 3rd Conference on Police and Customs Cooperation Centres (PCCCs) on 6 and 7 November 2012, Brussels, Belgium. Brussels, 30 November 2012, 16879/12.

(2011). Updated Catalogue of Recommendations for the correct application of the Schengen Acquis and Best practices: Police cooperation. Brussels, 15 March 2011, 15785/3/10 REV 3.

(2011). European Best Practice Guidelines for Police and Customs Cooperation Centres [updated]. Brussels, 15 April 2011, 9105/11 [PCCC guidelines].

(2010). Guide for Joint Police Operations (JPOs). Brussels, 23 November 2010, 16825/10 [JPO Guide].

(2009). Manual on cross-border operations. Brussels, 3 September 2009, 10505/4/09 REV 4 [CBOPS manual].

(2008) European Best Practice Guidelines for Police and Customs Cooperation Centres. Brussels, 3 October 2008, 13815/08;

(2006 [2018]) Schengen evaluation of the new Member States - Report on the Schengen Police Cooperation evaluation of SLOVENIA (February 2006). Brussels, 31 May 2018, 8396/06 DCL 1 (OR. en) [declassified version of 8396/06 RESTREINT UE/EU RESTRICTED; 11 April 2006].

(2006 [2018]) Schengen evaluation of the new Member States - Report on the Schengen Police Cooperation evaluation of Hungary (February 2006). Brussels, 31 May 2018, 8395/1/06 DCL 1 (OR. en) [declassified version of 8395/1/06 RESTREINT UE/EU RESTRICTED; 08 August 2006].

(2002 [2018]). France's reply to the questionnaire. Brussels, 25 May 2018, 8095/02 DCL 1 (OR. fr) [declassified version of ST 8095/02 RESTREINT UE; Brussels, 15 April 2002].

(2000) Initiative of the Republic of Finland with a view to the adoption of a Council Regulation determining the obligations as between Member States for the readmission of thirdcountry nationals [Outcome of proceedings - Expulsion Working Party/Mixed Committee], Brussels, 24 January 2000, 5599/00.

\section{European Commission}

(2020) Communication from the Commission on a New Pact on Migration and Asylum. Brussels,

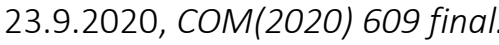

(2019). Communication from the Commission to the European Parliament, the European Council and the Council Progress report on the Implementation of the European Agenda on Migration. Brussels, 6.3.2019, COM(2019) 126 final.

(2018). Progress report on the Implementation of the European Agenda on Migration", Brussels, 14.3.2018 COM(2018) 250 final.

(2016). Communication from the Commission to the European Parliament, the European Council and the Council, Back to Schengen - A Roadmap. Brussels, 4.3.2016, COM(2016) 120 final [hereinafter Back to Schengen]. 
(2015). Communication from the Commission to the European Parliament, the Council, the European Economic and Social Committee and the Committee of the Regions, The European Agenda on Security. Strasbourg, 28.4.2015, COM(2015) 185 final.

(2015). Communication from the Commission to the European Parliament, the Council, the European Economic and Social Committee and the Committee of the Regions, A European Agenda on Migration. Brussels, 13.5.2015, COM(2015) 240 final.

(2015). Communication from the Commission to the European Parliament and the Council Progress Report on the Implementation of the hotspots in Italy. Strasbourg, 15.12.2015, $\operatorname{COM}(2015) 679$ final.

(2012). Communication from the Commission to the European Parliament and the Council Biannual report on the functioning of the Schengen area 1 November 2011 - 30 April 2012. Brussels, 16.5.2012, COM(2012) 230 final; in particular "Part II, Guidelines for Member States, Section B Police measures in the internal border zones".

(2012). Communication from the Commission to the European Parliament, the Council, Strengthening law enforcement cooperation in the EU: the European Information Exchange Model (EIXM). Brussels, 7.12.2012 COM(2012) 735 final.

(2010). Report from the Commission to the European Parliament and the Council on the application of Title III (Internal Borders) of Regulation (EC) No 562/2006 establishing a Community Code on the rules governing the movement of persons across borders (Schengen Borders Code). Brussels, 13.10.2010, COM(2010) 554 final.

(2004). Communication from the Commission to the European Parliament, the Council, Enhancing Police and Customs co-operation in the European Union. I) Report on achievements since the entry into force of the Treaty of Amsterdam. II) Proposals for Improvements. Brussels, 18.5.2004, COM(2004) 376 final.

(2010) Guidelines for Integrated Border Management in EC External Cooperation. EuropeAid and ICMPD.

\section{MULTILATERAL TREATIES}

Agreement between the Governments of the States of the Benelux Economic Union, the Federal Republic of Germany and the French Republic on the gradual abolition of checks at their common borders, signed in Schengen on 14 June 1985, OJ L 239, 22.9.2000 [hereinafter Schengen I]; The Schengen acquis [2000] OJ L 239/13.

Convention implementing the Schengen Agreement of 14 June 1985 between the Governments of the States of the Benelux Economic Union, the Federal Republic of Germany and the French Republic on the gradual abolition of checks at their common borders, , implementing the Agreement on the gradual abolition of checks at their common borders, signed in Schengen on 14 June 1985 Convention, signed in Schengen on 19 June 1990 (in force since 1995)[CISA]. The Schengen acquis [2000] OJ L 239/0019.

Convention between the Kingdom of Belgium, the Federal Republic of Germany, the Kingdom of Spain, the French Republic, the Grand Duchy of Luxembourg, the Kingdom of the Netherlands and the Republic of Austria on the stepping up of cross-border cooperation, particularly in combating terrorism, cross-border crime and illegal migration, signed by the contracting parties in Prüm (Germany) on 27 May 2005 [Prüm Convention].

Police Cooperation Convention for Southeast Europe (PCC SEE), signed on 5 May 2006, in force since 10 October 2007. [Signatory parties: Albania (ratification date 2006/in force 2007), $\mathrm{BiH}$ (2007/2007), North Macedonia (2007/2007), Romania (2007/2007), Serbia 
(2007/2007), Montenegro (2007/2008), Moldova (2008/2008), Bulgaria (2008/2009), Austria (2011/2011), Hungary (2012/2012), Slovenia (2012/2013), Croatia (2019/2019).

\section{BILATERAL AGREEMENTS (police cooperation)}

cross-border police cooperation / joint centres / readmissions (selection)

\section{$A T-D E$}

Readmission

Abkommen zwischen der Bundesregierung der Republik Österreich und der Regierung der Bundesrepublik Deutschland über die Rückübernahme von Personen an der Grenze (Rückübernahmeabkommen). StF: BGBI. III Nr. 19/1998.

Police and judicial cooperation

Vertrag zwischen der Republik Österreich und der Bundesrepublik Deutschland über die grenzüberschreitende Zusammenarbeit zur polizeilichen Gefahrenabwehr und in strafrechtlichen Angelegenheiten. StF: BGBI. III Nr. 210/2005.

\section{Joint centre}

Vereinbarung zwischen dem Bundesministerium für Inneres der Republik Österreich und dem Bundesministerium des Innern der Bundesrepublik Deutschland über die Zusammenarbeit im Gemeinsamen Zentrum Passau. StF: BGBI. III Nr 18/2018.

\section{AT-HU}

Readmission

Abkommen zwischen der Regierung der Republik Österreich und der Regierung der Republik Ungarn über die Übernahme von Personen an der gemeinsamen Grenze. BGBI. Nr. 315/1995 [09.10.1992, in force 20.04.1995]. (Integrated modification through BGBI. III Nr. 25/1998, Abkommen zwischen der Regierung der Republik Österreich und der Regierung der Republik Ungarn über die Änderungen des am 9. Oktober 1992 in Salzburg unterzeichneten Abkommens zwischen der Regierung der Republik Österreich und der Regierung der Republik Ungarn.

Joint centre

Vereinbarung zwischen der Österreichischen Bundesregierung und der Regierung der Republik Ungarn über die Zusammenarbeit in der gemeinsamen Kontaktdienststelle in Nickelsdorf-Hegyeshalom. StF: BGBI. III Nr. 7/2008.

\section{AT-SI}

\section{Readmission}

Abkommen zwischen der Regierung der Republik Österreich und der Regierung der Republik Slowenien über die Übernahme von Personen an der gemeinsamen Grenze. StF: BGBI. Nr. 623/1993.

\section{Joint centre (AT-IT-SI)}

Vereinbarung zwischen der Regierung der Italienischen Republik, der Österreichischen Bundesregierung und der Regierung der Republik Slowenien über die Zusammenarbeit im polizeilichen Zentrum in Thörl - Maglern (AT) StF: BGBI. III Nr. 59/2005; Dogovor med Vlado Italijanske republike, Zvezno vlado Republike Avstrije in Vlado Republike Slovenije o sodelovanju v policijskem centru v Vratih - Megvarjah (SI); Accordo tra il Governo della Repubblica Italiana, il Governo federale della Repubblica d'Austria e il Governo della Repubblica di Slovenia relativo alla cooperazione nel Centro di polizia di Thörl-Maglern (IT); 14.09.2004. StF: BGBI. III Nr. 59/2005.

\section{$D E-D K$}

Readmission

Abkommen vom 22. Juni 1954 zwischen der Regierung der Bundesrepublik Deutschland und der Königlich Dänischen Regierung zur Regelung der Frage der Abschiebung von Personen 
von der Bundesrepublik nach Dänemark und von Dänemark in die Bundesrepublik Deutschland. BAnz. 1954, Nr. 120.

Police Cooperation

Abkommen vom 21. März 2001 zwischen der Regierung der Bundesrepublik Deutschland und der Regierung des Königreichs Dänemark über die polizeiliche Zusammenarbeit in den Grenzgebieten.

$D E-S E$

Readmission

Abkommen vom 31. Mai 1954 zwischen der Regierung der Bundesrepublik Deutschland und der Königlich Schwedischen Regierung zur Regelung der Frage der Abschiebung von Personen von der Bundesrepublik Deutschland nach Schweden und von Schweden in die Bundesrepublik Deutschland. BAnz. 1954 Nr. 120.

\section{DE- Benelux}

Readmission

Abkommen vom 17. Mai 1966 zwischen der Regierung der Bundesrepublik Deutschland und den Regierungen des Königreichs Belgien, des Großherzogtums Luxemburg und des Königreichs der Niederlande über die Übernahme von Personen an der Grenze. GMBI. S. 339.

\section{$D E-F R$}

Police and customs cooperation

Abkommen vom 9. Oktober 1997 zwischen der Regierung der Bundesrepublik Deutschland und der Regierung der Französischen Republik über die Zusammenarbeit der Polizei- und Zoll-

Readmission behörden, in Kraft seit 1.4.2000 [Mondorf Agreement].

Bekanntmachung des deutsch-französischen Abkommens über die Übernahme und Durchbeförderung von illegal aufhältigen Personen und des Durchführungsprotokolls hierzu. Vom 6. Januar 2006. BGBL 2006, Teil II Nr. 4.

$A T-I T$

$\underline{\text { Readmission }}$

Abkommen zwischen der Bundesregierung der Republik Österreich und der Regierung der Italienischen Republik über die Übernahme von Personen an der Grenze / Accordo tra il Governo Federale della Repubblica d'Austria e il Governo della Repubblica Italiana sulla riammissione delle persone alla frontiera. Wien, 7.10.1997. BGBI. III - Nr. 160.

Police cooperation

Vertrag zwischen der Regierung der Republik Österreich und der Regierung der Italienischen Republik über die polizeiliche Zusammenarbeit. StF: BGBI. III Nr. 47/2017.

ES-FR

Police Cooperation

Convenio de Cooperación Transfronteriza en materia Policial y Aduanera entre el Reino de España y la República Francesa, hecho "ad referendum" en Blois el 7 de julio de 1998. [ES-FR deBlois Agreement].

Joint police stations

Acuerdo entre el Reino de España y la República Francesa sobre Creación de Comisarías Conjuntas en la Zona Fronteriza Común, hecho en París el 3 de junio de 1996.

Readmission

Acuerdo entre la República Francesa y el Reino de España sobre la readmisión de personas en situación irregular, hecho «ad referendum» en Málaga el 26 de noviembre de 2002 (BOE núm. 309) [abrogated the Acuerdo entre el Gobierno del Reino de España y el_ Gobierno de la República Francesa relativo a la admisión en puestos fronterizos de personiJs en situación de estancia ilegal, hecho en Madrid el 8 de enero de 1988. BOE núm. 108. 
Joint police stations

Acuerdo entre el Reino de España y la República Portuguesa sobre la Creación de Comisarías Comunes en Frontera, hecho "ad referendum" en Madrid a 19 Noviembre de 1997. BOE núm. 231.

Readmission

Convenio entre el Reino de España y la República Portuguesa relativo a la readmisión de personas en situación irregular, hecho en Granada el 15 de febrero de 1993. BOE núm. 77.

\section{$I T-F R$}

Police (and custom) cooperation

Accordo fra il Governo della Repubblica Italiana e il Governo della Repubblica Francese sulla Cooperazione Transfrontaliera in Materia di Polizia e Dogana, fatto a Chambéry il 03/10/1997.

\section{Readmission}

Décret $n^{\circ}$ 2000-652 du 4 juillet 2000 portant publication de l'accord entre le Gouvernement de la République française et le Gouvernement de la République italienne relatif à la réadmission des personnes en situation irrégulière (ensemble une annexe), signé à Chambéry le 3 octobre 1997. Journal officiel de la République française $n^{\circ} 0160$ du 12/07/2000.

\section{$F R-B E$}

Police (and custom) cooperation

Accord entre le Gouvernement de la République française et le Gouvernement du Royaume de Belgique relatif à la coopération transfrontalière en matière policière et douanière, signé à Tournai le 5 mars 2001 [Tourai I].

Accord entre le Gouvernement de la République française et le Gouvernement du Royaume de Belgique relatif à la coopération transfrontalière en matière policière et douanière, signé à Tournai le 18 mars 2013 [Tournai II].

\section{ES- Marocco}

Police cooperation

Acuerdo entre el gobierno del Reino de España y el gobierno del Reino de Marruecos en materia de cooperación policial transfronteriza, hecho "ad referendum" en Madrid el 16 de noviembre de 2010. BOE núm. 116.

\section{Historical (selection):}

(1818). Convention zwischen Preußen und Bayern wegen wechselseitiger Übernahme der Vagabunden, Berlin den 9. Mai 1818.

(1851). Gothaer Vertrag vom 15. Juli 1851 über die Aufnahme von Ausgewiesenen. (Ergänzt durch das Schlussprotokoll der Eisenacher Konferenzen vom 25. April 1854 und vom 29. Juli 1858).

(1980). Niederlassungsvertrag zwischen dem Deutschen Reich und der Schweizerischen Eidgenossenschaft, vom 31. Mai 1890. Deutsches Reichsgesetzblatt Band 1890, Nr. 21, pp. $131-135$.

(1904). Niederlassungsvertrag zwischen dem Deutschen Reiche und den Niederlanden. Vom 17. Dezember 1904. Deutsches Reichsgesetzblatt Band 1906, Nr. 51, Seite 879 -887; Nederl. Staatsblad No. 279 
(1909). Niederlassungsvertrag zwischen dem Deutschen Reich und der Schweizerischen Eidgenossenschaft, vom 13. November 1909 Mai, AS 11 515, 0.142.111.361.

(1957). Abkommen zwischen Österreich und der Bundesrepublik Deutschland über die Regelung des Grenzüberganges der Eisenbahnen. StF: BGBI. Nr. 239/1957.

(1957). Abkommen zwischen der Republik Österreich und der Bundesrepublik Deutschland über Erleichterungen der Grenzabfertigung im Eisenbahn-, Straßen- und Schiffsverkehr. StF: BGBI. Nr. 240/1957.

(1958). Abkommen zwischen der Regierung der Bundesrepublik Deutschland und der Regierung des Königreichs der Niederlande über die Erleichterung der Übernahme von Personen an der Grenze, geschlossen durch Notenwechsel vom 19. September/10. Oktober 1958.

(1984). Abkommen zwischen Frankreich und der BRD über den schrittweisen Abbau der Kontrollen an der deutsch-französischen Grenze. Saarbrücken, 13. Juli 1984. The Schengen acquis [2000] OJ L 239/19.

\section{NATIONAL LEGISLATION (selection)}

\section{Austria}

Bundesgesetz über die Organisation der Sicherheitsverwaltung und die Ausübung der Sicherheitspolizei (Sicherheitspolizeigesetz - SPG). StF: BGBI. Nr. 566/1991.

Bundesgesetz über die Durchführung von Personenkontrollen aus Anlaß des Grenzübertritts (Grenzkontrollgesetz - GrekoG). StF: BGBI. Nr. 435/1996.

Bundesgesetz über die Ausübung der Fremdenpolizei, die Ausstellung von Dokumenten für Fremde und die Erteilung von Einreisetitel (Fremdenpolizeigesetz 2005 - FPG). StF: BGBI. I Nr. 100/2005.

Bundesgesetz über die polizeiliche Kooperation mit den Mitgliedstaaten der Europäischen Union und der Agentur der Europäischen Union für die Zusammenarbeit auf dem Gebiet der Strafverfolgung (Europol), (EU - Polizeikooperationsgesetz, EU-PolKG). StF: BGBI. I Nr. 132/200.

Bundesgesetz, mit dem das Asylgesetz 2005, das Fremdenpolizeigesetz 2005 und das BFA Verfahrensgesetz geändert werden. StF: BGBI. I Nr. 24/2016.

\section{Germany}

Bundespolizeigesetz vom 19. Oktober 1994.BGBI. I S. 2978, 2979) [mit anschliesslichen Abänderungen]

Aufenthaltsgesetz in der Fassung der Bekanntmachung vom 25. Februar 2008 (BGBI. I S. 162) [mit anschliesslichen Abänderungen]

Erlass zur Anwendung von $\S 23$ Absatz 1 Nummer 3 Bundespolizeigesetz (BPolG) vom 7. März 2016 (GMBI S. 203).

\section{Italy}

Legge 24 luglio 2008, n. 125, Conversione in legge, con modificazioni, del decreto-legge 23 maggio 2008, n. 92, recante misure urgenti in materia di sicurezza pubblica, (GU n. 173 del 25-7-2008).

Legge 15 ottobre 2013, n. 119, Conversione in legge, con modificazioni, del decreto-legge 14 agosto 2013, n. 93, recante disposizioni urgenti in materia di sicurezza e per il contrasto 
della violenza di genere, nonche' in tema di protezione civile e di commissariamento delle province, (GU n.242 del 15-10-2013, in force since 16/10/2013.

\section{CASE LAW}

Court of Justice of the European Union (CJEU) - preliminary rulings

Judgment of 22 June 2010, Melki and Abdeli, Joint cases C-188/10 and C-189/10, ECLI:EU:C:2010:363.

Judgement of 19 July 2012, Adil, C-278/12 PPU, ECLI:EU:C:2012:508.

Jugement of 21. Juni 2017, A, C-9/16, EU:C:2017:483.

Judgement of 13 December 2018, Touring Tours und Travel GmbH and Sociedad de Transportes SA, Joint cases C-412/17 and C-474/17, ECLI:EU:C:2018:1005.

Opinion of Advocate General Bot, 6 September 2018 [Joined Cases C-412/17 and C-474/179), ECLI:EU:C:2018:671.

Judgement of 19 March 2019, Abdelaziz Arib, Case C-444/17, ECLI:EU:C:2019:220.

\section{European Court of Human Rights (EUtHR)}

Hirsi Jamaa and Others v. Italy, Application no. 27765/09, Council of Europe: European Court of Human Rights, 23 February 2012.

M.S.S. v. Belgium and Greece, Application no. 30696/09, Council of Europe: European Court of Human Rights, 21 January 2011.

Tarakhel v. Switzerland, Application no. 29217/12, Council of Europe: European Court of Human Rights, 4 November 2014.

\section{Germany (selection)}

VG Stuttgart, Urteil vom 11.4.2019 - 1 K 2888/18

VG Stuttgart, Urteil vom 11.4.2019 - 1 K 2888/18

VG Saarlouis, Urteil vom 28.09.2017 - VG 6 K 1184/16

VGH Baden-Württemberg, Urteil vom 13.02.2018-1 S 1469/17

OVG Saarlouis, Urteil vom 21.2.2019 - 2 A 806/17

BVerwG - Beschluss vom 13.12.2019, BVerwG 6 B 30.19 [ECLI:

DE:BVerwG:2019:131219B6B30.19.0]

\section{INFRINGEMENT PROCEEDINGS}

\section{European Commission}

Infringement nr. 2015/2203, formal notice (art. 258 TFEU), Italy, Home Affairs, Incorrect implementation of the Recast EURODAC REGULATION (EU) 603/2013

Infringement number 2014/4130, Formal notice (art. 258 TFEU), Germany, Home Affairs, Noncompliance of German Bundespolizei Gesetz with Art 20 and 21(a) of Regulation (EC) No 562/2006 (Schengen Borders Code), 16/10/2014. 


\section{ENDNOTES}

\section{PART I}

\section{Chapter 1}

${ }^{1}$ On referencing:

- All non-English texts sources quoted verbatim in this thesis have been translated by me. Translated quotes are evidenced as "[*]" in the main text. The original language excerpts are listed in Annex I.

- Legislation, policy and case law are referenced within the text through their respective numeral identification code. The full references can be found in the endnotes and in the legislation section. Press sources are referenced through author/institution in the text and the online links are included in the bibliography.

- In addition to direct quotes of interview material, when using double quotation marks in the text ("...") I am referring to an expression through which a certain phenomenon has been categorised and problematised in official discourse, policy, or law. I use single inverted commas ('...') to indicate that a word is questioned or used in a special way.

- Interview-excerpts which originally were not in English have been translated by me. Throughout the thesis I use masculine pronouns. Most of my interlocutors were male officers and not differentiating between genders guarantees equal anonymity. For the identification-codes, see the methodology chapter.

2 Regulation (EU) No 604/2013 of the European Parliament and of the Council of 26 June 2013 establishing the criteria and mechanisms for determining the Member State responsible for examining an application for international protection lodged in one of the Member States by a third-country national or a stateless person (recast) [2013] OJ L 180/31 [Dublin III, hereinafter Dublin Regulation]. The Dublin Regulation and the Eurodac Regulation (EU) No 603/2013 compose the "Dublin system". (See also n.92, n.93, n.103).

${ }^{3}$ Convention implementing the Schengen Agreement of 14 June 1985 between the Governments of the States of the Benelux Economic Union, the Federal Republic of Germany and the French Republic on the gradual abolition of checks at their common borders, implementing the Agreement on the gradual abolition of checks at their common borders, signed in Schengen on 14 June 1985 Convention, signed in Schengen on 19 June 1990 [hereinafter CISA].

${ }^{4}$ Treaty of Amsterdam amending the Treaty on European Union, the Treaties Establishing the European Communities and Certain Related Acts [1997] OJ C 340/1 [hereinafter Treaty of Amsterdam].

5 Treaty of Lisbon amending the Treaty on European Union and the Treaty establishing the European Community [2007] OJ C 306/1 [hereinafter Lisbon Treaty].

Consolidated version of the Treaty on the Functioning of the European Union [2012] OJ C 326 [hereinafter TFEU].

${ }^{6}$ Regulation (EU) 2016/399 of the European Parliament and of the Council of 9 March 2016 on a Union Code on the rules governing the movement of persons across borders (Schengen Borders Code) (codification) [2016] OJ L 77/1 [consolidated version, with subsequent amendments, hereinafter Schengen Borders Code or SBC]. See also n. 99, art. 23 SBC "Checks within the territory". Reference to prior versions of the SBC, namely Reg. (EU) No 610/2013 and Reg. (EC) No 562/2006, will be made occasionally and specified. The Regulation (EC) No 562/2006 entered into force in 2006 and replaced relevant provision of CISA and related Decisions. 
${ }^{7}$ At the time I initiated as a private citizen an active monitoring activity, subsequently carried out under the umbrella of the Bolzano based Alexander Langer Foundation. Upon notice of admission into the PhD programme (2016), I terminated my involvement in order to prevent any conflict of interest.

${ }^{8}$ My MA research in anthropology engaged with the production of evidence of torture used to substantiate asylum applications of victim-survivors and with categories of vulnerability within CEAS policy (Weissensteiner 2009; 2010; 2015). With regards to cooperation in security - not concerning policing but the military - I carried out an empirical study for a vocational training in conflict mediation, which focused on NATO CIMIC (2014).

${ }^{9}$ Communication from the Commission to the European Parliament, the Council, the European Economic and Social Committee and the Committee of the Regions, A European Agenda on Migration. Brussels, 13.5.2015, COM(2015) 240 final [hereinafter Agenda on Migration or EAM].

${ }^{10}$ Communication from the Commission to the European Parliament, the European Council and the Council, Back to Schengen - A Roadmap. Brussels, 4.3.2016, COM(2016) 120 final [hereinafter Back to Schengen Roadmap].

11 Commission Recommendation of 12.5 .2017 on proportionate police checks and police cooperation in the Schengen area. Brussels, 12.5.2017, C(2017) 3349 final.

12 Communication from the Commission on a New Pact on Migration and Asylum. Brussels, 23.9.2020, $\operatorname{COM(2020)609~final~[hereinafter~New~Pact~on~Migration~and~Asylum].~}$

${ }^{13}$ Gallagher's study concerned the Cross-Channel Intelligence Conference cooperation. When applied to other contexts and especially in multi-sited or comparative research, jurisdictional and functional differentiations in the police-organisation of the respective countries must be considered, especially regarding the diverse intermediate 'regional' authority levels.

14 TFEU (supra n.5). "Police cooperation" is covered in Title V ("Area of Freedom, Security and Justice"), Chapter 5 (art. 87-89). While it highlights that the Union shall establish police cooperation measures between all member states, the "General provisions" (Chapter 1) specify that

[it] shall be open to Member States to organise between themselves and under their responsibility such forms of cooperation and coordination as they deem appropriate between the competent departments of their administrations responsible for safeguarding national security. (Art.73, TFEU)

${ }^{15}$ CISA (supra n.3). "Police cooperation" is covered in Title III ("Police and Security"), chapter 1 (art. 39-47).

${ }^{16}$ Scholars have focused for example on the UK multilateral Channel cooperation (J. Sheptycki 1998; Gallagher 2002), police cooperation across the Irish-UK border (Walsh 2011), on the 'NebedeagPol' network between Netherlands, Belgium and Germany and cooperation in the Euroregion Meuse-Rhin (Soeters, Hofstede and Van Twuyver 1995; Brammertz 1999, Spapens 2008a; Fijnaut and Spapens 2010; Spapens 2010, Peters, Vanderhallen and Nelen 2016), on the French-German cooperation (Maguer 2002; Maguer 2007) and German-Polish PCCC cooperation (Gruschinske, Mario Hirschmann and Füger 2015). Other scholars, located along a spectrum of interest between police cooperation and migration policing, have focused for 
example on the German-Polish (Schwell 2010; Schwell 2008; Schwell 2017) and TcheckAustrian border (Darley 2008), on Belgium with with Germany and the Netherlands (Bernier 2018) and more specifically on migration-control and border reconfigurations between Italy, Austria and Germany (Schmidt-Sembdner 2019; Schmidt-Sembdner 2018), French policing and cross-border interactions on the border with Italy (Colombeau 2017; Colombeau 2019).

${ }^{17}$ Two other identified tensions regarded those between PCCCs and intergovernmental central channels for cooperation and a disjuncture in connections, for example in form of vertical tensions (between PCCCS and EU Agencies like Europol) as well as disjuncture in terms of each PCCC developing potentially different privileged collaborations with certain foreign units resulting in competition on horizontal level between PCCCs.

${ }^{18}$ E.g.: Coleman (2009) provided a historical overview of readmission agreements between European countries, but then focused on agreements with non-EU countries. Siebold's (2013, pp.201-204) subchapter titled "externalised responsibility" discussed the 1991 readmission agreement between Schengen members and (at the time non-Schengen) Poland.

${ }^{19}$ The study did not specify whether the survey questions referred to joint patrols in border-areas or also other forms of joint patrols, for example in occasion of events. The survey's aim was to gain a better understanding of the current state in order to identify which countries and organisations used joint patrols, their frequency, benefits and downsides (DCAF 2013).

${ }^{20}$ While the legal status of Euregions (Euroregion, Euregio, Euregion) varies, they are not dealing with police matters, as also pointed out by the editors, although important experiences in police cooperation do exist in territories that also have been recognised as Euroregions (Fijnaut and Spapens 2010). INTERREG programmes aimed at stimulating and financing interregional cooperation in the EU have only to a limited extend been used to finance activities in the security sector (Durà et al. 2018, p.78), which scholars consider to be little surprising "given the scarce role that Euregions tend to play in this kind of issues". Indeed, border-regions have been deemed both in policy and research a "laboratory" for EU integration (Sousa 2013; Lechevalier and Wielgohs 2013). Studies from other disciplines have extensively engaged with Euregions and border-regions within Europe and with cross-border initiatives as a "lens" to study EU-integration. This body of work has tendentially not focused on the vocational group of law enforcement and the field of security cooperation, but rather on cross-border cooperation on health, the environment, transport, etc. While a review thereof is here beyond scope, it would be interesting to engage in a future comparison and with theoretical frameworks on cross-border cooperation developed in this field of studies.

21 The "Franco-Italian Affair": In 2011, Italy issued six-month temporary residence permits on humanitarian grounds, mainly to Tunisian citizens who had arrived following the Arab Spring uprising in Tunisia. This permit allowed them to travel freely the Schengen space. France reintroduced internal border checks, resulting in the denial of entry of hundreds of Tunisian permit holders back to Ventimiglia. Not only France, but also Germany, Austria, Belgium and Denmark critiqued Italy for having issued these documents arguing it sidestepped the Dublin Regulation. Notably, as both Carrera and Zaiotti highlighted, in 1999 France had closed its borders on the same spot, preventing Albanians and Italians who aimed to participate in a demonstration in Paris. Following the 2011 dispute, with the 2013 reform of the SBC (Schengen Governance Package), were laid down enhanced monitoring and reporting procedures, the rules on temporary border control were more detailed (art. 25 and art. 26) and a new article was included (art. 29), allowing the reintroduction of internal border controls for up to two years in case of "serious deficiencies at the external borders which put the functioning of the Schengen area at risk". 
${ }^{22}$ Border control was first carried out under art. 28 of the Schengen Borders Code (a situation requiring immediate action, emergency procedure, unilateral action through prior member state notification - maximum 2 months), followed by an application of art. 27 (foreseeable events, general procedure - maximum 6 months). Subsequently member states indeed applied art. 29 (exceptional circumstances putting the overall functioning of the area without internal border control at risk as a result of persistent serious deficiencies relating to external border control as referred - maximum 2 years - dependent upon recommendation). The application of art. 29 was first recommended in 2016 through Council implementing Decision, upon proposal of the Commission, which took place after the Commission stated "serious deficiencies" in external border control in occasion of its Schengen Evaluation visit to Greece.

${ }^{23}$ The EMN is defined as EU network of migration and asylum experts, coordinated by the DG for Migration and Home Affairs of the European Commission. The Query was triggered by an academic research project on crimmigration, carried out by criminologist Van der Woude (EMN 2018b), as pointed out by the Dutch National Contact point of the EMN, which requested the survey.

\section{Chapter 3}

${ }^{24}$ This debate was triggered on the one hand by scholars who argued that there has been a radical qualitative change in policing, requiring an analysis of policing as security governance (Bayley and Shearing 1996). On the other hand, scholars sustained that notwithstanding major changes - private policing, technology, global policing, risk-based and security approaches there are important continuities in policing and thus in the analysis thereof (Reiner 2010) and that national differences of policing cannot be subsumed into an "'over-globalised' view of the world" (Jones and Newburn 2002).

${ }^{25}$ It is beyond my scope to provide a systematic review across and within disciplines. For a more comprehensive overview, see inter alia on 'internal security' Bossong and Rhinard 2016 and on police cooperation more broadly Hufnagel 2018; Bowling and Sheptycki 2012). A note on the contributions addressed in this section:

- The concept of spill-over (functional/political/cultural) was proposed as analytical tool in International Relations (IR) to describe and explain integration processes in a neofunctionalist perspective (Niemann 2016). It refers to a process in which intervention in one policy field requires interventions in other sectors to be effective, thus further integrative actions are pursued in order to reach the original objectives.

- Governance theory (in the disciplinary fields of political science, IR, comparative politics, public administration) figures very prominently in studies of internal security (Bossong and Lavenex 2016) and of police cooperation, e.g. through network-governance or multilevelgovernance theory, or in analysis of security governance (Den Boer 2010; Block 2011; Guille 2010; Gerspacher and Dupont 2007; Den Boer 2012). Governance scholars tend to concentrate on matters of efficiency, so-called "good governance" and democratic accountability (Kjaer 2004, p.15).

- (In)securitisation was associated initially with the sociological approach of the "Paris school" and the Journal Culture \& Conflicts. It redefined itself as "International Political Sociology" (Balzacq et al. 2010) and as "Political Anthropological Research of International Sociology" (Bigo 2016b). In particular since the 90s there has been a growing distinctive work within security studies in Europe, initially by scholars located within IR and political science and referred to as different "schools". In this context was placed also the Securitisation Theory put forward by Waever and Buzan or the "Copenhagen School", 
challenging liberal or realist approaches in security studies, which focused on security in terms of state-interest and in military terms. In the theoretical framework of the "Copenhagen-school", 'securitisation' was interlinked with speech act theory. It refers to processes by which an issue comes to be treated as a security issue: it is represented as a 'threat', which allows to move from the realm of normal politics into exceptional measures. Today the academic field of critical security studies contains various approaches (C.A.S.E. Collective 2006; Vaughan-Williams and Peoples 2015).

- Legal scholarship has followed the EU integration process in JHA closely (Peers 2011; Peers 2013; Guild and Geyer 2008; Carrera and Geyer 2008; Mitsilegas 2016; Mitsilegas, Monar and Rees 2003) and shares several concerns with approaches interested in governance and (in)securitisation and governmentality. Examples of such common concerns are accountability in transnational policing practices and the relationship between freedom, security and human rights.

${ }^{26}$ Police-cooperation is often approached as an interplay between three interrelated levels, thereby drawing on a landmark study by the Centre for the Study of Public Order at the University of Leicester (Benyon et al. 1993). The scholars mapped and described existing frameworks for police cooperation in Europe (90s) and ordered them in an inter-related threelevel typology. In short, macro-level referred to constitutional and international legal agreements and harmonisation of laws and regulations, meso-level to the operational police structures, practices, procedures and technology (including agreements between police forces), and micro-level to cooperation between officers on the ground in the prevention and detection of particular offenses. Theoretical shortcomings have been pointed out (Sheptycki 1995; M Anderson et al. 1995), such as that the model does not analyse relationship between the levels, and that it does not allow to explain how cooperation works.

It constitutes an important reference in many publications (Walsh 2011; Schwell 2007) and was deemed a "useful attempt to bring some clarity into the thick field of European policing structures" (Bowling and Kopf 2017) by revealing how different policing institutions overlap. The study (Benyon et al. 1993) is indeed, still to date a very interesting read, not only for revealing the overlapping in the mapping, but also with regards to the authors view regarding bi-or multilateral cooperation on meso- and micro-level.

${ }^{27}$ The expression of borderland is in the literature traditionally used to refer to the region or space adjacent to an inter-state border in one country, but some authors have also explicitly made the point that their unit of analysis - the borderland - included the 'lands' on both sites of an inter-state borderline (Baud and Van Schendel 1997). Other authors, for example Balibar (2011), argued whole countries can become borderlands.

${ }^{28}$ Legal or political scholars tend to refer to constellations composed by legal systems recognised by states. They have been labelled as "state,"“weak," "juristic,"'classic," (A. Griffiths 1986; J. Griffiths 2002; Sezgin 2004; F. von Benda- Beckmann 1997), "relative" (Vanderlinden 1989) or "legally constructed" (e.g. K. von Benda-Beckmann) or as "normative pluralism". In particular anthropologist have argued that the formal legal system is but one possibility and other normative registers (customary law, religious law, etc.) have to be considered on equal footing, not needing the recognition of the State to be valid (Griffiths 2010; Benda-Beckmann and Turner 2018).

${ }^{29}$ See also supra n.25.

30 In the subdisciplinary fields of criminology of mobility, border-criminology, transnational mobility control scholars discussed, e.g. forms of penality applied to non-citizens and their differences to more traditional forms of crime control; a shift in migration policing from the 
administrative to the criminal, and from the civilian to the military realm; the intruduction of new rationalities into police work and transformation of domestic policing increasingly into border policing and theoretical challenges in accounting for increased international cooperation and data exchange (inter alia Pickering and Weber 2013; Weber et al. 2004, Bowling and Sheptycki 2014).

${ }^{31}$ A narrow interpretation of criminalisation implies the use of substantive criminal law to enable the prosecution of immigration-related offences. Criminalisation can also refer to the use of "traditional" criminal law tools such as surveillance and detention (as well as prevention and pre-emption methods, which emerged within a security framework) applied in migration control. A very broad approach defines the criminalisation of migrants as discourses or practices that hold immigrants responsible for a large share of criminal offences.

32 I thank Lorenzo Pezzani for our email correspondence (January 2020) with regards to a forthcoming monograph titled viapolitics, edited by Walters, Pezzani and Heller, which clarified that the concept was not aiming to isolate vehicles and routes of migrants but that the volume intents to take into consideration the variety of other vehicles, such as those of humanitarian actors, state actors or private companies.

\section{Chapter 4}

33 Drawing on Tsing's (2000; 2005) conceptualisation of "patchwork ethnography", Pijl, Oude Breuil and Siegel (2011) highlighted the value of participant observation of interactions in multiple and not directly related locations for the purpose of analysing the workings of presumed to be uniform discourses, like the hegemonic discourse on human trafficking. Feldman $(2011 ; 2012)$ indeed moved beyond the privileging of "evidence obtained through direct sensory contact" and he proposed "nonlocal ethnography" to investigate how heterogenous elements come into relation and shape global processes, by producing localised effects without the need for direct connection among elements. He differentiated between direct connections and mediated relations, which characterise the workings of the EU as a migration apparatus or dispositif. Remaining indeed more localised in fieldwork but with many locales composing the field-site, Andersson's $(2014 ; 2017)$ multi-local research drew on the Manchester's school extended case method and situational analysis to track, trace and map the "system of the transnational illegality industry". Klepp (2011) tackled "multisited arenas of negotiation" between border protection and refugee protection: multi-sited research enables to move with and within the field. Engle Merry (2000) proposed a "deterritorialised ethnography" that follows patterns of circulation and does not restrict itself to predefined sites.

'Studying through", initially proposed as a research strategy by Reinhold, has three core elements (Wright and Reinhold 2011, p.101): a) it is a multi-sited ethnography with a wide conception of the field, that moves back and forth and up and down between sites and protagonists; b) as a history of the present it follows events and historically contingent effects; c) it incorporates an awareness of historical and political context and seeks an understanding of the institutionalisation of certain ways of governing.

${ }^{34}$ The DCGC doctoral programme included the possibility of carrying out an internship of choice during the second year of studies. At CEPOL I was placed in the unit responsible for assessing EU training needs of law enforcement. I have been involved in The Strategic Training Needs Assessment (EU -STNA) that aimed to identify EU level training priorities in the area of internal security and its external dimension, and in a training needs analysis on cross-border cooperation to counter migrant smuggling. I take this as occasion to underline that the 
activities I carried out as an intern are not content of my PhD research and do not form part of any data presented in this dissertation. The participation in the desk research for the EU STNA did equip me however with a sound knowledge on EU security policy, which facilitated my engagement with EU policy also in this dissertation.

35 Image 2: "Secondary movements" in Europe:
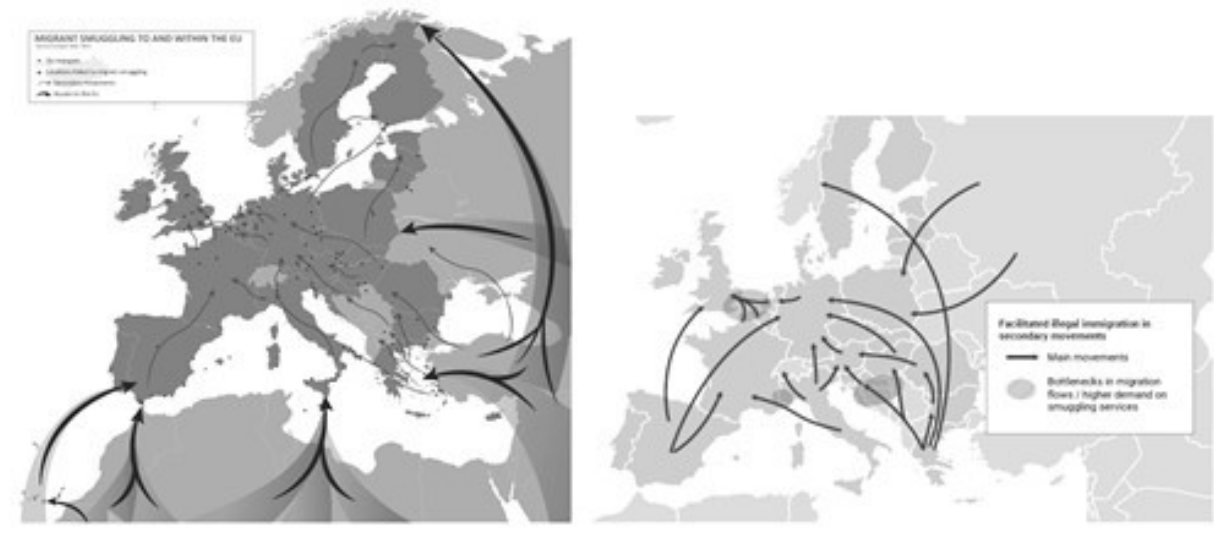

In these two visualisations produced by Europol (2016, p.6; 2019, p.12) the - notably unidirectional and clear - arrows produce a visualised "route" and the dots and circles represent so-called "criminal hubs" linked to migrant smuggling. As indicated previously, the production of knowledge upon "secondary movements" and their routes constitutes a priority on EU level. The relations between "facilitation" and "secondary movements" as visualisised here is a topic not investiated in this thesis and would call for future research.

${ }^{36}$ A note on 'counting': Most interviews were carried out with one respondent. On some occasions more than one interlocutor were present. In most cases one officer functioned as main respondent and the additional officer(s) intervened only punctually, or sometimes the officers equally participated by alternating in responding throughout the interview. These were counted as one interview. On one occasion, whilst initially two officers were present, the interview proceeded with first mainly one respondent, and then shifted to the second respondent: due to the different functions performed and the length of the conversation with each, they counted as two interviews. In two occasions, the interview was carried out with three officers. Different to the scenario described above, it resembled more a focus group than a classical interview, as all officers participated equally in a discussion and also posed questions to each-others. I counted them as 1 'interview' each. Interviews were almost exclusively carried out in the office of local or regional police directorates. On a few occasions, a shorter interview in the office was combined with conversations-en-route' (fieldnotes) whilst I was being accompanied to visit and observe for example patrol units or border-police infrastructure. In these occasions it was clarified (e.g. during note-taking, recorded as fieldnotes) that the conversation-parts included in this thesis were not 'off-record'. One interlocutor was indeed interviewed at length with regards to two very different roles. It was counted twice, which means correctly speaking, formal interviews comprised data from 28 interlocutors. 


\section{PART II}

\section{Chapter 5}

${ }^{37}$ Albania applied for EU membership in 2008 and holds EU candidate status since 2014. Together with Bosnia and Herzegovina, North Macedonia, Montenegro, Serbia, Kosovo, Albania is part of the so-called "Western Balkans". It has been the first non-EU country to have agreements for the deployment of Frontex officers in place, with the first operation on non-EU territory launched in May 2019. On the PCC SEE, see n.48.

${ }^{38}$ Similar joint exercises took place in Montenegro in 2019. After operationalising the agreement with Albania, in 2020, the EU Council finalised agreements with Montenegro and Serbia for cooperation with Frontex, aiming in particular to tackle "illegal immigration" (Council of the European Union 2020). Agreements have also been initialled with North Macedonia and Bosnia and Herzegovina and are pending finalisation. (See, for example, General Secretariat of the Council 2020).

${ }^{39}$ PCCCs can also include customs authorities. Centres without customs authorities are frequently referred to as "joint centres" or "P(C)CCs". I use the terms interchangeably and most often use the better known and shorter abbreviation of "PCCC". The centres included in this study through empirical research did not count with the presence of customs authorities.

${ }^{40}$ SIS (Schengen Information System) contains alerts on persons or objects issued by a member state and shared through SIS. In case of a 'hit', SIRENE officers at the national bureau (or SPOC) are responsible for any supplementary information exchange. "Object alerts" can regard vehicles, travel documents, credit cards, number plates and industrial equipment etc., which are sought for the purposes of seizure or use as evidence in criminal proceedings, while "person alerts" are of multiple type: "refusal of entry or stay" (regards third-country nationals who are not entitled to enter into or stay in the Schengen Area); "persons wanted for arrest" (for whom a European Arrest Warrant or Extradition Request has been issued); "missing persons"; persons sought to assist with a judicial procedure; "persons and objects for discreet or specific checks".

${ }^{41}$ For example: Joint Franco-German police stations already existed prior to 1999. In 1977 Germany and France signed the first agreement intended to intensify cooperation in the border-areas and in 1989 the border police forces established common commands in Kehl, Neuenberg and Saabrücken. According to Felsen (2012), the purpose of these commands was to improve cooperation in the border-areas, particularly in the field of "illegal immigration". The German-French Agreement of Mondorf-les-bains (1997) on co-operation between police and customs authorities in the border-regions (entered into force on 01 April 2000) substituted the prior cooperation agreement from 1977.

42 These statistics were published by the German authorities (Bundesministerium für Inneres, Digitalisierung und Migration Baden-Württemberg 2019, press-release) and correspond to those reported by Felsen (2012, p. 85) for the first 10 years of activity. Different statistics have been reported in other publications (Pudlat 2013; Wenda 2014). As specified by Felsen, in the former statistics a case or an investigation is one file, regardless of how many inquiries relate to it in the end. As such the statistics quoted do not quantitatively represent the information exchanged.

${ }^{43}$ Council Framework Decision 2006/960/JHA of 18 December 2006 on simplifying the exchange of information and intelligence between law enforcement authorities of the Member States 
of the European Union [2006] OJ L 386/89, corrected by Corrigendum [2007] OJ L 75/26. [hereinafter Swedish Initiative or SFD].

${ }^{44}$ CISA (supra n.3). Art. 39 CISA (Title III - Police and Security - Chapter 1 "police cooperation") regulates mutual assistance in information exchange. In 2012 the European Information Exchange Model (EIXM) was adopted, comprising two main legal instruments: the Prüm Council Decisions (2008/615/JHA and 2008/616/JHA) and the Swedish Framework Decision (2006/960/JHA [SFD]). Art. 39 (point 1, 2, 3) CISA have been replaced by the SFD, but in practice CISA still constitutes an important reference point; art. 39.4 and 39.5 regarding border-areas and countries that share a common border have not been replaced.

Transposition into national law has been done in different ways and in some countries the provisions of the SFD were adopted through several different national laws, as emerged inter alia in the implementation study on the EIXM (European Commission 2015c, p.26 ff). The Prüm Decisions are also of major relevance in the field of information exchange, but according to interview fieldwork data compared to the SFD it was considered of minor relevance for PCCCS information exchange.

${ }^{45}$ Supra n.11.

${ }^{46}$ Abkommen zwischen der Regierung der Bundesrepublik Deutschland und der Regierung der Französischen Republik über den schrittweisen Abbau der Kontrollen an der deutschfranzösischen Grenze (Saarbrücken, 13. Juli 1984) [hereinafter Saarbrück Agreement]

47 Abkommen zwischen der Republik Österreich und der Bundesrepublik Deutschland über Erleichterungen der Grenzabfertigung im Eisenbahn-, Straßen- und Schiffsverkehr [1955, in force 1957]. Published together with related measures in Bundesgesetzblatt für die Republik Österreich, 26/11/1957, agreements nr. 239-245). It regarded the "facilitation of border clearance procedures in road, rail and waterway transport" and was complemented by additional agreements aiming to ease border control procedures and cross-border transport, regulating the transfer of detainees, as well as the legal status of officers in the border-area of the neighbouring state (see also Pudlat 2013, p.98-103).

${ }^{48}$ Police Cooperation Convention for Southeast Europe, signed on May $6^{\text {th }} 2006$ by Ministers of the Interior of the contracting parties in force after ratification since 10 October 2007 [hereinafter PCC SEE].

The PCC SEE is a multilateral treaty ratified which serves as a legal basis for cross-border law enforcement cooperation between EU and non-EU countries. The initial signatory parties (Albania, Bosnia and Herzegovina, Macedonia, Moldova, Montenegro, Romania, Serbia), were later joined by Bulgaria (2008), Austria (2011), Hungary (2012), Slovenia (2012) and Croatia (2019). This initiative was supported especially by Austria and Germany. The intention and aim of the PCC SEE is to address organised and serious cross-border crime issues affecting the region, but also to align policing with standards and instruments in the EU and Schengen area (Police Cooperation Convention For Southeast Europe Secretariat n.d.).

${ }^{49}$ Convention between the Kingdom of Belgium, the Federal Republic of Germany, the Kingdom of Spain, the French Republic, the Grand Duchy of Luxembourg, the Kingdom of the Netherlands and the Republic of Austria on the stepping up of cross-border cooperation, particularly in combating terrorism, cross-border crime and illegal migration, signed by the contracting parties in Prüm (Germany) on 27 May 2005 [hereinafter Prüm Convention]. 
50 Council Decision 2008/615/JHA of 23 June 2008 on the stepping up of cross-border cooperation, particularly in combating terrorism and cross-border crime [2008] OJ L 210/1; Council Decision 2008/616/JHA of 23 June 2008 on the implementation of Decision 2008/615/JHA on the stepping up of cross-border cooperation, particularly in combating terrorism and cross-border crime [2008] OJ L 210/12 [hereinafter Prüm Decisions].

Art. 17 2008/615/JHA regulates joint patrols and other joint operations employed for maintaining public order and security and preventing criminal offenses; art. 18 regulates assistance in connection with mass gatherings, disasters and serious accidents, which may include dispatching officers, specialists and advisers and supplying equipment on request. The Prüm Decisions had to be transposed into national law and national legislation had to be adapted in case it did not yet provide yet a sufficient basis for operational police cooperation, albeit in the end it is the specific bilateral agreements that outline the competencies of foreign officers operating on the national territory. For example, Italy only in 2013 included in its national legislation a specific provision regarding foreign officers operating on Italian territory with reference to the Prüm framework.

${ }^{51}$ The Committee on Operational Cooperation on Internal Security (COSI) is a preparatory body of the Council of the EU and was set up by Council Decision [2010] based on provisions of art. 71 TFEU. The creation of a standing committee to be composed of members of the competent national ministries, was envisaged with the objective to facilitate coordination and strengthen operational cooperation of EU countries in the field of internal security. EU JHA Agencies can be invited to attend meeting, other EU organs - EU Commission, EU and national parliaments - do not have a direct role and are informed through reports. COSI plays also an important role in the EU Policy Cycle for organised and serious international crime (EMPACT). See also https://eur-lex.europa.eu/summary/glossary/internal security committee.html.

52 Commission Recommendation on proportionate police checks and police cooperation in the Schengen area - follow-up to the orientation debate in COSI on 20 June 2017 - September $6^{\text {th }}$ (11839/17), $11^{\text {th }}(11839 / 1 / 17$ REV 1$)$ and $22^{\text {nd }}(11839 / 2 / 17$ REV2).

${ }^{53}$ Ratifica ed esecuzione dell'Accordo tra il Governo della Repubblica italiana e il Governo della Repubblica di Slovenia sulla cooperazione transfrontaliera di polizia, fatto a Lubiana il 27 agosto 2007. LEGGE 7 aprile 2011, n. 60. (GU n. 100 del 2-5-2011).

${ }^{54}$ Ratifica ed esecuzione dell'Accordo tra il Governo della Repubblica italiana e il Governo della Repubblica d'Austria in materia di cooperazione di polizia, fatto a Vienna l'11 luglio 2014. LEGGE 3 novembre 2016, n. 209 (16 G 00222).

55 Under certain conditions, police officers of one country can continue a pursuit across the border into the neighbouring country (without or with temporal-spatial delimitations). This instrument has its base in CISA art. 41, but the concrete possibilities and limitations are set by specific bilateral agreements between neighbouring states, which are not 1:1 compatible.

${ }^{56}$ Legally these are two very different procedures, although in some language the terminology sounds similar and is at times also conflated in (media) reports. In German language, the term Zurückweisung stands for refusal of entry and rejection at the border. It is a policing-measure against unauthorised entry. It is applicable at external borders (also airports, harbours), but also on occasion of a temporary introduction of border control at internal borders. Zurückschiebung, readmission, is an administrative act that can take place within a certain time limit after a person is intercepted without authorisation of entry or stay (for example after an irregular border crossing or after his or her visa expired). 
57 Composed through data published in the annual statistical report Bilanz by the LPD Tirol (Landespolizeidirektion Tirol 2015; 2016; 2017; 2018; Tirol 2020). The differentiation between "active readmissions" (for which a readmission was sought) and "passive readmissions" (readmitted upon request) is frequently used in other linguistic contexts. (See also n.90).

58 Some authors situate first agreements in the $19^{\text {th }}$ and early $20^{\text {th }}$ century (Coleman 2009; Hailbronner 1997), while other have spoken of first-generation agreements for the 1950-60s and second-generation agreements in the 1990s (Lehnguth, Maaßen and Martin Schieffer 1998; Lehnguth 1997). Coleman highlighted two agreements as "milestones" in this development, the 1904 Treaty between Germany and the Netherlands on the right of establishment and the Benelux Treaty. I am in debt to Coleman for inspiration to trace historical developments. I draw here on my own assessment of primary legal sources and monographies of legal scholars analysing developments in the $19^{\text {th }}$ and early $20^{\text {th }}$ century, as well as more contemporary publications.

${ }^{59}$ It is also important to refer to Torpey's ( 2018) detailed historical reconstruction regarding both the new mobility possibilities for peasants freed from servitude and from labour or due obligations in early modern Europe. These were also related to the increased market liberalisation, as well as state practices to monopolise the means of movement (through administrative procedures, passports, citizenship laws) and to enforce mobility control. Reviewing different historical examples of expulsions, Walters (2010) pointed out how the expulsion of 'own' nationals and of groups has been a legitimate practice in many historical contexts. One of his points was that the 'categories' for whom expulsion has been considered legitimate or illegitimate in a particular time-space need to be re-problematised, and as such also the deportability of today's "third-country nationals" not be taken for granted.

${ }^{60}$ Convention zwischen Preußen und Bayern wegen wechselseitiger Übernahme der Vagabunden, Berlin den 9. Mai 1818. [Agreement between Prussia and Bavaria regarding the reciprocal readmission of vagabonds, 1818].

${ }^{61}$ The German-Swiss Treaty of 1890 in its 1909 codification took on board many of the articles of the 1904 Treaty between Germany and the Netherlands, specifically those regarding the procedures for readmission (Freiherrn-von-Overbeck 1908, 1912). I will therefore focus on the German-Dutch treaty. However, the main procedures (Art. 7 - 9) correspond to those already contained in the earlier bilateral agreement between Germany and Russia (1890), which however did not foresee any of the procedures including third-country nationals.

${ }^{62}$ Abkommen zwischen der Regierung der Bundesrepublik Deutschland und den Regierungen des Königreichs Belgien, des Großherzogtums Luxemburg und des Königreichs der Niederlande über die Übernahme von Personen an der Grenze, 17. Mai 1966.

63 Abkommen zwischen der Regierung der Bundesrepublik Deutschland und der Königlich Dänischen Regierung zur Regelung der Frage der Abschiebung von Personen von der Bundesrepublik nach Dänemark und von Dänemark in die Bundesrepublik Deutschland. Vom 22. Juni 1954 (BAnz. 1954, Nr. 120); Abkommen zwischen der Regierung der Bundesrepublik Deutschland und der Königlich Schwedischen Regierung zur Regelung der Frage der Abschiebung von Personen von der Bundesrepublik Deutschland nach Schweden und von Schweden in die Bundesrepublik Deutschland. Vom 31. Mai 1954 (BAnz. 1954 Nr. 120).

64 Notably, the document "Abkommen zur Erleichterung der Rückkehr ausreisepflichtiger Ausländer" [agreements to facilitate the return of foreigners required to leave] containing a table with Germany's bilateral readmission agreements was uploaded on the BMI homepage 
under the file-name rueckkehrfluechtlinge: "return of [or: returned] refugees".

${ }^{65}$ Supra n.3; and n.70.

${ }^{66}$ Abkommen zwischen der Bundesregierung der Republik Österreich und der Regierung der Italienischen Republik über die Übernahme von Personen an der Grenze / Accordo tra il Governo Federale della Repubblica d'Austria e il Governo della Repubblica Italiana sulla riammissione delle persone alla frontiera, zu Wien, am 7. Oktober 1997 (BGBI. III - Nr. 160)

${ }^{67}$ Abkommen zwischen der Bundesregierung der Republik Österreich und der Regierung der Bundesrepublik Deutschland über die Rückübernahme von Personen an der Grenze (Rückübernahmeabkommen) (BGBI. III Nr. 19/1998)

${ }^{68}$ Acuerdo entre la República Francesa y el Reino de España sobre la readmisión de personas en situación irregular, hecho «ad referendum» en Málaga el 26 de noviembre de 2002 (BOE núm. 309)

${ }^{69}$ Council Initiative of the Republic of Finland with a view to the adoption of a Council Regulation determining obligations as between the Member States for the readmission of third-country nationals (1999/C 353/05) [1999] OJ C 353/6. The initiative aimed to establish rules between member states: a) which member state is responsible to receive a person that might be readmitted through a reciprocal EU readmission agreement, and b) which member state would be responsible to readmit to its territory a third-country national found unlawfully present and who has travelled through several member states.

${ }^{70}$ Directive 2008/115/EC of the European Parliament and of the Council of 16 December 2008 on common standards and procedures in Member States for returning illegally staying thirdcountry nationals [2008] OJ L 348/98

${ }^{71}$ Other exceptions concern for example persons that have an authorisation to stay in another member state, or the discretion of member states to issue a "right to stay for compassionate, humanitarian or other reasons", as well as (although not explicitly referenced), the Dublin readmission scheme.

72 Proposal for a Directive of the European Parliament and of the Council on common standards and procedures in Member States for returning illegally staying third-country nationals (recast). Brussels, 12.9.2018 COM(2018) 634 final.

73 On the "Roosendaal method (Coleman (2009, chapter 1, p.16).

The Roosendaal method consisted of placing immigrants on a train in Roosendaal, a city on the border with Belgium, heading for France. This was a purported attempt at removal to a country outside the Benelux area, but was to all intents a unilateral act of removal across the border with Belgium. The Dutch authorities did not seek permission for transit across Belgian territory, nor secure readmission to France. The unescorted immigrants would often disembark at one of several stops at stations in Belgium. They would find their way back to the Netherlands, either of their own accord or at the hands of the Belgian authorities, only to be expelled in the same manner, etc. This resulted in cases of repeated expulsion of immigrants - also referred to as migrants "in orbit" - between the Netherlands and Belgium, and the subsequent tension in Dutch-Belgian relations. 
${ }^{74}$ At external borders, entry can be refused if a person does not possess a valid visa or travel document, if the person has valid travel documents but has an alert in SIS or is "considered a threat to public policy, internal security, public health or the international relations of EU countries". But also, if the person cannot justify to the border control authorities the purpose of his/her intended stay and show themselves to be in possession of enough means of subsistence. Similar to the regulations on bilateral readmission, a person that makes an asylum request at the internal border (and is negative in Eurodac, otherwise the Dublin procedure applies) is by law entitled to do so and cannot be readmitted or refused entry.

75 Judgement of 19 March 2019, Abdelaziz Arib, Case C 444/17, ECLI:EU:C:2019:220.

The preliminary ruling concerned France, the temporary introduction of border control and the applicability of administrative detention and carrier sanctions as a consequence of border control measures upon irregular entry, following an interception in the border-area. It is beyond scope to address the specific case, but the court also addressed the interpretation of "mutantis mutandis" (art. 32 SBC) according to which when border control at internal borders is reintroduced, the relevant provisions of Title II (relating to external borders) are to apply mutatis mutandis. The court argued that mutatis mutandis means that border controls reintroduced at an internal border of a Member State cannot be equated with border controls at an external border with regards to the border-crossing of a third-country national who has no right of entry. In addition, since the case regarded a border-area interception within the 20-kilometer zone from the border, it also argued that in such case it is obvious that the person is to be considered to have de facto and de juris entered the territory of the member state, and therewith falls under the category of irregular (or illegal) stay.

${ }^{76}$ Additionally, in German law (art. 13, Aufenthaltsgesetz) 'entry' is defined as the spatialtemporal crossing of the border-crossing point. For specific instances not a spatial, but temporal criterium is provided, that of having terminated the border procedure needed to ascertain legal entry or to finalise a denial of entry decision.

77 Bundesgesetz über die Durchführung von Personenkontrollen aus Anlaß des Grenzübertritts (Grenzkontrollgesetz - GrekoG), StF: BGBI. Nr. 435/1996.

78 They can of course also aim to control exit routes, when mobile border-area control seeks to counter unauthorised immigration, countries are more likely to control entry routes: empirical evidence of such exit controls was minor and related to specific circumstances.

${ }^{79}$ These procedures were discussed through art.12 and art.7 of the 1904 agreement between the Netherlands and Germany. The 1966 agreement between Benelux and Germany regarding the readmission of persons on the common border abrogated the 1958 agreement stipulated through an exchange of notes. Here the spatial-temporal link to border-area interceptions for fast-track readmissions is yet less concrete, than it is in the agreements stipulated or renewed in the 90s. Contemporary evidence of of this reconfiguration of former denial of entry practices can also be found in the explanatory notes to the 2016 Austrian reform package of legislation, see footnote on the Amendment to the Asylum Act, the Aliens Police Act and the Federal Office for Immigration and Asylum Procedures Act. 


\section{PART III}

\section{Chapter 7}

${ }^{80}$ All quotes in this section, if not otherwise specified, derive from interviews with PCCC officers. The PCCCs included within the empirical study (4 interview partners, 3 centres) were primarily, but not exclusively, engaged in cross-border information exchange, compared to some PCCCs assessed in the research literature, which carry out a broad range of activities (Felsen 2012). Although the sample was small - and each centre has its own particularities - data on the meanings attributed by officers to the work of PCCCs provided consistency and data saturation. On specific topics - including on aspects of migration related tasks - further research would be necessary to gain a better understanding. With more than 60 joint centres located in Europe and their plural composition, additional research would be of value.

${ }^{81}$ Andreas and Nadelmann (2006, p.232; referenced inter alia in Gerspacher 2008; Bowling and Sheptycki 2012):

The common sentiment that a cop is a cop no matter what page is worn, and a criminal a criminal regardless of citizenship or where the crime was committed, serves as a form of transnational value system that can override both political differences and formal procedures. It provides the oil and glue of international law enforcement.

82 This was already the case for the first PCCC analysed by Maguer: in its first years of work, $60 \%$ of the information exchange did not regard the border-area territories. This is the statistical dimension of the "paradox" the scholar identified at the time. This led to tensions with the central level which attempted to lower this quota, since as mentioned likewise by Felson (2011), this application of CISA (art 39.3.) was, initially, viewed critically.

${ }^{83}$ Supra $\mathrm{n} .43$.

84 "Secure Information Exchange Network Application" (SIENA) provided by Europol, aims to ensure "the secure exchange of sensitive and restricted information" (Europol n.d.).

${ }^{85}$ Including joint search patrols targeting particular crime fields, such as the smuggling of drugs or stolen vehicles, carried out by officers in non-uniformed clothes and vehicles, thus without their 'visible' and representative aim.

${ }^{86}$ The meeting (Tirana July 2018) was intended to address the regional response to increasing migration pressure and the shift in the route from Greece-Macedonia-Serbia-Croatia to Slovenia to the route from Greece-Albania-Montenegro-Bosnia and Herzegovina-CroatiaSlovenia (the so-called "Adriatic route"). It was hold under the "Western Balkan integrative internal security governance" (IISG) initiative, which has Border Security (Western Balkan Border Security initiative, WBBSI) as one of its three pillars. The objective of the IISG reads as follows: the "IISG aims to strengthen cooperation of the EU with the neighbouring region of the Western Balkans, whose security has had high implications on EU's own security" (WBBSI 2018, p.3). The IISG was endorsed by the Council in 2016. It is deemed to complement security elements of the "Berlin Process" and facilitate accession requirements in the field of JHA. See https://wb-iisg.com/event/meeting-of-border-police-chiefs/. http://wbbsi.wb-iisg.com/.

\section{Interlude}

${ }^{87}$ The Austrian-Italian Schengen border is about $400 \mathrm{~km}$ long and runs along the Alps, with the 
Länder Tirol, Salzburg and Kärnten on the Austrian side, and the regions of Trentino-SouthTyrol, Veneto and Friuli-Venezia-Giulia on the Italian side. Through the Treaty of St. Germain 1919 after World War I this borderline was established between the to be Republic of Austria and the Kingdom of Italy. The southern part of Tyrol which had been part of the Habsburg Empire became part of Italy. The border-line section of Kärnten (AT), Italy and Slovenia was established through a referendum. After conflicting years, which brought the "South-Tyrolean question" also in front of the UN Council, Southern Tyrol (as well as the Trentino) have become recognised as Italian provinces with Autonomy Status - due to the presence of a German (and Ladin) speaking minority population. Since 1998 South-Tyrol, Trentino and North-Tyrol form also a European cross-border-region, later institutionalised as Euregio Tyrol-SouthTyrolTrentino / "European Grouping for Territorial Cooperation" adopted through regulation n. 1082/2006 (EGTC).

${ }^{88} \mathrm{~A}$ former customs officer recalled posteriously his experience of arriving to be stationed here in 1968 (Durante 2012, p.42, chapter "Alto Adige / Südtirol: Loro \& Noi" [them \& us], translation):

"In the office we are all Italians, and apart from the director, we are all meridionali [from southern Italy]. The same is the case for the financial and the border police [Guardia di finanza \& Polizia di Frontiera]. The holy borders with for-century-enemy Austria, are reflected in, and are entrusted to, an army of terroni [depreciative expression for southern Italians]. Here, in SouthTyrol, the Germans [meaning the local German speaking population] represent two thirds of the population, but none of them is part of the public administration. Italy is the power that has militarily occupied South Tyrol and a real South-Tyrolean would never dream of putting himself to its service. Here everybody is a real South-Tyrolean: Italian by Passport, not by sentiment. Understanding them. [...] At the Brenner/o, we - customs, financial police and police - are the absolute majority. Not counting the hundreds of soldiers [...]. Thus, an Italian island within a German sea, on a border where a non-declared war is fought. A silent and mean one."

${ }^{89}$ Amendment to the Asylum Act, the Aliens Police Act and the Federal Office for Immigration and Asylum Procedures Act (FLG I No. 24/2016), mostly entering into force on 1 June 2016.

These changes to immigration and asylum law were adopted (and therewith justified) after in 2015 Austria had registered the second largest number of asylum applicants per inhabitant and third per capita in the EU. The main amendments regarded a) stricter provisions on family reunification, b) an emergency regulation restricting access to asylum proceedings in case of risk to public order and internal security, c) "temporary asylum", i.e. an initially time-limited residence status for persons granted asylum (see (EMN - National Contact Point Austria - IOM 2017). Regarding the topic of this study's topic, it should be pointed out, that the amendment to the Fremdenpolizeigesetz (FPG - Aliens Police Act) also concerned inter alia the extension of the maximum time limit for readmissions from 7 days to 14 days. Albeit this has received minor interest compared to other more drastic amendments, the governmental explanatory note to the amendments of the FPG is insightful. It made explicit reference to bilateral readmissions and provided a twofold motivation. The amendment aimed a) to facilitate the application of bilateral readmission possibilities for persons found irregularly on the territory and b) to provide "equal treatment" with those persons who indeed are refused entry during border control, i.e. it should not be more successful to circumvent a border control (Ausschusses für innere Angelegenheiten 2016, p.29ff). Following this amendment (of art 45. FPG), also the legal basis for administrative detention prior to a readmission has been 
amended extending it, under certain conditions, to 14 days (art. 39 FPG). The FPG first included the possibility of returning without formalities a person - who entered the territory without authorisation and who is intercepted in the border-area - to the neighbour country in the prior FPG law of 1954 (art. 10). Subsequently the time limit of 7 days was introduced. In motivating the 2016 extension to 14 days, the government committee argued that the prior time-limitation applied to a measure corresponding rather to today's denial of entry (p.29) and not a readmission. Accordingly, "with the extension of the deadline to 14 days the proximity to a presumed unauthorised border-crossing is still given and the proportionality maintained" (p.30).

${ }^{90}$ Image 3: Visualisation table 2: readmission trends, LPD Tirol

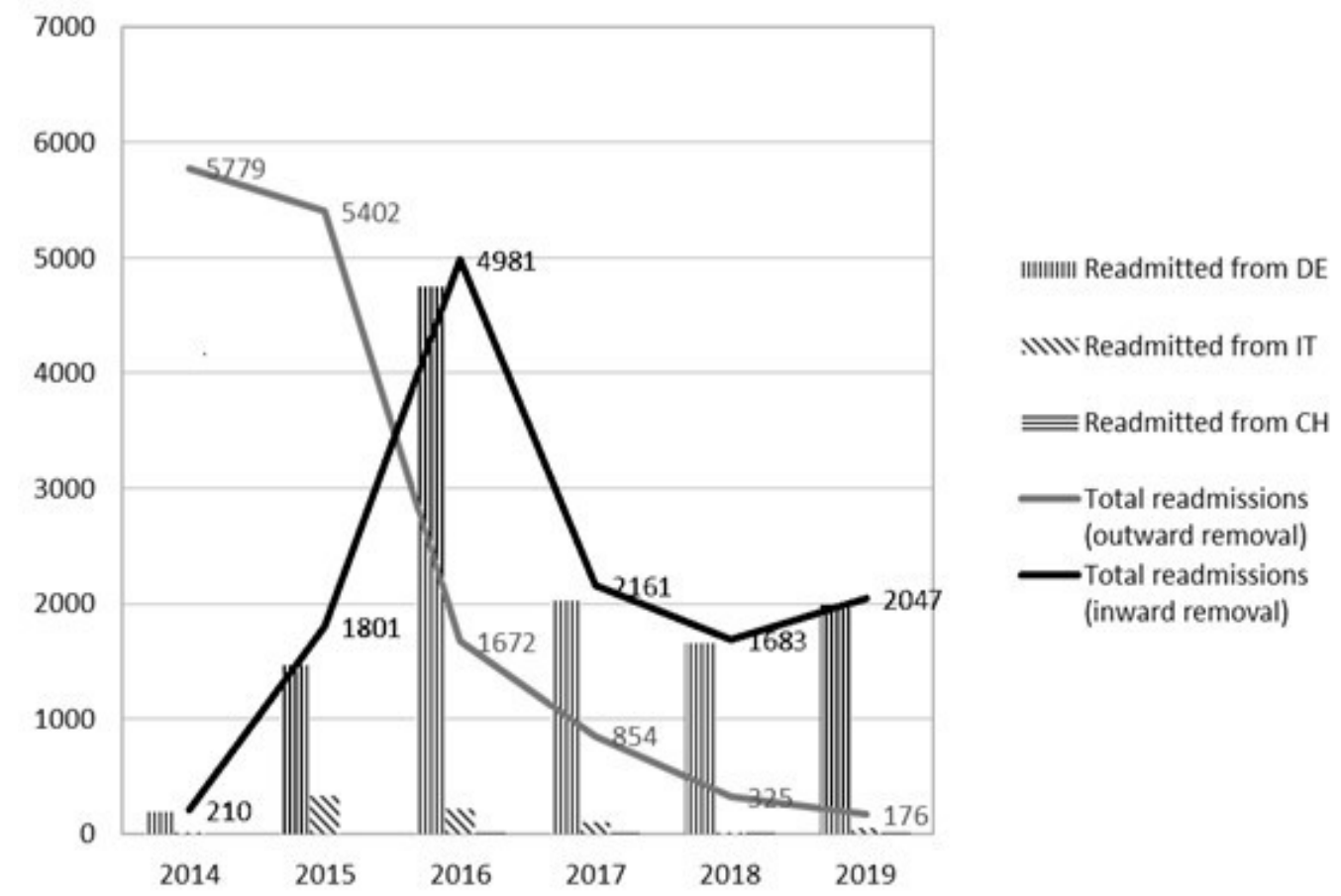

Composed by the author. Sources: supra n.57.

${ }^{91}$ The north Italian immigration police departments saw an increase in asylum applications of persons positive on Eurodac, for example with Dublin responsibility of Austria, France, Germany. This was amongst the reasons given for Italy's request to set up joint patrols with Austria to prevent entries, but also for setting up territorial Dublin units to accelerate Dublin readmissions procedures, which were not concluded before the 6 months' time-limit. (E.g. https://www.interno.gov.it/it/notizie/meno-33-sbarchi-nel-2017; Comitato Parlamentare Schengen 2019).

\section{Chapter 8}

92 Regulation (EU) No 603/2013 of the European Parliament and of the Council of 26 June on the establishment of 'Eurodac' for the comparison of fingerprints for the effective application of Regulation (EU) No 604/2013 establishing the criteria and mechanisms for determining the member state responsible for examining an application for international protection lodged in one of the Member States by a third-country national or a stateless person and on requests for the comparison with Eurodac data by Member States' law enforcement authorities and Europol for law enforcement purposes, and amending Regulation (EU) No 1077/2011 establishing European Agency for the operational management of large-scale IT systems in the 
area of freedom, security and justice (recast) [2013] OJ L 180/1 [hereinafter Eurodac Regulation].

The currently discussed Eurodac recast proposal aims to introduce several changes, such as the age lowered to 8, category 3 will become mandatory and stored etc. According to the Reg. (EU) No 603/2013 in force the main data-categories stored are:

- (category 1) the fingerprint sets of every person, aged 14 years or older (to be lowered to 8), who makes an application for international protection in a Member State;

- (category 2) any person 14 years or older, who is apprehended in connection with irregularly crossing the external border of a Member State;

- (category 3) data are the fingerprint sets that a Member State may transmit to Eurodac, with a view to checking whether a third-county national or a stateless person, aged 14 years or older, found illegally staying within its territory, has previously lodged an application for international protection. This type of transaction is not mandatory, so the figures reported might not be representative.

93 Commission Proposal for a Regulation of the European Parliament and of the Council establishing the criteria and mechanisms for determining the Member State responsible for examining an application for international protection lodged in one of the Member States by a third-country national or a stateless person (recast). Brussels, 4.5.2016, COM(2016) 270 final 2016/0133 (COD) [hereinafter COM Dublin IV proposal]

Dublin Regulation (supra n.2; see also n.103). The Dublin Regulation has its roots specifically in the Convention Implementing the Schengen Agreement (CISA 1990, chapter 7, in force 1995), later replaced by the 1990 Dublin Convention signed in Dublin (Dublin I, in force since 1997). After asylum matters shifted to first pillar community-competency through the Amsterdam Treaty, CEAS was initiated in 1999 through several (over time reviewed) legislative acts. The Dublin III Regulation has been in force since 01/01/2014 and replaced the 2003 Dublin (II) Regulation and the Dublin (I) Convention signed in 1990.

${ }^{94}$ Persons with refugee status or subsidiary protection are entitled to travel as 'tourists' within the Schengen area for 3 months, but without legal employment rights. After a five-year period, they can apply for a long-term-residency permit (Directive 2003/109/EC), which then allows them to move to a different member state for economic activities (Della Torre and de Lange 2018). This means that persons are bound to the "first country of entry" not only for the asylum procedure but for the following 5 years. It is not uncommon that persons leave the country nevertheless and live and work irregularly in a different member state and/or frequently move back and forth (see Borri and Fontanari 2015 on 'Lampedusa in Hamburg' as empirical case study). A stricter enforcement of the EU directive 2009/52/EC on sanctions against employers of 'illegally staying' third-country nationals, was also amongst the plan of the EAM. The New Pact on Migration and Asylum presented by the Commission (2020) proposed to lower the time from 5 to 3 years.

95 The proposals of the CEAS reform consisted in seven legislative components: recast Dublin Regulation; recast Eurodac Regulation; Regulation on the establishment of the European Union Agency for Asylum (EUAA); Regulation establishing a Common Procedure for International Protection in the EU; Qualification Regulation; recast of the Reception Conditions Directive; Regulation establishing a Union Resettlement Framework. The exclusion clause (reception withdrawn for persons engaging in secondary movements) was the most highly critiqued aspect of the Dublin 'reform', including by other EU stakeholders. The Reception recast proposal (COM(2016) 465 final) aimed to further 'harmonise' reception conditions, as differences in service provisions are presented as a pull factor for "secondary 
movements". In the Return Directive proposal (COM(2018) 634 final) unauthorised secondary movements are discussed in connection with the "risk of absconding" and deemed a challenge encountered in enforcing return decisions.

96 The 4-tier access model is one element of the IBM, as defined in 2006 by the Council. It comprises: measures in third countries, especially of origin and transit $\left(1^{\text {st }}\right.$ tier), cooperation with neighbouring countries $\left(2^{\text {nd }}\right)$, systematic border checks and surveillance $\left(3^{\text {rd }}\right)$ and control measures within the area of free movement, including in relation to return (European Commission 2010, pp.20-21; Council EU 2006, p.27).

${ }^{97}$ Commission Staff Working Document on Implementation of the Eurodac Regulation as Regards the Obligation to Take Fingerprints, Brussels, 27.5.2015 SWD(2015) 150 final.

It recommended: a) to inform the "data-subject" of the obligation to be fingerprinted, and that for the purpose of determining asylum responsibility not only fingerprints are deemed evidence of first entry; b) if the person does not ask for asylum, he/she can be detained under the return directive, $c$ ) asylum seekers could be detained (for the shortest time possible and necessary) or processed under accelerated procedure. When all this fails d):

It is suggested that if the initial counselling does not succeed, the Member State may consider resorting, in full respect of the principle of proportionality and the EU Charter of Fundamental Rights, to coercion as a last resort. If a Member States chooses to do this the data-subject should be informed that coercion may be used in order to take his/her fingerprints. If the data-subject still refuses to cooperate it is suggested that officials trained in the proportionate use of coercion may apply the minimum level of coercion required, while ensuring respect of the dignity and physical integrity of the data-subject, as specified in an approved procedure for taking fingerprints. This procedure should include a clear explanation to the data-subject of the steps the official intends to take in order to compel cooperation. The official should demonstrate that there was no other practicable alternative measure to using reasonable coercion. A caseby-case assessment should always be made of whether there is no such alternative, taking into account the specific circumstances and vulnerabilities of the person concerned. Member States may consider that it is never appropriate to use coercion to compel the fingerprinting of certain vulnerable persons, such as minors or pregnant women. If some degree of coercion is used for vulnerable persons it should be ensured that the procedure used is specifically adapted to such persons. It is suggested that the use of coercion should always be recorded and that a record of the procedure be retained for as long as necessary in order to enable the person concerned to legally challenge the actions. (Para. 7)

98 The guideline followed up on an EMN (2014) survey, on how member states normatively regulate detention and the use of force for fingerprinting. Some indicated the use of detention and/or that of a proportionate degree of coercion for the purpose of ensuring fingerprinting. Others neither foresaw detention nor coercion in their normative framework. Member states also differ in their experiences of resistance in fingerprinting for asylum matters and some countries tend to face passive resistance more frequently.

99 "Hotspot" notably initially designed a procedure, and not a facility, to enable registration upon arrival over the Mediterranean as well as relocation procedures. According to Tazzioli many migrants underwent the forced journey from Ventimiglia-Taranto eight or ten times, for which she spoke of dispersal politics. This is relevant to point out here, as these practices go beyond 
a logic of "registration".

100 The prosecution of Schleswig-Holstein in Germany was asked to express a legal opinion concerning proceedings against illegal stay or entry or smuggling of persons who arrived in Germany over the so-called "Balkan Route", in order to set out some guideline for law enforcement officers. The legal opinion was presented also in front of the Landtag of SchleswigHolstein (Innen- und Rechtsausschuss 18. WP - 120. Sitzung). A representative of the prosecution pointed out, that this was an exceptional circumstance, provided for by law, in which for humanitarian reasons, "refugees" were allowed to enter Germany despite entering through a "safe country". However, the prosecutor pointed out that there has never been an explicit ordinance to do so by the State Ministry, but it happened silently through "coherent behaviour". As quoted in the meeting notes (resume of hearing of Mr. Döllel, stellvertretender Generalstaatsanwalt, in Schleswig-Holsteinischer Landtag 2016, p.8):

Das habe es nicht einfacher gemacht. Auf der einen Seite habe es das tatsächliche Handeln an den Grenzen gegeben, als ob so ein Erlass vorgelegen hätte, auf der anderen Seite habe dieses stillschweigende Verhalten und auch das tatsächliche, faktische Verhalten nahegelegt, dass dies der Wille der entscheidenden Behörden sei. Strafrechtlich sei bei einem solchen Verhalten der Behörde, die eine Genehmigung in diesem skizzierten Sinne erteilen könne, diese Genehmigung zwar expressis verbis nicht erteile, aber aktiv das Verhalten stillschweigend dulde, nach der Lehre und gesicherter obergerichtlicher Rechtsprechung von einem Rechtfertigungsgrund auszugehen (...).

Translation:

This was considered to have made [the assessment] not easy. On the one hand, there were the concrete acts on the borders, as if an ordinance were there; on the other hand, has the silent behaviour, together with the factual one, suggested that this was the will of the deciding authority. Concerning such a behaviour of an authority - which could give the mentioned permission and does not do it exprissis verbis, but indeed tolerates that behaviour in an active and silent manner - in criminal proceedings by taking account of the doctrine and the established case law, can be deemed ground for justification.

The opinion (aimed at assessing the lawfulness of persons' entry) concluded that the authority's behaviour gave ground for justification which means that the act was not to be targeted for irregular entry and stay or smuggling. Based on the prosecutor's statement, a newly created temporary category was employed - the "invited" refugees" - who had arrived over the Balkan Route and were exempted from law enforcement measures on irregular entry, as were investigations on migrant smuggling.

101 One of the 'extra-ordinary' features of 2015-2016, was an almost consistent framing of the persons as "refugees" by interviewed officers. This is likely to relate to the refugee label that governments applied to certain nationalities for a brief period and only to those arriving through the "Balkan-Route". In 'ordinary' times the micro-level framing was more heterogenous, but the testimony quoted above was not an exception.

102 Drawing on French sociology and its impact on wider knowledge production in social science, Fassin argued that work inspired by the critical sociology of Bourdieu aims to render visible relationships of power and domination, while work inspired by Boltanski rather attends to the 
interpretation of the critique. Shifting analytical attention to the grammar of the critique, according to Fassin, means to renounce thinking and to reflect upon the meaning of violence (Fassin 2013, p.198 and note 135).

${ }^{103}$ Under ordinary legislative procedure (Art. 294 TFEU) the Parliament and the Council, upon a proposal of the Commission, adopt EU law in co-decision. In May 2016 the Commission presented a legislative proposal to reform the Dublin Regulation (COM(2016) 270 final). By September-November 2017 the LIBE Committee of the Parliament presented its amendments to the proposal and the parliament voted in favour of starting negotiations with the Council. In the Council, clauses upon responsibility and solidarity found no agreement. In June 2018, the Council concluded that a "consensus needs to be found on the Dublin Regulation to reform it based on a balance of responsibility and solidarity, taking into account the persons disembarked following Search and Rescue operations" (Council EU 6600/19, p.3; 9680/18; EUCO 9/18 point 12). The newly elected European Parliament assigned a new rapporteur to continue negotiations with the Council. The new work programme of the Commission was released on $23^{\text {rd }}$ of September 2020.

${ }^{104}$ Preliminary rulings by the CJEU (art. 267 TFEU) are a procedure in which a national court can refer a question to the CJEU regarding the interpretation or validity of Union law. Neither the main national proceedings nor the interpretation of national law is thereby referable and as the CJEU interpretation is deemed necessary for the national court's judgment, the national proceedings are on hold until the CJEU ruling, which in turn issues a binding interpretation on Union law.

See table n.6, Annex II. The first three cases, especially the first, found considerable treatment in (mostly) legal scholarship (Brouwer et al. 2015; Brouwer 2015a; Peers 2013; Illamola Dausa 2012; Dyevre 2011.; Fabiano 2010.; Moonen 2011; Guild et al. 2016, Van der Woude 2020), on the forth see Pascale (2020). Only the last case particularly regarded controls long exit routes for the purpose of preventing exit. It will be addressed in subchapter 8.5.

\section{${ }^{105}$ SBC, Article 23: Checks within the territory}

The absence of border control at internal borders shall not affect:

(a) the exercise of police powers by the competent authorities of the Member States under national law, insofar as the exercise of those powers does not have an effect equivalent to border checks; that shall also apply in borderareas. Within the meaning of the first sentence, the exercise of police powers may not, in particular, be considered equivalent to the exercise of border checks when the police measures:

(i) do not have border control as an objective;

(ii) are based on general police information and experience regarding possible threats to public security and aim, in particular, to combat cross-border crime;

(iii) are devised and executed in a manner clearly distinct from systematic checks on persons at the external borders;

(iv) are carried out on the basis of spot-checks;

(b) security checks on persons carried out at ports and airports by the competent authorities under the law of each Member State, by port or airport officials or carriers, provided that such checks are also carried out on persons travelling within a Member State;

(c) the possibility for a Member State to provide by law for an obligation to hold or carry papers and documents; 
(d) the possibility for a Member State to provide by law for an obligation on third-country nationals to report their presence on its territory pursuant to the provisions of Article 22 of the Convention implementing the Schengen Agreement of 14 June 1985 between the Governments of the States of the Benelux Economic Union, the Federal Republic of Germany and the French Republic on the gradual abolition of checks at their common borders ('the Schengen Convention').

${ }^{106}$ Adel [2012], para. 75; A [2017], para. 59 and 40:

the more extensive the evidence of the existence of a possible equivalent [border control] effect (...), apparent from the objective pursued by the checks carried out in a border area, from the territorial scope of those checks and from the existence of a distinction between the basis of those checks and that of those carried out in the remainder of the territory of the Member State concerned, the greater the need for strict detailed rules and limitations laying down the conditions for the exercise by the Member States of their police powers in a border-area and for strict application of those detailed rules and limitations, in order not to imperil the attainment of the objective of the abolition of internal border controls (...).

${ }^{107}$ An exception clause to the competency of the CJEU similar to the prior Art. 62.1 TEC is found under Art. 276 TFEU:

In exercising its powers regarding the provisions of Chapters 4 [judicial cooperation in criminal matters] and 5 [police cooperation] of Title $V$ of Part Three relating to the area of freedom, security and justice, the Court of Justice of the European Union shall have no jurisdiction to review the validity or proportionality of operations carried out by the police or other lawenforcement services of a Member State or the exercise of the responsibilities incumbent upon Member States with regard to the maintenance of law and order and the safeguarding of internal security.

108 Art. 72, TFEU:

This Title [TITLE V AREA OF FREEDOM, SECURITY AND JUSTICE] shall not affect the exercise of the responsibilities incumbent upon Member States with regard to the maintenance of law and order and the safeguarding of internal security.

109 Art. 73, TFEU:

It shall be open to Member States to organise between themselves and under their responsibility such forms of cooperation and coordination as they deem appropriate between the competent departments of their administrations responsible for safeguarding national security.

110 Infringement number 2014/4130, Noncompliance of German Bundespolizei Gesetz with Art 20 and 21(a) of Regulation (EC) No 562/2006 (Schengen Borders Code). Formal notice (art. 258 TFEU), Germany, Home Affairs, 16/10/2014.

${ }^{111}$ Bundespolizeigesetz vom 19. Oktober 1994 (BGBI. I S. 2978, 2979), das zuletzt durch Artikel 26 Absatz 1 des Gesetzes vom 20. November 2019 (BGBI. I S. 1724) geändert worden ist. 
112 Erlass zur Anwendung von § 23 Absatz 1 Nummer 3 Bundespolizeigesetz (BPolG). Vom 7. März 2016 (GMBI Nr. 10/2016, S. 203).

113 OVG Saarlouis Urteil vom 21.2.2019, 2 A 806/17.

${ }^{114}$ VG Stuttgart Urteil vom 11.4.2019, 1 K 2888/18.

${ }^{115}$ Beschluss vom 13.12.2019 - BVerwG 6 B 30.19 ECLI:DE:BVerwG:2019:131219B6B30.19.0.

116 In the case $1 S 1469 / 17$ (p. $16 \mathrm{ff}$, VGH Baden-Württemberg) the court pointed out that the BRAS 120 (2008) was handled as classified information (for internal use only) and could therefore not provide a framework that could be followed by the public or controlled by the court.

117 The 2012 guidelines were included in the first bi-annual Schengen Evaluation Communication (COM(2012) 230 final) and followed the 2010 report on the application of the SBC regulations on internal borders (COM(2010) 554 final). Therein caution was expressed that border-area controls could be disguised border controls and the need for legal guarantees delimiting powers was highlighted.

118 Brouwer et al (2015) however considered that even the Dutch framework does not provide sufficient legal certainty. The Dutch law specified for example the number of train carriages and the frequency of daily checks. A subsequent amendment provided for the possibility to intensify frequency and intensity in cases of "'a sudden or expected increase of irregular migrants crossing at the borders (art. $4.17 \mathrm{~b}$ Vreemdelingenbesluit)". This measure was applied end of 2015. National courts issued two opposite conclusions relating to such intensified checks (assessing the lawfulness of detention after apprehension): according to Brouwer et al this illustrates the uncertainty of the legal basis and the goals of border-area police checks in the Netherlands.

${ }^{119}$ Supra n.9.

${ }^{120}$ Checks aimed to target irregular migration of citizens from specific countries or geographical areas, related to their available police information (selection criteria) $(1,2,3)$. For example, "secondary movements" by citizen from specific third countries, an increase of detection of visa fraud from citizen of a specific third country or area etc.

121 E.g. Council Implementing Decision (EU) 2016/1989 of 11 November 2016 setting out a recommendation for prolonging temporary internal border control in exceptional circumstances putting the overall functioning of the Schengen area at risk [2016] OJ L 306/13. Upon: Commission Proposal for a Council Implementing Decision setting out a Recommendation for prolonging temporary internal border control in exceptional circumstances putting the overall functioning of the Schengen area at risk, Strasbourg, 25.10.2016 COM(2016) 711 final, p.4.; Council Implementing Decision (EU) 2017/246 of 7 February 2017 setting out a Recommendation for prolonging temporary internal border control in exceptional circumstances putting the overall functioning of the Schengen area at risk [2017] OJ L 36/59, para. 12.

${ }^{122}$ Annual Report on the functioning of the Schengen area European Parliament resolution of 30 May 2018 on the annual report on the functioning of the Schengen area (2017/2256(INI)), P8_TA(2018)0228, point 13.

${ }^{123}$ European Parliament legislative resolution of 4 April 2019 on the proposal for a regulation of 
the European Parliament and of the Council amending Regulation (EU) 2016/399 as regards the rules applicable to the temporary reintroduction of border control at internal borders (COM(2017)0571 - C8-0326/2017-2017/0245(COD)), P8_TA(2019)0356.

The Parliament inserted an amendment that border-crossings by a large number of third-country nationals should not be considered a "threat to public policy or internal security" (1). Regarding BAC, it included an amendment that "[w]hile it remains clear that police powers are different in their nature and purpose from border control" member state have art 23. powers at their disposal but need to make sure "that those police checks do not have border control as an objective". It suggested member states to "assess whether the situation could be adequately addressed by way of increased cross-border cooperation, both from an operational point of view and from that of information exchange between police and intelligence services" (2a). Under the criteria for introducing BC, it notably included the need to assess if "enhanced crossborder police cooperation or intensified police checks, are likely to sufficiently remedy the threat to public policy or internal security" (26b). This likewise fosters the proliferation of intensified BAC.

${ }^{124}$ EMPACT stands for the (four-year) EU policy cycle to tackle organised and serious international crime, wherein "facilitation of illegal immigration" has since its inception hold an important place.

${ }^{125}$ E.g. Council Framework Decision 2002/946/JHA on the strengthening of the penal framework to prevent the facilitation of unauthorised entry, transit and residence.

${ }^{126}$ Touring Tours und Travel GmbH (C-412/17) and Sociedad de Transportes SA (C-474/17).

127 Opinion of Advocate General Bot delivered On 6 September 2018 (ECLI:EU:C:2018:671). Joined Cases C-412/17 and C-474/17 Bundesrepublik Deutschland v Touring Tours Und Travel Gmbh (C-412/17), Sociedad De Transportes Sa (C-474/17), ECLI:EU:C:2018:1005.

In the preliminary ruling (n.128, above) the CJEU argued that ID checks carried out by private bus companies on travellers had the effect of border control. Under the assessed German carrier sanction law, coach transport providing a regular cross-border service within the Schengen area to Germany must check the passports and residence permits of passengers before they cross the German border. The court prohibited such national law as it produces checks considered as having an effect equivalent to border control. The case law enables one to point out the privatisation and governmentalisation of border practices, as here the 'powers' were carried out not by police forces but by employees of private bus companies. The court argued that such checks within the territory do have to be examined with reference to art. 23 and art. 22 of the SBC: since they are only carried out because it is a border-crossing transport, this reveals the objective of having a border control effect:

The fact that, in the present case, the checks at issue in the main proceedings are characterised by the particularly close connection which they have with the crossing of an internal border, inasmuch as that is specifically the event which triggers those checks, is particularly indicative of an 'effect equivalent to border checks' for the purposes of Article 21(a) of Regulation No 562/2006. (para. 68) 


\section{ANNEX I}

\section{Quotes from non-English public sources - original text}

\section{Chapter 1}

\subsection{POLICING-MOBILITIES IN THE BORDER-STRIP, pg.2(*)}

Carl August Ackermann (1856 [2012 re-print]), foreword:

Die s. g. Fremdenpolizei ist, obwohl der wichtigste Zweig der Polizei, ein ziemlich verrufenes Gebiet. Nicht allein, daß es wegen seiner unklaren Gränzen dem Theoretiker zu schaffen macht, es ist auch mißliebig bei dem größten Theile der auf inm thätigen Lokalbeamten, nicht minder beim Publikum.

\section{Chapter 6}

\subsection{INTRODUCTION, p.118(*)}

Expose $\mathrm{Nr} .39$ of the 11th legislation period (1904/05) of the Reichstag [legislative assembly of the German Empire], accompanying the Agreement on Establishment between the German Empire and the Netherlands, 1904: Niederlassungsvertrag zwischen dem Deutschen Reiche und den Niederlanden. Vom 17. Dezember 1904 (in RGBi. Nr. 51, 979 ff und MBI. 07 71; Nederl. Staatsblad No. 279, 2 ff). Reprinted in Heinrichs (1908, p.17-18, footnote nr. 1 to the agreement):

Seit einer Reihe von Jahren sind im Übernahmeverkehre mit den Niederlanden vielfach Unzuträglichkeiten hervorgetreten, indem teils Meinungsverschiedenheiten über den Umfang der Übernahmepflicht entstanden, teils von den Niederlanden ausgewiesene Personen, darunter auch Angehörige dritter Länder, ohne vorhergehende Anfrage über die deutsche Grenze abgeschoben wurden. An diese formlosen Abschiebungen, welche die Behörden in den deutschen Grenzbezirken vor schwierige polizeiliche Aufgaben stellen und erhebliche Kosten verursachen, haben sich oft langwierige diplomatische Erörterungen geknüpft; dabei ist von deutscher Seite wiederholt angeregt worden, den Übernahmeverkehr auf vertragsmässigem Wege in geordnete Bahnen zu lenken. Andererseits hat die Niederlaendische Regierung seit längerer Zeit den Wunsch zu erkennen gegeben, ihren Angehörigen ein vertragsmässiges Recht auf Aufenthalt und Niederlassung in Deutschland zu sichern, um sie auf diese Weise in höherem Masse als bisher gegen Ausweisungsmassnahmen zu schützen. (...)

\subsection{INTRODUCTION, p.118(*)}

Tweet by Matteo Salvini, Italian Ministry of Interior, 22 October 2018, https://twitter.com/matteosalvinimi/status/1054411895850131456.

"In attesa di incontrare il mio collega francese, I'Italia non cambia linea: a \#Claviere presidio fisso di polizia e verifiche a tappeto sui respingimenti di Parigi degli ultimi mesi [...]." 


\subsubsection{Tracing through time: readmission agreements, p. $123\left({ }^{*}\right)$}

Münsterberg (1887, p.130):

Als das bequemste und daher lange Zeit beliebteste Mittel galt bekanntlich in Ländern mit besonders starker Frequenz ausländischer Bettler und ähnlich lästiger Personen der sogenannte Schub, dh. ein Zwangstransport der Auszuweisenden bis and bezw. über die Grenze des Nachbarstaates, welchem damit in gleicher Weise die weitere Fürsorge freundnachbarlich überlassen wurde; er mochte seinerseits vorübergehende Hülfe leisten und demnächst die Ankömmlinge an die nächste Landesgrenze befördern.

\subsubsection{Tracing through time: readmission agreements, p.124 $\left(^{*}\right)$}

Convention zwischen Preußen und Bayern wegen wechselseitiger Übernahme der Vagabunden, Berlin den 9. Mai 1818. [Agreement between Prussia and Bavaria regarding the reciprocal readmission of vagabonds, 1818], art.1:

Es soll in Hinkunft kein Vagabunde oder Verbrecher der in das Gebiet des anderen der beiden hohen kontrahirenden Theile ausgewiesen werden, wenn derselbe nicht entweder ein Angehöriger desjenigen Staates ist, welchem er zugewiesen wird, und in demselben sein Heimwesen zu suchen habt, oder doch durch das Gebiet desselben, als ein Angehöriger eines rückwärts liegenden Staates nothwendig seinen Weg muss.

\subsubsection{Historical variants and a barometer for cross-border relations, p.131 (*)}

H.H. (1866, pp.142-143):

Die Vertreter des einen Standpunkt sind geneigt, das ganze Passwesen und jede aus demselben sich ergebene Gewähr gegen das Eindringen gefährlicher Personen in den Staat fallen zu lassen. Die Vertreter des anderen wünschen zwar ein möglichst grosses Gebiet für eine gleichmässige Behandlung des öffentlichen Verkehrs und innerhalb dieses Gebiets die mögliche Freiheit der Bewegung, halten jedoch an der Grenze dieses Gebiets eine strenge Passkontrolle als eine Gewähr gegen die von Aussen her drohenden Gefahren erforderlich.

Translation:

The exponents of one position are inclined to abandon the whole passportsystem and all from it deriving protections against the intrusion of dangerous persons into the state. The exponents of the other position, whilst desiring a possibly large territory of an equal treatment of public traffic and within that territory a possible freedom of movement, they retain that on the border of that territory a strict pass-control is necessary as protection against external threats.

\section{Chapter 7}

\subsubsection{Migration control - ethos of a joint task?, p.168}

Sterkl (2014)

Transit ins Irgendwo. Gemeinsam sollen Polizisten aus drei Ländern 
Flüchtlinge daran hindern, in Zügen nach Deutschland zu gelangen. Das klappt fast nie.

Transit to somewhere. Police officers from three countries shall prevent refugees to reach Germany by train. It seldomly works.

\section{Interlude}

Interlude, p.185 $\left(^{*}\right)$

Deutscher Bundestag (2014, p.2):

(...) hat Deutschland gemeinsam mit Italien und Österreich die bereits bestehende Zusammenarbeit zur Eindämmung des Migrationsdrucks im Binnengrenzraum und zur Bekämpfung international agierender Schleuserorganisationen intensiviert. Betroffen davon war auch die entsprechende konzeptionelle Neuausrichtung der bereits seit dem Jahr 2000 bestehenden bahnpolizeilichen trilateralen Streifen zwischen Italien, Österreich und Deutschland. Seit dem 10. November 2014 werden trilaterale Streifen in grenzüberschreitenden Fernreisezügen ausschließlich auf italienischem Hoheitsgebiet durchgeführt.

Translation:

(...) Germany has intensified together with Italy and Austria the existing cooperation aiming at the containment of migratory pressure in the internal Schengen-area and the fight of international smuggling-organisations. Affected by this was also the related conceptual reconfiguration of the trilateral trainline-patrols between Italy, Austria and Germany, that have existed since the year 2000. Since the 10th of November 2014 trilateral patrols on cross-border trains are carried out exclusively on Italian territory.

Interlude, p.185 (*)

Mario Deriu (SIULP police union), hearing at the Commissione straordinaria per la tutela e la promozione dei diritti umani (Extraordinary commission for the protection and promotion of human rights), meeting n. 98 , on the 08/06/2016:

(...) le scorte trilaterali hanno assunto funzioni e finalità diverse e distanti dal progetto dei padri fondatori dell'Europa unita. In buona sostanza, non una scelta politica e umanitaria risolutiva ma una impropria e inutile semplificazione: disporre dei poliziotti per evitare che i profughi possano raggiungere il Nord Europa. (...) II servizio- non più saltuario ma sistematico si effettua tutti i giorni su tutti i treni internazionali in partenza da Trento a Monaco di Baviera. [...] Gli operatori tedeschi e austriaci non si limitano a una 'osservazione partecipata e flessibile', ma intervengono anche in territorio italiano. (...) Da quanto osservato nei mesi scorsi, si riscontra il fallimento del ricorso alle scorte trilaterali, inutili, dispendiose e umilianti: così come pensate, rischiano di essere un percorso propedeutico alla ricostruzione di barriere e muri. (Commissione straordinaria [...] 2016, pp.3-4) 


\section{Chapter 8}

\subsubsection{Fingerprinting, "proportionality" and moral geography, p.193(*)}

Press-communication by the Austrian Mol (Bundesministerium für Inneres (BMI AT) 2015), „MiklLeitner: Wir kämpfen gegen Schlepper, nicht gegen Flüchtlinge. Die Polizei geht nach dem Prinzip der Verhältnismäßigkeit vor", Artikel Nr. 12752 vom Freitag, 4. September 2015, Source: https://bmi.gv.at/news.aspx?id=70377835747350715651453D.

'Der polizeiliche Umgang mit jenen Menschen, die keinen Asylantrag stellen, weil sie in ein anderes Land wollen, ist ebenso klar geregelt. Bei allen Handlungen der Polizistinnen und Polizisten gilt aber jedenfalls das Prinzip der Verhältnismäßigkeit. Wenn sich diese Menschen nicht im Rahmen der Verhältnismäßigkeit registrieren lassen und Gewalteskalationen drohen, weil sie grundsätzlich friedlich nach Deutschland weiterziehen wollen, 'dann werden sich ihnen unsere Polizistinnen und Polizisten nicht mit Gewalt entgegenstellen. Wir kämpfen gegen Schlepper und nicht gegen Familien und Kinder', so Mikl-Leitner.

Translation:

'The handling by the police of those persons who do not make an asylum application because they want to go to another country, is likewise regulated clearly. In all actions of the police officers is, however, valid the principle of proportionality. If those persons are not willing to be registered within the frame of proportionality and there is the threat of an escalation of violence, because in principle they want to continue peacefully towards Germany, 'then our police officers will not oppose them with force. We are fighting against smugglers, not against families and children', Mikl-Leitner said.

\subsubsection{Fingerprinting, "proportionality" and moral geography, p.194}

Felice Romano (SIULP) was interviewed with regards to testimonies of persons who had resisted fingerprinting and were subjected to violence in order to comply with fingerprinting in Italy's hotspots. Source: Brigida and Poeta (2016), video-reportage "Hotspot - le impronte dei migranti", published online by internazionale on the 12th of May 2016, min. 1:40-2:10, 2:40-3:10, 3:454:10):

Quando ci troviamo di fronte a questi cittadini che non si vogliono sottoporre all'identificazione, li poniamo in questi ... locali, in questi spazi, nei quali loro restano fino a che non riusciamo ad identificarli compiutamente. L'esigenza di arrivare addirittura all'uso della forza per il prelievo delle impronte, per l'identificazione è una richiesta fatta dalla Commissione Europea.

Io dico, che comunque, chiunque ha notizie di violenze, di denunciarle. Usare la forza per prelevare le impronte, a dei poveri disgraziati che scappano da scenari di guerra, da persecuzioni, è a nostro avviso non solo eticamente sbagliato, ma è soprattutto infruttifero. Abbiamo dimostrato che tecnicamente che il prelievo forzoso delle impronte non è valido ai fini di un riconoscimento certo.

L'Europa a nostro giudizio ha commesso un errore fondamentale. Quello di approcciare a questo fenomeno ritenendolo un problema di polizia, o di turbativa dell'ordine e della sicurezza pubblica. Questa robba non ha nulla a che vedere con la polizia. Questo è un problema sociale, umano e in quanto 
tale dev'essere affrontato.

Translation:

When we face citizens, who don't want to be subjected to the identification procedure, we put them in these ... locations, these spaces, where they stay until we can identify them properly. The exigency to even arrive to the use of force for fingerprinting is a request made by the European Commission.

I say, however, who has information about violence, should denounce it. To use force for the purpose of fingerprinting unfortunate persons who are fleeing war or persecution is not only ethically wrong, but importantly it is not working. We have shown that fingerprints taken forcefully are technically not valid to guarantee recognition.

Europe has made a fundamental mistake, the one to approach this phenomenon as a problem of policing or as a threat to public order. This stuff has nothing to do with the police, it is a social problem, a human issue, and as such it has to be responded to.

\subsubsection{Migratisation of security and response-ability, p.199}

Deriu, SIULP regional-police union representative, interview published in Bertoncin and Weissensteiner (2016):

abbiamo fatto presente quanto fosse complicato fotosegnalare persone che stavano scappando. E questo per un motivo molto semplice: il vincolo di Dublino III che obbliga i migranti a restare nel primo Paese d'approdo, impedendogli quindi di raggiungere il Nord, il loro obiettivo. (...) fotosegnalare è un obbligo giuridico, quindi va fatto, punto. Per i poliziotti si presentava anche il rischio di potenziali denunce. Davanti a persone che esercitavano una resistenza passiva, dovendo in qualche modo ricorrere alla forza, c'era il reale pericolo di procurare delle lesioni. Ma soprattutto c'era un grande disagio. (...) Ora, io capisco che bisogna essere rigorosi davanti alla legge, il nostro mandato istituzionale ce lo impone, ma di fronte a una situazione del genere mi sembrava una follia. (...) Mi sembrava giusto che la responsabilità cadesse sulla filiera gerarchica che aveva imposto questo Sistema. (...). Ritengo che il problema sia soprattutto di natura politica. Potendo rimodulare transitoriamente Dublino III, io credo che queste persone si farebbero identificare volontariamente e noi potremmo perfino pensare di accompagnarle dove vogliono arrivare.

Translation:

(...) it is very complicated to fingerprint persons who are escaping. And this for a very simple reason: the fact that identification is tied up with Dublin III, which constrains migrants to remain in their first country of arrival, forbidding them to reach further North, which is their aim. (...) identification is a legal obligation, it has to be done. For police officers there was also the problem of facing charges. In front of persons who oppose via passive resistance, if one needs to use some degree of force, one can produce lesions. But in particular, it causes a big unease. [Describes situation]. I understand that it is important to be stiff with the law, and our institutional role requests that from us, but in the face of such a situation it seems crazy to me. (...). Also, on top of that, 
the juridical liability is personal and will fall upon the officer who applied force. (...) It seems right to me that the responsibility would fall upon the hierarchical level that imposed this system. (...) I deem this to be primarily a political problem. If one could remodel Dublin III, I think these persons would voluntarily agree to be identified, and we could maybe even think of accompanying them where they want to go.

8.3.1. CJEU case law: (judicial) border-struggles surrounding art. 23 of the SBCChapter 8, p. 206

Erlass zur Anwendung von § 23 Absatz 1 Nummer 3 Bundespolizeigesetz (BPolG). Vom 7. März 2016 (GMBI Nr. 10/2016, S. 203):

a. Die Kontrollmaßnahmen sind nicht auf Dauer anzulegen, sondern erfolgen unregelmäßig zu unterschiedlichen Zeiten, an unterschiedlichen Orten und stichprobenartig unter Berücksichtigung des Reiseaufkommens.

b. Die Kontrollmaßnahmen finden nicht allein aus Anlass des Grenzübertritts statt Sie erfolgen auf der Grundlage von ständig aktualisierten Lageerkenntnissen und/oder (grenz-)polizeilicher Erfahrung, die die Bundespolizeidienststellen auf der Grundlage von eigenen Lageinformationen oder denen anderer Behörden entwickeln. Daher sind allgemeine oder konkrete polizeiliche Informationen und/oder Erfahrungen über grenzüberschreitende Kriminalität, z.B. über häufig genutzte Verkehrsmittel und -wege, bestimmte Verhaltensweisen, und die Analyse der verfügbaren Informationen über grenzüberschreitende Kriminalität, die aus eigenen Quellen oder von anderen Behörden stammen, Ausgangspunkt der Ausübung polizeilicher Maßnahmen sowie ihrer Intensität und Häufigkeit.

\subsubsection{CJEU case law: (judicial) border-struggles surrounding art. 23 of the $s B C$, p.209}

Press-statement by the German Mol (Bundesministerium des Innern, für Bau und Heimat (2017):

Bundesinnenminister Dr. Thomas de Maizière: "Die Binnengrenzkontrollen an der deutsch-österreichischen Landgrenze sind aus migrations- und sicherheitspolitischen Gründen derzeit weiterhin erforderlich. Ich bin froh, dass die EU-Kommission und auch der Rat der Europäischen Union diese Einschätzung teilt und begrüße die heutige Beschlussfassung im Rat ausdrücklich. Wir können erst dann zurück zu Schengen, wenn es die Entwicklung der Gesamtlage zulässt. Wir alle streben perspektivisch wieder einen Raum ohne Kontrollen an den Binnengrenzen an. Aber so bitter es auch ist: An dem Punkt sind wir noch nicht. Die von der Europäischen Kommission empfohlene Stärkung der Möglichkeiten zur polizeilichen Fahndungsmaßnahmen in den Grenzgebieten ist ein wichtiges und richtiges Zeichen. Keine Frage. Die sogenannte Schleierfahndung ist in vielen Ländern in Deutschland bereits ein etabliertes und bewährtes polizeiliches Instrument, das durc halle Mitgliedstaaten und auch in den Ländern verstärkt genutzt werden sollte. Aber: Die Schleierfahndung ist kein Ersatz für Grenzkontrollen." 


\section{ANNEX II}

\section{A - Background information: police organisation}

This section provides some background information to chapter-sections with regards to specific aspects of police organisation in Germany, Austria and Italy and eventual national functional or territorial jurisdiction aspects that matter for border-area policing. It is beyond the scope of this dissertation to provide a systematic comparative overview. The following notes are complementing specific aspects, mentioned in the main body of the thesis. Considering the dearth of police scholarship in/about Italy compared to, for example, Germany, the latter section is kept short, and the former outlined in more depth.

\section{Note on Germany:}

See chapter 5, p.103; chapter 8.2.

The police force responsible for border protection at the time was called Bundesgrenzschutz, transformed in 2005 into today's Bundespolizei (BPol).

As a federal republic, Germany is composed of 16 Länder or constituent states: it has two federal police forces (the Bundespolizei and the Bundeskriminalamt) and 16 state-police forces of the Länder (Länderpolizeien). The legal base outlining the tasks and competency of the Länder-policeforce rests with the Länder and thus the police-law of each Land outlines police organisation and tasks. The Schleierfahndung is often presented as a "Bavarian" invention, since the Land of Bavaria (in southern Germany) introduced it as one of the tasks of the police in its police law in May 1995, as subsequently did other police forces of the Länder in the mid-90s. As such, Bavaria could introduce Schleierfahndung in its police law independently of other German states, provided it was not in contrast to federal law. Today the possibility for, and specific policing powers of, Schleierfahnung differ amongst the police-laws of the Länder.

The "Bavarian Border Police" indeed existed initially between 1945 and 1998, when it was dissolved as separate police force. The role of Grenz-Beauftragter was maintained after 1998 and located at the level of the Bavarian Police-Directorate. In August 2018 the Bavarian Border Police force - Bayrische Grenzpolizei - was set up again with a new mandate, whereby there are still debates as to its legitimate competency and division of labour with the Bundespolizei.

\section{Note on Austria:}

See chapter 6, p.121; Interlude.

Austria has one unified police, the federal police called Bundespolizei (since the police reform of 2005). There are nine federal police directorates, the so-called Landespolizeidirektionen (LPD). 
Image 4: Police organisation (AT): Federal Police Directorates
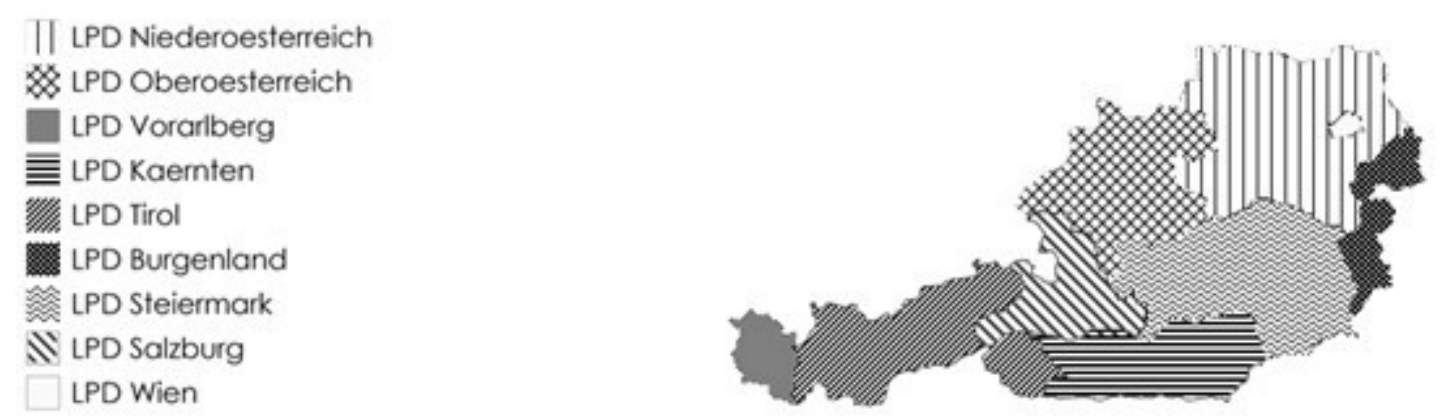

Image: created with mapchart.net and adapted by the author.

The competency for measures in the case of eventual temporary border control at internal borders as well as for compensatory measures in border-areas lies at the level of the LPD police directorates and their subordinate bodies (see Grenzkontrollgesetz and SicherheitsPolizeigesetz). Until 2019, each LPD hold a so-called EGFA department (Einsätze, Grenz- und Fremdenpolizeiliche Abteilung) comprising "operations", "border-policing" and "alien-policing".

It is here that "compensatory measures" (Ausgleichsmassnahmen, AGM) situate and are carried out operationally together with the AGM units of the lower levels. In the course of 2018/2019, the EGFA was split into two departments (operations; border and alien policing) a specific unit for border protection, called Puma, was created. While Austria unified its police forces (police, criminal police, gendarmery) in 2005, internal security cooperation with the Armed Forces exists within the framework of "assistance deployment" decided by the Federal Government, e.g. in the monitoring of the "green border" or in support to AGM measures. This military-police cooperation has a long history.

With exception of the directorate Vienna, all federal police directorates have internal Schengen borders with the neighbouring countries: Italy and Slovenia in the South, Hungary and Slovakia at East, the Check-Republic and Germany to the North, and Switzerland in the West.

On $16^{\text {th }}$ of September 2015 Austria introduced unilaterally border controls along the "Balkan Route" on the land-borders with Hungary and Slovenia, which has been extended multiple times, while towards Italy compensatory measures were reinforced.

\section{Note on Italy:}

See Interlude and Chapter 8, p.196.

Italy holds a centralised system and divides its internal security actors into two vocational groups. The civilian Polizia di Stato is subordinated to the Department of Public Security of the Ministry of Interior. Each Italian province holds a Questura, representing the Department of Public Security on provincial level, and a Prefettura, representing the ministry of interior on provincial level. Within the Polizia di Stato there is a huge functional differentiation amongst police forces: there is the railway police Polfrontiera (PolFer), the highway police (PolStrada), the border-police (PolFrontiera), the postal police, as well as special police forces. In addition, there are the military police forces of the Arma dei Carabinieri and of the Guardia di Finanza, subordinated to the Ministry of Defence and of the Ministry of Finances. Of relevance for the maritime borders is also the Guardia Costiera, a special corps of the Italian Navy, subordinated to the Ministry of Infrastructure and Transport. In addition, the military Operation Strade Sicure (Secure Streets, Law 24 July 2008, N. 125) establishes that Army personnel is available to the Prefects, for 
domestic deployment in the surveillance of high-risk sites and targets, and for patrolling activities together with the police forces. In Italy the border police sector is subdivided in 8 so-called "zones", which group together various regions of Italy. The directorate of each zone present the high-intermediate level, between the central border and immigration directorate at ministerial level, and the subordinate border police sectors and local commissariats.

Image 5: Police organisation (IT): Border Police Sectors
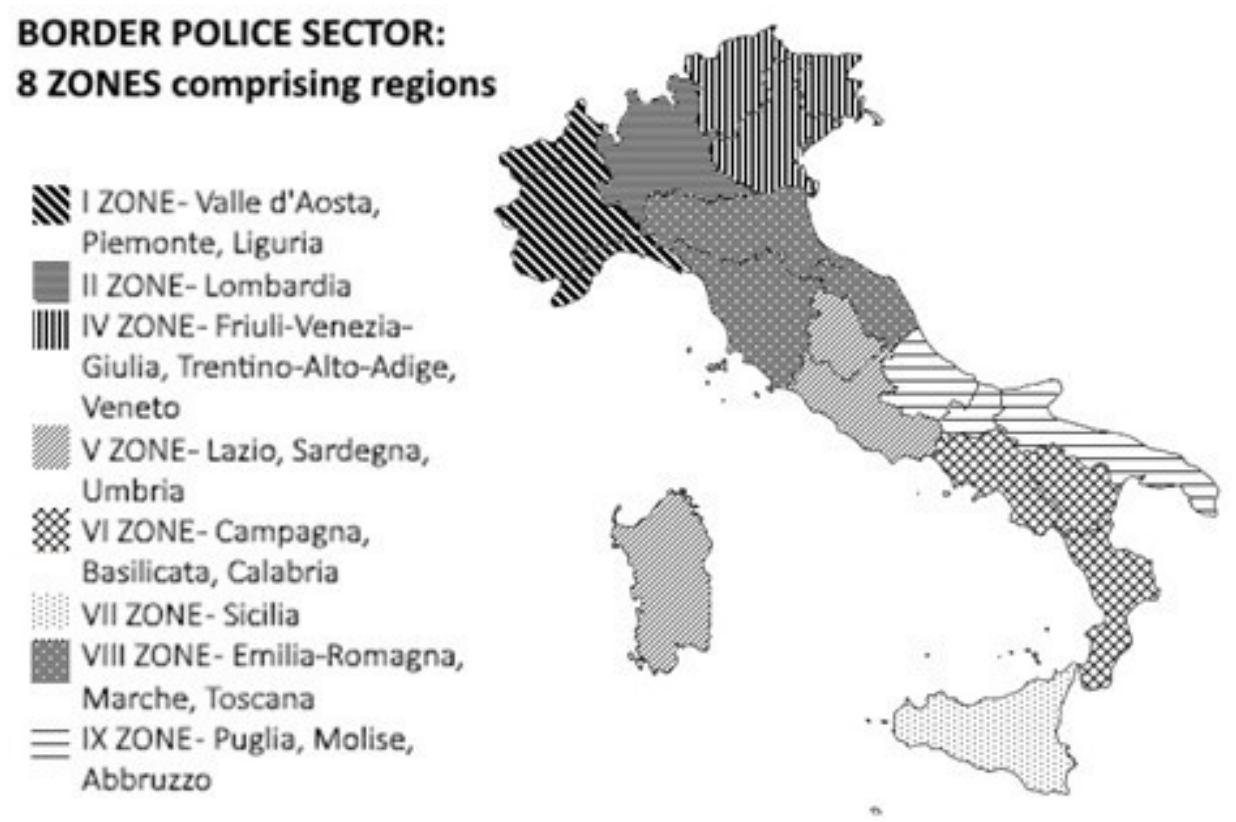

Image: created with mapchart.net and adapted by the author.

Italy has 3 border zones that have internal borders: bordering with France (I ZONE), Switzerland (II ZONE), Austria and Slovenia (IV ZONE). Besides the primarily responsible border police (Polfronteria), patrols in border-areas are also carried out by the railway police, the highway police, as well as other specialist units, such as the public order police (usually on duty during big sport events or demonstrations), which may be deployed to internal borders in support. The military police of the Carabinieri and the Guardia di Finanza might carry out patrols in borderareas. In addition, within the larger domestic military Operation Strade Sicure also military units have been deployed to support police forces in the border-areas. 'Cross-border' cooperation in Italy applies thus also to borders within the country across different public security actors, both civilian and military.

In 2014 there was the plan on the table to reorganise the Italian Border Police, foreseeing the reduction of the existing border police zones to 6 , and the transformation of various subordinate border police sections, either by transforming them into police commissariats or by incorporating the border police functions into the competencies of the respective Questuras. This would have affected, with regards to internal borders notably the border police sections of Ventimiglia, on the French border, Tarvisio on the Austrian border, Gorizia and Trieste on the border to Slovenia. With developments in 2015 the situation changed. In a prior reorganisation of the border-police in 2007/2009 (Ministero dell'Interno 2009), the border police section of the Brennero on the Austrian border had been supressed and transformed into a police commissariat with border police functions. As were other two border-police sectors in what formerly constituted the 3rd border-police zone, comprising the territory of the region Trentino-Alto-Adige. Lacking thus any border-police sector, the 3rd ZONE was abolished, and the jurisdictional area and functions were incorporated into that of the IV zone (formerly comprising only Friuli-Venezia-Giulia and Veneto). 
Some argued that this greatly reduced operational capacities and that activities in the borderarea were limited (Senato della Repubblica 2012 [Interrogazione $n^{\circ} 4-08296$ ]). The decree that formalised this reorganisation in 2009 explicitly referred also to the former art. 21 SBC (now art. 23), regarding the police powers to carry out checks in the border-area, arguing that the necessity to create border-area controls would be evaluated. The rationale for reducing personnel and offices is highlighted in the reorganisation plans of 2014 (Direzione Centrale per gli Affari Generali della Polizia di Stato 2014, p.3): "The institutional activity, since the entry of force of the Schengen Agreements, is limited to border-area control [controllo di 'retro valico'], which in the identified sectors does not offer particular profiles of operationality" (translation).

As such, border-area control was not considered to offer an operational justification for the permanence of border-police-sections along the internal borders. Indeed, a few years later (2018-2019), a new re-organisation plan of the border police was being presented: it foresees, inter alia, the creation of (a nominal transformation into) a land border police sector in Bardonecchia (border with France) and the return to having a border-commissariat at the Brennero (border with Austria) (Ministero dell'Interno 2019). With regards to operational cooperation, up to 2013 the Italian law did not explicitly contemplate the situation of police officers from other countries operating on Italian territory, except for Liaison Officers and police experts deployed to Italy for a short period of time in particular circumstances and tendentially unarmed. Recent bilateral police cooperation agreements refer as legal base to art 7-bis of the law 2013/119 (GU n.242 del 15-10-2013), which converted to law the legislative decree 2013/93. Interestingly, this law deals with "urgent measures in the field of security and contrast to gender violence [...]" and Art 7-bis was added to the text which was initially contained in the proposal of this legislative decree. During the bi-cameral legislation procedure, one chamber voted in contra and the argument was voiced, that this article had nothing to do with the rest of the law and was seemingly added to pass unnoticed. At the end however the article 7-bis "Joined operations in the field of international police agreements" was adopted. It stipulates that officers taking part in operations on Italian territory within activities regulated by bilateral police cooperation agreements, are attributed functions of public security actors (7-bis[1]) and depending on the respective bilateral agreements allowed to carry their weapons but only for self-defence (7-bis [2]), and that their civil and penal responsibility is regulated by the bilateral agreements and national law (7-bis [3]). This article has subsequently been cited as the main national legislative reference (together with the respective Prüm Decisions) in subsequent bilateral police cooperation agreements or agreements on joint patrols. 
B - Tables: Schengen, bilateral agreements \& jurisdiction

\section{SCHENGEN MEMBERS}

Table 3: Schengen-area membership and enlargement process

\begin{tabular}{|l|l|l|}
\hline State & Ratification & Implementation \\
\hline Belgium & 1985 & 1995 \\
\hline France & 1985 & 1995 \\
\hline Germany & 1985 & 1995 \\
\hline Luxembourg & 1985 & 1995 \\
\hline Netherlands & 1985 & 1995 \\
\hline Italy & 1990 & 1997 \\
\hline Portugal & 1991 & 1995 \\
\hline Spain & 1991 & 1995 \\
\hline Greece & 1992 & 2000 \\
\hline Austria & 1995 & 1997 \\
\hline Denmark & 1996 & 2001 \\
\hline Finland & 1996 & 2001 \\
\hline Iceland (non-EU) & 1996 & 2001 \\
\hline Norway (non-EU) & 1996 & 2001 \\
\hline Sweden & 1996 & 2001 \\
\hline Czech Republic & 2003 & 2007 \\
\hline Estonia & 2003 & 2007 \\
\hline Hungary & 2003 & 2007 \\
\hline Latvia & 2003 & 2007 \\
\hline Lithuania & 2003 & 2007 \\
\hline Malta & 2003 & 2007 \\
\hline Poland & 2003 & 2007 \\
\hline Slovakia & 2003 & 2007 \\
\hline Slovenia & 2003 & \\
\hline Switzerland \\
(non-EU) & & \\
\hline Liechtenstein (non-EU) & 2008 & \\
\hline Romania & EU-not yet Schengen & \\
\hline Croatia & EU-not yet Schengen & \\
\hline Bulgaria & EU-not yet Schengen & \\
\hline & & \\
\hline & 2004 & \\
\hline
\end{tabular}




\section{PCCCS/JOINT CENTRES}

Table 4: PCCCs/joint centres (referenced in the order of appearance in the main text [selection]).

\begin{tabular}{|c|c|c|}
\hline & Legal base at the time of establishment & Joint centre/s or $\mathrm{P}(\mathrm{C}) \mathrm{CC}$ \\
\hline $\begin{array}{l}\text { DTL } \\
\text { FR }\end{array}$ & $\begin{array}{l}\text { German-French Intergovernmental Agreement of Mondorf- } \\
\text { les-bains of } 09 \text { October } 1997 \text { on co-operation between } \\
\text { police and customs authorities in the border-regions } \\
\text { (entered into force on } 01 \text { April 2000). }\end{array}$ & $\begin{array}{l}\text { Offenburg (1999), } \\
\text { relocated to Kehl (2002) }\end{array}$ \\
\hline \multirow[t]{2}{*}{$\begin{array}{l}\text { ES } \\
\text { FR }\end{array}$} & $\begin{array}{l}\text { Acuerdo entre el Reino de España y la República Francesa } \\
\text { sobre Creación de Comisarías Conjuntas en la Zona } \\
\text { Fronteriza Común, hecho en París el } 3 \text { de junio de } 1996 .\end{array}$ & \multirow{2}{*}{$\begin{array}{l}\text { Le Perthus-La Junquera, } \\
\text { (1997), followed by } \\
\text { Canfranc-Comport- } \\
\text { Urdos, Les Melles Pont } \\
\text { du Roy, and Biriatou- } \\
\text { Irún. } \\
\text { Transformed in } 2002 \text { into } \\
\text { PCCCs. }\end{array}$} \\
\hline & $\begin{array}{l}\text { Convenio de Cooperación Transfronteriza en materia Policial } \\
\text { y Aduanera entre el Reino de España y la República Francesa, } \\
\text { hecho "ad referendum" en Blois el } 7 \text { de julio de } 1998 .\end{array}$ & \\
\hline $\begin{array}{l}\text { ES } \\
\text { PT }\end{array}$ & $\begin{array}{l}\text { Acuerdo entre el Reino de España y la República Portuguesa } \\
\text { sobre la Creación de Comisarías Comunes en Frontera, } \\
\text { hecho "ad referendum" en Madrid a } 19 \text { Noviembre de } 1997\end{array}$ & $\begin{array}{l}\text { Tuy/Valença do Minho, } \\
\text { Caya/Elvas, Vilar } \\
\text { Formoso/Fuentes de } \\
\text { Oñoro and Vila Real de } \\
\text { Santo } \\
\text { Antonio/Ayamonte. }\end{array}$ \\
\hline $\begin{array}{l}\text { IT } \\
\text { FR }\end{array}$ & $\begin{array}{l}\text { Accordo fra il Governo della Repubblica Italiana e il Governo } \\
\text { della Repubblica Francese sulla Cooperazione } \\
\text { Transfrontaliera in Materia di Polizia e Dogana, fatto a } \\
\text { Chambéry il 03/10/1997 }\end{array}$ & $\begin{array}{l}\text { Ventimiglia }(1989 / 2002) \\
\text { Modane }(1999 / 2002)\end{array}$ \\
\hline $\begin{array}{l}\text { AT } \\
\mathrm{HU}\end{array}$ & $\begin{array}{l}\text { VEREINBARUNG zwischen der Österreichischen } \\
\text { Bundesregierung und der Regierung der Republik Ungarn } \\
\text { über die Zusammenarbeit in der gemeinsamen } \\
\text { Kontaktdienststelle in Nickelsdorf-Hegyeshalom }\end{array}$ & $\begin{array}{l}\text { Nickelsdorf (2007), prior } \\
\text { joint border } \\
\text { commissariat (2001) }\end{array}$ \\
\hline $\begin{array}{l}\text { AT } \\
\text { IT } \\
\text { SI }\end{array}$ & $\begin{array}{l}\text { Vereinbarung zwischen der Regierung der Italienischen } \\
\text { Republik, der Österreichischen Bundesregierung und der } \\
\text { Regierung der Republik Slowenien über die Zusammenarbeit } \\
\text { im polizeilichen Zentrum in Thörl - Maglern. }\end{array}$ & $(2005)$ \\
\hline $\begin{array}{l}\text { AT } \\
\text { DE }\end{array}$ & $\begin{array}{l}\text { Vereinbarung zwischen dem Bundesministerium für Inneres } \\
\text { der Republik Österreich und dem Bundesministerium des } \\
\text { Innern der Bundesrepublik Deutschland über die } \\
\text { Zusammenarbeit im Gemeinsamen Zentrum Passau, signed } \\
\text { on 28/3/2017, in force with 1/2/2018. } \\
\text { Based on Vertrag zwischen der Republik Österreich und der } \\
\text { Bundesrepublik Deutschland über die grenzüberschreitende } \\
\text { Zusammenarbeit zur polizeilichen Gefahrenabwehr und in } \\
\text { strafrechtlichen Angelegenheiten (Art. 24). }\end{array}$ & $\begin{array}{l}\text { Passau, formalised as } \\
\text { joint centre in 2016, ad- } \\
\text { hoc centre set up in } 2015\end{array}$ \\
\hline $\begin{array}{l}\text { ES } \\
\text { Ma } \\
\text { roc } \\
\text { co }\end{array}$ & $\begin{array}{l}\text { Acuerdo entre el gobierno del Reino de España y el gobierno } \\
\text { del Reino de Marruecos en materia de cooperación policial } \\
\text { transfronteriza ( } 2010 \text { ), «BOE» núm. 116, de } 15 \text { de mayo de } \\
\text { 2012, páginas } 35412 \text { a } 35416 \text { ( } 5 \text { págs.), BOE-A-2012-6365 }\end{array}$ & $\begin{array}{l}\text { Tánger and Algeciras } \\
\text { (2012) }\end{array}$ \\
\hline
\end{tabular}

Table composed by the author. 


\section{BILATERAL READMISSION AGREEMENTS}

TABLE 5: Readmission agreements between member states (that share a common border): the following overview is twofold:

- TABLE 5(a): survey of readmission agreements carried out within the realm of the Finnish Initiative, published in Council EU, Inventory of readmission agreements. Brussels, 11 November 1999, 11486/1/99, REV 1;

- TABLE 5(b): selection, update and further detail on fast-track provisions: table composed by the author. 
Table 5(a): "Inventory of readmission agreements" (1999)

Source: Council of the European Union 11486/1/99 REV 1, pp.2-3

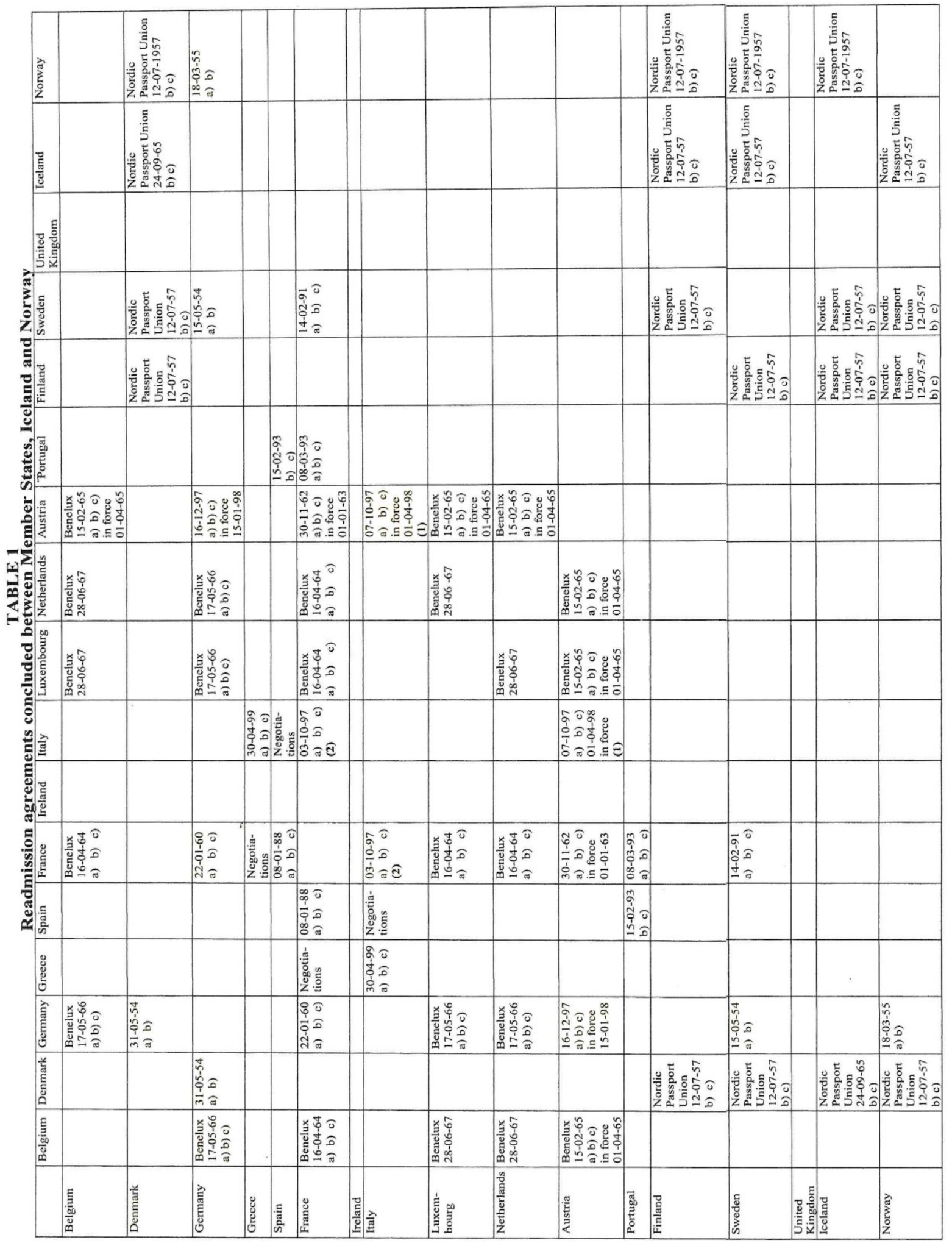

a) Provisions relating to the readmission of nationals of the Contracting Parties;

b) provisions relating to the readmission of third-country nationals;

c) provisions relating to transit for return purposes. 
Table 5(b):

\begin{tabular}{|c|c|c|c|c|c|}
\hline \multicolumn{6}{|c|}{$\begin{array}{c}\text { Bilateral readmission agreements between member states that share a common border } \\
\text { (selection) }\end{array}$} \\
\hline \multicolumn{3}{|c|}{ Selection } & \multicolumn{3}{|c|}{ Fast-track procedures contained agreements } \\
\hline \multicolumn{3}{|c|}{ Council EU 11486/1/99 REV1 } & \multicolumn{3}{|c|}{ by the auhor } \\
\hline \multicolumn{3}{|c|}{$\left[{ }^{*}=3^{\text {rd }}\right.$ country at the time $]$} & \multirow[t]{2}{*}{ currently in force } & \multirow{2}{*}{$\begin{array}{l}\text { eventual } \\
\text { time limits } \\
\text { for ordinary } \\
\text { procedure } \\
6 \text { months }\end{array}$} & \multirow{2}{*}{$\begin{array}{c}\text { timelimits for } \\
\text { simplefied } \\
\text { procedure } \\
7 \text { days } \\
\text { (art IV, part A \& B) }\end{array}$} \\
\hline $\begin{array}{l}\text { Germany } \\
\&\end{array}$ & Denmark & $31 / 05 / 1954$ & & & \\
\hline & Sweden & $31 / 05 / 1954$ & $x$ & 6 months & $\begin{array}{c}7 \text { days } \\
\text { (art IV, part A \& B) }\end{array}$ \\
\hline & Benelux & $17 / 05 / 1966$ & $\mathrm{x}$ & 6 months & $\begin{array}{l}1 \text { month } \\
\text { (art.5, art.5) }\end{array}$ \\
\hline & France & 22/01/1960 & $\begin{array}{l}\text { 19/2/2003, in } \\
\text { force with } \\
\text { protocol } \\
19 / 9 / 2005\end{array}$ & 6 months & 7 days (art.3.4) \\
\hline & Austria & $16 / 12 / 1997$ & $\begin{array}{c}x \\
\text { in force } \\
15 / 01 / 1998\end{array}$ & 6 months & 4 days (art. 2.2) \\
\hline \multirow[t]{3}{*}{ Austria \& } & Slovenia* & 01/09/1993 & $\begin{array}{c}x \\
\text { integrated by an } \\
\text { exchange of notes } \\
\text { in } 2013\end{array}$ & 90 days & 7 days (art. 3.3) \\
\hline & Italy & 07/10/1997 & $\begin{array}{c}x \\
\text { in force } \\
01 / 04 / 1998\end{array}$ & 6 months & 24 hrs (art. 6) \\
\hline & Hungary* & 09/10/1992 & $\begin{array}{c}x \\
\text { in force } \\
20 / 04 / 1995\end{array}$ & 90 days & 7 days (art. 3.3) \\
\hline \multirow[t]{3}{*}{ Italy \& } & Slovenia* & 03/09/1996 & $\begin{array}{c}X \\
\text { in force } \\
01 / 09 / 1997\end{array}$ & & $\begin{array}{c}24 \mathrm{hrs} \text { or } \\
\text { interception } \\
\text { within } 10 \mathrm{~km} \text { (art. } \\
6 \text { ) }\end{array}$ \\
\hline & $\mathrm{CH}^{*}$ & 10/09/1998 & $\begin{array}{c}x \\
\text { in force } \\
01 / 05 / 2000\end{array}$ & \multicolumn{2}{|c|}{$\begin{array}{c}\text { for border-area interceptions, } \\
\text { procedure established by local } \\
\text { authorities (art. 6) }\end{array}$} \\
\hline & France & 03/10/1997 & $\begin{array}{c}x \\
\text { in force } \\
01 / 12 / 1999\end{array}$ & \multicolumn{2}{|c|}{$\begin{array}{l}\text { single procedure } \\
3 \text { months (art. 5) }\end{array}$} \\
\hline France \& & Spain & 08/01/1988 & $\begin{array}{l}26 / 11 / 2002 \text {, in } \\
\text { force } 21 / 12 / 2003\end{array}$ & & 4 hours (art. 7 ) \\
\hline Spain \& & Portugal & 15/02/1993 & $\begin{array}{c}X \\
\text { in force since } \\
2 / 4 / 1995\end{array}$ & \multicolumn{2}{|c|}{$\begin{array}{l}\text { single procedure } \\
8 \text { days }\end{array}$} \\
\hline
\end{tabular}

Table composed by the author. Agreements may be accompanied and updated by additional implementing or operational protocols. 


\section{CASE LAW: PRELIMINARY RULINGS OF THE CJEU / PLURAL LEGAL ORDERS}

Table 6: Case law of the CJEU, art. 23. SBC (first three cases)

\begin{tabular}{|c|c|c|c|}
\hline & $\begin{array}{c}\text { Melki and Abdeli } \\
2010(\mathrm{FR})\end{array}$ & $\begin{array}{l}\text { Adil } 2012 \\
(\mathrm{NL})\end{array}$ & $\begin{array}{c}A 2016 \\
\text { (DE) }\end{array}$ \\
\hline \multicolumn{4}{|c|}{ EU LAWS } \\
\hline \multirow[t]{2}{*}{$\begin{array}{l}\text { EU } \\
\text { primary } \\
\text { law }\end{array}$} & \multicolumn{3}{|c|}{$\begin{array}{l}\text { Art. } 67.2 \text { TFEU (Title V): "(...) ensure the absence of internal border controls for persons and } \\
\text { shall frame a common policy on asylum, immigration and external border control, based } \\
\text { on solidarity between Member States, which is fair towards third-country nationals. (...)". } \\
\text { Art 77.2(e) TFEU: "For the purposes of paragraph 1, the European Parliament and the } \\
\text { Council, acting in accordance with the ordinary legislative procedure, shall adopt measures } \\
\text { concerning: (e) the absence of any controls on persons, whatever their nationality, when } \\
\text { crossing internal borders". } \\
\text { Art. } 72 \text { TFEU: Title V does not affect the exercise of Member States' responsibilities } \\
\text { regarding the maintenance of law and order and the safeguarding of internal security. } \\
\text { Schengen-Acquis, Protocol (N.19) annex to the Treaty of Lisbon. } \\
\text { Art. 26.2.TFEU: The internal market (...) an area without internal frontiers in which the free } \\
\text { movement of goods, persons, services and capital is ensured in accordance with the } \\
\text { provisions of the Treaties. } \\
\text { In extention: art. 3.2 TEU: "the Union shall offer its citizens an area of freedom, security and } \\
\text { justice without internal frontiers, in which the free movement of persons is ensured in } \\
\text { conjunction with appropriate measures with respect to external border controls, asylum, } \\
\text { immigration and the prevention and combating of crime". }\end{array}$} \\
\hline & Art. 267 TFEU & & \\
\hline $\begin{array}{l}\text { EU } \\
\text { secon- } \\
\text { dary } \\
\text { law }\end{array}$ & \multicolumn{3}{|c|}{$\begin{array}{l}\text { Art. } 22 \text { SBC, REGULATION (EU) 2016/399: "Crossing internal borders. Internal borders may } \\
\text { be crossed at any point without a border check on persons, irrespective of their nationality, } \\
\text { being carried out". [ex. Art. 20 SBC, REGULATION (EC) No 562/2006]. } \\
\text { Art. } 23 \text { SBC, REGULATION (EU) 2016/399: "Checks within the territory" [ex. art } 21 \text { SBC } \\
\text { REGULATION (EC) No 562/2006]. }\end{array}$} \\
\hline \multicolumn{4}{|c|}{ NATIONAL LAWS } \\
\hline Other & Constitution, art. 88 & & \\
\hline $\begin{array}{l}\text { Policing } \\
\text { law }\end{array}$ & & $\begin{array}{l}\text { Art. 6, Police-Law, (Politiewet } \\
\text { 1993) }\end{array}$ & $\begin{array}{l}\text { E.g. Art. 23.1., Law on the } \\
\text { Federal Police (Gesetz über die } \\
\text { Bundespolizei 'BpolG', 1994) } \\
\text { on 'identification and checking } \\
\text { of papers', art. } 22 \text { 'Questioning } \\
\text { and duty to provide } \\
\text { information' also on trains and } \\
\text { stations, as well as other } \\
\text { provisions, such as in t he } \\
30 / 50 \text { kilomater zone for } \\
\text { border protection measures. }\end{array}$ \\
\hline $\begin{array}{l}\text { Immi- } \\
\text { gration } \\
\text { law }\end{array}$ & $\begin{array}{l}\text { [French Legislation } \\
\text { Code on entry and } \\
\text { stay of foreign } \\
\text { nationals and right of } \\
\text { asylum (CESDA)] }\end{array}$ & $\begin{array}{l}\text { Art. 50.1.: mobile security } \\
\text { monitoring checks (MTV), } \\
\text { Law on foreign nationals } \\
\text { (Vreemdelingenwet 2000); } \\
\text { art: 4.17(a) decree on } \\
\text { foreign nationals } \\
\text { (Vreemdelingenbesluit } \\
\text { 2000) - checks } 20 \text { km into } \\
\text { the country and approx } 30 \\
\text { min or } 2 \text { stations after } \\
\text { train-crossings plus } \\
\text { restrictions in frequency } \\
\text { and intensity. } \\
336\end{array}$ & $\begin{array}{l}\text { [Competencies of the Bpol, } \\
\text { offences against Law on } \\
\text { Passports, the Law on } \\
\text { Residence or the Law on } \\
\text { Asylum.] }\end{array}$ \\
\hline
\end{tabular}




\begin{tabular}{|c|c|c|c|}
\hline $\begin{array}{l}\text { Criminal } \\
\text { law }\end{array}$ & $\begin{array}{l}\text { Art. } 78.2 \text { of the Code of } \\
\text { Criminal Procedure } \\
\text { (code de procédure } \\
\text { pénale) - ID checks } \\
\text { (20 kilometers behind } \\
\text { the border and first } \\
\text { stop within } 50 \\
\text { kilomenters on } \\
\text { international train- } \\
\text { routes). }\end{array}$ & & $\begin{array}{l}\text { Paragraph 113(1) of the Criminal } \\
\text { Code (Strafgesetzbuch 1998)- } \\
\text { resistance to public } \\
\text { offical.[Code of Criminal } \\
\text { Procedure art. Competencies } \\
\text { of the Bpol in the prosecution } \\
\text { of criminal offences. }\end{array}$ \\
\hline $\begin{array}{l}\text { Asylum } \\
\text { law }\end{array}$ & & $\begin{array}{l}\text { (Eurodac and Dublin } \\
\text { Regulation) }\end{array}$ & \\
\hline
\end{tabular}

Table composed by the author.

\section{Background to the cases:}

1) Joint cases Aziz Melki (C-188/10) and Selim Abdeli (C-189/10) [2010], EU:C:2010:363 [Melki \& Abdeli 2010]. The case concerned two Algerian nationals which were subject to a police control in the border-area to Belgium, placed into detention and received a deportation order due to their unlawful presence. The defense raised the issue of constitutionaly of art. 78.2 of the French Code of Criminal Procedure, arguing that it was against the rights and freedoms guaranteed by the French Constitution, since the Constitution according to art. 88 attributes constitutional value to the commitments resulting from the Lisbon Treaty [art. 67 TFEU and the Schengen borders code, concerning the absence of internal border controls], and arguing that as such the Criminal code was contrary to 67 TFEU and thus against the French Consititution. This case additionally included a question regarding art 267 TFEU, concerning access by French national courts to the ECJ for preliminary rulings.

2) Case C-278/12 PPU Adil [2012] EU:C:2012:508 [Adil 2012] concerned an Afghan national, who was apprehended by Dutch police on a bus coming from Germany and placed in administrative detention because authorities considered risk for absconding with reference to the asylum procedure. He made an asylum application and resulted already registered as asylum seeker in Norway. The request for a preliminary ruling concerned compliance of Dutch national law with art 67 TFEU and the SBC.

3) A vs Germany (C-9/16 [A 2016], EU:C:2017:483) concerned the case of a man who crossed on foot the Europe Bridge from Strasbourg (France) to Kehl (Germany) and was checked by German Federal Police in front of train station, 500 metres from the border. He resisted the check and was charged with the offence of resisting an enforcement officer under Paragraph 113(1) of the Criminal Code. The request for a preliminary ruling concerned compliance of German national law with art 67.2 TFEU with regards to powers to check within the 30-kilometre zone (e.g. art 23. BpolG), as well as on trains or on the premises of the railway-station (art. 22) in order to prevent or terminate unlawful entry into the territory of that member state. On the latter aspect, the court argued that "unlike the checks provided for in point (3) of Paragraph 23(1) of the BPolG, the sole objective of the checks provided for in Paragraph 22(1a) of that law is to prevent or terminate illegal entry into German federal territory, which might indicate that those checks have an effect equivalent to border checks, prohibited by Article 21(a)".

\section{See also in this thesis:}

- Judgement of 19 March 2019, Abdelaziz Arib, Case C-444/17, ECLI:EU:C:2019:220 (endnote n.75).

- Judgement of 13 December 2018, Touring Tours und Travel GmbH and Sociedad de Transportes SA, Joint cases C-412/17 and C-474/17, ECLI:EU:C:2018:1005 (endnote n.126, n.127). 


\title{
ANNEX III \\ STUDY DESCRIPTION: Information sheets for research participants
}

\section{A) Summary of the Study}

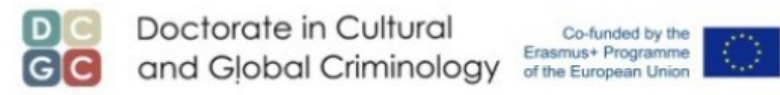

\author{
Information Sheet \\ PhD research in Cultural and Global Criminology \\ Title of the study: Security and migration in border-regions and in cross-border police cooperation
}

\section{Research carried out by}

Monika Weissensteiner

Erasmus+: Erasmus Mundus Joint Doctoral Candidate - Doctorate in Cultural and Global Criminology Willem Pompe Institute for Criminal Law and Criminology, Utrecht University School of Law

Institute for Criminological Research, Department of Social Sciences, Hamburg University

\section{Description of the study}

The research focuses on inner-European border-regions/internal borders and aims to study developments of cross-border police cooperation and policing in border-areas, with an attention towards the impact of migration and related cross-border crimes. The empirical part of the research aims to study challenges and experiences of law enforcement in the everyday work and in the use of bilateral or European instruments for cross-border cooperation, such as joint patrols or Police and Custom Cooperation Centres. The study is carried out in multiple Member States and border-regions. It is designed as interdisciplinary research, including analysis of relevant policy, legislation, agreements, as well as empirical research through field-observations and interviews with law enforcement practitioners and with other experts of relevance on national and EU level.

\section{Treatment of the data and publication of the findings}

All interviews and field-note observations will be treated anonymously through the use of key-codes during data collection and storage, and in publications through the use of fake personal names. Materials will be securely stored. Any additional details that would endanger the anonymity of the research participants will be treated as confidential and will not be disclosed. It has to be pointed out, that the notion of "confidentiality" in research refers generally to the treatment of information which requires a careful handling beyond the mere anonymity of the research participants. It does thus not refer to the meaning of confidential in terms of "classified information", which is information this study does by no means seek to acquire, to document or to disseminate. In the publication of empirical research findings will be differentiated between 1) a more historically oriented section, which will include a description of long-term developments of cross-border cooperation and for which the countries/border-regions will be identified, and 2) an analysis of current practices and challenges, for which country/region will not have to be disclosed in order to guarantee anonymity and confidentiality. Where necessary for presenting the analysis, countries/regions will be grouped together based on common denominators, and will not be identified individually.

\section{Institutional context and funding of the study}

This research project is part of a PhD research within the Erasmus Mundus Joint Doctoral Programme Doctorate in Cultural and Global Criminology (DCGC). The DCGC is a three-year interdisciplinary, collaborative PhD program carried out by a Consortium of four Universities and their Criminology departments: Utrecht University (Netherlands), University of Hamburg (Germany), ELTE University (Hungary) and Kent University (UK). In addition to the academic preparation (anthropology and criminology) the researcher has carried out an internship at the EU Agency for Law Enforcement Training (CEPOL). This study is financed through an Erasmus Mundus+ fellowship award by the EU funding program of the Education, Audiovisual and Culture Executive Agency (EACEA).

\section{Contact}

Monika Weissensteiner

Erasmus+: Erasmus Mundus Joint Doctoral Candidate - Doctorate in Cultural and Global Criminology Willem Pompe Institute for Criminal Law and Criminology, Utrecht University School of Law Institute for Criminological Research, Department of Social Sciences, Hamburg University E-mail:m.weissensteiner@uu.nl 


\section{B) Informed consent information sheet}

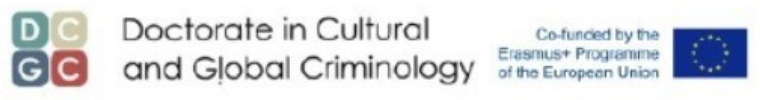

Information Sheet for Research Participants

Doctoral Research Project:

Security and migration in border-regions and in cross-border police cooperation

\section{Research carried out by}

Monika Weissensteiner

Erasmus+: Erasmus Mundus Joint Doctoral Candidate // Doctorate in Cultural and Global Criminology Utrecht University - Willem Pompe Institute for Criminal Law and Criminology, Utrecht University School of Law \& University of Hamburg - Institute for Criminological Research, Department of Social Sciences

\section{Research project description}

This research aims to study inner-European border areas and experiences and developments in the field of (cross-border) police cooperation. Particular focus will be given to security related challenges linked to migratory phenomena and (cross-border) crimes. The empirical part of the research aims to study challenges and experiences by security and law enforcement personnel in their everyday practices and the use of bilateral or European instruments for cross-border cooperation.

\section{Methodology}

The study is carried out in multiple Member States and designed as interdisciplinary research, including analysis of relevant policy, legislation, agreements, as well as field-observations and interviews with security practitioners and with relevant experts on national and EU level.

\section{Institutional context, funding and supervision}

This research project is part of a PhD research within the Erasmus Mundus Joint Doctoral Programme Doctorate in Cultural and Global Criminology (DCGC). The DCGC is a three-year interdisciplinary, collaborative $\mathrm{PhD}$ program carried out by a Consortium of four Universities and their Criminology departments: Utrecht University (Netherlands), University of Hamburg (Germany), ELTE University (Hungary) and Kent University (UK). The researcher, supervised by the universities Hamburg and Utrecht, has been awarded an Erasmus Mundus+ fellowship through the EU funding programme of the Education, Audiovisual and Culture Executive Agency (EACEA).

\section{Confidentiality of data ${ }^{1}$}

Material gathered during this research will be treated as confidential and securely stored. All interviews and field-note observations will be treated anonymously through the use of key-codes during data collection and storage, and in publications through the use of fake personal names. Any additional details that would endanger the anonymity of the research participants will not be revealed. In particular circumstances, such as interviews with official representatives, consent to identify position or person will in case be sought from the interviewed participant in occasion of the interview. The only person with access to interview-materials, personal information of the participants and to the fieldnotes will be the researcher carrying out the study.

\section{Publication of the study}

The findings of the research will result in a Phd thesis in Criminology and in academic publications, such as articles or a book. Research participants will not be able to be identified from the publications.

Supervisors, an internal and an external examiner will be informed about the results as they will read and examine the thesis. The confidentiality and the anonymity of the research participants will be ensured throughout this process.

1 The notion of "confidentiality" in research refers generally to the treatment of information which requires a careful handling beyond the mere anonymity of the research participants. It does thus not refer to the meaning of confidential in terms of "classified information", which is information this study does by no means seek to acquire, to document or to disseminate. 
In the publication of research findings will be differentiated:

a) A more historically oriented section will describe long-term developments of cross-border police cooperation, including in particular areas, for which place will be identified;

b) In the main sections concerning fieldwork data regarding recent experiences, potential identifiers - such as for example nationality, place, unit, role - of research participants will not be disclosed as a mean to guarantee anonymity and confidentiality. Whereas necessary for the analysis, member states will be grouped together based on common features and not identified individually.

\section{Participation in the study}

Participation in the study is voluntary and participants are free to withdraw at any time. The publication of the study will be made available to participating stakeholders, individual participants may contact the researcher to read the findings or to receive a summary.

Duration of the doctoral programme \& research project September 2016 - September 2019

\section{Contact}

[contact details] 


\section{REQUIRED INFORMATION: CV, declarations}

\section{CURRICULUM VITAE}

Monika Weissensteiner $(1983$, IT)

Erasmust: Erasmus Mundus Joint Doctoral Candidate

Doctorate in Cultural and Global Criminology (EQF level 8), 9/2016 - 2021

Institute for Criminological Research, Hamburg University (DE); Willem Pompe Institute for Criminal Law and Criminology, School of Law Utrecht University (NL); coord. Kent University (UK)

\section{Education}

Joint EU Masters Programme in Social \& Cultural Anthropology "CREOLE - Cultural Differences and Transnational Processes" (EQF level 7), 2007-2010, first class honours degree.

National University of Ireland, Maynooth (NUIM, IE); Université Lumière Lyon II (FR); Universitat Autónoma de Barcelona (ES).

Thesis: "Torture Evidence on Trial: (missing) scars, 'innocent scars', invisible wounds. Anthropological Reflections on the Documentation of Fear and Violence in European Asylum Procedures" (2009).

BA Degree in Anthropological Sciences (EQF level 6), Oct 2003-Mar 2007, summa cum laude. University of Bologna (IT); Erasmus: University of Vienna (AT).

Thesis: "Pain experience and representation. An anthropological analysis" (in Italian).

Vocational diplomas: "Mental health in situations of political violence and disasters" ( 9 months, ES); "Conflict Mediators - Peace Operators (18 months, IT) with thesis: "The civilmilitary hyphen. Experiences and perceptions of civil-military interaction in Afghanistan: case study Italy" (2014).

\section{Prior employment and collaborations}

Academic: teaching assistance (Utrecht University, NL); research assistant (Bolzano University, IT), project consultant (Bolzano University, IT), guest-lectures

Course instructor: accredited vocational trainings for health-care- \& social-workers, teachers, journalists (conflict mediation; medical anthropology, intercultural competencies, migration and international protection)

Third sector: NGO coordinator (IT); project officer (IT)

Internship: e.g., CEPOL European Union Agency for Law Enforcement Training, Budapest (HU) Illustrations: journal and book covers, illustration for research projects, non-academic products

\section{Other}

Awards: Erasmus+ Fellowship (E+EMJD), financed by the EACEA of the European Commission (2016); Ilse Waldthaler Price for Civil Courage and Social Responsibility (IT, 2016); three student merit awards (NUIM 2007-09; IT, Province of BZ 2003, 2007); recognitions for illustrations (UK 2009, IT 2011).

Functions: peer-reviewer; co-convenor of the EASA Anthropology of Security Network (2018- )

Publications: academia.edu/MonikaWeissensteiner \& non-academic publishing

Research interests: police cooperation, civil-military interaction, EU policy on security and on CEAS; medico-legal expertise; anthropology of security, legal anthropology, global criminology, border-studies, medical anthropology; combined with a concern for methodology, visual scholarship and public engagement. 


\section{DECLARATIONS}

\section{Declaration of work presented or published based fully or partially on this study:}

Conference presentations

- Policing mobilities - mobilising police: a view from inner-European Schengen borders in the context of the "refugee crisis". Presented at the International Migration Conference: $E U$ at the crossroads of migration: critical reflections on the 'refugee crisis' and new migration deals. Utrecht University, Netherlands, 7-8 May 2018.

- Small place, large issues: border-makings in the Austrian-Italian borderland. Presented at the Association of Borderland studies (ABS) 2nd World Conference, Panel: Habsburg Track Panel: Austria. Vienna and Budapest, 10-14 July 2018.

- "Playing ping-pong" with "the hot potato". On programs and technologies of government aiming to respond to unauthorised mobilities. Presented at at the Common Study Programme in Critical Criminology: Crime and Technological Culture. Copenhagen, 17-19 October 2018.

- $\quad$ In/de/securitisation of migration - setting the boundaries of the acceptable.

Perceptions of right and wrong by law enforcement officers. Preliminary reflections. Presented at EASA Anthropology of Security Network Conference: Security and Morality. Critical anthropological perspectives. Oslo, 28-29 March 2019.

Publications

- (forthcoming). BORDER-STRIP: a border-criminology ethnography. In (working title) Criminographics: a visual approach to cultural and global criminology. 


\title{
Erklärung / Declaration
}

Hiermit erkläre ich, Weissensteiner Monika, dass ich keine kommerzielle Promotionsberatung in Anspruch genommen habe. Die Arbeit wurde nicht schon einmal in einem früheren Promotionsverfahren angenommen oder als ungenügend beurteilt.

I hereby declare, that I have not sought commercial promotional advice. The work has not been accepted in a previous doctoral procedure or judged as insufficient.

Hamburg, 15/10/2020

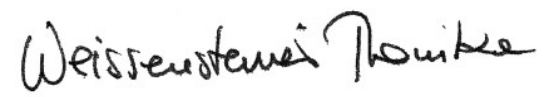

Ort, Datum / City, date

Unterschrift Doktorandin / Signature Candidate

\section{Eidesstattliche Versicherung / Declaration on oath}

Ich, Weissensteiner Monika, versichere an Eides statt, dass ich die Dissertation mit dem Titel:

I hereby declare upon oath that I have written the present dissertation:

\author{
"POLICING-MOBILITIES IN THE BORDER-STRIP. \\ CROSS-BORDER POLICE COOPERATION AND VIAPOLITICS \\ AT THE INTERNAL SCHENGEN-BORDERS OF THE EU \\ AREA OF FREEDOM, SECURITY AND JUSTICE"
}

selbst und bei einer Zusammenarbeit mit anderen Wissenschaftlerinnen oder Wissenschaftlern gemäß den beigefügten Darlegungen nach $\S 6 \mathrm{Abs}$. 3 der Promotionsordnung der Fakultät für Wirtschafts- und Sozialwissenschaften vom 18. Januar 2017 verfasst habe. Andere als die angegebenen Hilfsmittel habe ich nicht benutzt.

independently and have not used further resources and aids than those stated.

Hamburg, 15/10/2020

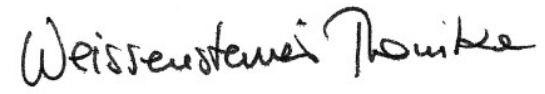

Ort, Datum / City, date

Unterschrift Doktorandin / Signature Candidate 